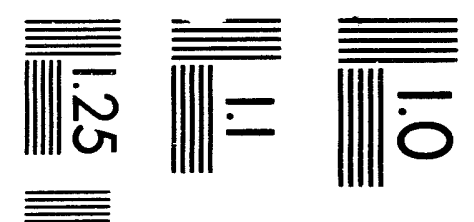

$$
\begin{aligned}
& \text { IIIII }
\end{aligned}
$$

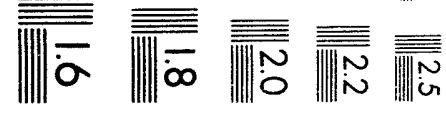



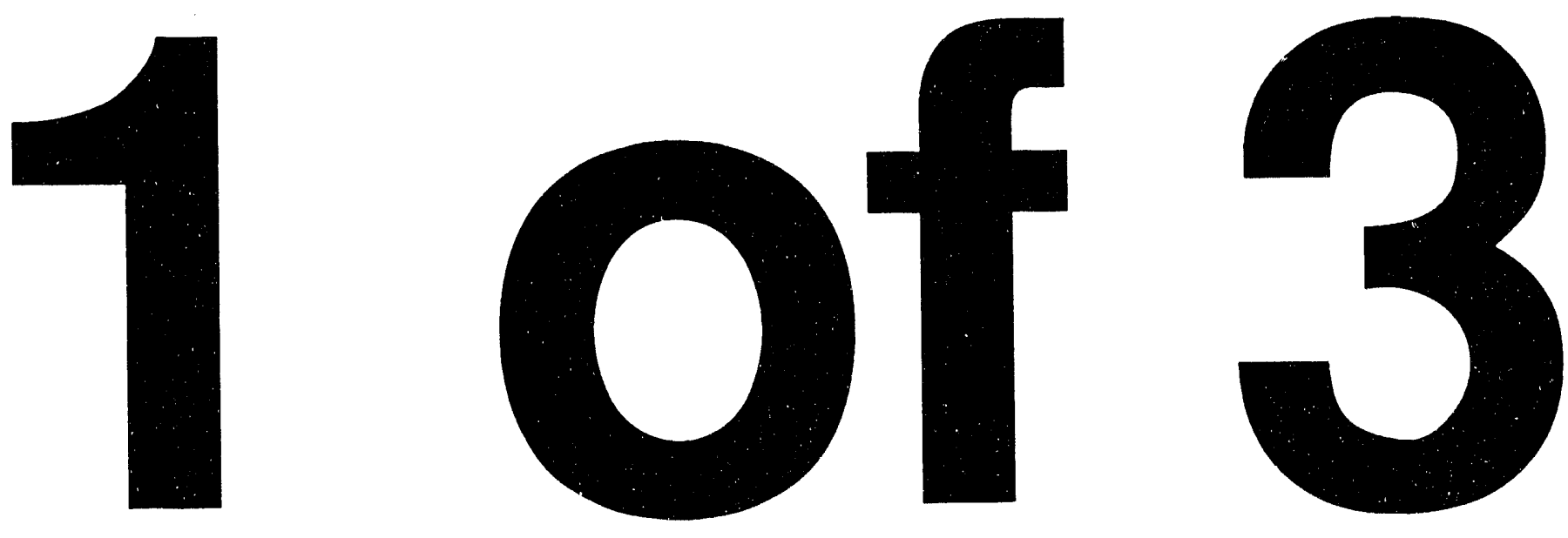


\title{
Natural Gas Annual 1992 Volume 1
}

\author{
November 1993
}

\section{Energy Information Administration}

Office of Oil and Gas

U.S. Department of Energy

Washington, D.C. 20585

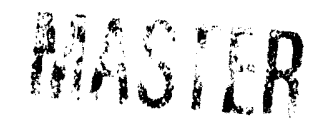

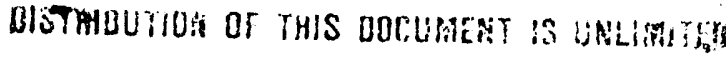

This report was prepared by the Energy Information Administration, the independent slatistical and analytical agency within the Department of Energy. The information contained herein should not be construed as advocating or reflecting any policy position of the Department of Energy or any other organization. 


\section{Contacts}

The Natural Gas Annual is prepared by the Energy Information Administration, Office of Oil and Gas, Reserves and Natural Gas Division under the direction of Diane W. Lique.

General information for this document may be obtained from Kendrick E. Brown, Jr. (202, 586-6077), Chief of the Data Operations Branch. Questions and comments concerning the contents of the Natural Gas Annual may be directed to Ann M. Ducca (202/ 586-6137) and Margo Natof (202/ 586-6303). Specific inquiries should be referred to the following subject specialists: Supply -. Donna Dunston (202/ 586-6135), Transmission -- Dolly Tolson (202/ 586-6664), Demand -- Sylvia Norris (202/ 586-6106), and Data diskettes -Sheila Darnell (202/ 586-6165). 


\section{Preface}

The Natural Gas Annual provides information on the supply and disposition of natural gas to a wide audience including industry, consumers, Federal and State agencies, and educational institutions. The 1992 data are presented in a sequence that follows natural gas (including supplemental supplies) from its production to its end use. Tables summarizing natural gas supply and disposition from 1988 to 1992 are given for each Census Division and each State. Annual historical data are shown at the national level. Volume 2 of this report presents State-level historical data.

The data in this publication are taken from surveys conducted by the Energy Information Administration (EIA), U.S. Department of Energy (DOE), to fulfill its responsibilities for gathering and reporting energy data. Two ElA surveys provide most of the information presented in this report--the mandatory Form EIA-176, "Annual Report of Natural and Supplemental Gas Supply and Disposition," and the voluntary Form EIA-627, "Annual Quantity and Value of Natural Gas Report." Form EIA-176 was submitted by respondents out of an identified universe of operators of fields, wells, or natural gas processing plants who distribute gas to end users or transport gas to or across a State border; operators of synthetic natural gas plants; natural gas distributors; natural gas pipeline companies; and companies that operate underground natural gas storage facilities. Form EIA-627 was submitted by the appropriate agencies of the 33 natural gas producing States.

Beginning with the collection of 1990 data, reporting to the Form EIA-176 is no longer proprietary. Selected company-level data are presented in the Demand section. The Supplement of this report presents a detailed profile of selected companies.

Other ElA surveys that provided information for this report are Forms EIA-816, "Monthly Natural Gas Liquids Report," and EIA-64A, "Annual Report of the
Origin of Natural Gas Liquids Production," for gas processed, plant fuel, and extraction loss data; Form EIA-857, "Monthly Report of Natural Gas Purchases and Deliveries to Consumers," for data on the city gate prices; Forms EIA-759, "Monthly Power Plant Report," and FERC-423, "Monthly Report of Cost and Quality of Fuels for Electric Plants," for data on the quantity and price of natural gas consumed by electric utilities; and Form FPC-14, "Annual Report for Importers and Exporters of Natural Gas," for data on the quantity and price of natural gas imports and exports. The EIA report. U.S. Crude Oil, Natural Gas, and Natural Gas Liquids Reserves, 1992 Annual Report, was the source of the reserves data.

Some of the data are collected under the authority of the Federal Energy Regulatory Commission (FERC), an independent commission within the DOE that has jurisdiction primarily in the regulation of electric utilities and the interstate natural gas industry. The United States Geological Survey (USGS) and the United States Minerals Management Service (MMS) of the Department of the Interior, and the Interstate Oil and Gas Compact Commission (IOGCC) were sources of supplemental information on production, the number of producing gas and gas-condensate wells, and wellhead values. The geographic coverage is the 50 States and the District of Columbia.

All volumes of natural gas in this publication are reported at 14.73 pounds per square inch absolute and 60 degrees Fahrenheit, except where noted. A glossary of terms is provided to assist users in understanding the data presented. A description of the data collection surveys appears in Appendix A. Appendix B describes metric and thermal conversion factors. Additional natural gas information sources are listed in Appendix C.

The tables of data that appear in this report are available for purchase on personal computer diskettes. See the inside cover for ordering information. 


\section{Contents}

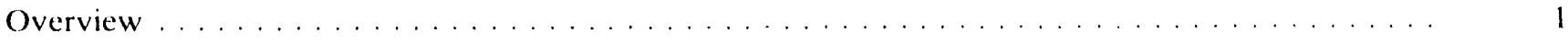

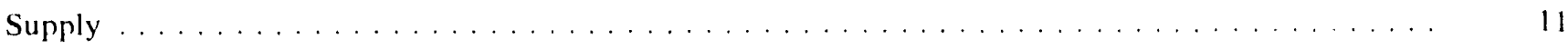

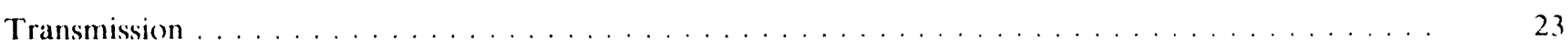

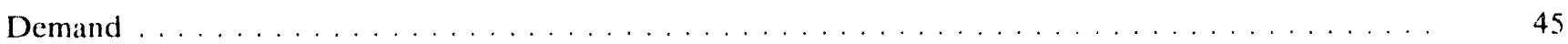

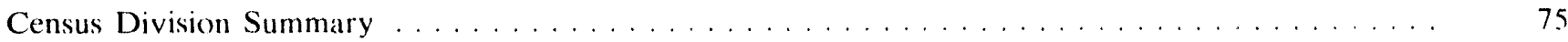

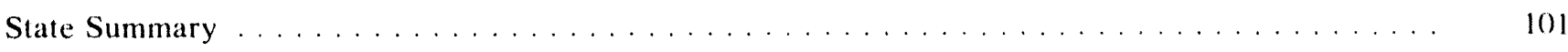

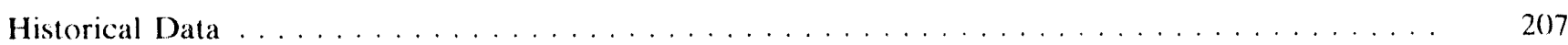

Appendices

A. Summary of Data Collection Operations and Report Methodology . . . . . . . . . . . 219

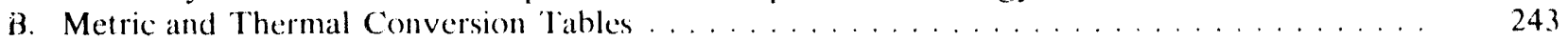

C. Selected Natural Gas and Retated Reports . . . . . . . . . . . . . . . . . . . . . . . 249

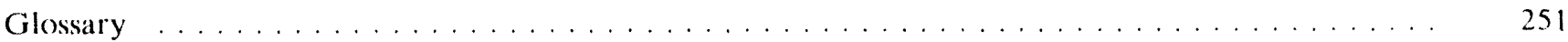




\section{Tables}

. Summary Statistics for Natural Gas in the United States, 1988-1992 . . . . . . . . . . . . .

Page

2. Natural Gas Production, Transmission, and Consumption by State, $1992 \ldots \ldots$

3. Gross Withdrawals and Marketed Production of Natural Cias by State, $1988-1992$

Offishore Gross Withdrawals of Natural Gas by State, 1988-1992

Number of Producing Gas and Gas Condensate Wells as of December 31, 1988-1992 . . .

Estimated Total Dry Natural Gas Proved Reserves by State, 1988-1992 . . . . . . . . . . . . .

Wellhead Value and Marketed Production of Natural Gas by State, 1988-1992

Volume and Average Price of Natural Gas Purchases from Producers by Type of Purchaser

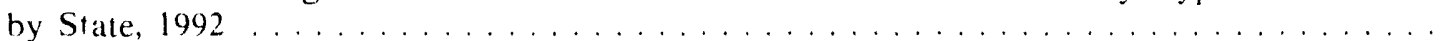

Interstate Movements and Movements Across U.S. Borders of Natural Gas by State, 1992.

Summary of U.S. Natural Gas Imports and Exports, 1988-1992 . . . . . . . . . . . .

Total Consumption and Net Imports of Natural Gas into the United States, 1972-1992 . . . Additions to and Withdrawals from Gas Storage by State, $1992 \ldots \ldots \ldots \ldots$ Underground Natural Gas Storage Capacity by State, December 31, $1992 \ldots \ldots$ Natural Gas Processed, Liquids Extracted, and Estimated Extraction Loss by State, 1992 . Supplemental Gas Supplies by State, 1992

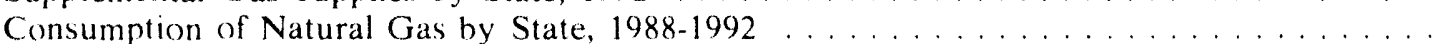
Natural Gas Delivered to Consumers by State, $1988-1992 \ldots \ldots \ldots \ldots \ldots \ldots$ Natural Gas Delivered to Commercial Consumers for the Account of Others by State, $1988-1992$

Natural 1988-1992

Natural Gas Delivered to Electric Utilities for the Account of Others by State, 1988-1992 . Average City Gate Price of Natural Gas in the United States, 1988-1992 . . . . . . . . . . . Average Price of Natural Cias Delivered to Consumers by State, 1991-1992.

Selected Volumes and Prices of Natural Gas Sold to Residential Customers in the United States, 1992

Selected Volumes and Prices of Natural Gas Sold to Commercial Customers in the United States, 1992 Leading Suppliers of Natural Gas to End Users in the United States, $1992 \ldots \ldots$. . . . . . . . Average Heat Content Price of Natural Gas Delivered to Consumers by State, 1988-1992 . . Average Consumption and Annual Cost of Natural Gas per Consumer by State, 1992 . . . . Volume and Average Price of Natural Gas Purchases from Transporters, by Type of Purchaser by State, 1992

Volume and Average Price of Gas Sold for Resale by State, 1992

Natural Gas Delivered to Consumers by Census Division, $1992 \ldots \ldots \ldots \ldots \ldots . \ldots . \ldots . . . \ldots$ Average Price of Natural Gas Delivered to Consumers by Census Division, 1991-1992 ...

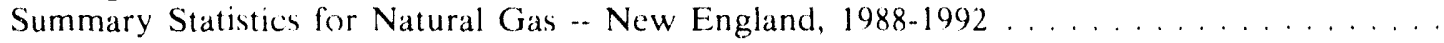

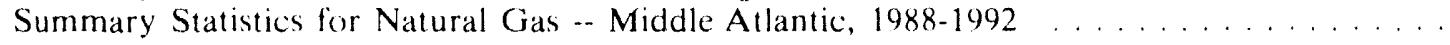
Summary Statistics for Natural Gas -- East North Central, $1988-1992$

Summary Statistics for Natural Gas -- West North Central, $1988-1992$

Summary Statistics for Natural Gas -- South Atlantic, $1988-1992$

Summary Statistics for Natural Gas -- East South Central, $1988-1992$

Summary Statistics for Natural Gas -- West South Central, 1988-1992

Summary Statistics for Natural Gas -- Mountain, $1988-1992$

Summary Statistics for Natural Gas -- Pacific Contiguous, 1988.1992

Summary Statistics for Natural Gas .- Pacific Noncontiguous, 1988-1992 . . . . . . . . . . Percent Distribution of Natural Gas Supply and Disposition by State, $1992 \ldots \ldots$. . . . . . . Percent Distribution of Natural Gas Delivered to Consumers by State, $1992 \ldots \ldots$. . . . . . . Summary Statistics for Natural Gas -- Alabama, 1988-1992

Summary Statistics for Natural Gas - Alaska, $1988-1992$

Summary Statistics for Natural Gas -- Arizona, 1988-1992

Summary Statistics for Natural Gas -- Arkansas, $1988-1992$

Summary Statistics for Natural Gas -- California, 1988-1992

Summary Statistics for Natural Gas -- Colorado, 1988-1992

Summary Statistics for Natural Gas -- Connecticut, 1988-1992

Summary Statistics for Natural Gas -.. Delaware, $1988-1992$

52.

Summary Statistics for Natural Gas -- District of Columbia, $1988-1992$ 
Summary Statistics for Natural Gas -- Hawaii, 1988-1992

Summary Statistics for Natural Gas -. Idaho, 1988-1992

Summary Statistics for Natural Gas -- Illinois, 1988-1992

Summary Statistics for Natural Gas .. Indiana, 1988-1992

Summary Statistics for Natural Gas -. Kentucky, 1988-1992

Summary Statistics for Natural Gas -. Maine, $1988-1992 \ldots \ldots \ldots \ldots \ldots \ldots \ldots \ldots \ldots$

64.

Summary Statistics for Natural Gas -. Maryland, 1988-1992

Summary Statistics for Natural Gas -- Massachusetts, $1988-1992 \ldots \ldots \ldots \ldots \ldots \ldots$

66.

Summary Statistics for Natural Gas -- Michigan, 1988-1992

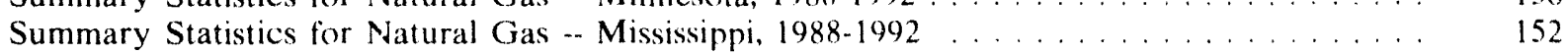

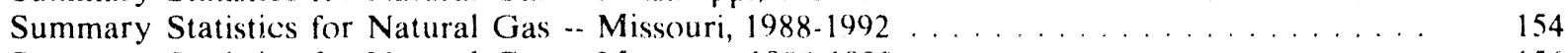

Summary Statistics for Natural Gas .. Montana, $1988-1992 \ldots \ldots \ldots \ldots \ldots \ldots \ldots$

Summary Statistics for Natural Gas .- Nebraska, $1988-1992 \ldots \ldots \ldots \ldots \ldots \ldots \ldots$

Summary Statistics for Natural Gas .. Nevada, $1988-1992 \ldots \ldots \ldots \ldots \ldots \ldots \ldots \ldots$

Summary Statistics for Natural Gas - New Hampshire, $1988-1992 \ldots \ldots \ldots \ldots \ldots \ldots \ldots$

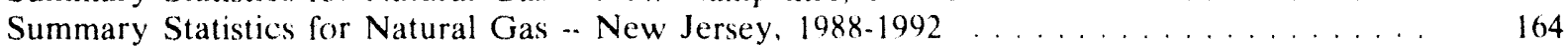

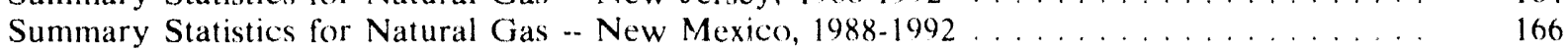

Summary Statistics for Natural Gas -- New York, $1988-1992 \ldots \ldots \ldots \ldots \ldots \ldots \ldots \ldots$

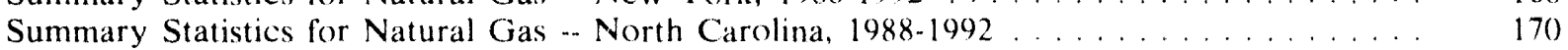

Summary Statistics for Natural Gas -. North Dakota, 1988-1992 . . . . . . . . . . . . 172

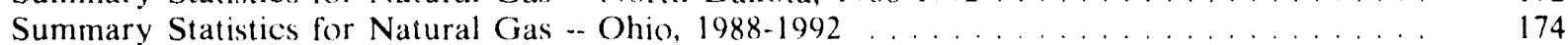

Summary Statistics for Natural Gas .. Oklahoma. $1988-1992 \ldots \ldots \ldots \ldots \ldots \ldots \ldots \ldots$

Summary Statistics for Natural Gas -. Oregon, $1988-1992 \ldots \ldots \ldots \ldots \ldots \ldots \ldots \ldots$

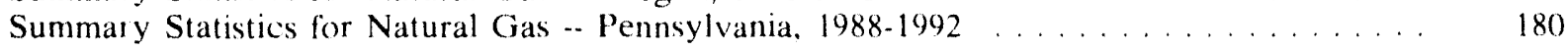

Summary Statistics for Natural Gas - Rhode Island, $1988-1992 \ldots \ldots \ldots \ldots \ldots \ldots \ldots$

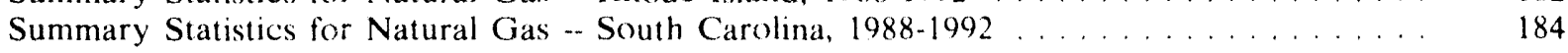

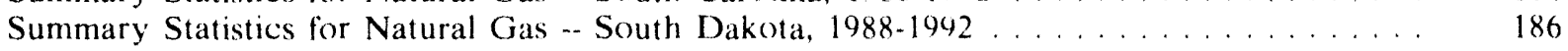

Summary Statistics for Natural Gas .. Tennessee, $1988-1992 \ldots \ldots \ldots \ldots \ldots \ldots$

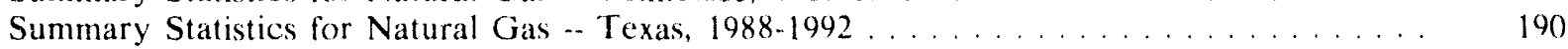

Summary Statistics for Natural Gas .. Utah, $1988-1992 \ldots \ldots \ldots \ldots \ldots \ldots \ldots \ldots \ldots . \ldots \ldots$

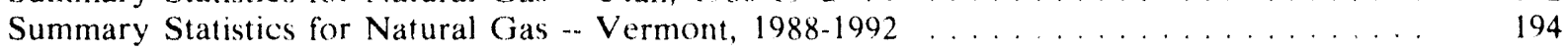

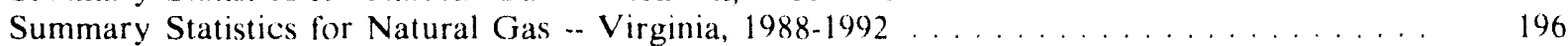

Summary Statistics for Natural Gas .. Washington, $1988-1992 \ldots \ldots \ldots \ldots \ldots \ldots \ldots$

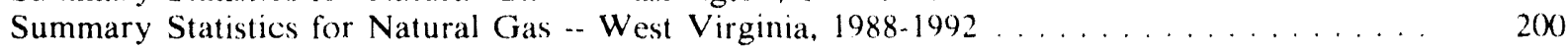

Summary Statistics for Natural Gas .. Wisconsin, $1988-1992 \ldots \ldots \ldots \ldots \ldots \ldots \ldots \ldots$

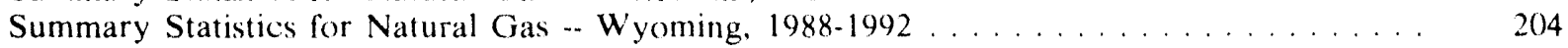

Quantity and Average Price of Natural Gas Production in the United States, 1930-1992 . . 2 209

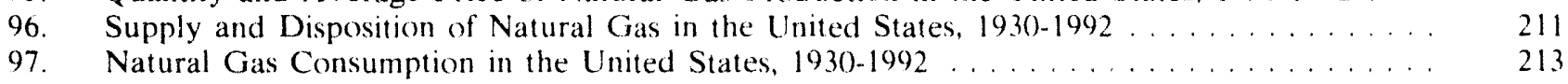

98. Average Price of Natural Gas Consumption in the United States, 1967-1992 . . . . . . 215

A1. Comparison of Electric Utility Natural Gas Consumption Data by State, $1992 \ldots \ldots \ldots .235$

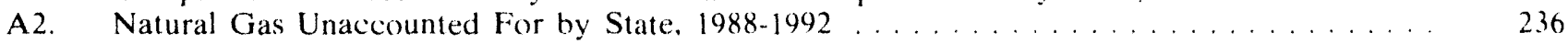

A3. Natural Gas Processed and Liquids Extracted at Natural Gas Processing Plants by State,

A4. Estimated Composition of Liquids Extracted at Natural Gas Processing Plants and the Re-

A5. Nulting Heat Content Extraction Loss by State, $1992 \ldots \ldots \ldots \ldots \ldots \ldots \ldots \ldots$. . . . . . . . . . . . . .

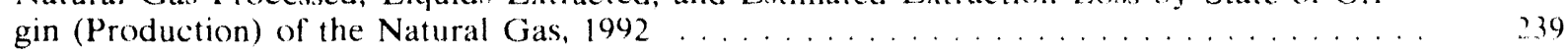

A6. Quantity of Natural Gas Used as Lease and Plant Fuel by State, $1992 \ldots \ldots \ldots \ldots \ldots 240$

B1. Summary Statistics for Natural Gas in the United States, Metric Equivalents, 1988-1992 ... 244

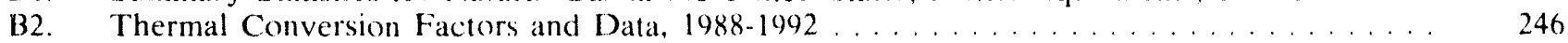




\section{Illustrations}

Page

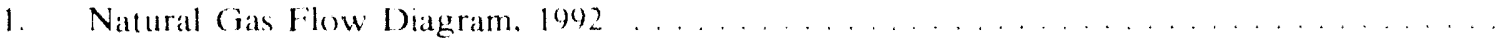

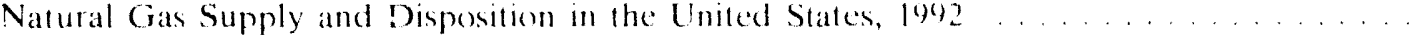

3. Marketed Production of Natural Gas in the United States, 1992 . . . . . . . . . . . . . . .

Marketed Production of Natural cias in Selected States, 1988-1992 . . . . . . . . . . .

5. Principal Interstate Natural Gas Flow Summary . . . . . . . . . . . . . . . . . . .

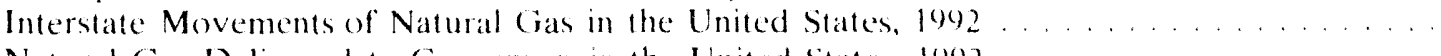

7. Natural Gas Delivered to Comsumers in the United States, 1992 ...............55

8. Percent of Natural Gas Deliveries in the United States Representing Deliveries for th:

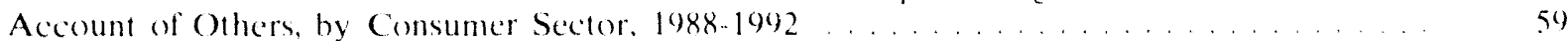

9. Average City Ciate Price of Natural Cas in the United States, $1992 \ldots \ldots$

Average Price of Natural Cas Delivered to U.S. Residential Consumers, 1992 . . . . . . . 66

11. Average Price of Natural Gas Delivered to U.S. Commercial consumers, 1992 .........

Average price of Natural Cas Delivered to U.S. Industrial Consumers, 1992 . . . . . . . 67

13. Average Price of Natural Gas Delivered to U.S. Electric Ltilities, $1992 \ldots \ldots$

14. Marketed Production of Natural Cas by Census Division, $1992 \ldots \ldots 76$

16. Natural Gas Supply and Disposition in the United States, 1965-1902 . . . . . . . . . . . 210

17. Natural Gas Delivered to Consumers in the United States, 19.3(1)-1992 . . . . . . . . . 212

18. Average Price of Natural Cas Delivered to U.S. Comsumers, 1967-1992 ............ 214

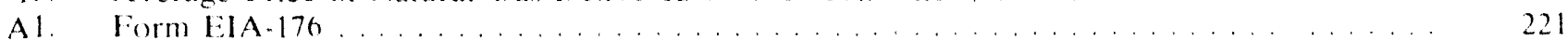

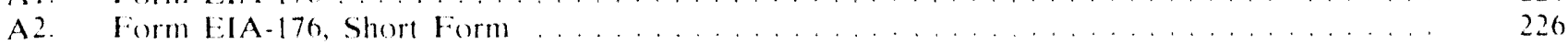

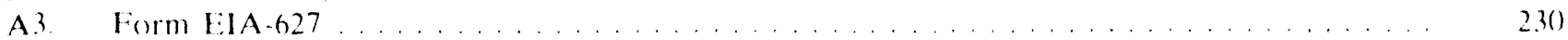




\section{Overview}

\section{Highlights}

In 1992 as the economy took an upward turn and most regions of the nation returned to normal weather, the natural gas industry showed modest growth. Marketed production of natural gas rose 1 percent while consumption increased 3 percent. Net imports continued to play an important role in meeting excess demand, accounting for 10 percent of domestic consumption.

Although the number of producing gas wells and active rotary rigs declined in 1992, dry production was 1 percent higher than in 1991. Coalbed methane production increased by 50 percent during the same period and represented approximately 3 percent of total dry production in 1992 .

Consumption of natural gas was higher in 1992 than in 1991 in the residential, commercial, and industrial sectors. The largest increase, 4 percent, occurred in the industrial sector, and much of it can be attributed to natural gas consumption by nonutility generators (NUG's). NUG's generate electricity for their own use and for sale to electric utilities, which in turn distribute it to consumers.

Most regions of the count ry returned to normal weather during the 1992-1993 heating season (NovemberMarch). This followed a period of 3 years of abovenormal weather which saw temperatures averaging over 9 percent warmer than normal.

\section{Figure 1. Natural Gas Flow Diagram, 1992}

(Trillion Cubic Feet)

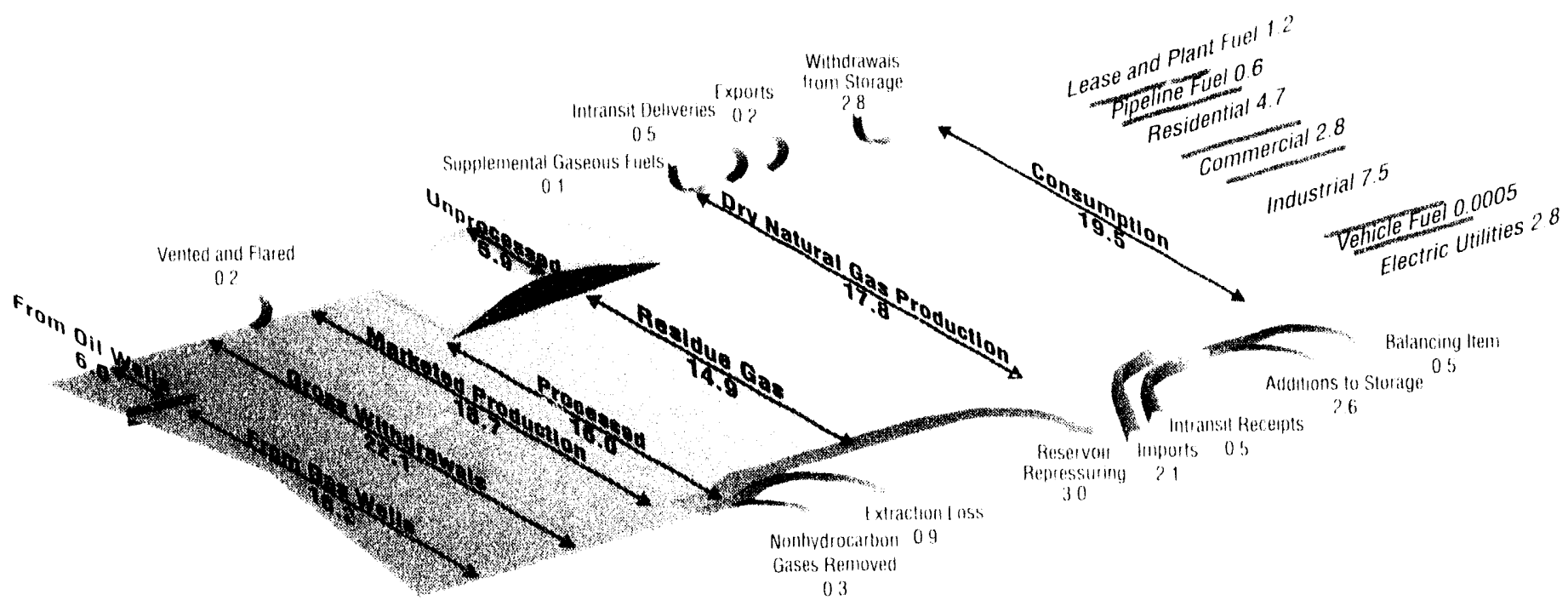

Note. Totals may not add due to independent rounding

Sources. Energy Information Administration (EIA), Form HA-176. "Annual Report of Natural and Supplemental Gas Supply and Disposition." Form ElA b27. "Annual Quantity and Value of Nalural Gas Report." Form FlA 816 "Monthly Natural Gas Liquids Report." Form E.IA-759. "Monthly Power Plant Report," Form FERC-423. "Monthly Report of Cost and Quality of Fuels for Flectuc Plants." Form FPC-14. "Annual Report for Imponters and Exporters of Natural Gas, U.S. Crude Oil Natural Gas, and Natual Gas Liquids Reserves. 1992. Anmual Report. DOE/L:IA 0216(92), and the U.S Minetals Management Service 
The impact of these lower temperatures is clearly evident over the past year. Both the residential and commercial sectors, the most weather-sensitive consuming groups, recorded increases in consumption of 12 percent and 8 percent, respectively during the past heating season.

Other weather-related events that impacted on natural gas markets over the past year were Hurricane Andrew in August of 1992 and the Midwest floods in the spring and summer of 1993. Hurricane Andrew, which disrupted natural gas production in the Gulf of Mexico, had a rather dramatic effect on the supply and price of natural gas. Events surrounding the impact of Andrew are discussed in detail in the Supply chapter.

Natural gas industry facilities were affected by the 4 -month long Midwest floods. Several pipelines that cross the Missouri and Mississippi Rivers were dislodged from the riverbed, and some companies restricted the volume of gas heing transported where pipelines were exposed by rushing water. Although the great flood of 1993 did cause much havoc and destruction in the Midwest, its effect on the natural gas market proved to be only minimal. The pipeline grid in the Mid-Continent demonstrated flexibility as dispatchers rerouted supplies through other pipelines.

\section{Energy Legislation}

After nearly a 2"year journey, Congress passed and the President signed a broad-range energy bill in late $\mathrm{OC}$ tober. The new energy bill titled "The Energy Policy Act of 1992" (EPACT) is the first overhaul of the Nation's energy laws in more than a decade. Included in the wide-ranging bill are provisions to promote the use of alternative-fuel vehicles; encourage research and development into advanced clean coal, natural gas, and advanced oil-recovery technologies; promote energy-efficient buildings, appliances, and technologies; remove obstacles to increased competition in electricity generation by amending the Public Utility Holding Company Act of 1935 and increasing transmission access; encourage the development of advanced nuclear power plants; and provide for permanent relief from the Alternative Minimum Tax for independent oil and gas producers.

\section{EPACT}

The EPACT does not contain a specific natural gas section. However, the bill amends Section 3 of the Natural Gas Act (NGA) with respect to natural gas imported from a nation "with which there is in effect a free trade agreement," so that (1) such imports (including LNG) "shall be treated as a 'first sale' within the meaning of Section 2(21) of the Natural Gas Policy
Act, and (2) the Commission shall not treat any imported natural gas on an unjust, unreasonable, unduly discriminatory, or preferential basis." Also, under this bill gas imports and exports both "shall be deemed to be consistent with the public interest, and applications . . shall be granted without modification or delay."

The provisions of the bill that impact the natural gas industry are:

Conservation and Energy Efficiency by Gas Utilities (Title I): Natural gas provisions of the Public Utility Regulatory Policies Act (PURPA) of 1978 are amended to require State-regulated gas utilities and State regulatory commissions to consider (1) implementing Integrated Resource Planning (IRP) for local gas utilities, and (2) allowing those utilities to earn a profit on investments in energy-efficiency techniques. States electing not to implement these requirements must hold a hearing to explain their decision.

Energy Efficiency/Environment (Title XXI): This section of the bill establishes a 5-year program on energyefficient natural gas and electric heating and cooling technologies for residential and commercial buildings. The program will cover heat pumps and other advanced gas technologies including fuel cells for residential and commercial applications. Proposals were due within 180 days.

Reduction of Oil Vulnerability (Title XX): This title establishes various programs to be conducted by DOE relating to oil and gas supply and demand enhancement. A mong other things, DOE must conduct a 5-year program on technologies to increase the recoverability of domestic oil resources through improving reservoir characterization, field testing and demonstrating enhanced oil recovery processes, transferring proven recovery technologies to producers and operators of wells that otherwise are likely to be abandoned in the near term, developing new recovery technologies, and other means. In conducting this program, DOE must consult with representatives of the oil and gas industry with respect to innovative research and development proposals to improve oil and gas recovery, submit a plan to Congress within 6 months of enactment to carry out accelerated field testing of technologies, and solicit proposals within 1 year.

A separate 5-year program will be conducted to increase the recoverable natural gas resource base including, but not limited to (1) more intensive recovery of gas from conventional sources, (2) extraction of gas from tight sands and Devonian shales or other unconventional sources, (3) surface gasification of coal, and (4) recovery of methane from biofuels including municipal solid waste. Still another 5-year program will address cofiring natural gas with coal in utility and large industrial boilers in order to determine optimal gas injection levels. DOE's appropriation was $\$ 29.7$ million for fiscal year 1993 and $\$ 45$ million for fiscal year 1994 for these two programs. 
Similarly, natural gas end-use technologies are targeted in a 5-year program to study (1) stationary source emissions control and sficicncy improvements including combustion systems, industrial processes, cogencration and waste fucls; and (2) natural gas storage including increased deliverability from existing gas storage facilities, new capabilities for storage near demand centers, and on-site storage at major energy consuming facilities.

These studies all will coincide with certain oil and gas demand reduction programs aimed at improving efficiency in the area of general transportation and especially advancing applications of natural gas and alternative fuel technology to improve automotive fuel economy.

Vehicular Natural Gas Jurisdiction (Title IV): The legislation adopts NGA amendments exempting from Federal jurisdiction anyone selling or transporting vehicular natural gas who (1) is not otherwise a natural gas company, or (2) is subject primarily to regulation by a State commission (whether or not the State is exercising such jurisdiction). "Vehicular natural gas" is defined as manufactured or natural gas that is ultimately used as a fuel in self-propelled vehicles.

Transportation or sale of natural gas by a nonutility in closed containers, or otherwise for use as a fuel in a self-propelled vehicle, is exempted from jurisdiction within the meaning of any State law, regulation, or order in effect prior to January 1, 1989 (except laws created for the protection of public safety).

Alternative Fuels-General (Title 111): The new law establishes minimum Federal fleet requirements of at least 5,000 alternative fuel vehicles (AFV's) in fiscal year 1993, 7,500 AFV's in fiscal year 1994, and 10,000 vehicles in fiscal year 1995. Of the total number of vehicles acquired for Federal fleets thereafter, at least 25 percent must be AFV's in 1996, 3.3 percent in 1997. 50 percent in 1998, and 75 percent in 1999.

The term "Federal fleet" means 20 or more light-duty motor vehicles located in a metropolitan statistical area or consolidated metropolitan area. Federal agencies are encouraged to arrange for fueling at commercial facilities that offer alternative fuels for sale to the public. To promote use of AFV's in Federal agencies (including the Postal Service), the Administrator of General Services may offer a reduction in fees charged to agencies for lease of alternative fueled vehicles below fees charged for lease of comparable conventionally fueled motor vehicles (up to 3 years after enactment).

Alternative Fuels and Non-Federal Programs (Title IV): The Federal Energy Regulatory Commission (FERC) is authorized to consider the environmental and other benefits of research and development on alternative fuel vehicles by the Gas Research Institute (GRI) or Electric Power Research Institute. If R\&D benefits exceed costs, FERC may exercise its authority under
Section 4 of the NGA to direct natural gas pipelines to recover the costs in their rates. FERC must also establish cost sharing (cofunding) requirements to the "maximum extent practicable," but with recognition that cost-sharing may not he practical for all natural gas transportation, pollution control, and emissions reduction projects.

\section{Energy Taxes}

On February 17, 1993, President Clinton introduced a proposal to levy new taxes on energy. This new comprehensive tax would be based on the heat content or output, measured in British Thermal Units (BTU's). This proposal was introduced as a part of the Administration's Economic Plan and was proposed specifically to reduce the deficit. Estimates of potential revenues from the imposition of the BTU tax range from $\$ 22$ billion estimated by the administration to $\$ 33$ billion estimated by the American Petroleum Institute.

The original proposal would have put a tax levy of 28 cents per million BTU on natural gas, half the rate proposed for petroleum products. This proposal met with serious and wide-ranging opposition from many segments of U.S. industry and various regions of the country. Though it was passed by the House of Representatives, it had little support in the Senate and was subsequently removed from the Budget package. In August, the Congress did pass the deficit reduction budget package which included a 4.3 cent tax increase per gallon on motor gasoline. Natural gas did not escape unscathed. Included in this Bill was the first Federal taxes on natural gas used as a vehicle fuel. The tax on compressed natural gas will be $\$ 5.89$ per equivalent gallon. This higher rate resulted from discussions held on the closing days of Congressional action on the 1993 Federal budget package. This compromise was based on the heat/energy content of a gallon of liquefied petroleum gas. These transportation fuel taxes are scheduled to go into effect on October 1, 1993.

\section{National Petroleum Council Study}

In December 1992, the National Petroleum Council (NPC) adopted a six-volume report, which has been in preparation for 2 years, entitled The Potential for Natural Gas in the United States. The NPC is a federal advisory committee to the Secretary of Energy. The sole purpose of the NPC is to advise, inform, and make recommendations to the Secretary of Energy on any matter requested by the Secretary relating to oil and natural gas or to the oil and gas industries.

This study is the result of a request by the Secretary of Energy in June 1990 for the NPC to undertake "a comprehensive analysis of the potential for natural gas 
to make a larger contribution ... to our Nation's energy supply . . . (and) ... to consider carefully the ... potential barriers that could impede the Celiverability of gas to the most economic, efficient and environmentally sound end users." The conclusions of the study are basically divided into four key findings:

- "Natural gas is an abundant domestic resource and can be produced and delivered at prices that allow both expansion of the market and continued development of resource."

The study projects technically recoverable natural gas resources of 1,295 trillion cubic feet, including 160 trillion cubic feet of currently "proved" reserves, another 616 trillion cubic feet recoverable from conventional sources (reserve appreciation and new fields), and 519 trillion cubic feet of nonconventional resources (coal bed methane, shales, tight sands, and other). The estimates also assume continuing technological advancement. During the past 20 years, the report noted, drilling costs have jeen reduced almost 3 percent annually below what they would have been absent advanced technology. The contribution of technology is expected to increase the Lower 48 States recoverable natural gas resource base by more than 200 trillion cubic feet between 1990 and 2010, a rate of growth consistent with that experienced over the past two decades.

With respect to natural gas availability from sources outside the Lower 48, NPC indicated that Canadian natural gas imports will probably continue to grow to 3 trillion cubic feet annually depending on domestic demand and trade restrictions; that Mexico will continue to be a net export market for U.S. producers over the next 10 years, but could become a supply source if economic conditions support development of Mexico's substantial resource base; that liquefied natural gas (LNG) imports are likely to remain low; and that calculated price and demand levels still appear inadequate to spur development of Alaskan North Slope gas resources or northern frontier gas in Canada for domestic consumption prior to 2010.

The NPC study further concluded that the existing natural gas transmission and storage network is more than capable of meeting existing firm requirements on an annual and peak-day basis. Specifically, the study noted that the national transportation system had a 1991 annual capability of 24 trillion cubic feet and peak-day capacity of approximately 120 billion cubic feet per day, above 1991 annual consumption of 19.2 trillion cubic feet and estimated firm peak-day demand of 102 billion cubic feet per day. This additional capacity "allows non-firm customers to use the capacity on peak days, provides redundance, adds reliabilty, and enables the system to support a growing U.S. gas market." However, the NPC cautioned that gas supply and consumption pat- terns are likely to shift by 2010 , creating a need for new transportation and storage facilities. Anticipated expenditures to accommodate this shift are comparable to average total industry investments over the past 20 years, the report added, and should not be a major constraint to future growth.

- "The natural gas market is increasingly diverse, with new challenges and opportunities."

The study said opportunities for growth vary sig. nificantly by region, State, and market sector. For example, natural gas demand is forecast to grow in the Southeast, the Northeast, and the Far West. But the heavily industrialized Midwest part of the country shows marginally low opportunities for growth, except in the area of cofiring with coal.

Under a moderate growth scenario, the report projected gas consumption growth in both absolute and relative terms, although coal is expected to grow somewhat faster than gas in the second decade due to higher gas prices relative to coal. The slower energy growth model, however, projected a constant gas market share due to slower demand increases in the industrial sector (resulting from assumptions of more aggressive conservation measures). In both cases, the study concluded that increased use of natural gas, even with higher prices, will help to reverse the growth of residual and distillate fuels, much of which are imported.

With respect to market growth, the report viewed industrial use as one of the largest potential market areas. Gas industry success in meeting this demand will depend on "combining aggressive marketing that identifies and satisfies customer needs with a commitment to champion and develop end-user technology," the NPC stated. "Use of highefficiency gas-processing equipment and energyefficient cogeneration applications are an essential approach that the gas industry needs to adopt to maintain its position in the industrial market."

ine study concluded that an even greater opportunity for growth in gas demand lies in the electric generation sector. However, "major obstacles" must be overcome to convert this growth potential to increased gas consumption. These obstacles include competition from other energy sources, a lack of understanding of factors that affect electric generators' fuel choices, uncertainty among potential customers whether the delivered price of natural gas will remain competitive with other energy sources and with demand-side measures, and reliability. Also, NPC noted that a key assumption of any projection of gas demand in the electric generation market is the annual electricity demand growth rate. Gas consumption for electric generation could be lower or higher depend- 
ing on demand-side activities and the economic growth rates.

Finally, the study projected vehicular natural gas demand reaching a level of 140 billion cubic feet per year by 2010 . A more optimistic projection and gas supply sensitive model indicated consumption rising to 640 billion cubic feet by 2010 . Even at this higher level, NPC concluded, "the natural gas industry could supply additional volumes of gas to the natural gas vehicle market without adversely affecting other markets."

- "Increased reliance on competitive market forces has improved the gas industry's ability to serve customer needs in a diverse and expanding marketplace."

Since FERC Order 436 in 1985, the NPC concluded that increased competition has lowered delivered gas prices, increased supply availability, and provided new service options for consumers. The nearly completed unbundling of pipeline sales and transportation services in Order 6.36 should foster competition for natural gas transportation and storage. In addition, creation of a secondary market for pipeline capacity in Order 636 "should further improve efficiencies by allowing capacity to be assigned to those who value it most, whether on a short-term or long-term basis. Such activity would also serve another important function that has traditionally been lacking in the industry: clear market signals regarding the need for new capacity."

Noting claims that Federal and State regulatory uncertainty is a major impediment to industry growth, the study asserted: "With parties willing to match their risk tolerance with costs and obligations, Federal and State regulatory policy initiatives must continue to support the move toward contract-defined relationships. Similarly, gas providers and consumers must be allowed to be accountable for their contractual decisions in the marketplace, not in regulatory proceedings. Contract diversity, a regulatory climate that honors contract sanctity, and active financial markets that can be used to manage risk can work together to assure that each market participant attains the desired degree of reliability and security," the study said.

- "The gas industry faces significant challenges requiring proactive steps by industry and government."

"Industry must grapple with reliability, customer orientation and marketing, and behavioral issues," the NPC said. The gov rnment, for its part, must foster choices that serve the public interest, to promote system efficiencies and to reduce regulatory uncertainty. In addition, both industry and government have a joint obligation to promote development and commercialization of technology, to lift access restrictions, and to pursue opportunities to increase natural gas use in order to help solve the Nation's air quality problems.

"The gas industry's challenge for technology development and commercialization," the study observed, "involves continued funding by the producing segment of the industry, increased incentives for investing in technology by the regulated segments, and justification for investment in commercialization of end-use technologies." "Also, the low level of Federal Government spending on gas-related technologies, relative to other energy sources, suggests a need to reexamine the potential benefits of investments in this segment, particularly in light of the evidence that natural gas is an abundant natural resource with superior environmental qualities."

The NPC study has been well received by all segments of the natural gas industry and other interested organizations. There appears to be a broadbased view that this study's contents, proposals, and projections will play an important role in the natural gas industry's continuing process of change. Time will tell whether the study proves to be the intended industrygovernment road map for gas market growth over the next 20 years. 
Table 1. Summary Statistics for Natural Gas in the United States, 1988-1992

\begin{tabular}{|c|c|c|c|c|c|}
\hline & 1988 & 1989 & 1990 & 1991 & 1992 \\
\hline & \multicolumn{5}{|c|}{ Reserves (billion cubic teet) } \\
\hline \multirow[t]{2}{*}{$\begin{array}{l}\text { Estimated Proved Reserves (dry) } \\
\text { as of December } 31\end{array}$} & 168,024 & 167.116 & 169,346 & 167,062 & 165,015 \\
\hline & \multicolumn{5}{|c|}{ Number of Gas and Gas Condensate Wells } \\
\hline \multirow[t]{2}{*}{ Producing at End of Year.. } & 257,279 & 262,483 & 269,790 & 276,987 & 276,014 \\
\hline & \multicolumn{5}{|c|}{ Production (million cubic feet) } \\
\hline $\begin{array}{l}\text { Gross Withdrawals } \\
\text { From Gas Wells } \\
\text { From Oil Wells }\end{array}$ & $\begin{array}{r}15,467,023 \\
5,532,229\end{array}$ & $\begin{array}{r}15,708,861 \\
5,365,564\end{array}$ & $\begin{array}{r}16,053,566 \\
5,469,055\end{array}$ & $\begin{array}{r}\text { R } 16,017,626 \\
\text { ค } 5,732,482\end{array}$ & $\begin{array}{r}16,164,874 \\
5,967,376\end{array}$ \\
\hline 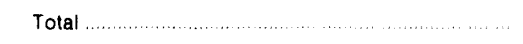 & 20.999 .255 & $21,074,425$ & $21,522,622$ & F $21,750,108$ & $22,132,249$ \\
\hline Repressuring . & $-2,478,382$ & $-2.475,179$ & $-2,489,040$ & P $-2,771,928$ & $-2,972,552$ \\
\hline Nonhydrocarbon Gases Pemoved & -459.883 & $-362,457$ & $-289,374$ & \& $-275,831$ & $-280,370$ \\
\hline Wet After Lease Separation ................ & $18.060,990$ & $18,236,789$ & $18,744,207$ & ค $18,702,348$ & 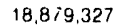 \\
\hline Vented and Flared & -142.525 & $-141,642$ & $-150,415$ & A -169.909 & -167.519 \\
\hline Marketed Production.. & $17,918,465$ & $18,095.147$ & $18,593,792$ & A $18,532.439$ & $18,711,808$ \\
\hline 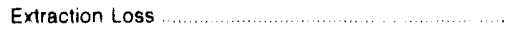 & $-815,844$ & $-784,502$ & -784.118 & $-834,637$ & $-871,905$ \\
\hline \multirow[t]{2}{*}{ 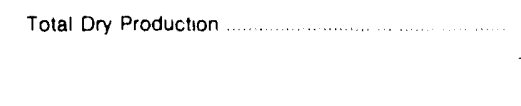 } & $17,102,621$ & $17,310,645$ & $17,809,674$ & ค $17,697,802$ & $17,839,903$ \\
\hline & \multicolumn{5}{|c|}{ Supply (million cubic feet) } \\
\hline Dry Production ........................ & $17,102.621$ & $17,310,645$ & $17,809,674$ & ค $17,697,802$ & $17,839,903$ \\
\hline Receipts at U.S. Borders & & & & & \\
\hline Imports & $1,293.812$ & $1,381,520$ & $1,532,259$ & $1,773,313$ & $2,137,504$ \\
\hline Intransit Receipts & 352.766 & 346,813 & 356.401 & 362.861 & 486,163 \\
\hline Withdrawals from Storage & & & & & \\
\hline Underground Storage.... & 2.243 .621 & $2,803.787$ & $1,933.786$ & $2,688,728$ & 2.723 .774 \\
\hline LNG Storage ............. & 26,390 & 50.274 & 52,544 & 63,090 & 48.534 \\
\hline Supplemental Gas Supplies & $101,: 34$ & 106.745 & 122.806 & A 112,606 & 117,919 \\
\hline Balancing Item ................... & $-452,492$ & -217.526 & -151.863 & A $-499,779$ & $-507,565$ \\
\hline \multirow[t]{2}{*}{ Total Supply } & $20,667,852$ & $21.782,258$ & $21,655,607$ & ค $22,198,621$ & $22,846,233$ \\
\hline & \multicolumn{5}{|c|}{ Disposition (million cubic feet) } \\
\hline Consumption & $18.029,588$ & $18,800,826$ & $18,715,090$ & A $19,035.156$ & $19,544,364$ \\
\hline Deliveries at U.S. Borders & & & & & \\
\hline Exports & 73.638 & 106,871 & 85,565 & 129.244 & 216.282 \\
\hline Intransit Deliveries & 353.350 & 346,811 & 355.688 & 362.588 & 486.161 \\
\hline Additions to Storage & & & & & \\
\hline Underground Storage ...... & 2.174 .328 & $2,491,283$ & $2,433,450$ & 2.608 .373 & $2,555,393$ \\
\hline LNG Storage & 36.949 & 36.467 & 65,814 & 63,259 & $44 \cap 33$ \\
\hline \multirow[t]{2}{*}{ Total Disposition . } & 20.667 .853 & $21.782,258$ & $21.655,607$ & R $22,198,621$ & $22,846,233$ \\
\hline & \multicolumn{5}{|c|}{ Consumption (million cubic feel) } \\
\hline Lease and Plant Fuel & $1,095,883$ & $1,069,902$ & $1.236,392$ & $1,129,268$ & $1,170,821$ \\
\hline Pipeline Fuel ................ & 613.912 & 629,308 & 659.816 & 601,305 & 587.710 \\
\hline Delivered to Consumers & & & & & \\
\hline Residential ....................... & 4.630 .330 & 4.780 .638 & $4,391,324$ & $4,555,659$ & $4,690,065$ \\
\hline Commercial & 2.670 .465 & $2,717.722$ & 2.622 .721 & A $2,728.581$ & $2,802,751$ \\
\hline Industrial & $6,383,382$ & $6,816,244$ & $7,018.414$ & $A 7,230,962$ & $7,526,898$ \\
\hline Venicle Fuel & NA & $\mathrm{P}_{4}$ & 270 & 367 & 511 \\
\hline 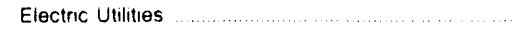 & $2,635,616$ & $2,787,012$ & 2.786 .153 & ค $2,789,014$ & $2.765,608$ \\
\hline Total Delivered to Consumers & 16.319 .793 & $17,101,615$ & 16.818 .882 & A $17,304,582$ & $17,785,833$ \\
\hline \multirow[t]{2}{*}{ Total Consumption } & $18,029,588$ & $18,800,826$ & $18,715.090$ & R $19,035,156$ & $19.544,364$ \\
\hline & \multicolumn{5}{|c|}{ Delivered for the Account of Others (million cubic feet) } \\
\hline Residential & NA & A 3,497 & 31,302 & 36.440 & $41 . \overline{433}$ \\
\hline Commercial $\ldots \ldots \ldots \ldots$ & 247.051 & 295,604 & 352,521 & R 405.919 & 471,009 \\
\hline industrial $\ldots \ldots \ldots \ldots \ldots$ & $3.663,187$ & $4,297,693$ & $4,544,535$ & $4,863,923$ & $5,248,609$ \\
\hline Electric Utilities & 1.076 .253 & $1,152,181$ & $1.390,340$ & $1,580.077$ & $1,697,363$ \\
\hline
\end{tabular}


Table 1. Summary Statistics for Natural Gas in the United States, 1988-1992 (Continued)

\begin{tabular}{|c|c|c|c|c|c|}
\hline & 1988 & 1989 & 1990 & 1991 & 1992 \\
\hline & \multicolumn{5}{|c|}{ Number or Consumers } \\
\hline 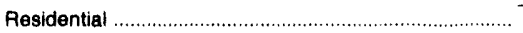 & $48,474,449$ & $49,309,593$ & $50,187,178$ & $51,593,206$ & $52,331,397$ \\
\hline 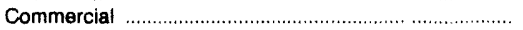 & $4,124,745$ & $4,168,048$ & $4,236,280$ & ค $4,357,252$ & $4,409,699$ \\
\hline 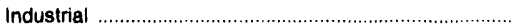 & 199,041 & 225,346 & 218,341 & ค 216,529 & 209,616 \\
\hline \multirow[t]{2}{*}{ Vehicle Fuel } & NA & ค 3 & 1,007 & 1,106 & 1,033 \\
\hline & \multicolumn{5}{|c|}{ Average Annual Consumption per Consurner (thousand cubic feet) } \\
\hline 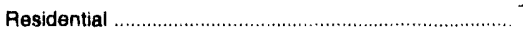 & 96 & 97 & 87 & 88 & 90 \\
\hline 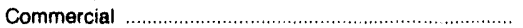 & 647 & 652 & 619 & 626 & 636 \\
\hline 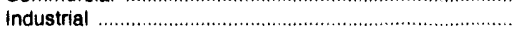 & 32,071 & 30,248 & 32,144 & A 33,395 & 35,908 \\
\hline \multirow[t]{2}{*}{ 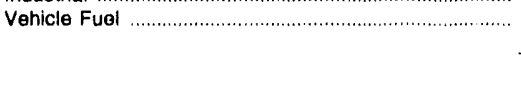 } & NA & P 1 & 268 & 331 & 494 \\
\hline & \multicolumn{5}{|c|}{ Average Annual Cost per Consumer (dollars) } \\
\hline 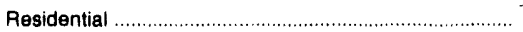 & 523 & 547 & 507 & 514 & 528 \\
\hline Commercial . & 3,001 & 3,092 & 2,989 & 3,013 & 3,103 \\
\hline \multirow{2}{*}{ Vehicle Fuel } & NA & 0 & 910 & 1,314 & 2,002 \\
\hline & \multicolumn{5}{|c|}{ Average Heating Value (Btu per cubic toot) } \\
\hline \multirow[t]{2}{*}{ Delivered to Consumers } & 1.029 & 1,031 & 1,031 & 1,030 & 1,030 \\
\hline & \multicolumn{5}{|c|}{ Average Prices for Natural Gas (dollars per thousand cubic feet) } \\
\hline Wellhead (Marketed Production) & $\$ 1.69$ & $\$ 1.69$ & $\$ 1.71$ & $\$ 1.64$ & $\$ 1.74$ \\
\hline Imports & 1.84 & 1.82 & 1.94 & 1.82 & 1.85 \\
\hline Exports & 2.74 & 2.51 & 3.10 & 2.59 & 2.25 \\
\hline 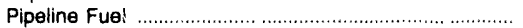 & 2.10 & 2.01 & 1.95 & 1.87 & 2.07 \\
\hline City Gate & 2.92 & 3.01 & 3.03 & 2.90 & 3.01 \\
\hline \multicolumn{6}{|l|}{ Delivered to Consumers } \\
\hline Residential & 5.47 & 5.64 & 5.80 & 5.82 & 5.89 \\
\hline 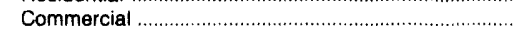 & 4.63 & 4.74 & 4.83 & 4.81 & 4.88 \\
\hline 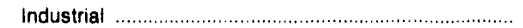 & 2.95 & 2.96 & 2.93 & 2.69 & 2.84 \\
\hline 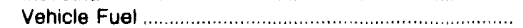 & NA & -. & 3.39 & 3.96 & 4.05 \\
\hline \multirow[t]{2}{*}{ 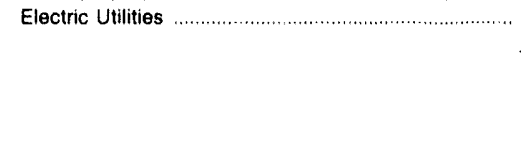 } & 2.33 & 2.43 & 2.38 & 2.18 & 2.36 \\
\hline & \multicolumn{5}{|c|}{$\begin{array}{l}\text { Average Price of Purchases from Producers, Gatherers, } \\
\text { and/or Processing Plant Operators } \\
\text { (dollars per thousand cubic feet) }\end{array}$} \\
\hline by Interstate Pipelines. & $\$ 2.04$ & $\$ 2.02$ & $\$ 2.15$ & $\$ 1.99$ & $\$ 2.15$ \\
\hline by Intrastate Pipelines & 1.88 & 1.88 & 1.92 & 1.69 & 1.79 \\
\hline 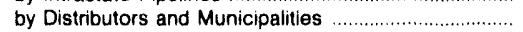 & 2.73 & 2.69 & 2.69 & 2.60 & 2.57 \\
\hline 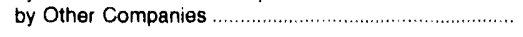 & 1.84 & 1.84 & 1.86 & 1.80 & 1.78 \\
\hline \multirow[t]{2}{*}{ Total } & 2.07 & 2.11 & 2.18 & 2.04 & 2.13 \\
\hline & \multicolumn{5}{|c|}{$\begin{array}{c}\text { Average Price of Purchases from Interstate Pipelines, Intrastate Pipelines } \\
\text { and/or Distributors } \\
\text { (dollars per thousand cubic feet) }\end{array}$} \\
\hline by Interstate Pipelines & $\$ 3.02$ & $\$ 3.07$ & $\$ 2.78$ & $\$ 2.68$ & $\$ 2.58$ \\
\hline 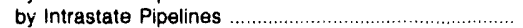 & 2.51 & 2.38 & 2.09 & 1.83 & 1.98 \\
\hline by Distributors and Municipalities & 3.10 & 3.20 & 3.31 & 3.18 & 3.28 \\
\hline 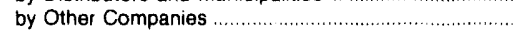 & 2.75 & 2.83 & 297 & 2.77 & 2.85 \\
\hline \multirow[t]{2}{*}{ Total } & 3.01 & 3.13 & 3.14 & 3.01 & 3.10 \\
\hline & \multicolumn{5}{|c|}{ Average Price of Sales for Resale (dollars per thousand cubic feet) } \\
\hline by Interstate Pipelines & $\$ 3.27$ & $\$ 4.02$ & $\$ 3.84$ & $\$ 3.90$ & $\$ 4.09$ \\
\hline by Intrastate Pipelines & 2.45 & 2.80 & 2.86 & 2.62 & 2.71 \\
\hline by Distributors and Municipalities & 3.54 & 3.57 & 3.59 & 3.58 & 3.21 \\
\hline by Other Companies ............................................... & 2.06 & 1.65 & 1.64 & 1.75 & 1.74 \\
\hline Total & 2.72 & 3.05 & 2.83 & 3.00 & 3.07 \\
\hline
\end{tabular}

A $=$ Revised data.

Note: Prices for gas delivered to consumers are calculated using only onsystem sales data No imputations are made for prices of gas delivered for the account of others. In previous years, prices were calculated using reported values and values imputed for gas delivered for the account of others. The United States includes the 50 States and the previous years, prices were calculated using reported values and values imputed for gas delivered for the account of others. The United States includes the 50 States and the

Sources: Energy Information Administration (EIA), Form EIA-176, "Annual Report of Natural and Supplemental Gas Supply and Disposition;" Form EIA-627, "Annual Quantity and Value of Natural Gas Report:" Form ElA-857, "Monthly Report of Natural Gas Purchases and Deliveries to Consumers;" Form ElA-816, "Monthly Natural Gas Liquids Report;" Form EIA-759, "Monthly Power Plant Peport;" Form FERC-423, "Monthly Report of Cost and Quality of Fuels for Electric Plants;" Form FPC-14, "Annual Report for Importers and Exporters of Natural Gas:" U.S. Crude Oil, Natural Gas, and Natural Gas Liquids Reserves, 1992 Annual Report, DOE/EIA-0216(92); and the U.S. Minerals Management Service. 
Figure 2. Natural Gas Supply and Disposition in the United States, 1992

Gross Withdrawals From Gas and Oil Wells 22.1

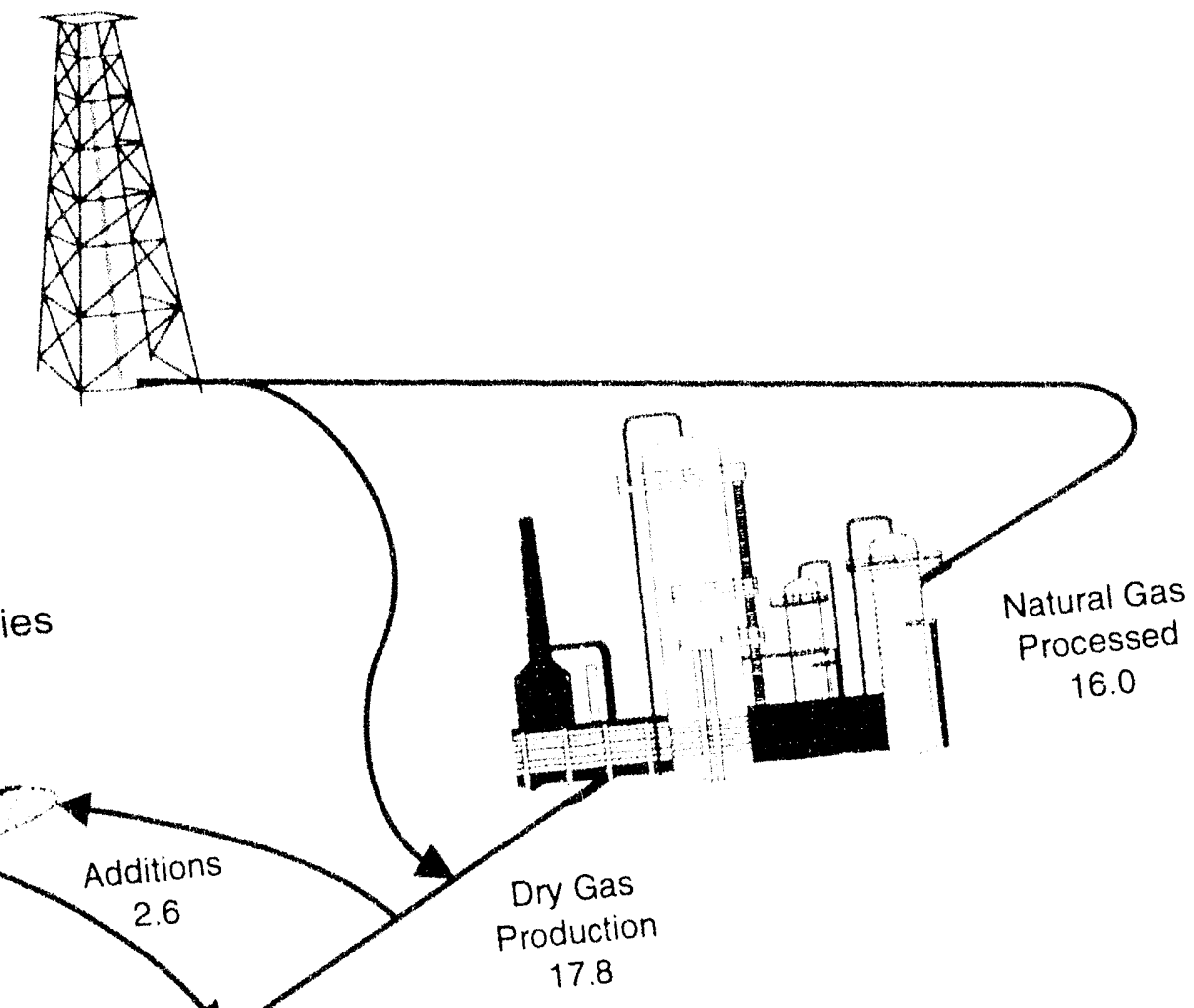

2.8

Natural Gas

Storage Facilities
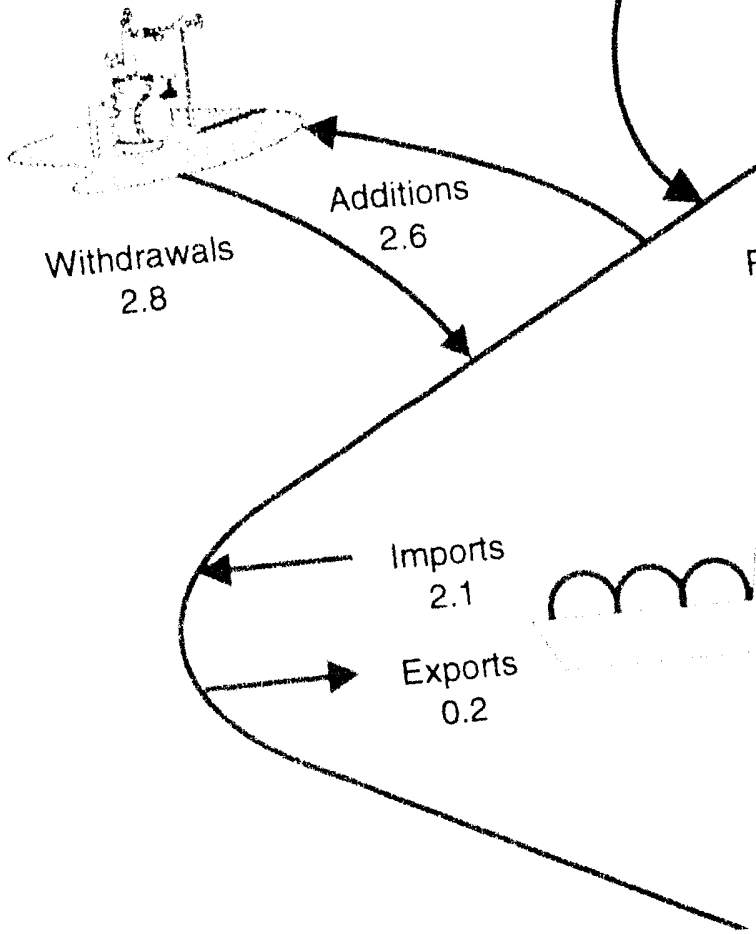

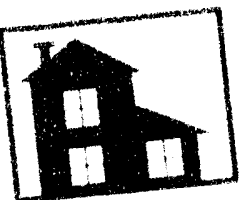

Residential 4.7

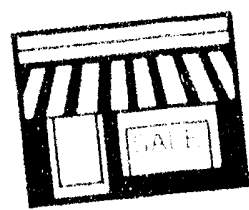

Commercial

2.8

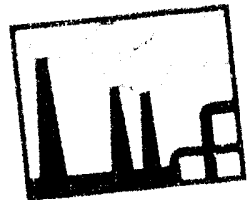

Industrial

7.5

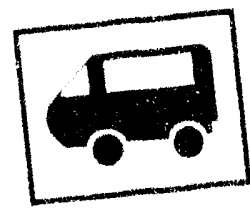

Venicle Fuel 0.0005

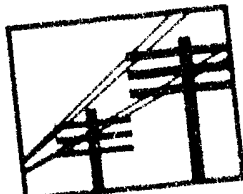

Electric Utility

2.8 
Table 2. Natural Gas Production, Transmission, and Consumption by State, 1992 (Million Cubic Feet)

\begin{tabular}{|c|c|c|c|c|c|c|c|c|}
\hline State & $\begin{array}{l}\text { Marketed } \\
\text { Production }\end{array}$ & Extraction loss & $\begin{array}{l}\text { Balancing } \\
\text { Item" }\end{array}$ & $\begin{array}{c}\text { Nel } \\
\text { Interstate } \\
\text { Movements }\end{array}$ & $\begin{array}{l}\text { Nel Move- } \\
\text { ments Across } \\
\text { U.S. Borders }\end{array}$ & $\begin{array}{l}\text { Net Storage } \\
\text { Cranges }\end{array}$ & $\begin{array}{c}\text { Supplemental } \\
\text { Gas } \\
\text { Supplies }\end{array}$ & Consumption \\
\hline Alabama . & 355,099 & 5,490 & $-30,213$ & $-40,535$ & 0 & 239 & 171 & 278,794 \\
\hline Alaska ..... & 443,597 & 32,004 & 24,060 & 0 & $-52, ?$ & 0 & 0 & 383,121 \\
\hline Arizona ...................... & 771 & 0 & 4,718 & 126,726 & $-2,505$ & 0 & 0 & 129,650 \\
\hline Arkansas. & 202,479 & 413 & $-20,293$ & 42,289 & 0 & -515 & 0 & 224,576 \\
\hline California ........................... & 365,632 & 12,385 & 38,452 & $1,610.708$ & 0 & $-28,158$ & 0 & $2,030,564$ \\
\hline 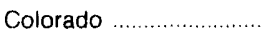 & 323.041 & 18,149 & $-13,191$ & $-50,647$ & 0 & $-4,860$ & 7,158 & 253,073 \\
\hline Connecticut .................... & 0 & 0 & $-7,691$ & 118,601 & 0 & -355 & 40 & 111,303 \\
\hline 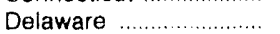 & 0 & 0 & $-1,696$ & 37,634 & 0 & -5 & 3,665 & 39,608 \\
\hline D.C. & 0 & 0 & -465 & 33,422 & 0 & 0 & 0 & 32,957 \\
\hline Florida & 6,657 & 2.563 & 7,573 & 341,325 & 0 & 0 & 0 & 352,992 \\
\hline Georgia & 0 & 0 & 9,847 & 332,967 & 0 & 16 & 166 & 342,965 \\
\hline 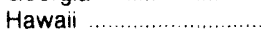 & 0 & 0 & -16 & 0 & 0 & 0 & 2,711 & 2,695 \\
\hline 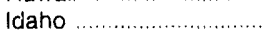 & 0 & 0 & -7.330 & $-440,253$ & 496,451 & -47 & 0 & 48,915 \\
\hline 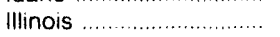 & 347 & 100 & $-44,689$ & $1,021,441$ & 0 & $-8,387$ & 8,042 & 993,428 \\
\hline 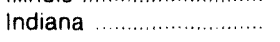 & 174 & 0 & $-1,733$ & 480,369 & 0 & $-1,179$ & 3,507 & 483,496 \\
\hline lowa. & 0 & 0 & $-15,634$ & 242,675 & 0 & $-3,846$ & 45 & 230,932 \\
\hline Kansas & 658,007 & 42,733 & $-32,874$ & $-257,668$ & 0 & $-18,486$ & 0 & 343,217 \\
\hline Kentucky ......................... & 79,690 & 2,342 & $-55,636$ & 174,733 & 0 & 6,573 & 5 & 189,877 \\
\hline Louisianá ......................... & $4,914,300$ & 132,656 & 33,706 & $-3,295,694$ & 12,637 & $-13,511$ & 0 & $1,545,804$ \\
\hline Maine ............................. & 0 & 0 & -26 & 5,161 & 0 & 4 & 0 & 5.131 \\
\hline Maryland & 33 & 0 & $-10,859$ & 192,423 & 0 & 422 & 126 & 181,300 \\
\hline 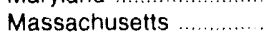 & 0 & 0 & $-10,049$ & 272,622 & 30,479 & $-1,844$ & 105 & 295,001 \\
\hline Michigan ......................... & 194,815 & 8,093 & 58,803 & $1,129,512$ & $-500,801$ & $-2,251$ & 14,694 & 891,181 \\
\hline Minnesota ......................... & 0 & 0 & 35,488 & $-581,763$ & 855,300 & 256 & 52 & 308.821 \\
\hline 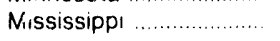 & 91.697 & 416 & 54.787 & 95,107 & 0 & 1,732 & 0 & 239,442 \\
\hline Missouri ............................ & 27 & 0 & $-3,927$ & 244,630 & 0 & -15 & 0 & 240,745 \\
\hline Montana .......................... & 53,867 & 907 & $-15,444$ & $-457,024$ & 452,467 & $-12,602$ & 0 & 45,561 \\
\hline Nebraska ....................... & 1,177 & 3 & $-18,422$ & 123,182 & 0 & 517 & 1,437 & 106,853 \\
\hline 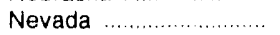 & 30 & 0 & $-10,782$ & 79,067 & 0 & -71 & 30 & 68,416 \\
\hline New Hampshire ........... & 0 & 0 & $-2,219$ & 18,975 & 0 & 0 & 96 & 16,852 \\
\hline New Jersey ...................... & 0 & 0 & 51,223 & 480,627 & 0 & -49 & 14,362 & 546.260 \\
\hline New Mexico ................... & $1,268,863$ & 75,520 & $-83,792$ & -911.733 & 0 & $-5,057$ & 0 & 202,875 \\
\hline New York & 23,508 & 0 & -60.556 & 561,333 & 435,470 & 1,942 & 1,190 & 959,004 \\
\hline North Carolina ............... & 0 & 0 & $-11,985$ & 191,486 & 0 & -92 & 2 & 179.595 \\
\hline North Dakota & 54,883 & 6,055 & $-7,998$ & $-62,738$ & 0 & 0 & 58,496 & 36,588 \\
\hline Ohio. & 144,815 & 72 & 4,785 & 643,869 & 0 & $-15,672$ & 1,051 & 810,121 \\
\hline 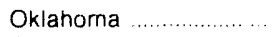 & $2,017,356$ & 104,609 & $-112,462$ & $-1,266,516$ & 0 & $-10,058$ & 0 & 543,827 \\
\hline 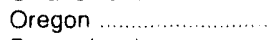 & 2,580 & 0 & 27,923 & 90,940 & 0 & -904 & 2 & 122,350 \\
\hline Pennsylvania ................... & 138,675 & 604 & -28.977 & 579,240 & 0 & 5.945 & 132 & 682,521 \\
\hline Rhode Island .................. & 0 & 0 & 3,935 & $73,32 ?$ & 0 & -420 & 155 & 77,833 \\
\hline South Carolina ................. & 0 & 0 & 9,179 & 128,868 & 0 & 16 & 26 & 138,057 \\
\hline South Dakota ................ & 1,456 & 0 & $-1,036$ & 26,225 & 0 & 11 & 10 & 26,645 \\
\hline Tennessee ....................... & 1,770 & 0 & 70,754 & 168,860 & 0 & -306 & 12 & 241.702 \\
\hline 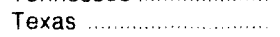 & $6,145,862$ & 374,126 & $-64,200$ & $-2,181,297$ & -93.408 & $-43,441$ & 1 & $3,476,274$ \\
\hline 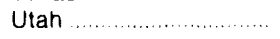 & 171,293 & 11,851 & $-92,653$ & 60,343 & 0 & 4,482 & 0 & 122,649 \\
\hline Vermont & 0 & 0 & 3 & $-9,653$ & 17,248 & 0 & 3 & 7,601 \\
\hline Virgınıa ........ & 24,733 & 0 & $-14,334$ & 189,401 & 0 & 6 & $2: 5$ & 200,039 \\
\hline Washington ... & 0 & 0 & $-55,862$ & $-51,772$ & 270.477 & $-6,137$ & 180 & 169,161 \\
\hline West Virginia ................... & 182,000 & 9,436 & 25,017 & $-76,901$ & 0 & -8.180 & 0 & 128,861 \\
\hline 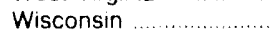 & 0 & 0 & $-20,151$ & 351,672 & 0 & -59 & 1 & 331.581 \\
\hline 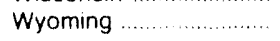 & 842,576 & 31,378 & $-110,627$ & $-585,561$ & 0 & $-8,536$ & 0 & 123,547 \\
\hline ................. & $18,711,808$ & 871,905 & $-507,565$ & 0 & $1,921,225$ & -172.882 & 117,919 & $19,544,364$ \\
\hline
\end{tabular}

a Balancing Item volumes are equal to Total Disposition (net storage changes plus extraction loss plus consumption) minus Total Supply (marketed production plus net interstate movements plus net movements across U.S. borders plus supplemental gas supplies).

b Positive numbers denote net receipts; negative numbers denote net deliveries.

$c$ Negative numbers indicate withdrawals from storage in excess of additions to storage and are, therefore, additions to total supply

Note: Totals may not equal sum of components due to independent rounding.

Sources: Energy Information Administration (EIA). Form EIA-176. "Annual Report of Natural and Supplemental Gas Supply and Disposition," Form ElA. 627. "Annual Quantity and Value of Natural Gas Report," "Form ElA-816, "Monthly Natural Gas Liquids Report," ; Form EIA-759, "Monthly Power Plant Feport,": and the U.S. Minerals Management Service 


\section{Supply}

\section{Production}

In 1992, marketed production of natural gas continued its recent flat trend. It fell $11 .$. percent from 1990 to 1991 and rose by 1 percent from 1991 to 1992, to 18.7 trillion cubic feet. Currently production levels depend chiefly on two factors: demand (which includes domestic consumption, storage, and exports) and price. While demand has been strong, largely due to low prices, those same low prices have caused the Nation's excess productive capacity, often termed the "gas hubble," to slowly diminish. In is present environment of flat production levels, excess demand is being mel by natural gas imports which reached record levels in 1992.
Gross withdrawals reached 22.1 trillion cubic feet in 1992 (Table 3). Production of coalhed methane more than doubled. The number represented about 3 percent of total U.S. dry production. The number of producing gas wells and gas-condensate wells reached 276,014, only slightly less than the all-time high of 276,987 wells reached in 1991 (Table 5). The number of rotary rigs active continued its downward trend, to 721 in 1992 , a record low.

Two technical reviews produced during the past year deal with important, newly emergent upstream technologies. The first review, "Three Dimensional Seismology -- A New Perspective," appeared as a feature article in the December 1992 issues of the Natural Gas Monthly and the Petroleum Supply Monthly.

Figure 3. Marketed Production of Natural Gas in the United States, 1992 (Million Cubic Feet)

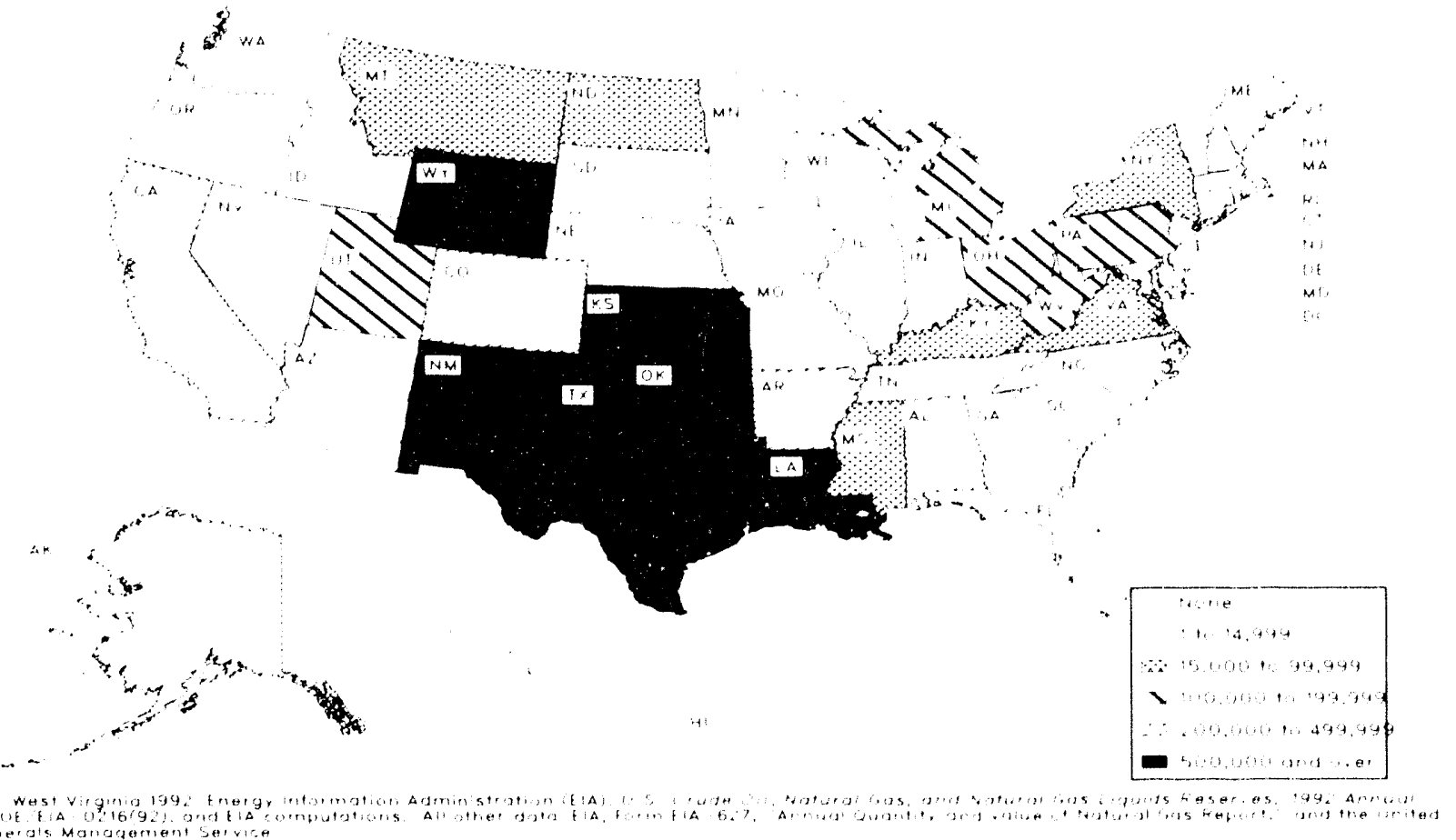


The second review, Drilling Sideways -- A Review of Horizontal Well Technology and Its Domestic Application (DOE/EIA-TR-0565) was published in April 1993, with a condensed version appearing as a feature article in the June 1993 Petroleum Supply Monthly. Thoroughly documented, both of the technology reviews consider the theory underlying the pertinent technology, its history, its current application, and the costs and benefits of its use.

Another technical report, Largest U.S. Oil and Gas Ficlds (DOE/E1A-TR-0567) published in August 1993, provides "top 100" field listings relative to proved reserves (year-end 1991 rankings), as well as the "Iop $100 "$ in three other categories: 1991 annual production, cumulative production through 1991, and year-end 1991 estimated ultimate recovery. Also presented are similar listings based on the fields' total hydrocarbons, and comparisons of the cont ribution of crude oil versus natural gas, and large fields versus small fields.

\section{Wellhead Prices}

The national average wellhead price for natural gas rebounded in 1992 to $\$ 1.74$ per thousand cubic feet, up by o percent from 1991. This is the highest level for wellhead prices since 1986. A recovering economy and the decline of excess productive capacity contributed to the increase. Also, when Hurricane Andrew shut down some gas-producing operations in the Gulf of Mexico in August 1992, prices rose in anticipation of supply interruptions.

\section{Drilling}

Exploration and development activities incrementally add to existing reserves of natural gas. Indicators that have in the past been good guides to exploration and development activity, and thus to reservers additions. are the numbers of active seismic crews, rotary rigs running, and well completions. In 1992, as in 1991, all three of these indicators declined.

The 1992 average number of active seismic crews, 76 , was the lowest since 1935 and represents a continuation of the 11-year precipitous fall from the historical peak of 681 in 1981. The seismic crew count is continuing to drop slightly in the first 5 months of 1993 to an average of 75 . As was the case in 1991, many major U.S.-based companies are moving their exploration efforts to foreign countries, looking for larger potential discoveries and more favorable government policies. Their exodus from the U.S., of course, causes the seismic and drilling contractors to follow suit, which explains some of the drop in the domestic seismic crew count. The rest is due to a general decrease in domestic exploration. A look at the international sessmic crew count also shows a continuing decline since 1988 to the lowest level seen in more than 20 years. Industry estimates are that about 80 percent of international seismic crews are U.S. based.

After a 1990 increase due to briefly increased oil prices in the months following the Iraqi invasion of Kuwait in August 1990, the number of rotary rigs active in the United States continued its downward trend to 721 in 1992. a record low. The 5 -month average for 1993 is also down, 10 671. Similarly, well completions declined in 1992 to 22,650), the lowest level in more than 20 years, following a brief increase in 1990 and a decline in 1991. The 1990) well completion increase was largely the result of a surge in drilling for coalbed methane that occurred prior to expiration of the December 31 , 1990 (since extended until December 31, 1992) deadline to qualify for the Section 29 tax credit for new unconventional gas. In $199_{\alpha}$, coalbed methane drilling activity continued to slow down from the rates achieved during the 1990 boom.

\section{Coalbed Methane Production}

U.S. coalbed methane production has increased dramatically from 26 billion cubic feet in 1987 to 535 billion cubic feet in 1992. It increased over 50 percent from 1991 levels alone, to comprise about 3 percent of total U.S. dry gas production. So, despite lower levels of new drilling for coalbed methane in 1992, production levels increased at an even greater rate than in 1991. This is because operators are drilling many production wells as opposed to a few, more risky wildeat wells. Also, the wells that have been producing for a year or two have "dewatered" enough that their gas production has actually increased with time. A reverse decline curve phenomenon due to dewatering is common in coalbed methane wells. Drilling has slowed down probably because many of the "sweet spots," or the most obvious and easily developed prospects, have already been drilled, and the operators did not want to explore less well-known or less productive areas given the low 1992 gas price.

\section{Tight Gas Production}

Another nonconventional gas resource that has been increasingly developed in recent years is gas obtained from very low permeability, or "tight," reservoirs. It has recently been estimated by the National Petroleum Council (NPC) that U.S. recoverable nonconventional gas resources, including tight gas, Devonian/Antrim shales, and coalbed methane, amount to 1.065 trillion cubic feet, allowing for the use of only currently available technology. Tight gas accounts for 232 trillion cubic feet of that total: the Rocky Mountain basins contain 53 percent of that volume, 12 percent is in the Arkla/East Texas basins, 9 percent is in the Midcontinent area, 8 percent is in each of the Texas Culf Coast and Permian basins, 6 percent is in the Appalachian Basin. and 4 percent lies in other basins. Assuming the application of advanced technology, tight gas 
resources would amount to 349 trillion cubic feet, or 117 trillion cubic feet more, and total nonconventional gas resources would amount to 1,295 trillion cubic feet. The NPC predicts that tight gas will account for onehalf of the domestic gas supply by the year 2030 .

Most gas production in the United States, about 90) percent, is from conventional reservoirs. However, since 1980, operators could take either the Section 29 tax credit (worth about 52 cents per million Btu) or a higher incentive price (available per the Natural Gas Policy Act of 1978) for tight gas, depending on the price of oil. The rationale for having these incentives was that initial production rates from these kinds of reservoirs are very low and, therefore, some kind of economic incentive must be present to induce operators to explore for and develop these resources.

For the purposes of developing its production statistics, the Energy Information Administration defines tight reservoirs as those that meet the Federal Energy Regulatory Commission's (FERC) definition of tight. They are generally characterized by an average reservoir rock permeability to gas of 0.1 millidarcies or less and, absent artificial stimulation, by production rates that are not in excess of 5 barrels of oil per day and certain specified daily volumes of gas which increase with depth. The EIA tight gas production statistics exclude production from "geologically tight" reservoirs that have not been classified tight according to the FERC rules, and cover only production from wells drilled in tight reservoirs that were classified, from 1978 through 1992, as tight according to the FERC. Based on this definition, U.S. tight gas production increased from 68 billion cubic feet in 1979 to 1,251 billion cubic feet in 1991 , accounting for almost 7 percent of U.S. marketed natural gas production in the latter year. All of EIA's tight gas production volumes are eligible for the Section 29 tax credit. Although the qualification period for the credit expired at the end of 1992, wells that were drilled between 1978 and May 1988, and from November 5, 1990 to year end 1992 are eligible for the credit for a period of 10 years. It remains to be seen what effect if any the expiration of the Section 29 tax credit will have on 1993 production levels.

\section{Prorationing}

In the spring and summer of 1992, Oklahoma and Texas revised their prorationing rules and Louisiana considered revising its rule. Critics of this action charged that the rule changes were an attempt $t$ o limit production in order to raise the extremely low gas prices at the time. Proponents felt that the changes were needed because the old rules were outdated and no longer matched the changed realities of the industry. In addition, proponents felt revised rules were needed to bring stability to a vastly oversupplied market in order to protect the future viability of domestic production and exploration capabilities. This debate led to the MarkeyScheuer Amendment to the House comprehensive en- ergy bill, which greatly restricted States' rights to establish prorationing rules. This amendment and the entire natural gas title were dropped from the Energy Policy Act of 1992 which was passed in October 1992.

The concept of prorationing has existed at least since the Natural Gas Act of 1938 exempted the gathering and production of natural gas from federal regulation, leaving it up to the individual States. Prorationing rules are designed to prevent waste of gas resources and to protect the correlative rights of landowners under whose properties the gas resources lie. Correlative rights refer to the rights that lessors of adjoining properties have to receive the benefits of the oil and gas reserves beneath their respective properties. Correlative rights are protected by preventing improper drainage or siphoning off of reserves from beneath one prop. erty by wells on one or more adjoining properties. For many years, nearly every producing State has had laws that provide for various production control mechanisms, administered by State regulatory agencies, to prevent the waste of gas resources and to protect correlative rights

Oklahoma and Kansas both increased their production levels to help meet the increased demand resulting from Hurricane Andrew. In 1993, Oklahoma has increased their allowable production from 35 percent of the wells' wellhead absolute open flow to 45 percent in the third and fourth quarters. Texas has set allowables in March, May, June, July, and August that were higher than the actual production in those months in 1992. These limits were raised to meet the heavy demand 10 fill storage and to allow producers to take advantage of the higher wellhead gas prices. Louisiana is hoping to have their new prorationing regulations in place by the end of 1993.

\section{Reserves}

Proved reserves of dry natural gas declined just over 1 percent or 2,047 billion cubic feet in 1992. All four leading gas producing areas, Texas, the Gulf of Mexico Federal Offshore. Oklahoma, and Louisiana, had large proved reserves declines totaling 4,649 billion cubic feet. Partially offsetting these declines, four States had large increases in their coalbed methane reserves: Virginia, New Mexico, Colorado, and Alahama. Reserves in these States increased by 1.957 billion cubic feet from 1991. The scheduled end in December of tax credits for new unconventional gas wells spurred drillins for coalbed methane and tight gas to high levels in the last half of 1992. Therefore, total gas well complelions dropped only 16 percent to 7,640. However, exploratory gas well completions reached a new 20-year low after dropping 27 percent during 1992.

Reserves in coalbed methane fields increased to 10,034 billion cubic feet, a 23-percent increase in 1992, to ac- 
count for h percent of total U.S. gas reserves. Coalhed methane production increased almost sixfold in just 3 years $t o$ account for 3 percent of $U$.S. gas production. Exploitation of the coalbed methane resouree has rapidly expanded because of a large tax credit incentive and improved understanding of the underlying production technology. The tax credit in 1992 was about $\$(0.90$ per thousand cubic feet of coalbed methane produced, about half the average U.S. wellhead price.

Of the several components of change in proved reserves, tote discoveries are those reserves attributable to field extensions, new fields, and new reservoirs in old fields. They result from drilling exploratory wells. U.S. total discoveries of dry gas reserves in 1992 were 7,948 billion cubic leet, a decline from the 1991 level and 34 percent lower than the average during the prior 10 years. Over half of them were in Iexas and the Ciulf of Mexico Federal offshore. New field discoveries of 649 billion cubic feet were down substantially from the 1991 level and 59 percent lower than the prior 10-year average of 1.592 billion cubic fect. Extensions (4,675 hillion cubic feet) were also lower, dropping 31 percent below the prior 10-year average. Gats reserve additions from new reservoirs increased some what to 1,724 billion cubic feet, but were much fower than the prior lo-vear average.

The net of revisions and adjustments for natural gas in 1992 wats 8,328 billion cubic feet. In recent years, the net of revisions and adjustments has played a growing role in sustaining lower 48 States natural gas proved reserves. In 1992, 7.883 billion cubic feet of these were added. 74 percent more than the lower 48 States average for the prior lo years.

This increasing recovery of gas from the resource base of old fields is entanced hy the application of new technologies like 3-D seismology, horizontal drilling. and hetter fracturing treatments and well completions. Total discoveries for the lower 48 States were only 6.904 billion cubic feet in 1992. This was the second time since 1977 that lower 48 States total diseoveries were lower than the net of revisions and adjustments. There were proved reserves of 34.118 hillion cubic feet of natural gas, wet after lease separation, located in monproducing reservours. They are included in the total proved reserves figures and represent 2 ) percemt of the total.

\section{Spot and Futures Markets}

During the first several months of 1992, malural gas spot market prices were low due to mild weather contditions, lack of demand, and high gas storage levels. Prices increased slightly in April and May due to reported producer shut-ins, cold weather in the Northeast, and concerns about the impact of prorationing proposals. Producers had shut in more gas and had reduced drilling, leading to less newly discovered conventional gas coming on line. Prices remained steady for the next several months due to the low storage levels for that time of the year.

The overall natural gas spot price increased substantially since June, as compared with the corresponding month a year carlier, until August when Hurricane Andrew hit. By the end of August, the natural gas spot prices were quite high but wot as high as September's futures prices. After the Hurricane struck, natural gas fulures prices fluctualed dramatically, due fo uncertainty about the extent of damage from the storm and consequent decrease in production. There was concern that there might be a shortage in the coming winter. Hurricanc Andrew only disrupted a small amount of the Nation's production and other supplies were diverted from being injected into storage to fulfill contracts. A perecived shorlage of gas in storage available for the winter heating season, rather than high demand, pushed october and November prices up. Foward the end of 1992, the spot market increased slightly, hut not significantly, as compared with the same lime in 1991. The increase was primarily due to the onset of the winter heating season domand.

During the first few months of 1993, spen market prices were lower, however not as low as durmg the corresponding period in 1992. Rolatively mild weather for January and February 199.3 contributed to lower demand. However, the cooler March and April weather in the West. Midwest, and Northeast caused heavy storage withdrawak, higher demand, and slightly higher prices. Prices remanted steady hecause several clectric utilities switched from nuclear power to natural gats $t 0$ perform seasonal maintenance and minor repairs. lower storage levels for April and May 1993, increased demand for storage injections, which in turn, forced buyers to purchase natural gas at slightly higher prices. Spot prices in July 1993 were less than $\$ 2.00$ per thousand cubic feret. similar to those of the previous year. These prees increased in September fo reflect the conlinued high rate of storage injections, which have avcraged over 400 billion cubic feet per month since May 1943

The matural gas futures market is a specialized market in eomtrats for future delevery of gas under specified conditions. These contracts, traded on the New York Mercantile Exchange (NYMLX) smee April 1990, are primarily financial instruments. They enable firms which produce gats or have a need for gas to manage price risk. Unlike the spot matket, transatetions on the futures markel do not represent the actual purchase or sale of gas but rather the promise of a purchase or sale. Approximalely 3104 percent of all contracts eventually result in the actual delivery of gas. Another financlat instrument, matural gas options, has been traded on the NYMl:X since (october 1992. While futures contracts represent promises to buy or sell nalural gas, which the traders are obligated to carry out should the contract not he liquidated. options offer the right to 


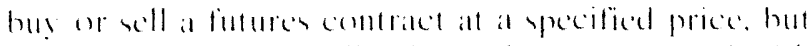
whihout the specific ohligation to bus. Compared with trating volume in futtres contlatets, the natlural geas (1)ptems market is moch smaller.

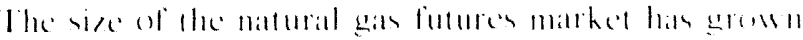

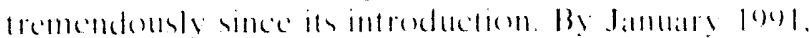

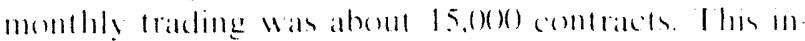

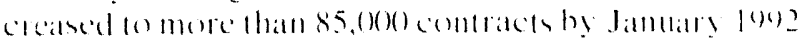

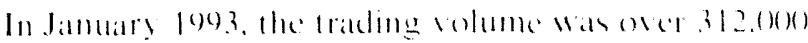

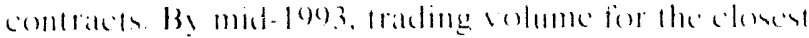

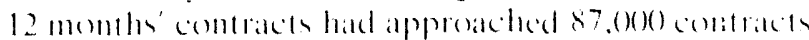
in a single wa'k

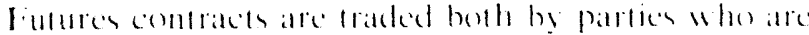
in the natural gas hustmes, using the comtrited at a

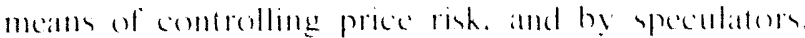

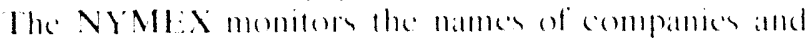
individuals bolding at least 25 open-interest comldacts. which are simply comblate oulstanding al the cold of a daly s trating. Natural gar matheting companter gent crally aceoume for about half of the open mteres ba calle of the nature of their husiness, they alle hoth om the husing and selling side. Produces and ollewe an

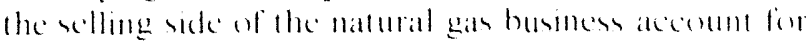

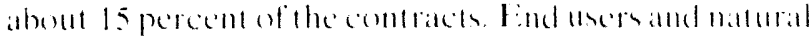
gats processems. whe are (1) the husing side of the nal

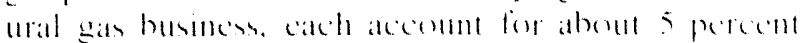

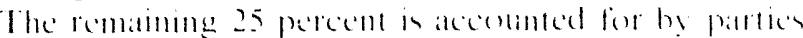

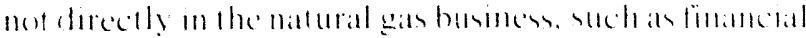
mintlitions or speculators

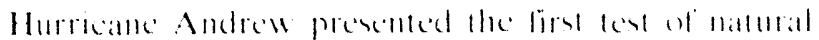

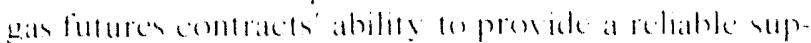

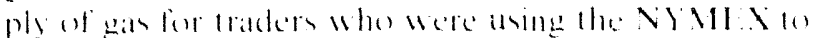

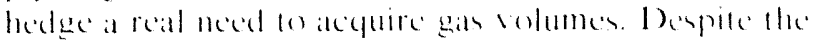

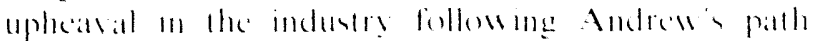

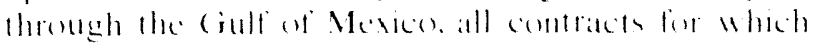

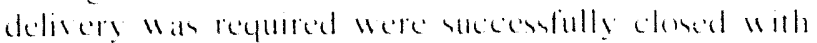
the tramser of gas. Hasme pased that tert. Hadme

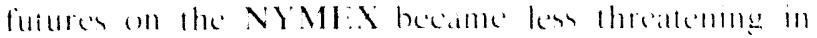

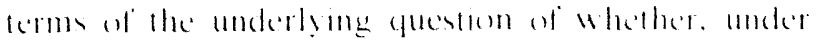

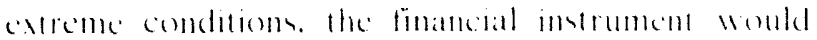

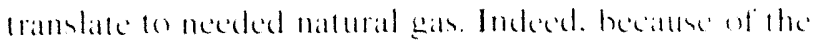
power of the tixhange on fores delivery under the

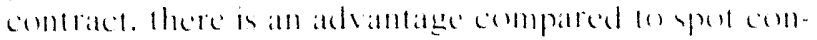
tracts. where there is a distressing propensit! of parties to simply walk alwaly from deals.

Trading on the NYMEX has dereloped inter atehele fo: price discovery providing an indes price for lirms which are not imsolved in the fotures mathes. Soltement prices are published in mest ypapers and the indus-

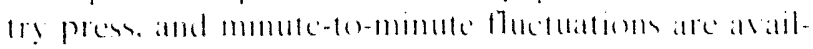

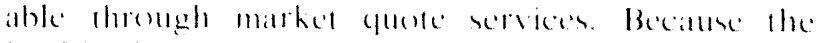

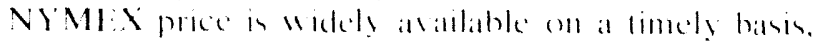

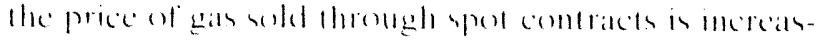

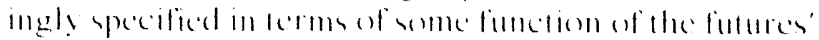
picis:

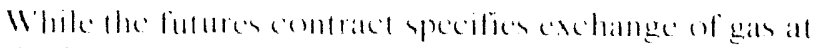

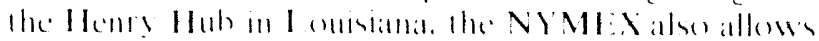

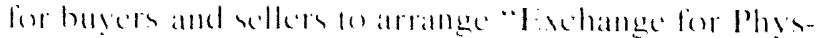

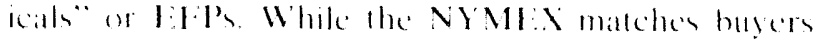
and sellere for exchange al the Hemry Hab, under

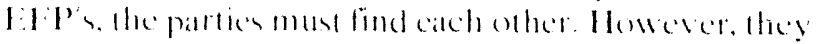

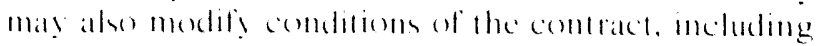
delisery pome and the price of the gats the latler is important since there are signticiant differences in the price of gas frem ome pan of the eountry to another.

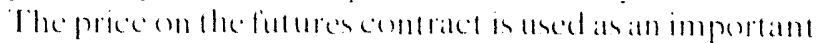

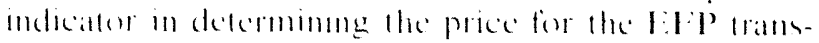
action and then a discount or premiom is applied 10 compensate for regenal price differences. Thus the

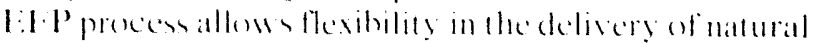

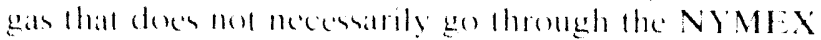
delisers point at the Hems Huh, while still using the futures prose of determme the cost of the gas and re-

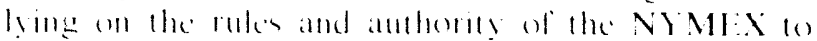
assure delisers

\section{Outlook for Supply}

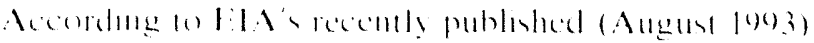

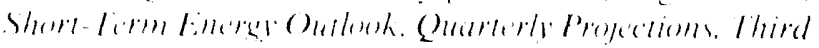

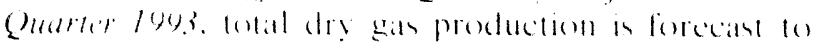

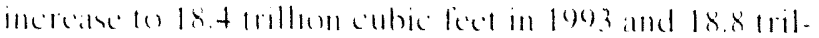

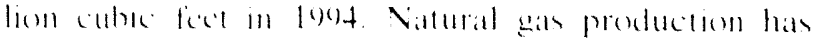

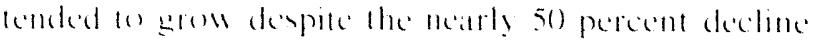

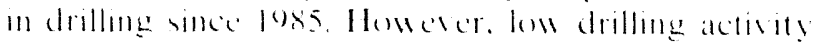
in the late of rising demand has hatromed the gap beaween production and productare capacios, particas.

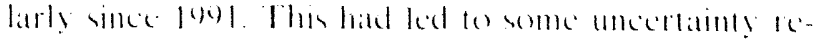

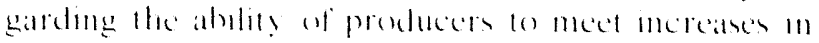
peateperiod demand whhoul increasing reliance on worhmge gas storage and Canadran imports.

Reliance on matural gits imports will continue w rise 10 2.09 trillion cubic lect in 199.3 and 102.35 trillion

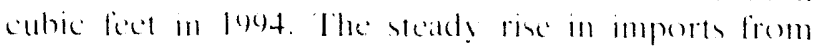
Camada has been made pomible by the rapid grometh in gas pipelime capacity. Import pipeline capacity has

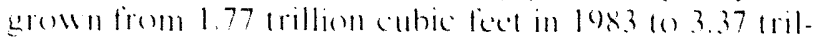
lion cubic feet in 1093. In 1904. capacity in expected

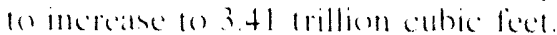


Figure 4. Marketed Production of Natural Gas in Selected States, 1988-1992

Loulsiana

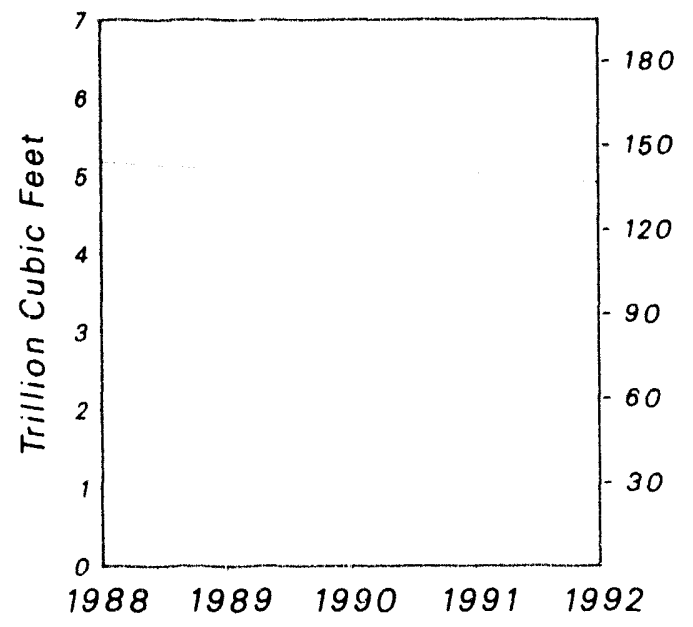

Texas

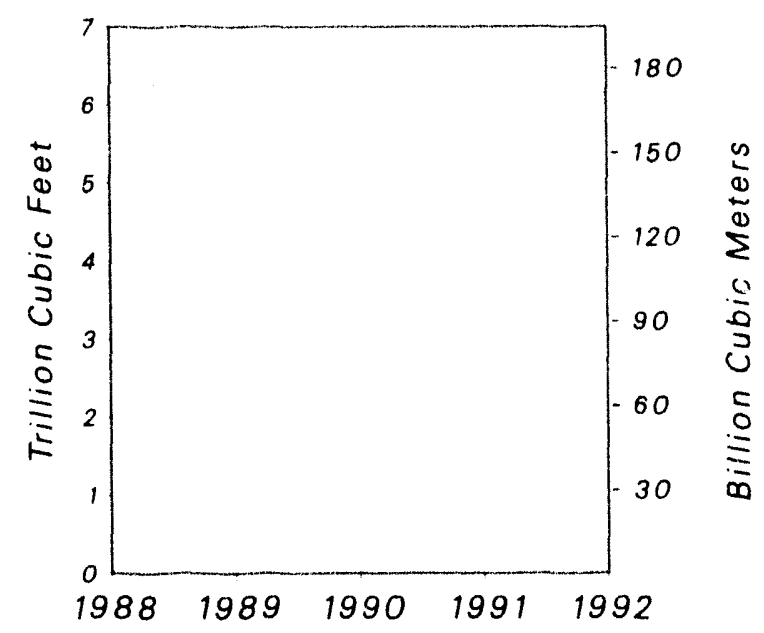

Oklahoma

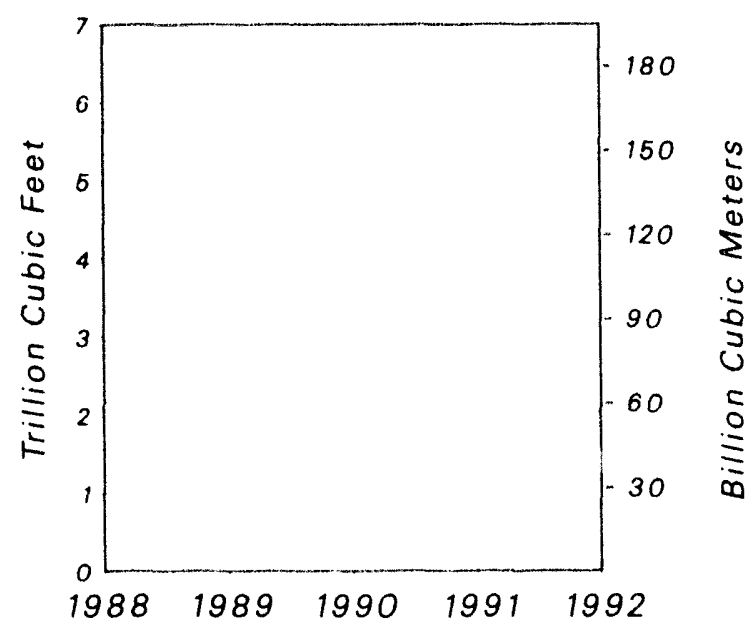

All Other States

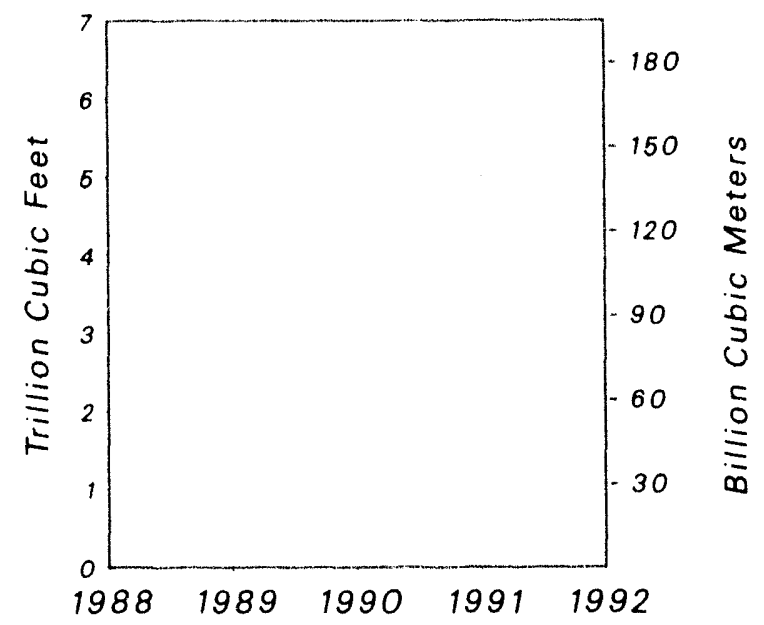

Sources: West Virginia, 1992: Energy Information Administration (EłA), US Crude Oil, Natural Gas, and Natural Gas Liquids Reserves, 1992 Annual Report. DOE/EIA-0216(92): and EIA computations. All other data Form ElA-627. "Annual Quantity and Value of Natural Gas Report." and the United

States Minerals Management Service. 
Table 3. Gross Withdrawals and Marketed Production of Natural Gas by State, 1988-1992

(Million Cubic Feet)

\begin{tabular}{|c|c|c|c|c|c|c|c|}
\hline \multirow{2}{*}{$\begin{array}{c}\text { Year } \\
\text { and } \\
\text { State }\end{array}$} & \multicolumn{3}{|c|}{ Gross Withdrawals } & \multirow{2}{*}{ Repressuring } & \multirow{2}{*}{$\begin{array}{c}\text { Nonhydro- } \\
\text { carbon } \\
\text { Gases } \\
\text { Removed }\end{array}$} & \multirow{2}{*}{$\begin{array}{l}\text { Vented } \\
\text { and } \\
\text { Flared }\end{array}$} & \multirow{2}{*}{$\begin{array}{l}\text { Marketed } \\
\text { Production }\end{array}$} \\
\hline & $\begin{array}{l}\text { From Gas } \\
\text { Wells }\end{array}$ & $\begin{array}{l}\text { From Oil } \\
\text { Wells }\end{array}$ & Total & & & & \\
\hline 1988 Total. & $15.467,023$ & $5,532.229$ & $20,999,255$ & $2,478,382$ & 459,883 & 142,525 & $17,918,465$ \\
\hline 1989 Total. & $15,708,861$ & $5,365,564$ & $21,074,425$ & $2,475,179$ & 362,457 & 141,642 & $18,095,147$ \\
\hline 4990 Total. & $16,053,566$ & $5,469,055$ & $21,522,622$ & $2,489,040$ & 289,374 & 150,415 & $18,593,792$ \\
\hline …................ & A $16,017,626$ & A $5,732,482$ & ค $21,750,108$ & A $2,771,928$ & ค 275,831 & ค 169,909 & ค $18,532,439$ \\
\hline 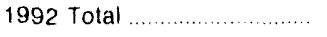 & $16.164,874$ & $5,967,376$ & $22,132,249$ & $2,972,552$ & 280,370 & 167,519 & $18,711,808$ \\
\hline Alabama Total & 403.848 & 9,766 & 413,614 & 29,996 & 26,719 & 1,799 & 355,099 \\
\hline Onshore & 212.243 & 9,766 & 222,009 & 29,996 & 21,066 & 1.727 & 169,220 \\
\hline State Offshore & 112,311 & 0 & 112,311 & 0 & 5,653 & 72 & 106,586 \\
\hline Federal Offshore & 79,294 & 0 & 79,294 & 0 & 0 & 0 & 79,294 \\
\hline 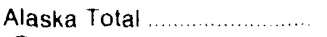 & 198.603 & $2,427,110$ & $2,625,713$ & $2,168,019$ & 0 & 14.097 & 443,597 \\
\hline Onshore & 88,537 & $2,320,799$ & $2,409,336$ & $2,083,397$ & 0 & 9,481 & 316,456 \\
\hline State Offshore $\ldots . . . . . . . . . . . .$. & 110,067 & 106,311 & 216,377 & 84,622 & 0 & 4.616 & 127,141 \\
\hline Federal Otfshore & 0 & 0 & 0 & 0 & 0 & 0 & 0 \\
\hline Arizona & 721 & 72 & 794 & 0 & 0 & 23 & 771 \\
\hline (2) & 171,543 & 39,364 & 210,906 & 8.056 & 0 & 371 & 202,479 \\
\hline California Total ...................... & 154.055 & 294,800 & 448,855 & 81,330 & 1.142 & 751 & 365,632 \\
\hline Onshore & 140,108 & 246.274 & 386,382 & 77.660 & 1,142 & 751 & 306,829 \\
\hline State Offshore $\ldots \ldots \ldots \ldots \ldots \ldots$ & 0 & 7.242 & 7.242 & 31 & NA & NA & 7,211 \\
\hline Federal Offshore .................. & 13,947 & 41,284 & 55.231 & 3,639 & NA & NA & 51,592 \\
\hline 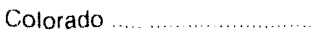 & 256,426 & 77.568 & 333.994 & 9,085 & 0 & 1.868 & 323,041 \\
\hline Florida $\ldots$ & 0 & 7.584 & 7,584 & 0 & 682 & 245 & 6,657 \\
\hline 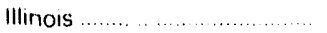 & 337 & 10 & 347 & 0 & 0 & 0 & 347 \\
\hline 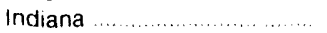 & 174 & $\mathrm{a}$ & 174 & 0 & 0 & 0 & 174 \\
\hline 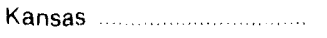 & 580,572 & 79,169 & 659,741 & 1,092 & NA & 642 & 658,007 \\
\hline 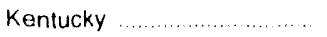 & 79.690 & a & 79,690 & • & $\cdot$ & - & 79.690 \\
\hline Louisiana Tota! ..................... & $4,347,709$ & 629,760 & 4.977 .470 & 42,631 & NA & 20,538 & $4,914,300$ \\
\hline Onshore & $1,363,397$ & 171,636 & $1,535,033$ & 3.223 & NA & 20,538 & $1,511,271$ \\
\hline State Offshore & 116,470 & 21,631 & 138.101 & NA & NA & NA & 138,101 \\
\hline Federal Offshore .............. & $2,867,842$ & 436,493 & $3,304,336$ & 39,408 & NA & NA & $3.264,928$ \\
\hline Maryland & 33 & 0 & 33 & 0 & 0 & 0 & 33 \\
\hline Michigan ............................. & 120.287 & 80,192 & 200,479 & 2.340 & NA & 3,324 & 194,815 \\
\hline 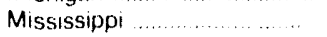 & 145,153 & 20,384 & 165,538 & 24,993 & 45,772 & 3,076 & 91.697 \\
\hline 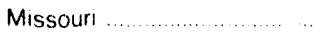 & 27 & 0 & 27 & 0 & 0 & 0 & 27 \\
\hline Montana & 46.918 & 7,892 & 54,810 & 180 & NA & 763 & 53,867 \\
\hline Nebraska & 486 & 691 & 1,177 & $\cdot$ & $*$ & $\star$ & 1.177 \\
\hline 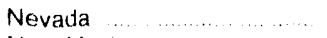 & 0 & 30 & 30 & 0 & 0 & 0 & 30 \\
\hline 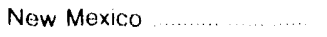 & $1,067,477$ & 222.303 & $1,289,780$ & 16,540 & 2.751 & 1,626 & $1,263,863$ \\
\hline 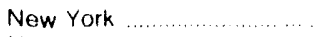 & 22,697 & 824 & 23,521 & 0 & 0 & 13 & 23,508 \\
\hline North Dakota & 12,461 & 47.518 & 59.979 & 2,391 & 508 & 2,197 & 54,883 \\
\hline Ohio $\ldots \ldots \ldots \ldots$ & 144.815 & a & 144,815 & NA & NA & NA & 144,815 \\
\hline Oklahoma & $1,674,405$ & 342,950 & $2,017.356$ & NA & NA & NA & $2,017,356$ \\
\hline Oregon $\ldots \ldots \ldots \ldots \ldots \ldots \ldots$ & 2,580 & 0 & 2,580 & 0 & 0 & 0 & 2,580 \\
\hline Pennsylvania ......................... & 138,675 & $a$ & 138,675 & NA & NA & NA & 138,675 \\
\hline 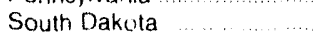 & 1,006 & 5,957 & 6,963 & 30 & 0 & 5,476 & 1,456 \\
\hline 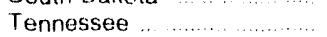 & a & 1,770 & 1,770 & NA & NA & NA & 1,770 \\
\hline 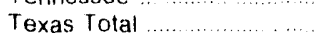 & $5,406,256$ & $1,301,756$ & $6,708,012$ & 362,458 & 180,003 & 19,689 & $6.145,862$ \\
\hline Onshore & $4,032,016$ & $1,264,850$ & $5,296,865$ & 362.458 & 180,003 & 19,689 & $4,734,715$ \\
\hline State Offshore $\ldots \ldots \ldots \ldots$ & 76,638 & 1,625 & 78,263 & NA & NA & NA & 78,263 \\
\hline Federal Offshore ............... & $1,297,602$ & 35,281 & $1,332,883$ & NA & NA & NA & $1,332.883$ \\
\hline 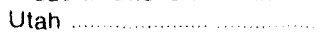 & 229,494 & 84,781 & 314,275 & 141,698 & NA & 1.284 & 171,293 \\
\hline Virginia & 24.733 & 0 & 24,733 & 0 & 0 & 0 & 24,733 \\
\hline West Virginia & E 182,000 & a & E 182,000 & NA & NA & NA & E 182,000 \\
\hline Wyoming & 751,693 & 285,125 & $1,036,817$ & 81,712 & 22,793 & 89,736 & 842,576 \\
\hline
\end{tabular}

a Breakdcini if gross withdrawais from gas or oil wells not provided by State agency.

E Estimatec vata.

- Less than 500,000 cubic leet

A Revised data.

NA Not available

Note: Totals may not equal sum of components due to independent rounding.

Sources: West Virginia, 1992. Energy Information Administration (ElA), U.S. Crude Oil. Natural Gas, and Natural Gas Liquds Reserves, 1992 Annual Report, DOE/EIA.0216(92); and EIA computations All other data. Form EIA.627. "Annual Quantity and Value of Natural Gas Report," and the United States Minerals Management Service. 
Table 4. Offshore Gross Withdrawals of Natural Gas by State, 1988-1992 (Million Cubic Feet)

\begin{tabular}{|c|c|c|c|c|c|c|c|}
\hline \multirow{2}{*}{$\begin{array}{c}\text { Year } \\
\text { and } \\
\text { State }\end{array}$} & \multicolumn{3}{|c|}{ State } & \multicolumn{3}{|c|}{ Federal } & \multirow{2}{*}{$\begin{array}{c}\text { Total } \\
\text { Offshore }\end{array}$} \\
\hline & $\begin{array}{c}\text { From } \\
\text { Gas Wells }\end{array}$ & $\begin{array}{l}\text { From } \\
\text { Oil Wells }\end{array}$ & Total & $\begin{array}{c}\text { From } \\
\text { Gas Wells }\end{array}$ & $\begin{array}{l}\text { From } \\
\text { Oil Wells }\end{array}$ & Total & \\
\hline 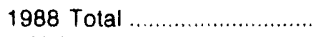 & 355,370 & 78,841 & 434,211 & $4,249,592$ & 497,072 & $4,746,664$ & $5,180,875$ \\
\hline Alabama & 9,440 & 0 & 9,440 & 0 & 0 & 0 & 9,440 \\
\hline Alaska & 57,878 & 43,562 & 101,440 & 0 & 0 & 0 & 101,440 \\
\hline California ............. & 1,413 & 9,728 & 11,141 & 17,931 & 31,236 & 49,167 & 60,308 \\
\hline 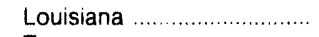 & 190,695 & 23,950 & 214,645 & $2,992,004$ & 426,945 & $3,418,949$ & $3,633,594$ \\
\hline Texas ................................... & 95,944 & 1,601 & 97,545 & $1,239,657$ & 38,891 & $1,278,548$ & $1,376,093$ \\
\hline 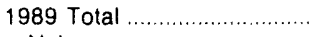 & 376,033 & 83,584 & 459,617 & $4,286,261$ & 485,150 & $4,771,411$ & $5,231,028$ \\
\hline Alabama & 13,018 & 0 & 13,018 & 0 & 0 & 0 & 13,018 \\
\hline 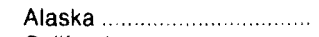 & 72,430 & 50,165 & 122,595 & 0 & 0 & 0 & 122,595 \\
\hline ......................... & 855 & 8,243 & 9,098 & 12,246 & 38,545 & 50,791 & 59,889 \\
\hline Louisiana ............................. & 181,332 & 22,673 & 204,005 & $2,970,536$ & 403,144 & $3,373,680$ & $3,577,685$ \\
\hline 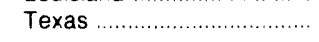 & 108,398 & 2.503 & 110.901 & $1,303,479$ & 43,461 & $1,346,940$ & $1,457,841$ \\
\hline 1990 Total & 383,544 & 79,108 & 462,652 & $4,562,144$ & 484,516 & $5,046,660$ & $5,509,312$ \\
\hline 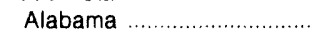 & 19,861 & 0 & 19,861 & 0 & 0 & 0 & 19,861 \\
\hline 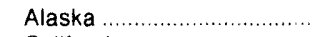 & 94,642 & 49,422 & 144,064 & 0 & 0 & 0 & 144,064 \\
\hline California .............................. & 340 & 7,743 & 8,083 & 15,640 & 34,332 & 49,972 & 58,055 \\
\hline 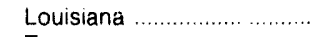 & 161,292 & 20,948 & 182,240 & $3,140,870$ & 408,654 & $3,549,524$ & $3,731,764$ \\
\hline Texas .................................. & 107,409 & 995 & 108,404 & $1,405,634$ & 41,530 & $1,447,164$ & $1,555,568$ \\
\hline 1991 Total & 359,112 & 99,688 & 458,800 & $4,314,407$ & 535,250 & $4,849,657$ & $5,308,457$ \\
\hline Alabama & 32,603 & 0 & 32,603 & 0 & 0 & 0 & 32,603 \\
\hline 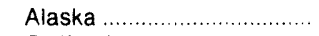 & 100,733 & 70,932 & 171.665 & 0 & 0 & 0 & 171,665 \\
\hline 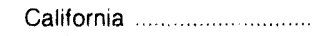 & 0 & 7.610 & 7,610 & 16,464 & 35,391 & 51,855 & 59,465 \\
\hline 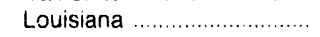 & 128,891 & 19,538 & 148,429 & $2,946,749$ & 455,052 & $3,401,801$ & $3,550,230$ \\
\hline 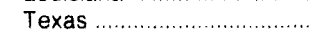 & 96,885 & 1,608 & 98,493 & $1,351,194$ & 44,807 & $1,396,001$ & $1,494,494$ \\
\hline 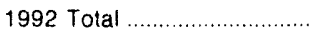 & 415,486 & 136,809 & 552,294 & $4,258,686$ & 513,058 & $4,771,744$ & $5,324,039$ \\
\hline Alabama & 112,311 & 0 & 112,311 & 79,294 & 0 & 79,294 & 191,605 \\
\hline 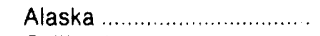 & 110,066 & 106.311 & 216,377 & 0 & 0 & 0 & 216,377 \\
\hline 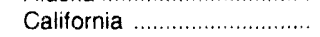 & 0 & 7,242 & 7,242 & 13,947 & 41,284 & 55,231 & 62,473 \\
\hline 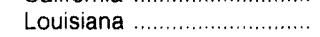 & 116,470 & 21.631 & 138,101 & $2,867,842$ & 436,493 & $3,304,336$ & $3,442,437$ \\
\hline 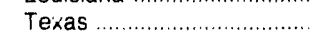 & 76,638 & 1,625 & 78,263 & $1,297,602$ & 35,281 & $1,332,883$ & $1,411,147$ \\
\hline
\end{tabular}

Note: For individual State and U.S. production, see Table 3.

Sources: Appropriate State agencies' responses to informal data requests and the United States Mirierals Management Service. 
Table 5. Number of Producing Gas and Gas Condensate Wells by State as of December 31, 1988-1992

\begin{tabular}{|c|c|c|c|c|c|}
\hline State & 1988 & 1989 & 1990 & 1991 & 1992 \\
\hline 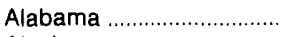 & 1,264 & 1,701 & 2,362 & 3,392 & 3,350 \\
\hline Alaska & 91 & 108 & 111 & 110 & 112 \\
\hline 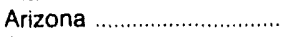 & 0 & 3 & 5 & 6 & 6 \\
\hline 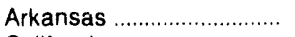 & 2,996 & 2,830 & 2,952 & 2,780 & 3,500 \\
\hline 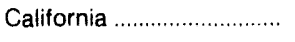 & 1,469 & 1,214 & 1,162 & 1,377 & 1,126 \\
\hline Colorado ............................ & 4,426 & 5,125 & 5,741 & 5,562 & 5,912 \\
\hline 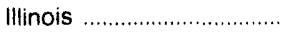 & 293 & 241 & 356 & 373 & 382 \\
\hline 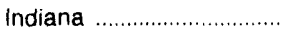 & 1,295 & 1,310 & 1,307 & 1,334 & 1,333 \\
\hline 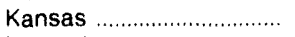 & 15,300 & 13,935 & 16,980 & 17,948 & 18,400 \\
\hline 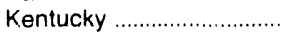 & 10,777 & 11,248 & 11,713 & 12,169 & 12,483 \\
\hline 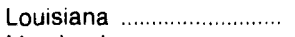 & 14,071 & 16,309 & 16,889 & 15,271 & 13,512 \\
\hline 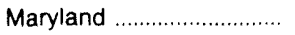 & 8 & 8 & 7 & 7 & 9 \\
\hline 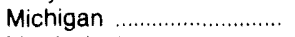 & 988 & 1,207 & 1,438 & 2,620 & 3,257 \\
\hline Mississippi ........................... & 634 & 543 & 585 & 629 & 507 \\
\hline Missouri ............................... & 4 & 4 & 8 & 6 & 5 \\
\hline 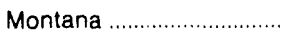 & 2,553 & 2,700 & 2,607 & 2,802 & 2,890 \\
\hline 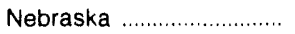 & 18 & 15 & 11 & 12 & 22 \\
\hline New Mexico ........................ & 15,909 & 17.087 & 17,124 & 20,021 & 18,040 \\
\hline 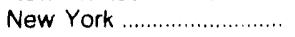 & 5,090 & 5,304 & 5,525 & 5,737 & 5,906 \\
\hline North Dakota ....................... & 61 & 61 & 103 & 100 & 104 \\
\hline Ohio & 33,793 & 34,450 & 34,586 & 34,760 & 34,784 \\
\hline 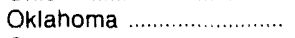 & 27,307 & 27,443 & 24,547 & 28,216 & 28,902 \\
\hline 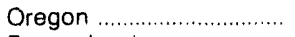 & 14 & 18 & 19 & 16 & 16 \\
\hline Pennsylvania ....................... & 28,000 & 30,000 & 30,300 & 31,000 & 31,000 \\
\hline South Dakota ...................... & 51 & 53 & 54 & 54 & 38 \\
\hline Tennessee .......................... & 802 & 700 & 690 & 650 & 600 \\
\hline 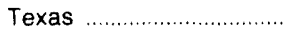 & 50,588 & 48,609 & 50,867 & 47,615 & 46,298 \\
\hline 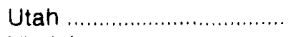 & 665 & 834 & 822 & 913 & 1,006 \\
\hline 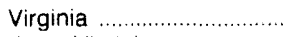 & 728 & 752 & 819 & 886 & 1,153 \\
\hline West Virginia ........................ & 35,800 & 36,240 & 37.500 & 37,800 & 38,250 \\
\hline 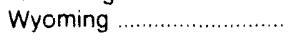 & 2,284 & 2,431 & 2.600 & 2,821 & 3,111 \\
\hline 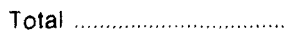 & 257,279 & 262,483 & 269,790 & 276,987 & 276,014 \\
\hline
\end{tabular}

Sources: Energy Information Administration (EIA), Form EIA-627, "Annual Quantity and Value of Natural Gas Report," the United States Minerals Man. agement Service (MMS), and World Oil magazine. 
Table 6. Estimated Total Dry Natural Gas Proved Reserves by State, 1988-1992 (Billion Cubic Feet)

\begin{tabular}{|c|c|c|c|c|c|}
\hline State & 1988 & 1989 & 1990 & 1991 & 1992 \\
\hline Alabama & 809 & 2,761 & 4,125 & 5,414 & 5,802 \\
\hline Alaska & 9,078 & 8,939 & 9,300 & 9,553 & 9,638 \\
\hline 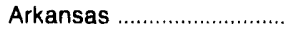 & 1,986 & 1,772 & 1,731 & 1,669 & 1,750 \\
\hline 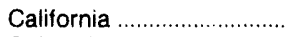 & 3,519 & 3,374 & 3,185 & 3,004 & 2,778 \\
\hline Colorado ............................. & 3,535 & 4,274 & 4,555 & 5,767 & 6,198 \\
\hline 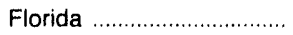 & 51 & 46 & 45 & 38 & 47 \\
\hline 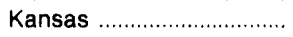 & 10,104 & 10,091 & 9,614 & 9,358 & 9,681 \\
\hline 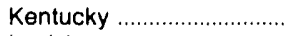 & 923 & 992 & 1,016 & 1,155 & 1,084 \\
\hline 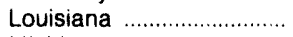 & 12,224 & 12,516 & 11,728 & 10,912 & 9,780 \\
\hline Michigan & 1,323 & 1,342 & 1,243 & 1,334 & 1,223 \\
\hline Mississippi .......................... & 1,143 & 1,104 & 1,126 & 1,057 & 869 \\
\hline 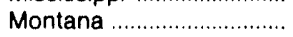 & 819 & 867 & 899 & 831 & 859 \\
\hline New Mexico ......................... & 17,166 & 15,434 & 17,260 & 18,539 & 18,998 \\
\hline 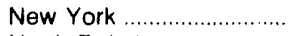 & 351 & 368 & 354 & 331 & 329 \\
\hline North Dakota ................... & 541 & 561 & 586 & 472 & 496 \\
\hline Ohio & 1,229 & 1,275 & 1,214 & 1,181 & 1,161 \\
\hline 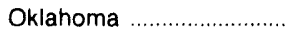 & 16,495 & 15,916 & 16,151 & 14,725 & 13,926 \\
\hline 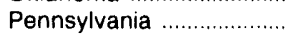 & 2,072 & 1,642 & 1.720 & 1,629 & 1,528 \\
\hline 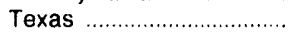 & 38,167 & 38,381 & 38,192 & 36,174 & 35,093 \\
\hline 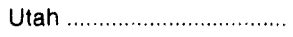 & 1,298 & 1,507 & 1,510 & 1,702 & 1,830 \\
\hline 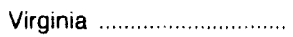 & 230 & 217 & 138 & 225 & 904 \\
\hline 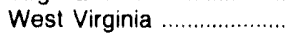 & 2,306 & 2,201 & 2,207 & 2,528 & 2,356 \\
\hline 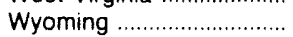 & 10,308 & 10,744 & 9,944 & 9,941 & 10,826 \\
\hline Federal Offshore & 32,264 & 30,709 & 31,433 & 29,448 & 27,767 \\
\hline 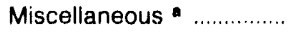 & 83 & 83 & 70 & 75 & 92 \\
\hline 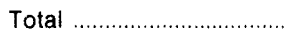 & 168,024 & 167,116 & 169,346 & 167,062 & 165,015 \\
\hline
\end{tabular}

- -.:-Includes Arizona, Illinois, Indiana, Maryland, Missouri, Nebraska, Nevada, Oregon, South Dakota, and Tennessee

Source: Energy Information Administration (EIA), U.S. Crude Oil, Nalural Gas, and Natural Gas Liquids Reserves, 1992 Annual Report, DOE/EIA$0216(92)$. 
Table 7. Wellhead Value and Marketed Production of Natural Gas by State, 1988-1992

\begin{tabular}{|c|c|c|c|c|c|}
\hline \multirow{2}{*}{$\begin{array}{l}\text { Year } \\
\text { and } \\
\text { State }\end{array}$} & \multicolumn{2}{|c|}{ Reported Wellhead Value } & \multirow{2}{*}{$\begin{array}{c}\text { Average Wellhead } \\
\text { Price } \\
\text { (dollars per } \\
\text { thousand cubic feet) }\end{array}$} & \multirow{2}{*}{$\begin{array}{l}\text { Marketed } \\
\text { Production } \\
\text { (million } \\
\text { cubic feet) }\end{array}$} & \multirow{2}{*}{$\begin{array}{l}\text { Imputed Wellhead Value } \\
\text { of } \\
\text { Marketed Productionb } \\
\text { (thousand dollars) }\end{array}$} \\
\hline & $\begin{array}{l}\text { Volume } \\
\text { (million } \\
\text { cubic teet) }\end{array}$ & $\begin{array}{l}\text { Value } \\
\text { (thousand } \\
\text { dollars) }\end{array}$ & & & \\
\hline 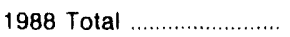 & $15,419,723$ &.- & $\$ 1.69$ & $17,918,465$ & $\$ 30,286,936$ \\
\hline 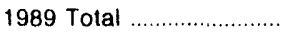 & $15,432.773$ & - & 1.69 & $18,095,147$ & $30,627,215$ \\
\hline 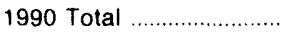 & $16,408,437$ & -. & 1.71 & $18,593,792$ & $31,754,803$ \\
\hline 1991 Total ............................... & A $15,770,393$ & - & 1.64 & P $18,532,439$ & A $30,327,779$ \\
\hline 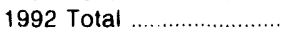 & $15,852,090$ & $\ldots$ & 1.74 & $18,711,808$ & $32,570,827$ \\
\hline 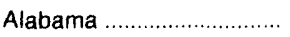 & c 51,219 & c $\$ 117,543$ & c 2.29 & 355,099 & 813,178 \\
\hline 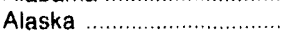 & 206,259 & 290,027 & 1.41 & 443,597 & 625,471 \\
\hline Arizona & 730 & 1,351 & 1.85 & 771 & 1,426 \\
\hline 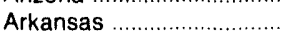 & c 85,177 & c 183,227 & c 2.15 & 202,479 & 435,330 \\
\hline 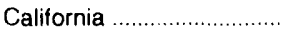 & c 195,515 & c 458,164 & c 2.34 & 365,632 & 855,579 \\
\hline Colorado & 314,105 & 430,324 & 1.37 & 323,041 & 442.566 \\
\hline 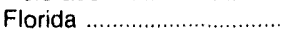 & 3,849 & 9,676 & 2.51 & 6,657 & 16,708 \\
\hline 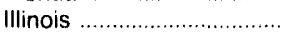 & 346 & 743 & 2.15 & 347 & 746 \\
\hline Indiana & 174 & 350 & 2.01 & 174 & 350 \\
\hline 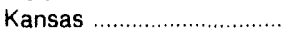 & 640,583 & 987,003 & 1.54 & 658,007 & $1,013,330$ \\
\hline 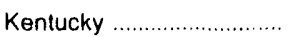 & 79,690 & 153,312 & 1.92 & 79,690 & 153,005 \\
\hline 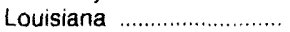 & d $3,404,963$ & d $5,903,756$ & 1.73 & $4,914,300$ & $8,501,739$ \\
\hline 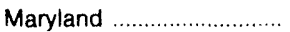 & 33 & 63 & 1.91 & 33 & 63 \\
\hline Michigan …......................... & 190,637 & 516,913 & 2.71 & 194,815 & 527,949 \\
\hline Mississippi .......................... & 129,340 & 212,689 & 1.64 & 91,697 & 150,382 \\
\hline 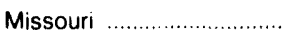 & 27 & 42 & 1.56 & 27 & 42 \\
\hline 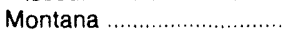 & 50,359 & 81,745 & 1.62 & 53,867 & 87,265 \\
\hline 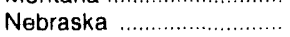 & 1,177 & 2,094 & 1.78 & 1,177 & 2,094 \\
\hline Nevada & 0 & - & $\ldots$ & 30 & $\ldots$ \\
\hline New Mexico ....................... & $1,274,220$ & $2,038,989$ & 1.60 & $1,268,863$ & $2,030,181$ \\
\hline 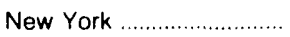 & 22.543 & 50,722 & 2.25 & 23,508 & 52,893 \\
\hline North Dakota ................... & 3,994 & 7,849 & 1.97 & 54,883 & 108,120 \\
\hline 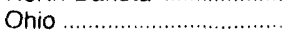 & 143,381 & 336,671 & 2.35 & 144,815 & 340,315 \\
\hline Oklahoma & $1,937,224$ & $3,285,072$ & 1.70 & $2,017,356$ & $3,429,505$ \\
\hline 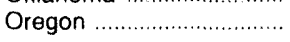 & 2,580 & 3,338 & 1.29 & 2,580 & 3,328 \\
\hline Pennsylvania ....................... & 138,675 & 270,416 & 1.95 & 138,675 & 270,416 \\
\hline South Dakota & 1,006 & 1,797 & 1.79 & 1,456 & 2,607 \\
\hline 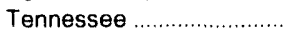 & 1,770 & 3,164 & 1.79 & 1,770 & 3,168 \\
\hline 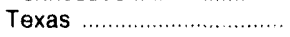 & $5,893,069$ & $10,425,203$ & 1.77 & $6,145,862$ & $10,878,176$ \\
\hline Utah & 86,682 & 141,663 & 1.63 & 171,293 & 279,208 \\
\hline 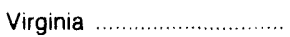 & 24,734 & 45,757 & 1.85 & 24,733 & 45,756 \\
\hline West Virginia & 202.775 & 610,353 & 3.01 & E 182,000 & E 547,820 \\
\hline Wyoming & 765,254 & 866,038 & 1.13 & 842,576 & 952,111 \\
\hline
\end{tabular}

- ... Quantity of production associated with reported wellhead value. A number of States reported values associated with quantities other than marketed production

b Average wellhead price times marketed production does not equal imputed value of marketed production due to independent rounding.

c Quantity and value data obtained from Energy Information Administration Form ElA-176. "Annual Report of Natural and Supplemental Gas Supply and Disposition."

- Quantity and value data obtained trom the United States Minerals Management Service (MMS)

- : Most of Nevada's marketed production was consumed as lease fuel.

E Estimated data.

A Revised data.

-. Not applicable

Sources: West Virginia, 1992: Energy Information Administration (EIA), U.S. Crude Oil. Natural Gas, and Natural Gas Liquids Reserves, 1992 Annual Report, DOE/EIA-0216(92); and EIA computations. All other data: Form ElA-627, "Annual Quantity and Value of Natural Gas Feport," and the United States Minerals Management Service. 
Table 8. Volume and Average Price of Natural Gas Purchases from Producers by Type

of Purchaser by State, 1992

(Volumes in Million Cubic Feet, Prices in Dollars per Thousand Cubic Feet)

\begin{tabular}{|c|c|c|c|c|c|c|c|c|c|c|}
\hline \multirow{3}{*}{ State } & \multicolumn{10}{|c|}{ Natural Gas Purchased By: } \\
\hline & \multicolumn{2}{|c|}{$\begin{array}{l}\text { Interstate } \\
\text { Pipeline } \\
\text { Companies }\end{array}$} & \multicolumn{2}{|c|}{$\begin{array}{l}\text { Intrastate } \\
\text { Pipeline } \\
\text { Companies }\end{array}$} & \multicolumn{2}{|c|}{$\begin{array}{l}\text { Distributors } \\
\text { and } \\
\text { Municipalities }\end{array}$} & \multicolumn{2}{|c|}{$\begin{array}{c}\text { Other } \\
\text { Companies }\end{array}$} & \multicolumn{2}{|c|}{$\begin{array}{c}\text { Total } \\
\text { All } \\
\text { Companies }\end{array}$} \\
\hline & Volume & $\begin{array}{l}\text { Average } \\
\text { Price }\end{array}$ & Volume & $\begin{array}{l}\text { Average } \\
\text { Price }\end{array}$ & Volume & $\begin{array}{l}\text { Average } \\
\text { Price }\end{array}$ & Volurne & $\begin{array}{l}\text { Average } \\
\text { Price }\end{array}$ & Volume & $\begin{array}{c}\text { Average } \\
\text { Price }\end{array}$ \\
\hline Alabarna & 34,290 & $\$ 2.31$ & 4,179 & $\$ 2.20$ & 12,727 & $\$ 2.30$ & 0 & - & 51,196 & $\$ 2.30$ \\
\hline 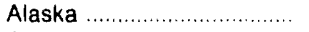 & 0 & $-\cdot$ & 31,054 & 1.92 & 0 & $\cdots$ & 48,292 & $\$ 1.55$ & 79,346 & 1.70 \\
\hline Arizona ............ & 0 & $\cdots$ & 0 & $-\cdot$ & 7,559 & 2.65 & 0 & + & 7,559 & 2.65 \\
\hline 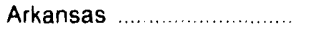 & 63,649 & 1.97 & 0 & $\sim$ & 13,600 & 3.06 & 12,384 & 1.98 & 89,633 & 2.14 \\
\hline California ........................... & 12,608 & 3.11 & 7,332 & 1.86 & 160,872 & 2.30 & 14,702 & 2.36 & 195,515 & 2.34 \\
\hline Colorado & 63,154 & 1.94 & 47 & 1.49 & 43,233 & 2.20 & 3,714 & 1.16 & 110,149 & 2.02 \\
\hline Florida $\ldots$. & 279 & 1.68 & 252 & 2.00 & 31 & 3.19 & 0 & - & 563 & 1.91 \\
\hline 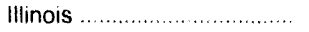 & 5,842 & 3.06 & 0 & - & 2,048 & 2.13 & 0 & - & 7,890 & 2.82 \\
\hline 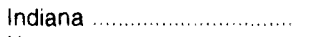 & 0 & $-\cdot$ & 0 & - & 679 & 2.45 & 0 & - & 679 & 2.45 \\
\hline Kansas $\ldots \ldots \ldots \ldots \ldots \ldots \ldots \ldots \ldots \ldots \ldots$ & 86,827 & 1.72 & 18,580 & 1.68 & 6.120 & 2.39 & 21,805 & 1.89 & 133,332 & 1.77 \\
\hline Kentucky. & 8,468 & 2.04 & 1,037 & 1.82 & 6,276 & 2.58 & 3,251 & 2.07 & 19,032 & 2.21 \\
\hline Louisiana ............................ & 426.733 & 2.24 & 137,534 & 1.63 & 30,021 & 1.98 & 146,705 & 1.73 & 740,993 & 2.02 \\
\hline Maryland .............................. & 4 & 2.04 & 0 & $-\cdot$ & 53.951 & 2.46 & 0 & $\ddot{-}$ & 53,955 & 2.46 \\
\hline 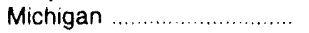 & 0 & - & 0 & $\cdots$ & 163,533 & 2.98 & 3,326 & 2.23 & 166,858 & 2.97 \\
\hline 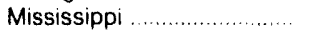 & 42,176 & 2.82 & 5,215 & 1.66 & 11,559 & 1.92 & 549 & 1.47 & 59,499 & 2.53 \\
\hline 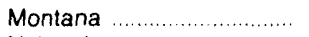 & 29,069 & 1.90 & 0 & $-\cdot$ & 12,686 & 2.19 & 221 & 2.66 & 41,976 & 1.99 \\
\hline Nebraska .......... & 573 & 1.74 & 0 & $\cdots$ & 0 & $\cdots$ & 0 & -- & 573 & 1.74 \\
\hline New Mexico ........................ & 26,342 & 1.63 & 0 & $\cdots$ & 55,619 & 1.86 & 23,554 & 2.22 & 105,515 & 1.88 \\
\hline New York ........... & 737 & 2.16 & 0 & $-\cdot$ & 28.756 & 2.52 & 0 & -- & 29,493 & 2.52 \\
\hline North Dakota ....................... & 3,975 & 1.97 & 0 & $-\cdot$ & 0 & -- & 19 & .52 & 3,994 & 1.97 \\
\hline Ohio $\ldots . . . . . .$. & 1,123 & 4.20 & 0 & -- & 57,805 & 2.52 & 636 & 2.34 & 59,564 & 2.55 \\
\hline Oklahoma & 140,249 & 201 & 80.261 & 1.77 & 848 & 1.98 & 180,637 & 1.72 & 401,995 & 1.83 \\
\hline 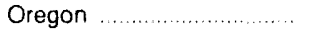 & 0 & $\cdots$ & 0 & - & 2,263 & 1.95 & 0 & $\cdots$ & 2,263 & 195 \\
\hline Pennsylvania .......................... & 69,754 & 2.03 & 2.959 & 1.70 & 130,949 & 2.67 & 1,184 & 2.44 & 204,846 & 2.44 \\
\hline 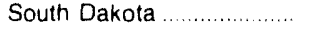 & 263 & 1.63 & 0 & $-\cdot$ & 0 & $\cdots$ & 0 & -- & 263 & 1.63 \\
\hline 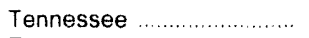 & 660 & 2.50 & 0 & $\ldots$ & 354 & 2.41 & 143 & 2.66 & 1,156 & 2.49 \\
\hline 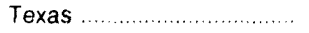 & 223,792 & 2.10 & 502,988 & 1.83 & 222,966 & 2.80 & 168,586 & 1.81 & $1,118,332$ & 2.07 \\
\hline 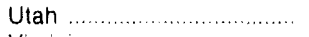 & 16,063 & 2.99 & 0 & $\cdots$ & 342 & 2.16 & 1.155 & 2.14 & 17,560 & 2.92 \\
\hline Virginia ............ & 12.061 & 2.29 & 0 & $-\cdot$ & 3,835 & 2.72 & 0 & $\cdots$ & 15,896 & 2.40 \\
\hline West Virginia $\ldots . . . . . . . . . . . . . . .$. & 20,032 & 319 & 3.293 & 2.12 & 34,027 & 2.82 & 2,264 & 2.42 & 59,616 & 2.89 \\
\hline Wyoming & 103,309 & 2.09 & 3,333 & 1.43 & 1,694 & 2.01 & 436 & 1.48 & 108,772 & 2.06 \\
\hline Total …............................... & $1,392,033$ & 2.15 & 798,064 & 1.79 & $1,064,355$ & 257 & 633,560 & 178 & $3,888,012$ & 2.13 \\
\hline
\end{tabular}

- includes all respondents who classified themselves as integrated oil and gas companies, producers, gatherers, processors, storage operators, SNG plant operators, or other on their EIA-176 survey response.

- Not applicable.

Notes: Totals may not equal sum of components due to independent rounding. The purchased gas volumes and prices shown represent essentially the same transactions defined as "first sales" in the Natural Gas Policy Act of 1978 with the exception of direct sales to consumers and gas purchased or produced offsystem are not included in the totals or averages. Producers aiso include Gatherers and/or Processing Plant Operators.

Source: Energy Information Administration (EIA). Form EIA-176, "Annual Report of Natural and Supplemental Gas Supply and Disposition." 


\section{Transmission}

A complex grid of natural gas pipelines, extending a quarter of a million miles, crisscrosses the Nation and connects all States except Alaska, Hawaii, and Vermont. Natural gas flow's predominately northeastward, originating primarily from the major producing centers in Texas and I.nusiana, and 10 a lesser extent from producing areas in (Oklahoma and New Mexice. At the northern U.S. horder, pipelines from Canada reach into California, the northern States of the Midwest. and the Northeast (including Vermont). And at the southern U.S. horder, the pipeline network extends into Mexico, making an integrated market for the North American continent.
During 1992, Texas and I oulsiana produced 11.1 trillion cubic feet of natural gas, 59 percent of the nation's total marketed production (Table 3). These two States logether, however, only consumed 45 percent of their own natural gas production. The remainder was sent toother States and exported to Mexico. With 18 percent of markeled production, Oklahoma and New Mexico were also net exporters of natural gas. Imports from Canada also played an important role in the U.S. natural gas industry in 1992, accounting for 10 percent of total consumption. The net receipts associated with the Nation's flow of natural gas were highest in California, Illinois and New York where comsumption was high and in considerable excess of local production.

Figure 5. Principal Interstate Natural Gas Flow Summary

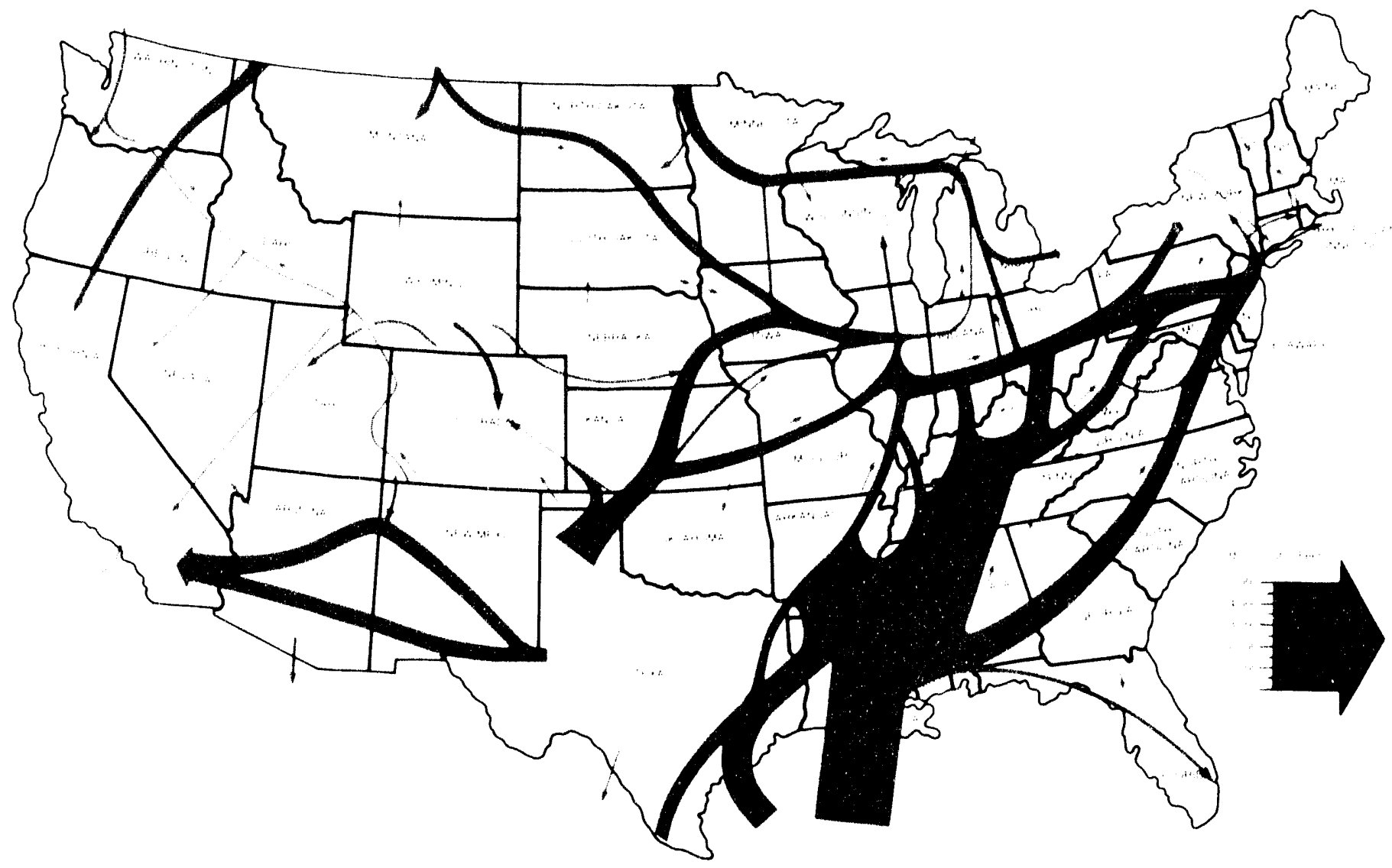




\section{Pipeline Construction}

According to the Energy and Environment Analysis, Inc., in a study commissioned by the Interstate Natural Gas Association of America, the rate of new construction will drop over the next 5 years (1993-1997). New construction will add $10,30(0)$ miles of pipeline in the United States to the existing 331,00() miles of pipeline operating in North America. This contrasts with the 13,411 miles of new pipeline constructed in the years 1988101992 . Several recently announced pipeline construction projects that will have significant impact on the markets they serve are discussed in this section.

The Portland Natural Gas Transmission System is proposed to deliver 250 million cubic feet per day upon its completion in November 1997. It will run from the Canadian border at Jay. Vermont, to an interennect with Temnessee Gas Pipeline at Haverhill, Massachusetts.

In New York, the Empire State Pipeline received the necessary permits to begin construction. The 155-mile line from the Niagara River to Rochester then to Oswego County is expected to be in operation by $\mathrm{No}_{0}$ vember 1, 1993. Initially it will deliver 200) million cubic feet per day expanding to $4(x)$ million cubic feet per day by January $1,1995$.

In Florida, there are thres pipeline construction proposals. The SunShine In erstate Transmission Company has proposed a 17()-mile line from Pascagoula, Mississippi, to Okaloosa County. Filorida, where it would eonnect with the SunShine Pipeline Company's proposed $5(0)$-mile intrastate pipeline which will extend to Polk County, and possibly later to Okeechobec County. The initial capacity would be 250 million cabic feet per day in 1995 possibly expanding $606(0)$ million cubic feet per day in 1999 .

The Florida Gas Transmission Phase 111 expansion project is projected to be completed by November 1994. The line that will run from Louisiana to the Tampa, Florida, area will add over 500 million cubic feet per day capacity.

Sonat has held an open season for shirpers on its proposed PenPipe system which would run from near Tal. lahassee 10 the Tampa area. This $2(00$-mile line would have a capacity of 260 million cubic feet per day and would be completed by February 1996

Pacific Gas Transmission is nearing completion of its system expansion which will add approximately 9()$)$ million cubic feet per day of capacity from Alberta to California. Completion is expected by November 1993.

TransCanada Pipelines and Sierra Pacific Resources Company have proposed the Tuscarora Pipeline, a 229-mile line from an interconnection with Pacific (
Transmission near Malin, Oregon, to Sierra's Tracy Power Plant in northern Nevada. This pipeline will serve industrial users as well as several communities in northeastern California that do not now have gas service. It is expected to be in operation by November 1 . 1995.

\section{Natural Gas Imports and Exports}

Natural gas import and export activity in North America during 1992 indicated the continued emergence of an integrated market for the continent. Brisk trading took place between Canada and the United States and from the United States into Mexico. Some of the highlights of the year for U.S. imports and exports were:

- The United States imported a record level of 2,(194 billion cubic feet of natural gas from Canada, 23 pereent higher than the previous record set in 1991.

- The proportion of U S. natural gas consumption represented by nee imports climbed again, for the sixth consecutive year, reaching 10 pereent in 1992

- Canadian imports to the Northeastern United States rose dramatically while those to California fill slightly

- Exports of natural gas to Mexicecontinued their sharp climb. They reached go billion cubic feet, one and one-half times higher than in 1901 and six temes higher than in 1990)

- Adding to the cexport capacity to Mexico, Valero Pipeline began operattons on August 1, 1962, on its 3.5-mile interconnect that links Valero's system near Pentas, Texas, to the Petroleos Mexicanos (Pemex) Pipeline near Reynosa, Tamaulipas.

- Exports a Canada also rose sharply 1068 billion cubie feet, mere than four times higher than the 1991 level and 76 percent higher than the record level for the last 20 years set in 1989.

- As in the previous year. liquelied natural gas (INC) was imported only from Algeria. Compared to 1991, I.NG imports fell 32 pereent to 4.3 billion cubic feet. Algeria is more interested in supplying I.NG to the European market where the price is higher than the U.S. price. In Europe, INe prices are more closely tied to oil prices.

In 1992, the United States imported large volumes of natural gas from Canada and a small amount from Al. geria, and exported gas 10 Mexico, Canada, and Japan. The price of naturai gas imports increased by 1 percent from 1991 to $\$ 1.85$ per thousand cubic feet while the price for gas exports dropped by 1.3 percent. Prices for gas exports to Canada and Japan fell, but the price of exports to Mexicon rose. 


\section{Imports from Canada}

During 1992, growing demand, competitive prices, and additional pipeline capacity resulted in increased natural gas imports from Canada. For the fifth consecutive year, they reached a record level. Canadian imports during 1992 totaled 2,094 billion cubic feet, 23 percent more than in 1991 and 45 percent higher than 1990 . Although the price of Canadian gas rose by 2 percent from 1991 to $\$ 1.84$ per thousand cubic feet in 1992, it remained competitive. The 1992 price was still 4 percent less than the 1990 price

Canadian natural gas imports are marketed in the United States primarily in four geographical areas: the Northeast, the Midwest, the Pacific Northwest, and California. Import volumes increased in all areas except California.' In the Northeast, imports from Canada more than doubled. The import capacity available on the Iropuosis Pipeline and demand for natural gas by nomutility generators (NIG's) contributed to the increase in the Northeast. NUGis generate electricity for their own use and for sale to electric utilities, which in turn distribute it to consumers

The State of Californats Public Utility Commission and the National Energy Board (NEB) of Canada disagreed during the past year about how to manage the transportation and sale of natural gas from Alberta, Camada, 10 northern Califormia. The effect of orders ssued by the NEB in June 1992 on Canadian gas and transportation services to California was to prevent the displacement of Canadian gas imported into Califormia under long-term contracts by gas imported under short-term agreements

There are currently wo pipeline expansion projects for transporting natural gas from Alberta, Canada, to California. The Pacific Gas Transmission (PGT) profect, a virtual doubling of its Alherta-California gas pupeline capacity, is scheduled for completion by Norember 1993. Altamont Gas Transmisson Company has delayed construction of its pipeline expansion project because of the falling gas demand in California and the PGT expansion. The project was originally envisoned to supply only the California market. However, new plans call for about one-third of the gas (o) g1) (1) Califorma, with the remander serving Nevada. Ctah. Colorado, and possibly Mexico.'

According to the Energy Information Administration publication, Short-Term Energy Outlook. Third Quarter 1993. hice U.S. use of Canadan natural gas imports will contmue to rise. The report projects that total natural gas net imports will account for over 10 percent of total U.S. gas consumption in 1993 and over 11 percent in 1994 . The steady rise in imports from Canada is possible because of the rapid expansion in gas pipeline capacily.

In 1992. 122 companies reported imports of natural gas by pipeline from Canada, compared with 105 companies in 1991 and 85 in 1990. Two companies, Northwest Alaskan Pipeline Co. with 337 billion cubic feet and Pacific (Bas Transmission Corp. with 309 billion cubic feet, accounted for 31 percent of all pipeline imports.

Each month of 1992 showed an increase in Canadian gas imports when compared to imports for the same month of 1991. In January the increase was less than 1 percent. However, in every other month of 1992 the increase was much greater. From February through September and in November, the increases were 20 percent or larger.

\section{Exports to Mexico}

Continuing a dramatic climb, U.S. natural gas exports to Mexico rose to 96 billion cubic feet in 1992. more than 50 percent higher than in 1991 and 6 times greater than in 1990. Fconomic growth along Mexico's northern border region, as well as that nation's desire to reduce air pollution, have recently created demand for natural gas.

Mexico has ample natural gas reserves but plans to continue to be a net importer of natural gas while it concentrates on developing its oil reserves. ${ }^{4}$ Its refineries produce large quantities of residual fuel oil, the major source of fuel for its electric utilities. "Since 1984, Mexico has not exported any gas 6 the United States.

Under Mexico's move loward a more market-based economy, gas prices, previously set by petroleos Mexicanos (Pemex), should follow the market Pemex, the Mexican state-controlled oil and gas company, recently reorganized. The goal of the reorganzation is to introduce competition into their oil and gas industry and to streamline management." Each of the new Pemex suhsidiaries will be required to show a profit.' These events, fogether with the eontinued availability of residual fuel oil, may dampen the growth in the Mexican gas market previously anticipated. A drop in the volume of U.S. exports to Mexico has already been observed during 1993*

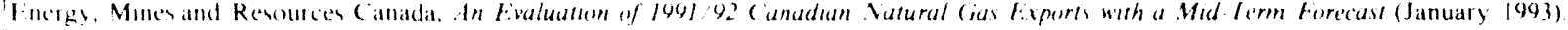

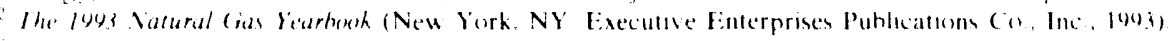


On August 1, 1992, Valero Transmission began flowing natural gas through its new pipeline which connects its existing pipeline near Penitas, Texas, 10 Pemex's pipeline outside of Reynosa, Mexico. The largest gas transmission interconnection between the United States and Mexico, it has a capacity of 400 million cubic feet per day. In December 1992, El Paso Natural Gas Company announced a project to construct a pipeline from the border near Clint. Texas, to the Samalayuca II power plant near Ciudad Juarez, Mexico."

Twenty-two companies reported exports to Mexico in 1992, the same number as in the previous year. Three companies, Amoco Energy Trading Company with 12 billion cubic feet, P.M.I. Commercio International with 14 billion cubic feet, and Trinity Pipeline with 15 billion cubic feet, accounted for 42 percent of pipeline exports to Mexico. The average price was $\$ 1.90$ per thousand cubic feet in 1992, 8 percent more than in 1991, and 1 percent more than 1990.

\section{Exports to Canada}

U.S. natural gas exports to Canada rose sharply during 1992 to 68 billion cubic feet, more than four times the level in 1991 and 76 percent higher than the record level for the last 20 years set in 1989. Western Gas Marketing L.td, exported ahout one-third of the total volume of gas delivered from the United States into Canada. This company acquired gas from U.S. sources to help TransCanada Pipeline meet its firm service requirements. Transcanada experienced an interruption in service in 1992 due to scheduled maintenance of its pipeline. It will return this gas to Western Gas Marketing over the next 2 years."

Ten companies exported gas to Canada in 1992, the same number as in 1991. Compared to 1991, monthly exports of gas to Canada rose sharply during the months of March through October in 1992. The average price fell to $\$ 1.8 .3$ per thousand cubic feet in 1992. 4 percent less than in 1991.

Exports to Canada are not expected to remain at this high level in 1993, primarily due to two reasons: first, the Western Gas Marketing activity in 1992 was unusual, and second, U.S gas has not penetrated the Canadian market under normal competitive circumstances." The continuing deregulation of the industry and additional proposed pipeline capacity may make U.S. gas more competitive in the Canadian market in the future
Natural gas trading between the United States and Canada frequently includes backhaul arrangements. A backhaul transaction occurs when a transporting pipeline redelivers gas at a point upstream from the point of receipt. For example, a transaction could be made by a pipeline to move gas downstream from Canada into a U.S. receipt point. Prior to completing this transaction, the pipeline could make a new arrangement to redeliver the gas in Canada before moving it down through the border. Since this type of transaction does not result in the gas actually crossing the border, gas movements arranged via backhaul are not included in the tables in this report

\section{Liquefied Natural Gas}

Natural gas can be transmitted in a vapor state via pipeline or in a liquid form, liquefied natural gas (LNG). Liquefaction makes overseas transportation possible. The volume of natural gas is greatly reduced when converted from the vapor state to liquid form. A 600-to-1 volume reduction is achieved by lowering the temperature of natural gas to approximately minus 260 degrees Fahrenhelt. During 1992, the United States imported LNG from Algeria and exported it to Japan. Algerian I.NG imports represented 2 percent of U.S gas imports, while LNG exports to Japan represented 24 percent of U.S. natural gas exports.

Approximately 71 percent of the $L$ NG imported from Algeria was delivered to the Distrigas Corporation receiving terminal located in Everett, Massachusetts just north of Boston. The remaining 29 percent was delivered to the Pan National Gas Sales terminal in Lake Charles, Louisiana. LNG imports totaled 43 billion cubic feet in 1992, nearly one-third less than in 1991. Algeria is more interested in supplying LNG to the Eufropean market where the price is higher than the U.S. price.

Phillips Alaska Natural Gas Corp. and Marathon Oil Co. exported LNG from the Kenai Peninsula in southern Alaska to Japan during 1992. These exports totaled 53 billion cubic feet, continuing the flat trend in LNG exports.

\section{Storage}

Underground working gas storage levels at the beginning of the 1992-1993 heating ceason (November 1 , 1992) were 3.2 trillion cubic feet, only 3 percent less than the previous year. Natural gas working storage

\footnotetext{
\$ The Journal of Cimmere (Wednesday May 26. 1993)

"Oll and (ias, Journal (February 8,1993$)$

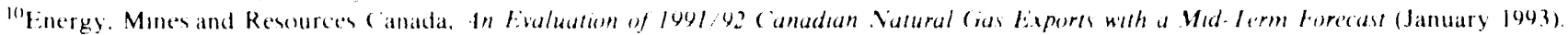

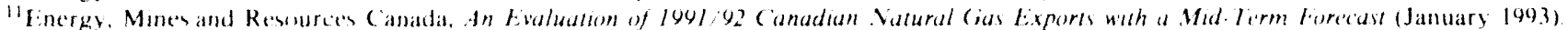


volumes dropped to 1.2 trillion cubic feet at the end of March 1993, the lowest level in years. Net winter withdrawals for the heating season were 2.0 trillion cubic feet compared to 1.8 trillion cubic feet the previous heating season. Injections into storage were lower in the early part of 1993 than the previous two years. The blizzard of March 1993 and the frigid cold weather in February caused some storage customers to withdraw large amounts of gas, dropping supplies below targeted levels

FERC Order 636, which will be implemented in November 1993, will open up pipeline company storage facilities for use by third parties. Pipeline companies began depleting volumes they owned in slorage before Order 636 unbundling goes into effect to reduce commodity costs that may not be passed to customers. Large amounts of storage capacity will be opened to transportation customers when Order 636 provisions are fully implemented. Order 636 restructuring filings submitted to FERC by interstate (jurtsdictional) storage operators indicate that 801090 percent of working gas storage capacity will become available to customers. The storage operators plan to retain the remaining 10 to 20 percent for load balancing, system management, and support of "no-notice" service.

\section{Order 636: The Restructuring Rule}

The Federal Energy Regulatory Commisson (FERC) issued Order 636 on April 8, 1992. The main components of the (order are

- Interstate natural gas pipeline companies must provide transportation services unbundled from sales services

- Interstate pipeline companies can sell gas at market-based rates.

- Pipeline companies must offer a new "no-notice" firm transportation service (i.te, advance notice by the shipper is not required) if they provided bundled cilygate firm sales service on May 18. 1992 .

- Pipeline companies must provide open-access transportation that is equal on quality for all gats supplies whether purchased from the pipeline company or not.

- Pipeline companies must provide customers with open access to storage

- Tariff provisions cannot inhibit the development of market centers or production pooling areas

- Two new generic capacity assignment mechanisms were established. One authorizes and requires pipeline companies to provide firm shippers on downstream pipelines with access to capacity on upstream pipelines that is held by the down- stream pipeline. The second authorizes a reallo. cation mechanism so that firm shippers can release unwanted capacity to those wanting it. These reassignments must first be posted on an clectronic bulletin board.

- In most instances, the straight fixed-variable rate design must be used for billing and allocation purposes; other rate designs, however, may be adopted for ratemaking purposes such as cost classification. Pipeline companies are required to use various ratemaking techniques to miligate "significant" changes in revenue responsibility to any customer class. If changes in revenue responsibility for any customer class still exceed 10 percent after mitigation, pipeline companies must phase in the increase over a 4-year period. This phase-in period is a temporary mitigation measure serving the primary purpose of softening unmitigated cost increases associated with the rate-design change.

- Pipeline companies may abandon sales and interruptible transportation service to any existing customer upon expiration or termination of the contract without seeking case-by-case approval from FERC. Service under firm transportation contracts for 1 year or less may also be abandoned. Under longer term contracts, such service maty be abandoned only if the existing customer fails to match the offer for the capacity made by another potential customer

- Firm shippers must have flexibility in changing receipt points

These new rules go into effect November 1, 199.3. The combination of Order 6.36 and "The Energy Policy Act of 1992" (FPACT) should have substantial implications for the gas industry. EPAC'T provides the opportunity for increased use of gas in the tramsportation sector and in electricity generation by nonutility power producers and encourages increased growth in gaspowered electric generation plants. Order 6.36, "the restructuring rule," will provide opportunities to all natural gas industry segments to improve efficiency and reliahility

\section{Electronic Bulletin Boards}

FERC Order 6.36 requires that interstate pipeline companies maintain electronic bulletin boards $(E B B)$ as an equitable way for pipeline customers to obtain information about capacity release and other services offered by the pipelines in a timely and nondiscrimmatory manner. The EBB will contain data on firm capacity available directly from the transporter or released capacity from firm transportation customers. Information needed to make transactions must be posted by the pipelines in a timely fashion and be available $t o$ all traders. 
The electronic bulletin boards must be interactive for the bidding and posting process. Transporters who cannot provide on-line interactive bidding and posting must explain why in their restructuring plan. The transporter's EBB must be available by the effective date of the tariff starting the company's capacity release program. Historical data do not have to be available on the EBB but must be available by some medium.

An industry task force was established to propose standardization on the EBB. The task force submitted its recommendations to FERC in July 1993. On July 30 , 1993, FERC issued a Notice of Proposed Rulemaking which essentially adopted the task force recommendations. The proposed rule would take effect on April 1, 1994. The rule would only cover capacity release transactions by standardizing the data required and specifying operational and file transfer protocols. Other information to be posted on the EBB will be determined later. An industry standards board has been proposed to monitor the development of recommended standards as Order 636 is implemented. 
Table 9. Interstate Movements and Movements Across U.S. Borders of Natural Gas by State, 1992

(Million Cubic Feet)

\begin{tabular}{|c|c|c|c|c|}
\hline \multirow[b]{2}{*}{ State } & \multirow{2}{*}{$\begin{array}{l}\text { State or Country } \\
\text { From/To }\end{array}$} & \multicolumn{3}{|c|}{ Volume } \\
\hline & & $\begin{array}{l}\text { Receipts } \\
\text { From }\end{array}$ & $\begin{array}{c}\text { Deliveries } \\
\text { To }\end{array}$ & Net" \\
\hline \multicolumn{5}{|c|}{ Alabama } \\
\hline & Florida ... & 29 & 327,556 & $-327,528$ \\
\hline & , n........................ & 0 & $1,418,312$ & $-1,418,312$ \\
\hline & Mississippi ........ & $2,792,458$ & 45,000 & $2,747,458$ \\
\hline & 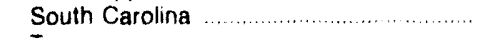 & & $b_{6}$ & -6 \\
\hline & 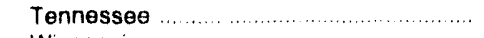 & 424 & $1,042,556$ & $-1,042,133$ \\
\hline & Wisconsin & 0 & b 13 & -13 \\
\hline & 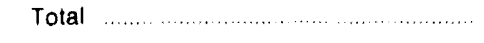 & $2,792,910$ & $2,833,444$ & $-40,535$ \\
\hline \multicolumn{5}{|l|}{ Alaska } \\
\hline & Japan & 0 & c 52,532 & -52.532 \\
\hline & Total ......... & 0 & 52,532 & -52.532 \\
\hline \multicolumn{5}{|c|}{ Arizona } \\
\hline & California & 0 & $1,083,121$ & $-1,083,121$ \\
\hline & Mexico ..... & 0 & 2,565 & $-2,565$ \\
\hline & Nevada & 0 & 34,376 & $-34,376$ \\
\hline & New Mexico $\ldots \ldots \ldots \ldots \ldots \ldots$ & $1,244.223$ & 0 & $1,244,223$ \\
\hline & Total & $1,244,223$ & $1,120,062$ & 124.161 \\
\hline \multicolumn{5}{|c|}{ Arkansas } \\
\hline & $\ldots \ldots \ldots \ldots \ldots \ldots \ldots \ldots \ldots \ldots \ldots \ldots \ldots \ldots \ldots \ldots$ & $1,605,426$ & 136.460 & $1.468,967$ \\
\hline & - & 0 & $1,602,086$ & $-1,602,086$ \\
\hline & Missouri .... & 641 & 449,782 & $-449,141$ \\
\hline & (. & 339,222 & 0 & 339,222 \\
\hline & Texas $\ldots \ldots$ & 290,257 & 4,930 & 285.327 \\
\hline & Total & $2,235,546$ & $2,193,2.58$ & 42,289 \\
\hline \multicolumn{5}{|c|}{ California } \\
\hline & Arizona & $1,083,121$ & 0 & $1,083,121$ \\
\hline & … & 180,832 & 0 & 180,832 \\
\hline & 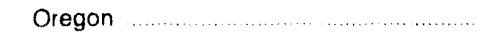 & 346,755 & 0 & 346,755 \\
\hline & Total & $1,610,708$ & 0 & $1,610,708$ \\
\hline \multicolumn{5}{|c|}{ Colorado } \\
\hline & 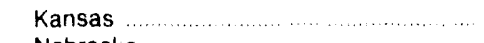 & 93 & 77.652 & $-77,560$ \\
\hline & Nebraska $\ldots \ldots \ldots$ & 108,534 & 118.093 & $-9,559$ \\
\hline & New Mexico $\ldots$ & 23,204 & 158,660 & $-135,456$ \\
\hline & Oklahoma $\ldots \ldots \ldots \ldots \ldots \ldots$ & 19,976 & 76,586 & $-56,611$ \\
\hline & Utah & 56,219 & 10,356 & 45,863 \\
\hline & Wyoming & 315,098 & 132,423 & 182,676 \\
\hline & Total .................. & 523,124 & 573,771 & $-.50,647$ \\
\hline \multicolumn{5}{|c|}{ Connecticut } \\
\hline & Massachusetts & 2,449 & 0 & 2,449 \\
\hline & New York & 334,523 & 57,811 & 276.712 \\
\hline & Rhode Island & 0 & 160,560 & $-160,560$ \\
\hline & Total ............. & 336,972 & 218,371 & 118.601 \\
\hline \multicolumn{5}{|c|}{ Delaware } \\
\hline & $\ldots \ldots \ldots \ldots \ldots \ldots \ldots \ldots \ldots \ldots$ & 0 & 3,230 & $-3,230$ \\
\hline & 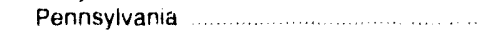 & 40,864 & 0 & 40,864 \\
\hline & Total $\ldots \ldots . . . .$. & 40,864 & 3,230 & 37,634 \\
\hline \multicolumn{5}{|c|}{ District of Columbia } \\
\hline & 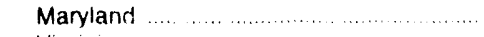 & 11,346 & 0 & 11,346 \\
\hline & Virginia & 22,076 & 0 & 22,076 \\
\hline
\end{tabular}

See footnotes at end of table. 
Table 9. Interstate Movements and Movements Across U.S. Borders of Natural Gas by State, 1992 (Continued)

(Million Cubic Feet)

\begin{tabular}{|c|c|c|c|c|}
\hline \multirow[b]{2}{*}{ State } & \multirow{2}{*}{$\begin{array}{l}\text { State or Country } \\
\text { From/To }\end{array}$} & \multicolumn{3}{|c|}{ Volume } \\
\hline & & $\begin{array}{l}\text { Receipts } \\
\text { From }\end{array}$ & $\begin{array}{l}\text { Deliveries } \\
\text { To }\end{array}$ & Net \\
\hline \multicolumn{5}{|c|}{ District of Columbia } \\
\hline & Total ................ & 33,422 & 0 & 33,422 \\
\hline \multicolumn{5}{|c|}{ 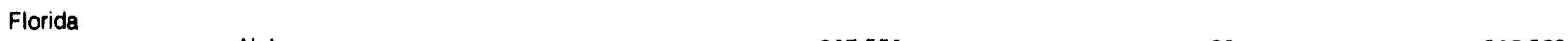 } \\
\hline & 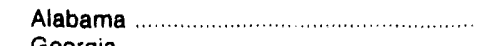 & 327,556 & 29 & 327,528 \\
\hline & Georgia & 13,798 & 0 & 13,798 \\
\hline & 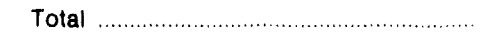 & 341,354 & 29 & 341,325 \\
\hline \multicolumn{5}{|c|}{ Georgia } \\
\hline & 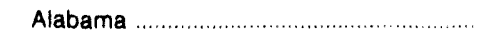 & $1,418,312$ & 0 & $1,418,312$ \\
\hline & Florida & 0 & 13,798 & $-13,798$ \\
\hline & 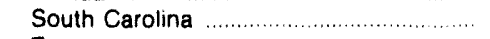 & 0 & $1,065,949$ & $-1,065,949$ \\
\hline & Tennessee & 0 & 5,599 & $-5,599$ \\
\hline & 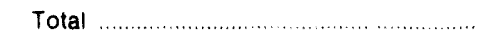 & $1,418,312$ & $1,085,345$ & 332,967 \\
\hline \multicolumn{5}{|c|}{ 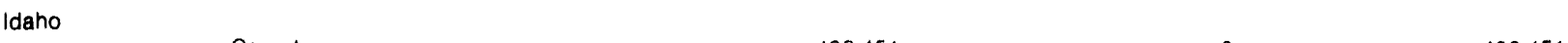 } \\
\hline & 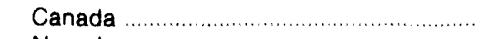 & 496,451 & 0 & 496,451 \\
\hline & 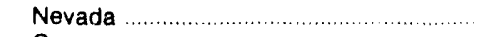 & 0 & 40,293 & $-40,293$ \\
\hline & 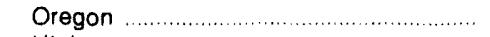 & 101,735 & 0 & 101,735 \\
\hline & Utah & 83 & 0 & 83 \\
\hline & Washington & 1,771 & 489,429 & $-487,658$ \\
\hline & 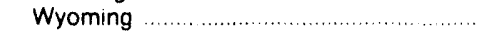 & 0 & 14.120 & $-14,120$ \\
\hline & Total & 600,040 & 543,842 & 56,198 \\
\hline \multicolumn{5}{|l|}{ Illinois } \\
\hline & 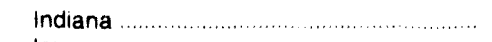 & 167,936 & 836,916 & $-668,980$ \\
\hline & 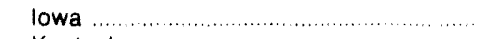 & 831.679 & 30,679 & 800,999 \\
\hline & 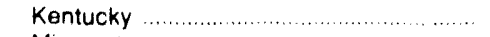 & 390,368 & 0 & 390,368 \\
\hline & 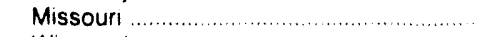 & 742,981 & 12,236 & 730,744 \\
\hline & 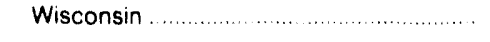 & 1,293 & 232,983 & $-231,690$ \\
\hline & 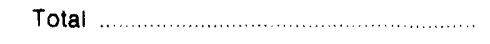 & $2,134,256$ & $1,112,815$ & $1,021,441$ \\
\hline \multicolumn{5}{|c|}{ Indiana } \\
\hline & Illinois .... & 836.916 & 167.936 & 668,980 \\
\hline & 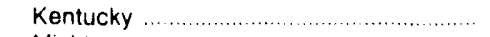 & 726,236 & 0 & 726,236 \\
\hline & 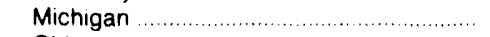 & 0 & 148,079 & $-148,079$ \\
\hline & Ohio & 0 & 766,768 & $-766,768$ \\
\hline & (2) & 1.563 .152 & $1,082,783$ & 480,369 \\
\hline \multicolumn{5}{|l|}{ lowa } \\
\hline & 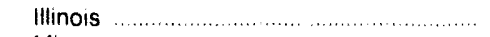 & 30.679 & 831,679 & $-800,999$ \\
\hline & 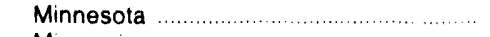 & 461,828 & 195,239 & 266,590 \\
\hline & 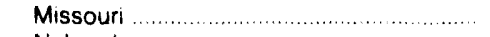 & 230,275 & 0 & 230,275 \\
\hline & 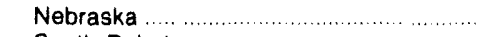 & 547,031 & 0 & 547,031 \\
\hline & South Dakota & 269 & 491 & -222 \\
\hline & 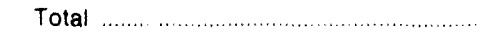 & $1,270,083$ & $1,027,408$ & 242,675 \\
\hline \multicolumn{5}{|c|}{ Kansas } \\
\hline & 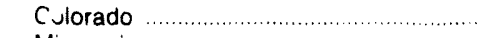 & 77,652 & 93 & 77,560 \\
\hline & 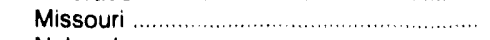 & 0 & 511.396 & $-511,396$ \\
\hline & 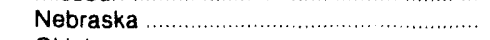 & 2 & 771,795 & $-771,793$ \\
\hline & Oklahoma & 969,819 & 21,858 & 947,961 \\
\hline & 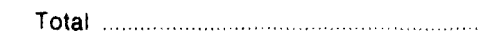 & $1,047,474$ & $1,305,142$ & $-257,668$ \\
\hline \multicolumn{5}{|c|}{ Kentucky } \\
\hline & 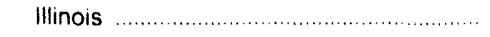 & 0 & 390,368 & $-390,368$ \\
\hline
\end{tabular}

See footnotes at end of table. 
Table 9. Interstate Movements and Movements Across U.S. Borders of Natural Gas by State, 1992 (Continued)

(Million Cubic Feet)

\begin{tabular}{|c|c|c|c|c|}
\hline \multirow[b]{2}{*}{ State } & \multirow{2}{*}{$\begin{array}{l}\text { State or Country } \\
\text { From/To }\end{array}$} & \multicolumn{3}{|c|}{ Volume } \\
\hline & & $\begin{array}{l}\text { Receipts } \\
\text { From }\end{array}$ & $\begin{array}{l}\text { Deliveries } \\
\text { To }\end{array}$ & Net" \\
\hline \multicolumn{5}{|c|}{ Kentucky } \\
\hline & Indiana & 0 & 726,236 & $-726,236$ \\
\hline & Ohio & 6,091 & $1,140,317$ & $-1,134,226$ \\
\hline & Tennessee & $3,191,791$ & 2,128 & $3,189,664$ \\
\hline & West Virginia & 0 & 764.102 & $-764,102$ \\
\hline & Total & $3,197,882$ & $3,023,149$ & 174,733 \\
\hline \multicolumn{5}{|c|}{ Louisiana } \\
\hline & Algeria & c 12,637 & 0 & 12,637 \\
\hline & Arkansas & 136,460 & $1,605,426$ & $-1,468,967$ \\
\hline & 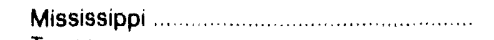 & 942 & $3,550,317$ & $-3,549,374$ \\
\hline & 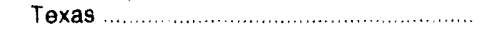 & $1,732,781$ & 10.135 & $1,722,647$ \\
\hline & Total & $1,882,820$ & $5,165,877$ & $-3,283,057$ \\
\hline \multicolumn{5}{|l|}{ Maine } \\
\hline & 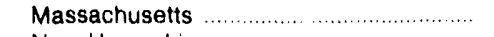 & b 26 & 0 & 26 \\
\hline & New Hampshire & 5,135 & 0 & 5,135 \\
\hline & Total & 5,161 & 0 & 5,161 \\
\hline \multicolumn{5}{|c|}{ Maryland } \\
\hline & Delaware & 3,230 & 0 & 3,230 \\
\hline & District of Columbia . & 0 & 11,346 & $-11,346$ \\
\hline & Pennsylvania & 59,014 & 732,000 & $-672,985$ \\
\hline & 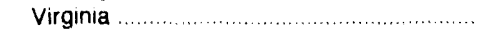 & 896,839 & 23,315 & 873,524 \\
\hline & Total $\ldots \ldots \ldots \ldots \ldots \ldots \ldots \ldots$ & 959,084 & 766.661 & 192,423 \\
\hline \multicolumn{5}{|c|}{ Massachusetts } \\
\hline & Algeria $\ldots . . . . .$. & c 30,479 & 0 & 30,479 \\
\hline & Connecticut & 0 & 2.449 & $-2,449$ \\
\hline & Maine & 0 & b 26 & -26 \\
\hline & New Hampshire & 0 & 14,457 & $-14,457$ \\
\hline & 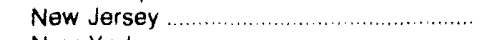 & 0 & b 14 & -14 \\
\hline & New York & 202,331 & 0 & 202,331 \\
\hline & 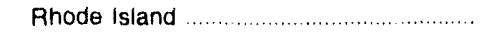 & 132,486 & 45,248 & 87,238 \\
\hline & Total & 365,295 & 62,194 & 303,101 \\
\hline \multicolumn{5}{|c|}{ Michigan } \\
\hline & Canada $\ldots \ldots \ldots$ & 38,568 & 539,369 & $-500,801$ \\
\hline & Indiana & 148,079 & 0 & 148,079 \\
\hline & Ohio & 288,724 & 0 & 288,724 \\
\hline & 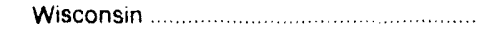 & 698,977 & 0,268 & 692,709 \\
\hline & Total & $1,174,348$ & 545,637 & 628,711 \\
\hline \multicolumn{5}{|c|}{ Minnesota } \\
\hline & Canada & 855.300 & 0 & 855,300 \\
\hline & lowa & 195,239 & 461,828 & $-266,590$ \\
\hline & North Dakota & 0 & 7,886 & $-7,886$ \\
\hline & 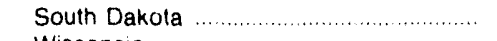 & 505,390 & 0 & 505,390 \\
\hline & 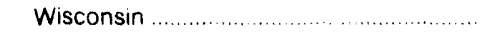 & 6,001 & 818,678 & $-812,678$ \\
\hline & $\ldots \ldots \ldots \ldots \ldots \ldots \ldots \ldots$ & $1,561,929$ & $1,288,392$ & 273,537 \\
\hline \multicolumn{5}{|c|}{ Mississippi } \\
\hline & Alabama & 45.000 & $2,792,458$ & $-2,747,458$ \\
\hline & Arkansas & $1,602,086$ & 0 & $1,602,086$ \\
\hline & Louisiana & $3,550,317$ & 942 & $3,549,374$ \\
\hline & 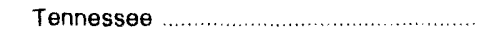 & 860 & $2,309.756$ & $-2,308,896$ \\
\hline & Total & $5,198,262$ & $5,103,156$ & 95,107 \\
\hline
\end{tabular}

See footnotes at end of table. 
Table 9. Interstate Movements and Movements Across U.S. Borders of Natural Gas by State, 1992 (Continued)

(Million Cubic Feet)

\begin{tabular}{|c|c|c|c|c|}
\hline \multirow[b]{2}{*}{ State } & \multirow{2}{*}{$\begin{array}{l}\text { State or Country } \\
\text { From/To }\end{array}$} & \multicolumn{3}{|c|}{ Volume } \\
\hline & & $\begin{array}{l}\text { Receipts } \\
\text { From }\end{array}$ & $\begin{array}{c}\text { Deliveries } \\
\text { To }\end{array}$ & Net* \\
\hline \multicolumn{5}{|c|}{ Missouri } \\
\hline & Arkansas & 449,782 & 641 & 449,141 \\
\hline & Illinois & 12,236 & 742,981 & $-730,744$ \\
\hline & 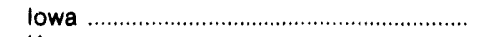 & 0 & 230,275 & $-230,275$ \\
\hline & 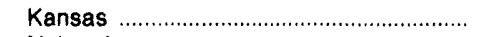 & 511,396 & 0 & 511,396 \\
\hline & 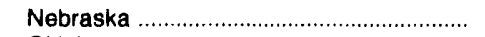 & 232,880 & 0 & 232,880 \\
\hline & 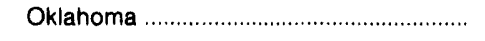 & 12,730 & 497 & 12,233 \\
\hline & Total & $1,219,024$ & 974,394 & 244,630 \\
\hline \multicolumn{5}{|c|}{ Montana } \\
\hline & Canada & 467,036 & 14,569 & 452,467 \\
\hline & 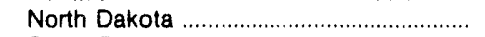 & 13,429 & 457,706 & $-444,277$ \\
\hline & South Dakota & 0 & 6,969 & $-6,969$ \\
\hline & 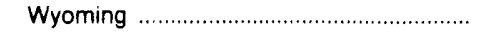 & 8,362 & 14,140 & $-5,777$ \\
\hline & 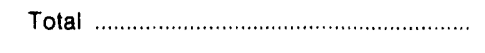 & 488,827 & 493,384 & $-4,557$ \\
\hline \multicolumn{5}{|c|}{ Nebraska } \\
\hline & 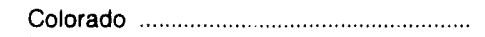 & 118,093 & 108,534 & 9,559 \\
\hline & lowa & 0 & 547,031 & $-547,031$ \\
\hline & 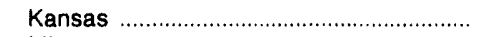 & 771,795 & 2 & 771,793 \\
\hline & 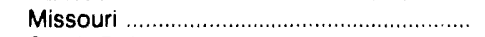 & 0 & 232,880 & $-232,880$ \\
\hline & 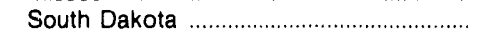 & 0 & 10,188 & $-10,188$ \\
\hline & 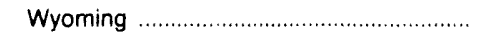 & 131,929 & 0 & 131,929 \\
\hline & 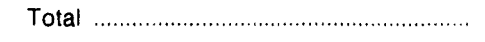 & $1,021,817$ & 898,635 & 123,182 \\
\hline \multicolumn{5}{|c|}{ Nevada } \\
\hline & 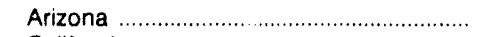 & 34,376 & 0 & 34,376 \\
\hline & 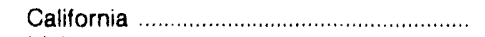 & 0 & 180,832 & $-180,832$ \\
\hline & 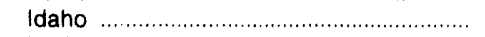 & 40,293 & 0 & 40,293 \\
\hline & 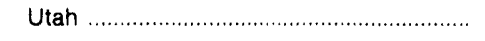 & 185,231 & 0 & 185,231 \\
\hline & 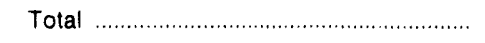 & 259.899 & 180,832 & 79,067 \\
\hline \multicolumn{5}{|c|}{ New Hampshire } \\
\hline & 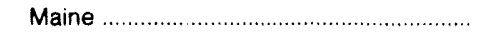 & 0 & 5,135 & $-5,135$ \\
\hline & 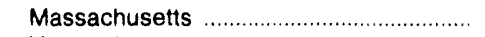 & 14,457 & 0 & 14,457 \\
\hline & 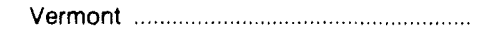 & 9,653 & 0 & 9,653 \\
\hline & 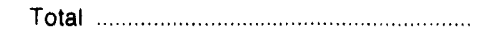 & 24,110 & 5,135 & 18,975 \\
\hline \multicolumn{5}{|c|}{ New Jersey } \\
\hline & 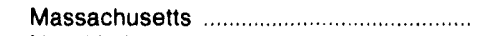 & b 14 & 0 & 14 \\
\hline & 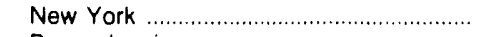 & 0 & 628,131 & $-628,131$ \\
\hline & Pennsylvania & $1,108,744$ & 0 & $1,108,744$ \\
\hline & ............................ & $1,108,758$ & 628,131 & 480,627 \\
\hline \multicolumn{5}{|c|}{ New Mexico } \\
\hline & (2) & 0 & $1,244,223$ & $-1,244,223$ \\
\hline & 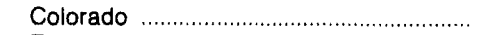 & 158,660 & 23,204 & 135,456 \\
\hline & 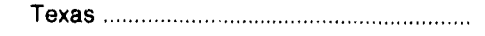 & 278,127 & 81,093 & 197,034 \\
\hline & 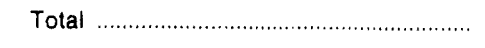 & 436,787 & $1,348,520$ & $-911,733$ \\
\hline \multicolumn{5}{|c|}{ New York } \\
\hline & 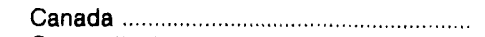 & 435,470 & 0 & 435,470 \\
\hline & 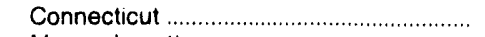 & 57,811 & 334,523 & $-276,712$ \\
\hline & 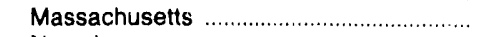 & 0 & 202,331 & $-202,331$ \\
\hline & 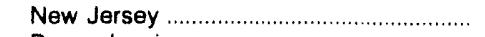 & 628,131 & 0 & 628,131 \\
\hline & 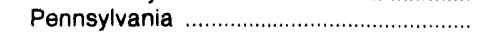 & 435,235 & 22,990 & 412,245 \\
\hline & 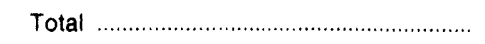 & $1,556,648$ & 559,844 & 996,803 \\
\hline
\end{tabular}

See footnotes at end of table. 
Table 9. Interstate Movements and Movements Across U.S. Borders of Natural Gas by State, 1992 (Continued)

(Million Cubic Feet)

\begin{tabular}{|c|c|c|c|c|}
\hline \multirow[b]{2}{*}{ State } & \multirow{2}{*}{$\begin{array}{l}\text { State or Country } \\
\text { From /To }\end{array}$} & \multicolumn{3}{|c|}{ Volume } \\
\hline & & $\begin{array}{l}\text { Receipts } \\
\text { From }\end{array}$ & $\begin{array}{l}\text { Deliveries } \\
\text { To }\end{array}$ & Net \\
\hline \multicolumn{5}{|c|}{ North Carolina } \\
\hline & $\begin{array}{l}\text { South Carolina } \\
\text { Virginia }\end{array}$ & $\begin{array}{r}937,086 \\
6,637\end{array}$ & $\begin{array}{r}0 \\
752,237\end{array}$ & $\begin{array}{r}937,086 \\
-745,600\end{array}$ \\
\hline & Total & 943,723 & 752,237 & 191,486 \\
\hline \multicolumn{5}{|c|}{ North Dakota } \\
\hline & 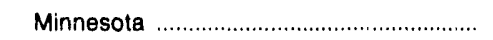 & 7,886 & 0 & 7,886 \\
\hline & 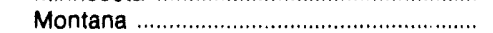 & 457,706 & 13,429 & 444,277 \\
\hline & 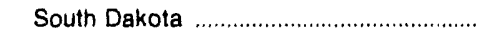 & 0 & 514,901 & $-514,901$ \\
\hline & 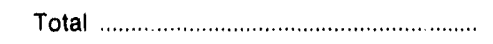 & 465,592 & 528,330 & $-62,738$ \\
\hline \multicolumn{5}{|l|}{ Ohio } \\
\hline & Indiana & 766,768 & 0 & 766,768 \\
\hline & Kentucky & $1,140,317$ & 6,091 & $1,134,226$ \\
\hline & Michigan & 0 & 288,724 & $-288,724$ \\
\hline & 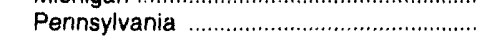 & 11,909 & 493,236 & $-481,327$ \\
\hline & West Virginia & 206,676 & 693,750 & $-487,074$ \\
\hline & Total & $2,125,670$ & $1,481,800$ & 643,869 \\
\hline \multicolumn{5}{|c|}{ Oklahoma } \\
\hline & 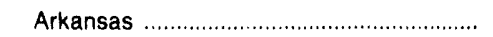 & 0 & 339,222 & $-339,222$ \\
\hline & Colorado & 76,586 & 19,976 & 56,611 \\
\hline & 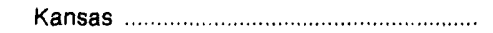 & 21,858 & 969,819 & $-947,961$ \\
\hline & 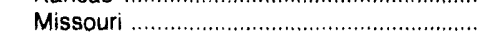 & 497 & 12,730 & $-12,233$ \\
\hline & Texas & 446,921 & 470,632 & $-23,710$ \\
\hline & 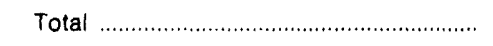 & 545,863 & $1,812,379$ & $-1,266,516$ \\
\hline \multicolumn{5}{|c|}{ Oregon } \\
\hline & California & 0 & 346,755 & $-346,755$ \\
\hline & idaho & 0 & 101,735 & $-101,735$ \\
\hline & Washington & 541,201 & 1,771 & 539,430 \\
\hline & Total & 541,201 & 450,261 & 90,940 \\
\hline \multicolumn{5}{|c|}{ Pennsylvania } \\
\hline & Delaware & 0 & 40,864 & $-40,864$ \\
\hline & 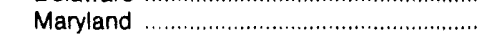 & 732,000 & 59,014 & 672,985 \\
\hline & 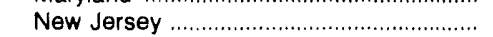 & 0 & $1,108,744$ & $-1,108,744$ \\
\hline & New York & 22,990 & 435,235 & $-412,245$ \\
\hline & Ohio & 493,236 & 11,909 & 481,327 \\
\hline & West Virginia & 992,678 & 5,897 & 986,780 \\
\hline & 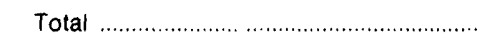 & $2,240,904$ & $1,661,664$ & 579,240 \\
\hline \multicolumn{5}{|c|}{ Rhode Island } \\
\hline & 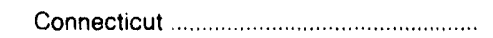 & 160,560 & 0 & 160,560 \\
\hline & 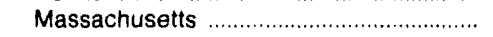 & 45,248 & 132,486 & $-87,238$ \\
\hline & Total & 205,808 & 132,486 & 73,322 \\
\hline \multicolumn{5}{|c|}{ South Carolina } \\
\hline & Alabama & b 6 & 0 & 6 \\
\hline & Georgia & $1,065,949$ & 0 & $1,065,949$ \\
\hline & North Carolina & 0 & 937,086 & $-937,086$ \\
\hline & Total & $1,065,954$ & 937,086 & 128,868 \\
\hline \multicolumn{5}{|c|}{ South Dakota } \\
\hline & lowa & 491 & 269 & 222 \\
\hline & Minnesota & 0 & 505,390 & $-505,390$ \\
\hline
\end{tabular}

See footnotes at end of table. 
Table 9. Interstate Movements and Movements Across U.S. Borders of Natural Gas by State, 1992 (Continued)

(Million Cubic Feet)

\begin{tabular}{|c|c|c|c|c|}
\hline \multirow[b]{2}{*}{ State } & \multirow{2}{*}{$\begin{array}{l}\text { State or Country } \\
\text { From/To }\end{array}$} & \multicolumn{3}{|c|}{ Volume } \\
\hline & & $\begin{array}{l}\text { Receipts } \\
\text { From }\end{array}$ & $\begin{array}{l}\text { Deliveries } \\
\text { To }\end{array}$ & Net* \\
\hline \multicolumn{5}{|c|}{ South Dakota } \\
\hline & Montana ............................................... & 6,969 & 0 & 6,969 \\
\hline & 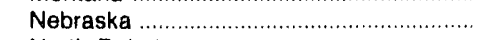 & 10,188 & 0 & 10,188 \\
\hline & 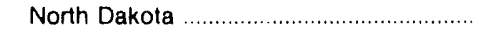 & 514,901 & 0 & 514,901 \\
\hline & 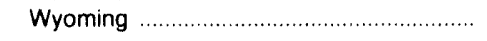 & 0 & 665 & -665 \\
\hline & 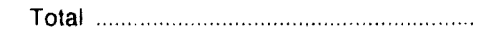 & 532,549 & 506,324 & 26,225 \\
\hline \multicolumn{5}{|c|}{ Tennessee } \\
\hline & Alabama & $1,042,556$ & 424 & $1,042,133$ \\
\hline & 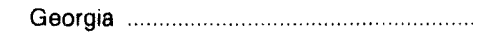 & 5,599 & 0 & 5,599 \\
\hline & 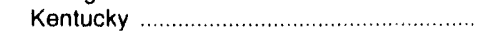 & 2,128 & $3,191,791$ & $-3,189,664$ \\
\hline & 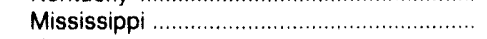 & $2,309,756$ & 860 & $2,308,896$ \\
\hline & 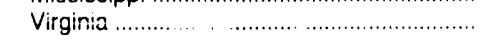 & 1,896 & 0 & 1,896 \\
\hline & Total & $3,361,934$ & $3,193,074$ & 168,860 \\
\hline \multicolumn{5}{|c|}{$\mathrm{At}$} \\
\hline & Arkansas & 4,930 & 290,257 & $-285,327$ \\
\hline & 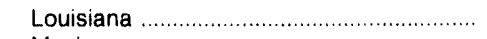 & 10,135 & $1,732,781$ & $-1,722,647$ \\
\hline & 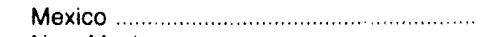 & 0 & 93,408 & $-93,408$ \\
\hline & 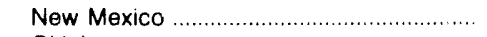 & 81,093 & 278,127 & $-197,034$ \\
\hline & 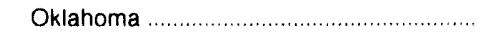 & 470,632 & 446,921 & 23,710 \\
\hline & Total & 566,789 & $2,841,494$ & $-2,274,705$ \\
\hline \multicolumn{5}{|c|}{ Oat 20} \\
\hline & Colorado & 10,356 & 56,219 & $-45,863$ \\
\hline & 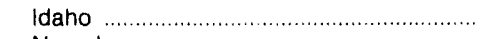 & 0 & 83 & -83 \\
\hline & 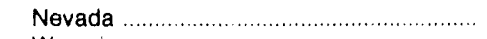 & 0 & 185,231 & $-185,231$ \\
\hline & 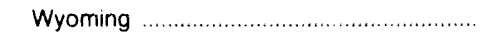 & 323,297 & 31,777 & 291,519 \\
\hline & 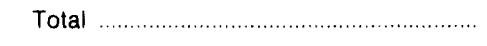 & 333,653 & 273,310 & 60,343 \\
\hline \multicolumn{5}{|c|}{ Vermont } \\
\hline & Canada ................ & 17.248 & 0 & 17,248 \\
\hline & 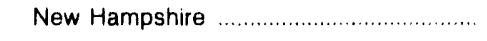 & 0 & 9,653 & $-9,653$ \\
\hline & 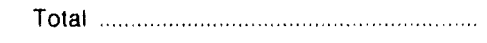 & 17,248 & 9,653 & 7,595 \\
\hline \multicolumn{5}{|c|}{ 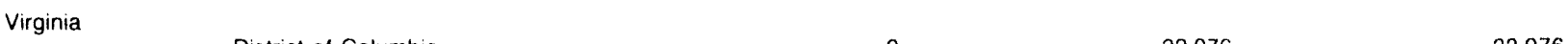 } \\
\hline & 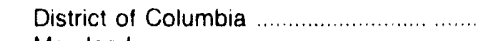 & 0 & 22,076 & $-22,076$ \\
\hline & 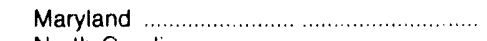 & 23,315 & 896,839 & $-873,524$ \\
\hline & North Carolina & 752,237 & 6,637 & 745,600 \\
\hline & 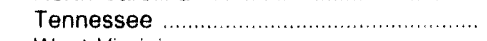 & 0 & 1,896 & $-1,896$ \\
\hline & 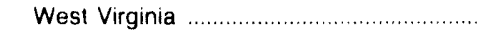 & 343,866 & 2.570 & 341,296 \\
\hline & 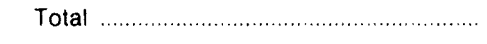 & $1,119,418$ & 930,018 & 189,401 \\
\hline \multicolumn{5}{|c|}{ Washington } \\
\hline & 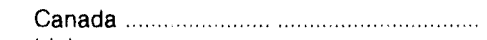 & 270,477 & 0 & 270,477 \\
\hline & 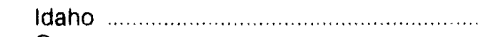 & 489,429 & 1,771 & 487,658 \\
\hline & 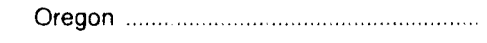 & 1,771 & 541,201 & $-539,430$ \\
\hline & 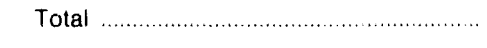 & 761,677 & 542,972 & 218,705 \\
\hline \multicolumn{5}{|c|}{ West Virginia } \\
\hline & 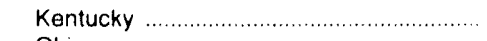 & 764,102 & 0 & 764,102 \\
\hline & Ohio & 693,750 & 206,676 & 487,074 \\
\hline & Pennsylvania & 5,897 & 992,678 & $-986,780$ \\
\hline & $\ldots \ldots \ldots \ldots \ldots \ldots \ldots \ldots \ldots \ldots \ldots \ldots \ldots \ldots \ldots \ldots \ldots$ & 2,570 & 343,866 & $-341,296$ \\
\hline & Total & $1,466,319$ & $1,543,220$ & $-76,90$ \\
\hline \multicolumn{5}{|c|}{ Wisconsin } \\
\hline & Alabama & b 13 & 0 & 13 \\
\hline
\end{tabular}


Table 9. Interstate Movements and Movements Across U.S. Borders of Natural Gas by State, 1992 (Continued)

(Million Cubic Feet)

\begin{tabular}{|c|c|c|c|c|}
\hline \multirow[b]{2}{*}{ State } & \multirow{2}{*}{$\begin{array}{l}\text { State or Country } \\
\text { From/To }\end{array}$} & \multicolumn{3}{|c|}{ Volume } \\
\hline & & $\begin{array}{l}\text { Receipts } \\
\text { From }\end{array}$ & $\begin{array}{l}\text { Deliveries } \\
\text { To }\end{array}$ & Net" \\
\hline \multicolumn{5}{|c|}{ Wisconsin } \\
\hline & 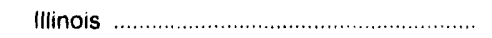 & 232,983 & 1,293 & 231.690 \\
\hline & 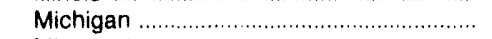 & 6,268 & 698,977 & $-692,709$ \\
\hline & 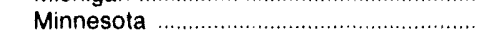 & 818,678 & 6,001 & 812,678 \\
\hline & 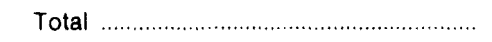 & $1,057,942$ & 706,270 & 351,672 \\
\hline \multicolumn{5}{|c|}{ Wyoming } \\
\hline & 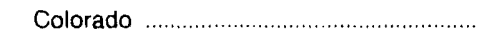 & 132,423 & 315,098 & $-182,676$ \\
\hline & Idaho ....... & 14,120 & 0 & 14,120 \\
\hline & Montana ............. & 14,140 & 8,362 & 5,777 \\
\hline & (n) & 0 & 131,929 & $-131,929$ \\
\hline & South Dakota & 665 & 0 & 665 \\
\hline & 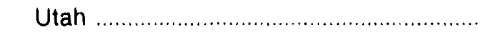 & 31,777 & 323,297 & $-291,519$ \\
\hline & 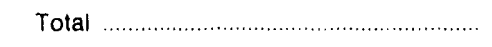 & 193,125 & 778,686 & $-585,561$ \\
\hline \multicolumn{2}{|c|}{ 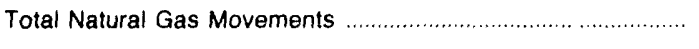 } & $55,198,462$ & $53,277,237$ & $1,921,225$ \\
\hline \multicolumn{2}{|c|}{ 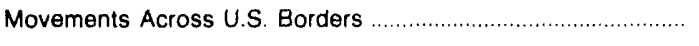 } & $2,623,667$ & - 702,443 & $1,921,224$ \\
\hline \multicolumn{2}{|c|}{ 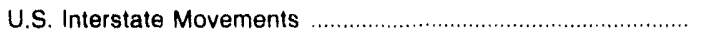 } & $52,574,794$ & $52,574,794$ & 0 \\
\hline
\end{tabular}

- =Positive numbers denote net receipts; negative numbers denote net deliveries.

b = Trucked liquetied natural gas (LNG)

c = LNG transported by tanker.

$d=$ Volumes include 2,137,504 miltion cubic feet of imports from Algeria and Canada, and 486,163 million cubic feet of intransit natural gar . ceipts from Canada.

- Volumes include 216,282 million cubic feet of exports to Japan, Canada, and Mexico and 486,161 million cubic feet of intransit natural gas deliveries to Canada.

Note: Totals may not equal sum of components due to independent rounding

Source: Energy information Administration (EIA), Form E|A-176, "Annual Report of Natural and Supplemental Gas Stipply and Disposition." 
Figure 6. Interstate Movements of Natural Gas in the United States, 1992 (Million Cubic Feet)

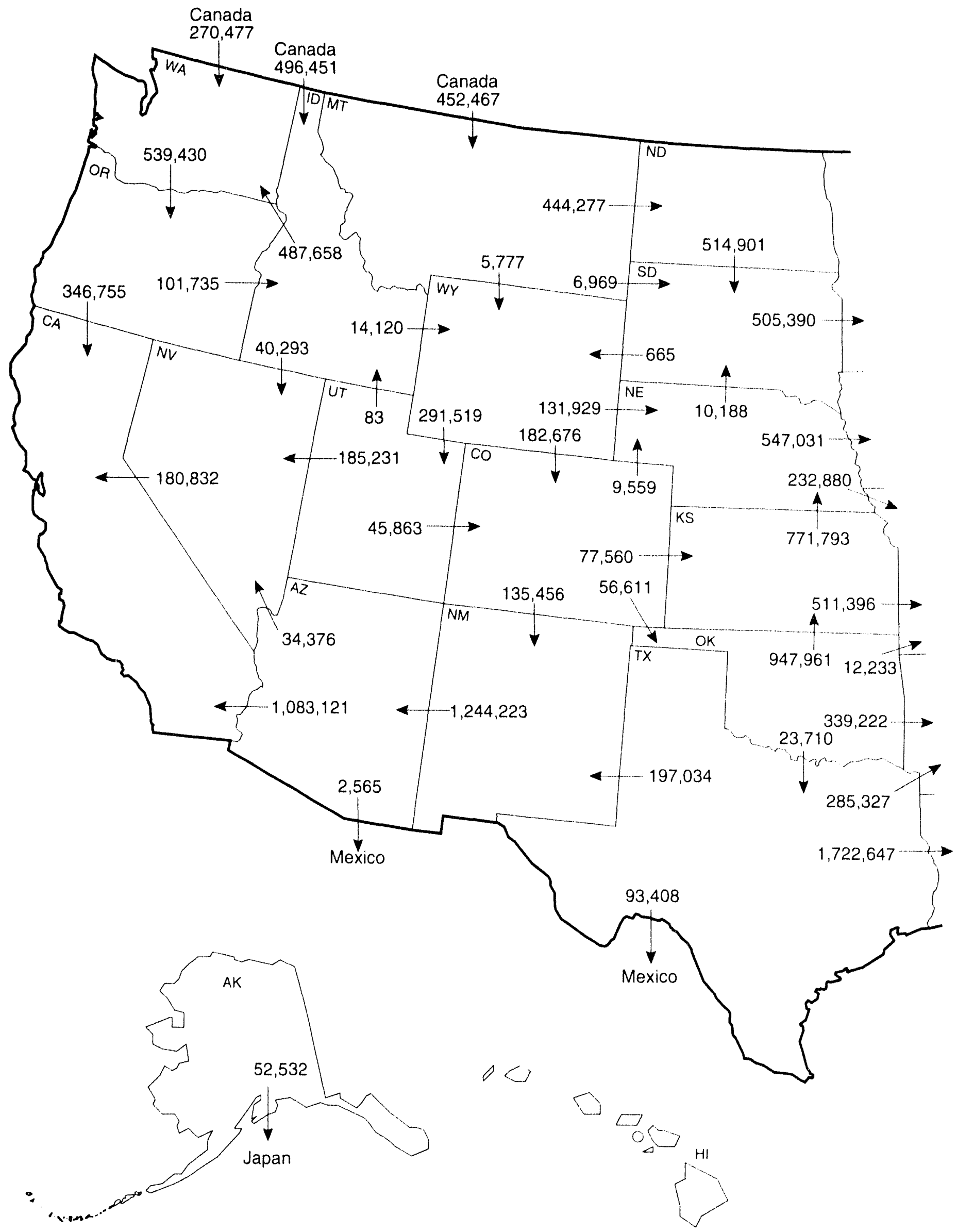

36

Energy Information Administration/Natural Gas Annual 1992 Volume 1 


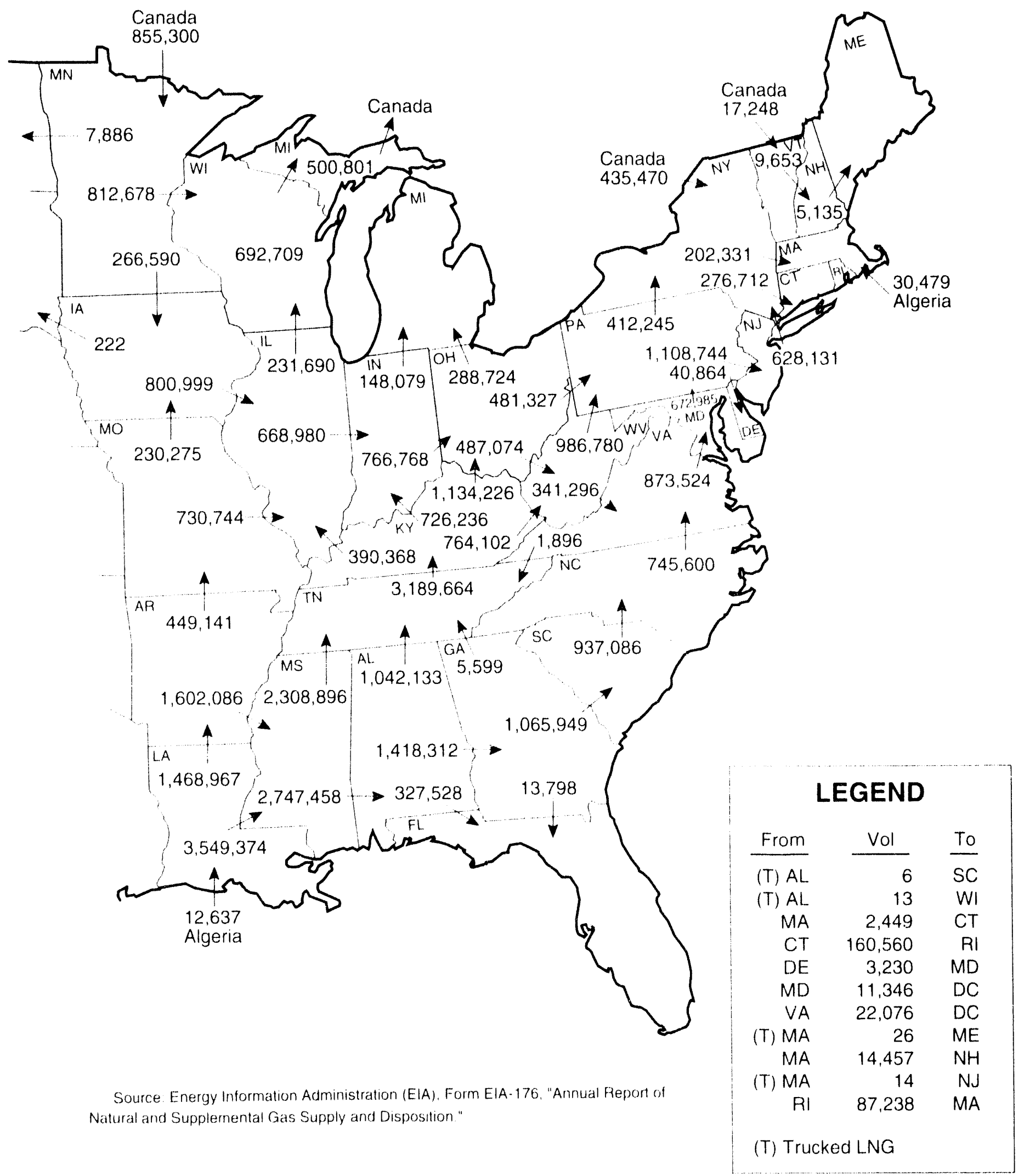


Table 10. Summary of U.S. Natural Gas Imports and Exports, 1988-1992

\begin{tabular}{|c|c|c|c|c|c|}
\hline & 1988 & 1989 & 1990 & 1991 & 1992 \\
\hline & \multicolumn{5}{|c|}{ Volume (million cubic feet) } \\
\hline \multicolumn{6}{|l|}{$\begin{array}{l}\text { Imports } \\
\text { Pipeline }\end{array}$} \\
\hline , & $1,276,322$ & $1,339,357$ & $1,448,065$ & $1,709.716$ & $2,094,387$ \\
\hline \multirow{3}{*}{$\begin{array}{l}\text { Algeria } \\
\text { Total Imports }\end{array}$} & 17.490 & 42,163 & 84,193 & 63,596 & 43,116 \\
\hline & $1,293,812$ & $1,381,520$ & $1,532,259$ & $1,773,313$ & $2,137,504$ \\
\hline & \multicolumn{5}{|c|}{ Average Price (dollars per thousand cubic teet) } \\
\hline \multicolumn{6}{|l|}{$\begin{array}{l}\text { Imports } \\
\text { Pipeline }\end{array}$} \\
\hline $\begin{array}{l}\text { Canada } \\
\text { LNG }\end{array}$ & $\$ 1.83$ & $\$ 1.81$ & $\$ 1.91$ & $\$ 1.81$ & $\$ 1.84$ \\
\hline Algeria & 2.71 & 2.22 & 2.47 & 2.36 & 2.54 \\
\hline \multirow[t]{2}{*}{ 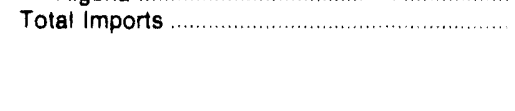 } & 184 & 1.82 & 194 & 1.83 & 1.85 \\
\hline & \multicolumn{5}{|c|}{ Volume (million cubic feet) } \\
\hline \multicolumn{6}{|l|}{$\begin{array}{l}\text { Exports } \\
\text { Pipeline }\end{array}$} \\
\hline Canada & 19.738 & 38,443 & 17,359 & 14.791 & 67,777 \\
\hline Mexico & 2,327 & 17,004 & 15,659 & 60,448 & 95,973 \\
\hline \multicolumn{6}{|l|}{ LNG } \\
\hline 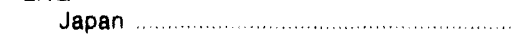 & 51,573 & 51.424 & 52.546 & 54,005 & 52,532 \\
\hline \multirow[t]{2}{*}{ Total Exports } & 73,638 & 106,871 & 85,565 & 129,244 & 216,282 \\
\hline & \multicolumn{5}{|c|}{ Average Price (dollars per thousand cubic leet) } \\
\hline \multicolumn{6}{|l|}{ Exports } \\
\hline Canada & $\$ 2.02$ & $\$ 2.00$ & $\$ 2.70$ & $\$ 191$ & $\$ 1.83$ \\
\hline$\ldots \ldots \ldots \ldots \ldots \ldots \ldots$ & 321 & 2.14 & 188 & 1.76 & 1.90 \\
\hline Total Pipeline Exports $\ldots \ldots \ldots \ldots \ldots$ & 214 & 2.05 & 2.31 & 179 & 1.88 \\
\hline \multicolumn{6}{|l|}{ LNG } \\
\hline Japan & 2.98 & 3.01 & 3.59 & 371 & 343 \\
\hline Total Exports $\ldots \ldots \ldots$ & 2.74 & 2.51 & 3.10 & 259 & 2.25 \\
\hline
\end{tabular}

Source Energy Information Administration, Form FPC.14. "Annual Report for Importers and Exporters of Nalural Gas." 
Table 11. Total Consumption and Net Imports of Natural Gas into the United States, 1972-1992

(Billion Cubic Feet)

\begin{tabular}{|c|c|c|c|}
\hline Year & Total Consumption & Net Imports & $\begin{array}{l}\text { Net Imports as } \\
\text { Percentage of } \\
\text { Total Consumption }\end{array}$ \\
\hline $1972 \ldots \ldots \ldots \ldots$ & 22,101 & 941 & 4.3 \\
\hline $1973 \ldots \ldots \ldots \ldots \ldots$ & 22,049 & 956 & 4.3 \\
\hline 1974 & 21,223 & 882 & 4.2 \\
\hline$\ldots \ldots \ldots \ldots \ldots \ldots \ldots \ldots \ldots$ & 19,538 & 880 & 4.5 \\
\hline 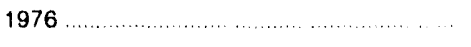 & 19.946 & 899 & 4.5 \\
\hline 1977. & 19,521 & 955 & 4.9 \\
\hline 1978 & 19.627 & 913 & 4.7 \\
\hline $1979 \ldots \ldots \ldots \ldots$ & 20,241 & 1,198 & 59 \\
\hline $1980 \ldots \ldots \ldots \ldots \ldots \ldots$ & 19,877 & 936 & 4.7 \\
\hline$\ldots \ldots \ldots \ldots \ldots \ldots \ldots \ldots \ldots$ & 19,404 & 845 & 4.4 \\
\hline ............ & 18,001 & 882 & 4.9 \\
\hline 1983 & 16.835 & 865 & 5.1 \\
\hline$\ldots \ldots \ldots \ldots$ & 17.953 & 788 & 4.4 \\
\hline 1985 & 17,281 & 894 & 5.2 \\
\hline 1986. & 16,221 & 689 & 4.2 \\
\hline 1987. & 17,211 & 939 & 5.5 \\
\hline $1988 \ldots \ldots \ldots$ & 18.030 & 1.220 & 6.8 \\
\hline 1989 & 18.801 & 1.275 & 68 \\
\hline 1990 & 18.715 & 1,447 & 7.7 \\
\hline $1991 \ldots \ldots$ & 19,054 & 1,644 & 8.6 \\
\hline 1992. & 19,544 & 1,921 & 9.8 \\
\hline
\end{tabular}

Sources: 1972-1975 Bureau of Mines, Minerals Yearbook. "Natural Gas" chapter 1976-1978 Energy Information Administration (ElA). Energy Data Reports, Natural Gas Annual 1979 . ElA. Natural Gas Production" and Consumption 1979 1980-1992 ElA, Forms ElA.176. "Annual Report of Natural and Supplemental Gas Supply and Disposition," and Form FPC-14. "Annual Report for importers and Exporters of Natural Gas." 
Table 12. Additions to and Withdrawals from Gas Storage by State, 1992

(Million Cubic Feet)

\begin{tabular}{|c|c|c|c|c|c|c|c|}
\hline \multirow{2}{*}{ State } & \multicolumn{3}{|c|}{ Underground Storage } & \multicolumn{3}{|c|}{ LNG Storage } & \multirow{2}{*}{$\begin{array}{c}\text { Net Change } \\
\text { in } \\
\text { Storage }\end{array}$} \\
\hline & Injections & Withdrawals & $\mathrm{Net}$ & Additions & Withdrawals & Net & \\
\hline Alabama & 0 & 0 & 0 & 501 & 262 & 239 & 239 \\
\hline 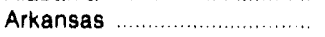 & 2.461 & 2,975 &.-514 & 50 & 51 & -1 & -515 \\
\hline 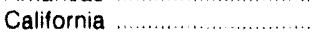 & 148,039 & 176,158 & -28.120 & 13 & 51 & -38 & $-28,158$ \\
\hline 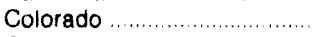 & 23,061 & 27,921 & $-4,860$ & 0 & 0 & 0 & -4.860 \\
\hline 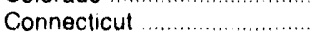 & 0 & 0 & 0 & 359 & 714 & -355 & -355 \\
\hline 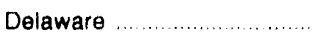 & 0 & 0 & 0 & 61 & 66 & -5 & -5 \\
\hline 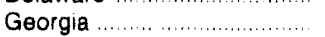 & 0 & 0 & 0 & 1.573 & 1,557 & 16 & 16 \\
\hline 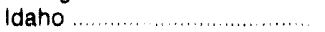 & 0 & 0 & 0 & 1,338 & 1.385 & -47 & -47 \\
\hline 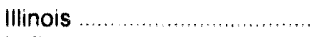 & 214,404 & 223,012 & $-8,608$ & 570 & 348 & 222 & $-8,387$ \\
\hline 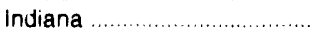 & 25,770 & 26.611 & -840 & 849 & 1,188 & .339 & -1.179 \\
\hline$\ldots \ldots \ldots \ldots \ldots \ldots$ & 65,818 & 70,077 & -4.259 & 4.659 & 4.247 & 412 & -3.846 \\
\hline Kansas & 84,249 & 102,735 & $-18,486$ & 0 & 0 & 0 & $-18,486$ \\
\hline Kentucky & 49,367 & 42,795 & 6.573 & 0 & 0 & 0 & 6.573 \\
\hline 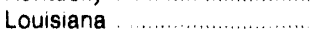 & 193,051 & 207,010 & $-13,958$ & 12,545 & 12,097 & 448 & $-13,511$ \\
\hline 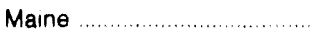 & 0 & 0 & 0 & 26 & 22 & 4 & 4 \\
\hline 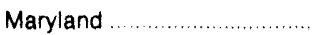 & 19,502 & 19,169 & 333 & 804 & 715 & 89 & 422 \\
\hline Massachusetts & 0 & 0 & 0 & 5,147 & 6,990 & -1.844 & $.1,844$ \\
\hline 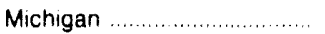 & 390,465 & 392,716 & -2.251 & 0 & 0 & 0 & $-2,251$ \\
\hline Minnesota & 1,372 & 1,329 & 43 & 3,594 & 3,380 & 2.13 & 256 \\
\hline 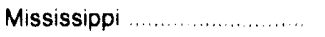 & 55.105 & 53.373 & 1.732 & 0 & 0 & 0 & 1,732 \\
\hline Missouri & 3,080 & 3,094 & -15 & 0 & 0 & 0 & -15 \\
\hline 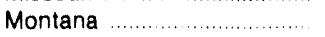 & 11,708 & 24.310 & $-12,602$ & 0 & 0 & 0 & $-12,602$ \\
\hline 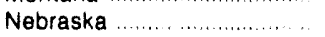 & 10,254 & 9,848 & 407 & 283 & 173 & 111 & 517 \\
\hline Nevada & 0 & 0 & 0 & 83 & 155 & -71 & -71 \\
\hline 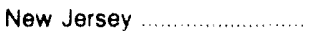 & 0 & 0 & 0 & 2,422 & 2.471 & -49 & -49 \\
\hline New Mexico & 19,963 & 21,421 & -2.458 & 0 & 2,599 & .2599 & $-5,057$ \\
\hline New York ............................. & 62,265 & 60,693 & 1,572 & 732 & 363 & 370 & 1,942 \\
\hline North Carolina & 0 & 0 & 0 & 1.030 & 1,122 & -92 & -92 \\
\hline Ohio & 160,009 & 175,682 & $-15,672$ & 0 & $\begin{array}{r}1 \\
0\end{array}$ & 0 & $-15,672$ \\
\hline Oklahoma ............................. & 97,468 & 107,526 & -10.058 & 0 & 0 & 0 & -10.058 \\
\hline Oregon ........... & 6.114 & 6,985 & -872 & 376 & 409 & -33 & -904 \\
\hline Pennsylvania. & 383,762 & 377,889 & 5,873 & 2,869 & 2.797 & 72 & 5,945 \\
\hline Rhode Island & 0 & 0 & 0 & 796 & 1,216 & -420 & -420 \\
\hline South Carolina & 0 & 0 & 0 & 339 & 323 & 16 & 16 \\
\hline South Dakota. & 0 & 0 & 0 & 24 & 13 & 11 & 11 \\
\hline Tennessee ...... & 0 & 0 & 0 & 2.759 & 3,065 & -306 & -306 \\
\hline 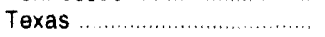 & 340,602 & 384,042 & $-43,441$ & 0 & 0 & 0 & $-43,441$ \\
\hline Utah & 31,222 & 26,740 & 4,482 & 0 & 0 & 0 & 4,482 \\
\hline Virginia & 0 & 0 & 0 & 173 & 168 & 6 & 6 \\
\hline 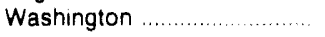 & 13,294 & 18.960 & -5.667 & 0 & 471 & .471 & -6.137 \\
\hline West Virginia. & 138,647 & 146,827 & $-8,180$ & 0 & 0 & 0 & $-8,180$ \\
\hline 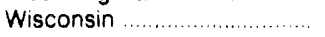 & 0 & 0 & 0 & 57 & 117 &. .59 & -59 \\
\hline 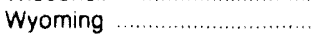 & 5,340 & 13,876 & $-8,536$ & 0 & 0 & 0 & -8.536 \\
\hline 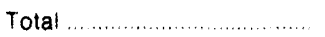 & $2,555,393$ & $2,723,774$ & $-168,381$ & 44,033 & 48,534 & $-4,501$ & $-172,882$ \\
\hline
\end{tabular}

Note: Totals may not equal sum of components due to independent rounding.

Source: Energy Information Administration, Form ElA-176. "Annual Report of Natural and Supplemental Gas Supply and Disposition" 
Table 13. Underground Natural Gas Storage Capacity by State, December 31, 1992 (Capacity in Billion Cubic Feet)

\begin{tabular}{|c|c|c|c|c|c|c|c|c|c|}
\hline \multirow{2}{*}{ State } & \multicolumn{2}{|c|}{$\begin{array}{l}\text { Interstate } \\
\text { Companies }\end{array}$} & \multicolumn{2}{|c|}{$\begin{array}{l}\text { Intrastate } \\
\text { Companies }\end{array}$} & \multicolumn{2}{|c|}{$\begin{array}{l}\text { Independent } \\
\text { Companies }\end{array}$} & \multicolumn{3}{|c|}{ Total } \\
\hline & $\begin{array}{l}\text { Number of } \\
\text { Active } \\
\text { Fields }\end{array}$ & Capacity & $\begin{array}{c}\text { Number of } \\
\text { Active } \\
\text { Fields }\end{array}$ & Capacity & $\begin{array}{c}\text { Number of } \\
\text { Active } \\
\text { Fields }\end{array}$ & Capacity & $\begin{array}{c}\text { Number of } \\
\text { Active } \\
\text { Fields }\end{array}$ & Capacity & $\begin{array}{c}\text { Percerit } \\
\text { of U.S. } \\
\text { Capacity }\end{array}$ \\
\hline Arkansas & 0 & 0 & 4 & 31 & 0 & 0 & 4 & 31 & 0.39 \\
\hline (n. & 0 & 0 & 10 & 472 & 0 & 0 & 10 & 472 & 5.95 \\
\hline Colorado & 4 & 62. & 5 & 44 & 0 & 0 & 9 & 106 & 1.33 \\
\hline lllinois & 7 & 286 & 22 & 663 & 0 & 0 & 29 & 950 & 11.97 \\
\hline Indiana & 5 & 11 & 20 & 95 & 0 & 0 & 25 & 106 & 1.34 \\
\hline lowa & 9 & 280 & 0 & 0 & 0 & 0 & 9 & 280 & 3.53 \\
\hline 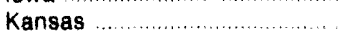 & 19 & 286 & 1 & 4 & 0 & 0 & 20 & 291 & 3.66 \\
\hline Kentucky & 6 & 167 & 17 & 43 & 0 & 0 & 23 & 210 & 2.65 \\
\hline Louisıana & 8 & 530 & 1 & 9 & 0 & 0 & 9 & 539 & 6.80 \\
\hline 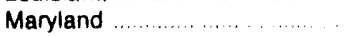 & 1 & 62 & 0 & 0 & 0 & 0 & 1 & 62 & 79 \\
\hline Michigan ... & 29 & 728 & 17 & 266 & 0 & 0 & 46 & 994 & 12.54 \\
\hline Minnesota & 0 & 0 & 1 & 7 & 0 & 0 & 1 & 7 & .09 \\
\hline 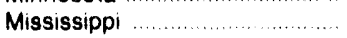 & 3 & 107 & 2 & 8 & 0 & 0 & 5 & 115 & 145 \\
\hline 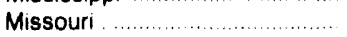 & 0 & 0 & $i$ & 31 & 0 & 0 & 1 & 31 & 39 \\
\hline Montana $\ldots \ldots \ldots \ldots \ldots$ & 1 & 287 & 4 & 88 & 0 & 0 & 5 & 375 & 473 \\
\hline Nebraska & 2 & 93 & 0 & 0 & 0 & 0 & 2 & 93 & 1.18 \\
\hline New Mexico .... & 1 & 69 & 2 & 26 & 0 & 0 & 3 & 95 & 1.19 \\
\hline New York & 22 & 160 & 1 & 8 & 0 & 0 & 23 & 168 & 212 \\
\hline 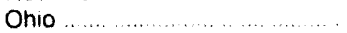 & 15 & 437 & 7 & 155 & 0 & 0 & 22 & 591 & 7.46 \\
\hline OkJahoma $\ldots \ldots \ldots$ & 5 & 207 & 2 & 27 & 5 & 127 & 12 & 360 & 4.53 \\
\hline Oregon ........... & 0 & 0 & 2 & 11 & 0 & 0 & 2 & 11 & .14 \\
\hline Pennsylvania & 35 & 609 & 8 & 37 & 7 & 23 & 50 & 669 & 8.44 \\
\hline 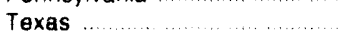 & 13 & 365 & 12 & 229 & 1 & 2 & 26 & 595 & 7.50 \\
\hline Utah & 3 & 112 & 0 & 0 & 1 & 3 & 4 & 115 & 1.45 \\
\hline 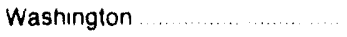 & 1 & 34 & 0 & 0 & 0 & 0 & 1 & 34 & 43 \\
\hline West Virginia & 27 & 476 & 0 & 0 & 12 & 49 & 39 & 525 & 6.62 \\
\hline Wyoming & 3 & 76 & 4 & 30 & 0 & 0 & 7 & 106 & 1.33 \\
\hline Total & 219 & 5.445 & 143 & 2,282 & 26 & 204 & 388 & 7,932 & 100.00 \\
\hline
\end{tabular}

Source: Energy Information Administration (ElA). Form ElA.191. "Underground Gas Storage Repon" 
Table 14. Natural Gas Processed, Liquids Extracted, and Estimated Extraction Loss by State, 1992

\begin{tabular}{|c|c|c|c|c|}
\hline \multirow{2}{*}{$\begin{array}{c}\text { Plant } \\
\text { Location }\end{array}$} & \multirow{2}{*}{$\begin{array}{c}\text { Natural } \\
\text { Gas } \\
\text { Processed } \\
\text { (million cubic feet) }\end{array}$} & \multirow{2}{*}{$\begin{array}{c}\text { Total } \\
\text { Liquids } \\
\text { Extracted } \\
\text { (thousand barrels) }\end{array}$} & \multicolumn{2}{|c|}{ Extraction Loss } \\
\hline & & & $\begin{array}{l}\text { Volume } \\
\text { (million cubic feet) }\end{array}$ & $\begin{array}{c}\text { Estimated } \\
\text { Heat } \\
\text { Content } \\
\text { (billion Btu) }\end{array}$ \\
\hline Alabama & 126,910 & 4,121 & 5,490 & 17,265 \\
\hline Alaska $\ldots \ldots \ldots$ & $2,121,838$ & 27,056 & 32,004 & 120,461 \\
\hline Arkansas $\ldots \ldots$ & 156,573 & 332 & 413 & 1,399 \\
\hline California & 243.692 & 10,171 & 12,385 & 42,970 \\
\hline Colorado & 256,019 & 13,169 & 18,149 & 50.752 \\
\hline$\ldots \ldots \ldots \ldots \ldots \ldots \ldots$ & 226,254 & $2,3: 7$ & 2,563 & 8,976 \\
\hline Illinois $\ldots \ldots \ldots \ldots$ & 942 & 88 & 100 & 382 \\
\hline Kansas $\ldots \ldots \ldots$ & 943,923 & 30.359 & 42,733 & 119,330 \\
\hline Kentucky & 47.425 & 1,795 & 2.342 & 7.076 \\
\hline 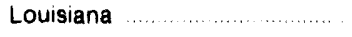 & $4,466,425$ & 93.744 & 132,656 & 352,328 \\
\hline Michigan & 186.144 & 6,207 & 8.093 & 24.692 \\
\hline$\ldots \ldots \ldots \ldots \ldots \ldots \ldots \ldots$ & 4,822 & 319 & 416 & 1,358 \\
\hline Montana & 12,697 & 698 & 907 & 2.925 \\
\hline Nebraska & 65 & 3 & 3 & 0 \\
\hline New Mexicu & 722,433 & 53.543 & 75,520 & 196,848 \\
\hline 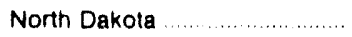 & 50,462 & 4,675 & 6,055 & 19,505 \\
\hline Ohio $\ldots \ldots \ldots \ldots$ & 2,730 & 55 & 72 & 231 \\
\hline Oklahoma $\ldots \ldots \ldots \ldots \ldots \ldots$ & $1,071,426$ & 73,518 & 104,609 & 271,626 \\
\hline Pennsylvanıa & 11,540 & 436 & 604 & 1.815 \\
\hline 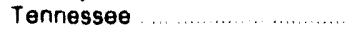 & 0 & 0 & 0 & 0 \\
\hline Texas $\ldots \ldots \ldots$ & $4,231,145$ & 264,766 & 374,126 & $1,006,822$ \\
\hline Utah $\ldots \ldots \ldots \ldots \ldots \ldots \ldots \ldots \ldots \ldots \ldots \ldots$ & 319,017 & 8.513 & 11,851 & 35,974 \\
\hline 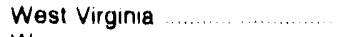 & 115,260 & 6.657 & 9.436 & 25,171 \\
\hline Wyoming & 728,113 & 23.778 & 31,378 & 92,294 \\
\hline Total & $16,045.855$ & 626,320 & 871.905 & $2,400,202$ \\
\hline
\end{tabular}

Note: Totals may not equal sum of components due to independent rounding

Sources: Natural Gas Processed, Total Liquids Extracted, and Extraction Loss Volume: Energy Intormation Administration (ElA), Form EIA-64A, "Annual Report of the Origin of Natural Gas Liquids Prorluction" Estimated Heat Content Extraction Loss: Estimated, assuming the inakeup of total liquids pro. duction as reported on Form EIA.64A for each State was proportional to the components and products ultimately separated in the States as reported on the 12 monthly reports on Energy Intormation Administration. Form ElA-816, "Monthly Natural Gas Liquids Report." and applying the following conversion factors to the individual component and product production estimates (million Btu extraction loss per barrel of liquid produced) etharie. 3 .082: propane, 3.836, normal butane, 4.326; isobutane. 3.974, pentanes plus, 4.620 
Table 15. Supplemental Gas Supplles by State, 1992

(Million Cubic Feet)

\begin{tabular}{|c|c|c|c|c|c|}
\hline State & $\begin{array}{c}\text { Synthelic } \\
\text { Natural } \\
\text { Gas }\end{array}$ & $\begin{array}{l}\text { Propane- } \\
\text { Air }\end{array}$ & $\begin{array}{c}\text { Refinery } \\
\text { Gas }\end{array}$ & Other & Total \\
\hline Alabama . & 0 & 25 & 0 & - 146 & 171 \\
\hline Colorado & 0 & 5 & 0 & b 7,153 & 7,158 \\
\hline 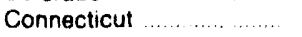 & 0 & 40 & 0 & 0 & 40 \\
\hline Delaware & 0 & 0 & 3,665 & 0 & 3,665 \\
\hline Georgia & 0 & 12 & 0 & - 154 & 166 \\
\hline 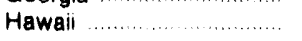 & 2,711 & 0 & 0 & 0 & 2,711 \\
\hline . & 8,021 & 21 & 0 & 0 & 8,042 \\
\hline Indiana & 0 & 380 & 457 & c 2,670 & 3,507 \\
\hline lowa & 0 & 2 & 0 & 43 & 45 \\
\hline Kentucky & 0 & 5 & 0 & 0 & 5 \\
\hline Maryland & 0 & 126 & 0 & 0 & 126 \\
\hline Massachusetts & 0 & 105 & 0 & 0 & 105 \\
\hline Michigan & 0 & 2 & 0 & d 14,682 & 14,694 \\
\hline 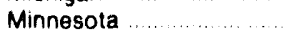 & 0 & 52 & 0 & 0 & 52 \\
\hline Nebraska & 0 & 14 & 0 & $a, b \quad 1,422$ & 1,437 \\
\hline Nevada $\ldots . . . . . . . . . . .$. & 0 & 30 & 0 & 0 & 30 \\
\hline New Hampshire $\ldots . . . . .$. & 0 & 96 & 0 & 0 & 96 \\
\hline New Jersey & 0 & 0 & 12,610 & $\bullet, 1.751$ & 14,362 \\
\hline New York & 0 & 67 & 0 & $\cdot 1,123$ & 1,190 \\
\hline 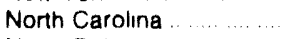 & 0 & 2 & 0 & 0 & 2 \\
\hline North Dakota & 58,496 & 0 & 0 & 0 & 58,496 \\
\hline$\ldots \ldots \ldots \ldots$ & 0 & 20 & 0 & 1,030 & 1,051 \\
\hline Oregon & 0 & 2 & 0 & 0 & 2 \\
\hline Pennsylvania & 0 & 132 & 0 & 0 & 132 \\
\hline Rhode Island ............. & 0 & 155 & 0 & 0 & 155 \\
\hline South Carolina & 0 & 26 & 0 & 0 & 26 \\
\hline South Dakota .............. & 0 & 8 & 0 & - 3 & 10 \\
\hline Tennessee & 0 & 12 & 0 & 0 & 12 \\
\hline 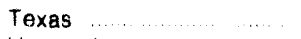 & 0 & 1 & 0 & 0 & 1 \\
\hline 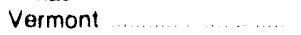 & 0 & 3 & 0 & 0 & 3 \\
\hline Virginıa $\ldots . . . \ldots \ldots$ & 0 & 245 & 0 & 0 & 245 \\
\hline Washington $\ldots \ldots . . . .$. & 0 & 24 & 0 & 157 & 180 \\
\hline Wisconsin & 0 & 1 & 0 & 0 & 1 \\
\hline Total $\ldots \ldots \ldots \ldots \ldots \ldots$ & 69,229 & 1.613 & 16,732 & 30,345 & 117.919 \\
\hline
\end{tabular}

- Biomass gas

b =: Alr injection for Btu stabilization

c Coke oven gas.

- Blast furnace gas.

- Manufactured gas

Note: Totals may not equal sum of components due to independent rounding

Source: Energy Information Administration (EIA). Form ElA-176. "Annual Report of Natural and Supplemental Gas Supply and Disposition." 


\section{Demand}

As the economy fook an upward furn in 1992, demand for natural gat rose 3 pereent. Factors that have contributed 10 demand increases in recent years continued gas prices competitive with other fuels, the unbundling of services in the interstate pipeline industry, and the environmental benefits of natural gas. The following sections discuss comsumption activity, issues that may encourage increased use of natural gas, and the oullowk for natural gats demand.

\section{Consumption}

\section{Residential}

Consumption in the residential sector responds largely 10 weather-related home-heating requirements The colder it is, the more gas customers need Some conservation measures, such as lurming down the thermo. stat, are possible, hut consumers must meet their basic needs. Although the last 3 years were warmer than normal, residential consumption in 1992 was 3 percent higher than in 1991 and 7 percent higher than in 1990). The number of residential consumers has increased steadily. There were 52.3 million residential customers in 1992, I percent more than in 1991 and 8 percent higher than in 1988 .

Natural gas took 60 percent of the new home market during 1992, a reversal of the trend in the 1970's when new homes were built to be heated and cooled by electricity. Natural gas also increased its share of energy conversioms of existing homes during the year.

Renewed interest in natural gas cooling, a technology that has existed for over a century, may produce benefits for residential and commercial energy consumers. Gas cooling can be used for refrigeration, distillation, and air conditioning. Electric utilities anticipate that gas cooling in residences and commercial operations may help to offset new electric peak-load demand.

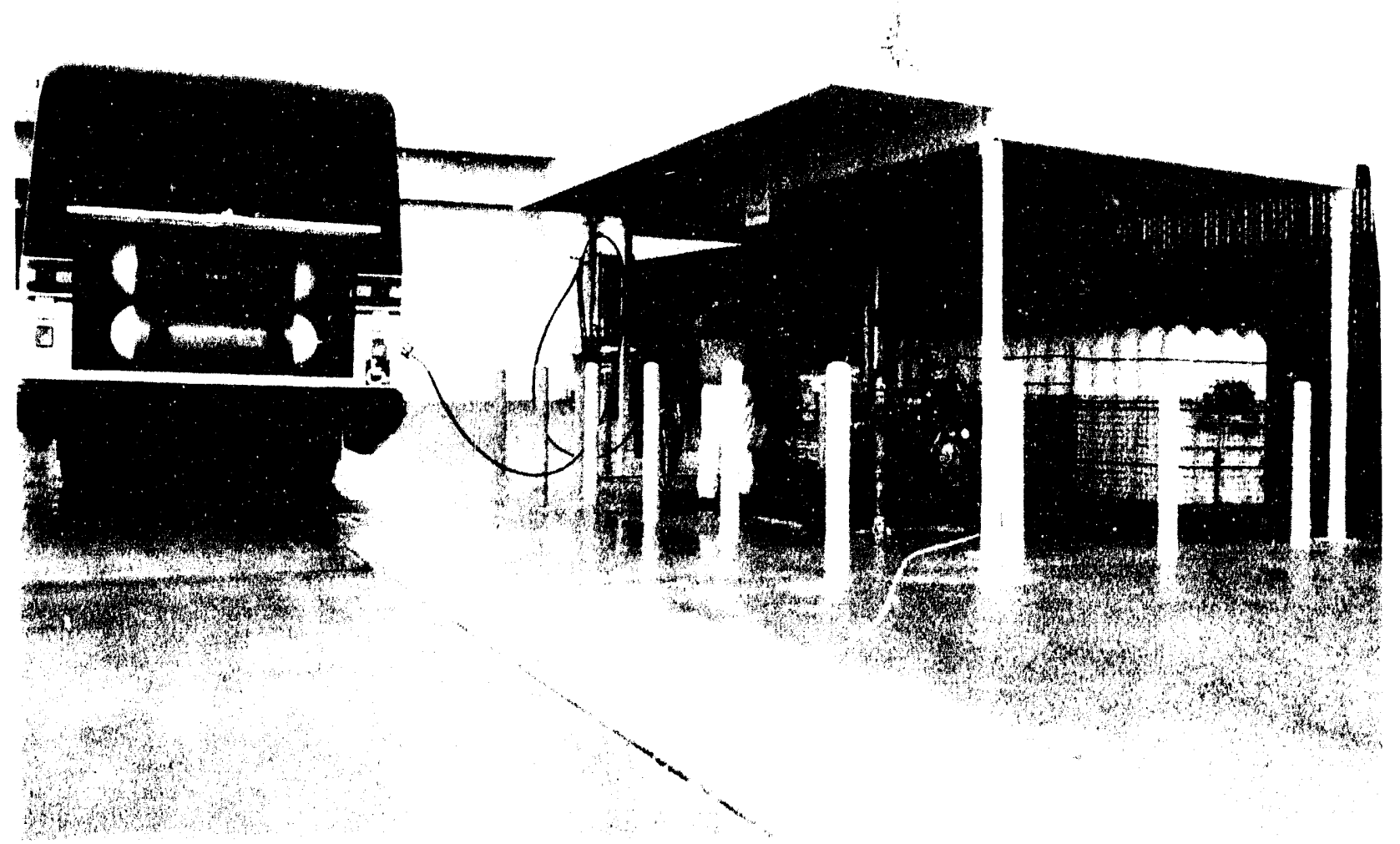

A passenger hus is shown at a typical utility owned refueling station. 


\section{Commercial}

The commercial sector comprises hospitals, schools, hotels, restaurants, retail stores and a variety of other service firms, and local, State, and Federal agencies. It also includes gas used in agriculture. This sector behaves much like the residential sector. The weather, which determines basic heating needs, drives natural gas consumption levels for this sector, which behaves much like the residential sector.

During 1992, commercial consumption reached a record 2.8 trillion cubic feet, surpassing the previous record level set in 1979. The number of customers also continued to rise steadily to 4.4 million.

\section{Industrial}

Industrial energy consumption is a function of the $\mathrm{Na}$ tion's economic health. In addition to the state of the economy, price competitiveness of natural gas with alternate fuels and its availability drive the demand for natural gas in the industrial sector. In 1992, the economy recovered slowly and industrial consumption of natural gas rose 4 percent from the previous year to 7.5 trillion cubic feet, its highest level since 1974. Much of the increase can be attributed to natural gas consumption by nonutility generators (NUG's). NUG's generate electricity for their own use and for sale to electric utilities, vo in turn distribute it to consumers.

Historically, the industrial sector is the largest consuming sector, accounting for 42 percent of deliveries to all sectors. Consumption in this sector has been rising in recent years, as spot market sales increased and prices declined. Although industrial consumption levels are up, the number of consumers has declined slightly but steadily in recent years. Since 1980, it has been in the range of approximately 183,000 to 225,000 . There were 209,616 industrial consumers in 1992.

\section{Electric Utility}

The electric utility sector consumed 2.8 trillion cubic feet of natural gas in 1992, 1 percent less than in 1991. This consumption level has remained nearly constant since 1989. Competitive prices for natural gas, coupled with its status as the most environmentally benign fossil fuel, make it an attractive fuel for this sector.

\section{Vehicle Fuel}

Although the amount of natural gas delivered for use as vehicle fuel is very small compared to deliveries to other consuming sectors, in 1992 it was 511 million cubic feet, 39 percent higher than in 1991 and nearly twice the 1990 amount. The deliveries for vehicle fuel use reported on the Form EIA-176 generally are de- liveries to vehicle fueling stations. Many of these fueling stations are used primarily or exclusively by the respondent's fleet vehicles. Numbers of vehicle fuel consumers, as shown in Table 17, refers to numbers of stations rather than numbers of vehicles. According to the Natural Gas Vehicle Coalition located in Arlington, Virginia, there were an estimated 25 to 30 thousand natural gas vehicles in operation during 1992.

\section{Deliveries for the Account of Others}

With the unbundling of services in the natural gas industry, deliveries for the account of others play a role of growing importance in the commercial, industrial, and electric utility sectors. These deliveries are defined as deliveries to end users by transporters that do not own the gas but deliver it for others. (Generally this service is not available to residential consumers since they are usually not in the position to enter contracts on an individual basis. Rather, they are "captive" to purchasing decisions of their local distribution companies and utilities.) Of the total volumes of gas delivered to consumers in the commercial, electric, and industrial sector, 57 percent was delivered for the account of others in 1992, compared with 54 percent in 1991 and 51 percent in 1990. In 1987 the level was 38 percent.

In the industrial sector, deliveries for the account of others rose in 1992 to 70 percent of total industrial deliveries, up from 67 percent in 1991 and 65 percent in 1990. The growth in deliveries for the account of others in this sector has been dramatic, increasing from 25 percent of total deliveries to industrial consumers in 1984. Of the 46 States that reported deliveries to industrials for the account of others in 1992, 39 States reported more than half of their total industrial deliveries by this method.

The level of participation by the electric utility sector is approaching the industrial sector level. The electric utility level reached 64 percent in 1992, compared to 59 percent in 1991 and 51 percent in 1990. The commercial sector has shown slow but steady increases in the level of deliveries for the account of others. It has risen by about 2 percent each year, from 9 percent in 1988 to 17 percent in 1992.

\section{Consumer Prices}

As shown in Table 22, the price of natural gas delivered to consumers rose from 1991 to 1992 by 1 percent in the residential sector and by 2 percent in the commercial sector. These prices had remained virtually the same from 1990 to 1991. Residential and commercial customers have limited options for obtaining gas and constant service requirements. Most of them acquire gas from local distribution companies.

By contrast, prices for deliveries to industrial consumers rose by 6 percent and to electric utilities by 8 per- 
cent from 1991 to 1992. These sharper increases follow declines of 8 percent from 1990 to 1991 in both of these sectors. Frequently these types of customers can use interruptible service and can contract for spot market gas. Each of these options provides the opportunity to purchase lower priced gas.

The consumer prices shown in this report, with the exception of electric utility prices, are reported on the Form EIA-176 and include only onsystem sales. No prices are reported for deliveries for the account of others. In 1992, 69 percent of the gas delivered to industrial consumers was delivered for the account of others. Thus the industrial prices represent prices for only 31 percent of the gas delivered to industrial consumers. Electric utility prices are reported on the Form FERC-423, and include all purchases. See Appendix A, "Summary of Data Collection Operations and Report Methodology," for more detailed discussions of consumer prices and electric utility data.

\section{Nonutility Generation of Electricity}

The Public Utility Regulatory Policies Act of 1978 (PURPA) has a provision that obligates electric utilities to purchase power from cogeneration plants. This provision was written to efficiently use waste material to generate heat and light. The Energy Policy Act of 1992 targets self-sufficiency in national energy. This bill creates a new class of independent power producers (IPPs) called exempt wholesale generators (EWG) which fits many of these cogeneration projects.

An EWG, as defined by section 32(a)(1) of the Public Utility Holding Company Act (PUHCA), is a person determined by the Federal Energy Regulatory Commission (FERC) to be engaged directly, or indirectly, through one or more affiliates, and exclusively in the business of owning and/or operating all or part of one or more eligible facilities and selling electric energy at wholesale. The Energy Policy Act removes restrictions on utility ownership of IPP's which can generate and sell electricity free from utility ownership restrictions. If a person or facility is granted EWG status, they will be exempt from regulation under PUHCA.

The law has eliminated a major barrier for utilityaffiliated and nonaffiliated power producers who want to compete to build new non- rate-based power plants. EWG's will differ from PURPA qualifying facilities in two ways. First, they will not be required to meet PURPA's cogeneration or renewable fuels limitations and second, utilities will not be required to purchase power from EWGs.

In the 1970's, nonutility-owned electricity generating capacity in the United States totalled 19 gigawatts, the majority of which was capacity owned by industrial companies providing electricity for their own use. Utility-owned capacity increased by an average rate of just over 6 percent during that same period. The nonutility share of capacity declined throughout the 70 's. This decline was reversed in the late 80 's, when nonutility capacity was growing rapidly because of the specifications in PURPA and the economic, regulatory, and technological factors that led to its passage. Nonutility capacity grew by 14 percent annually, increasing by almost 120 percent between 1985 and 1991 . Although nonutilities accounted for only 6 percent of the total in 1991, they added more net capacity during 1990 and 1991 than did utilities. This strongly suggests a reemergence of nonutilities as important producers of electricity.

A 2 year, joint venture by the Gas Research Institute (GRI) and ARINC Corp., an engineering consulting firm, has concluded that cogeneration systems powered by natural gas exceed the reliability of central station power generating units. The study included data from 122 natural gas cogeneration units representing about 2,200 megawatts of installed capacity operating for nearly 2 million service generating hours. The project identified the cause of outages at the units and collected the information to improve the operational reliability of existing cogeneration systems. GRI said gas cogeneration can improve operations of utilities because the small scattered units are more reliable than one or more large central stations of similar capacity.

Canadian natural gas exporters have also been penetrating the U.S. NUG's market. Canadian gas is competitively priced and offer the elements that NUG's require: long-term gas contracts, price predictability, and dedicated gas reserves. In 1991/1992, 146 billion cubic feet of Canadian natural gas was sold to the U.S. NUG market, representing 17 percent of that market. By 1996, it is predicted Canadian gas will be increasing its U.S. NUG market share to over 30 percent. New pipelines are being built in Canada in order to penetrate NUG's markets, as well as to seek alternative markets with even more upside price potential.

Finally, the new enacted Energy Policy Act and the FERC rulemakings that will result from it, particularly on transmission access, deserve special note. The Act is one of the most important energy bills of recent times, particularly with respect to electric power. It contains provisions for reforming the PUHCA. These new provisions reduce considerably the constraints on nonutilities entering the electricity generation industry and give FERC much broader authority to require utilities owning electric power transmission facilities to provide nonutilities and other utilities access to their transmission systems. FERC rulemakings will implement this legislation, and the outcome of those rulemakings could have substantial effects on the direction and magnitude of future changes in the industry. 


\section{New Technology}

Major opportunities for new gas technologies include fuel cells, gas cooling, and natural gas vehicles. The Department of Energy, through the Office of Fossil Energy, is a major funder and supporter of natural gas technology and increased gas use and beginning in fiscal year 1994, has requested over $\$ 20($ ) million for natural gas RD\&D funding. The new Administration has also proposed a 5 year investment package of $\$ 263$ million for gas technology. This funding would be in addition to already existing Department of Energy funding levels. In addition, industry- supported organizations will continue their efforts in developing new gas technologies. Together, these efforts are funding RD\&D projects in excess of $\$ 110$ million annually.

\section{Natural Gas Vehicles}

Driven primarily by environmental and energy security concerns, the United States has recently embarked on its first serious attempt to replace oil-derived fuels in the transportation sector. Spearheading this undertaking at the national level are the Federal Clean Air Act Amendments of 1990) and the Energy Policy Act enacted by Congress in Octoher 1992. Both law's include comprehensive and meaningful alternative fuel use initiatives.

The Clear Air Act Amendments of 1990 include a variety of initiatives designed to promote alternative fuel use by vehicles. One of the most significant is aimed at government and private commercial vehicle fleets in 22 highly polluted cities, home 1031 percent of the population. Beginning in 1998, 30 percent of the new automobiles purchased for centrally fueled fleets of more than 10 vehicles must meet exceptionally low emissions standards that are more stringent than those required for other communities or for other vehicles in these 22 cities. Gasoline-powered vehicles may not be able to meet these more stringent standards, but vehicles running on alternative fuels, such as natural gas, almost certainly can. By 1999,50 percerit of new fleet vehicles purchased must meet these low emissions standards, and by 2000$), 70$ percent must do so. Fleets of heavy-duty trucks (weighing between $8.5(5)$ and 26,000 pounds) must also begin phasing in alternative fuel use in 1998, at a rate of 50 percent of new purchases.

In a separate provision, the Clean Air Act Amendments require automobile companies to manufacture for sale at least 150,000) altemative fuel vehictes in California annually, beginning in model year 1996, as part of a pilot program. The number expands to $3(K),()(N)$ in model year 1999. A June 1991 study by the Gas Research Institute estimates that, just to comply with the alternative transportation fuel requirements of the Clean Air Act, 602,500 natural gas vehicles could be operating by the year $2(K K)$ in the 22 United States cities targeted by the act and the State of Califormat.
The Energy Policy Act of 1992 alternative fuel provisions will initially impact on Federal and State government fleet vehicles. During the past year numerous events and activities have occurred in the alternative fuel and natural gas vehicle markets. Some of the highlights are listed below

The number of natural gas vehicle (NGV) fueling stations in operation in the United States increased to 701 as reported in the American Gas Association's Directory of Natural Gas Vehicle (NGV) Refueling Stations. Products and Services. Forty-four States and the District of Columbia now have NGV fueling facilities. California ranks first with 80 and Texas's total of 6.3 ranks second.

The California Air Resources Board (ARB) announced that the engine in a 1993 natural gas Dodge Ram van is the first to be certified under the board's low emission vehicle (I.EV) standard. According to ARB, the Chrysler engine is the cleanest medium-duty van and truck engine ever certified by the board. The van's emissions are as low as those produced by many passenger cars. The emissions not only meet current L.EV standards, but are low enough to meet more stringent standards that take effect in 1998. The Chrysler engine, a 5.2-liter (318 cubic-inch) V-8, is specifically designed for compressed natural gas and uses a unique emissions control strategy, including multiport fuel injection and a three-way catalytic converter. The 1993 version is guaranteed to meet the LEV standards for up to 120,000 miles.

Environmental regulators and the big three U.S. automakers signed an agreement to work together to develop the technology for monitoring and enforcing future emissions standards. Research scientists from Chrysler Corp., Ford Motor Co., General Motors Corp., Navistar, the U.S. Environmental Protection Agency, and the California Air Resources Board plan to develop ways of measuring hard-to-detect car and truck exhaust emissions, as well as the evaporative emissions associated with the fueling process.

The tax deduction for natural gas vehicles under the Energy Policy Act has resulted in a flood of orders for conversion and original equipment vehicles for delivery after its effective date of July 1. 1993. The tax provisions give cars, vans and light-duty pickups a deduction of up $t(0, \$ 2,(K))$. Up to $\$ 5,(0)()$ is available for vehicles over $10,(0)(0)$ pounds, and up to $\$ 50),(0)()$ is a vailable for trucks over 26,000 pounds or buses that carry at least 20 passengers. Refueling equipment for alternative fuels is eligible for up to $\$ 1(0),(0)$ in deductions.

Ford Motor Co., Southern California Gas Co., and Gas Research Institute have announced a project that could lead to the first U.S. production of passenger cars that run solely on natural gas. The development of a natural gas vehicle, hased on the full-size Ford Crown Victoria, is expected to be completed in the mid-1990s. The prototype 4.6 liter. $V 8$ engine has a higher compression ratio than a gasoline engine and is equipped with an 
electronically controlled gaseous-fuel injection system and a special catalyst to control exhaust emissions. The car also has sensors that monitor engine performance and make adjustments to accommodate variations in the composition of the natural gas fuel. The vehicle's natural gas is stored in four cylinders installed in place of the standard gasoline tank.

United Parcel Service (UPS) opened a quick-fill NGV station in Oklahoma City, Oklahoma that will be used to fuel 70 UPS delivery cars being converted to run on compressed natural gas. UPS plans to open another station in Tulsa. Its two Oklahoma stations, together with a Dallas station and fleet, and other fleets in New York City, Washington, and Los Angeles make the UPS alternative fuel initiative the largest such project in the United States by a private company.

New York City's Mayor, David Dinkins, announced that the city will acquire 232 natural gas vehicles by December 1993 and an additional 800 vehicles driven by alternative fuels of all types by the end of the 1994 fiscal year. New York presently operates a fleet of 240 vehicles operating on alternative fuels, including nat. ural gas, methanol, and electricity.

\section{Fuel Cells}

Fuel cells are similar to electric batteries in that they both have an anode, an electrolyte, and a cathode When you turn on a flashlight, the batteries produce electricity from a chemical reaction that takes place inside them. But unlike your typical battery that has a limited life and the need for recharging periodically, the fuel cell operates continuously, producing electricity as long as hydrogen is supplied to the anode and oxygen is supplied to the cathode. The electrochemical potential of the reaction creates a voltage in each cell. These cells are linked in series in the form of a fuel cell stack, which is considered the "engine" of a fuel cell system.

Fuel cells generate emission-free power by converting two abundant elements, hydrogen and oxygen into electricity emitting only heat and water. First proposed 150 years ago, early models were cumbersome and were considered impractical for automotive use. Using alkaline electrolytes, the first practical fuel cells powered NASA's Apollo and Skylah missions in the early 1960's. These same alkaline electrolytes are still used today in the Space Shuttle missions.
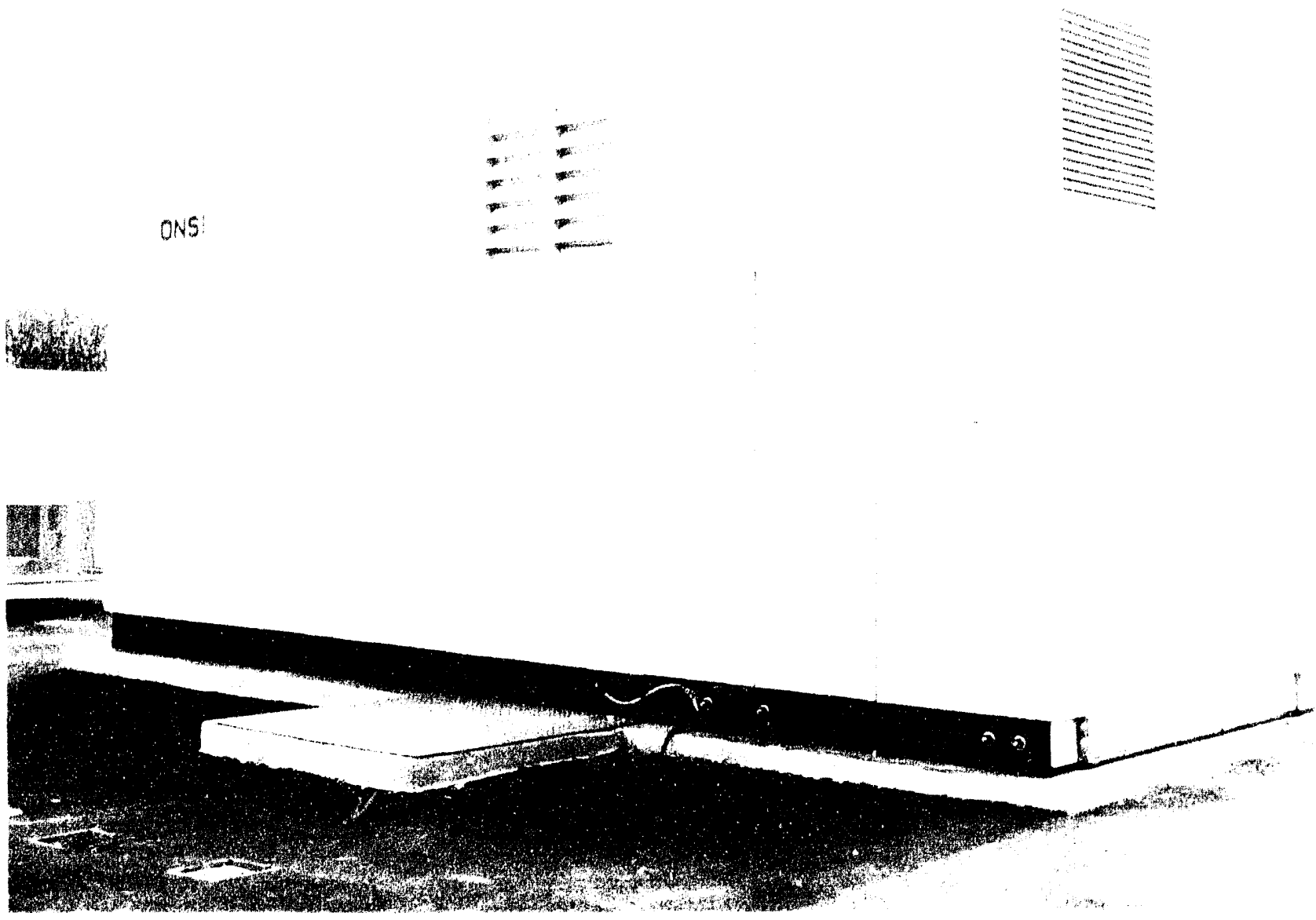

1 view of a 200-hilowest phosphoric acid fucl cell power plant, located in South Windsor. Connecticut. 
Fuel cells operate by converting the chemical energy of natural gas directly into electricity and heat without the need for combustion. This process is extremely quiet and virtually emission free. When used to cogenerate electricity and heat simultaneously, fuel cells convert over 80 percent of their natural gas fuel into useful energy, more than twice the efficiency level of conventional power plants. They need less fuel for energy production and deliver more energy per dollar of fuel cost than any other commercial technology. Fuel cells can use natural gas, methane, or other inputs to produce hydrogen, or they may use stored hydrogen directly to make continuous electricity to power a high-efficiency electric motor.

The four main types and the most developed fuel cells are phosphoric acid, polymer, molten carbonate, and solid oxide. These fuel cells are distinguishable by the type of electrolyte used. The first commercially available fuel cell used phosphoric acid, a liquid electrolyte. Developed by International Fuel Cells Corporation, a subsidiary of United Technologies Corporation, these fuel cells operate at temperatures of 400 degrees $F$ with an electric efficiency of 40 to 45 percent. Polymer, or proton-exchange membrane fuel cells operate at about 200 degrees $F$ with 50 percent electrical efficiency. Molten carbonate fuel cells use a lithium/potassium carbonate electrolyte mixture and are hest suited for large industrial and electric utility disfersed power plants. Their operating temperature, much greater than phosphoric acid fuel cells, is $1200 \mathrm{~F}$ with electric efficiency at 45 to 55 percent. Market entry is expected in the late 1990's with sizes ranging from 500 kilowatts to 2 megawatts. Distinguished by its ceramic material composition and operations at high temperatures, 1800) degrees $F$, solid-oxide fuel cells are well suited for commercial and light industrial applications. The solidoxide fuel cell's electrical efficiency is 45 to 50 percent. With utilization of the heat generated by fuel cells, each type's overall energy efficiencies are in the range of 75 to 80 percent.

In April 1993, Equitech, a division of Equitable Resources, Inc., dedicated the first commercial fuel cell in Pennsylvania. Equitable, one of 10 natural gas industry companies, will be involved in a nationwide program that calls for the placement of 22 units over the next 2 years. The first of the two fuel cells are to be installed at Equitable's Riverview installation, located in the Pittsburgh area; the second site is still under consideration.

Fuel cell power plants produce half the level of carbon dioxide emissions of conventional power plants and are much quieter. With continued growth in demand, electric utilities can save money and time by not having to expand existing transmission and distribution lines. This enables the users to reduce the heating costs due to the high efficiency of the power plants.
Peoples Natural Gas, in cooperation with Duquesne Light recently erected and sponsored a 200 kilowatt fuel cell at the Pittsburgh International Airport. This new operation is one of only 25 natural gas fuel cells operating in the United States. This fuel cell will provide 5 percent of the power to the electric grid in a hangar area of the airport, the equivalent amount of electricity to power 50 homes. The fuel cell was manufactured by ONSI, a subsidiary of International Fuel Cells, with support from the Gas Research Institute, the U.S. Department of Energy, the Electric Power Research Institute, and gas and electric utilities.

The U.S. Department of Energy is canvassing for two vendors to develop a multifueled 500 to 2000 kilowatt fuel cell power plant. The plant is expected to compete economically in the electric power market by the year 2000. Initially, these fuel cells will be powered by natural gas but ultimately will be switched to run on coal or biomass-derived gas. The emphasis is on continuing to develop and improve the overall economics of producing clean electricity from molten carbonate fuel cells.

With the capability of generating 200 kilowatts, each fuel cell is equivalent to the average of 200 homes' monthly energy requirement. However, much higher outputs can be achieved by units now under development, or by linking individual cells together. There are great benefits and advantages of the fuel cells over central power plants: shorter const ruction and planning time, and more finely tuned capacity additions to meet demand growth. From the energy users perspective, these can total up $t 0$ significant economies. ${ }^{12}$

The fuel cell is evolving into the ultimate emission-free power source for highway and railway vehicles besides just producing energy on site or for distribution elsewhere. With new technologies and environmental mandates to produce zero emission vehicles by the year 2000 , the fuel cell concept is becoming a reality.

What makes the fuel cell technology so attractive is that, compared to the burning of coal in a conventional boiler-fired electricity generating plant, approximately one-third of the chemical energy is converted into electrical energy. Pollution is minimal at the point of use because none of the inputs to the fuel cells are burnt, an advantage over the internal combustion engine which makes the project environmentally important. Moreover, battery-powered vehicles typically require 6 to 8 hours to recharge and have a limited range while a fuel cell vehicle can refuel in approximately $10 \mathrm{~min}$ utes.

Because they have no moving parts, fuel cells usually use small amounts of platinum as a catalyst, and they are exceptionally easy to maintain and are noise-free. Due 10 their modular construction, stack assembly is

12 PR Newswire PR Newswire Assuriation: Inc (April 19, 199,3) 
easy and allows units to be added or removed as required. The automotive life cycle may be maintenance free for potentially 300,000$)$ kilometers.

Because fuel cells require onboard tanks to supply oxygen, they are better used in minivans and trucks, which have larger storage areas than passenger vehicles. These vehicles could achieve 300 miles, the eorivalent of a combustion engine car, due to their abulity to accommodate the hydrogen tanks.

Energy Partners, after 3 years of development, hopes to take its prototype pollution-free vehicle "the Green Car" for its first test run. The hydrogen-powered fuel cell vehicle may be on its way to Washington, D.C., this year. Hydrogen is both flammable and buoyant. It is flammable over a wider range of concentrations than either gasoline or natural gas, but due to its buoyancy, it dissipates more rapidly than either of these fuels in a spill.

Ballard Power Systems, Inc, in June 1993, unveiled a prototype fuel cell powered municipal transit bus. As a demonstration model it still needs some fine tuning: a range of 100 miles and a capacity of 20 passengers means its journeys are relatively short.

\section{Natural Gas Cooling}

Commercial gas cooling in the United States amounts to only 5 percent of the current air-conditioning market. Natural gas cooling systems suffer from a significant first-cost disadvantage when compared to electric equipment on a capacity or per ton basis. Installation costs are also significantly high for gas. For example, an average efficiency electric air conditioner unit in the 300 to 900 ton category costs between $\$ 175$ to $\$ 275$ per ton installed whereas a comparable gas unit is in the $\$ 400$ to $\$ 500$ range. However, in many parts of the country, gas air-conditioning does enjoy an overall life-cycle cost advantage, and increased market share for gas cooling is expected. Department of Energy funding on gas cooling RD\&D will exceed $\$ 7.8$ million in fiscal year 1994 . This represents an almost 50 percent increase over the previous year's funding.

\section{Environmental Issues}

\section{Clean Air Act Amendments}

Despite falling behind schedule in promulgating the Clean Air Act Amendments of 1990 (CAAA), the Environmental Protection Agency (EPA) finalized several new rules during 1992. In July, EPA issued the first rules to implement the operating permit requirement under Title V. Each State will be required to impose operating permit requirements on major sources of air pollutants, including sources subject to hazardous air pollutant restrictions, the acid rain program, and new source performance standards. This program enables EPA to monitor compliance after the construction permit is issued and enforce as necessary.

The EPA also decided that minor revisions to these operating permits would not be subject to advance public comment. Once States establish the criteria for defining a minor revision, they may then impose the requirements. The EPA did, however, reserve the right to bar permit revisions within 45 days and allows States 90 days from submission to prohibit adoption of permit changes.

Acid rain provisions will require many utilities to make extensive pollution control modifications to their power plants. In July, EPA codified the Wisconsin Electric Power Company fix rule. This final rule excludes utilities engaged in pollution control modifications from stringent new source review and new source performance standards. This could possibly encourage utilities to modify existing coal-fired boilers to burn natural gas

Title IV, Acid Rain rules were finalized by EPA on October 26, 1992, covering the Sulfur Dioxide ( $\left.\mathrm{SO}_{2}\right)$ allowance system, permits, continuous emission monitoring, excess emissions, and administrative appeals. States were required to submit compliance plans by November 15, 1992. The EPA will have 1 year to accept or reject compliance plans. The proposed nit rogen oxides $\left(N O_{x}\right)$ rule will he finalized in late 1993. These rules require 50 percent reduction in $\mathrm{SO}_{2}$ and 10 percent reduction in $N O_{x}$ by 2000 for specific plants covering 21 States. Phase I compliance in 1995 will affect 268 units at 111 plants.

The first 1-day emissions allowance auction was conducted by EPA in March 1993. The allowance system was established under Title IV for the trading of credits of $\mathrm{SO}_{2}$ emissions. The Chicago Board of Trade (CBOT) will administer this futures market program for 3 years. CBOT will collect bids and payment, collect direct-sale applications and payments, tabulate the auction, and publish results.

Duquesne Light of Pennsylvania, which helped pioneer cofiring of natural gas, was the first investorowned utility to publicly purchase $\mathrm{SO}_{2}$ allowances. This process of burning natural gas in conjunction with another fuel can reduce $\mathrm{SO}_{2}$ and $\mathrm{NO}_{x}$ emissions. In May 1992, even before $\mathrm{SO}_{2}$ markets were established, Duquesne purchased 15,000) allowances to be delivered, 5,000 per year heginning in 1995.

Other natural gas companies plan to offer allowance buyback deals for industrial and utility customers affected by Phase I rules if customers switch to natural gas. Under Enron's structured program, industrial and utility customers are offered a 5 year fixed-price con- 
tract. Mobil Natural Gas and Tenneco Gas, however, plan to offer deals on a case-by-case basis.

In March 1993, the New Jersey Department of Environmental Protection and Energy proposed a rule which requires utilities and industrial sources to reduce $N O_{x}$ emissions levels. This will be the first major rule mandated by the CAA to affect New Jersey stationary sources. Further, the agency approved the use of natural gas during the ozone season if low $N O_{x}$ burners are not available.

On July 30, 1993, EPA set guidelines allowing States to permit seasonal switching from oil or coal to natural gas so utilities can meet $N O_{x}$ emissions standards. States that do not meet standards complying with CAAA rules, must devise new plans by November 1994.

\section{Global Climate Change}

Another environmental issue of interest to the natural gas industry was global climate change. The first International Earth Summit in June 1992, focused on global climate change. Morethan 150 nations, including the United States, signed the Framework Convention of Climate Change. This treaty requires nations to develop and submit national action plans (NAP) to reduce greenhouse gas emissions, most notably carbon dioxide. Natural gas, being the fossil fuel with the lowest carbon dioxide emissions, could benefit in achieving these goals.

To help the United States meet the global warming emission reductions commitment, EPA has developed the Natural Gas Star Program. On March 3, 1993, EPA announced a voluntary program developed for natural gas companies to reduce methane emissions. The Natural Gas Star Program participants aim to implement cost-effective operations, maintenance, and equipment practices. They plan to improve inspection and maintenance practices to reduce leakage; replace gas venting equipment with new low-emissions technology: and repair or replace leaking pipelines. In cooperation with the American Gas Association, EPA will offer workshops on this program to encourage additional participants while looking for ways to remove regulatory barriers.

In May 1993, the White House announced plans to create six different workgroups under the newly created Interagency Climate Change Mitigation Group whose task is to develop a new NAP called for at the Earth Summit. The workgroups will deal with energy supply, energy demand, transportation, methane and other greenhouse gases besides $\mathrm{CO}_{2}$, and joint implementation.

\section{Demand-Side Management/Integrated Resource Planning}

Demand-side management (DSM), which includes conservation and load-shaping programs, is growing within the natural gas industry. DSM is part of the integrated resource planning (IRP) or least cost planning concept which was initially devised for the electric utility industry. The IRP process is used by public utility commissions (PUC) and utilities in an effort to balance supply and demand options in a utility's investment plans to meet future energy needs with maximum efficiency at the lowest cost. Some of the individual programs that are included in the IRP process can include the following initiatives:

- Demand-side activities include load management with the objective to reduce peak demand, as measured in kilowatts or therms, or to shift peak demand to off-peak periods. The reduction of peak demand reduces the need to build or buy new generating capacity in the case of electric utilities, or to add transmission or storage capacity in the case of gas utilities.

- Conservation means to reduce the amount of energy used. Conservation results in reduced fuel use and reduced or avoided environmental impacts

- Supply-side activities include actions to increase the ability to obtain energy. In the case of an electric utility this includes production, transmission, and distribution of electricity. In the case of a gas utility this refers to the extraction, transmission, storage, or distribution of gas.

- Environmental Externalities refers to an environmental cost borne by society that is not immediately reflected in the price paid by the producer or consumer.

- Rate payer tests measure the economic efficiency. Examples of such tests include the All Ratepayers (Total Resource Cost), Non-Participants (Rate Impact Measurement), Participants, Utility, and Societal tests.

IRP involves a new approach to the delivery and pricing of utility services. Prior to IRP, electric and gas utilities primarily viewed themselves as providers of electricity and natural gas; following the implementation of IRP, the utilities are much more heavily involved in the customers' fuel decisions--including equipment, fuel utilization, and fuel choice. IR $P$ is gaining increasing momentum in its application.

A recent survey by Lawrence Berkeley Laboratory and the National Association of Regulatory Utility Commissioners 13 showed 15 jurisdictions with gas IRPs enforced thru PUC rules or informally practiced the

13 Surve'y of State Regulatory Activities on Least Cost Planning for Cas Ltilities. April 1981 
District of Columbia, Illinois, Iowa, Nevada, New Jersey, Oregon, Vermont, Washington, and Wisconsin) or under development (California, Connecticut, Hawaii, Massachusetts, New York, and Rhode Island). Seven States were found to have gas IRPs under consideration (Alabama, Colorado, Maryland, Michigan, Montana, New Hampshire, and Ohio). Of the 29 States that are not actively considering IRP for natural gas distribution utilities, two States (Nebraska and Texas) do not regulate natural gas distribution at the State level and nine States (Arizona. Delaware, Georgia, Kansas, Kentucky, Missouri, Pennsylvania, Utah, and Virginia) are analyzing the experience with an electric IRP process before going forward with an application of IRP principles on the natural gas side.

These results seem to indicate a great degree of interest in IRP for natural gas distribution utilities themselves as well as a large potential for even greater interest as the results of the electric utility experience with IRP become available. This will have a large and direct effect on the demand for natural gas.

Gas utilities began complying with State Public Utility Commission orders to develop, file, and implement DSM and IRP. During these early developments some utilities have transferred some appropriate features from electricity to gas. Most DSM plans now focus on conservation projects to reduce gas consumption.

\section{Outlook for Demand}

Total demand for natural gas is expected to continue to grow steadily to 20.4 trillion cubic feet in 1993 anc to 21.1 trillion cubic feet in 1994. Growth in demanc will be achieved despite rising natural gas prices. By 1994 , the average wellhead price will exceed $\$ 2.25$ pei thousand cubic feet, the highest level since 1985.

Demand growth is due to a combination of factors including stronger economic growth, relatively cold winter weather, and an increase in gas-fired electricity generation. Rising consumption of natural gas in the past few years has been supported by substantial ex. pansion of the interstate pipeline system. From 1991 through 1992, about 4.4 billion cubic feet per day of additional interstate pipeline capacity was placed in service in the lower 48 States.

Natural gas demand is projected to grow the fastest in the residential sector in 1993, primarily the result of close 10 normal winter weather in 1993 relative to 1992. Industrial growth is mainly due to rising manufacturing output and increasing consumption of gas by nonutility electricity generators. Gas use to generate electricity by both electric utility generators and industrial nonutility generators is forecast 10 increase as the economy accelerates. Gas will also replace some nuclear power generation in the utility sector as a number of nuclear plants are expected to be down for maintenance and refueling. These projections can be found in EIA's recently (August 1993) released publication Short-Term Energy Outlook, Quarterly Projections, Third Quarter 1993. 
Table 16. Consumption of Natural Gas by State, 1988-1992 (Million Cubic Feet)

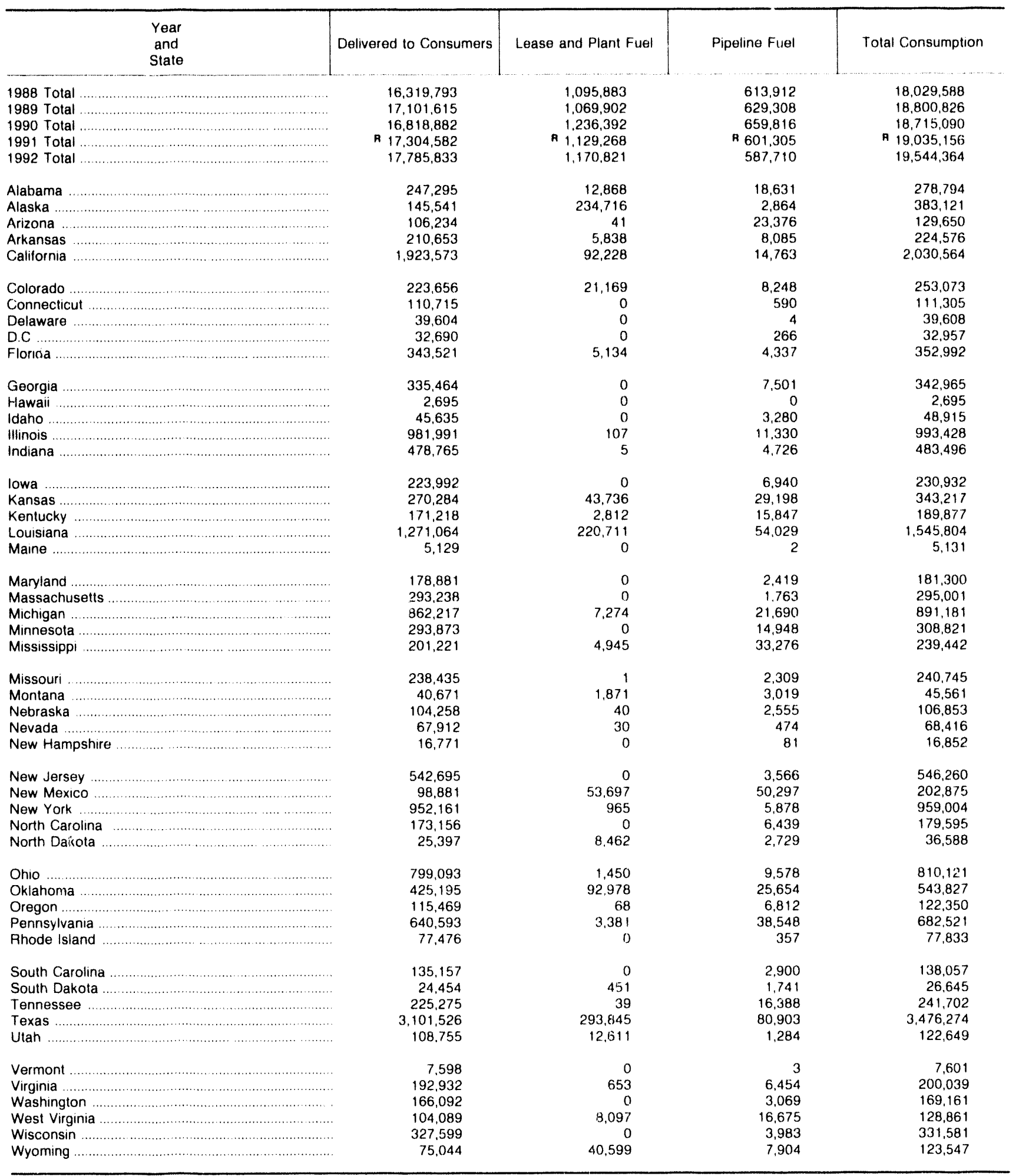

ค - Revised data.

Note: Totals may not equal sum of components due to independent rounding.

Sources: Energy Information Administration (EIA), Form EIA-176, "Annual Report of Natural and Supplemental Gas Supply and Disposition;" Form EIA-64A, "Annual Report of the Origin of Natural Gas Liquids Production," and Form ElA.?59, "Monthly Power Plant Report" 
Figure 7. Natural Gas Delivered to Consumers In the United States, 1992

(Million Cubic Feet)

Residential
Total $=4,690,065$

New rork

8.1

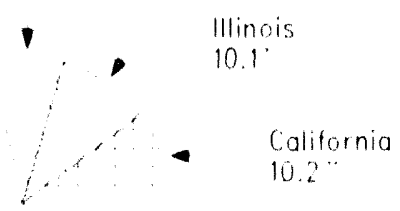

All Other States

$71.6^{\prime \prime}$
Commercial

Total $=2802.751$

Michigan

6.2 .

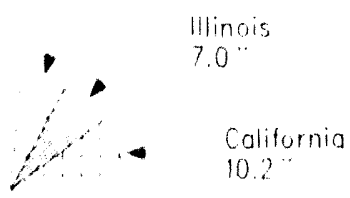

All Other Stotes

$76.6^{\prime \prime}$
Industrial
Total $=7,526,898$

Louisiana

12.4

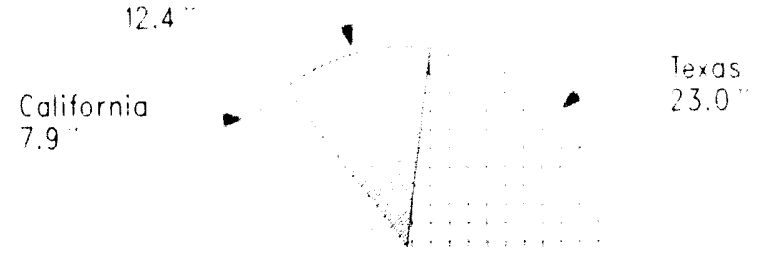

All Other States

$56.7^{\prime \prime}$
Electric Utilities

Total $=2,765,608$

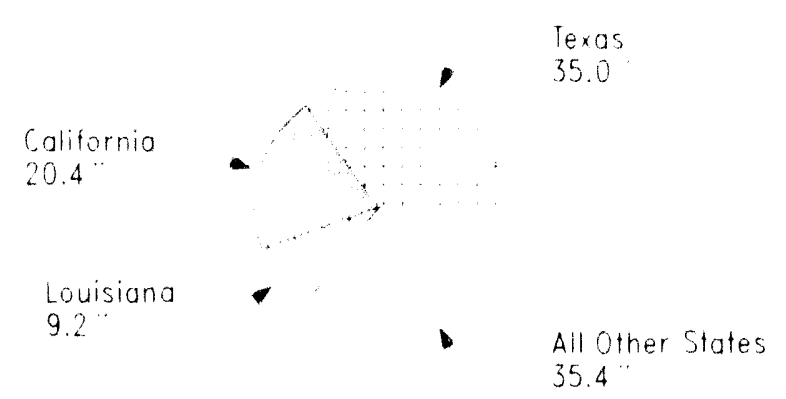

Sources: Energy Information Administration (EIA). Form ElA-759, "Monthly Power Plant Report" and Form EIA-176. "Annual Report of Natural and Supplemental Gas Supply and Disposition." 
Table 17. Natural Gas Delivered to Consumers by State, 1988-1992

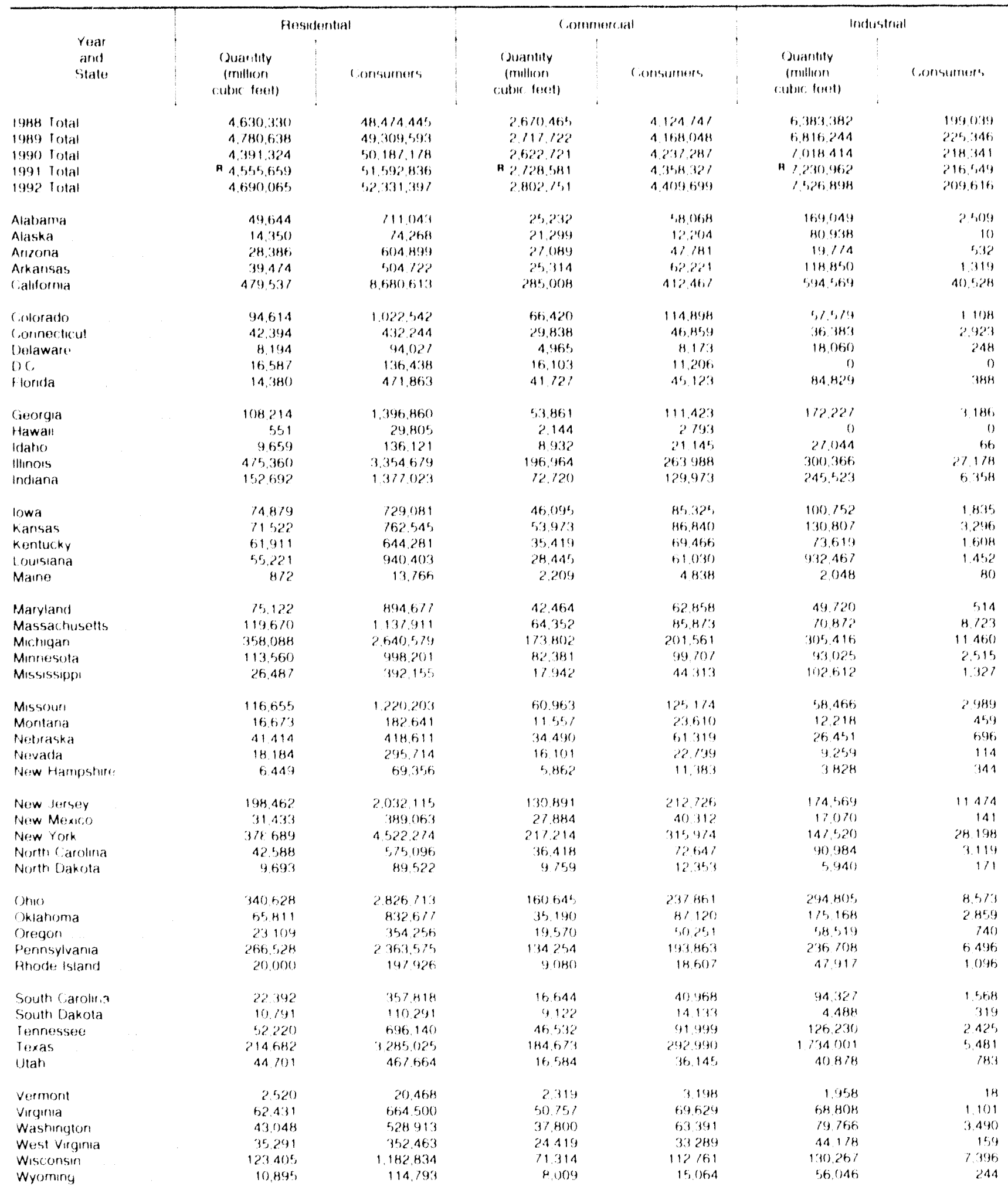

Seet footnotes at end of table 
Table 17. Natural Gas Delivered to Consumers by State, 1988-1992 (Continued)

\begin{tabular}{|c|c|c|c|c|c|}
\hline \multirow{2}{*}{$\begin{array}{c}\text { Year } \\
\text { and } \\
\text { State }\end{array}$} & \multicolumn{2}{|c|}{ Vehicle Fuel } & \multirow{2}{*}{$\begin{array}{l}\text { Electric Utilities } \\
\text { Quantity } \\
\text { (million } \\
\text { cubic feet) }\end{array}$} & \multirow{2}{*}{$\begin{array}{c}\text { Delivered to Consumers } \\
\text { Quantity } \\
\text { (million } \\
\text { cubic feet) }\end{array}$} & \multirow{2}{*}{$\begin{array}{l}\text { Healing Value } \\
\text { (Btu per } \\
\text { Cubic Foot) }\end{array}$} \\
\hline & $\begin{array}{l}\text { Quantity } \\
\text { (million } \\
\text { cubic teet) }\end{array}$ & Consumers & & & \\
\hline 1988 Total & NA & NA & $2,635,616$ & 16.319 .793 & 1,029 \\
\hline 1989 Total & NA & NA & $2,787,012$ & $17,101,615$ & 1.031 \\
\hline 1990 Total & 270 & 1.007 & $2,786,153$ & $16,818,882$ & 1,031 \\
\hline 1991 Total & 367 & 1.106 & ค $2,789,014$ & A $17,304,582$ & 1,030 \\
\hline 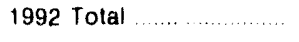 & 511 & 1,033 & $2,765,608$ & 17.785 .833 & 1,030 \\
\hline Alabama & 3 & 1 & 3,368 & 247.295 & 1,028 \\
\hline Alaska & 0 & 0 & 28,953 & 145,541 & 1,002 \\
\hline Arizona ........ & 46 & 10 & 30,939 & 106,234 & 1,031 \\
\hline 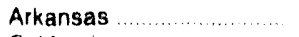 & 0 & 0 & 27,015 & 210,653 & 1.009 \\
\hline California ........ & 27 & 65 & 564,432 & $1,923,573$ & 1.029 \\
\hline Colorado & 23 & 5 & 5,019 & 223,656 & 1.023 \\
\hline Connecticut ........................ & $\cdot$ & 3 & 2,100 & 110.715 & 1.028 \\
\hline 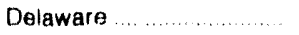 & 0 & 0 & 8,384 & 39,604 & 1.035 \\
\hline D.C $\ldots \ldots \ldots \ldots$ & 0 & 0 & 0 & 32,690 & 1.007 \\
\hline Flonda & 9 & 6 & 202,576 & 343.521 & 1.049 \\
\hline Georgia & 0 & 0 & 1,162 & 335,464 & 1.025 \\
\hline 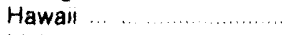 & 0 & 0 & 0 & 2,695 & 1,073 \\
\hline 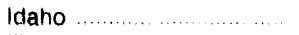 & 0 & 0 & 0 & 45,635 & 1,030 \\
\hline Illinois & 8 & 16 & 9,293 & 981,991 & 1.018 \\
\hline Indiana $\ldots \ldots \ldots \ldots \ldots \ldots$ & 59 & 16 & 7.772 & 478,765 & 1.011 \\
\hline lowa $\ldots \ldots \ldots \ldots$ & 1 & 3 & 2,265 & 223.992 & 1,004 \\
\hline 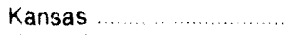 & 0 & 0 & 13,981 & 270.284 & 987 \\
\hline 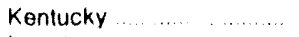 & $\cdot$ & 1 & 269 & 171,218 & 1.058 \\
\hline Louisiana ....................... & 9 & 2 & 254.922 & $1,271,064$ & 1,044 \\
\hline Maine $\ldots \ldots \ldots \ldots$ & 0 & 0 & 0 & 5.129 & 1,013 \\
\hline Maryland $\ldots . . . .$. & 0 & 0 & 11,575 & 178,881 & 1,028 \\
\hline Massachusetts & 2 & 1 & 38,341 & 293,238 & 1,037 \\
\hline Michigan $\ldots . . . . . . . . .$. & 4 & 1 & 24,908 & 862,217 & 1,020 \\
\hline 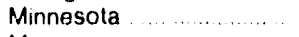 & 0 & 0 & 4.906 & 293,873 & 1,011 \\
\hline Mississippi $\ldots \ldots \ldots \ldots$ & 0 & 0 & 54,180 & 201,221 & 1,047 \\
\hline Missouri .......... & 0 & 0 & 2,351 & 238,435 & 1,002 \\
\hline Montana $\ldots \ldots \ldots \ldots \ldots$ & 2 & 2 & 220 & 40.671 & 1.023 \\
\hline Nebraska $\ldots \ldots \ldots$ & $\cdot$ & 1 & 1.903 & 104,258 & 979 \\
\hline Nevada $\ldots \ldots \ldots \ldots$ & 12 & 2 & 24,355 & 67.912 & 1,031 \\
\hline New Hampshire ............... & 0 & 0 & 633 & 16.771 & 1,009 \\
\hline 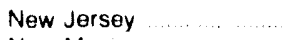 & 0 & 0 & 38,772 & 542,695 & 1,026 \\
\hline Now Mexico $\ldots . . . . . . . .$. & 7 & 1 & 22.486 & 98,881 & 1.040 \\
\hline New York ..................... & 6 & 10 & 208,731 & 952.161 & 1.029 \\
\hline North Carolina & 7 & 2 & 3,159 & 173,156 & 1.034 \\
\hline North Dakota & 3 & 4 & 1 & 25,397 & 1.045 \\
\hline Ohio $\ldots \ldots \ldots \ldots \ldots$ & 59 & 675 & 2,956 & 799,093 & 1,036 \\
\hline Oklahoma & 45 & 13 & 148,980 & 425,195 & 1.026 \\
\hline Oregon $\ldots . . . . . . . . . . .$. & 6 & 13 & 14,264 & 115,469 & 1.035 \\
\hline Pennsylvanıa .................... & 3 & 21 & 3,100 & 640,593 & 1,036 \\
\hline Phode Island & 9 & 96 & 469 & 77,476 & 1.018 \\
\hline South Carolina ................. & 0 & 0 & 1,795 & 135.157 & 1,027 \\
\hline South Dakota & 5 & 2 & 48 & 24,454 & 1.015 \\
\hline Tenne isee $\ldots . . . . . . \ldots \ldots$ & 2 & 2 & 291 & 225,275 & 1,031 \\
\hline Texas $\ldots \ldots \ldots$ & 4 & 2 & 968,165 & $3,101,526$ & 1,043 \\
\hline Utah & 15 & 20 & 6,576 & 108,755 & 1,078 \\
\hline 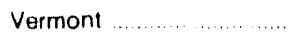 & 0 & 0 & 801 & 7.598 & 895 \\
\hline Virginia $\ldots . . . . \ldots \ldots \ldots \ldots$ & 0 & 0 & 10,936 & 192,932 & 1,039 \\
\hline Washington & 94 & 19 & 5,385 & 166.092 & 1,033 \\
\hline West Virginia $\ldots . . . . . . . . . . .$. & $\cdot$ & 1 & 201 & 104,089 & 1.065 \\
\hline Wisconsin $\ldots \ldots \ldots$ & 28 & 12 & 2,584 & 327,599 & 1,009 \\
\hline Wyoming $\ldots \ldots \ldots$ & 10 & 5 & 83 & 75,044 & 1,058 \\
\hline
\end{tabular}

\footnotetext{
- Less than 500.000 cubic leet

R Revised data

Na Not available

Note: Totals may not equal sum of components due to independent rounding Number of vehicle fuel consumers generally refers to the number of fuel. ing stations.

Sources: Energy Information Administration (EIA), Form EIA.176. "Annual Repon of Natural and Supplemental Gas Supply and Disposition," and Form EIA-759, "Monthly Power Plant Report."
} 
Table 18. Natural Gas Delivered to Commercial Consumers for the Account of Othersa by State, 1988-1992

(Million Cubic Feet)

\begin{tabular}{|c|c|c|c|c|c|c|c|c|c|c|}
\hline \multirow[b]{2}{*}{ State } & \multicolumn{2}{|c|}{1988} & \multicolumn{2}{|c|}{1989} & \multicolumn{2}{|c|}{1990} & \multicolumn{2}{|c|}{1991} & \multicolumn{2}{|c|}{1992} \\
\hline & $\begin{array}{l}\text { Delivered } \\
\text { for the } \\
\text { Account } \\
\text { of Others }\end{array}$ & $\begin{array}{c}\text { Percent of } \\
\text { Total } \\
\text { Commercial } \\
\text { Deliveries }\end{array}$ & $\begin{array}{l}\text { Delivered } \\
\text { for the } \\
\text { Account } \\
\text { of Others }\end{array}$ & $\begin{array}{c}\text { Percent of } \\
\text { Total } \\
\text { Commercial } \\
\text { Deliveries }\end{array}$ & $\begin{array}{l}\text { Delivered } \\
\text { for the } \\
\text { Account } \\
\text { of Others }\end{array}$ & $\begin{array}{c}\text { Percent of } \\
\text { Total } \\
\text { Commercial } \\
\text { Deliveries }\end{array}$ & $\begin{array}{l}\text { Delivered } \\
\text { for the } \\
\text { Account } \\
\text { of Others }\end{array}$ & $\begin{array}{c}\text { Percent of } \\
\text { Total } \\
\text { Commercial } \\
\text { Deliveries }\end{array}$ & $\begin{array}{l}\text { Delivered } \\
\text { for the } \\
\text { Account } \\
\text { of Others }\end{array}$ & $\begin{array}{c}\text { Percent of } \\
\text { Total } \\
\text { Commercial } \\
\text { Deliveries }\end{array}$ \\
\hline Alabama & 2,278 & 89 & 4.498 & 17.0 & 4,967 & 205 & 4.112 & 173 & 4.868 & 19.3 \\
\hline Arizona $\ldots \ldots \ldots$ & 1.311 & 4.6 & 1,796 & 60 & 1,219 & 4.3 & $1,8^{7}$ & 6.8 & 2,021 & 7.5 \\
\hline Arkansas & 1,723 & 6.3 & 1,870 & 7.0 & 1.939 & 77 & 2.198 & 8.5 & 2,343 & 9.3 \\
\hline Californa & 10,862 & 4.4 & 21,109 & 8.1 & 38,337 & 134 & 67, 882 & 22.2 & 72,782 & 25.5 \\
\hline$\ldots \ldots \ldots \ldots \ldots$ & 1,574 & 2.3 & 1,789 & 27 & 1,800 & 2.7 & 2.763 & 4.0 & 2.993 & 4.5 \\
\hline Connecticut & 513 & 1.9 & 2,680 & 87 & 1,169 & 40 & 1,887 & 70 & 1.037 & 3.5 \\
\hline$\ldots \ldots \ldots$ & 0 & -. & 0 & w & 0 & .. & 417 & 2.7 & 155 & 10 \\
\hline$\ldots \ldots . . . .$. & 0 & -. & 0 & .. & 881 & 24 & 1,005 & 26 & 964 & 23 \\
\hline$\ldots \ldots .$. & 3.418 & 61 & 5,176 & 100 & 5.721 & 116 & 6,395 & 12.5 & 6,389 & 119 \\
\hline$\ldots \ldots \ldots \ldots$ & 1.161 & 14.1 & 1.121 & 12.0 & 1.035 & 121 & 1.192 & 124 & 1,278 & 14.3 \\
\hline Illinois & 49,942 & 23.2 & 60,159 & 31.0 & 84.936 & 42.4 & 79.512 & 41.0 & 83.264 & 42.3 \\
\hline$\ldots \ldots \ldots \ldots$ & 3,473 & 48 & 3.579 & 49 & 2,906 & 4.3 & 3,947 & 58 & 2,319 & 3.2 \\
\hline lowa $\ldots \ldots$ & 774 & 17 & 980 & 2.1 & 1.068 & 24 & 1.097 & 2.4 & 1.974 & 43 \\
\hline 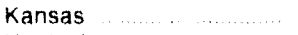 & 2,193 & 3.6 & 4.037 & 6.9 & 4,701 & 8.4 & 6,321 & 108 & 8,408 & 15.6 \\
\hline 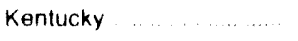 & 1,501 & 4.2 & 1,828 & 5.1 & 1.575 & 5.0 & 2,035 & 6.0 & 2,451 & 69 \\
\hline Louisiana & 18 & 1 & 16 & 0 & 0 & -. & 233 & 9 & 3,552 & 12.5 \\
\hline$\ldots \ldots \ldots \ldots$ & 800 & 3.1 & 1,010 & 3.8 & 1,052 & 44 & 1.308 & 3.4 & 1.692 & 4.0 \\
\hline Massachuselts $\ldots \ldots \ldots$ & 36 & 1 & 14 & 0 & 32 & 1 & 96 & 2 & 140 & 2 \\
\hline Michigan $\ldots \ldots$ & 47,678 & 284 & 52,120 & 29.6 & 48,061 & 30.1 & 52,444 & 31.7 & 54.248 & 31.2 \\
\hline 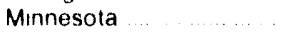 & 2.524 & 3.2 & 3,527 & 4.1 & 3.220 & 41 & 4,094 & 48 & 3.134 & 3.8 \\
\hline Mississippi & 0 & .. & 0 & .. & 777 & 44 & 731 & 41 & 645 & 36 \\
\hline 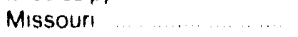 & 2,400 & 38 & 4,851 & 7.7 & 8,306 & 14.0 & 8,910 & 14.1 & 8,817 & 145 \\
\hline 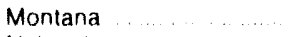 & 13 & 1 & 242 & 18 & 261 & 21 & 327 & 25 & 533 & 4.6 \\
\hline Nebraska $\ldots \ldots$ & 894 & 23 & 571 & 1.5 & 2.231 & 6.1 & 3.294 & 82 & 4,063 & 11.8 \\
\hline Nevada $\ldots \ldots, \ldots \ldots \ldots$ & 725 & 49 & 575 & 3.8 & 346 & 23 & 1.563 & 92. & 1,889 & 117 \\
\hline New Jersey . . ............... & 1,558 & 1.5 & 2.578 & 22 & 5,978 & 52 & 7.401 & 61 & 10.012 & 76 \\
\hline New Mexico & 2,280 & 7.3 & 3,386 & 119 & 4,008 & 16.9 & 5.570 & 22.3 & 8,361 & 300 \\
\hline New York. & 19.944 & 106 & 28,376 & 144 & 31.904 & 16.4 & 38.556 & 19.3 & 48,552 & 22.4 \\
\hline North Carolina $\ldots . . . .$. & 1,424 & 44 & 2.126 & 6.4 & 1,696 & 5.4 & 1.725 & 5.0 & 1.497 & 41 \\
\hline North Dakota ............. & 716 & 7.3 & 2.082 & 196 & 2,585 & 253 & 3,223 & 300 & 3,035 & 31.1 \\
\hline Onio $\ldots$ & 20,433 & 129 & 21,903 & 13.6 & 18,258 & 127 & 20,033 & 13.3 & 23,188 & 144 \\
\hline$\ldots \ldots$ & 12.217 & 25.5 & 3.988 & 10.0 & 2.944 & 79 & 3,445 & 87 & 4,052 & 11.5 \\
\hline$\ldots \ldots$ & 221 & 12 & 353 & 1.7 & 464 & 2.3 & 477 & 2.1 & 433 & 22 \\
\hline Pennsylvanıa $\ldots \ldots \ldots$ & 12.476 & 9.8 & 19.406 & 150 & 27,144 & 216 & 28,528 & 227 & 32.481 & 242 \\
\hline Rhode Island $\ldots \ldots \ldots$ & 1,080 & 12.9 & 1,411 & 16.1 & 330 & 41 & 0 & .. & 0 & 0 \\
\hline South Carolina & 153 & 9 & 302 & 1.8 & 341 & 22 & 278 & 1.8 & 239 & 14 \\
\hline South Dakola & 321 & 3.8 & 695 & 79 & 1,161 & 13.6 & 1,723 & 18.2 & 1,603 & 17.6 \\
\hline Tennessee $\ldots \ldots \ldots \ldots$ & 1,191 & 26 & 864 & 20 & 1,092 & 25 & 1,961 & 4.3 & 1.680 & 3.6 \\
\hline Texas $\ldots \ldots \ldots \ldots$ & 21,863 & 12.5 & 16.935 & 90 & 17,645 & 102 & ค 19,287 & A 107 & 37,443 & 20.3 \\
\hline Virginia $\ldots \ldots \ldots \ldots \ldots \ldots$ & 997 & 2.4 & 1.274 & 29 & 2,804 & 6.8 & 2,826 & 6.4 & 4.719 & 9.3 \\
\hline Washıngton & 1.022 & 2.8 & 2,291 & 60 & 2.462 & 6.4 & 3.247 & 78 & 4,831 & 12.8 \\
\hline West Virginia & 8,904 & 39.7 & 8,952 & 380 & 8,955 & 419 & 9.496 & 45.1 & 10,536 & 43.1 \\
\hline Wisconsin & 4.443 & 6.6 & 5,128 & 73 & 6.189 & 9.3 & 6.414 & 90 & 6.229 & 8.7 \\
\hline Wyoming $\ldots \ldots \ldots$ & 0 & -. & 7 & 1 & 21 & 2 & 89 & 1.0 & 160 & 2.0 \\
\hline Total & 247,051 & 9.3 & 295,604 & 110 & 352,521 & 134 & ค 405.919 & 14.9 & 471,009 & 16.8 \\
\hline
\end{tabular}

- These deliveries included quantities covered by long-term contracts and gas involved in short-term or spot market sales

R Revised data

-- Not applicable

Note: Totals may not equal sum of components due to independent rounding.

Source Energy Information Administration (EIA), Form EIA.176. "Annual Report of Natural and Supplemental Gas Supply and Disposition" 
Figure 8. Percent of Natural Ga:s Deliveries in the United States Representing Deliveries for the Account of Others, by Consumer Sector, 1988-1992

Commercial

Industrial

70

Electric Utilities

60

50

Note: These deliveries included quantities covered by long-term contracts and gas involved in short-term or spot market sales. Beginning with 1990 data,

commercial volumes include natural gas delivered for vehicle fuel.

Source: Energy Information Administration. Form ElA-176, "Annual Report of Natural and Supplemental Gas Supply and Disposition." 
Table 19. Natural Gas Delivered to Industrial Consumers for the Account of Others ${ }^{a}$ by State, 1988-1992

(Million Cubic Feet)

\begin{tabular}{|c|c|c|c|c|c|c|c|c|c|c|}
\hline \multirow[b]{2}{*}{ State } & \multicolumn{2}{|c|}{1988} & \multicolumn{2}{|c|}{1989} & \multicolumn{2}{|c|}{1990} & \multicolumn{2}{|c|}{1991} & \multicolumn{2}{|c|}{1992} \\
\hline & $\begin{array}{c}\text { Delivered } \\
\text { for the } \\
\text { Account } \\
\text { of Others }\end{array}$ & $\begin{array}{c}\text { Percent of } \\
\text { Total } \\
\text { Industrial } \\
\text { Deliveries }\end{array}$ & $\begin{array}{l}\text { Delivered } \\
\text { for the } \\
\text { Account } \\
\text { of Others }\end{array}$ & $\begin{array}{c}\text { Percent of } \\
\text { Total } \\
\text { Industrial } \\
\text { Deliveries }\end{array}$ & $\begin{array}{l}\text { Delivered } \\
\text { for the } \\
\text { Account } \\
\text { of Others }\end{array}$ & $\begin{array}{c}\text { Percent of } \\
\text { Total } \\
\text { Industrial } \\
\text { Deliveries }\end{array}$ & $\begin{array}{l}\text { Delivered } \\
\text { for the } \\
\text { Account } \\
\text { of Others }\end{array}$ & $\begin{array}{c}\text { Percent of } \\
\text { Total } \\
\text { Industrial } \\
\text { Deliveries }\end{array}$ & $\begin{array}{l}\text { Delivered } \\
\text { for the } \\
\text { Account } \\
\text { of Others }\end{array}$ & $\begin{array}{c}\text { Percent of } \\
\text { Total } \\
\text { Industrial } \\
\text { Deliveries }\end{array}$ \\
\hline Alabama & 70,229 & 50.0 & 93,168 & 62.5 & 96,889 & 66.5 & 106,274 & 68.6 & 118,457 & 70.1 \\
\hline Alaska ......... & 30,824 & 45.5 & 26,605 & 44.8 & 28,165 & 36.6 & 23,363 & 30.9 & 24,455 & 30.2 \\
\hline Arizona & 17,155 & 70.9 & 11,478 & 55.0 & 10,421 & 56.7 & 9,966 & 51.9 & 13,925 & 70.4 \\
\hline 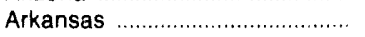 & 79,343 & 75.7 & 104,237 & 80.6 & 93,332 & 77.6 & 84,515 & 80.6 & 102,468 & 86.2 \\
\hline 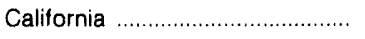 & 171,228 & 36.9 & 283,611 & 55.8 & 346,643 & 61.3 & 422,738 & 70.2 & 430,836 & 72.5 \\
\hline 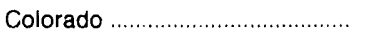 & 23,309 & 61,0 & 29,106 & 56.7 & 33,799 & 69.0 & 36,685 & 65.3 & 39,040 & 67.8 \\
\hline 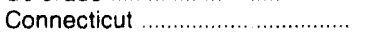 & 453 & 2.3 & 1,681 & 8.5 & 3,572 & 14.0 & 10,370 & 31.8 & 12,514 & 34.4 \\
\hline Delaware & 3,089 & 20.9 & 3,682 & 24.3 & 4,847 & 28.4 & 5,509 & 34.1 & 6,316 & 35.0 \\
\hline Florida .............. & 18,054 & 23.9 & 19,078 & 25.3 & 34,996 & 41.2 & 49,468 & 59.3 & 56,893 & 67.1 \\
\hline 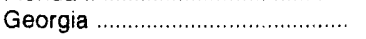 & 80,806 & 53.7 & 97,521 & 64.0 & 101,295 & 62.5 & 105,563 & 63.2 & 111,987 & 65.0 \\
\hline Idaho. & 19,961 & 96.4 & 22,781 & 99.5 & 23,075 & 98.9 & 26,565 & 99.6 & 26,963 & 99.7 \\
\hline Illinois ........ & 175,591 & 65.2 & 196,197 & 70.4 & 221,564 & 80.4 & 256,186 & 84.6 & 255,365 & 85.0 \\
\hline 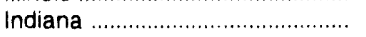 & 167,798 & 76.7 & 172,022 & 78.2 & 179,733 & 78.8 & 178,941 & 78.6 & 188,562 & 76.8 \\
\hline 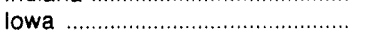 & 60,931 & 59.7 & 49,800 & 55.7 & 58,222 & 64.5 & 70,066 & 71.9 & 83,004 & 82.4 \\
\hline$\ldots \ldots \ldots \ldots \ldots \ldots \ldots \ldots \ldots \ldots$ & 68,052 & 62.9 & 78,314 & 77.8 & 95,606 & 81.8 & 104,828 & 84.9 & 117,419 & 89.8 \\
\hline 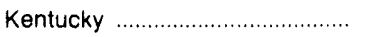 & 37,451 & 62.3 & 44,164 & 69.0 & 50,673 & 74.1 & 52,422 & 73.2 & 47,776 & 64.9 \\
\hline 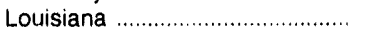 & 331,658 & 42.6 & 476,295 & 53.0 & 483,858 & 53.2 & 505,590 & 54.7 & 582,295 & 62.4 \\
\hline Maine & 0 & .0 & 0 & .0 & 70 & 3.5 & 91 & 4.1 & 0 & .0 \\
\hline Maryland ........ & 39,873 & 62.1 & 44,669 & 67.4 & 39,245 & 63.5 & 39,686 & 84.2 & 39,740 & 79.9 \\
\hline 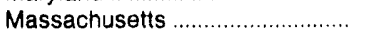 & 254 & .8 & 566 & 1.6 & 4,309 & 9.7 & 15,856 & 29.0 & 38,685 & 54.6 \\
\hline 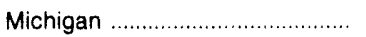 & 153,051 & 80.1 & 158,992 & 82.4 & 247.139 & 88.1 & 242,652 & 89.2 & 277,506 & 90.9 \\
\hline Minnesota & 34,281 & 44.1 & 42,966 & 52.7 & 51,265 & 58.0 & 53,727 & 58.2 & 53,665 & 57.7 \\
\hline 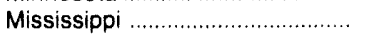 & 40,868 & 44.0 & 47,098 & 48.0 & 51.694 & 51.3 & 54,398 & 52.0 & 55,973 & 54.5 \\
\hline 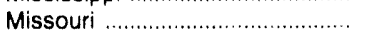 & 16,101 & 29.7 & 24,219 & 45.0 & 36,711 & 67.3 & 42,745 & 74.7 & 44,131 & 75.5 \\
\hline 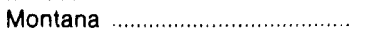 & 1,101 & 13.2 & 2,600 & 26.3 & 3,306 & 35.1 & 4,493 & 45.5 & 10,078 & 82.5 \\
\hline 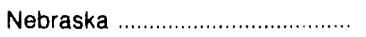 & 15,783 & 48.9 & 17,311 & 56.7 & 14,304 & 55.6 & 13,266 & 53.6 & 15,558 & 58.8 \\
\hline 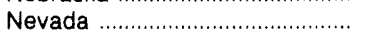 & 4,964 & 68.8 & 6,966 & 88.6 & 6,457 & 86.0 & 5,687 & 85.9 & 8,569 & 92.6 \\
\hline New Hampshire ........................... & 0 & .0 & 0 & .0 & 52 & 1.6 & 202 & 5.9 & 0 & .0 \\
\hline New Jersey .................................. & 27,017 & 34.9 & 32,598 & 38.5 & 36,790 & 40.7 & 44,419 & 44.1 & 77,276 & 44.3 \\
\hline New Mexico ................................... & 11,611 & 78.9 & 15,473 & 82.7 & 16,346 & 34.7 & 17,305 & 89.5 & 16,339 & 95.7 \\
\hline 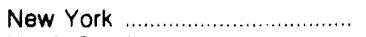 & 47,259 & 52.0 & 58,333 & 60.2 & 60,359 & 59.6 & 83,934 & 70.6 & 113,074 & 76.7 \\
\hline 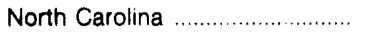 & 13,263 & 17.7 & 24,687 & 29.9 & 24,962 & 29.0 & 23,348 & 27.5 & 17,302 & 19.0 \\
\hline North Dakota ........................... & 2,206 & 56.6 & 3,336 & 73.7 & 3,296 & 75.6 & 3,901 & 76.1 & 4,656 & 78.4 \\
\hline 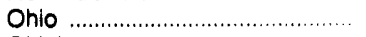 & 227,745 & 81.3 & 233,517 & 83.9 & 239,551 & 86.0 & 246,062 & 88.0 & 260,609 & 88.4 \\
\hline 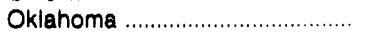 & 97,836 & 60.0 & 89,950 & 48.0 & 78,309 & 40.2 & 104,773 & 58.0 & 133,643 & 76.3 \\
\hline 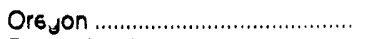 & 26,019 & 65.4 & 34,133 & 78.0 & 38,128 & 78.0 & 44,521 & 80.9 & 46,434 & 79.3 \\
\hline 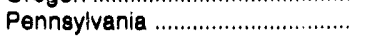 & 134,510 & 58.8 & 171,850 & 71.0 & 179,492 & 76.3 & 183,097 & 79.1 & 182,522 & 77.1 \\
\hline Rhode Island .............................. & 660 & 14.8 & 815 & 17.6 & 583 & 13.3 & 23,032 & 85.7 & 42,457 & 88.6 \\
\hline 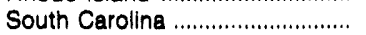 & 13,667 & 19.8 & 15,959 & 21.4 & 20,817 & 24.0 & 25,368 & 29.6 & 31,176 & 33.1 \\
\hline 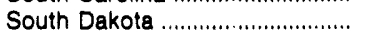 & 1,425 & 30.5 & 1,954 & 39.4 & 3,124 & 53.9 & 2,090 & 44.9 & 2,129 & 47,4 \\
\hline 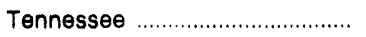 & 33,243 & 32.2 & 40,190 & 38.0 & 43.605 & 39.7 & 51,462 & 44.4 & 63,666 & 50.4 \\
\hline 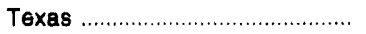 & $1,176,854$ & 70.2 & $1,298,541$ & 73.0 & $1,231,679$ & 72.0 & $1,227,979$ & 69.3 & $1,190,677$ & 68.7 \\
\hline 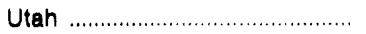 & 16.092 & 53.0 & 24,288 & 71.5 & 28,108 & 79.2 & 36,534 & 84.7 & 36,087 & 88.3 \\
\hline 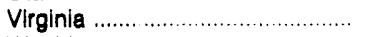 & 25,852 & 48.7 & 36,779 & 63.7 & 53,144 & 712 & 42,709 & 71.2 & 51,223 & 74.4 \\
\hline 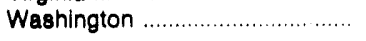 & 21,620 & 31.1 & 30,274 & 41.3 & 36,929 & $47:$ & 44,526 & 55.8 & 49,811 & 62.6 \\
\hline West Virginia & 33,433 & 82.7 & 35,992 & 72.0 & 36,632 & 76.3 & 32,142 & 78.6 & 37,034 & 83.8 \\
\hline 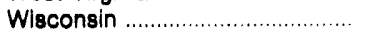 & 78,618 & 64.5 & 80,400 & 63.1 & 67,869 & 55.7 & 73,777 & 57.3 & 76,161 & 58.5 \\
\hline 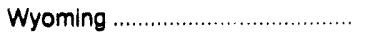 & 12,051 & 77.9 & 13,496 & 83.2 & 23,569 & 91.6 & 31,093 & 93.7 & 54,053 & 96.4 \\
\hline 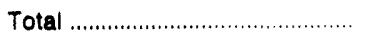 & $3,663,187$ & 57.4 & $4,297,693$ & 63.0 & $4,544,535$ & 64.8 & $4,863,923$ & 67.3 & $5,248,609$ & 69.7 \\
\hline
\end{tabular}

- =These deliveries included quantities covered by long-term contracts and gas involved in short-term or spot market sales.

A $=$ Revised data

- Not applicable

Note: Totals may not equal sum of components due to independent rounding.

Source: Energy information Administration (EIA), Form ElA-176, "Annual Report of Natural and Supplemental Gas Supply and Disposition." 
Table 20. Natural Gas Delivered to Electric Utilities for the Account of Others ${ }^{a}$ by State, 1988-1992 (Million Cubic Feet)

\begin{tabular}{|c|c|c|c|c|c|c|c|c|c|c|}
\hline \multirow[b]{2}{*}{ State } & \multicolumn{2}{|c|}{1988} & \multicolumn{2}{|c|}{1989} & \multicolumn{2}{|c|}{1990} & \multicolumn{2}{|c|}{1991} & \multicolumn{2}{|c|}{1992} \\
\hline & $\begin{array}{l}\text { Delivered } \\
\text { for the } \\
\text { Account } \\
\text { of Others }\end{array}$ & $\begin{array}{l}\text { Percent of } \\
\text { Total Elec- } \\
\text { tric } \\
\text { Utility } \\
\text { Deliveries }\end{array}$ & $\begin{array}{c}\text { Delivered } \\
\text { for the } \\
\text { Account } \\
\text { of Others }\end{array}$ & $\begin{array}{l}\text { Percent of } \\
\text { Total Elec- } \\
\text { tric } \\
\text { Utility } \\
\text { Deliveries }\end{array}$ & $\begin{array}{l}\text { Delivered } \\
\text { for the } \\
\text { Account } \\
\text { of Others }\end{array}$ & $\begin{array}{c}\text { Percent of } \\
\text { Total Elec- } \\
\text { tric } \\
\text { Utility } \\
\text { Deliveries }\end{array}$ & $\begin{array}{l}\text { Delivered } \\
\text { for the } \\
\text { Account } \\
\text { of Others }\end{array}$ & $\begin{array}{c}\text { Percent of } \\
\text { Total Elec- } \\
\text { tric } \\
\text { Utility } \\
\text { Deliveries }\end{array}$ & $\begin{array}{l}\text { Delivered } \\
\text { for the } \\
\text { Account } \\
\text { of Others }\end{array}$ & $\begin{array}{c}\text { Percent of } \\
\text { Total Elec- } \\
\text { tric } \\
\text { Utility } \\
\text { Deliveries }\end{array}$ \\
\hline 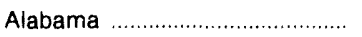 & 886 & 39.8 & 1,456 & 64.4 & 2.287 & 63.7 & 3,045 & 77.5 & 2,739 & 75.2 \\
\hline Alaska & 5,908 & 20.9 & 6,773 & 24.9 & 6,495 & 28.2 & 0 & 0 & 8,925 & 31.1 \\
\hline Arizona & 20,431 & 83.3 & 25,708 & 48.9 & 14,222 & 63.4 & 13,831 & 80.4 & 40,553 & 99.9 \\
\hline 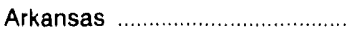 & 0 & .0 & 19,593 & 100.0 & 29,049 & 100.0 & 25,180 & 96.6 & 25,647 & 96.7 \\
\hline 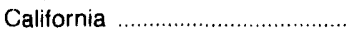 & 55,488 & 10.3 & 87,126 & 16.7 & 114,142 & 25.3 & 225,773 & 49,8 & 406,235 & 697 \\
\hline 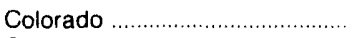 & 4,603 & 50.2 & 5,624 & 57.4 & 4,904 & 73.5 & 6,097 & 77.4 & 3.931 & ax: is \\
\hline 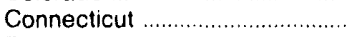 & 0 & 0 & 2,519 & 76.9 & 4,796 & 100.0 & 4.518 & 100.0 & 1881 & thit. \\
\hline Delaware & 409 & 10.8 & 313 & 4.7 & 35 & .3 & 39 & 3 & $4 i$ & \\
\hline Florida & 16,059 & 10.4 & 11,526 & 6.1 & 68,783 & 36.0 & 168,412 & 84.8 & $186 \%$ & \\
\hline 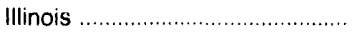 & 2,461 & 59.4 & 4,603 & 80.1 & 6,682 & 87.1 & 9,150 & 89.9 & u & \\
\hline Indiana & 1,979 & 58.8 & 2,933 & 72.2 & 5,011 & 76.4 & 7,997 & 81.5 & & j) \\
\hline lowa .... & 1,784 & 42.1 & 1,183 & 42.5 & 1.137 & 38.1 & 1,256 & 33.3 & &, 5.6 \\
\hline 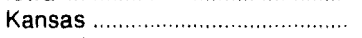 & 4,003 & 27.8 & 9,822 & 60.5 & 17,288 & 71.1 & 23,059 & 707 & & 54.6 \\
\hline 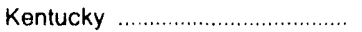 & 0 & .0 & 0 & .0 & 0 & .0 & 32 & 141 & & .0 \\
\hline 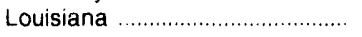 & 181,223 & 71.7 & 170,098 & 79.0 & 231,753 & 85.5 & 209,258 & 82.2 & $4 i$ & 86.8 \\
\hline Maryland ............ & 0 & .0 & 0 & .0 & 8,483 & 48.2 & 6,430 & 39.8 & 3,691 & 35.4 \\
\hline 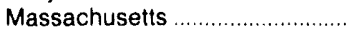 & 2 & .0 & 4,079 & 7.8 & 18,328 & 33.0 & 16,832 & 44.4 & 22,672 & 65.0 \\
\hline 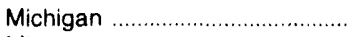 & 1,934 & 77.9 & 885 & 61.9 & 23,015 & 98.6 & 20,960 & 98.1 & 19,162 & 98.1 \\
\hline 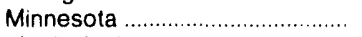 & 1,463 & 47.8 & 1,553 & 61.1 & 1.970 & 57.4 & 1,657 & 28.0 & 1,443 & 28.1 \\
\hline 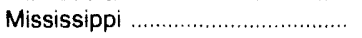 & 26,010 & 96.0 & 45,785 & 96.0 & 62,412 & 94.9 & 57,297 & 94.5 & 41,304 & 79.6 \\
\hline 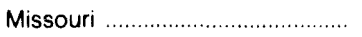 & 1,879 & 51.6 & 2,485 & 76.4 & 2,015 & 44.4 & 2,869 & 23.2 & 1,418 & 52.3 \\
\hline 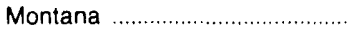 & 0 & .0 & 0 & .0 & 118 & 28.7 & 178 & 68.7 & 99 & 44.5 \\
\hline 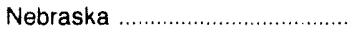 & 2 & .1 & 679 & 29.6 & 2,793 & 79.0 & 2,612 & 77.6 & 1,038 & 57.9 \\
\hline 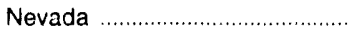 & 6,903 & 64.3 & 22,374 & 98.2 & 23,193 & 94.7 & 21,403 & 98.5 & 28,675 & 99.2 \\
\hline 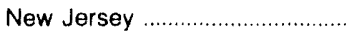 & 315 & .6 & 1.144 & 2.1 & 1,432 & 2.9 & 2,056 & 3.2 & 623 & 1.6 \\
\hline 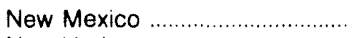 & 13,760 & 88.9 & 19,941 & 94.8 & 23,532 & 95.5 & 26,421 & 95.7 & 17,325 & 95.9 \\
\hline 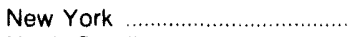 & 10,511 & 7.1 & 16,216 & 9.0 & 21,280 & 9.6 & 23,485 & 11.1 & 19,893 & 9.9 \\
\hline 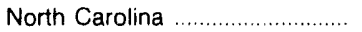 & 840 & 85.5 & 1,593 & 98.3 & 2,149 & 82.9 & 2,106 & 67.5 & 461 & 15.4 \\
\hline Ohio & 0 & .0 & 301 & 31.5 & 656 & 57.7 & 2,695 & 86.5 & 2,147 & 84.2 \\
\hline 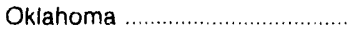 & 163,015 & 88.0 & 166,455 & 89.4 & 160,721 & 90.2 & 131,393 & 81.8 & 137,019 & 86.9 \\
\hline Oregon ............. & 0 & .0 & 13,148 & 100.0 & 7,458 & 100.0 & 10,798 & 100.0 & 12,818 & 100.0 \\
\hline 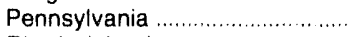 & 935 & 25.3 & 2,075 & 40.3 & 1,291 & 42.1 & 1.801 & 73.6 & 3,252 & 82.2 \\
\hline 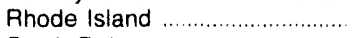 & 0 & .0 & 342 & 60.7 & 1,033 & 99.4 & 1,771 & 99.9 & 466 & 100.0 \\
\hline 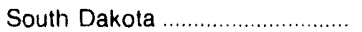 & 0 & .0 & 41 & 33.4 & 139 & 97.3 & 151 & 86.9 & 714 & 92.6 \\
\hline Tennessee .................................. & 0 & .0 & 0 & 0 & 563 & 95.2 & 143 & 64.1 & 219 & 74.1 \\
\hline 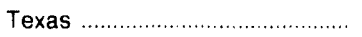 & 551,078 & 56.8 & 493,095 & 56.0 & 515.120 & 52.4 & 534,110 & 56.2 & 449,615 & 51.8 \\
\hline Utan & 0 & .0 & 0 & .0 & 445 & 87.9 & 4.562 & 99.6 & 5,434 & 99.5 \\
\hline 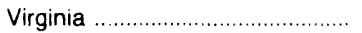 & 654 & 97.3 & 3,062 & 96.0 & 4,945 & 81.4 & 9,441 & 99.8 & 11,669 & 100.0 \\
\hline Washington & 877 & 49.9 & 7.035 & 89.4 & 48 & 35.5 & 88 & 63.5 & 3.597 & 79.7 \\
\hline 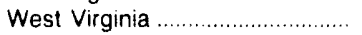 & 0 & .0 & 0 & .0 & 0 & 0 & 159 & 100.0 & 204 & 100.0 \\
\hline 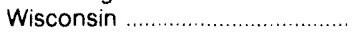 & 842 & 40.8 & 615 & 40.0 & 618 & 45.6 & 1,013 & 44.0 & 1,899 & 70.4 \\
\hline ……… & $1,076,253$ & 42.5 & $1,152,181$ & 45.0 & $1,390,340$ & 50.7 & $1,580,077$ & 58.5 & $1,697,363$ & 63.7 \\
\hline
\end{tabular}

a $\quad \therefore$ These deliveries included quantities covered by long-term contracts and gas involved in short-term or spot market sales.

A $=$ Revised data.

-- - Not applicable.

Note: Totals may not equal sum of components due to independent rounding

Source: Energy Information Administration (EIA). Form EIA-176, "Annual Report of Natural and Supplemental Gas Supply and Disposition." 
Figure 9. Average City Gate Price of Natural Gas in the United States, 1992

(Dollars per Thousand Cubic Feet)

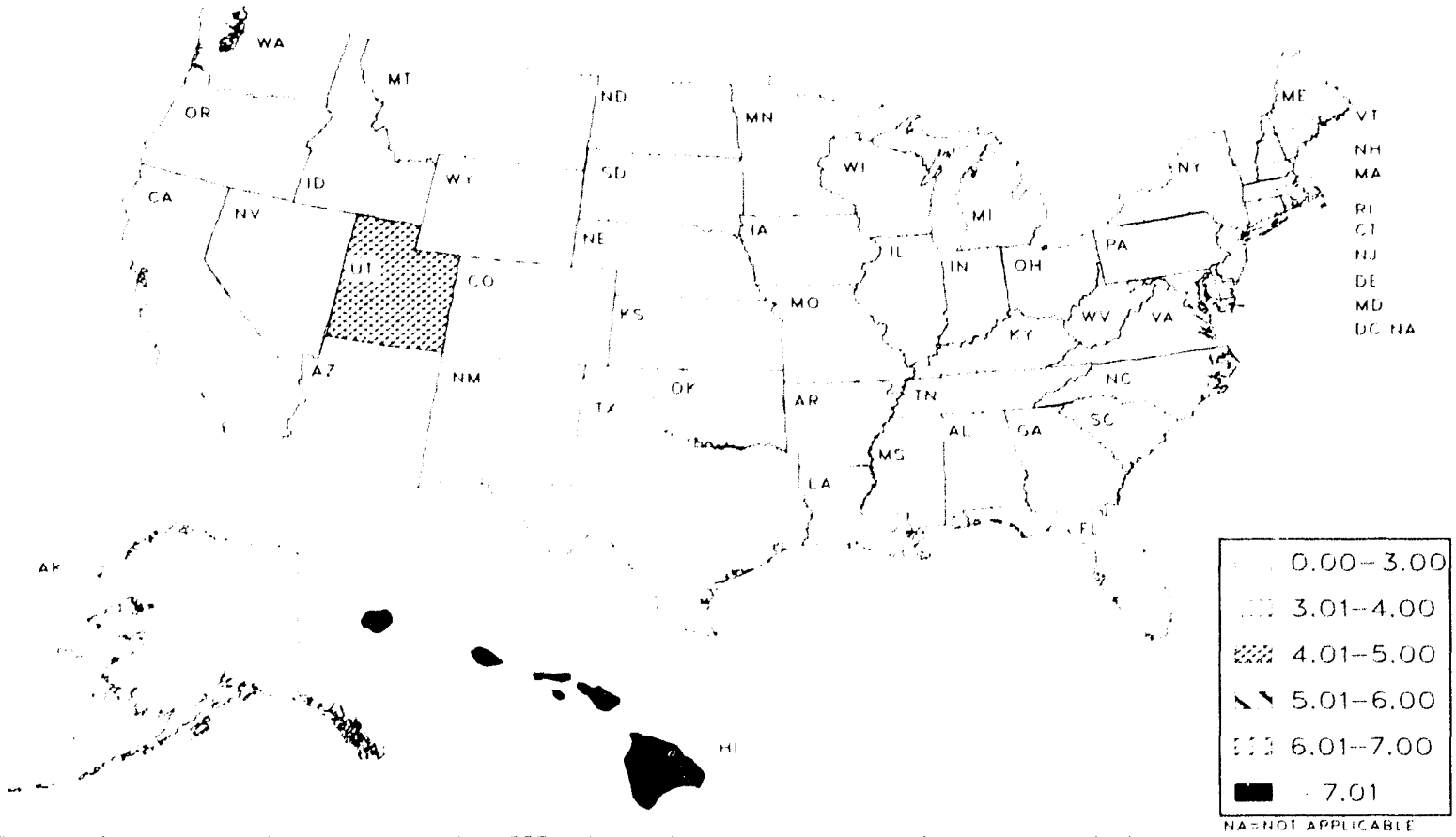


Table 21. Average City Gate Price of Natural Gas in the United States, 1988-1992 (Dollars per Thousand Cubic Feet)

\begin{tabular}{|c|c|c|c|c|c|}
\hline \multirow{2}{*}{ State } & \multicolumn{5}{|c|}{ Average Price } \\
\hline & 1988 & 1989 & 1990 & 1991 & 1992 \\
\hline Alabama & $\$ 3.16$ & $\$ 3.00$ & $\$ 3.13$ & $\$ 3.11$ & $\$ 3.21$ \\
\hline Alaska & .33 & .33 & .34 & .32 & 34 \\
\hline 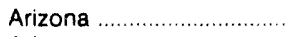 & 2.51 & 2.67 & 2.73 & 2.45 & 2.33 \\
\hline 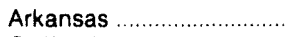 & 2.43 & 2.47 & 2.41 & 2.45 & 2.60 \\
\hline 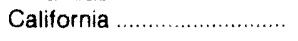 & 2.60 & 2.75 & 2.90 & 2.80 & 2.72 \\
\hline 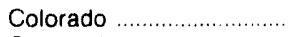 & 3.07 & 2.96 & 2.94 & 2.85 & 2.85 \\
\hline Connecticut ........................ & 3.27 & 3.46 & 3.66 & 3.50 & 3.73 \\
\hline 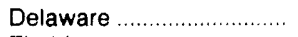 & 2.88 & 2.82 & 2.76 & 2.54 & 2.83 \\
\hline 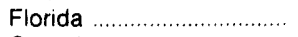 & 2.46 & 2.63 & 2.71 & 2.51 & 2.61 \\
\hline 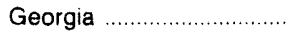 & 3.60 & 3.54 & 3.43 & 3.38 & 3.28 \\
\hline Hawaii ...... & 6.21 & 6.49 & 7.67 & 8.74 & 7.72 \\
\hline 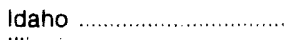 & 2.14 & 2.17 & 2.08 & 2.14 & 2.18 \\
\hline 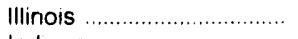 & 2.74 & 2.99 & 3.09 & 2.91 & 3.20 \\
\hline 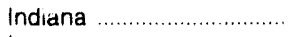 & 3.13 & 3.13 & 3.15 & 3.05 & 3.08 \\
\hline 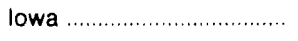 & 2.92 & 2.80 & 2.86 & 2.73 & 3.20 \\
\hline 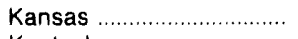 & 2.05 & 2.28 & 2.76 & 2.62 & 2.50 \\
\hline 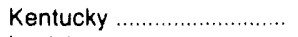 & 2.94 & 3.01 & 3.07 & 2.83 & 3.02 \\
\hline 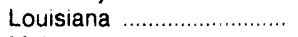 & 3.09 & 2.98 & 2.97 & 2.56 & 2.48 \\
\hline 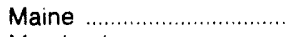 & 3.00 & 3.23 & 3.06 & 3.00 & 3.17 \\
\hline 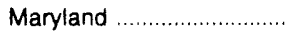 & 3.15 & 3.20 & 3.16 & 3.05 & 3.20 \\
\hline Massachusetts …............... & 3.00 & 3.20 & 3.34 & 3.37 & 3.52 \\
\hline 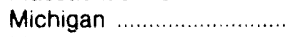 & 3.41 & 3.24 & 3.12 & 3.08 & 3.04 \\
\hline 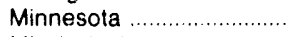 & 2.79 & 2.72 & 2.83 & 2.63 & 2.92 \\
\hline Mississippi ........................ & 3.29 & 3.08 & 2.89 & 2.55 & 2.62 \\
\hline 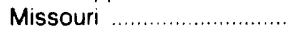 & 2.87 & 3.00 & 3.14 & 2.92 & 2.86 \\
\hline Montana ............................. & 3.69 & 3.43 & 3.30 & 3.69 & 3.45 \\
\hline Nebraska ........................... & 3.03 & 2.91 & 2.95 & 2.75 & 2.91 \\
\hline 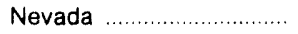 & 2.87 & 3.33 & 2.75 & 2.33 & 2.37 \\
\hline New Hampshire ............... & 3.04 & 3.28 & 3.51 & 3.40 & 3.58 \\
\hline New Jersey ....................... & 3.03 & 3.17 & 3.23 & 3.14 & 3.29 \\
\hline Oregon & 3.01 & 2.67 & 2.47 & 2.39 & 2.34 \\
\hline New Mexico ........................ & 2.58 & 2.66 & 2.63 & 2.49 & 2.25 \\
\hline 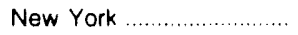 & 2.91 & 3.07 & 3.05 & 2.92 & 3.01 \\
\hline North Carolina ................... & 2.87 & 3.01 & 2.88 & 2.69 & 2.88 \\
\hline North Dakota ..................... & 3.42 & 3.12 & 3.07 & 3.49 & 3.28 \\
\hline Ohio $\ldots \ldots \ldots \ldots \ldots$ & 3.26 & 3.31 & 3.09 & 3.05 & 3.26 \\
\hline 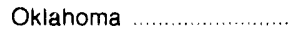 & 2.24 & 2.07 & 2.03 & 2.04 & 2.22 \\
\hline Pennsylvania ........................ & 3.15 & 3.26 & 3.47 & 3.27 & 3.29 \\
\hline 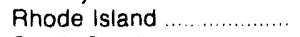 & 3.43 & 3.68 & 3.71 & 3.68 & 3.82 \\
\hline South Carolina .................... & 3.46 & 3.46 & 3.14 & 2.95 & 3.23 \\
\hline South Dakota & 3.18 & 3.04 & 3.12 & 3.11 & 3.10 \\
\hline Tennesser ........................ & 2.77 & 2.81 & 2.88 & 2.73 & 2.90 \\
\hline Texas & 3.05 & 3.33 & 3.14 & 2.88 & 3.06 \\
\hline 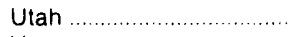 & 3.14 & 3.59 & 3.91 & 3.89 & 4.09 \\
\hline 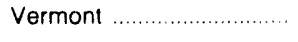 & 2.59 & 2.59 & 2.88 & 2.87 & 2.93 \\
\hline 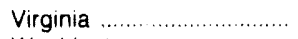 & 2.87 & 3.13 & 3.09 & 2.76 & 2.91 \\
\hline Washington ......................... & 2.32 & 2.20 & 1.95 & 1.91 & 1.90 \\
\hline 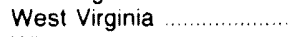 & 3.43 & 3.75 & 3.54 & 3.58 & 3.23 \\
\hline Wisconsin $\ldots \ldots \ldots \ldots$ & 3.62 & 3.40 & 3.34 & 3.17 & 3.36 \\
\hline 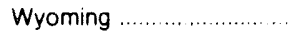 & 3.15 & 2.99 & 3.00 & 3.04 & 2.90 \\
\hline U.S. Average ................. & 2.92 & 3.01 & 3.03 & 2.90 & 3.01 \\
\hline
\end{tabular}

Source. Energy Intormation Administration (EIA), Form ElA-857, "Monthly Report of Natural Gas Purchases and Deliveries to Consumers." 
Table 22. Average Price of Natural Gas Delivered to Consumers by State, 1991-1992 (Dollars per Thousand Cubic Feet)

\begin{tabular}{|c|c|c|c|c|c|c|c|c|c|}
\hline \multirow{2}{*}{ State } & \multicolumn{3}{|c|}{ Residential } & \multicolumn{3}{|c|}{ Commercial } & \multicolumn{3}{|c|}{ Industrial } \\
\hline & 1991 & 1992 & $\begin{array}{l}\text { Percent } \\
\text { Change }\end{array}$ & 1991 & 1992 & $\begin{array}{l}\text { Percent } \\
\text { Change }\end{array}$ & 1991 & 1992 & $\begin{array}{l}\text { Percent } \\
\text { Change }\end{array}$ \\
\hline Alabama & $\$ 7.05$ & $\$ 6.74$ & -4.4 & $\$ 5.74$ & $\$ 5.71$ & -0.5 & $\$ 3.00$ & $\$ 3.07$ & 2.3 \\
\hline Alaska & 4.18 & 3.79 & -9.3 & 2.89 & 2.64 & -8.7 & 1.18 & 1.18 & .0 \\
\hline Arizona & 6.99 & 7.24 & 3.6 & 5.07 & 5.20 & 2.6 & 3.51 & 4.16 & 18.5 \\
\hline Arkansas & 4.98 & 5.10 & 2.4 & 4.35 & 4.38 & .7 & 3.06 & 3.13 & 2.3 \\
\hline 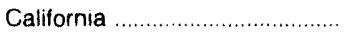 & 6.27 & 5.97 & -4.8 & 5.50 & 5.15 & -6.4 & 3.96 & 3.67 & -7.3 \\
\hline Colorado & 4.59 & 4.56 & -.7 & 4.04 & 4.00 & -1.0 & 2.34 & 2.20 & -6.0 \\
\hline 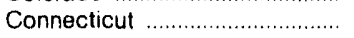 & 8.74 & 8.96 & 2.5 & 6.90 & 7.20 & 4.3 & 4.84 & 4.92 & 1.7 \\
\hline Delaware & 5.86 & 6.13 & 4.6 & 4.81 & 4.94 & 2.7 & 3.09 & 3.25 & 5.2 \\
\hline D.C. & 7.07 & 7.61 & 7.6 & 5.17 & 5.36 & 3.7 & .. & .. & -. \\
\hline Florida & 8.98 & 9.08 & 1.1 & 4.92 & 4.98 & 1.2 & 3.11 & 3.22 & 3.5 \\
\hline . & 6.70 & 6.44 & -3.9 & 5.67 & 5.55 & -2.1 & 3.34 & 3.50 & 4.8 \\
\hline Hawaii & 22.93 & 18.03 & -21.4 & 13.36 & 13.34 & -.2 & .. & -. & .. \\
\hline 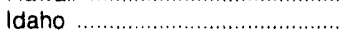 & 5.19 & 5.23 & 8 & 4.42 & 4.40 & -.5 & 2.94 & 2.97 & 1.0 \\
\hline Illinois & 4.95 & 5.09 & 2.8 & 4.56 & 4.65 & 2.0 & 3.77 & 3.75 & -.5 \\
\hline 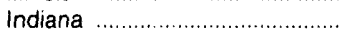 & 5.46 & 5.43 & -.6 & 4.61 & 4.57 & -.9 & 3.53 & 3.39 & -4.0 \\
\hline lowa & 4.81 & 5.23 & 8.7 & 3.99 & 4.27 & 7.0 & 2.65 & 3.55 & 34.0 \\
\hline 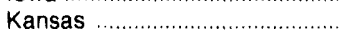 & 4.38 & 4.70 & 7.3 & 3.32 & 3.53 & 6.3 & 2.67 & 2.61 & -2.3 \\
\hline 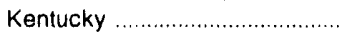 & 4.87 & 5.01 & 2.9 & 4.44 & 4.47 & .7 & 3.23 & 3.23 & .0 \\
\hline Louisiana & 5.77 & 5.60 & -3.0 & 4.90 & 4.79 & -2.3 & 1.74 & 1.93 & 10.9 \\
\hline Maine & 6.86 & 6.95 & 1.3 & 6.02 & 6.19 & 2.8 & 4.69 & 4.14 & -11.7 \\
\hline 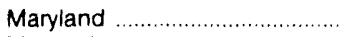 & 6.16 & 6.43 & 4.4 & 5.04 & 5.24 & 4.0 & 3.51 & 3.56 & 1.4 \\
\hline 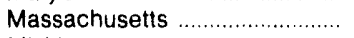 & 8.11 & 7.92 & -2.4 & 6.17 & 5.86 & -5.0 & 3.99 & 4.14 & 3.8 \\
\hline 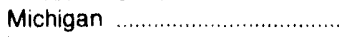 & 5.07 & 5.06 & -.2 & 4.70 & 4.65 & -1.1 & 4.00 & 3.92 & -2.0 \\
\hline 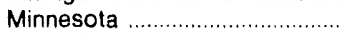 & 4.52 & 4.86 & 7.5 & 3.81 & 4.10 & 7.6 & 2.78 & 3.05 & 9.7 \\
\hline 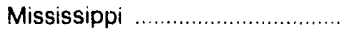 & 5.21 & 4.95 & -5.0 & 4.28 & 4.13 & -3.5 & 2.35 & 2.53 & 7.7 \\
\hline 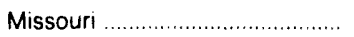 & 5.14 & 5.11 & -.6 & 4.50 & 4.47 & -.7 & 4.08 & 3.87 & -5.2 \\
\hline 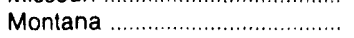 & 4.52 & 4.80 & 6.2 & 4.35 & 4.46 & 2.5 & 3.22 & 4.19 & 30.1 \\
\hline Nebraska & 4.64 & 4.82 & 3.9 & 3.87 & 3.99 & 3.1 & 2.76 & 2.92 & 5.8 \\
\hline Nevada & 5.61 & 5.59 & -.4 & 4.34 & 4.33 & -.2 & 4.21 & 4.07 & -3.3 \\
\hline New Hampshire .......................... & 7.14 & 7.55 & 5.7 & 6.35 & 6.74 & 6.1 & 4.31 & 4.49 & 4.2 \\
\hline 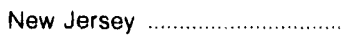 & 6.73 & 6.94 & 3.1 & 5.21 & 5.54 & 6.3 & 3.65 & 3.42 & -6.3 \\
\hline New Mexico .................................. & 5.40 & 4.75 & -12.0 & 4.15 & 3.36 & -19.0 & 3.53 & 6.86 & 94.3 \\
\hline 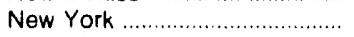 & 7.35 & 7.58 & 3.1 & 5.47 & 5.75 & 5.1 & 4.72 & 4.93 & 4.4 \\
\hline North Carolina & 6.24 & 6.60 & 5.8 & 4.53 & 4.79 & 5.7 & 3.24 & 3.34 & 3.1 \\
\hline 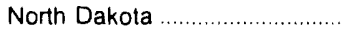 & 4.82 & 5.00 & 3.7 & 4.34 & 4.52 & 4.1 & 3.19 & 3.25 & 1.9 \\
\hline Ohio & 5.28 & 5.20 & -1.5 & 4.76 & 4.72 & -.9 & 4.09 & 4.15 & 1.5 \\
\hline Oklahoma & 4.72 & 4.96 & 5.1 & 3.91 & 4.23 & 8.2 & 1.69 & 2.02 & 19.5 \\
\hline Oregon & 6.13 & 6.17 & .7 & 4.75 & 4.73 & -.4 & 3.41 & 3.36 & -1.5 \\
\hline 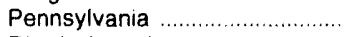 & 6.76 & 6.60 & -2.4 & 6.00 & 5.87 & -2.2 & 4.02 & 3.75 & -6.7 \\
\hline 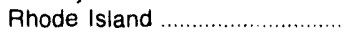 & 7.63 & 7.68 & .7 & 6.03 & 6.32 & 4.8 & 5.40 & 4.66 & -13.7 \\
\hline 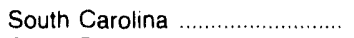 & 6.98 & 7.03 & .7 & 5.56 & 5.65 & 1.6 & 2.95 & 3.13 & 6.1 \\
\hline 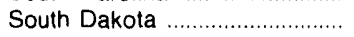 & 4.94 & 5.15 & 4.3 & 4.04 & 4.19 & 3.7 & 3.31 & 3.63 & 9.7 \\
\hline 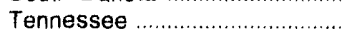 & 5.19 & 5.50 & 6.0 & 4.76 & 5.06 & 6.3 & 3.22 & 3.44 & 6.8 \\
\hline Texas & 5.71 & 5.78 & 1.2 & 4.01 & 4.09 & 2.0 & 1.93 & 2.12 & 9.8 \\
\hline 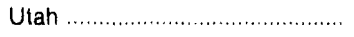 & 5.44 & 5.44 & .0 & 4.50 & 4.40 & -2.2 & 3.69 & 3.91 & 6.0 \\
\hline 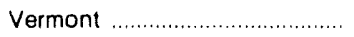 & 6.23 & 6.70 & 7.5 & 5.24 & 5.67 & 8.2 & 2.99 & 3.28 & 9.7 \\
\hline Virginia & 6.80 & 6.69 & -1.6 & 4.85 & 4.97 & 2.5 & 3.81 & 3.72 & -2.4 \\
\hline 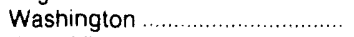 & 4.68 & 5.00 & 6.8 & 4.06 & 4.32 & 6.4 & 2.79 & 2.91 & 4.3 \\
\hline West Virginia & 6.50 & 6.31 & -2.9 & 6.11 & 5.48 & -10.3 & 2.95 & 2.89 & -2.0 \\
\hline 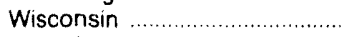 & 5.61 & 5.87 & 4.6 & 4.62 & 4.81 & 4.1 & 3.16 & 3.38 & 7.0 \\
\hline 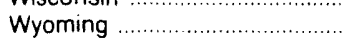 & 4.74 & 4.72 & $\begin{array}{l}4.0 \\
-.4\end{array}$ & 4.31 & 4.26 & -1.2 & 3.03 & 2.91 & -4.0 \\
\hline 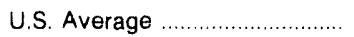 & 5.82 & 5.89 & 1.2 & 4.81 & 4.88 & 1.5 & 2.69 & 2.84 & 5.6 \\
\hline
\end{tabular}


Table 22. Average Price of Natural Gas Delivered to Consumers by State, 1991-1992 (Continued) (Dollars per Thousand Cubic Feet)

\begin{tabular}{|c|c|c|c|c|c|c|}
\hline \multirow[b]{2}{*}{ State } & \multicolumn{3}{|c|}{ Vehicle Fuel } & \multicolumn{3}{|c|}{ Electric Utilities } \\
\hline & 1991 & 1992 & $\begin{array}{l}\text { Percent } \\
\text { Change }\end{array}$ & 1991 & 1992 & $\begin{array}{l}\text { Percen } \\
\text { Change }\end{array}$ \\
\hline Alabama & .. & $\$ 6.46$ & .. & $\$ 1.91$ & $\$ 2.28$ & 19.4 \\
\hline 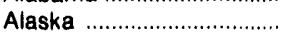 & .. & .. & .- & .53 & .57 & 7.5 \\
\hline Arizona ................................ & 3.82 & 3.63 & -5.0 & 2.06 & 2.28 & 10.7 \\
\hline Arkansas .............................. & .. & & & 1.44 & 1.57 & 9.0 \\
\hline 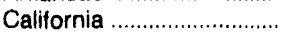 & 5.77 & 6.43 & 11.4 & 2.95 & 2.81 & -4.8 \\
\hline Colorado & 3.44 & 3.45 & 3 & 2.14 & 2.14 & .0 \\
\hline Connecticut ......................... & .. & 12.45 & .. & 2.16 & 2.74 & 26.9 \\
\hline Delaware ................................ & -- & -. & -- & 2.49 & 2.70 & 8.4 \\
\hline 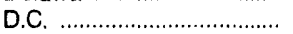 & .. & .. & .. & .. & .. & .. \\
\hline Florida .............................. & 4.73 & 4.44 & -6.1 & 2.17 & 2.30 & 6.0 \\
\hline 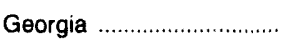 & .. & -. & .. & 2.83 & 2.89 & 2.1 \\
\hline 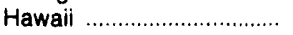 & .- & .. & .. & -. &. & .. \\
\hline Idaho ……............................ & .. & .. & .. & .. & .. & .. \\
\hline Illinois ....................................... & 3.41 & 3.80 & 11.4 & 2.14 & 2.24 & 4.7 \\
\hline 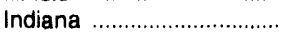 & 4.71 & 4.25 & -9.8 & 2.38 & 2.48 & 4.2 \\
\hline lowa & 3.11 & 3.99 & 28.3 & 2.70 & 3.08 & 14.1 \\
\hline Kansas .................................. & .. & .. & .. & 1.65 & 1.94 & 17.6 \\
\hline Kentucky ............................. & .. & 3.78 & .. & 2.65 & 2.77 & 4.5 \\
\hline Louisiana ............................... & 3.56 & 4.30 & 20.8 & 1.59 & 1.91 & 20.1 \\
\hline 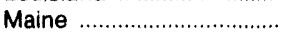 & .. &.. & -. & .. & .. & .. \\
\hline Maryland ................................. & .. & .. & .. & 2.36 & 2.66 & 12.7 \\
\hline Massachusetts ..................... & 3.90 & 3.65 & -6.4 & A 2.27 & 2.68 & 18.1 \\
\hline Michigan ………………........ & 2.15 & .99 & -54.0 & .76 & .81 & 6.6 \\
\hline Minnesota ........................... & .. & .. & .. & 8 1.71 & 1.85 & 8.2 \\
\hline Mississippi ............................ & .. &.. & -- & 1.61 & 1.85 & 14.9 \\
\hline 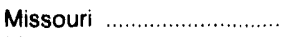 & .. & .. & .. & 1.51 & 1.89 & 25.2 \\
\hline 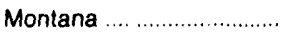 & 4.50 & 4.51 & .2 & 4.33 & 3.30 & -23.8 \\
\hline Nebraska ............................ & .. & .. & .. & 1.85 & 2.28 & 23.2 \\
\hline Nevada & 3.72 & 3.45 & -7.3 & 1.78 & 1.91 & 7.3 \\
\hline New Hampshire ............... &.- &. & .. & .. & 2.20 & - \\
\hline New Jersey ....................... & .- & .. & .. & 2.02 & 2.18 & 7.9 \\
\hline New Mexico ......................... & .. & .. & .- & 1.73 & 1.99 & 15.0 \\
\hline New York ......................... & 4.68 & 5.47 & 16.9 & 2.30 & 2.48 & 7.8 \\
\hline North Carolina ...................... & 4.65 & 5.08 & 9.2 & 2.76 & 2.96 & 7.2 \\
\hline 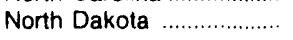 & 3.34 & 4.25 & 27.2 & 4.36 & 4.18 & -4.1 \\
\hline Ohio & 2.97 & 3.12 & 5.1 & ค 2.19 & 2.31 & 5.5 \\
\hline Oklahoma & 3.83 & 3.06 & -20.1 & 2.98 & 3.20 & 7.4 \\
\hline Oregon & .. & 2.17 & .. & 1.59 & 1.97 & 23.9 \\
\hline Pennsylvanıa ........................ & 5.26 & 5.97 & 13.5 & 3.05 & 3.06 & .3 \\
\hline 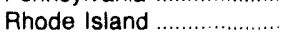 & 3.77 & 3.88 & 2.9 & ค 2.04 & 2.20 & 7.8 \\
\hline South Carolina & .. & .. & .. & 1.53 & 1.73 & 13.1 \\
\hline South Dakota & 4.13 & 4.08 & -1.2 & A 1.77 & 2.88 & 62.7 \\
\hline Tennessee ........................... & 4.11 & 4.35 & 5.8 & - 2.52 & 2.49 & -1.2 \\
\hline Texas ............................. & 5.49 & 4.53 & -17.5 & 2.03 & 2.25 & 10.8 \\
\hline Utah & 5.52 & 5.42 & -1.8 & 1.72 & 1.87 & 8.7 \\
\hline Vermont ........................... & .- & .- & .. & R 1.72 & 2.00 & 16.3 \\
\hline Virginia ................................ & .. & .. & .. & 1.90 & 2.47 & 30.0 \\
\hline 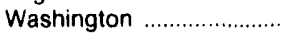 & 4.06 & 4.20 & 3.4 & 4.02 & 3.31 & -17.7 \\
\hline West Virginia & .. & 2.90 & .. & 3.63 & 3.53 & -2.8 \\
\hline Wisconsin ........................... & 3.44 & 3.69 & 7.3 & 2.72 & 2.42 & -11.0 \\
\hline 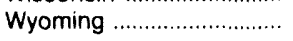 & 5.66 & 5.74 & 1.4 & 3.51 & 3.33 & -5.1 \\
\hline U.S. Average & 3.96 & 4.05 & 2.3 & 2.18 & 2.36 & 8.3 \\
\hline
\end{tabular}

R = Revised data.

- Average prices calculated from data reported on Form EIA-176.

Sources: Eneigy Information Administration (EIA), Form ElA-176, "Annual Report of Natural and Supplemental Gas Supply and Disposition;" and the Federal Energy Regulatory Commission (FERC), Form FERC-423, "Monthly Report of Cost and Quality of Fuels for Electric Plants." 
Figure 10. Average Price of Natural Gas Delivered to U.S. Residential Consumers, 1992 (Dollars per Thousand Cubic Feet)

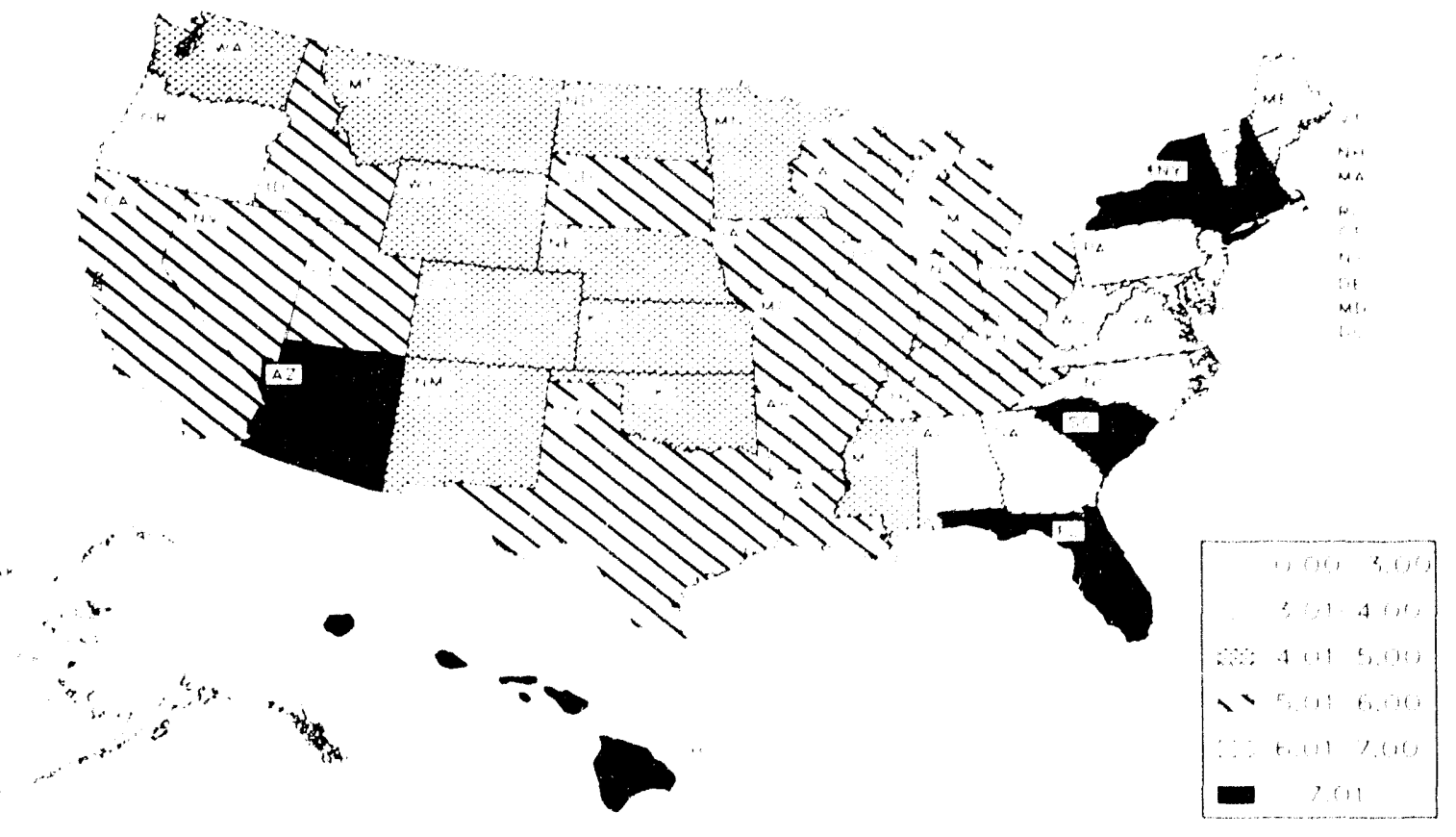

Figure 11. Average Price of Natural Gas Delivered to U.S. Commercial Consumers, 1992 (Dollars per Thousand Cubic Feet)

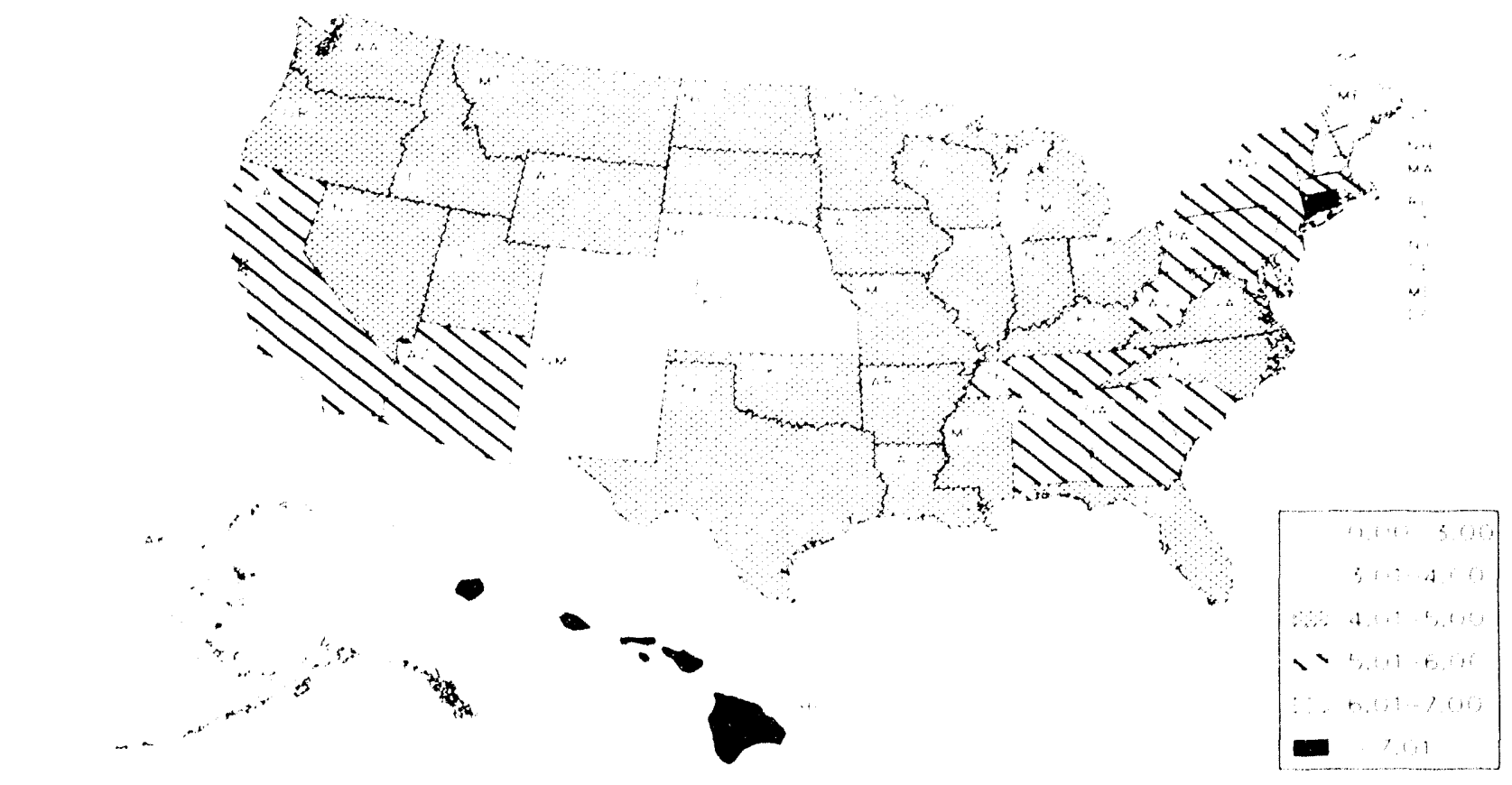


Figure 12. Average Price of Natural Gas Delivered to U.S. Industrial Consumers, 1992

(Dollars per Thousand Cubic Feet)

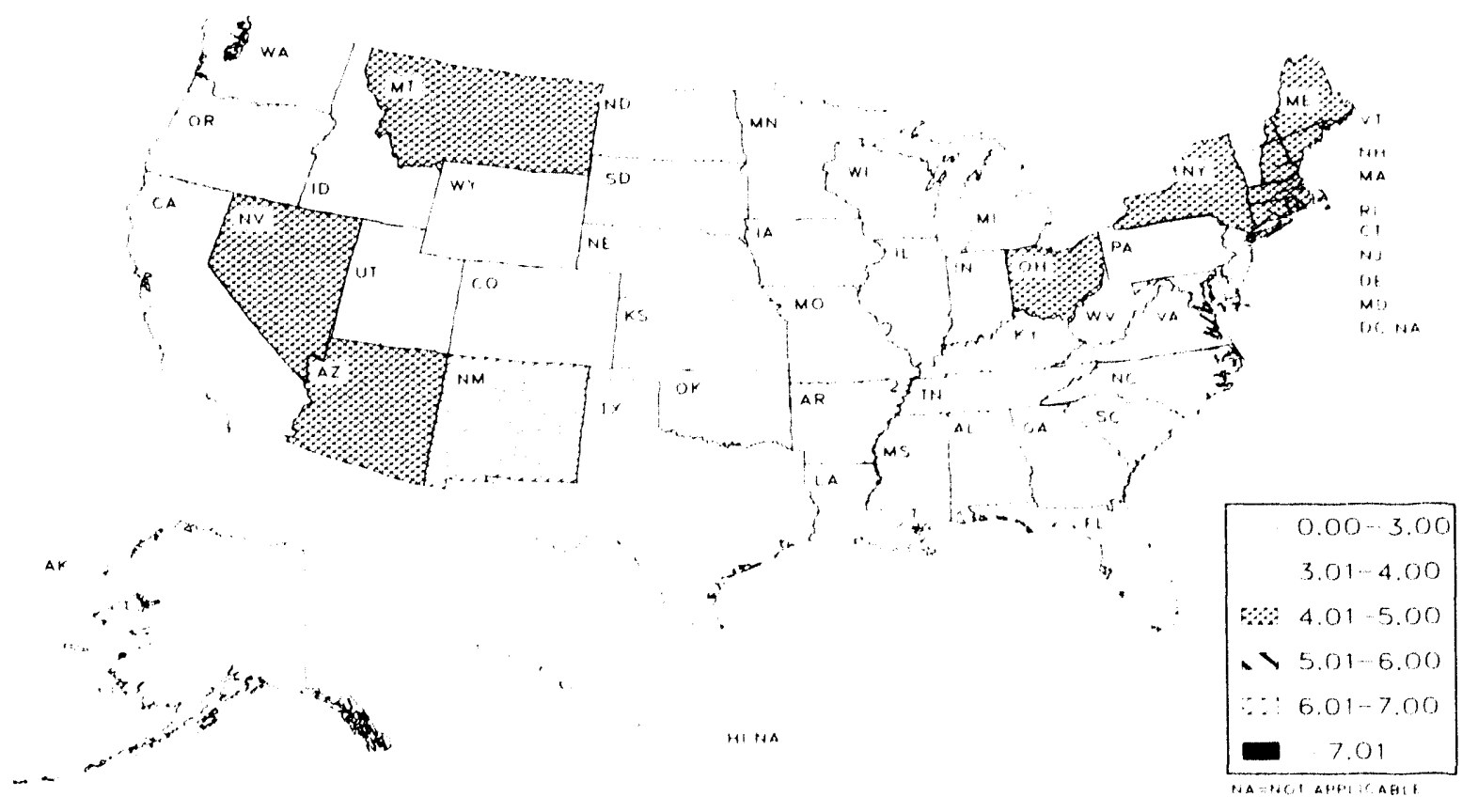

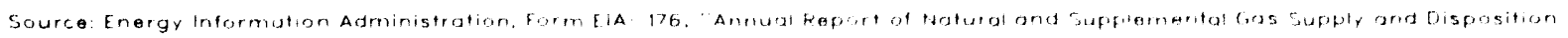

Figure 13. Average Price of Natural Gas Delivered to U.S. Electric Utilities, 1992

(Dollars per Thousand Cubic Feet)

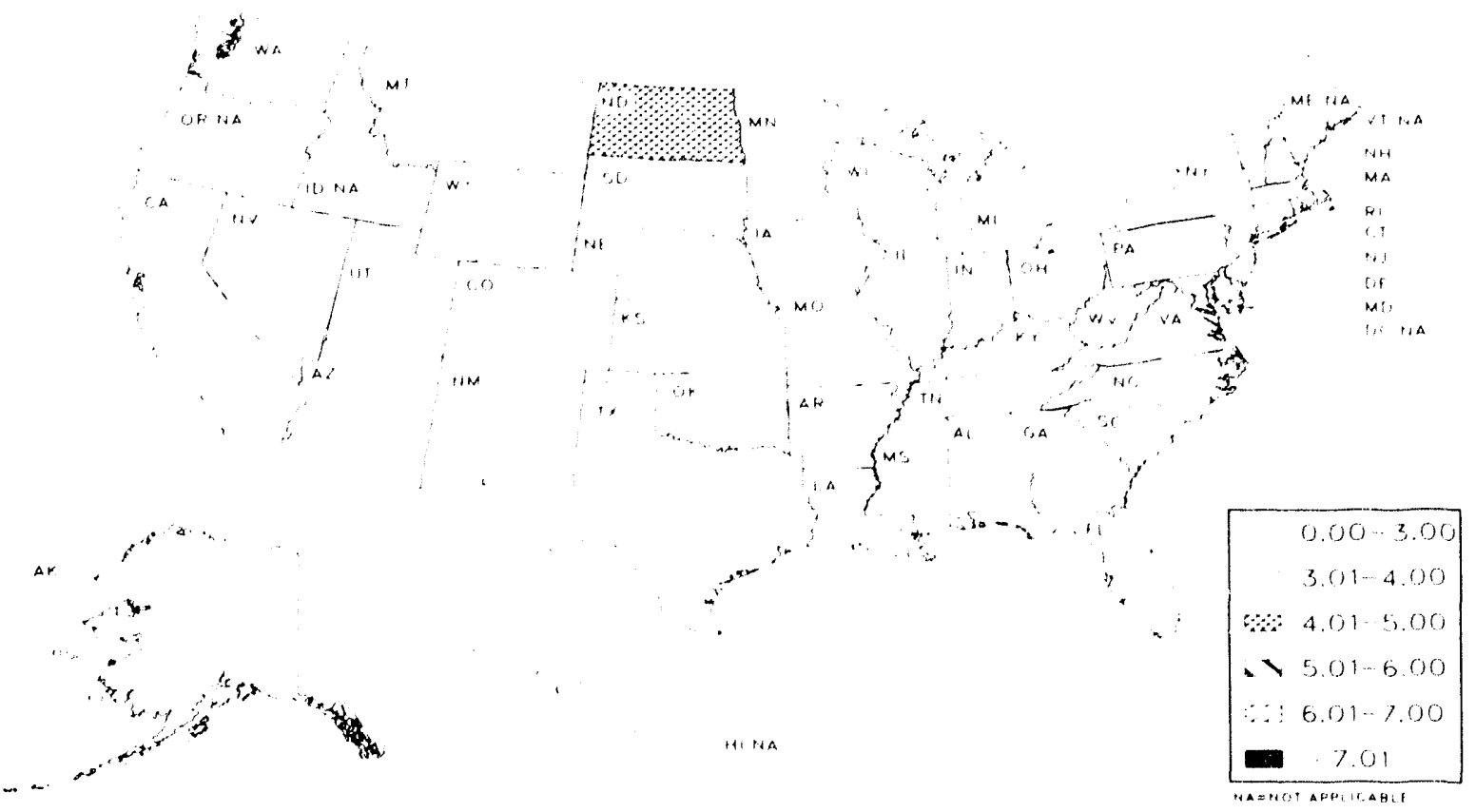

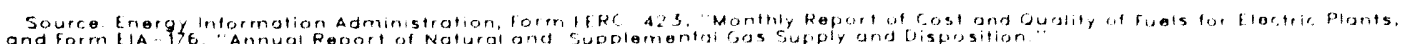


Table 23. Selected Volumes and Prices of Natural Gas Sold to Residential Customers in the United States, 1992

(Volumes in Thousand Cubic Feet, Prices in Dollars per Thousand Cubic Feet)

\begin{tabular}{|c|c|c|c|}
\hline Company & State & Volume & Price \\
\hline $\begin{array}{l}\text { Southern California Gas Co } \ldots \ldots \ldots \ldots \ldots \\
\text { Northern Illinois Gas Co } \ldots \ldots \ldots \ldots \ldots \ldots \\
\text { Pacific Gas \& Elec Co } \ldots \ldots \ldots \ldots \ldots \ldots \ldots \ldots \\
\text { Consumers Pwr Co } \\
\text { Columbia Gas }\end{array}$ & $\begin{array}{l}\text { CA } \\
\text { IL } \\
\text { CA } \\
\text { MI } \\
\text { OH.PA }\end{array}$ & $\begin{array}{l}241,052,167 \\
223,900,874 \\
191,208,015 \\
165,842,812 \\
161,657,122\end{array}$ & $\begin{array}{r}\$ 6.12 \\
4.49 \\
5.74 \\
4.96 \\
5.83\end{array}$ \\
\hline 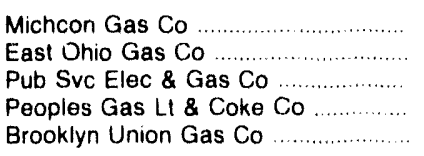 & $\begin{array}{l}\mathrm{Ml} \\
\mathrm{OH} \\
\mathrm{NJ} \\
\mathrm{II} \\
\mathrm{NY}\end{array}$ & $\begin{array}{r}149,006,221 \\
137,800,627 \\
123,758,501 \\
119,334,962 \\
97,723,952\end{array}$ & $\begin{array}{l}5.24 \\
4.75 \\
6.54 \\
5.93 \\
8.97\end{array}$ \\
\hline 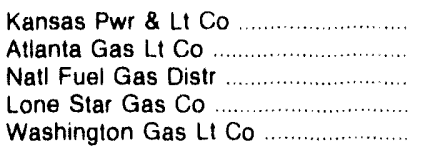 & $\begin{array}{l}\text { KS,MO } \\
\text { GA } \\
\text { NY,PA } \\
\text { TX } \\
\text { MD, VA,DC }\end{array}$ & $\begin{array}{l}90,556,001 \\
89,413,341 \\
86,995,889 \\
86,971,921 \\
75,125,274\end{array}$ & $\begin{array}{l}4.71 \\
6.46 \\
6.44 \\
6.22 \\
6.68\end{array}$ \\
\hline 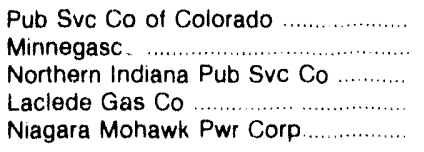 & $\begin{array}{l}\text { CO } \\
\text { MN,NE,SD } \\
\text { IN } \\
\text { MO } \\
\text { NY }\end{array}$ & $\begin{array}{l}71,816,826 \\
68,625,195 \\
66,154,058 \\
53,787,579 \\
52,327,891\end{array}$ & $\begin{array}{l}4.49 \\
4.81 \\
5.44 \\
5.27 \\
6.76\end{array}$ \\
\hline 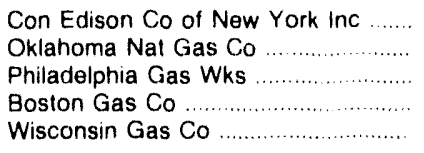 & $\begin{array}{l}\text { NY } \\
\text { OK } \\
\text { PA } \\
\text { MA } \\
\text { WI }\end{array}$ & $\begin{array}{l}51,716,500 \\
51,644,485 \\
51,558,886 \\
50,097,885 \\
45,640,000\end{array}$ & $\begin{array}{l}8.52 \\
4.95 \\
7.56 \\
7.71 \\
6.23\end{array}$ \\
\hline 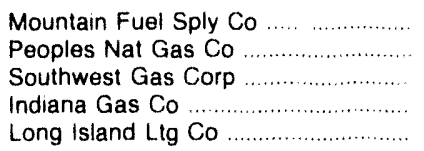 & $\begin{array}{l}\text { UT } \\
\text { PA } \\
\text { AZ,CA,NV } \\
\text { IN } \\
\text { NY }\end{array}$ & $\begin{array}{l}44,356,971 \\
41,514,375 \\
41,150,657 \\
40,486,673 \\
37,588,401\end{array}$ & $\begin{array}{l}5.45 \\
5.94 \\
7.07 \\
5.98 \\
7.35\end{array}$ \\
\hline $\begin{array}{l}\text { Baltimore Gas \& Elec Co } \\
\text { New Jersey Nat Gas Co } \\
\text { Illinois Pwr Co } \\
\text { Cincinnati Gas \& Elec Co } \\
\text { Philadelphia Elec Co }\end{array}$ & $\begin{array}{l}\text { MD } \\
\mathrm{NJ} \\
\mathrm{IL} \\
\mathrm{OH} \\
\mathrm{PA}\end{array}$ & $\begin{array}{l}37,473,379 \\
34,670,107 \\
33,891,829 \\
32,545,459 \\
31,569,000\end{array}$ & $\begin{array}{l}6.47 \\
8.23 \\
5.34 \\
5.48 \\
6.92\end{array}$ \\
\hline $\begin{array}{l}\text { Washington Nat Gas Co } \ldots \ldots \ldots \ldots \ldots \ldots \\
\text { Alabama Gas Corp } \\
\text { San Diego Gas \& Elec Co } \ldots \ldots \ldots \ldots \ldots \ldots \ldots \ldots \\
\text { Rochester Gas \& Elec Co } \\
\text { Northern States Pwr Co }\end{array}$ & $\begin{array}{l}\text { WA } \\
\text { AL } \\
\text { CA } \\
\text { NY } \\
\text { MN }\end{array}$ & $\begin{array}{l}30,443,868 \\
30,434,990 \\
29,819,374 \\
28,988,463 \\
28,971,157\end{array}$ & $\begin{array}{l}5.26 \\
6.79 \\
5.98 \\
6.66 \\
4.93\end{array}$ \\
\hline 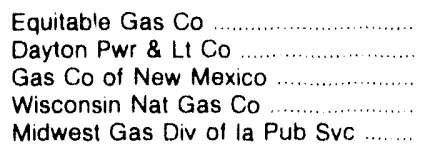 & $\begin{array}{l}P A \\
O H \\
N M \\
W \mid \\
\mid A\end{array}$ & $\begin{array}{l}28,533,020 \\
27,572,441 \\
26,801,046 \\
26,155,873 \\
24,908,061\end{array}$ & $\begin{array}{l}8.04 \\
4.63 \\
4.69 \\
5.66 \\
5.60\end{array}$ \\
\hline 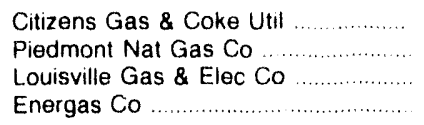 & $\begin{array}{l}\text { IN } \\
\text { NC, SC } \\
\text { KY } \\
\text { TX }\end{array}$ & $\begin{array}{l}24,488,597 \\
23,193,452 \\
22,465,117 \\
21,768,176\end{array}$ & $\begin{array}{l}5.18 \\
6.41 \\
4.28 \\
4.61\end{array}$ \\
\hline 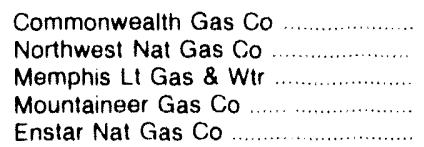 & $\begin{array}{l}\text { MA } \\
\text { OR,WA } \\
\text { TN } \\
\text { WV } \\
\text { AK }\end{array}$ & $\begin{array}{l}21,739,122 \\
19,931,372 \\
19,473,248 \\
18,317,361 \\
14,169,017\end{array}$ & $\begin{array}{l}8.52 \\
6.26 \\
4.58 \\
6.04 \\
3.81\end{array}$ \\
\hline
\end{tabular}

Note: The natural gas companies with large amounts of onsystem sales to residential consumers were selected from the respondents to the Form EIA-176, "Annual Report of Natural and Supplemental Gas Supply and Disposition." Prices are calculated from the company total reported volumes of onsystem sales to residential consumers and the total reported associated revenue. When more than one State of operation is indicated, the price has been calculated from the sum of the volumes and revenues reported by the company for all of the States shown.

Source: Energy Information Administration (E|A), Form ElA-176, "Annual Report of Natural and Supplemental Gas Supply and Dispostion." 
Table 24. Selected Volumes and Prices of Natural Gas Sold to Commercial Customers In the United States, 1992

(Volumes in Thousand Cubic Feet, Prices in Dollars per Thousand Cubic Feet)

\begin{tabular}{|c|c|c|c|}
\hline Company & State & Volume & Price \\
\hline 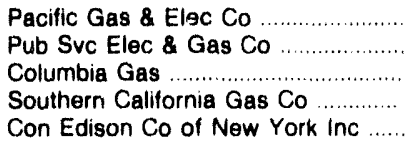 & $\begin{array}{l}\text { CA } \\
\text { N.J } \\
\text { OH,PA } \\
\text { CA } \\
\text { NY }\end{array}$ & $\begin{array}{r}132,243,117 \\
91,912,904 \\
66,276,893 \\
64,404.452 \\
55,493,208\end{array}$ & $\begin{array}{r}\$ 4.53 \\
5.25 \\
5.20 \\
6.18 \\
4.95\end{array}$ \\
\hline $\begin{array}{l}\text { Consumers Pwr Co } \\
\text { Northern lllinois Gas Co } \\
\text { Pub Sve Co of Colorado } \\
\text { Michcon Gas Co } \\
\text { East Ohio Gas Co }\end{array}$ & $\begin{array}{l}\mathrm{MI} \\
\mathbb{L} \\
\mathrm{CO} \\
\mathrm{MI} \\
\mathrm{OH}\end{array}$ & $\begin{array}{l}53,173,605 \\
51,932,243 \\
47,387,252 \\
47,223,792 \\
45,924,181\end{array}$ & $\begin{array}{l}4.43 \\
4.38 \\
3.85 \\
5.00 \\
4.35\end{array}$ \\
\hline $\begin{array}{l}\text { Washington Gas Lt Co } \\
\text { Minnegasco } \\
\text { Kansas Pwr \& Lt Co } \\
\text { Atlanta Gas LI Co } \\
\text { Lone Star Gas Co }\end{array}$ & $\begin{array}{l}\text { DC,MD,VA } \\
\text { MN } \\
\text { KS,MO } \\
\text { GA } \\
\text { TX }\end{array}$ & $\begin{array}{l}45,536,022 \\
44,764,799 \\
39,554,316 \\
39,542,476 \\
37,197,394\end{array}$ & $\begin{array}{l}5.08 \\
3.92 \\
4.20 \\
5.51 \\
5.3\end{array}$ \\
\hline 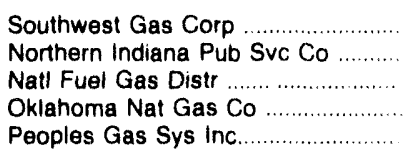 & $\begin{array}{l}\text { AZ,NV } \\
\text { IN } \\
N Y, P A \\
O K \\
\text { FL }\end{array}$ & $\begin{array}{l}29,169,745 \\
26,058,936 \\
25,476,816 \\
23,604,609 \\
22,861,112\end{array}$ & $\begin{array}{l}5.00 \\
4.75 \\
5.53 \\
4.34 \\
4.87\end{array}$ \\
\hline 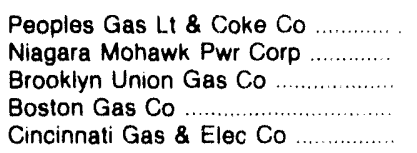 & $\begin{array}{l}\text { II. } \\
\text { NY } \\
\text { NY } \\
\text { MA } \\
\text { OH }\end{array}$ & $\begin{array}{l}21,552,228 \\
21,404,775 \\
20,882,285 \\
24,318,253 \\
20,573,934\end{array}$ & $\begin{array}{l}5.44 \\
6.12 \\
7.08 \\
4.98 \\
4.85\end{array}$ \\
\hline 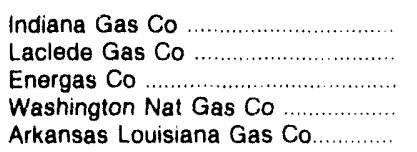 & $\begin{array}{l}\text { IN } \\
\text { MO } \\
\text { TX } \\
\text { WA } \\
\text { AR,LA }\end{array}$ & $\begin{array}{l}20,564,659 \\
20,310,034 \\
19,886,645 \\
19,106,792 \\
18,745,984\end{array}$ & $\begin{array}{l}4.88 \\
4.52 \\
3.40 \\
4.58 \\
4.74\end{array}$ \\
\hline $\begin{array}{l}\text { Philadelphia Elec Co } \\
\text { Long Island Ltg Co } \\
\text { Wisconsin Gas Co } \\
\text { Enstar Nat Gas Co } \\
\text { Kn Energy Inc }\end{array}$ & $\begin{array}{l}\text { PA } \\
N Y \\
W I \\
A K \\
K S, N E\end{array}$ & $\begin{array}{l}18,635,000 \\
17,786,001 \\
17,742,000 \\
16,659,181 \\
16,308,822\end{array}$ & $\begin{array}{l}6.00 \\
6.56 \\
5.86 \\
3.03 \\
3.75\end{array}$ \\
\hline 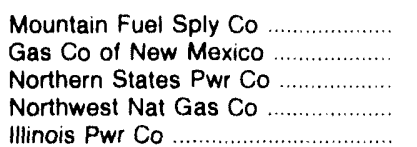 & $\begin{array}{l}\text { UT } \\
\text { NM } \\
\text { MN } \\
\text { OR } \\
\text { IL }\end{array}$ & $\begin{array}{l}16,225,787 \\
15,519,339 \\
15,410,096 \\
15,301,467 \\
15,194,699\end{array}$ & $\begin{array}{l}4.43 \\
3.19 \\
4.39 \\
4.79 \\
4.08\end{array}$ \\
\hline 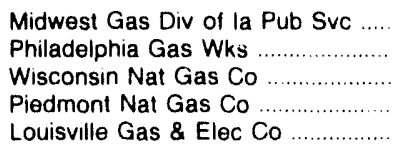 & $\begin{array}{l}\text { IA } \\
P A \\
W I \\
N C \\
K Y\end{array}$ & $\begin{array}{l}14,871,583 \\
14,531,615 \\
14,053,449 \\
13,792,452 \\
13,391,403\end{array}$ & $\begin{array}{l}4.29 \\
6.49 \\
4.48 \\
4.98 \\
3.78\end{array}$ \\
\hline 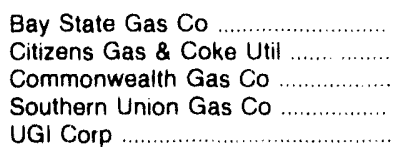 & $\begin{array}{l}M A \\
\text { IN } \\
M A \\
T X \\
P A\end{array}$ & $\begin{array}{l}13,373,586 \\
13,331,428 \\
13,157,302 \\
12,096,550 \\
12,504,190\end{array}$ & $\begin{array}{l}608 \\
418 \\
6.32 \\
3.60 \\
6.48\end{array}$ \\
\hline 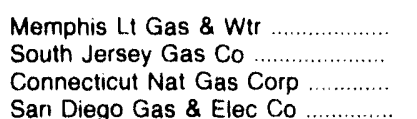 & $\begin{array}{l}\mathrm{TN} \\
\mathrm{NJ} \\
\mathrm{CT} \\
\mathrm{CA}\end{array}$ & $\begin{array}{r}11,836,529 \\
11,445,435 \\
10,191,008 \\
9,501,595\end{array}$ & $\begin{array}{l}3.91 \\
5.43 \\
6.75 \\
6.25\end{array}$ \\
\hline
\end{tabular}

Note: The natural gas companies with large amounts of onsystem sales to commercial consumers were selected from the respondents to the Form EIA-176, "Annual Report of Natural and Supplemental Gas Supply and Disposition." Prices are calculated from the company total reported volumes of onsystem sales to commercial consumers and the total reported associated revenue. When more than one State of operation is indicated, the price has been calculated from the sum of the volumes and revenues reported by the company for all of the States shown.

Source: Energy Information Administration (EIA), Form ElA-176, "Annual Report of Natural and Supplemental Gas Supply and Dispostion." 
Table 25. Leading Suppliers of Natural Gas to End Users in the United States, 1992 (Million Cubic Feet)

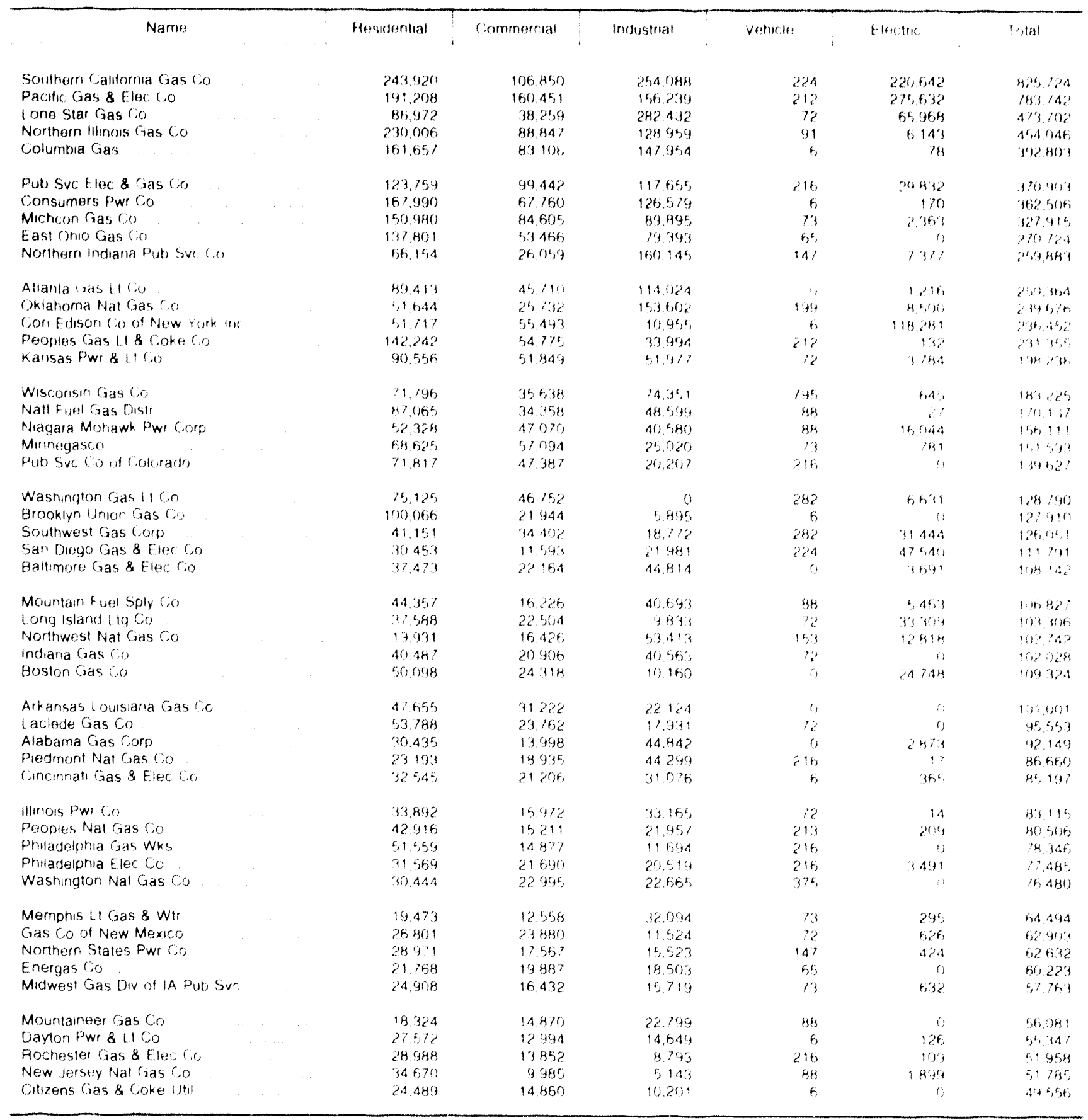

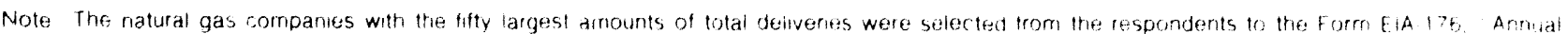
Report of Natural and Supplemental Gas Supply and Dispositon for each company the lotal delivenes mciude detiveries for residential comingriat in. dustral, and electric utility consumers, detivenes of natural gas for vehicle fuel, and all volumes transponted to consumers for the aciount of others the: totals are surrmed from each compary's repots in all States of operatons Number of vencle fuel consumers generally refers lo the number id fueteng stations

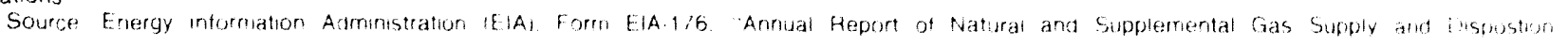


Table 26. Average Heat Content Price of Natural Gas Dellvered to Consumers by State, 1988-1992 (Cents per Therm)

\begin{tabular}{|c|c|c|c|c|c|}
\hline $\begin{array}{l}\text { Year } \\
\text { and } \\
\text { State }\end{array}$ & Residential & Compnercial & Industrial & Vehicle Fuel & Electric Utilities \\
\hline 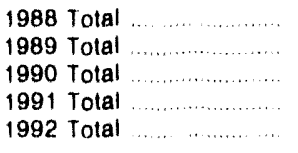 & $\begin{array}{l}53.2 \\
54.7 \\
56.2 \\
56.5 \\
57.2\end{array}$ & $\begin{array}{r}45.0 \\
46.0 \\
46.8 \\
\text { ค } 46.7 \\
47.4\end{array}$ & $\begin{array}{l}28.6 \\
28.7 \\
28.5 \\
26.2 \\
27.6\end{array}$ & $\begin{array}{l}\text { NA } \\
\text { NA } \\
32.9 \\
38.5 \\
39.3\end{array}$ & $\begin{array}{l}22.6 \\
23.6 \\
23.1 \\
21.2 \\
22.9\end{array}$ \\
\hline $\begin{array}{l}\text { Alabarna } \\
\text { Alaska } \\
\text { Arizona } \\
\text { Arkansas } \\
\text { Californa }\end{array}$ & $\begin{array}{l}65.6 \\
37.8 \\
70.2 \\
50.5 \\
58.0\end{array}$ & $\begin{array}{l}55.6 \\
26.3 \\
50.4 \\
43.4 \\
50.0\end{array}$ & $\begin{array}{l}29.9 \\
11.7 \\
40.3 \\
31.0 \\
35.7\end{array}$ & $\begin{array}{r}62.9 \\
. . \\
35.2 \\
.0 \\
62.4\end{array}$ & $\begin{array}{r}22.2 \\
5.7 \\
2.2 .1 \\
15.6 \\
27.3\end{array}$ \\
\hline $\begin{array}{l}\text { Colorado } \\
\text { Connecticut } \\
\text { Delaware } \\
\text { District of Columbia } \\
\text { Florida }\end{array}$ & $\begin{array}{l}44.6 \\
87.2 \\
59.3 \\
75.5 \\
86.5\end{array}$ & $\begin{array}{l}39.1 \\
70.0 \\
47.7 \\
53.2 \\
47.5\end{array}$ & $\begin{array}{r}21.6 \\
47.8 \\
31.4 \\
307\end{array}$ & $\begin{array}{r}33.7 \\
121.1 \\
. . \\
42.3\end{array}$ & $\begin{array}{r}20.9 \\
26.7 \\
26.1 \\
21.9\end{array}$ \\
\hline 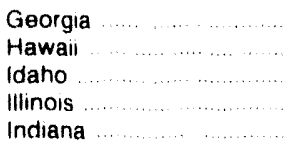 & $\begin{array}{r}62.9 \\
168.1 \\
50.8 \\
50.0 \\
53.7\end{array}$ & $\begin{array}{r}54.2 \\
124.4 \\
42.7 \\
45.6 \\
45.2\end{array}$ & $\begin{array}{r}34.1 \\
28.8 \\
36.8 \\
33.5\end{array}$ & $\begin{array}{r}. . \\
. . \\
37.3 \\
42 .\end{array}$ & $\begin{array}{r}28.2 \\
\ldots \\
\ldots \\
22.0 \\
24.5\end{array}$ \\
\hline $\begin{array}{l}\text { lowa } \\
\text { Kansas } \\
\text { Kentucky } \\
\text { Louisiana } \\
\text { Maine }\end{array}$ & $\begin{array}{l}52.1 \\
47.6 \\
47.3 \\
53.7 \\
68.6\end{array}$ & $\begin{array}{l}42.5 \\
35.8 \\
42.3 \\
45.9 \\
611\end{array}$ & $\begin{array}{l}35.3 \\
26.4 \\
30.5 \\
18.5 \\
40.8\end{array}$ & $\begin{array}{r}39.7 \\
\ldots \\
35.8 \\
41.2 \\
. .\end{array}$ & $\begin{array}{r}30.7 \\
19.7 \\
26.2 \\
18.3 \\
\quad .\end{array}$ \\
\hline $\begin{array}{l}\text { Maryland } \\
\text { Massachusetts } \\
\text { Michigan } \\
\text { Minnesota } \\
\text { Mississippi }\end{array}$ & $\begin{array}{l}62.6 \\
76.4 \\
49.6 \\
48.0 \\
473\end{array}$ & $\begin{array}{l}50.9 \\
56.5 \\
45.6 \\
40.6 \\
39.4\end{array}$ & $\begin{array}{l}34.6 \\
39.9 \\
38.4 \\
30.1 \\
24.2\end{array}$ & $\begin{array}{r}35.2 \\
9.7 \\
. . \\
. .\end{array}$ & $\begin{array}{r}25.9 \\
25.8 \\
7.9 \\
18.3 \\
17.7\end{array}$ \\
\hline $\begin{array}{l}\text { Missouri } \\
\text { Montana } \\
\text { Nebraska } \\
\text { Nevada } \\
\text { New Hampshire }\end{array}$ & $\begin{array}{l}51.0 \\
47.0 \\
49.2 \\
54.2 \\
74.8\end{array}$ & $\begin{array}{l}44.6 \\
43.6 \\
40.8 \\
42.0 \\
66.8\end{array}$ & $\begin{array}{l}38.6 \\
41.0 \\
29.8 \\
39.5 \\
44.5\end{array}$ & $\begin{array}{r}\ddot{. .} \\
44 . \overline{1} \\
33.4 \\
. .\end{array}$ & $\begin{array}{l}18.9 \\
32.3 \\
23.3 \\
18.5 \\
21.8\end{array}$ \\
\hline 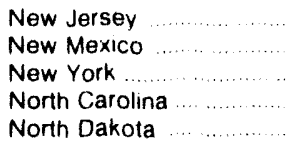 & $\begin{array}{l}67.6 \\
45.6 \\
73.7 \\
63.8 \\
47.8\end{array}$ & $\begin{array}{l}54.0 \\
32.3 \\
55.9 \\
46.3 \\
43.2\end{array}$ & $\begin{array}{l}33.4 \\
66.0 \\
47.9 \\
32.3 \\
31.1\end{array}$ & $\begin{array}{r}\cdots \\
53.1 \\
49.1 \\
40.7\end{array}$ & $\begin{array}{l}21.2 \\
19.1 \\
24.1 \\
28.6 \\
40.0\end{array}$ \\
\hline 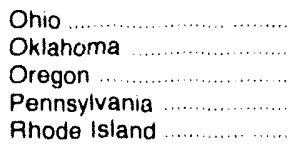 & $\begin{array}{l}50.2 \\
48.3 \\
59.6 \\
63.7 \\
75.4\end{array}$ & $\begin{array}{l}45.6 \\
41.2 \\
45.7 \\
56.7 \\
62.1\end{array}$ & $\begin{array}{l}40.1 \\
19.6 \\
32.5 \\
36.2 \\
45.8\end{array}$ & $\begin{array}{l}30.1 \\
29.8 \\
20.9 \\
57.7 \\
38.1\end{array}$ & $\begin{array}{l}22.3 \\
31.2 \\
19.0 \\
29.5 \\
21.6\end{array}$ \\
\hline $\begin{array}{l}\text { South Carolina } \\
\text { South Dakota } \\
\text { Tennessee } \\
\text { Texas } \\
\text { Utah }\end{array}$ & $\begin{array}{l}68.5 \\
50.7 \\
53.3 \\
55.4 \\
50.4\end{array}$ & $\begin{array}{l}55.0 \\
41.3 \\
49.1 \\
39.2 \\
40.8\end{array}$ & $\begin{array}{l}30.5 \\
35.8 \\
33.3 \\
20.3 \\
36.3\end{array}$ & $\begin{array}{r}. .2 \\
40.2 \\
42.2 \\
43.5 \\
50.2\end{array}$ & $\begin{array}{l}16.8 \\
28.4 \\
24.2 \\
21.6 \\
17.3\end{array}$ \\
\hline $\begin{array}{l}\text { Vermont } \\
\text { Virginia } \\
\text { Washington } \\
\text { West Virginia } \\
\text { Wisconsin } \\
\text { Wyoming }\end{array}$ & $\begin{array}{l}67.3 \\
64.4 \\
48.4 \\
59.2 \\
58.2 \\
44.6\end{array}$ & $\begin{array}{l}57.0 \\
47.9 \\
41.8 \\
51.4 \\
47.7 \\
40.2\end{array}$ & $\begin{array}{l}33.0 \\
35.8 \\
28.1 \\
27.2 \\
33.5 \\
27.5\end{array}$ & $\begin{array}{r}. . \\
40.7 \\
27.2 \\
36.5 \\
54.3\end{array}$ & $\begin{array}{l}20.1 \\
23.8 \\
32.0 \\
33.1 \\
24.0 \\
31.5\end{array}$ \\
\hline
\end{tabular}

A Revised data.

$\overline{-}=$ Not applicable

Source: Energy Information Administration (EIA), Form ElA.176. "Annual Report of Natural and Supplemental Gas Supply and Disposition; and the Fed. eral Energy Regulatory Commission (FERC), Form FERC-423, "Monthly Report of Cost and Quality of Fuels for Electric Plants." 
Table 27. Average Consumption and Annual Cost of Natural Gas per Consumer by State, 1992

\begin{tabular}{|c|c|c|c|c|c|}
\hline \multirow{2}{*}{ State } & \multicolumn{2}{|c|}{ Residential } & \multicolumn{2}{|c|}{ Commercial } & \multirow{2}{*}{ 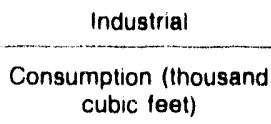 } \\
\hline & $\begin{array}{c}\text { Consumption (thousand } \\
\text { cubic feet) }\end{array}$ & $\begin{array}{c}\text { Cost } \\
\text { (dollars) }\end{array}$ & $\begin{array}{c}\text { Consumption (thousand } \\
\text { cubic feet) }\end{array}$ & $\begin{array}{c}\text { Cost } \\
\text { (dollars) }\end{array}$ & \\
\hline Alabama & 70 & $\$ 471$ & 435 & $\$ 2,482$ & 67,377 \\
\hline Alaska & 19.3 & 732 & 1.745 & 4,606 & $8,093,795$ \\
\hline 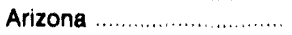 & 47 & 340 & 567 & 2,947 & 37,169 \\
\hline Arkansas & 78 & 399 & 407 & 1,783 & 90,106 \\
\hline Californis & 55 & 330 & 691 & 3,556 & 14.671 \\
\hline Colorado & 93 & 422 & 578 & 2,315 & 51,967 \\
\hline Connecticut & 98 & 879 & 637 & 4,584 & 12,447 \\
\hline 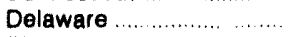 & 87 & 535 & 607 & 2.999 & 72,823 \\
\hline District of Cilumbia ........ & 122 & 925 & 1,437 & 7,704 & 0 \\
\hline Florida & 30 & 277 & 925 & 4,603 & 218,632 \\
\hline Georgia ....... & 77 & 499 & 483 & 2,685 & 54,057 \\
\hline Hawail .......................... & 18 & 334 & 768 & 10,243 & 0 \\
\hline Idaho .............................. & 71 & 371 & 422 & 1.858 & 409,762 \\
\hline 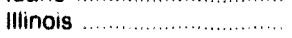 & 142 & 721 & 746 & 3,466 & 11,052 \\
\hline Indiana & 111 & 602 & 559 & 2,555 & 38,616 \\
\hline lowa & 103 & 537 & 540 & 2,306 & 54,905 \\
\hline Kansas & 94 & 441 & 622 & 2,195 & 39,687 \\
\hline Kentucky & 96 & 481 & 510 & 2,280 & 45,783 \\
\hline Louisiana ............................ & 59 & 329 & 466 & 2,234 & 642.195 \\
\hline Maine & 63 & 440 & 457 & 2,825 & 25,595 \\
\hline Maryland .... & 84 & 540 & 676 & 3,537 & 96,731 \\
\hline Massachusetts & 105 & 833 & 749 & 4,391 & 8,125 \\
\hline Michigan & 136 & 686 & 862 & 4,008 & 26,651 \\
\hline Minnesota & 114 & 552 & 826 & 3,389 & 36,988 \\
\hline Mississippi & 68 & 335 & 405 & 1,672 & 77,326 \\
\hline 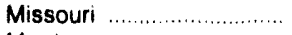 & 96 & 488 & 487 & 2,179 & 19,560 \\
\hline 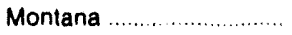 & 91 & 439 & 490 & 2.185 & 26,620 \\
\hline Nebraska & 99 & 477 & 562 & 2,247 & 38,005 \\
\hline Nevada & 61 & 344 & 706 & 3,055 & 81,222 \\
\hline New Hampshire .................. & 93 & 702 & 515 & 3,469 & 11,128 \\
\hline New Jersey ..................... & 98 & 678 & 615 & 3,411 & 15,214 \\
\hline New Mexico & 81 & 383 & 692 & 2.324 & 121,064 \\
\hline Now York ......................... & 84 & 635 & 687 & 3,954 & 5,232 \\
\hline North Carolina ...................... & 74 & 489 & 501 & 2,399 & 29,171 \\
\hline North Dakota & 108 & 541 & 790 & 3,567 & 34,739 \\
\hline Ohio & 121 & 627 & 675 & 3,187 & 34,388 \\
\hline Oklahoma & 79 & 392 & 404 & 1,709 & 61,269 \\
\hline Oregon & 65 & 403 & 389 & 1,841 & 79,080 \\
\hline Pennsylvania ........................ & 113 & 745 & 693 & 4,065 & 36,439 \\
\hline Rhode Island ...................... & 101 & 776 & 488 & 3,083 & 43,720 \\
\hline South Carolina & 63 & 440 & 406 & 2,294 & 60,158 \\
\hline South Dakota ..................... & 98 & 503 & 645 & 2,707 & 14,068 \\
\hline Tennesser & 75 & 412 & 506 & 2,562 & 52,054 \\
\hline Texas ............................... & 65 & 377 & 630 & 2,578 & 316,366 \\
\hline 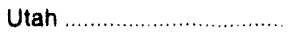 & 96 & 520 & 459 & 2,017 & 52,207 \\
\hline Vermont & 123 & 825 & 725 & 4,110 & 108,751 \\
\hline Virginia & 94 & 628 & 729 & 3,626 & 62,496 \\
\hline Washington & 81 & 407 & 596 & 2,575 & 22,856 \\
\hline West Virginia & 100 & 632 & 734 & 4,017 & 277,850 \\
\hline Wisconsin & 104 & 613 & 632 & 3,041 & 17,613 \\
\hline 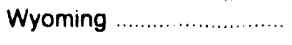 & 95 & 448 & 532 & 2,263 & 229,698 \\
\hline U.S. Average & 90 & 528 & 636 & 3,103 & 35,908 \\
\hline
\end{tabular}

Note: Beginning in 1987, industrial costs per consumer are not calculated since values associated with gas delivered for the account of others are not available. Each year since 1982, these values have represented an increasingly large portion of the total industrial value. By 1987 , a meaningful average cost per consumer could no longer be calculated without them. Commercial consumption and cost does not include deliveries of natural gas for use as ve. hicle fuel.

Source: Energy Information Administration (EIA), Form EIA-176, "Annual Report of Natural and Supplemental Gas Supply and Disposition." 
Table 28. Volume and Average Price of Natural Gas Purchases from Transporters by Type of Purchaser by State, 1992

(Volumes in Million Cubic Feet, Prices in Dollars per Thousand Cubic Feet)

\begin{tabular}{|c|c|c|c|c|c|c|c|c|c|c|}
\hline \multirow{3}{*}{ State } & \multicolumn{10}{|c|}{ Natural Gas Purchased By: } \\
\hline & \multicolumn{2}{|c|}{$\begin{array}{c}\text { Interstate } \\
\text { Pipeline } \\
\text { Companies }\end{array}$} & \multicolumn{2}{|c|}{$\begin{array}{c}\text { Intrastate } \\
\text { Pipeline } \\
\text { Companies }\end{array}$} & \multicolumn{2}{|c|}{$\begin{array}{l}\text { Distributors } \\
\text { and } \\
\text { Municipalities }\end{array}$} & \multicolumn{2}{|c|}{$\begin{array}{c}\text { Other } \\
\text { Companies }\end{array}$} & \multicolumn{2}{|c|}{$\begin{array}{c}\text { Total } \\
\text { All } \\
\text { Companies }\end{array}$} \\
\hline & Volume & $\begin{array}{c}\text { Average } \\
\text { Price }\end{array}$ & Volume & $\begin{array}{c}\text { Average } \\
\text { Price }\end{array}$ & Volume & $\begin{array}{l}\text { Average } \\
\text { Price }\end{array}$ & Volume & $\begin{array}{c}\text { Average } \\
\text { Price }\end{array}$ & Volume & $\begin{array}{l}\text { Average } \\
\text { Price }\end{array}$ \\
\hline Alabama & 1,337 & $\$ 15.68$ & 437 & $\$ 2.25$ & 106,099 & $\$ 3.21$ & 0 & .. & 107,873 & $\$ 3.36$ \\
\hline Alaska & 0 & .. & 0 & .. & 31,079 & 2.65 & 1,202 & $\$ 0.34$ & 32,281 & 2.57 \\
\hline Arizona & 0 & -. & 0 & *. & 4,923 & 2.64 & 293 & 2.08 & 5,217 & 2.61 \\
\hline 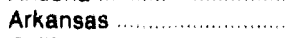 & 3,677 & 2.86 & 0 &.. & 2,624 & 1.79 & 51,182 & 2.98 & 57.482 & 2.92 \\
\hline California $\ldots \ldots \ldots \ldots \ldots$ & 0 & $\cdot \cdot$ & 0 & - & 670,333 & 2.85 & 0 &. & 670,333 & 2.85 \\
\hline Colorado ..... & 13,642 & 1.72 & 0 &.. & 134,219 & 3.04 & 5,836 & 3.77 & 153,697 & 2.95 \\
\hline Connecticut ........................ & 0 & .. & 0 &. & 65,317 & 4.24 & 0 & .. & 65,317 & 4.24 \\
\hline 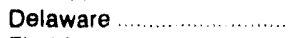 & 0 & .. & 0 &.. & 2,461 & 3.80 & 3,853 & 2.71 & 6,314 & 3.14 \\
\hline Florida & 31 & 3.19 & 0 & $\cdots$ & 77,960 & 2.64 & 2,702 & 2.77 & 80,692 & 2.64 \\
\hline 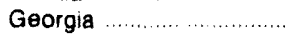 & 2.499 & 3.02 & 0 & $\cdot \cdot$ & 209,707 & 3.28 & 0 & .. & 212.206 & 3.27 \\
\hline 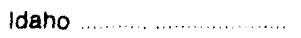 & 308,990 & 190 & 0 &.. & 15,745 & 2.22 & 0 & .. & 324,735 & 1.92 \\
\hline 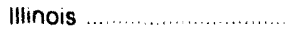 & 88 & 2.99 & 0 & .. & 499,767 & 3.40 & 921 & 2.55 & 500,776 & 3.39 \\
\hline 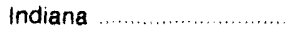 & 0 & 2.66 & 0 & .. & 112,115 & 3.27 & 7 & 3.70 & 112,122 & 3.27 \\
\hline lowa & 91,998 & 1.98 & 0 &.. & 81,934 & 4.12 & 0 & $\ldots$ & 173,932 & 2.99 \\
\hline 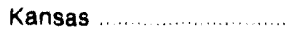 & 22,560 & 2.68 & 0 &.$\cdot$ & 18,504 & 3.06 & 61,294 & 2.99 & 102.358 & 2.93 \\
\hline 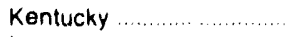 & 82,986 & 3.33 & 40 & 1.99 & 88,111 & 3.07 & 903 & 2.33 & 172,040 & 3.19 \\
\hline Louisiana ..................... & 1,853 & 3.52 & 27,025 & 1.95 & 74.763 & 2.53 & 61,935 & 2.08 & 165.576 & 2.28 \\
\hline Maıne & 0 & .. & 0 & .. & 4,789 & 3.15 & 0 & .. & 4.789 & 3.15 \\
\hline 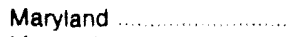 & 0 & .. & 0 &.. & 45,635 & 4.95 & 0 & .. & 45,635 & 4.95 \\
\hline Massachusetts ................. & 0 & $\cdots$ & 0 & -. & 204,009 & 3.88 & 30,479 & 2.88 & 234,488 & 3.75 \\
\hline$\ldots \ldots \ldots \ldots \ldots$ & 150 & 8.13 & 0 & .. & 173,860 & 3.53 & 0 & .. & 174,010 & 3.53 \\
\hline Minnesola & 65,065 & 2.25 & 0 &.. & 168,466 & 3.29 & 111 & 3.32 & 233,641 & 3.00 \\
\hline Mississippi $\ldots \ldots \ldots \ldots \ldots$ & 10.891 & 3.58 & 3.537 & 1.71 & 35.091 & 2.97 & 11 & 2.59 & 49,530 & 3.02 \\
\hline 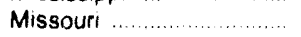 & 60 & 2.29 & 0 & .. & 119,386 & 2.91 & 63,816 & 2.80 & 183.262 & 2.87 \\
\hline Montana ....................... & 0 & -. & 0 &.$\cdot$ & 15.142 & 2.73 & 147 & 3.66 & 15.289 & 2.74 \\
\hline Nebraska & 876 & 2.05 & 0 & .. & 33,526 & 2.95 & 5,887 & 7.91 & 40.288 & 3.65 \\
\hline Nevada $\ldots \ldots \ldots \ldots$ & 0 & -. & 0 &.. & 1,670 & 4.78 & 0 & .. & 1,670 & 4.78 \\
\hline New Hampshire ............. & 10,440 & 3.03 & 0 &.. & 16,650 & 3.58 & 0 & .. & 27.090 & 3.37 \\
\hline New Jersey ....................... & 16,672 & 7.11 & 0 &.. & 462,937 & 2.88 & 0 & -- & 479,609 & 3.03 \\
\hline 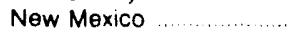 & 18,942 & 1.19 & 0 &.. & 8,835 & 2.50 & 652 & 2.24 & 28.429 & 1.62 \\
\hline$\ldots \ldots \ldots \ldots \ldots$ & 31,557 & 5.44 & 137 & 3.74 & 371,853 & 3.63 & 0 & .. & 403,547 & 3.78 \\
\hline North Carolina ............. & 0 & .. & 1.092 & 2.96 & 130.247 & 2.82 & 0 &.- & 131.339 & 2.82 \\
\hline North Dakota & 0 & -- & 0 & .. & 12,603 & 3.98 & 0 &.. & 12.603 & 3.98 \\
\hline Ohio & 8.128 & 32 & 0 & .. & 284,122 & 3.90 & 57 & 3.10 & 292,306 & 3.80 \\
\hline Oklahoma & 10,121 & 1.75 & 15,962 & 1.97 & 5,449 & 2.47 & 68,229 & 2.97 & 99,761 & 2.66 \\
\hline Oregon & 0 &.. & 0 & .. & 40.262 & 2.52 & 0 & .. & 40,262 & 2.52 \\
\hline Pennsylvania $\ldots . . . . . . . . . . . .$. & 105,533 & 3.35 & 355 & 2.09 & 149,395 & 4.37 & 30,135 & 3.10 & 285.418 & 3.86 \\
\hline Rhode Island $\ldots \ldots \ldots$ & 0 & -. & 0 & .. & 36,224 & 3.66 & 0 & -. & 36,224 & 3.66 \\
\hline South Carolina ................... & 0 &.. & 75,909 & 2.51 & 63.414 & 3.10 & 13,447 & 2.77 & 152.770 & 2.77 \\
\hline 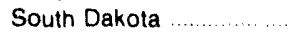 & 0 & .. & 0 & .. & 22,356 & 3.14 & 0 &.. & 22,356 & 3.14 \\
\hline 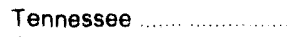 & 83,421 & 3.05 & 0 & -. & 89,397 & 3.08 & 13,153 & 3.55 & 185.971 & 3.10 \\
\hline 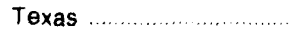 & 28,016 & 1.71 & 225,655 & 1.81 & 332,396 & 2.87 & 27.091 & 2.21 & 613,158 & 2.39 \\
\hline Utah & 9,917 & 1.32 & 0 & .. & 35,183 & 4.06 & 0 & .. & 45,101 & 3.46 \\
\hline 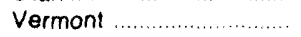 & 0 & .. & 0 & .. & 7,595 & 2.93 & 0 & .. & 7.595 & 2.93 \\
\hline Virginia $\ldots \ldots \ldots \ldots . . . . . . . . . . .$. & 3,919 & .22 & 0 & .. & 87,544 & 3.43 & 0 & .. & 91.463 & 3.29 \\
\hline Washington & 0 & .. & 0 & .. & 9,020 & 3.21 & 16,241 & 3.01 & 25,261 & 3.08 \\
\hline 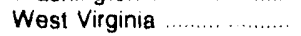 & 6 & 2.71 & 893 & 3.13 & 16,634 & 5.40 & 944 & 3.16 & 18,476 & 5.17 \\
\hline 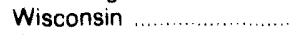 & 13,335 & 3.60 & 0 & .- & 238.525 & 3.42 & 0 & .. & 251,860 & 3.43 \\
\hline 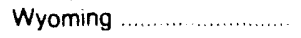 & 3,991 & 1.96 & 0 & .. & 7.985 & 3.16 & 12,576 & 2.32 & 24.552 & 2.54 \\
\hline 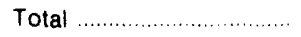 & 950,698 & 2.58 & 351,042 & 1.98 & $5,425,860$ & 3.28 & 473,104 & 2.85 & $7,200.704$ & 3.10 \\
\hline
\end{tabular}

- Not applicable.

Notes: Transporters include interstate pipelines, intrastate pipelines, and/or distributors. Totals may not equal sums due to independent rounding.

Source: Energy Information Administration (E|A), Form ElA-176. "Annual Report of Natural and Supplemental Gas Supply and Disposition." 
Table 29. Volume and Average Price of Gas Sold for Resale by State, 1992 (Volumes in Million Cubic Feet, Prices in Dollars per Thousand Cubic Feet)

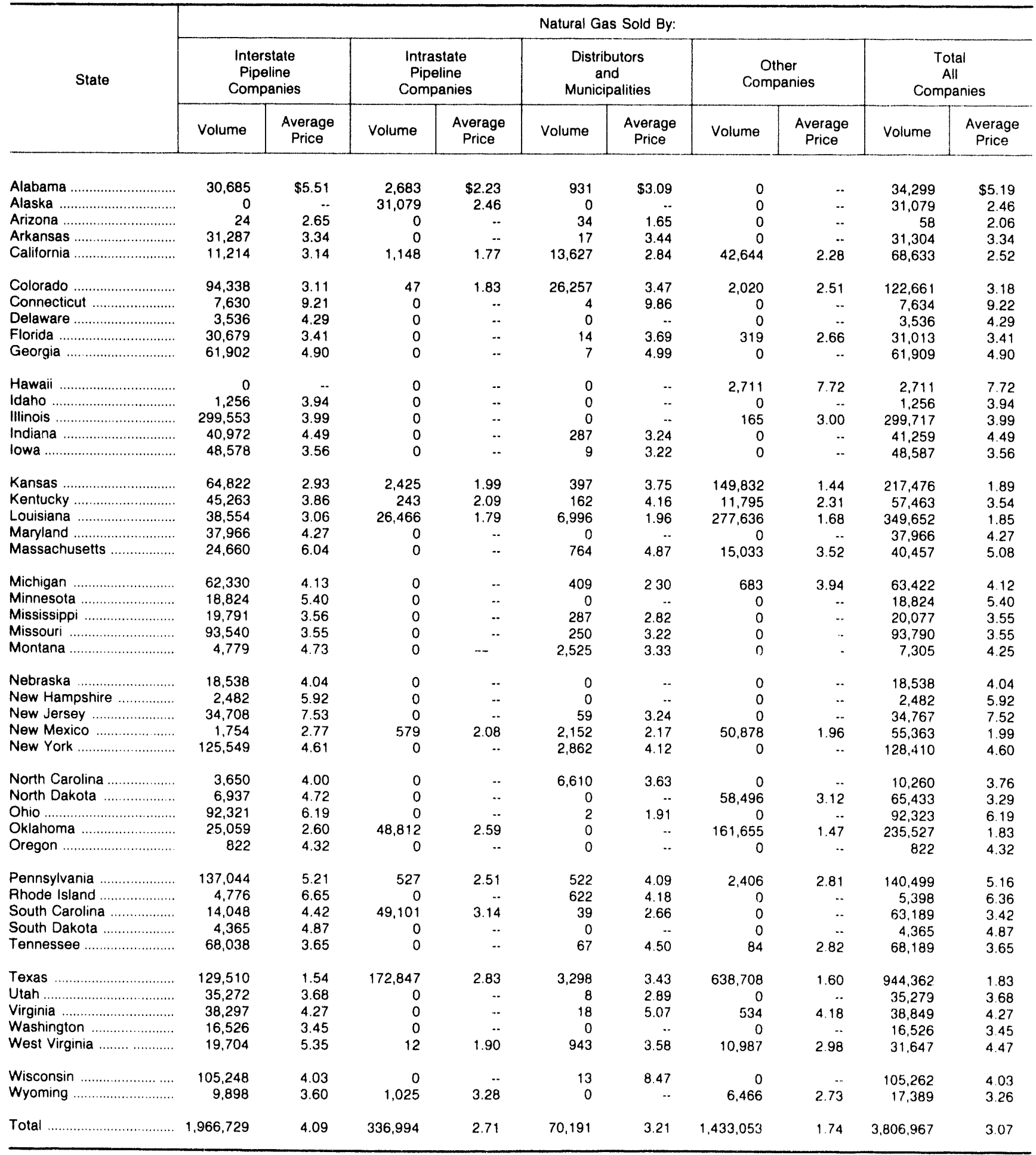

Notes: Totals may not equal sum of components due to independent rounding. The volumes shown include duplicate or multiple transactions where gas was purchased and resold by intermediates. The average prices shown are, therefore, composite averages of the multiple transactions.

Source: Energy Information Admiristration (EIA), Form EIA-176, "Annual Report of Natural and Supplemental Gas Supply and Disposition." 


\section{Census Division Summary}

\section{Production}

The West South Central Census Division produced 13.3 trillion cubic feet of natural gas, 71 percent of the marketed production of natural gas in the United States and showed an increase in production from 1991 to 1992 of 3 percent, compared to the national increase of 1 percent. In the Mountain Census Division, the second leading producer, production rose 16 percent to 2.7 trillion cubic feet. It declined in the Middle Atlantic, the East North Central, the South Atlantic, and the Pacific Contiguous Census Divisions. These four census divisions together represented 6 percent of the nation's marketed production.

All of the natural gas produced in the Pacific Noncontiguous Census Division, which includes the diverse States of Alaska and Hawaii, came from Alaska. Most of Alaska's gross withdrawals were returned to reservoirs for pressure maintenance primarily because there is no way to bring natural gas produced on the North Slope to market. Alaska exports about 12 percent of its marketed production to Japan in the form of liquefied natural gas (LNG).

\section{Consumption}

Deliveries of natural gas to residential consumers rose 10 percent or more from 1991 to 1992 in the New England. Middle Atlantic, and the South Atlantic Census Divisions. Deliveries to commercial consumers followed a pattern very similar to the residential sector during this same time period. The increases were greatest on the east coast, in the New England Census Division (14 percent), followed by the South Atlantic ( 8 percent), and the Middle Atlantic ( 7 percent) Census Divisions. In the East North Central, East South Central. and Pacific Noncontiguous Census Divisions deliveries to both residential and commercial consumers rose in the range of 2 percent to 6 percent.

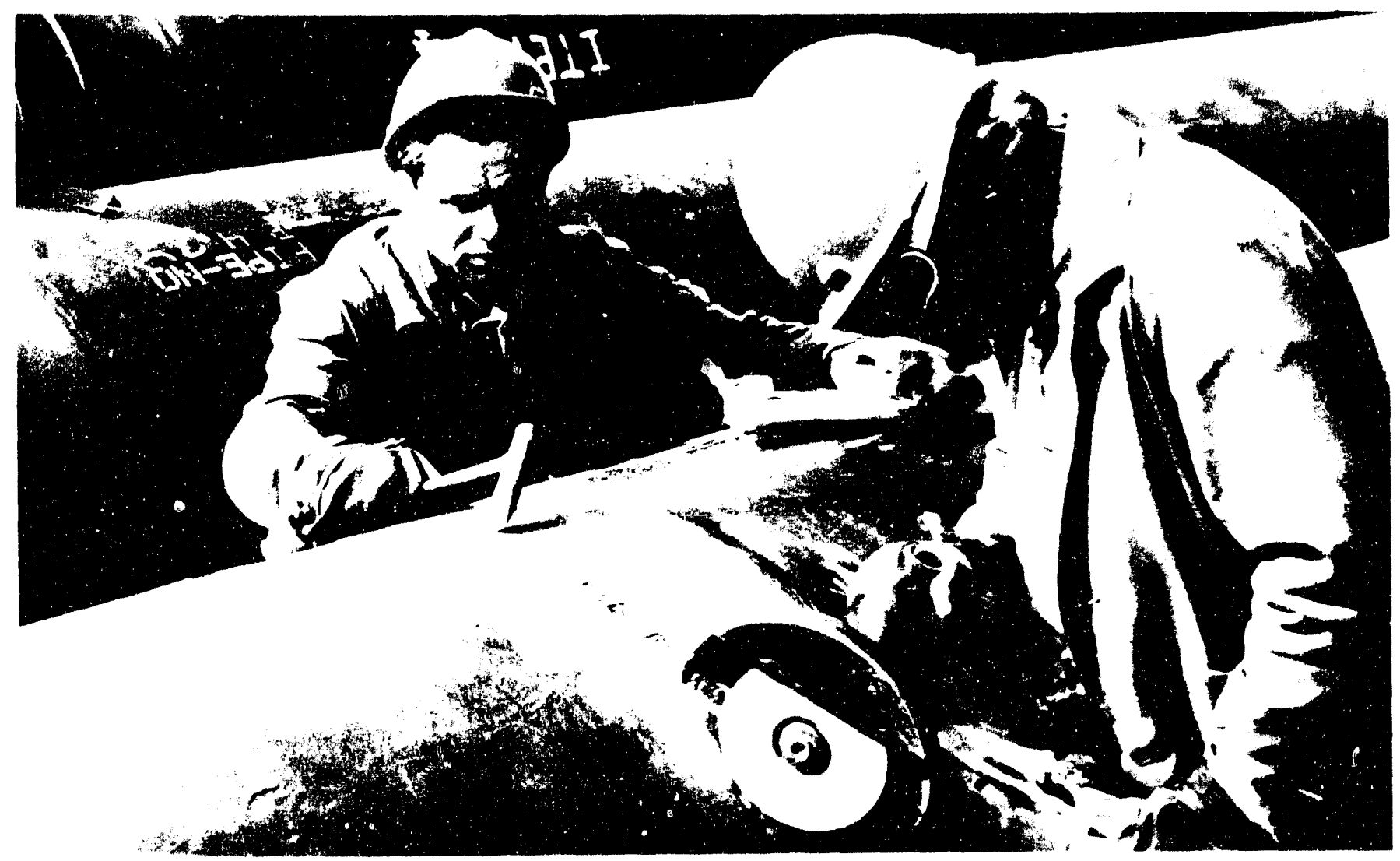

Welders grind seams on a 48 -me hipeline secton, prour 10 installation. 


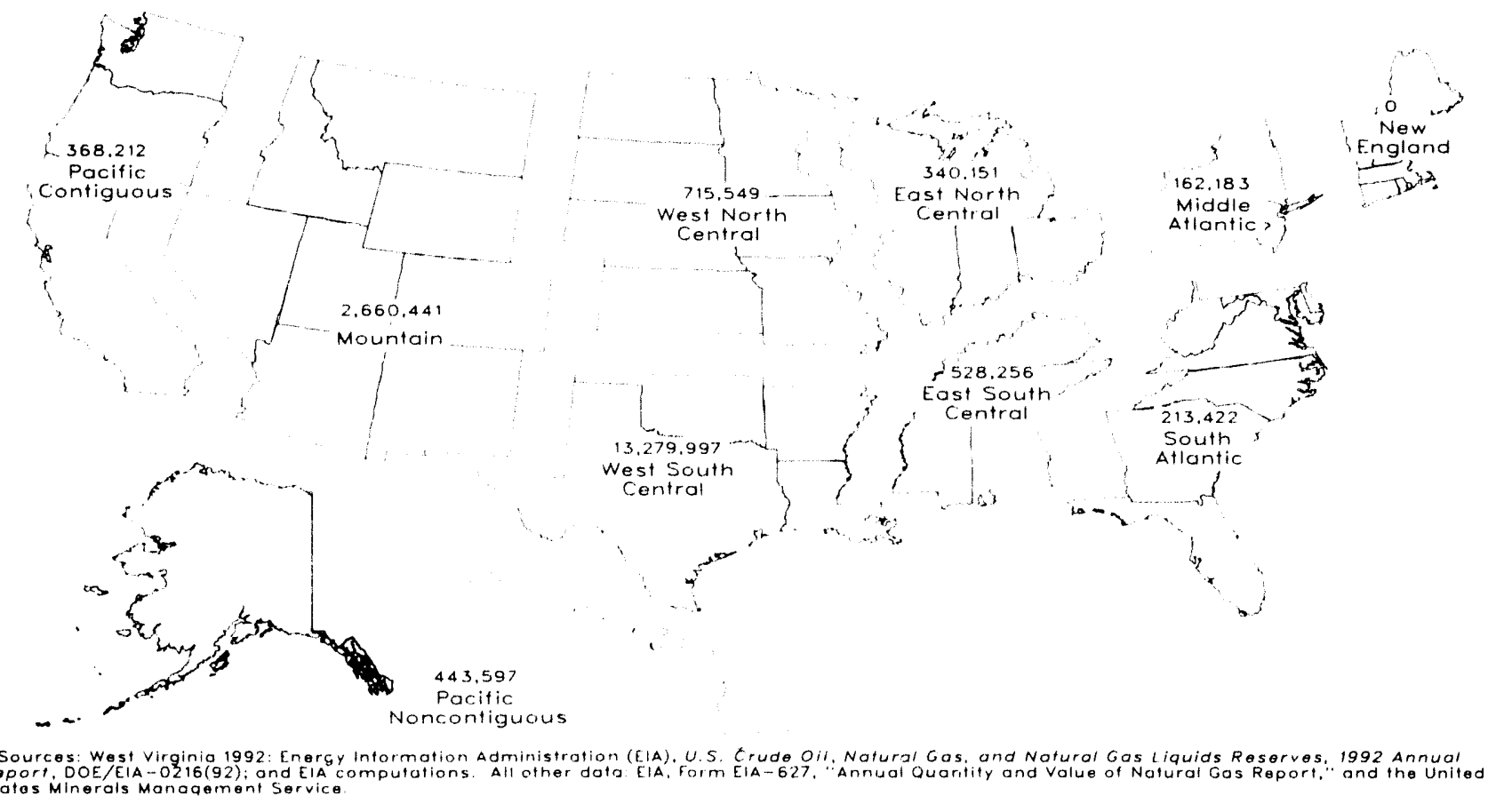

Natural gas deliveries to industrial consumers rose from 1991 to 1992 in all but 2 census divisions. The largest percentage increases were 34 percent in New England, 24 percent in the Middle Atlantic, and 12 percent in the Mountain Census Divisions. Deliveries to industrials fell by 22 billion cubic feet in the West South Central and by 5 billion cubic feet in the Pacific Contiguous Census Divisions.

While the volume of natural gas delivered for vehicle fuel use is small when compared to deliveries for other sectors, it rose 39 percent from 1991 to 1992. Increases were seen in every census division except the Middle Atlantic, where volumes dropped by more than half, and the Pacific Noncontiguous, where no volumes were reported.

For the electric utility sector, deliveries of natural gas were lower in 1992 than they were in 1991 in most of the census divisions. The percentage decrease was greatest in the West North Central Census Division where volumes dropped by more than half. Gas deliv- eries to electric utilities for 1992 fell by less than 1 percent for the Nation.

With 28 percent of the gas deliveries to consumers, the West South Central Census Division continued to be the leading consumer of natural gas during 1992. This census division was also by far the leading consumer of natural gas in the industrial and electric utility sectors, representing 39 percent and 51 percent, respectively, of the gas deliveries in the Nation to these sectors.

The East North Central Census Division ranked second in natural gas consumption. The primary consuming sector for natural gas in this census division was the residential sector, which received 42 percent of the deliveries to consumers in the region during 1992. It relies on supplies from other census divisions to meet its natural gas demand. It also has a large percentage of the Nation's underground storage capacity that enables it to meet its consumption requirements during peak periods in the winter months. 
Figure 15. Natural Gas Delivered to Consumers by Census Division, 1992

(Million Cubic Feet)

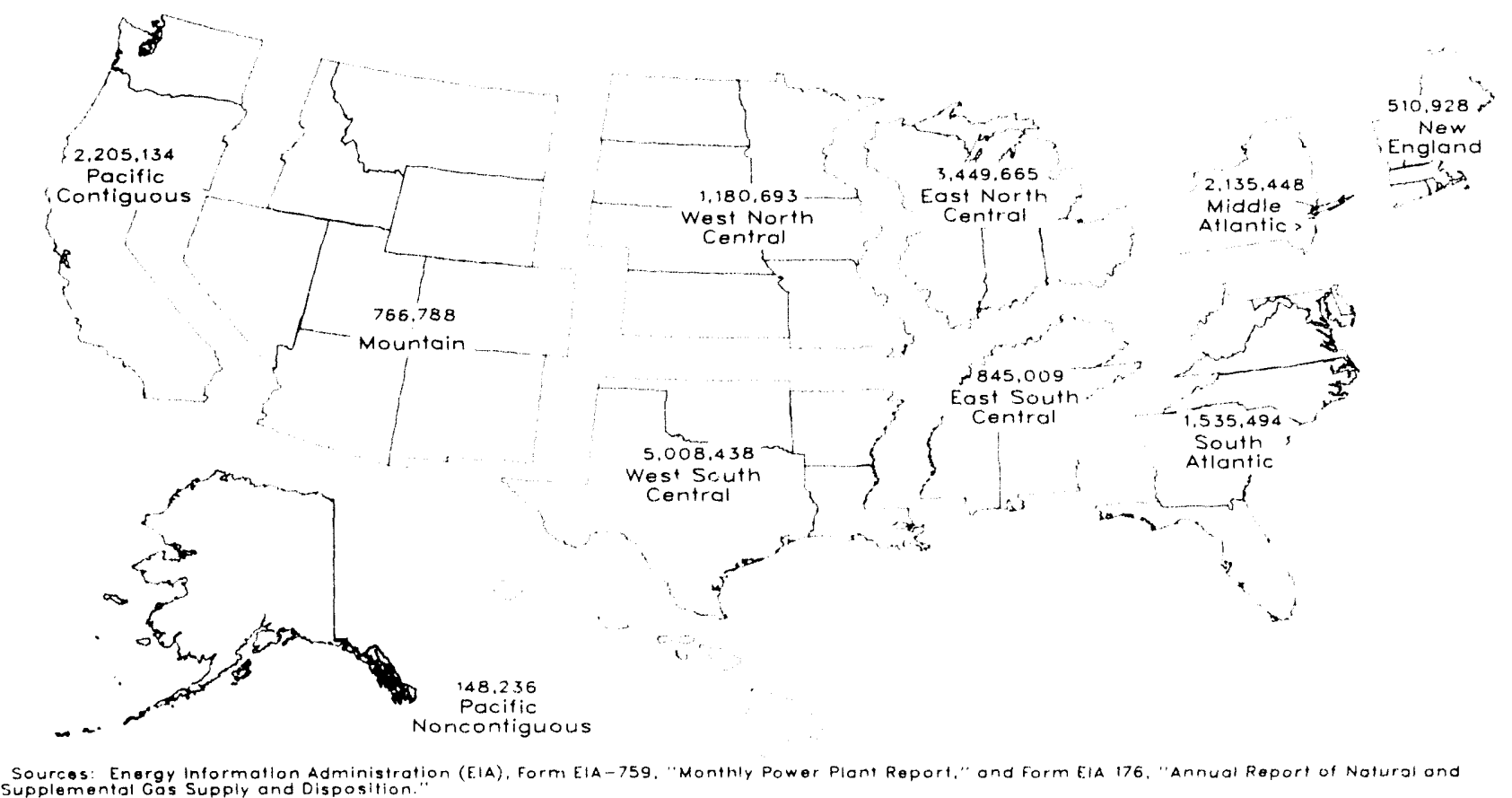

\section{Prices}

Residential natural gas prices were relatively flat from 1991 to 1992 in all census divisions except the West North Central where they went up 5 percent and in the Pacific Noncontiguous Census Division where prices went down 13 percent. The eastern regions-- New England, Middle Atlantic, and South Atlantic--had the highest residential prices, ranging from $\$ 6.66$ to $\$ 8.09$ per thousand cubic feet. From 1991 to 1992, the percentage difference in the price of gas delivered to commercial consumers ranged from a drop of 6 percent ( Pacific Noncontiguous) to an increase of 5 percent (West North Central).

The price of deliveries to indusirial consumers rose for all census divisions from 1991 to 1992 except the Middle Atlantic and the Pacific Contiguous Census Divisions, where it fell by 6 percent. Alaska receives all of the natural gas delivered to industrials in the Pacific Noncontiguous Census Division. For two consecutive years, it remained by far the lowest priced gas delivered to industrials in the Nation, only $\$ 1.18$ per thousand cubic feet.

The national average price of natural gas delivered for use as vehicle fuel in 1992 was $\$ 4.05$ per thousand cubic feet. The price in the Middle Atlantic increased 19 percent from the previous year, to $\$ 5.65$, the highest price of all census divisions in deliveries for use as vehicle fuel. The volumes and prices reported for vehicle fuel use generally are for deliveries to vehicle fueling stations.

The lowest prices for gas deliveries to consumers were paid by electric utilities. From 1991 to 1992 these prices rose more than 7 percent for all but the East North Central and the Pacific Contiguous Census Divisions. In the Pacific Noncontiguous Census Division, the price of gas delivered to electric utilities rose 8 percent to $\$ 0.57$ per thousand cubic feet. It remains the lowestpriced gas delivered to electric utilities among all 10 census divisions. All deliveries of natural gas to electric utilities in this census division were made in Alaska. 
Table 30. Natural Gas Delivered to Consumers by Census Division, 1992

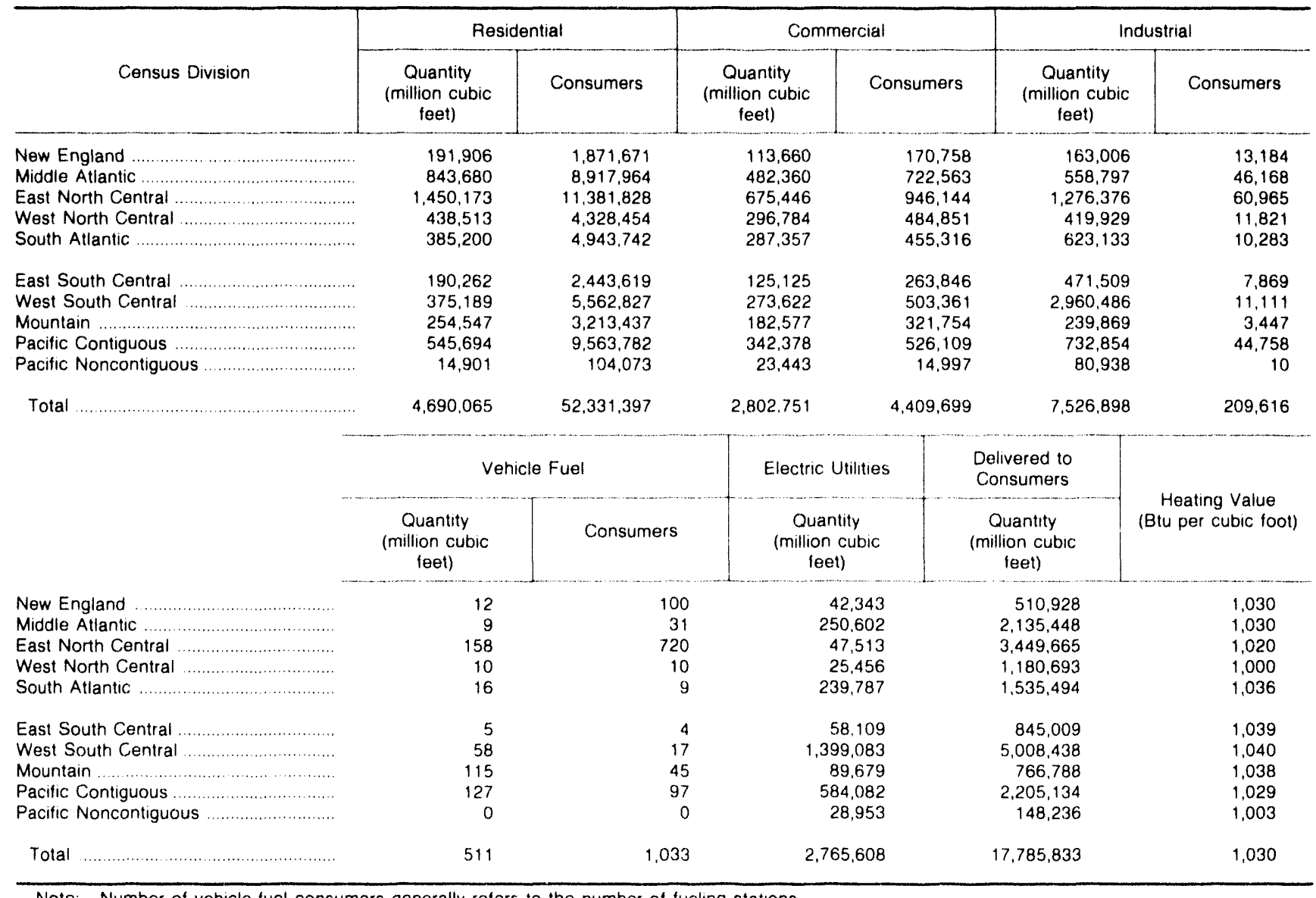

Note: Number of vehicle fuel consumers generally refers to the number of fueling stations.

Sources: Energy Information Administration (E|A.), Form E|A-759, "Monthly Power Plant Report." and Form ElA.176, "Annual Report of Natural and Supplemental Gas Supply and Disposition." 
Table 31. Average Price of Natural Gas Delivered to Consumers by Census Division, 1991 - 1992 (Dollars per Thousand Cubic Feet)

\begin{tabular}{|c|c|c|c|c|c|c|c|}
\hline \multirow{2}{*}{ Census Division } & & \multicolumn{2}{|c|}{ Residential } & \multicolumn{4}{|c|}{ Commercial } \\
\hline & & 1991 & 1992 & \multicolumn{2}{|r|}{1991} & \multicolumn{2}{|r|}{1992} \\
\hline 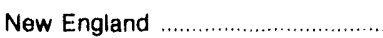 & .................. & $\$ 8.14$ & $\$ 8.09$ & \multicolumn{2}{|r|}{$\$ 6.34$} & \multicolumn{2}{|r|}{$\$ 6.29$} \\
\hline 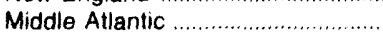 & (n.................. & 7.02 & 7.12 & \multicolumn{2}{|r|}{5.53} & \multicolumn{2}{|r|}{5.72} \\
\hline East North Central & (n).................. & 5.17 & 5.22 & \multicolumn{2}{|r|}{4.66} & \multicolumn{2}{|r|}{4.68} \\
\hline 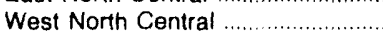 & (n) & 4.74 & 4.97 & \multicolumn{2}{|r|}{3.91} & \multicolumn{2}{|r|}{4.11} \\
\hline South Atlantic & $\ldots \ldots \ldots \ldots$ & 6.64 & 6.66 & \multicolumn{2}{|r|}{5.13} & \multicolumn{2}{|r|}{5.19} \\
\hline East South Central & ........ & 5.56 & 5.59 & \multicolumn{2}{|r|}{4.77} & \multicolumn{2}{|r|}{4.87} \\
\hline 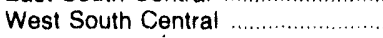 & (n)................. & 5.47 & 5.53 & \multicolumn{2}{|r|}{4.12} & \multicolumn{2}{|r|}{4.22} \\
\hline 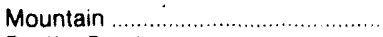 & ................... & 5.22 & 5.16 & \multicolumn{2}{|r|}{4.34} & \multicolumn{2}{|r|}{4.24} \\
\hline Pacific Contiguous & 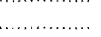 & 6.14 & 5.90 & \multicolumn{2}{|r|}{5.25} & \multicolumn{2}{|r|}{5.01} \\
\hline Pacific Noncontiguous .................. & $\ldots \ldots \ldots \ldots$ & 4.90 & 4.32 & \multicolumn{2}{|r|}{3.87} & \multicolumn{2}{|r|}{3.62} \\
\hline & \multicolumn{2}{|c|}{ Industrial } & \multicolumn{3}{|c|}{ Vehicle Fuel } & \multicolumn{2}{|c|}{ Electric Utilities } \\
\hline & 1991 & 1992 & 1991 & 1992 & & 1991 & 1992 \\
\hline 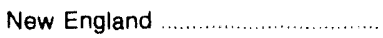 & $\$ 4.34$ & $\$ 4.44$ & $\$ 3.78$ & $\$ 4.06$ & & A $\$ 2.24$ & $\$ 2.66$ \\
\hline 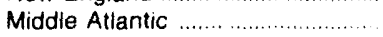 & 4.04 & 3.80 & 4.74 & 5.65 & & 2.24 & 2.44 \\
\hline 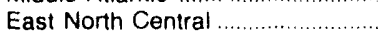 & 3.64 & 3.65 & 3.62 & 3.63 & & ค 1.60 & 1.54 \\
\hline 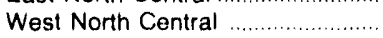 & 2.91 & 3.20 & 3.69 & 413 & & 1.70 & 2.05 \\
\hline 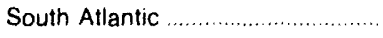 & 3.21 & 3.33 & 472 & 4.67 & & 2.18 & 2.35 \\
\hline East South Central ......................... & 2.92 & 3.08 & 411 & 5.56 & & 1.63 & 1.88 \\
\hline 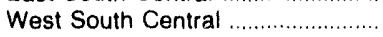 & 1.86 & 2.06 & 3.87 & 3.35 & & 2.05 & 2.28 \\
\hline 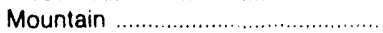 & 3.00 & 3.07 & 4.05 & 4.11 & & 1.87 & 2.07 \\
\hline 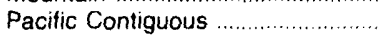 & 3.76 & 3.54 & 427 & 4.58 & & 2.92 & 2.79 \\
\hline 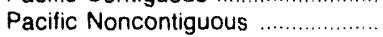 & 1.18 & 1.18 & .. & .. & & .53 & .57 \\
\hline
\end{tabular}

P = Revised data

-- Not applicable.

Note: All average prices are volume weighted

Sources: Energy information Administration (EIA), Form FERC.423, "Monthly Report of Cost and Quality of Fuels for Electric Plants," and Form ElA-176, "Annual Report of Natural and Supplemental Gas Supply and Disposition." 


\section{Natural Gas 1992}

Net Interstate Movements

Million

Cu. Feot

626,755

Marketed Production

Million
Cu. Feet
0

Parcont of

National Total

.00

Deliveries to Consumers

?

Residential:

191.906

4.09

A.

ast

Commercial:

113,660

4.06

$\therefore$

Industrial:

163,006

2.17

$D$ Vehicle Fuel:

12

2.35

$A$

Electric Utility:

42,343

1.53

Total:

510,928

2.87

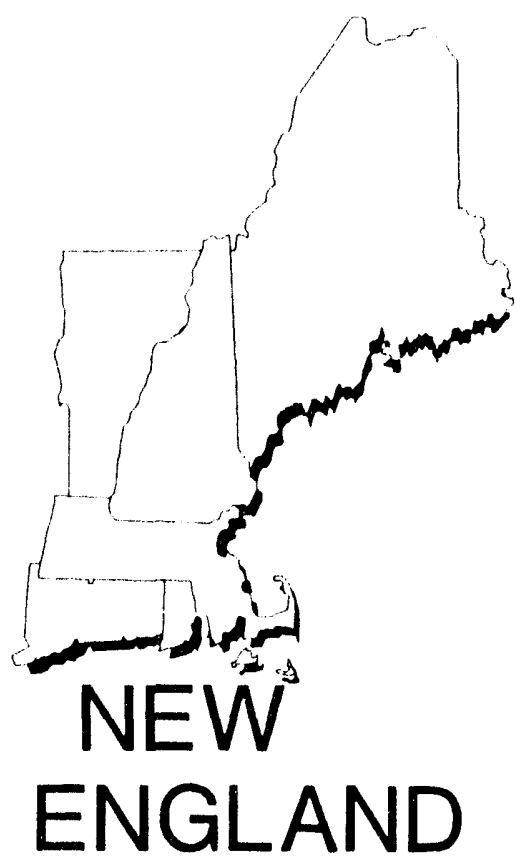

Table 32. Summary Statistics for Natural Gas -- New England, 1988-1992

\begin{tabular}{|c|c|c|c|c|c|}
\hline & 1988 & 1989 & 1990 & 1991 & 1992 \\
\hline & \multicolumn{5}{|c|}{ Reserves (billion cubic feet) } \\
\hline \multirow[t]{2}{*}{$\begin{array}{l}\text { Estimated Proved Reserves (dry) } \\
\text { as of December } 31\end{array}$} & 0 & 0 & 0 & 0 & 0 \\
\hline & \multicolumn{5}{|c|}{ Number of Gas and Gas Condensate Wells } \\
\hline Producing at End of Year. & 0 & 0 & 0 & 0 & 0 \\
\hline $\begin{array}{l}\text { Gross Withdrawals } \\
\text { From Gas Wells } \\
\text { From Oil Wells }\end{array}$ & $\begin{array}{l}0 \\
0\end{array}$ & $\begin{array}{l}0 \\
0\end{array}$ & $\begin{array}{l}0 \\
0\end{array}$ & $\begin{array}{l}0 \\
0\end{array}$ & $\begin{array}{l}0 \\
0\end{array}$ \\
\hline 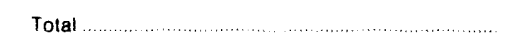 & 0 & 0 & 0 & 0 & 0 \\
\hline … & 0 & 0 & 0 & 0 & 0 \\
\hline Nonhydrocarbon Gases Removed & 0 & 0 & 0 & 0 & 0 \\
\hline Wet After Lease Separation & 0 & 0 & 0 & 0 & 0 \\
\hline Vented and Flared & 0 & 0 & 0 & 0 & 0 \\
\hline \multirow[t]{2}{*}{ Total Dry Production } & 0 & 0 & 0 & 0 & 0 \\
\hline & \multicolumn{5}{|c|}{ Supply (million cubic teet) } \\
\hline Receipts at Region Borders & 0 & 0 & 0 & 0 & 0 \\
\hline Imports & 25,595 & 51,380 & 67,956 & 46.108 & 47.727 \\
\hline Intransit Roceipts & 0 & 0 & 0 & 0 & 0 \\
\hline \multirow{2}{*}{\multicolumn{6}{|c|}{ Withdrawals from Storage }} \\
\hline & & & & & \\
\hline Underground Storage. & 0 & 0 & 0 & 0 & 0 \\
\hline LNG Storage & 9,023 & 18.610 & 7,363 & 9.857 & 8.943 \\
\hline Supplemental Gas Supplies & 2.004 & 1,755 & 684 & 493 & 399 \\
\hline Balancing Itern & $-31,821$ & -26.123 & $-3,638$ & ค $-15,117$ & 16.046 \\
\hline Total Supply & 359,474 & 413.661 & 425.549 & ค 439.979 & 577.877 \\
\hline
\end{tabular}

See lootnotes at end of table 
Table 32. Summary Statistics for Natural Gas -- New England, 1988-1992 (Continued)

\begin{tabular}{|c|c|c|c|c|c|}
\hline & 1988 & 1985 & 1990 & 1991 & 1992 \\
\hline & \multicolumn{5}{|c|}{ Disposition (million cutsic feet) } \\
\hline Consumption & 351,650 & 402.225 & 417,029 & A 433.744 & 513,723 \\
\hline \multicolumn{6}{|l|}{ Deliveries at Region Borders } \\
\hline Exports & 0 & 0 & 0 & 0 & 0 \\
\hline Intransit Deliveries & 0 & 0 & 0 & 0 & 0 \\
\hline Interregion Deliveries & 482 & 123 & 78 & 53 & 57,826 \\
\hline \multicolumn{6}{|l|}{ Additions to Storage } \\
\hline Underground Storage & 0 & 0 & 0 & 0 & 0 \\
\hline LNG Storage & 7.343 & 11,313 & 8,443 & 6,182 & 6,328 \\
\hline \multirow[t]{2}{*}{ Total Disposition } & 359,475 & 413,661 & 425,549 & P 439,979 & 577.877 \\
\hline & \multicolumn{5}{|c|}{ Consumption (miltion cubic feel) } \\
\hline Lease and Plant Fuel... & 0 & 0 & 0 & 0 & 0 \\
\hline Pipeline Fuel & 2.663 & 2.969 & 1.872 & 2,235 & 2.796 \\
\hline \multicolumn{6}{|l|}{ Delivered to Consumers } \\
\hline Residential $\ldots \ldots \ldots \ldots \ldots \ldots$ & 174,158 & 179,686 & 170,679 & 166,036 & 191,906 \\
\hline 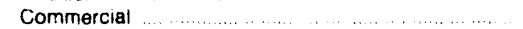 & 93.115 & 100,169 & 96.899 & 97,242 & 113,660 \\
\hline Industrial & 60,340 & 65,452 & 81,334 & 121,658 & 163,006 \\
\hline Vehicle Fuel & NA & NA & 8 & 9 & 12 \\
\hline 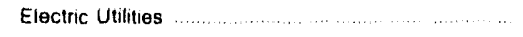 & 21,374 & 53,949 & 66,238 & 46,564 & 42,343 \\
\hline Total Delivered to Consumers & 348,986 & 399,256 & 415.157 & 431.509 & 510.928 \\
\hline \multirow[t]{2}{*}{ Total Consumption } & 351,650 & 402,225 & 417.029 & 433.744 & 513.723 \\
\hline & \multicolumn{5}{|c|}{ Delivered for the Account of Others (million cubic feet) } \\
\hline Pesidential & NA & NA & 0 & 0 & 0 \\
\hline Commercial & 1,628 & 4,105 & 1.531 & 1.983 & 1.177 \\
\hline industrial & 1,367 & 3.062 & 8.587 & 49,551 & 93,656 \\
\hline \multirow[t]{2}{*}{ 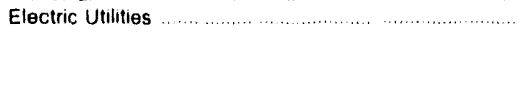 } & 2 & 6,940 & 24.157 & 23,121 & 25,019 \\
\hline & \multicolumn{5}{|c|}{ Number of Consumers } \\
\hline Residential & $1,794,845$ & $1,822,633$ & $1,838,051$ & $1,854,346$ & $1,871,671$ \\
\hline 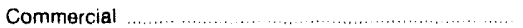 & 166,283 & 169,870 & 166,624 & 171.798 & 170,758 \\
\hline Industrial & 11,558 & 17.551 & 11,194 & 9.489 & 13.184 \\
\hline \multirow[t]{2}{*}{ Vehicle Fuel } & NA & NA & 85 & 96 & 100 \\
\hline & \multicolumn{5}{|c|}{ Average Annual Consumption per Consumer (thousand cubic feet) } \\
\hline Residential. & 97 & 99 & 93 & 90 & 103 \\
\hline Commercial & 560 & 590 & 582 & 566 & 666 \\
\hline Industrial & 5.221 & 3.729 & 7,266 & 12,821 & 12,364 \\
\hline \multirow[t]{2}{*}{ 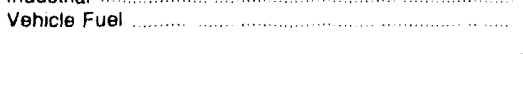 } & NA & NA & 90 & 98 & 121 \\
\hline & \multicolumn{5}{|c|}{ Average Annual Cost per Consumer (dollars) } \\
\hline 대 & $\$ 659$ & $\$ 727$ & $\$ 732$ & $\$ 729$ & $\$ 830$ \\
\hline Commercial & 3,240 & 3,378 & 3,619 & 3,514 & 4,142 \\
\hline \multirow[t]{2}{*}{ Vehicle Fuel } & NA & NA & 350 & 370 & 491 \\
\hline & \multicolumn{5}{|c|}{ Average Heating Value (Btu per cubic foot) } \\
\hline \multirow[t]{2}{*}{ Delivered to Consumers } & 1.029 & 1,034 & 1.034 & 1.033 & 1.030 \\
\hline & \multicolumn{5}{|c|}{ Average Prices for Natural Gas (dollars per thousand cubic feet) } \\
\hline 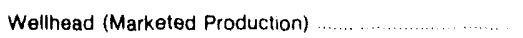 & 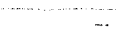 & -.. & - & $\cdots$ & - \\
\hline Imports & $\$ 262$ & $\$ 2.38$ & $\$ 285$ & $\$ 2.98$ & $\$ 287$ \\
\hline Exports …1. & . & -. & -. & $\ldots$ & - \\
\hline Pipeline Fuel & 239 & 2.83 & 302 & ค 291 & 2.95 \\
\hline City Gate & 310 & 3.30 & 345 & 3.42 & 3.59 \\
\hline \multicolumn{6}{|l|}{ Delivered to Consumers } \\
\hline Residential ..................... & 6.79 & 738 & 7.88 & 814 & 8.05 \\
\hline 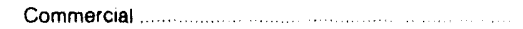 & 589 & 598 & 6.32 & 6.34 & 629 \\
\hline Industrial & 406 & 425 & 44 ? & 4.34 & 4.44 \\
\hline 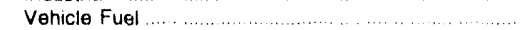 & NA & NA & 386 & 3.78 & 406 \\
\hline Electric Utilities & 229 & 250 & 253 & P 224 & 266 \\
\hline
\end{tabular}

A $=$ Revised data.

NA = Not available.

- $=$ Not applicable. Note: Deliveries to electric utlities (consumption) are reported on the Form EiA.759 "Monthly Power Plant Report" Deliveries to electric utities for the account of
others are ieported on the Form EiA.176. "Annual Report of Natural and Supplemental Gas Supply and Disposition." See the discussion on electric uttity data and Table At in Ap. pendix A for a comparison of reporting to these two forms. Tolais may riot add due to independent rounding Census Division includes Connecticut, Maine. Massachusetts. New Hampshire, Rhode island, and Vermont.

Sources: Energy Intormation Administration (EIA). Form ElA.176. "Annual Report of Natural and Supplemental Gas Supply and Disposition." Form ElA-627, "Anriual Quantity and Value of Natural Gas Repor,." Form ElA-857. "Monthly Report of Natural Gas Purchases and Detiveries to Consumers." Form FiA.816. "Monthly Natural Gas Liquids Report." Form ElA.759. "Monthly Power Plant Report." Form FERC-423. "Monthly Report of Cost and Qualty of Fuels for Electric Plants. "Form ElA-191, "Underground Gas Storage Report."

Form FPC.14, "Annual Report for Importers and Exporters of Natural Gas," US Crude Oil. Natural Gas. and Natural Gas Liquids Reservesi. 1992 Annual Report. DOE. /EIA.

0216(92), and the U.S Minerals Management Service 
Natural Gas 1992

Net Interstate Movements

Million

Cu. Foel

Marketed Production

Million
Cu. Fooi
162,183

$2,056,670$

Deliveries to Consumers

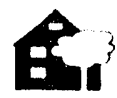

Residential:

843,680

Percent of

National Total

$\begin{array}{ll}162,183 & .87\end{array}$

18

asts

Commercial:

482,360

17.99

EM

Industrial:

558,797

17.21

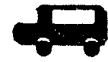

Vehicle Fuel:

9

7.42

$A$

Electric Utility:

250,602

1.76

9.06

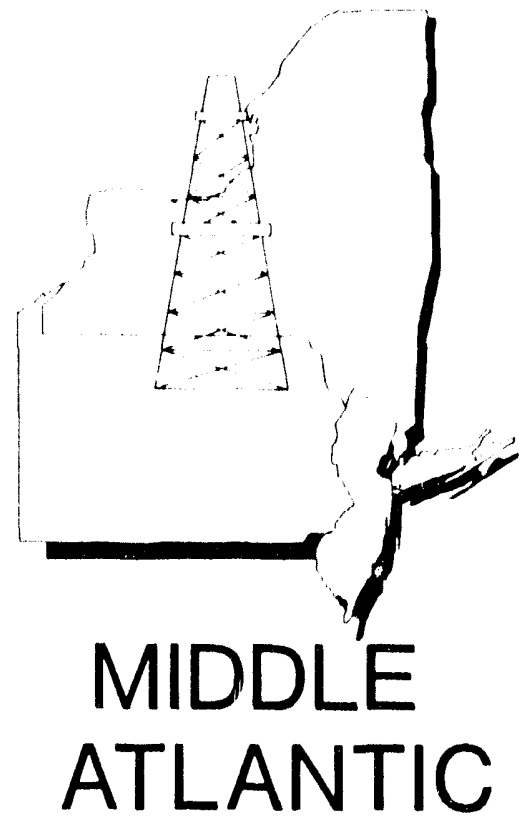

Total:

$2,136,448$

12.01

Table 33. Summary Statistics for Natural Gas -- Middle Atlantic, 1988-1992

\begin{tabular}{|c|c|c|c|c|c|}
\hline & 1988 & 1989 & 1990 & 1991 & 1992 \\
\hline & \multicolumn{5}{|c|}{ Reserves (billion cubic leet) } \\
\hline \multirow[t]{2}{*}{$\begin{array}{l}\text { Estimaled Proved Reserves (dry) } \\
\text { as of December } 31\end{array}$} & 2,423 & 2,010 & 2.074 & 1.960 & 1,857 \\
\hline & \multicolumn{5}{|c|}{ Number of Gas and Gas Condensate Wells } \\
\hline \multirow[t]{2}{*}{ Producing at End of Year } & 33.090 & 35,304 & 35,825 & 36,737 & 36.906 \\
\hline & \multicolumn{5}{|c|}{ Production (milion cubic teet) } \\
\hline $\begin{array}{l}\text { Gross Withdrawals } \\
\text { From Gas Wells } \\
\text { From OIl Weils }\end{array}$ & $\begin{array}{r}193,512 \\
1.044\end{array}$ & $\begin{array}{r}216,117 \\
1,126\end{array}$ & $\begin{array}{r}195,758 \\
7,249\end{array}$ & $\begin{array}{r}174.377 \\
901\end{array}$ & $\begin{array}{r}1.1,372 \\
824\end{array}$ \\
\hline$\ldots \ldots+\ldots \ldots \ldots \ldots$ & 194.556 & 217,243 & 203.007 & 175.278 & 162.196 \\
\hline Repressuring & 0 & 0 & 0 & 0 & 0 \\
\hline Nonhydrocarbon Gases Removed & 0 & 0 & 0 & 0 & 0 \\
\hline Wet After Lease Separation & 194,556 & 217,243 & 203,007 & 175,278 & 162,196 \\
\hline Vented and Flared & 4,012 & 5.036 & 375 & 1 & 13 \\
\hline Extraction Loss & 272 & 254 & 300 & 395 & 604 \\
\hline \multirow[t]{2}{*}{ Total Dry Production } & 190.272 & 211.953 & 202,332 & 174,882 & 161,579 \\
\hline & \multicolumn{5}{|c|}{ Supply (million cubic teet) } \\
\hline $\begin{array}{l}\text { Dry Production } \\
\text { Receipls at Region Borders }\end{array}$ & 190,272 & 211.953 & 202,332 & 174.882 & 161.579 \\
\hline $\begin{array}{l}\text { Imports } \\
\text {. }\end{array}$ & 70.993 & 67.956 & 98.217 & 188,233 & 435.470 \\
\hline Intransit Receipts & 0 & 0 & 0 & 0 & 0 \\
\hline Interregion Receipts & 2,094684 & 2.134 .229 & $2,238.103$ & $2,017,328$ & $2,275.739$ \\
\hline \multicolumn{6}{|l|}{ Withdrawals from Storage } \\
\hline Underground Storage & 421,216 & 695,966 & 336.895 & 770,498 & 438.582 \\
\hline LNG Storage & $6,75 \%$ & 7.281 & 4.281 & 4.942 & 5.630 \\
\hline Supplemental Gas Suppiles & 15.828 & 16,083 & 10,567 & ค 15.689 & 15,684 \\
\hline Baiancing ltem & -52.544 & 55.421 & -46.914 & A 80,699 & $-38,310$ \\
\hline Total Supply & $2.747,207$ & $3.078,047$ & $2.843,481$ & $3,252,270$ & 3.294 .375 \\
\hline
\end{tabular}


Table 33. Summary Statistics for Natural Gas -- Middle Atlantic, 1988-1992 (Continued)

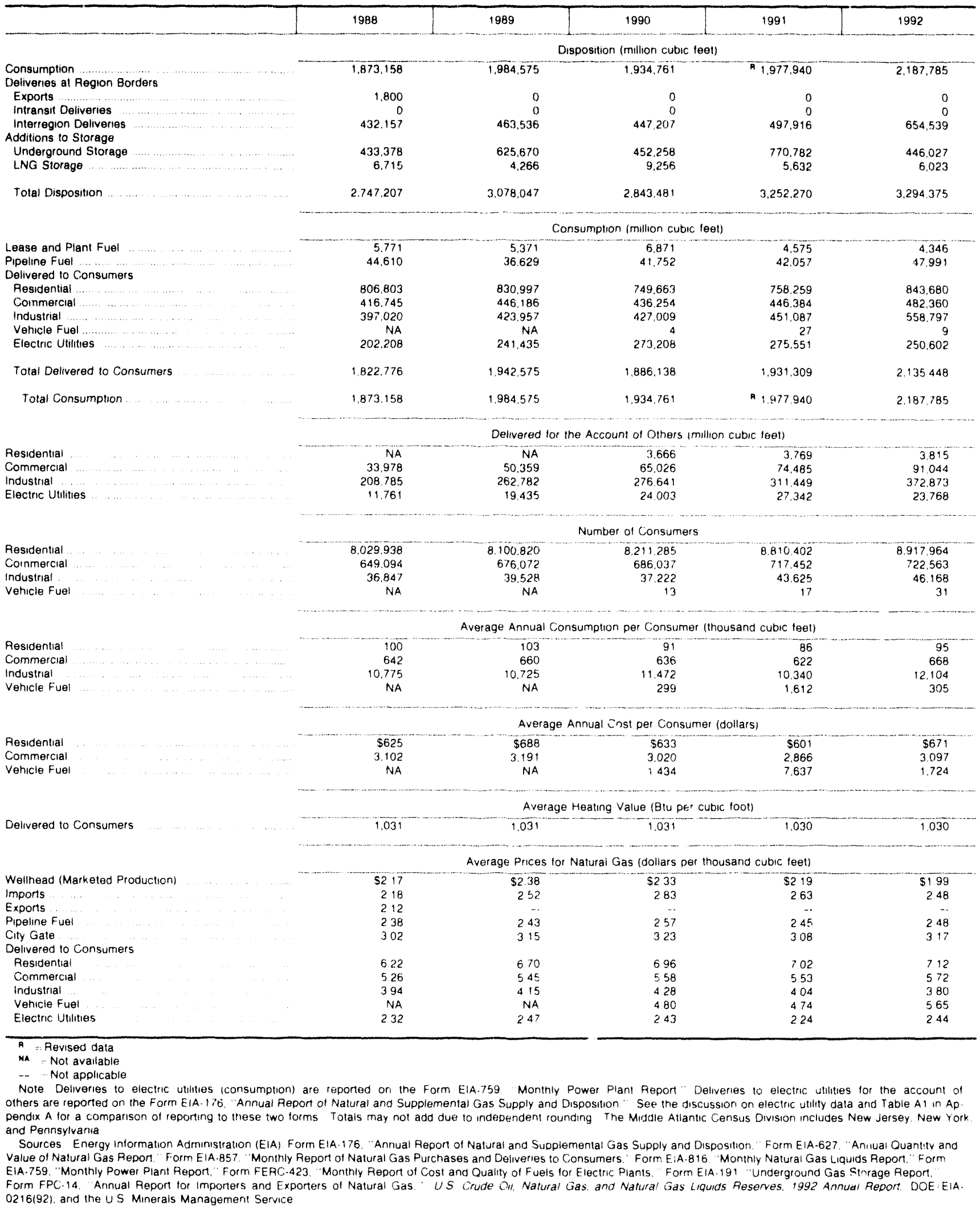




\section{Natural Gas 1992}

Net Interstate Movements
Marketed Production

Deliveries to Consumers

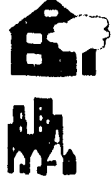

Residential:

$1,450,173$

Commercial:

675,446

$\rightarrow$

Industrial:

$1,276,376$

158

Vehicle Fuel:

47,513

$A$

Electric Utility:

Total:

$3,449,665$
Million

Cu. Fool

$3,126,062$

Percent of National Total 1.82

30.92

24.10

16.96

30.92

1.72

EAST NORTH CENTRAL

Table 34. Summary Statistics for Natural Gas -- East North Central, 1988-1992

\begin{tabular}{|c|c|c|c|c|c|}
\hline & 1988 & 1989 & 1990 & 1991 & 1992 \\
\hline & \multicolumn{5}{|c|}{ Reserves (bition cubic feet) } \\
\hline \multirow[t]{2}{*}{$\begin{array}{l}\text { Estimated Proved Reserves (dry) } \\
\text { as of December } 31\end{array}$} & 2.552 & 2617 & 2.457 & 2.515 & 2.384 \\
\hline & \multicolumn{5}{|c|}{ Number of Gas and Gas Condensate Wells } \\
\hline \multirow[t]{2}{*}{ Producing at End of Year } & 36,369 & 37.208 & 37687 & 39.087 & 39,756 \\
\hline & \multicolumn{5}{|c|}{ Production (miltion cubic feet) } \\
\hline $\begin{array}{l}\text { Gross Withdrawals } \\
\text { From Gas Wells } \\
\text { From Oil Wells }\end{array}$ & $\begin{array}{r}253.272 \\
66.977\end{array}$ & $\begin{array}{r}255.853 \\
68.596\end{array}$ & $\begin{array}{r}262.360 \\
71.150\end{array}$ & $\begin{array}{r}269.184 \\
80.578\end{array}$ & $\begin{array}{r}265.613 \\
80.202\end{array}$ \\
\hline$\ldots \ldots \ldots \ldots \ldots$ & 320.249 & 324.449 & 333.510 & 349.762 & 345.815 \\
\hline $\begin{array}{l}\text { Repressuring } \\
\text { Nonhydrocarbon Gases Removed }\end{array}$ & $\begin{array}{r}2,340 \\
0\end{array}$ & $\begin{array}{r}2,768 \\
0\end{array}$ & 2.340 & 2,340 & 2,340 \\
\hline 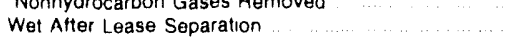 & 317.909 & 321,681 & 331.170 & 347.422 & $\begin{array}{r}0 \\
343,475\end{array}$ \\
\hline Vented and Flared . & 3.324 & 4.070 & 3,324 & 3.324 & 3.324 \\
\hline \multirow[t]{2}{*}{ Total Dry Production } & 303.997 & 307,598 & 319.390 & 335,846 & 331.886 \\
\hline & \multicolumn{5}{|c|}{ Supply (million cubtc feet) } \\
\hline Dry Production & 303.997 & 307.598 & 319,390 & 335.846 & 331.886 \\
\hline \multicolumn{6}{|l|}{ Receipls at Region Borders } \\
\hline Imports & 997 & 0 & 0 & 1.151 & 38.568 \\
\hline Intransit Receipts & 0 & 0 & 0 & 0 & 0 \\
\hline Interregion Receipts & $4,262,200$ & 4.649 .403 & 4.582 .681 & 4.386 .230 & 4868,856 \\
\hline \multicolumn{6}{|l|}{ Withdrawals from Storage } \\
\hline Underground Storage & 859.976 & 824.358 & 650.372 & 765.615 & 818.020 \\
\hline LNG Storage & 741 & 1.147 & 1,224 & 1,397 & 1,653 \\
\hline Suppiemental Gas Supplies & 16.494 & 15.744 & 31.111 & 25.854 & 27,295 \\
\hline Balancing ltem $\ldots$ & 106.567 & -12.833 & 132,329 & 12.454 & -2.983 \\
\hline Total Supply & $5,550,972$ & 5.785 .417 & $5,717,108$ & R $5,528.547$ & $6,083.295$ \\
\hline
\end{tabular}


Table 34. Summary Statistics for Natural Gas -- East North Central, 1988-1992 (Continued)

\begin{tabular}{|c|c|c|c|c|c|}
\hline & 1988 & 1989 & 1890 & 1981 & 1992 \\
\hline & \multicolumn{5}{|c|}{ Disposition (million cubic feet) } \\
\hline Consumption . & $3,293,880$ & $3,376,939$ & $3,263,719$ & $3,369.738$ & $3,509,808$ \\
\hline \multicolumn{6}{|l|}{ Deliveries at Region Borders } \\
\hline Exports & 17,900 & 38,361 & 17,284 & 14.751 & 67,763 \\
\hline 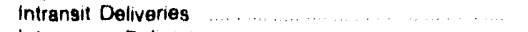 & 331,155 & 325,320 & 331,862 & 346.290 & 411,606 \\
\hline Interregion Deliveries $\ldots \ldots \ldots$ & $1,205,484$ & $1,272.133$ & $1,296,327$ & $1,071.028$ & $1,241,993$ \\
\hline \multicolumn{6}{|l|}{ Additions to Storage } \\
\hline Underground Storage & 695.586 & 771,699 & 805.891 & 724,941 & 790,648 \\
\hline LNG Storage & 6.967 & 965 & 2.025 & 1,798 & 1.477 \\
\hline \multirow[t]{2}{*}{ Total Disposition } & $5,550,972$ & $5,785,417$ & $5.717,108$ & $5,528,547$ & $6,083,295$ \\
\hline & \multicolumn{5}{|c|}{ Consumption (million cubic feet) } \\
\hline Lease and Plant Fuel. & 13,193 & 11,941 & 14,367 & 11.218 & 8.836 \\
\hline Pipeline Fuel ........... & 54.751 & 53,386 & 52.841 & ค 48.723 & 51,307 \\
\hline \multicolumn{6}{|l|}{ Delivered to Consumers } \\
\hline Residential ............. & 1.436 .407 & $1,503,742$ & 1.332 .422 & 1.396 .426 & $1,450,173$ \\
\hline Commercial $\quad \ldots \ldots \ldots \ldots$ & 680.594 & 677.584 & 636.759 & ค 649,640 & 675,446 \\
\hline Industrial & $1,081,033$ & $1,097,403$ & $1,184,725$ & $1,210,895$ & $1,276,376$ \\
\hline Vehicle Fuel $\ldots \ldots \ldots \ldots \ldots$ & NA & NA & 142 & 149 & 158 \\
\hline Electric Utilities $\ldots$ & 21,901 & 32,883 & 42.463 & 52,588 & 47.513 \\
\hline Total Delivered to Consumers $\ldots \ldots \ldots$ & 3.225 .936 & $3,311,612$ & 3.196 .511 & A $3,309,797$ & 3.449 .665 \\
\hline \multirow[t]{2}{*}{ Total Consumption } & 3.293 .880 & 3376.939 & $3,263,719$ & $3.369,738$ & $3.509,808$ \\
\hline & \multicolumn{5}{|c|}{ Delivered for the Account of Others (million cubic teet) } \\
\hline Residential. & NA & NA & 25.409 & 30,953 & 33985 \\
\hline Commercial $\ldots \ldots \ldots \ldots \ldots \ldots \ldots$ & 125,969 & 142.888 & 160.350 & 162.350 & 169.248 \\
\hline 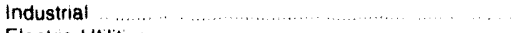 & 802.803 & 841.128 & 955.856 & 997.618 & $1,058,204$ \\
\hline \multirow[t]{2}{*}{ Electric Utilities $\ldots . . . . . . . . . . . . . . . . . . . . .}$. & 7.216 & 9,337 & 35,982 & 41,815 & 39.062 \\
\hline & \multicolumn{5}{|c|}{ Number of Consumers } \\
\hline Residential & $10,698.172$ & $10.898,521$ & $11,078,902$ & $11.242,141$ & 11.381 .828 \\
\hline 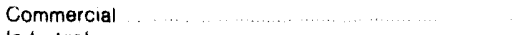 & 902.306 & 894.907 & 917.654 & 934.355 & 946,144 \\
\hline Industrial ... & 52,209 & 58,472 & 59.385 & 60.001 & 60.965 \\
\hline \multirow[t]{2}{*}{ Vehicle Fuel } & NA & NA & 875 & 883 & 720 \\
\hline & \multicolumn{5}{|c|}{ Average Annual Consumption per Consumer (thousand cubic teet) } \\
\hline Residential & 134 & 138 & 120 & 124 & 127 \\
\hline$\ldots \ldots . . . . . .$. & 754 & 757 & 694 & 695 & 714 \\
\hline Industrial $\ldots \ldots \ldots$ & 20.706 & 18.768 & 19.950 & 20183 & 20.936 \\
\hline \multirow[t]{2}{*}{$\ldots+\ldots \ldots+\ldots \ldots+\ldots+\ldots$} & NA & NA & 162 & 168 & 219 \\
\hline & \multicolumn{5}{|c|}{ Average Annual Cost per Consumer (dollars) } \\
\hline 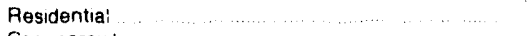 & $\$ 684$ & $\$ 716$ & $\$ 614$ & $\$ 628$ & $\$ 649$ \\
\hline Commercial $\ldots \ldots$ & 2.835 & 2,825 & 2,418 & 2,430 & 2.502 \\
\hline \multirow[t]{2}{*}{ 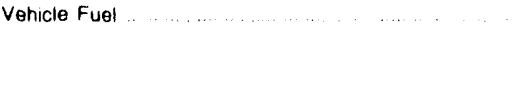 } & NA & NA & 503 & 604 & 790 \\
\hline & \multicolumn{5}{|c|}{ Average treating value (Btu per cubic foot) } \\
\hline \multirow[t]{2}{*}{ Delivered to Consumers. } & 1.023 & 1,026 & 1.024 & 1.023 & 1.021 \\
\hline & \multicolumn{5}{|c|}{ Average Prices for Natural Gas (dollars per thousand cubic feet) } \\
\hline 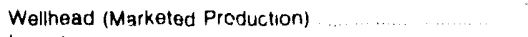 & $\$ 2.84$ & $\$ 285$ & $\$ 278$ & $\$ 261$ & $\$ 2.56$ \\
\hline 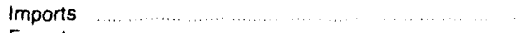 & 159 & $\cdots$ & $\cdots$ & 170 & 160 \\
\hline Exports & 201 & 200 & 270 & 191 & 183 \\
\hline Pipelint Fuel $\ldots \ldots$ & 246 & 219 & 212 & 156 & 164 \\
\hline City Gate & 315 & 318 & 313 & 303 & 318 \\
\hline \multicolumn{6}{|l|}{ Delivered to Consumers } \\
\hline Residential $\ldots \ldots \ldots \ldots \ldots \ldots$ & 5.10 & 519 & 520 & 5.17 & 522 \\
\hline Commercial $\ldots \ldots \ldots \ldots \ldots$ & 461 & 473 & 4.66 & 4.66 & 468 \\
\hline$\ldots \quad \ldots \ldots=0$ & 384 & 391 & 380 & 364 & 365 \\
\hline$\ldots \ldots<\cdots$ & NA & NA & 310 & 362 & 363 \\
\hline Electric Utilities & 167 & 144 & 149 & A 160 & 154 \\
\hline
\end{tabular}

Ra Revised data

NA = Not available

-.. Not applicable Note Deliveries 10 electric utilties (consumption) are reported on the Form ElA-759. "Monthly Power Plant Peport" Delivenes 10 electric utilties for the account of
others are reported on the Form ElA.176, "Annual Report of Naturat and Supplemental Gas Supply and Disposition" See the discussion on electric utility data and Table A1 in Ap. pendix A for a comparison of reporting to these two torms. Totals may not add due to independent tounding The Eusi North Ceritral Census Division includes illinots. Indiana. Michigan, Ohio, and Wisconsin

Sources Energy information Administration (EIA), Form EIA.176. "Annual Report ol Natural and Supplemental Gas Supply and Disposition, " Form EIA-627. "Annual Quantity and Value ol Natural Gas Report." Form ElA.857. "Monthly Report of Natural Gas Purchases and Detivenes to C.onsurners." Form E.IA.B16. "Monthly Natural Gas Liquids Report, Form EIA.759. "Monthly Power Plant Report." Furm FERC.423. "Monthly Peport of Cost and Quality of Fuels tor Electric Plants " Form ElA.191. "Underground Gas Storage Feport." Form FPC-14. "Annual Repon for importers and Exporters of Natural Gas." US Crude Olt. Natural Gas, and Nalural Gas Liquids Reserves. 1992 Annual Report. DOE/EIA. $0216(92)$, and the US Minerals Management Service 
Natural Gas 1992

Million

Net Interstate Movements

$$
\text { Cu. Foot }
$$

Marketed Production

Million
Cu Foet
715,549

589,843

Percent of

Nalional Tolal

3.82

\section{Deliveries to Consumers}

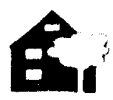

Residential:

438,513

9.36

A.

asto

Commercial:

296,784

10.59

- ill

Industrial:

419,929

5.58

Vehicle Fuel:

10

1.96

成

Electric Utility:

25,456

.92

Total:

$1,180,693$

6.64
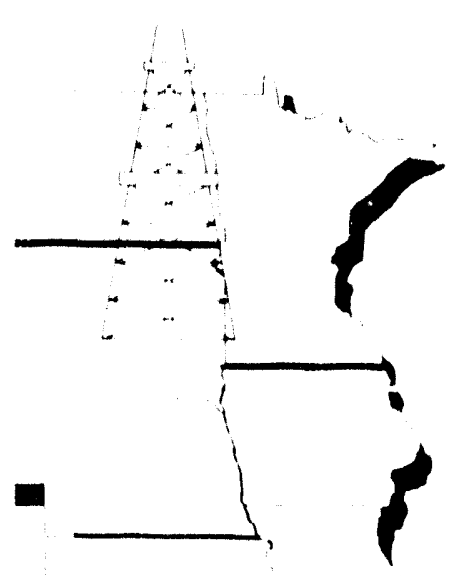

$i$

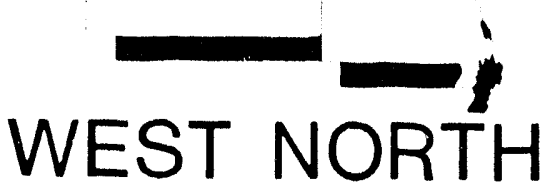

CENTRAL

Table 35. Summary Statistics for Natural Gas .- West North Central, 1988-1992

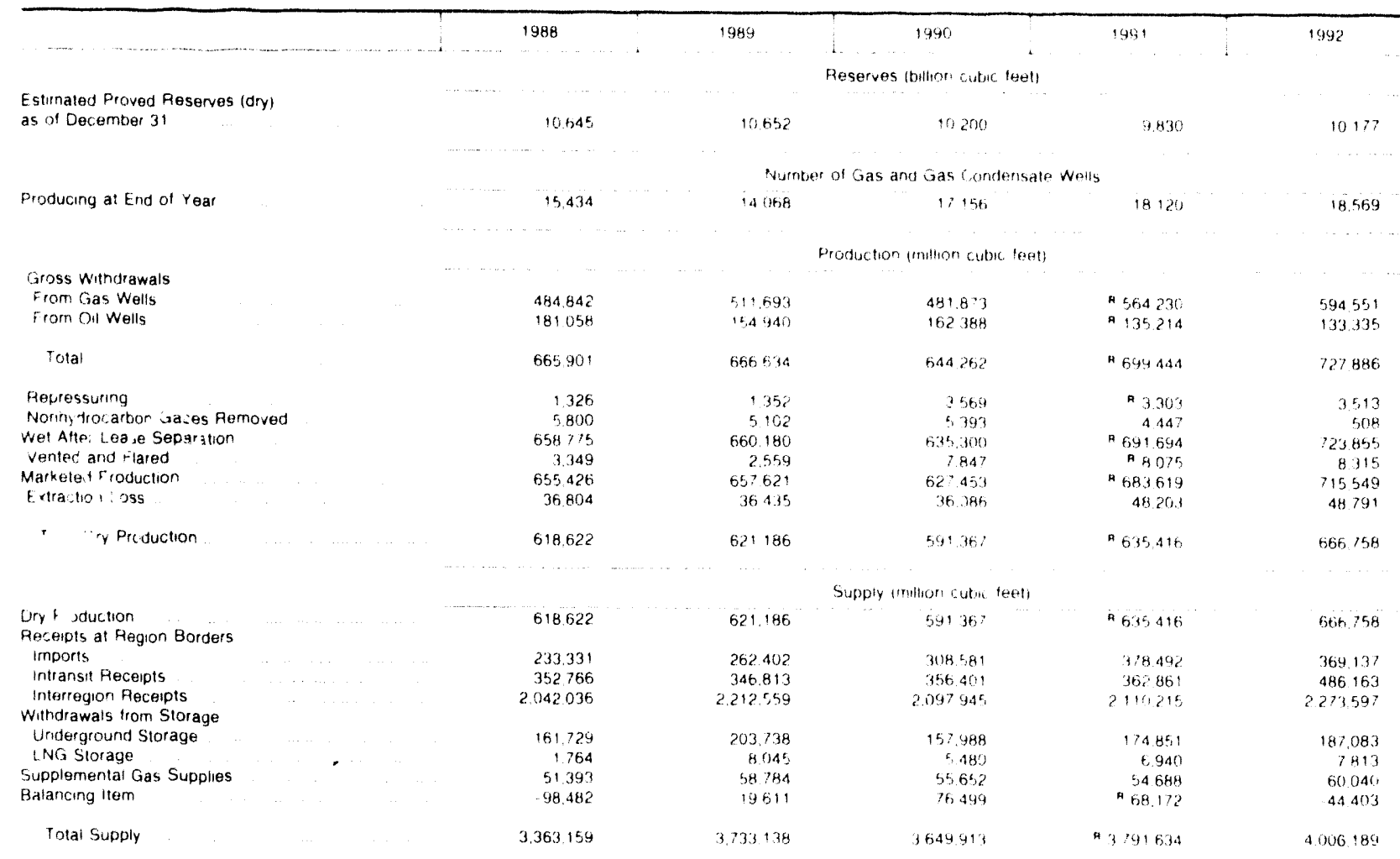

See footnotes at end of table 
Table 35. Summary Statistics for Natural Gas -- West North Central, 1988-1992 (Continued)

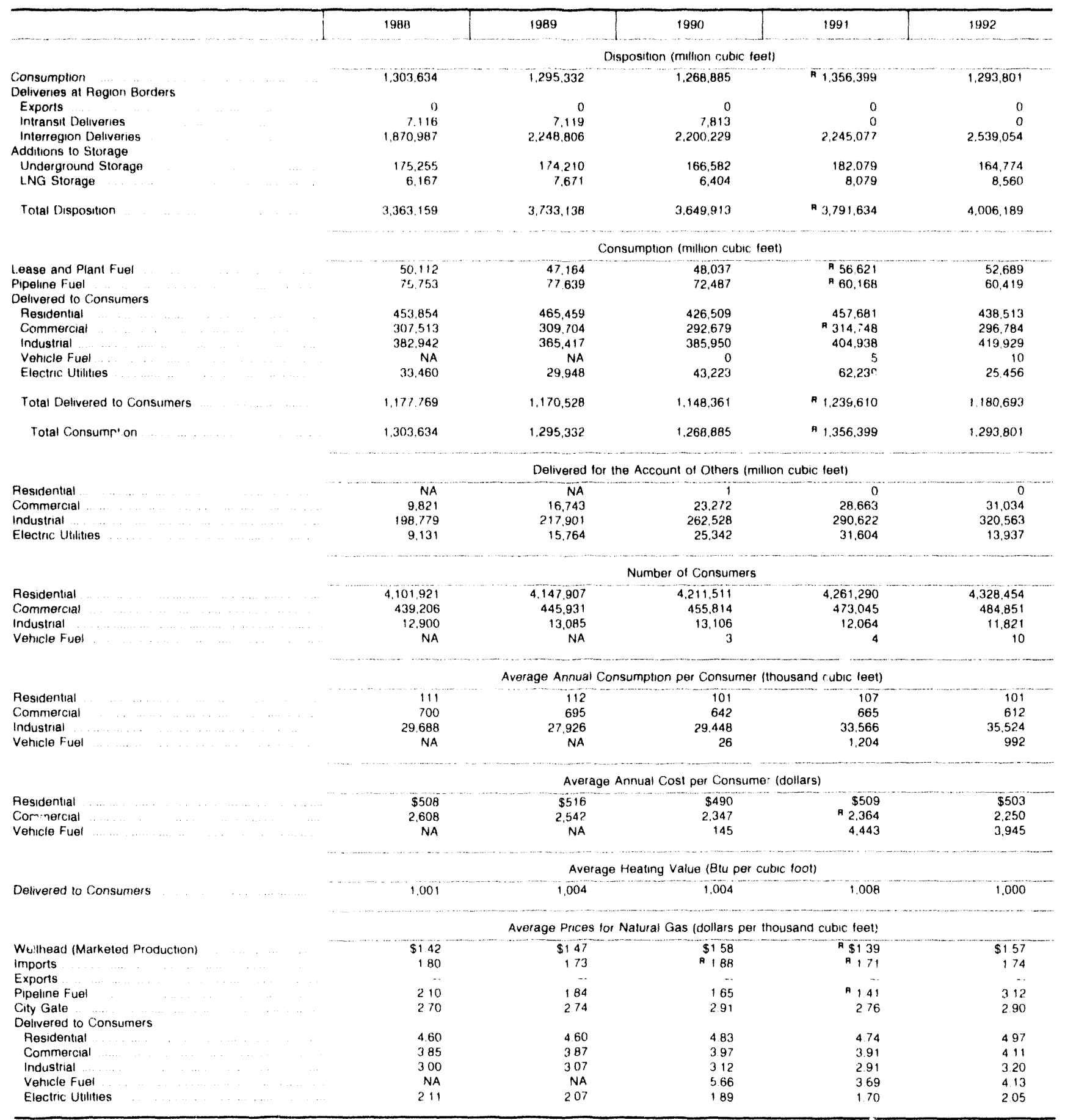

A Revised data

Na. Not available

Note: Deliveries to electric uttlities (consumption) are riported on the Form ElA-759. "Monthly Power Plant Feport" Deliveries to electric utilities tor the account of others are reported on the Form ElA-176. "Annual Report of Naturat and Supplemental Gas Supply and Disposition "See the discusston on eleciric utility data and Table A1 in Ap. pendix A for a comparison of reporting to these two forms Totals may not add due to independent rounding 1 he West North Central Census Division includes lowa. Kansas, Min. nesota. Missouri, Nebraska. North Dakota. and South Dab.ota

Sources: Energy Information Administration (E/A). Form ElA.176. "Annual Report of Natural and Supplemental Gas Supply and Disposition." Form EIA.627, "Annual Ouantity and Value of Natural Gas Report." Formi EIA.857. "Monthly Report of Naturat Gas Purchases and Deliveries to Consumers, "Form EIA-816, "Monthly Natural Gas Liquids Report." Form ElA.759. "Monthly Power Plant Report, "Form FERC.423, "Monthly Peport of Cost and Quality of Fueis for Electric Plants." Form ElA-191. "Uiderground Gas Storage Report." ElA.759. "Monthly Power Plant Report." Form FERC.423, "Monthly Report of Cost and Quality of Fueis for Electric Plants. "Form ElA-191. "Underground Gas Storage Report,"
Form FPC.14 "Annual Report for Importers and Exporters of Natural Gas." US Crude Oil, Natural Gas, and Natural Gas Liquids Reserves, 1992 Annual Report. DOE.ElA. 0216 (92). and the US Minerals Management Service 


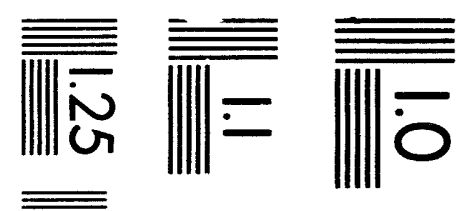

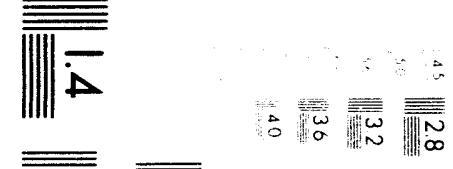

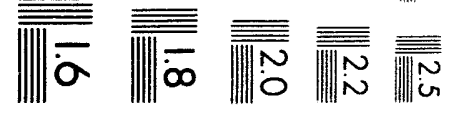



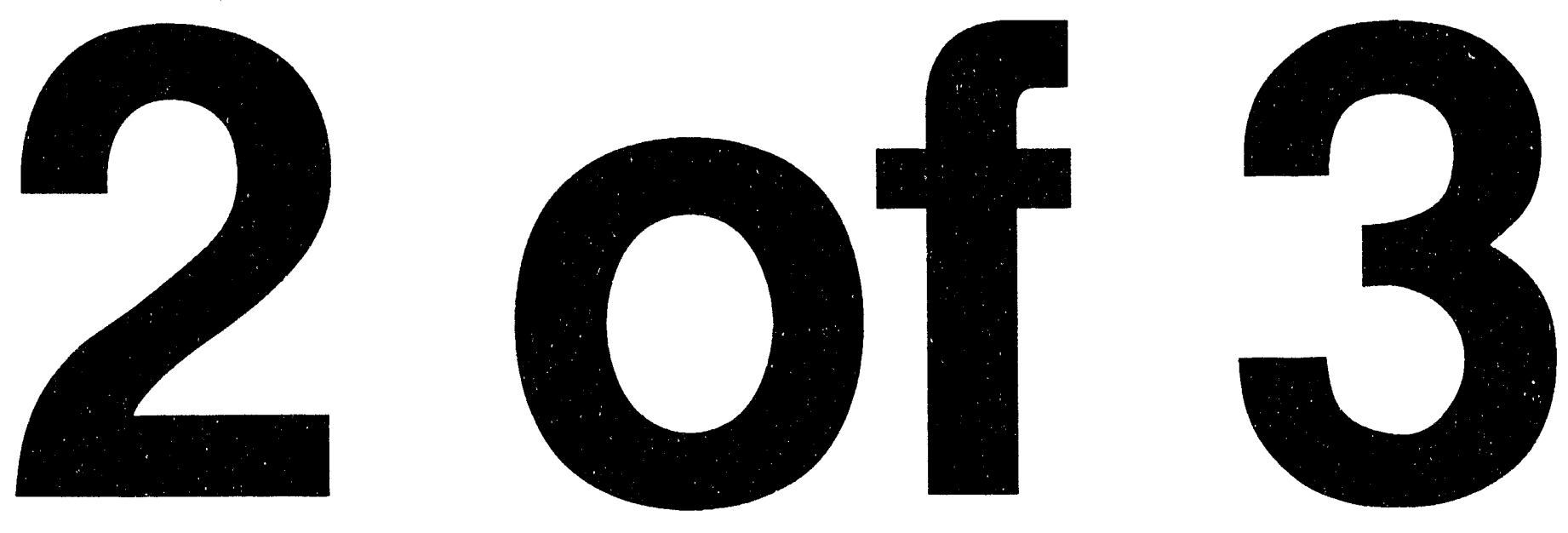
Natural Gas 1992

Net Interstate Movements

Million

Cu. Foot

Marketed Production
Million
Percent of
1.14

$1,370,624$

Deliveries to Consumers

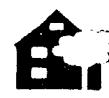

Residential:

385,200

8.21

A

Commercial:

287.357

10.25

Industrial:

623,133

8.28

$\underset{-\infty}{-\infty}$

Vehicle Fuel:

16

3.13

A

Electric Utility:

239,787

8.67

Total:

$1,535,494$

8.63

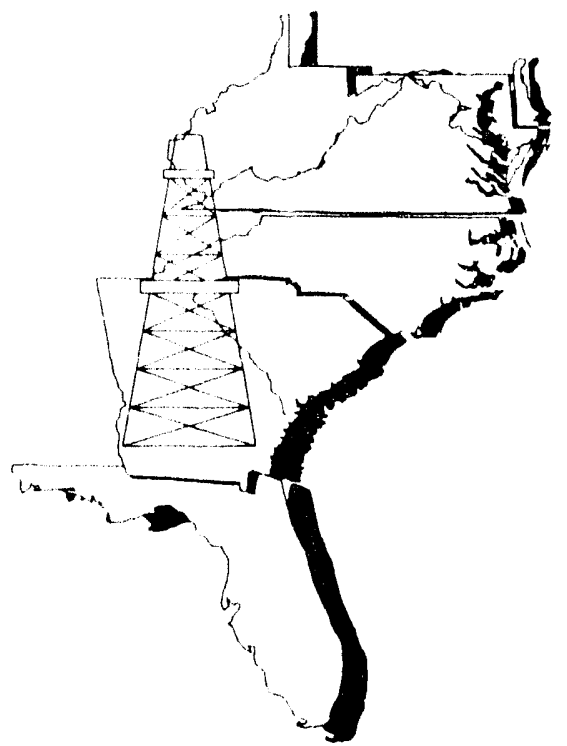

SOUTH

Table 36. Summary Statistics for Natural Gas -- South Atlantic, 1988-1992

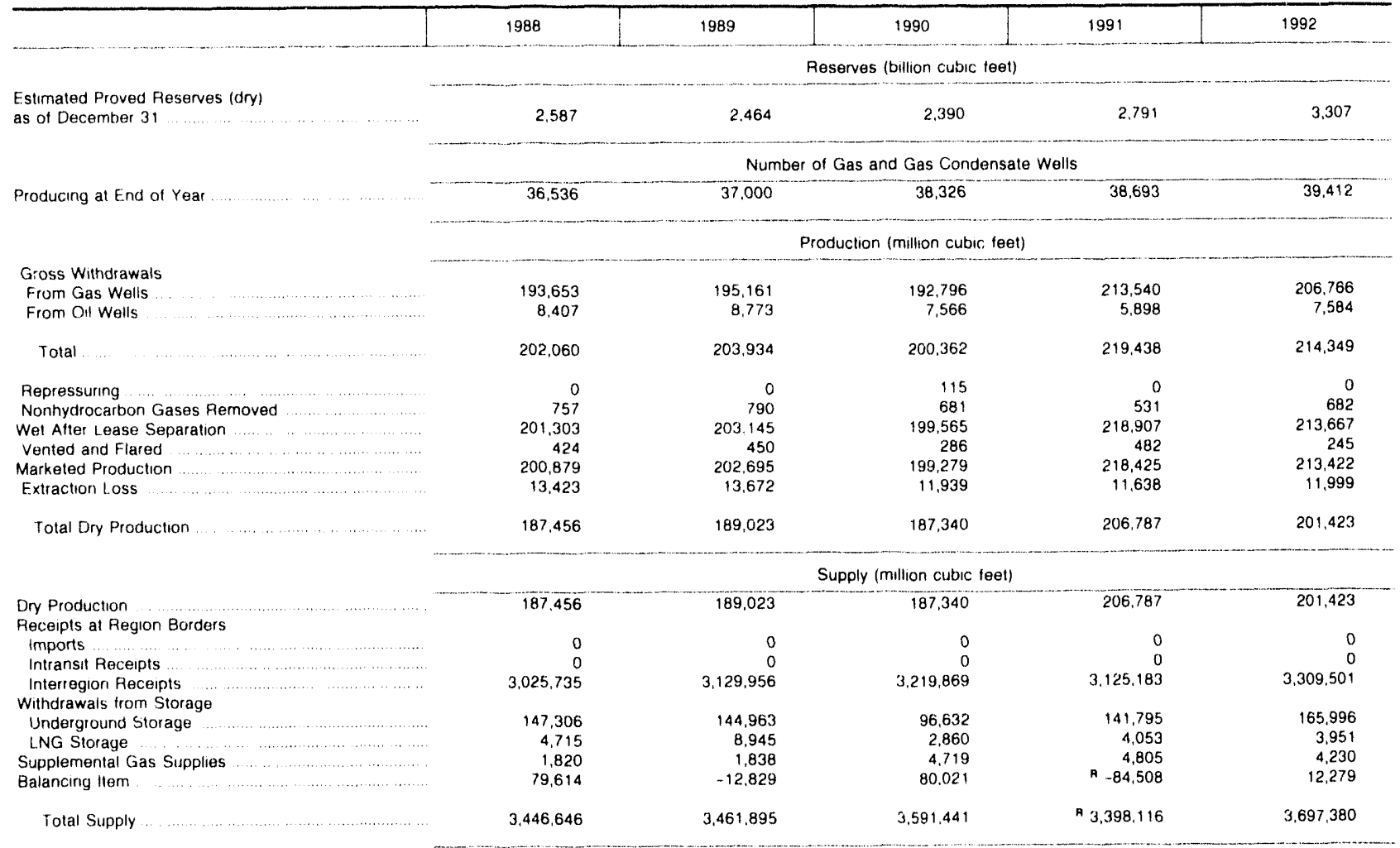

See footnotes at end of table. 
Table 36. Summary Statistics for Natural Gas -- South Atlantic, 1988-1992 (Continued)

\begin{tabular}{|c|c|c|c|c|c|}
\hline & 1988 & 1989 & 1990 & 1991 & 1992 \\
\hline & \multicolumn{5}{|c|}{ Disposition (million cubic teet) } \\
\hline 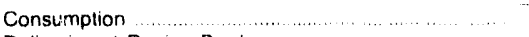 & $1.401 .30 \mathrm{~A}$ & $1,481,036$ & $1.471,278$ & ค $1,498,898$ & $1,596,374$ \\
\hline \multicolumn{6}{|l|}{ Deliveries at Region Borders } \\
\hline Exports & 0 & 0 & 0 & 0 & 0 \\
\hline Intransit Deliveries & 0 & 0 & 0 & 0 & 0 \\
\hline 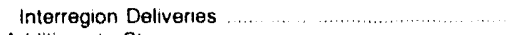 & $1,916,923$ & $1,838.970$ & $1,968,272$ & $1,768,014$ & $1,938,87 \%$ \\
\hline \multicolumn{6}{|l|}{ Additions to Storage } \\
\hline Underground Storage & 120,974 & 133,969 & 145,648 & 126,760 & 158,149 \\
\hline LNG Storage & 5,445 & 7,920 & 6.243 & 4.443 & 3.980 \\
\hline \multirow[t]{2}{*}{ Tutal Disposition } & $3,446,646$ & $3,461,895$ & $3,591,441$ & R $3,398,116$ & $.1,380$ \\
\hline & \multicolumn{5}{|c|}{ Consumption (million cubic teet) } \\
\hline Lease and Plant Fuel. & 16,155 & 17,250 & 11,837 & ค 11,822 & 13,884 \\
\hline Pipeline Fuel & 42.237 & 39,027 & 37.572 & 37,646 & 46.996 \\
\hline \multicolumn{6}{|l|}{ Delivered to Consumers } \\
\hline 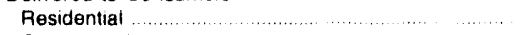 & 378,393 & 374,906 & 329,510 & A 345,654 & 385,200 \\
\hline 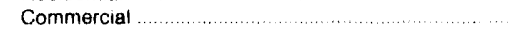 & 253,093 & 252,149 & 236,458 & A 263,448 & 287.357 \\
\hline Industrial & 542.535 & 574.725 & 621,487 & 585,297 & 623.134 \\
\hline Vehicie Fuel & NA & NA & 2 & 8 & 16 \\
\hline 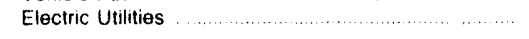 & 168,894 & 222,979 & 234.412 & 255,024 & 239.787 \\
\hline Total Delivered to Consumers .... & 1.342 .916 & $1,424,760$ & $1,421,869$ & ค $1,449,430$ & $1,535,49.4$ \\
\hline \multirow[t]{2}{*}{ Total Consumption . } & $1.401,308$ & $1,481,036$ & $1,471,278$ & ค $1,498,898$ & 1.596 .374 \\
\hline & \multicolumn{5}{|c|}{ Delivered for the Account of Others (million cubic tset) } \\
\hline 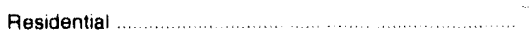 & NA & NA & 87 & 85 & 89 \\
\hline 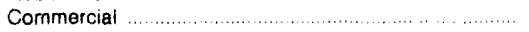 & 15.695 & 18,840 & $2:, 450$ & 23,450 & 26,192 \\
\hline Industrial & 228,037 & 278,366 & 315,938 & 323.793 & 351,672 \\
\hline \multirow[t]{2}{*}{ Electric Utuities } & 17,962 & 16,494 & 84,394 & 186.587 & 202.596 \\
\hline & \multicolumn{5}{|c|}{ Number of Consumers } \\
\hline Residential. & 4.411 .913 & $4,521,601$ & $4,624,549$ & A. 727.189 & 4,943742 \\
\hline Commercial & 402,258 & 420.970 & 4.30 .880 & R $_{4} \div, 720$ & 455,316 \\
\hline Industrial & 14,898 & 15,138 & 14,788 & ค 10,524 & 10.283 \\
\hline \multirow[t]{2}{*}{ 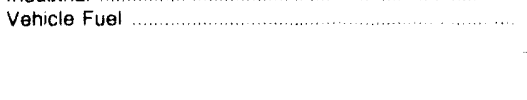 } & NA & NA & 2 & 5 & 9 \\
\hline & \multicolumn{5}{|c|}{ Average Annual Consumption per Consumer (thousand cubic leet) } \\
\hline Residential & 86 & 83 & 71 & 73 & 78 \\
\hline Commercial $\ldots \ldots \ldots \ldots$ & 629 & 599 & 549 & 590 & 631 \\
\hline 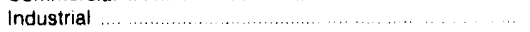 & 36.417 & 37,966 & 42,026 & * 55,615 & 60.598 \\
\hline \multirow[t]{2}{*}{ Vehicle Fuel $\ldots \ldots \ldots \ldots \ldots \ldots$} & NA & NA & 964 & 1.543 & 9.826 \\
\hline & \multicolumn{5}{|c|}{ Average Annual Cost per Consumer (dollars) } \\
\hline Residential. & $\$ 526$ & $\$ 534$ & $\$ 478$ & $\$ 485$ & $\$ 519$ \\
\hline Commercial & 2,943 & 2,889 & 2.639 & 2,754 & 2,976 \\
\hline \multirow[t]{2}{*}{ 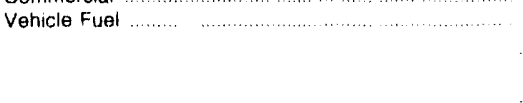 } & NA & NA & 4,303 & 7,286 & 8.526 \\
\hline & \multicolumn{5}{|c|}{ Average Heating Vaiue (Btu per cubic foot) } \\
\hline \multirow[t]{2}{*}{ Delivered to Consumers } & 1.036 & 1,036 & 1,036 & 1.037 & 1.036 \\
\hline & \multicolumn{5}{|c|}{ Average Prices for Natural Gas (doliars per thousand cubic feet) } \\
\hline Wellhead (Marketed Production) & $\$ 2.90$ & $\$ 2.99$ & $\$ 309$ & $\$ 2.88$ & $\$ 2.86$ \\
\hline Imports & -. & - & $\cdots$ & $-\cdot$ & .. \\
\hline Exports & $\cdots$ & $\cdots$ & $\cdots$ & - & - \\
\hline Pipeline Fuel & 2.54 & 2.70 & 2.29 & 2.07 & 232 \\
\hline City Gate & 312 & 321 & 313 & 2.97 & 306 \\
\hline \multicolumn{6}{|l|}{ Delivered to Consumers } \\
\hline Residential ................... & 6.13 & 6.44 & 6.71 & 6.64 & 666 \\
\hline Commercial & 4.99 & 5.21 & 529 & 513 & 519 \\
\hline industrial & 3.43 & 3.59 & 3.56 & 321 & 33.4 \\
\hline 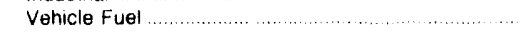 & NA & NA & 4.47 & 4.72 & 467 \\
\hline Electric Utilities & 2.16 & 2.53 & 2.56 & 218 & 2.35 \\
\hline
\end{tabular}

R $=$ Revised data

NA $=$ Not available.

Na... Not applicable.

Note: Deliveries to electric utitities (consumption) are reported on the Form ElA.759 "Monthly Power Plant Report" Deliveries to electric utilities for the arcount of others are reported on the Form ElA.176. "Annual Report of Natural and Supplemental Gas Supply and Disposition." See the discussion on electric utility data and Table A1 in Ap. pendix A for a comparison of reporting to these two lorms. Totals may not add due to independent rounding. The South Atlantic Census Division includes Delaware, District of Co lumbia, Florida, Georgia, Maryland, North Carolina, South Carolina, Virginia, and West Virginia.

Sources: Energy Information Administration (EIA). Form EIA-176. "Annual Report of Natural and Supplemental Gas Supply and Disposition," Form ElA-627, "Anrtual Quantity and Value of Natural Gas Report," Form EIA-857. "Monthly Report of Natural Gas Purchases and Deliveries to Consurners." Form EiA.816, "Monthly Natural Gas Liquids Report." Form EIA-759 "Monthly Power Plant Report, Form FERC-423. "Monthly Report of Cost and Quality of Fuels tor Electric Plants. "Form ElA-191. "Underground Gas Storage Report." Form FPC-14. "Annual Report for Importers and Exporters of Natural Gas," US Crude Oit. Natural Gas, and Nalural Gas Liquids Resenves, 1992 Annual Report, DOE:EIA. 0216(92); and the U.S Minerals Management Service 
Natural Gas 1992

Net Interstate Movements

Marketed Production

Million
Cu. Feet
528,256

Million

Cu. Feat

398,165

Percent of

National Total

2.82

\section{Deliveries to Consumers}

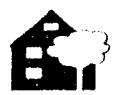

Residential:

190.262

Commercial:

125,125

471.509

Industrial:

Vehicle Fuel:

5

$A$

Electric Utility:

58,109

Total:

845,009
4.06

4.46

6.26

.98

2.10

4.75

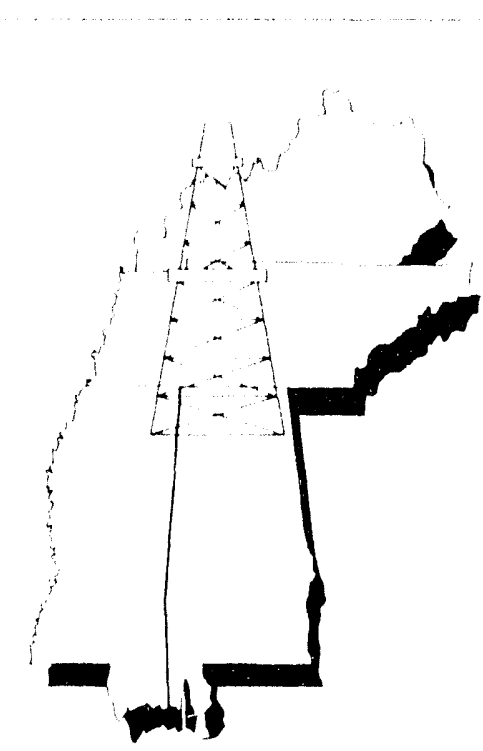

EAST SOUTH

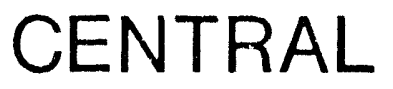

Table 37. Summary Statistics for Natural Gas -- East South Central, 1988-1992

\begin{tabular}{|c|c|c|c|c|c|}
\hline & 1988 & 1989 & 1990 & 1991 & 1992 \\
\hline & \multicolumn{5}{|c|}{ Reserves (billion cuuk: teet) } \\
\hline \multirow[t]{2}{*}{$\begin{array}{l}\text { Estimaled Proved Reserves (dry) } \\
\text { as of December } 31\end{array}$} & 2.875 & 4,857 & 5.267 & 7,626 & 7.755 \\
\hline & \multicolumn{5}{|c|}{ Number of Gas and Gas Condensate Wells } \\
\hline \multirow[t]{2}{*}{ Producing at End of Year } & 13,477 & 14,192 & 15,350 & 16,840 & 16,940 \\
\hline & \multicolumn{5}{|c|}{ Production (millior cubic teet) } \\
\hline $\begin{array}{l}\text { Gross Withdrawals } \\
\text { From Gas Wells } \\
\text { From Oil Wells }\end{array}$ & $\begin{array}{r}464,652 \\
23,310\end{array}$ & $\begin{array}{r}430.762 \\
23.711\end{array}$ & $\begin{array}{r}437,266 \\
27,269\end{array}$ & $\begin{array}{r}\text { A } 455,666 \\
29,742\end{array}$ & $\begin{array}{r}628,692 \\
31,920\end{array}$ \\
\hline$\ldots \ldots+\cdots+\cdots$ & 487.963 & 454.473 & 464.534 & 485.407 & 660,612 \\
\hline$\ldots \ldots+\ldots \ldots$ & 62.392 & 58,646 & 64,802 & 54,614 & 54.989 \\
\hline Nonhydrocarbon Gases Removed $\ldots$ & 88,929 & 84.750 & 86.879 & ค 66,159 & 72.491 \\
\hline Wet After Lease Separation & 336,642 & 311,077 & 312.853 & A 364,631 & $5,3,3,132$ \\
\hline Vented and Flared $\ldots \ldots \ldots$ & 7,336 & 5,704 & 5,561 & 4.992 & 4.876 \\
\hline Marketed Production $\ldots$ & 329,306 & 305.373 & 307.292 & A 359.639 & 528.256 \\
\hline Extraction Loss $\ldots \ldots$ & 7,727 & 6,846 & 7.289 & 7.689 & 8.248 \\
\hline \multirow[t]{2}{*}{ Total Dry Production. } & 321.579 & 298.527 & 300,009 & A 351.950 & 520,008 \\
\hline & \multicolumn{5}{|c|}{ Supply (millon cubic feet) } \\
\hline Dry Production & 321,579 & 298.527 & 300,009 & 351.950 & 520,008 \\
\hline \multicolumn{6}{|l|}{$\begin{array}{l}\text { Dry production } \\
\text { Receipts at Region Borders }\end{array}$} \\
\hline Imports ............ & 0 & 0 & 0 & 0 & 0 \\
\hline Intransit Feceipts & 0 & 0 & 0 & 0 & 0 \\
\hline Interregion Receipts & 5.156 .840 & $5.310,907$ & 5.364 .263 & 5.158 .169 & $5,166.017$ \\
\hline \multicolumn{6}{|l|}{ Withdrawals from Storage } \\
\hline Undergiound Storage & 111,024 & 133,295 & 78.733 & 102.760 & 96,168 \\
\hline$(-\ldots \ldots \ldots \ldots \ldots \ldots \ldots \ldots$ & 2.496 & 4,691 & 2.814 & 2.452 & 3,326 \\
\hline Supplemental Gas Supplies $\ldots \ldots \ldots$ & 59 & 138 & 326 & 342 & 188 \\
\hline Balancing Item $\quad \ldots \quad \ldots \ldots \ldots$ & $-192,745$ & $-166,333$ & $-76,949$ & म -62.667 & $39,69 ?$ \\
\hline Total Supply & 5.399 .254 & $5,581,226$ & $5,669,195$ & A $5,563,006$ & $5,825,399$ \\
\hline
\end{tabular}

See foomotes at end of table 
Table 37. Summary Statistics for Natural Gas -- East South Central, 1988-1992 (Continued)

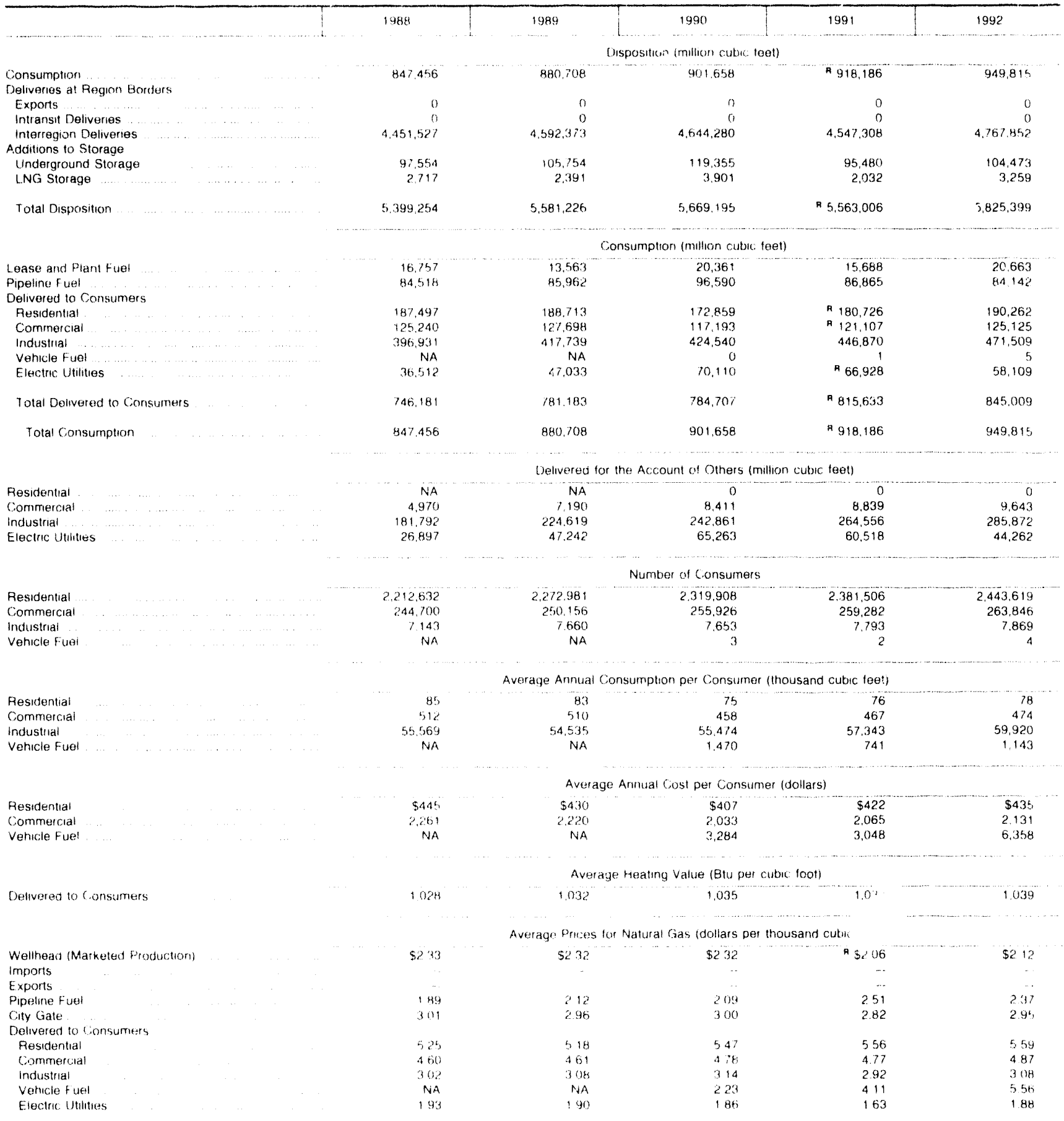

R. Revised data

Na. Nol avallable

Not applicatile

Note Delivertes to electre utilties fconsumption) are reportid on the form EiA.759. "Monthly Powet Plant Report "Deliveries to electric utilties for the account of

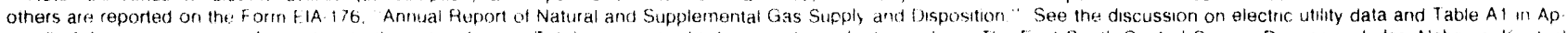
pendix A for a comparison of reporting to these two forms Totals may not add due to independent rounding The East South Central Census Division includes Alabama. Kentucky. Mississippl and Tennessee

Sources: Energy Intormation Admirnstration (EIA) Form E.1A 1/6. "Annial Report of Natural and Supplemental Gas Supply and Dispostion." Form EIA.627 "Annual Quantity and

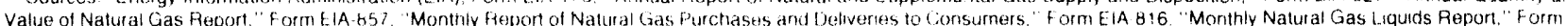

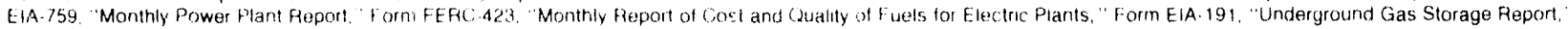

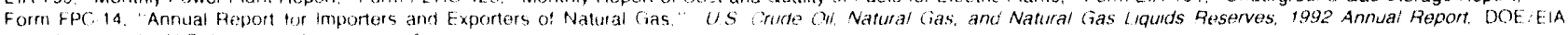
$0216(92)$, and the US Milerals Mankachement Service 


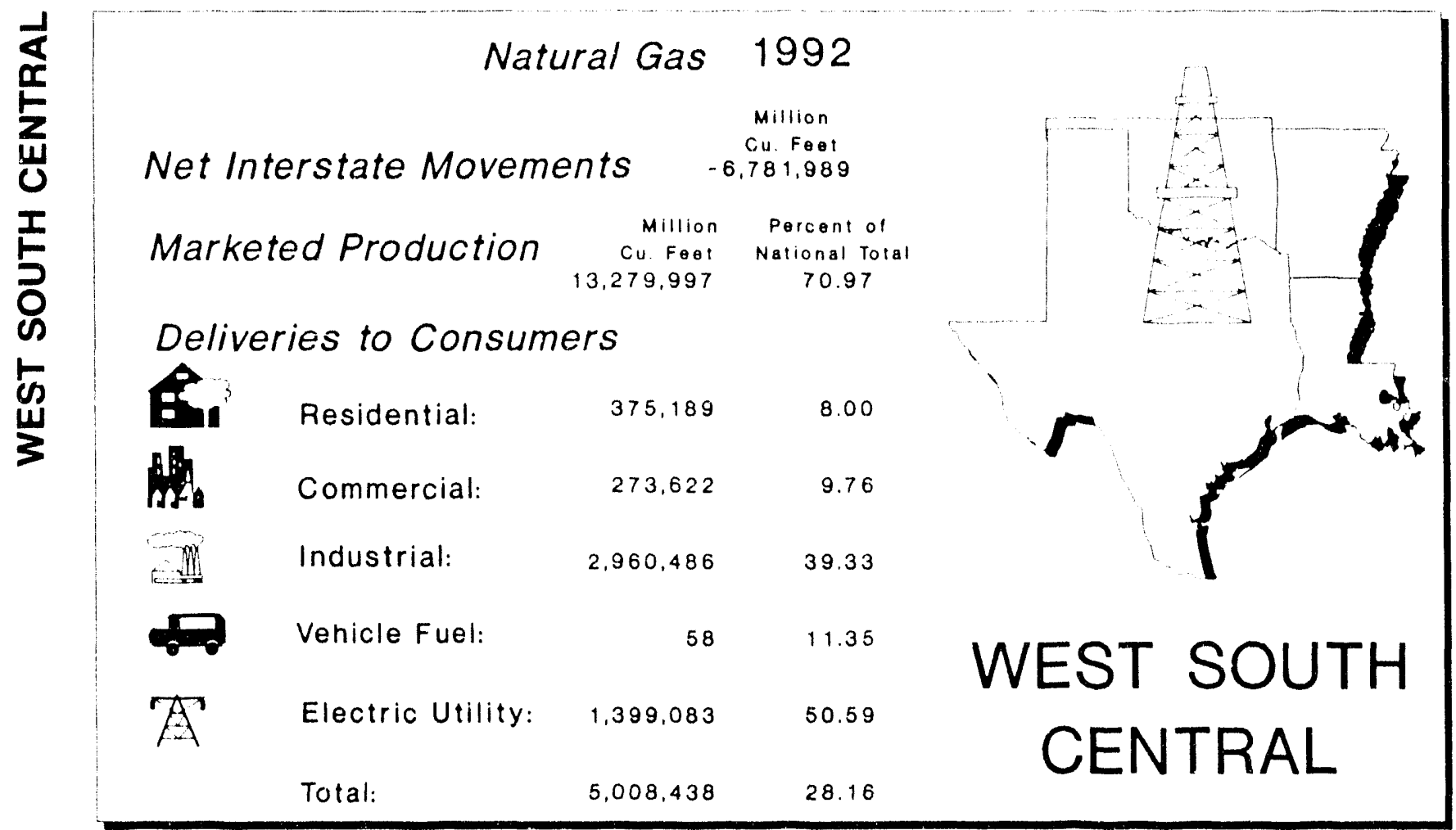

Table 38. Summary Statistics for Natural Gas -- West South Central, 1988-1992

\begin{tabular}{|c|c|c|c|c|c|}
\hline & 1988 & 1989 & 1990 & 1991 & 1992 \\
\hline & \multicolumn{5}{|c|}{ Reserves (billion cubic teet) } \\
\hline \multirow[t]{2}{*}{$\begin{array}{l}\text { Estimated Proved Reserves (dry) } \\
\text { as of December } 31\end{array}$} & 99.584 & 97.798 & 97,781 & 91.766 & 87,198 \\
\hline & \multicolumn{5}{|c|}{ Number of Gas and Gas Condensate Wells } \\
\hline \multirow[t]{2}{*}{ Producing at End of Year } & 94,962 & 95.191 & 95.255 & 93,882 & 92,212 \\
\hline & \multicolumn{5}{|c|}{ Production (million cubic teet) } \\
\hline $\begin{array}{l}\text { Gross Withdrawals } \\
\text { From Gas Wells } \\
\text { From Oll Wells }\end{array}$ & $\begin{array}{r}11.979,006 \\
2,546,549\end{array}$ & $\begin{array}{r}12.037 .731 \\
2.422 .423\end{array}$ & $\begin{array}{r}12,293.195 \\
2,371.221\end{array}$ & 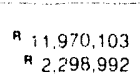 & $\begin{array}{r}11.599 .913 \\
2.313,831\end{array}$ \\
\hline Total & $14,524,555$ & 14.460 .154 & $14.6644 ! 7$ & ค $14,269.095$ & $13.913,744$ \\
\hline Repressuring & 524.724 & 517.518 & 441.033 & F 410.867 & 413,146 \\
\hline Nonhydrocarbon Gases Rernoved & 144.134 & 159.113 & 155,631 & ค 173,399 & 180,003 \\
\hline Wet After Lease Separation & 13.855697 & 13.783 .523 & 14.067 .753 & A 13.684 .829 & 13.320 .596 \\
\hline Vented and Flared. & 55.777 & 52.778 & 49.191 & 51.260 & 40.599 \\
\hline Extraction Loss & 582.211 & 560.396 & 559.089 & 585,032 & 611,804 \\
\hline \multirow[t]{2}{*}{ Total Dry Production. } & 13.217 .709 & 13.170 .349 & 13.459 .473 & A 13.048 .536 & 12668.193 \\
\hline & \multicolumn{5}{|c|}{ Supply (million cubic feet) } \\
\hline $\begin{array}{l}\text { Dry Production } \\
\text { Receipts at Region Borders }\end{array}$ & 13.217 .709 & 13.170 .349 & 13.459 .473 & A 13.048 .536 & $12,668,193$ \\
\hline $\begin{array}{l}\text { Heceipts at hegion Boiders } \\
\text { imports }\end{array}$ & 0 & 3.934 & 30.750 & 33,284 & 12,637 \\
\hline Intransil Receipts & 0 & 0 & 0 & 0 & 0 \\
\hline Interregion Receipts & 110,019 & 98.130 & 110.539 & $14 \cdot 685$ & 181.618 \\
\hline \multicolumn{6}{|l|}{ Withdrawals from Storage } \\
\hline Underground Storage & 346.128 & 533.471 & 358,992 & 476.871 & 701,553 \\
\hline LNG Storage & 54 & 62 & 26.229 & 32.775 & 12,149 \\
\hline Supplementai Gas Supplies & 4 & 9 & 1.240 & 1.076 & 1 \\
\hline Balancing ltem & $-80,272$ & 276.667 & $.51,580$ & R $.287,733$ & $-163,249$ \\
\hline Total Supply & 13.593 .642 & 14082.622 & 13935.643 & A $13,452.494$ & 13.412 .902 \\
\hline
\end{tabular}

See footnotes at end of table 
Table 38. Summary Statistics for Natural Gas -- West South Central, 1988-1992 (Continued)

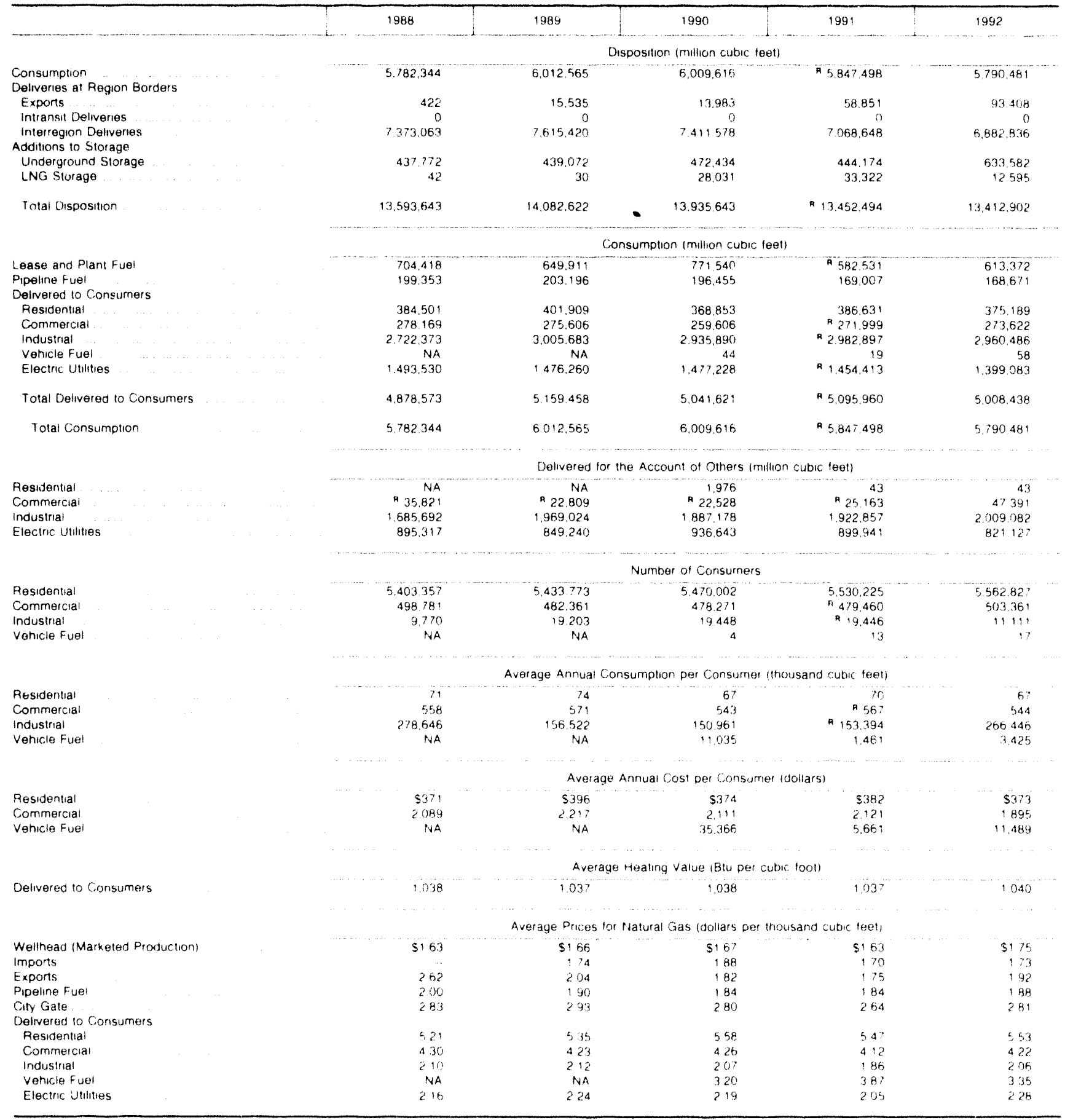

P. Revised data Not availabie

Note Deitveries to electric utilties (consumption are reported or the Form ElA.759 Monthly Power Plant Report Deliveries to electhc utilties tor the account of others are reported on the Form E.A. 176 . "Annual Report of Natual and Supplemental Gas Supply and Disposition" See the discussion on electric utitity data and Tatje: A1 in Ap pendix A for a comparison of reporting to these two torms Tolals may not add due to independent rounding The West South Central Census Division includes Aikansas. Louls. ana. Oklahoma, and Texas

Sources Energy Intormation Administration (ElA) Form EiA.176. "Anriual Report of Naturai and Supplemental Gas Suppiy and Disposition." Form EiA.62?, "Annual Ouantity and Value ol Natural Sas Report. Form ElA.857. Monthly Repon of Natural Gas Furchases and Deliveries io Consumers " Form ElA .816. Monthly Natural Gas Liquids Report Form ElA.759. "Monthiy Power Plant Peport."Form FERC.423. "Monthly Report of Cost and Ouality of Fuels for Eiectric Plants "Form ElA.191. "Uniderground Gas Storage Report. Form fPC. 14 . Annuat Report tor Importers and Exporters of Naturai Gas. US Crude Ot. Natural Gas and Natural Gas Liquids Reserves 1992 . Annual Repon. DOE ElA. $02: 6(92)$. and the US Minerals Management Service 
Natural Gas 1992

Net Interstate Movements $\quad-1,232,728$
Marketed Production Million Percent of
Cu Feet National Total
$2,660,441 \quad 14.22$

Deliveries to Consumers

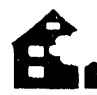

Residential:

254,547

5.43

A.

ins

Commercial:

182,577

6.51

in:

Industrial:

239,869

3.19

Vehicle Fuel:

115

22.50

成

Electric Utility:

89,679

3.24

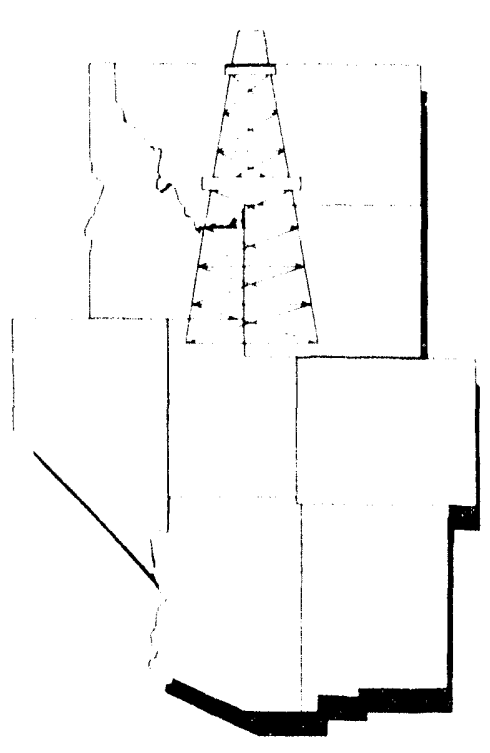

Total:

766.788

4.31

Table 39. Summary Statistics for Natural Gas -- Mountain, 1988-1992

\begin{tabular}{|c|c|c|c|c|c|}
\hline & 1988 & 1949 & 1991 & 1991 & $199 ?$ \\
\hline & \multicolumn{5}{|c|}{ Heserves (tilltorn cuther teret) } \\
\hline \multirow{3}{*}{$\begin{array}{l}\text { Esturnated Proved Fuserves (dry) } \\
\text { as of Decernibe } 31\end{array}$} & & & & & \\
\hline & $331: 6$ & $32,8: 6$ & $34.16 \%$ & 36780 & 36.711 \\
\hline & \multicolumn{5}{|c|}{ Number of (jas and Gas Conderisate Wells } \\
\hline \multirow[t]{2}{*}{ Producing at Fnd of $Y$ ear } & $25,4: 77$ & 34180 & 24.8949 & 32.125 & 30.965 \\
\hline & \multicolumn{5}{|c|}{ Froduction (milton cutse feet) } \\
\hline Gross Withdrawais & & & & & \\
\hline From Gas Wells, & 1.633 .834 & 175011 & 837968 & " 2000040 & $2,352.72 \%$ \\
\hline From Oil Wells & 632.045 & $5,95,5,524$ & hasas & मे $710.1 \% 1$ & hill 71 \\
\hline Totai & $215^{6}, 480$ & 2313532 & 2510391 & $* 2810<10$ & $30(30.499$ \\
\hline Fepressuring & 244.793 & $23: 14,98$ & $26,6,31 ?$ & 291.275 & 249.215 \\
\hline Nontiydrocarbon Gases Removert & 219431 & 111599 & 39.341 & 30507 & 25,544 \\
\hline Wet After Lease Separation & $1,70200^{2,5}$ & 1.964 .335 & 2,14114 & ค 2.384 .429 & 2.755 .741 \\
\hline Vented and Flared & 56.552 & 58528 & 1,860 & 89.561 & 95299 \\
\hline Marketed Production & 1645.503 & 1.909 .807 & $2.142 .25 \mathrm{im}$ & A $2.298 \mathrm{H6H}$ & $2,660,441$ \\
\hline Extraction loss & 126687 & 123,574 & $127.065^{4}$ & 133.202 & 137.805 \\
\hline \multirow[t]{2}{*}{ Totat Dry Production } & 15188916 & $1.786,229$ & $2.115,193$ & A 2165,6665 & $2,522,6336$ \\
\hline & \multicolumn{5}{|c|}{ Supply (millot cubse, teet) } \\
\hline Dry Production & 1,518816 & $1 / 85224$ & 2.015 .193 & ${ }^{\circ} 2.165 .666$ & 2522636 \\
\hline $\begin{array}{l}\text { Receipls al Region Borders } \\
\text { Imports }\end{array}$ & 822069 & $325_{1}, 175_{3}$ & $A 5 B, 313$ & 890.431 & 963.487 \\
\hline Intransit Receipls & & & 0 & 0 & 0 \\
\hline Interregion Recelpts & $R^{6}, 2,5,5$ & $74209^{2}$ & 122243 & 748,360 & $5,24,329$ \\
\hline \multicolumn{6}{|l|}{ Withdrawals trom Storage } \\
\hline Underground Storage & $\begin{array}{r}85.854 \\
578\end{array}$ & 1) 20204 & 96269 & $11588 ?$ & 114.258 \\
\hline $\begin{array}{l}\text { LNG Storage } \\
\text { Supplemental Gas Suppies }\end{array}$ & $10.674^{6}$ & $\begin{array}{r}584 \\
9394\end{array}-2010$ & $\begin{aligned} 1,17 ? \\
15,504\end{aligned}$ & 207 & 4.138 \\
\hline $\begin{array}{l}\text { Supplemental Gas Supplies } \\
\text { Balancing ltem }\end{array}$ & 98510 & .82 .808 & $\begin{array}{r}15,50.4 \\
15,5.584\end{array}$ & $\begin{array}{r}6778 \\
\text { ค. } 189,212\end{array}$ & $\begin{array}{r}788 \\
\quad 180\end{array}$ \\
\hline Total Supply & +192.204 & $3.422,713$ & 355,1077 & $\$ 738170$ & 3806.947 \\
\hline
\end{tabular}

See footnotes at end of table 
Table 39. Summary Statistics for Natural Gas -- Mountain, 1988-1992 (Continued)

\begin{tabular}{|c|c|c|c|c|c|}
\hline & 1988 & 1989 & 1990 & 1991 & 1992 \\
\hline & \multicolumn{5}{|c|}{ Disposition (million cubic teet) } \\
\hline 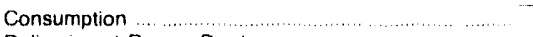 & 847,503 & 934,586 & 966,764 & ค 995,700 & 994,586 \\
\hline \multicolumn{6}{|l|}{ Deliveries at Region Borders } \\
\hline Exports & 1.944 & 1.552 & 1,751 & 1,638 & 2.579 \\
\hline Intransit Deliveries & 15.080 & 14,372 & 16,013 & 16,298 & 14,554 \\
\hline Interregion Deliveries & $2,238,704$ & $2,389,139$ & $2.461,917$ & $2,615,769$ & $2,703,411$ \\
\hline \multicolumn{6}{|l|}{ Additions to Storage } \\
\hline Underground Storage & 88,232 & 82,111 & 104,016 & 107,659 & 90.294 \\
\hline LNG Storage & 742 & 954 & 648 & 1,108 & 1.422 \\
\hline \multirow[t]{2}{*}{ Total Disposition . } & $3,192,205$ & $3,422,713$ & $3,551,107$ & $3,738,170$ & $3,806.947$ \\
\hline & \multicolumn{5}{|c|}{ Consumption (million cubic feet) } \\
\hline Lease and Plant Fuel. & 112,914 & 112,818 & 146.699 & A, 119,308 & $130,0 \uparrow 7$ \\
\hline Pipeline Fuel ................. & 76,865 & 96,542 & 124,339 & 119.585 & 97,881 \\
\hline \multicolumn{6}{|l|}{ Delivered to Consumers } \\
\hline Residential. & 242,688 & 245,933 & 247,862 & 268,895 & 254,547 \\
\hline (1) & 189,628 & 186,890 & 178.818 & 189.292 & 182.577 \\
\hline Industrial & 159,206 & 181,587 & 188.109 & 214.179 & 239,869 \\
\hline Vehicle Fuel ..................... & NA & NA & 12 & 72 & 115 \\
\hline 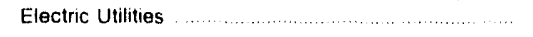 & 66,203 & 110,815 & 80,924 & 84.369 & 89,679 \\
\hline Total Delivered to Consumers. & 657.724 & 725,226 & 695,725 & 756.808 & 766,788 \\
\hline \multirow[t]{2}{*}{ Total Consumption } & 847,503 & 934,586 & 966,764 & A 995,700 & 994,686 \\
\hline & \multicolumn{5}{|c|}{ Delivered for the Account of Others (million cubic feet) } \\
\hline Residential & NA & NA & 163 & $335^{-}$ & 0 \\
\hline 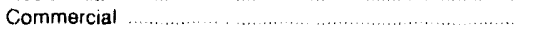 & 7,064 & 8,916 & 8,689 & 13,380 & 17,234 \\
\hline Industrial & 106,243 & 126,188 & 145,081 & 168,328 & 205,053 \\
\hline \multirow[t]{2}{*}{ Electric Utilities } & 45,696 & 73,648 & 66.414 & 72.490 & 96,017 \\
\hline & \multicolumn{5}{|c|}{ Number of Consumers } \\
\hline Residential & $2,910,190$ & $2,971,291$ & $3,050,987$ & $3,180,712$ & $3,213,437$ \\
\hline 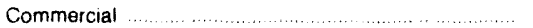 & 301,696 & 303,674 & 309,920 & 322,744 & 321,754 \\
\hline Industrial & 4.427 & 4,355 & 5,362 & 4.432 & 3,447 \\
\hline \multirow[t]{2}{*}{ Vehicle Fuel } & NA & NA & 7 & 37 & 45 \\
\hline & \multicolumn{5}{|c|}{ Average Annual Consumption per Consumer (thousand cubic teet) } \\
\hline Residential & 83 & 83 & 81 & 85 & 79 \\
\hline 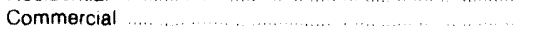 & 629 & 615 & 577 & 587 & 567 \\
\hline Industrial $\ldots$ & 35,962 & 41,696 & 35,082 & 48,325 & 69,588 \\
\hline \multirow[t]{2}{*}{ Venicle Fuet } & NA & NA & 1,720 & 1.958 & 2,562 \\
\hline & \multicolumn{5}{|c|}{ Average Annual Cost per Consumer (dollars) } \\
\hline 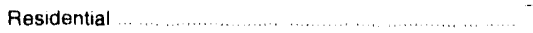 & $\$ 421$ & $\$ 427$ & $\$ 423$ & $\$ 440$ & $\$ 409$ \\
\hline 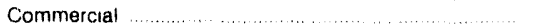 & 2.472 & 2,459 & 2,367 & 2,363 & 2.177 \\
\hline \multirow[t]{2}{*}{ 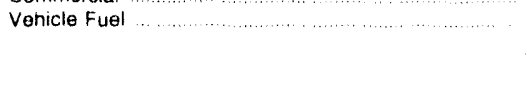 } & NA & NA & 5.661 & 7.351 & 8,811 \\
\hline & \multicolumn{5}{|c|}{ Average Heating Value (Btu per cubrc foot) } \\
\hline \multirow[t]{2}{*}{ Delivered to Consumers } & 1.034 & 1.037 & 1.038 & 1.039 & 1.039 \\
\hline & \multicolumn{5}{|c|}{ Average Prices for Natural Gas (dollars per thousand cubic feet) } \\
\hline Wellhead (Marketed Production) & $\$ 168$ & $\$ 145$ & $\$ 1.49$ & न $\$ 1.29$ & $\$ 143$ \\
\hline Imports & 1.82 & 182 & 1.85 & 1.73 & 1.68 \\
\hline Exports & 3.30 & a 3.12 & 2.39 & 2.21 & 1.42 \\
\hline 두… & 184 & 166 & 171 & 1.44 & 1.48 \\
\hline City Gate & 2.87 & 2.97 & 2.92 & 2.80 & 2.75 \\
\hline \multicolumn{6}{|l|}{ Delivered to Consumers } \\
\hline 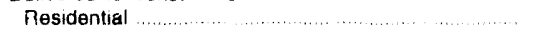 & 5.05 & 516 & 5.21 & 5.22 & 5.16 \\
\hline 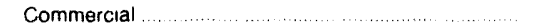 & 4.09 & 4.20 & 4.31 & 4.34 & 4.24 \\
\hline Industrial & 3.37 & 3.02 & 328 & 300 & 3.07 \\
\hline 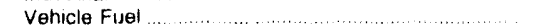 & NA & NA & 3.79 & 4.05 & 4.11 \\
\hline Electric Utilitios & 235 & 2.26 & 2.18 & 187 & 2.07 \\
\hline
\end{tabular}

A $=$ Revised data.

ma Not available

- - Not applicable.

Note: Deliveries to electric utilities (consumption) are reported on the Form EIA-759. "Monthly Power Plant Report." Deliveries to electric utilities for the account of others are reported on the Form ElA-176. "Annual Report of Natural and Supplemental Gas Supply and Disposition." See the discussion on electric utility data and Fable Al in Ap. pendix $A$ for a comparison of reporting to these two forms Totals may not add due to independent rounding The Mountain Census Division includes Arizona, Colorado. Idaho. pendx A rop a companison ol reponng to these two tc

Sources: Energy Information Administration (EIA), Form ElA.176. "Annual Report of Natural and Supplemental Gas Supply and Disposition," Form ElA-627, "Annual Quantity and Value of Natural Gas Feport," Form ElA.857, "Monthly Report of Natural Gas Purchases and Deliveries to Consumers," Form ElA.816. "Monthly Natural Gas Liquids Report," Form EIA.753. "Monthly Power Plant Report," Form FERC-423, "Monthly Pepont of Cost and Quality of Fuels for Electric Plants, " Form ElA-;91, "Underground Gas Storage Fepurt," Form FPC-14. "Annual Report for Importers and Exporters of Natural Gas," U.S. Crude Oil. Natural Gas, and Natural Gas liquids Reserves, 1992 Annual Report. DOE/EIA 0216(92); and the U.S Minerals Management Service. 
Natural Gas 1992

Net Interstate Movements

Million

$\mathrm{Cu}$. Feel

Million percent of

Marketed Production Cu. Feat National Total

$368,212 \quad 1.97$

Deliveries to Consumers

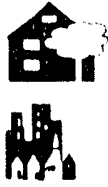

Residential:

545,694

11.64

Commercial:

342,378

12.22

ifl

Industrial:

732,854

9.74

$\longrightarrow$ Vehicle Fuel:

127

24.85

A

Electric Utility:

584,082

21.12

PACIFIC

Total:

$2,205,134$

1240

\section{CONTIGUOUS}

Table 40. Summary Statistics for Natural Gas -- Pacific Contiguous, 1988-1992

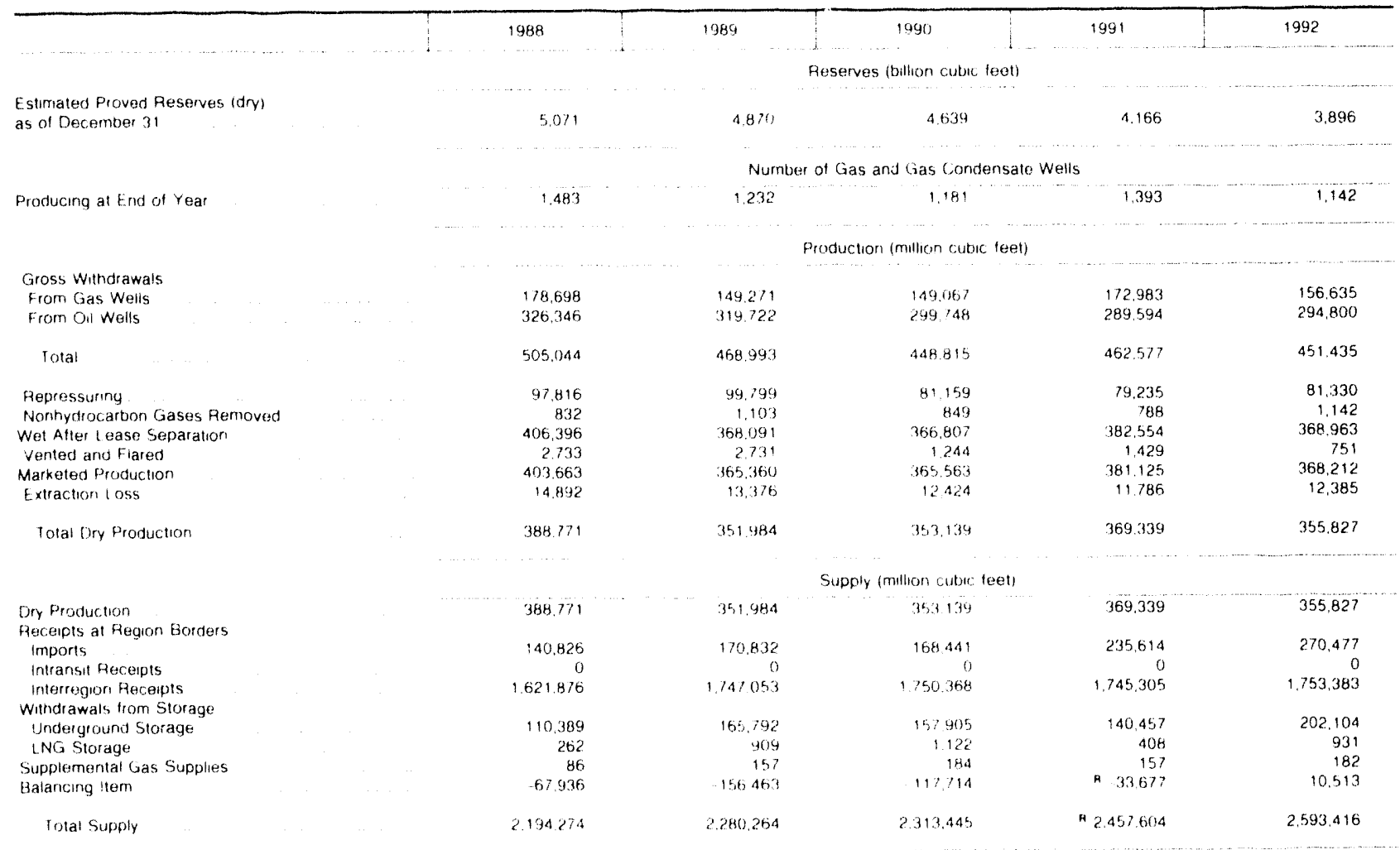


Table 40. Summary Statistics for Natural Gas -- Pacific Contiguous, 1988-1992 (Continued)

\begin{tabular}{|c|c|c|c|c|c|}
\hline & 1988 & 1989 & 1990 & 1991 & 1992 \\
\hline & \multicolumn{5}{|c|}{ Disposition (million cubic leet) } \\
\hline Consumption .................... & $2,038,394$ & $2,108,638$ & $2,1,36,008$ & R $2,267,140$ & $2,322,074$ \\
\hline \multicolumn{6}{|l|}{ Deliveries at Region Borders } \\
\hline Exports & 0 & 0 & 0 & 0 & 0 \\
\hline Intransit Deliveries & 0 & 0 & 0 & 0 & 0 \\
\hline 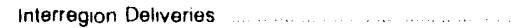 & 29,488 & 11,868 & 9,309 & 33,302 & 103.506 \\
\hline \multicolumn{6}{|l|}{ Additions to Storage } \\
\hline Underground Storage ........... & 125,582 & 158.799 & $16 ; .265$ & $1+n 0$ & 167,446 \\
\hline LNG Storage $\ldots \ldots \ldots \ldots$ & 811 & 958 & 864 & 662 & 389 \\
\hline \multirow[t]{2}{*}{ Total Dispositio. } & $2,194,274$ & $2,28 \div 264$ & $2,313,445$ & ค $2,457,604$ & $2,593,416$ \\
\hline & \multicolumn{5}{|c|}{ Consumption (million cubic feet) } \\
\hline Lease and Plant Fuel & 22,893 & 19,645 & 22.805 & 104,311 & 92,296 \\
\hline Pipeline Fuel ... ..... & 31,199 & 32,084 & 34,200 & 32,422 & 24,644 \\
\hline \multicolumn{6}{|l|}{ Delivered to Consumers } \\
\hline Residentral ... ................ & 552.938 & 575,139 & 578,235 & 581.243 & 545,694 \\
\hline 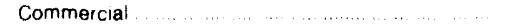 & 303,476 & 317.86 & 344.710 & 351,675 & 342,378 \\
\hline Industrial ... & 573,196 & 624,939 & 692,520 & 737,404 & 132.85 .4 \\
\hline 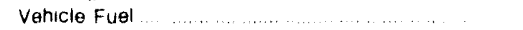 & NA & NA & 54 & 76 & 127 \\
\hline Electric Utilities $\ldots \ldots \ldots \ldots$ & 554.691 & 538.962 & $46.1,982$ & ค 460,009 & $5,84,082$ \\
\hline Total Delivered to Consurmurs $\ldots \ldots \ldots \ldots \ldots$ & 1.984 .301 & 2.056 .909 & $2,079,002$ & A 2.130 .407 & $2,205,134$ \\
\hline \multirow[t]{2}{*}{ Total Consumption } & $2,038,394$ & $2,108,638$ & $2,136,008$ & ค $2,267.140$ & $2,322,074$ \\
\hline & \multicolumn{5}{|c|}{ Detivered for the Account of Others (millton cubic leet) } \\
\hline Residential & NA & NA & 0 & 1.256 & 3,502 \\
\hline Commercral & 12,105 & 23,753 & 41,263 & 67.606 & 78.045 \\
\hline Industrial ... & 218,866 & 348.018 & 421,700 & 511.785 & 527,181 \\
\hline \multirow[t]{2}{*}{ Electric Utilities } & 56.365 & 107,309 & 121648 & $236,6 \times 9$ & 422,650 \\
\hline & \multicolumn{5}{|c|}{ Number of Consumers } \\
\hline Residential & $8,814,108$ & $9,041.556$ & 9.282 .038 & $9,503,129$ & 9.563 .782 \\
\hline Commercial ................ & 505.920 & 509.459 & 520,396 & 537,539 & 526.109 \\
\hline Industrial $\ldots$ & 49.278 & 50.346 & 50.175 & 49.147 & 44,758 \\
\hline \multirow[t]{2}{*}{ Vehicle Fuel } & NA & NA & 15 & 49 & 97 \\
\hline & \multicolumn{5}{|c|}{ Average Arnual Consumption per Consumer (thousand cubic feet) } \\
\hline Residential & 63 & 64 & 62 & 61 & 57 \\
\hline Commercial & 600 & 624 & 661 & 654 & 651 \\
\hline Industrial & 11,632 & 12.413 & 13.802 & 15.004 & 16.374 \\
\hline \multirow[t]{2}{*}{ Venicle Fuel } & NA & NA & 3,615 & 1,544 & 1,308 \\
\hline & \multicolumn{5}{|c|}{ Average Annual Cost per Consumsr (dollars) } \\
\hline Fesidential & $\$ 356$ & $\$ 357$ & $\$ 358$ & $\$ 375$ & $\$ 334$ \\
\hline$\ldots \ldots+\ldots, \ldots$ & 2.714 & 2,800 & 2,903 & 2,774 & 2,519 \\
\hline \multirow[t]{2}{*}{ Vehicle Fuel } & NA & NA & 14.858 & 6.587 & 5.995 \\
\hline & \multicolumn{5}{|c|}{ Average Heating value (Btu per cubic toot) } \\
\hline \multirow[t]{2}{*}{ Delivered to Consumers } & 1.030 & 1.037 & 1.031 & 1,027 & 1.030 \\
\hline & \multicolumn{5}{|c|}{ Average Prices for Natural Gas (dollars per thousand cubic teet) } \\
\hline Welthead (Marketed Production) & $\$ 239$ & $\$ 231$ & $\$ 236$ & A $\$ 245$ & $\$ 233$ \\
\hline Imports & 173 & 148 & 1.61 & 159 & 147 \\
\hline$\ldots=\ldots+\ldots$ & $\ldots$ & .. & .. &.- & ... \\
\hline$\ldots$ & 231 & 227 & 228 & 2.19 & 167 \\
\hline City Gate. & 259 & 270 & 280 & 269 & 262 \\
\hline \multicolumn{6}{|l|}{ Delivered to Consumers } \\
\hline$\ldots \ldots+\ldots$ & 568 & 560 & 5.74 & 5.14 & 590 \\
\hline Commercial & 471 & 485 & 499 & 525 & 501 \\
\hline Industrial & 366 & 362 & 371 & 375 & 354 \\
\hline Vethicle Fuel & NA & NA & 411 & 427 & 458 \\
\hline Electric Utilities & 293 & 307 & 309 & 292 & 279 \\
\hline
\end{tabular}

\section{A .: Revised data.}

we $=$ Not avallabie

Not applicable

Note Deliveries to electric utilities (consumption) are reported on the Form ElA.759, "Monthly Power Plant Report" Deliveries to electic utilties lor the account of others are reported on the Form ElA-176. "Annual Report of Natural and Supplemental Gas Supply and Disposition" See the discussion or electric utlity data and Table A1 in Ap. pendix A for a comparison of reporting to these two forms Totais may not add due to independent rounding. The Pacific Contiguous Census Division includes California. Oregon. and Washingion

Sources Energy Information Administration (EIA). Form ElA-176. "Annual Report of Natural and Supplemental Gas Supply and Disposition." Form ElA-627, "Annual Quantity and Value of Natural Gas Repon,." Form EIA.857, "Monthly Feport of Natural Gas Purchases and Deliverles tc Consumers." Form ElA.81E. "Monthly Natural Gas Liquids Report," Form ElA.759, "Monthly Power Plant Report." Form FERC.423. "Munthly Report of Cost and Quality of Fuels lor Electric Plants. "Form ElA 191. "Underground Gas Storage Report. Form FPC.14. "Annual Report tor Importers and Exporters of Naturai Gas," U S Crude OIl, Nalural Gas. and Natural Gas Liquids Reserves, 1992 Annual Report, DOEi EiA $0216(92)$, and the US Minerals Management Service 
Natural Gas 1992

Net Interstate Movements

Million

Cu. Feel

Marketed Production

Million
Cu. Fo日

443,597

$-52,532$

Deliveries to Consumers

ar?

Residential:

$: 4,901$

Percent of

National Total

2.37

A.

inst

Commercial:

23,443

$C$

Industrial:

80,938

$\longrightarrow$ Vehicle Fuel:

0

$A$

Electric Utility:

28,953

Total:

148.236

.32

.84

1.08

.00

1.05

NONCONTIGUOUS

Table 41. Summary Statistics for Natural Gas -- Pacific Noncontiguous, 1988-1992

\begin{tabular}{|c|c|c|c|c|c|}
\hline & 1988 & 1989 & 1990 & 1991 & 1992 \\
\hline & \multicolumn{5}{|c|}{ Reserves (billion cubic teet) } \\
\hline \multirow[t]{2}{*}{$\begin{array}{l}\text { Estimated Proved Reserves (dry) } \\
\text { as of December } 31\end{array}$} & 9.078 & 8.939 & 9.300 & 9,553 & 9,638 \\
\hline & \multicolumn{5}{|c|}{ Number of Gas and Gas Condensate Wells } \\
\hline \multirow[t]{2}{*}{ Prorlucing at End of Year } & 91 & 108 & 111 & 110 & 112 \\
\hline & \multicolumn{5}{|c|}{ Production (million cubic feet) } \\
\hline Gross Withdrawals & & & & & \\
\hline From Gas Wells $\ldots \ldots \ldots \ldots \ldots$ & 186.554 & 194.262 & 204,093 & 197,502 & 198,603 \\
\hline From Oll Wells $\ldots \ldots \ldots \ldots \ldots \ldots \ldots \ldots \ldots \ldots \ldots \ldots \ldots$ & $1,746.493$ & $1,770,751$ & $1,849,231$ & * 2.181 .393 & $2,427,110$ \\
\hline Total $\ldots \ldots \ldots \ldots$ & $1,933,047$ & $1,965,013$ & $2,053,324$ & ค 2.378 .896 & $2,625,713$ \\
\hline Repressuring & $1,545,391$ & $1.561,498$ & $1,639,689$ & ค $1,930,290$ & $2.168,019$ \\
\hline 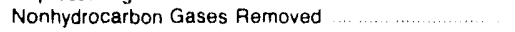 & 0 & 0 & 0 & 0 & 0 \\
\hline 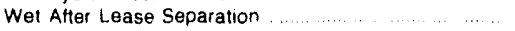 & 387.656 & 403,515 & 413,634 & 448,605 & 457,694 \\
\hline Vented and Flared & 9.018 & 9,786 & 10.727 & 10.784 & 14,097 \\
\hline 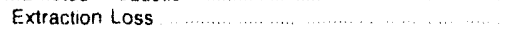 & 23,240 & 19,932 & 21,476 & 28.440 & 32.004 \\
\hline \multirow[t]{2}{*}{ Total Dry Production } & 355,398 & 373.797 & 381.431 & $R_{409,382}$ & 411,593 \\
\hline & \multicolumn{5}{|c|}{ Supply (milion cubsic teet) } \\
\hline Dry Production .............. & 355,398 & 373,797 & 381,431 & 409,382 & 411,593 \\
\hline Receipts at Region Borders & & & & & \\
\hline Imports & 0 & 0 & 0 & 0 & 0 \\
\hline Intransit Receipts & 0 & 0 & 0 & 0 & 0 \\
\hline Interregion Receipts. & 0 & 0 & 0 & 0 & 0 \\
\hline \multicolumn{6}{|l|}{ Withdrawals from Storage } \\
\hline Underground Storage & 0 & 0 & 0 & 0 & 0 \\
\hline LNG Storage. & 0 & 0 & 0 & 0 & 0 \\
\hline Supplemental Gas Suppliess & 2,801 & 2.844 & 2,817 & 2.725 & 2.711 \\
\hline Balancing Item & -16.364 & -994 & 13,671 & 11,810 & 24,044 \\
\hline Total Supply & 341,835 & 375,647 & 397.920 & 423,916 & 438.348 \\
\hline
\end{tabular}

See lootnotes at end of table. 
Table 41. Summary Statistics for Natural Gas -- Pacific Noncontiguous, 1988-1992 (Continued)

\begin{tabular}{|c|c|c|c|c|c|}
\hline & 1988 & 1989 & 1990 & 1991 & 1992 \\
\hline & \multicolumn{5}{|c|}{ Disposition (million cubic feet) } \\
\hline 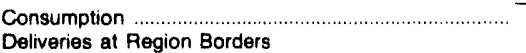 & 290,262 & 324,223 & 345,374 & 369,911 & 385,816 \\
\hline Exports & 51,573 & 51,424 & 52,546 & 54,005 & 52,532 \\
\hline 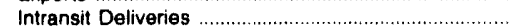 & 0 & 0 & 0 & 0 & 0 \\
\hline 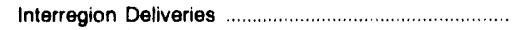 & 0 & 0 & 0 & 0 & 0 \\
\hline \multicolumn{6}{|l|}{ Additions to Storage } \\
\hline Underground Storage & 0 & 0 & 0 & 0 & 0 \\
\hline LNG Storage & 0 & 0 & 0 & 0 & 0 \\
\hline \multirow[t]{2}{*}{ Total Disposition } & 341,835 & 375,647 & 397,920 & 423,916 & 438,348 \\
\hline & \multicolumn{5}{|c|}{ Consumption (million cubic feet) } \\
\hline Lease and Plant Fuel & 153,670 & 192,239 & 193,875 & 223,194 & 234.716 \\
\hline Pipeline Fuel & 1,961 & 1.876 & 1,708 & 2,597 & 2,864 \\
\hline \multicolumn{6}{|l|}{ Delivered to Consumers } \\
\hline Residential & 13,092 & 14,153 & 14,730 & 14,107 & 14,901 \\
\hline Commercial & 22,891 & 23,867 & 23.845 & 23,046 & 23,443 \\
\hline 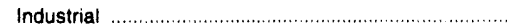 & 67,805 & 59,341 & 76,849 & 75,637 & 80,938 \\
\hline 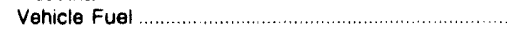 & NA & NA & 0 & 0 & 0 \\
\hline 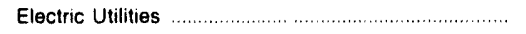 & 30,843 & 32,746 & 34,366 & 31,330 & 28,953 \\
\hline Total Delivered to Consumers & 134,631 & 130,108 & 149,791 & 144.120 & 148,236 \\
\hline \multirow[t]{2}{*}{ Total Consumption } & 290.262 & 324.223 & 345,374 & 369,911 & 385,816 \\
\hline & \multicolumn{5}{|c|}{ Delivered for the Account of Others (million cubic feet) } \\
\hline Residential. & NA & NA & 0 & 0 & 0 \\
\hline 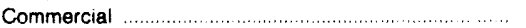 & 0 & 0 & 0 & 0 & 0 \\
\hline Industrial & 30,824 & 25,605 & 28,165 & 23,363 & 24,455 \\
\hline \multirow[t]{2}{*}{ 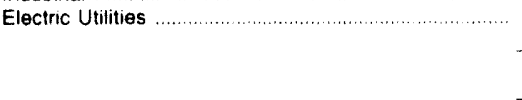 } & 5,908 & 6.773 & 6,495 & 0 & 8,925 \\
\hline & \multicolumn{5}{|c|}{ Number of Corsumers } \\
\hline Residential. & 97,373 & 98,510 & 99,945 & 102,266 & 104.073 \\
\hline 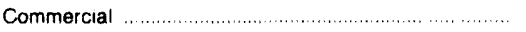 & $\$ 4,501$ & 14,648 & 14,758 & 14,857 & 14,997 \\
\hline Industrial & $\cdot$ & $\cdot$ & $\cdot$ & • & 10 \\
\hline \multirow[t]{2}{*}{ Vehicle Fuel } & NA & NA & 0 & 0 & 0 \\
\hline & \multicolumn{5}{|c|}{ Average Annual Consumption per Consumer (thousand cubic feet) } \\
\hline 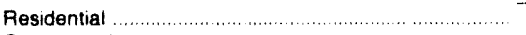 & 134 & 144 & 147 & 138 & 143 \\
\hline 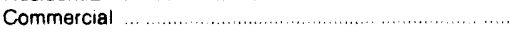 & 1.579 & 1,591 & 1,616 & 1,551 & 1,563 \\
\hline Industrial & $6,164,078$ & $7,417,676$ & $9,606,167$ & $9,454,647$ & $8,093,795$ \\
\hline \multirow[t]{2}{*}{ Venicle Fuel ..................................................... } & NA & NA & 0 & 0 & 0 \\
\hline & \multicolumn{5}{|c|}{ Average Annual Cost per Consumer (dollars) } \\
\hline Residential.. & $\$ 536$ & $\$ 591$ & $\$ 631$ & $\$ 676$ & $\$ 618$ \\
\hline \multirow{3}{*}{$\begin{array}{l}\text { Commercial } \\
\text { Vehicle Fuel }\end{array}$} & 5,371 & 5,347 & 5,703 & 6,003 & 5.656 \\
\hline & NA & NA & 0 & 0 & 0 \\
\hline & \multicolumn{5}{|c|}{ Average Heating Value (Btu per subic toot) } \\
\hline \multirow[t]{2}{*}{ Delivered to Consumers. } & 1.005 & 1.001 & 956 & 1.003 & 1,003 \\
\hline & \multicolumn{5}{|c|}{ Average Prices for Natural Gas (dollars per thousand cubic feet) } \\
\hline Wellhead (Marketed Production) & $\$ 1.27$ & $\$ 136$ & $\$ 1.38$ & न $\$ 148$ & $\$ 141$ \\
\hline Imports & $-\cdot$ & -. & $-\cdot$ & $\cdots$ & .. \\
\hline Exports & 2.98 & 301 & 3.59 & 3.71 & 3.43 \\
\hline Pipelıne Fuet & 1.01 & 1.13 & 1.08 & 1.32 & 1.12 \\
\hline 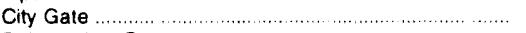 & 4.72 & 4.79 & 5.62 & 6.06 & 5.45 \\
\hline \multicolumn{6}{|l|}{ Delivered to Consumers } \\
\hline 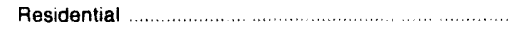 & 3.99 & 4.11 & 4.28 & 4.90 & 432 \\
\hline 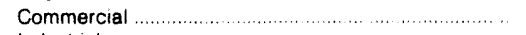 & 3.40 & 3.36 & 3.53 & 3.87 & 3.62 \\
\hline 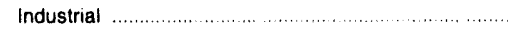 & 1.07 & 1.08 & 1.21 & 1.18 & 118 \\
\hline Vehicle Fuel & NA & NA & $-\cdot$ & & -. \\
\hline 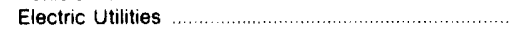 & 1.34 & 1.36 & 1.59 & .53 & .57 \\
\hline
\end{tabular}

- = Less than 500 industrial consumers

A $=$ Revised data.

NA Not available.

-- Not applicable.

Note: Deliveries to electric utlities (consumption) are reported on the Form ElA.759, "Monthly Power Plant Re ,ort." Deliveries 10 electric utilities for the account of others are reported on the Form ElA-176. "Annual Report of Natural and Supplemental Gas Supply and Disposition." S.,e the discussion on electric utility data and Table A1 in Appendix $A$ for a comparison of reporting to these two forms. Totals may not add due to independent rounding. The $r$ acific Noncontiguous Census Division includes Alaska and Ha. waii.

Sources: Energy Intormation Administration (EIA). Form EIA-176. "Annual Report of Natural and Supplemental Gas Supply and Dispositi n, "Form ElA.627, "Arınual Quantity and Value of Natural Gas Report," Form EIA-857 "Monthly Report of Natural Gas Purchases and Deliveries to Consumers," Form ElA-816, "Monthly Natural Gas Liquids Report," Form

ElA-759, "Monthly Power Plant Report," Form FERC-423. "Monthly Report of Cost and Quality of Fuels for Electric Plants," Form ElA-191. "Underground Gas Storage Report,"

Form FPC-14, "Annual Report for Importers and Exporters of Natural Gas." US. Crude OII. Natural Gas, and Natural Gas Liquids Resenes, 1992 Annual Report. DOE/EIA. 0216(92); and the U.S. Minerals Management Service. 


\section{State Summary}

Texas and Louisiana continue to lead the Nation as the major producers of natural gas, followed by Oklahoma. These three States together accounted for 13.1 trillion cubic feet or 70 percent of the U.S. total marketed production in 1992.

The Nation's offshore natural gas was produced by Alabama, Alaska, California, Louisiana and Texas, and together they produced about one-fourth of the total U.S. gross withdrawals. Louisiana continues to be by far the largest contributor ( 65 percent) to the total U.S. offshore withdrawals. More than half ( 69 percent) of Louisiana's total gross withdrawals are offshore, while
Texas' offshore gross withdrawals are nearly onefourth of its total.

Texas and I andiana. the major producing States. to-

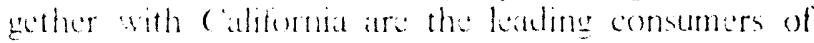

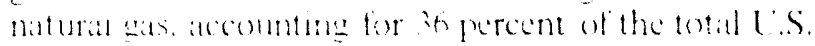

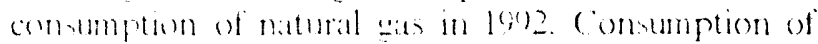

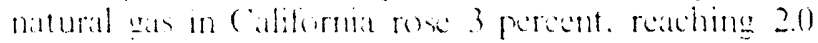
triblion cubic bet in lon?

Detailed information on ratural gas supply, disposition, and prices for each State for 1988 to 1992 are presented in Tables 44 through 94.

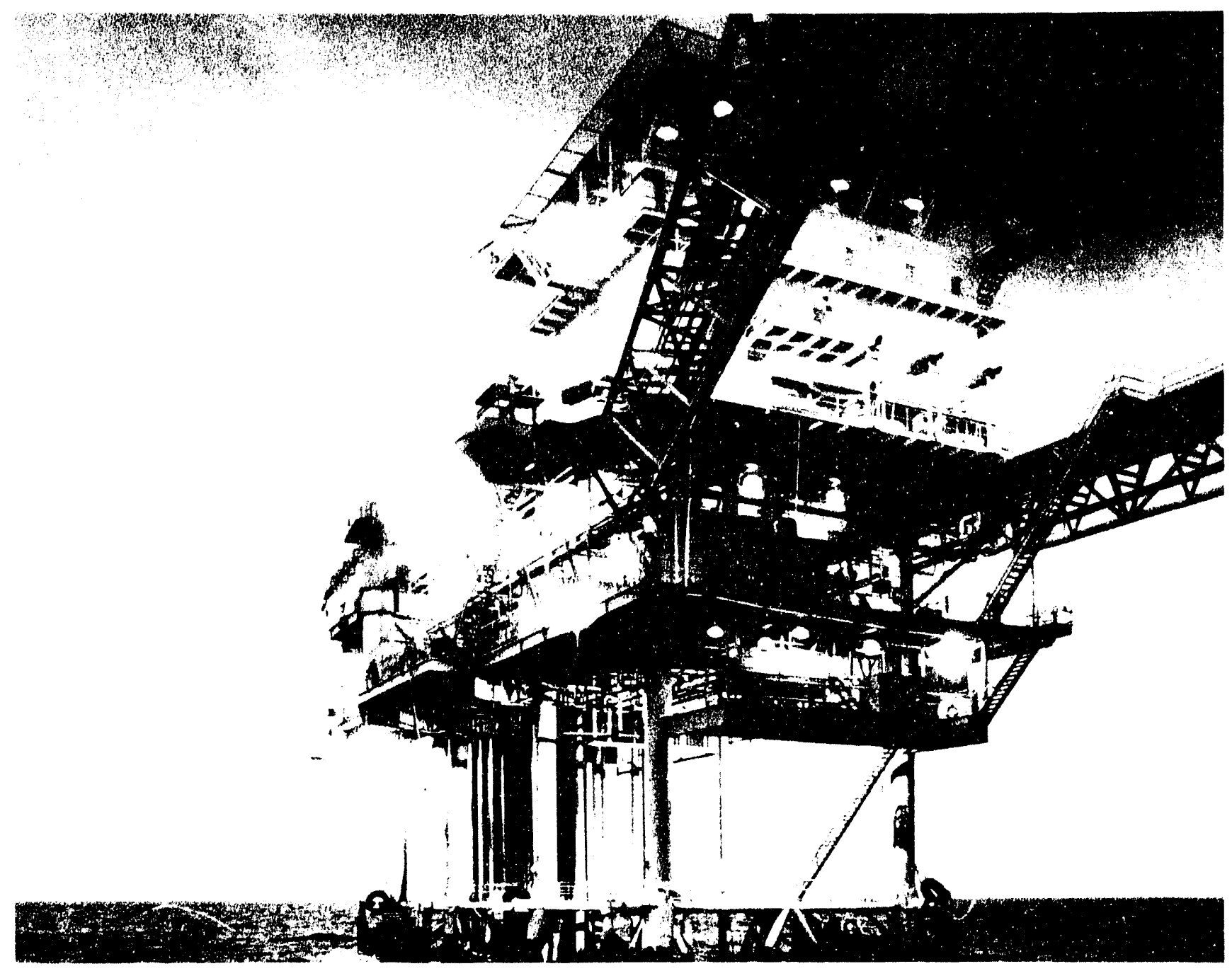

A view of an offshore drilling platform. 
Table 42. Percent Distribution of Natural Gas Supply and Disposition by State, 1992

\begin{tabular}{|c|c|c|c|}
\hline State & $\begin{array}{l}\text { Estimated } \\
\text { Proved Reserves (dry) }\end{array}$ & Marketed Production & Total Consumption \\
\hline Alabama & $3.52 \%$ & $1.90 \%$ & $1.43 \%$ \\
\hline 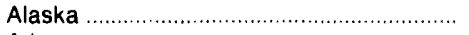 & 5.84 & 2.37 & 1.96 \\
\hline Arizona & NA & * & .66 \\
\hline 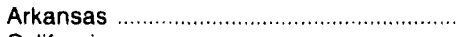 & 1.06 & 1.08 & 1.15 \\
\hline 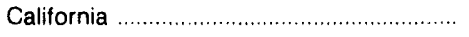 & 2.36 & 1.95 & 10.39 \\
\hline 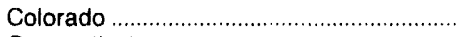 & 3.76 & 1.73 & 1.29 \\
\hline 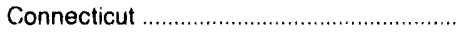 & -. & -. & .57 \\
\hline 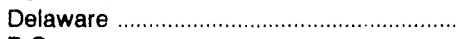 & $*$ & .. & .20 \\
\hline D.C & .. & -. & .17 \\
\hline Florida & .03 & .04 & a 1.83 \\
\hline Georgia & -. & .. & 1.75 \\
\hline 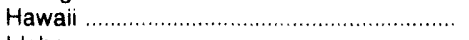 & $\cdots$ & -. & .01 \\
\hline 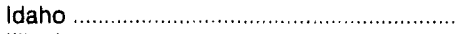 & -- & 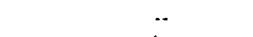 & .25 \\
\hline Illinois & NA & $*$ & 5.08 \\
\hline Indiana & NA & " & 2.47 \\
\hline lowa & $\because$ & -- & 1.18 \\
\hline 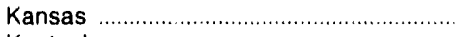 & 5.87 & 3.52 & 1.76 \\
\hline 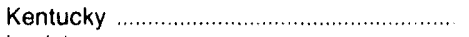 & .66 & .43 & .97 \\
\hline 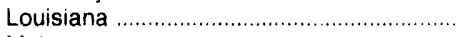 & - 17.84 & 26.26 & 7.91 \\
\hline 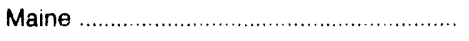 & -. & -. & .03 \\
\hline 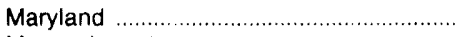 & NA & • & .93 \\
\hline 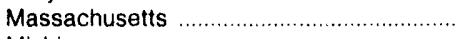 & 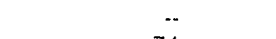 & $\cdots$ & 1.51 \\
\hline Michigan & .74 & 1.04 & 4.56 \\
\hline 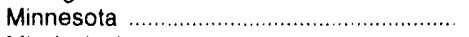 & -- & -. & 1.58 \\
\hline 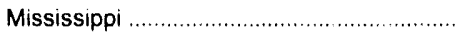 & .53 & 49 & 1.23 \\
\hline 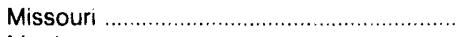 & NA & * & 1.23 \\
\hline Montana & .52 & .29 & .23 \\
\hline 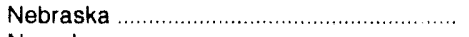 & NA & .01 & .55 \\
\hline Nevada & NA & • & .35 \\
\hline New Hampshire ..................................... & .. & -. & .09 \\
\hline 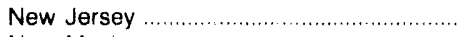 & $\cdots$ & $\cdots$ & 2.79 \\
\hline 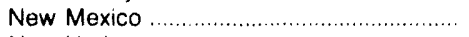 & 11.51 & 6.78 & 1.04 \\
\hline 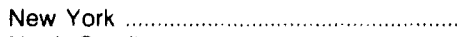 & .20 & .13 & 4.91 \\
\hline 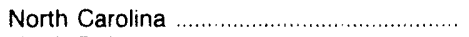 & .. & -. & .92 \\
\hline North Dakota & .30 & .29 & .19 \\
\hline 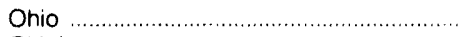 & .70 & .77 & 4.15 \\
\hline 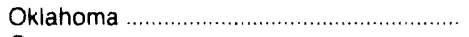 & 8.44 & 10.78 & 2.78 \\
\hline Oregon & NA & .01 & .63 \\
\hline 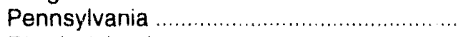 & .93 & .74 & 3.49 \\
\hline 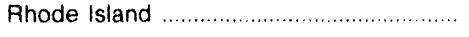 & $-\cdot$ & $\cdot \cdot$ & .40 \\
\hline 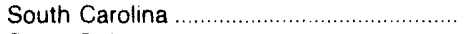 & $-\cdot$ & - & .71 \\
\hline South Dakota & NA & .01 & 14 \\
\hline Tennessee & NA & .01 & 1.24 \\
\hline 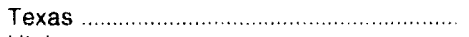 & 25.51 & 32.84 & 17.79 \\
\hline Utah & 1.11 & .92 & .63 \\
\hline 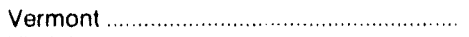 & -- & -- & .04 \\
\hline Virginia & .55 & .13 & 1.02 \\
\hline 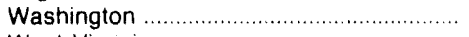 & $\because$ & 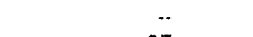 & .87 \\
\hline 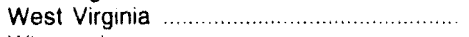 & 1.43 & .97 & .66 \\
\hline 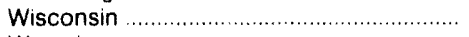 & - &.- & 1.70 \\
\hline 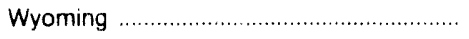 & 6.56 & 4.50 & .63 \\
\hline
\end{tabular}

- : Includes Offshore Federal Domain.

- Value less than 01 percent.

NA $=$ Not available.

- Not applicable.

Sources: Energy Information Administration (EIA). Form EIA-176, "Annual Report of Natural and Supplemental Gas Supply and Disposition," Form ElA. 627. "Annual Quantity and Value of Natural Gas Report," and EIA Report, U.S. Crude Oil, Natural Gas, and Natural Gas Liquids Reserves, 1992 Annual Report," DOE/EIA-0216(92) 
Table 43. Percent Distribution of Natural Gas Delivered to Consumers by State, 1992

\begin{tabular}{|c|c|c|c|c|c|}
\hline State & Residential & Commercial & Industrial & Vehicle Fuel & Electric Utilities \\
\hline & & & & \multicolumn{2}{|c|}{. } \\
\hline 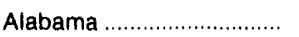 & $1.06 \%$ & $0.90 \%$ & $2.25 \%$ & $0.59 \%$ & $0.12 \%$ \\
\hline Alaska & .31 & .76 & 1.08 & .. & 1.05 \\
\hline 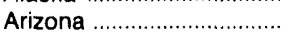 & .61 & 97 & .26 & 9.00 & 1.12 \\
\hline 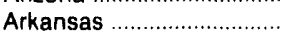 & .84 & .90 & 1.58 & -. & .98 \\
\hline 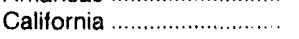 & 10.22 & 10.17 & 7.90 & 5.28 & 20.41 \\
\hline 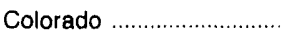 & 2.02 & 2.37 & .76 & 4.50 & .18 \\
\hline 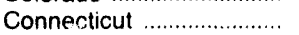 & .90 & 1.06 & .48 & .. & .08 \\
\hline Delaware & 17 & .18 & .24 & -. & .30 \\
\hline D.C. & .35 & .57 & .. & -. &.- \\
\hline Florida & 31 & 1.49 & 1.13 & 1.76 & 7.32 \\
\hline 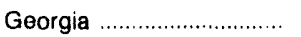 & 2.31 & 1.92 & 2.29 & $\ldots$ & .04 \\
\hline 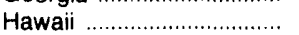 & .01 & .08 & .. & .. & .. \\
\hline Idaho & .21 & .32 & .36 & -. & -- \\
\hline 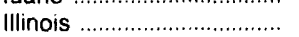 & 10.14 & 7.03 & 3.99 & 1.57 & .34 \\
\hline 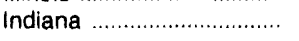 & 3.26 & 2.59 & 3.26 & 11.55 & .28 \\
\hline lowa & 1.60 & 1.64 & 1.34 & .- & .08 \\
\hline 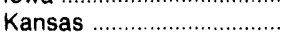 & 1.52 & 1.93 & 1.74 & -- & .51 \\
\hline Kentucky & 1.32 & 1.26 & .98 & -. & .01 \\
\hline Louisiana & 1.18 & 1.01 & 12.39 & -. & 9.22 \\
\hline 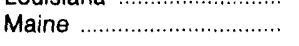 & .02 & .08 & .03 & $\cdot-$ & .. \\
\hline 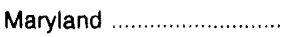 & 1.60 & 1.52 & .66 & -. & .42 \\
\hline 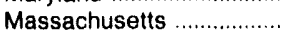 & 2.55 & 2.30 & .94 & .39 & 1.39 \\
\hline 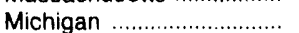 & 7.64 & 6.20 & 4.06 & .78 & .90 \\
\hline 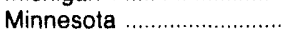 & 2.42 & 2.94 & 1.24 & .00 & 18 \\
\hline Mississippi ............................ & .56 & .64 & 1.36 & .00 & 1.96 \\
\hline Missouri ............................... & 2.49 & 2.18 & .78 & .. & .09 \\
\hline 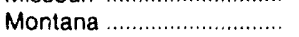 & .36 & .41 & .16 & .39 & .01 \\
\hline 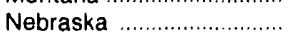 & .88 & 1.23 & .35 & $\ldots$ & .07 \\
\hline 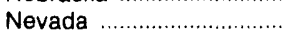 & .39 & .57 & .12 & 2.35 & 88 \\
\hline New Hampshire .............. & .14 & 21 & .05 & -. & .02 \\
\hline New Jersey ......................... & 4.23 & 4.67 & 2.32 & -. & 1.40 \\
\hline New Mexico ...................... & .67 & 99 & .23 & 1.37 & .81 \\
\hline 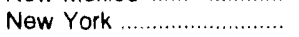 & 8.07 & 7.75 & 1.96 & 1.17 & 7.55 \\
\hline 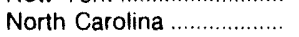 & .91 & 1.30 & 1.21 & 1.37 & .11 \\
\hline 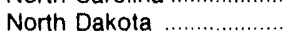 & .21 & .35 & .08 & .59 & $\cdot$ \\
\hline 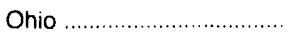 & 7.26 & 5.73 & 3.92 & 11.55 & .11 \\
\hline Oklahoma & 1.40 & 1.26 & 2.33 & 8.81 & 5.39 \\
\hline Oregon & .49 & .70 & .78 & 1.17 & .52 \\
\hline Pennsylvania ....................... & 5.68 & 4.79 & 3.14 & .59 & 11 \\
\hline 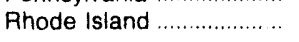 & .43 & .32 & .64 & 1.76 & .02 \\
\hline South Carolina .................... & .48 & .59 & 1.25 & .. & .06 \\
\hline 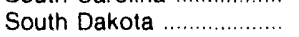 & .23 & .33 & .06 & .98 & -. \\
\hline 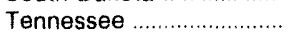 & 1.11 & 1.66 & 1.68 & .39 & .01 \\
\hline Texas & 4.58 & 6.59 & 23.04 & .78 & 35.01 \\
\hline 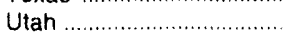 & .95 & .59 & .54 & 2.94 & .24 \\
\hline Vermont ............................. & .05 & .08 & .03 & .. & .03 \\
\hline Virginia & 1.33 & 1.81 & .91 & .. & .40 \\
\hline Washington & .92 & 1.35 & 1.06 & 18.40 & .19 \\
\hline 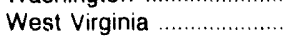 & .75 & .87 & .59 &.. & .01 \\
\hline 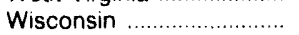 & 2.63 & 2.54 & 1.73 & 5.48 & .09 \\
\hline 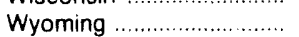 & .23 & .29 & .74 & 1.96 & .. \\
\hline
\end{tabular}

* Value less than 01 percent.

-- $\doteq$ Not applicable.

Sources: Energy Information Administration, Form EIA-176, "Annual Report of Natural and Supplemental Gas Supply and Disposition," and Form ElA. 759. "Monthly Power Plant Report." 
Natural Gas 1992

Net Interstate Movements

Million

Cu. Foet
0

$\begin{array}{ccc}\text { Marketed Production } & \begin{array}{c}\text { Million } \\ \text { Cu. Foet } \\ 355,099\end{array} & \begin{array}{c}\text { Percent of } \\ \text { National Total } \\ 1.90\end{array}\end{array}$

Deliveries to Consumers

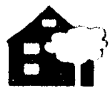

Residential:

49,644

1.06

A

inst

Commercial:

25,232

.90

in

Industrial:

169,049

2.25

$\underset{\rightarrow \infty}{0}$

Vehicle Fuel:

3

.59

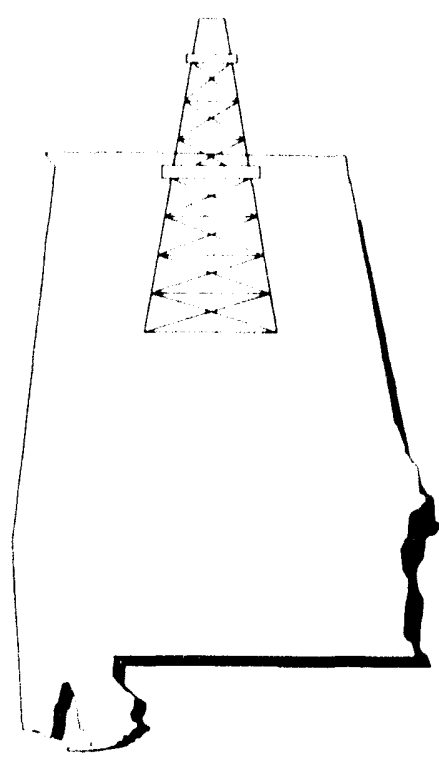

A

Electric Utility:

3,368

.12

Total:

247,295

1.39

ALABAMA

Table 44. Summary Statistics for Natural Gas -- Alabama, 1988-1992

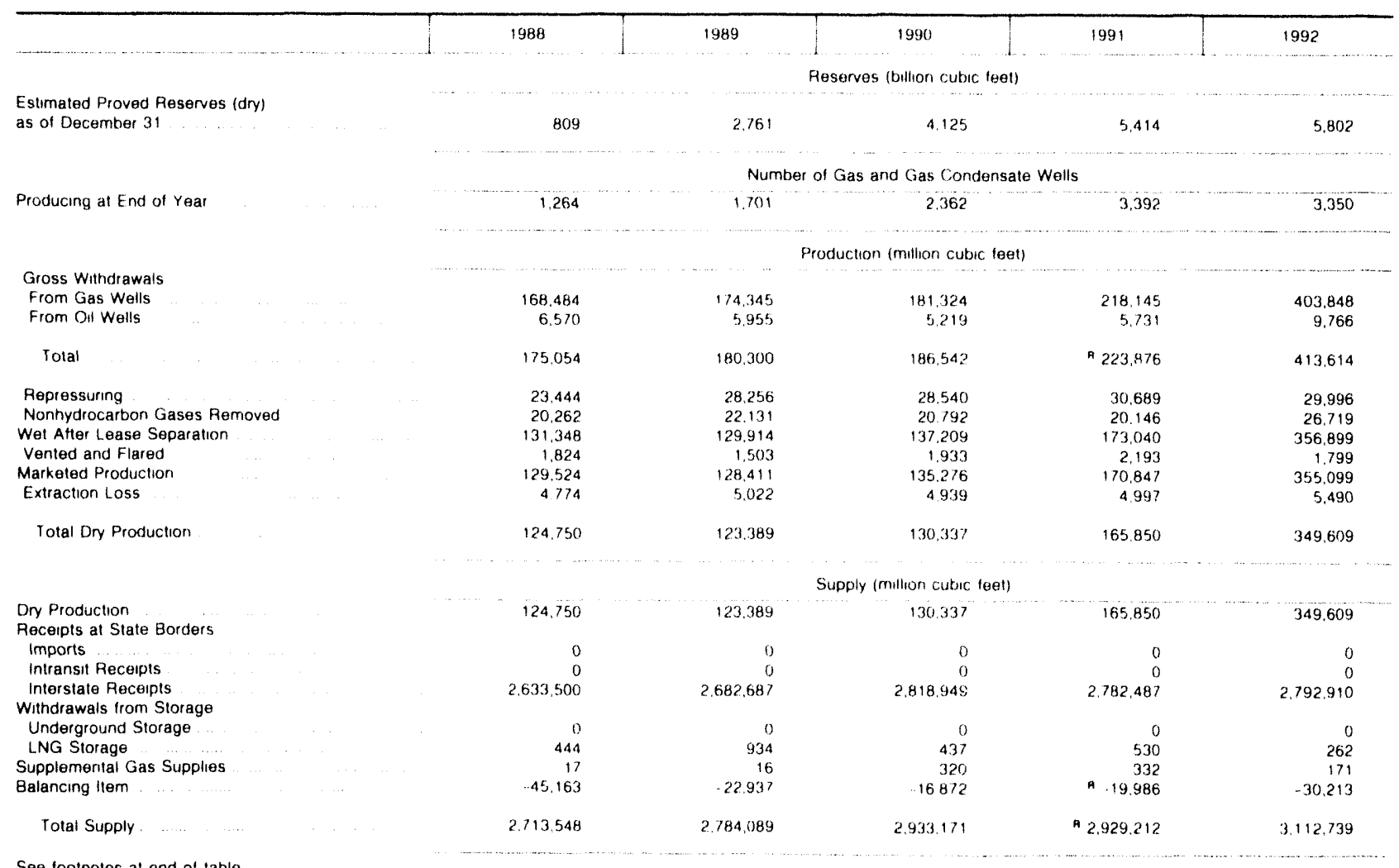


Table 44. Summary Statistics for Natural Gas -- Alabama, 1988-1992 (Continued)

\begin{tabular}{|c|c|c|c|c|c|}
\hline & 1988 & 1989 & 1990 & 1991 & 1992 \\
\hline & \multicolumn{5}{|c|}{ Disposition (million cubic teet) } \\
\hline Consumption $\ldots \ldots \ldots \ldots \ldots$ & 236.356 & 245,081 & 243,803 & A 253.674 & 278,794 \\
\hline \multicolumn{6}{|l|}{ Deliveries at State Borders } \\
\hline Exports & 0 & 0 & 0 & 0 & 0 \\
\hline 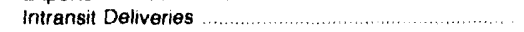 & 0 & 0 & 0 & 0 & 0 \\
\hline Interstate Deliveries & $2,476,584$ & 2.538496 & $2,688.474$ & 2.674 .828 & $2,833,444$ \\
\hline \multicolumn{6}{|l|}{ Additions to Storage } \\
\hline Underground Storage & 0 & 0 & 0 & 0 & 0 \\
\hline LNG Storage & 607 & 512 & 893 & 511 & 501 \\
\hline \multirow[t]{2}{*}{ Total Disposition } & $2,713,547$ & $2,784,089$ & $2,933,171$ & A $2,929,212$ & $3,112,739$ \\
\hline & \multicolumn{5}{|c|}{ Consumption (million cubic feet) } \\
\hline Lease and Plant Fuel & 6.655 & 6.152 & 9,881 & 8,627 & 12,868 \\
\hline Pipeline $\mathrm{Fu}, \ldots \ldots \ldots$ & 12.115 & 13,534 & 14,636 & 16.482 & 18.631 \\
\hline \multicolumn{6}{|l|}{ Delivered to vonsumers } \\
\hline Residential ....... & 49,913 & 48,118 & 45,411 & 46.149 & 49,644 \\
\hline 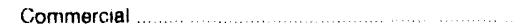 & 25,562 & 26,469 & 24,287 & 23.711 & 25.232 \\
\hline Industrial & 140.536 & 149,047 & 145.628 & 154,825 & 169,049 \\
\hline Vehicle Fuel & NA & NA & 3 & 0 & 3 \\
\hline 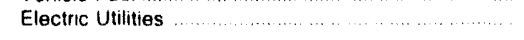 & 2,574 & 1,760 & 3,958 & A 4,081 & 3,368 \\
\hline Total Delivered to Consumers & 217,586 & 225,395 & 219.286 & ${ }^{R} 228,765$ & 247.295 \\
\hline \multirow[t]{2}{*}{ Total Consumption } & 236,356 & 245.081 & 243,803 & R 253,874 & 278.794 \\
\hline & \multicolumn{5}{|c|}{ Delivered for the Account of Others (miltion cubic feet) } \\
\hline Residential & NA & NA & 0 & 0 & 0 \\
\hline Commercial .... & 2,278 & 4,498 & 4,967 & 4.112 & 4,868 \\
\hline Industrial $\ldots \ldots \ldots$ & 70,229 & 93,168 & 96,889 & 106,274 & 118,457 \\
\hline \multirow[t]{2}{*}{ 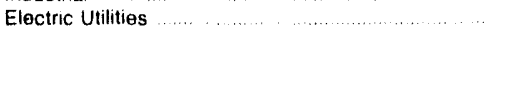 } & 886 & 1.456 & 2,287 & 3,045 & 2,739 \\
\hline & \multicolumn{5}{|c|}{ Numbet of Consumers } \\
\hline$\ldots$ & 668.432 & 683,528 & 686,149 & 700.195 & 711.043 \\
\hline Commercial $\ldots \ldots \ldots \ldots$ & 55.400 & 56,822 & 56,903 & 57.265 & 58.068 \\
\hline 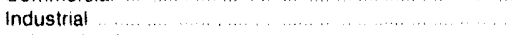 & 2,293 & 2.380 & 2.431 & 2.523 & 2,509 \\
\hline \multirow[t]{2}{*}{ 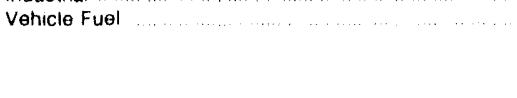 } & NA & NA & 1 & 0 & 1 \\
\hline & \multicolumn{5}{|c|}{ Average Annuat Consumption per Consumer (thousand cubic teet) } \\
\hline$\ldots \ldots-\ldots \ldots \ldots \ldots \ldots$ & 73 & 70 & 66 & 66 & 70 \\
\hline$(\ldots \ldots \ldots+\ldots$ & 461 & 466 & 427 & 414 & 435 \\
\hline 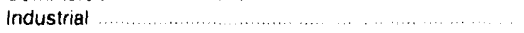 & 61,289 & 62.625 & 59.904 & 61,365 & 67,377 \\
\hline \multirow[t]{2}{*}{ Vehicie Fuel $\ldots \ldots \ldots \ldots . . . . \ldots \ldots \ldots$} & NA & NA & 2,555 & 0 & 2.632 \\
\hline & \multicolumn{5}{|c|}{ Average Annual Cost per Consumer (dollars) } \\
\hline$(-\ldots \ldots \ldots \ldots \ldots \ldots$ & $\$ 476$ & $\$ 441$ & $\$ 435$ & $\$ 464$ & $\$ 471$ \\
\hline Commercial . . . . . & 2,434 & 2.405 & 2,318 & 2,378 & 2.482 \\
\hline \multirow[t]{2}{*}{ 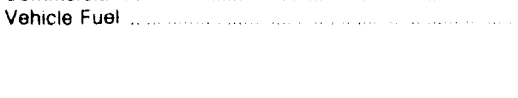 } & NA & NA & 1,893 & 0 & 17.013 \\
\hline & \multicolumn{5}{|c|}{ Average Heating Value (Btu per cubic fool) } \\
\hline \multirow[t]{2}{*}{ Delivered to Consumers } & 1,029 & 1.030 & 1.029 & 1,027 & 1,028 \\
\hline & \multicolumn{5}{|c|}{ Average Prices for Natural Gas (dollars per thousand cubic feet) } \\
\hline Wellhead (Marketed Production) $\ldots \ldots \ldots$ & $\$ 265$ & $\$ 2.72$ & $\$ 2.75$ & $\$ 2.33$ & $\$ 2.29$ \\
\hline Imports & - & $\cdots$ & $\ldots$ & $\cdots$ & -. \\
\hline Exports & ... & $\cdots$ & $\ldots$ & $\cdots$ & .. \\
\hline Pipeline Fuel & 230 & 260 & 217 & 302 & 224 \\
\hline$\ldots \ldots \ldots \ldots$ & 316 & 300 & 3.13 & 311 & 3.21 \\
\hline \multicolumn{6}{|l|}{ Delivered to Consumers } \\
\hline Residential & 651 & b2 27 & 657 & $i 05$ & 674 \\
\hline Commercial & 528 & 516 & 543 & 574 & 571 \\
\hline$\quad \ldots \ldots$ & 300 & 302 & 316 & 300 & 307 \\
\hline $\begin{array}{lllll}\ldots & \ldots & \ldots & \ldots\end{array}$ & NA & NA & 74 & $\ldots$ & 646 \\
\hline Electric Utilities & 215 & 227 & 222 & 191 & 228 \\
\hline
\end{tabular}

R. Revised data

- Not applicable

Note. Deliveries to electric uthties (consumptiont are reported on the Form ElA-759. "Monthly Power Plant Repont" Delivenes to electric utilties tot the account of Note: Deliveries to electric utilities (consumption) are reported on the Form ElA.759, "Monthly Power Plant Report "Deiveries to electric utilites tor the account of
others are reported on the Form ElA.176. "Annual Renort of Natural and Supplemental Gas Supply and Disposition." See the discussion on electric utility data and Table A1 in Ap. pendix $A$ for a comparison of reporting to these two forms. Totals may not add due to independent rounding

Sources Energy Intormation Administration (EIA). Form EIA-176. "Annual Report of Natural and Supplemental Gas Supply and Dispostion." Form EIA-627, "Annual Quantity and Value of Natural Gas Report." Form EIA.857. "Monthly Report of Natural Gas Purchases and Deliveries to Consumers. "Form ElA-E16. "Monthly Natural Gas Liquids Report," Form! EIA-759, "Monthly Power Plant Report." Form FERC.423, "Monthly Report of Cost and Quality of Fuets for Electric Plants. "Form EiA-191. "Underground Gas Storage Report," Form FPC-14. "Annual Report for Importers and Exporters of Natural Gas," US Crude Oi. Natural Gas. and Natural Gas Liquids Reserves, Iggz Annual Report, DOE/ElA 0216(92); and the U.S. Minerais Management Service. 
Natural Gas 1992

Net Interstate Movements

N Illon

Net Interstate Movements

Marketed Production

Million
Cu. Foot
443,597

Cu. Foet

$-52,632$

Percent of

National Total

2.37

Deliveries to Consumers

$\mathrm{E}^{3}$

Residential:

14,350

.31

4.

inst

Commercial:

21,299

.76

Industrial:

80.938

Vehicle Fuel:

0

1.08

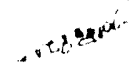

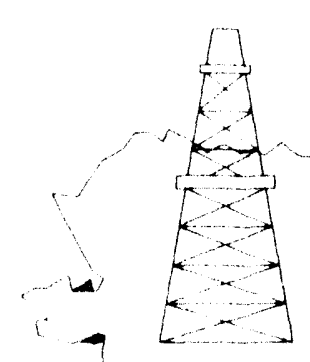

$\rightarrow$

Electric Utility:

28,953

.00

ALASKA

成

Total:

145.541

1.05

.82

Table 45. Summary Statistics for Natural Gas -- Alaska, 1988-1992

\begin{tabular}{|c|c|c|c|c|c|}
\hline & 1988 & 1989 & 1990 & 1991 & 1992 \\
\hline & \multicolumn{5}{|c|}{ Reserves (billion cubic feet) } \\
\hline \multirow[t]{2}{*}{$\begin{array}{l}\text { Estimated Proved Reserves (dry) } \\
\text { as of Decomber } 31\end{array}$} & 9.078 & 8.939 & 9,300 & 9.553 & 9,638 \\
\hline & \multicolumn{5}{|c|}{ Number of Gas and Gas Condensate Wells } \\
\hline \multirow[t]{2}{*}{ Producing at End of Year } & 91 & 108 & 111 & 110 & 112 \\
\hline & \multicolumn{5}{|c|}{ Production (miltion cubic leat) } \\
\hline Gross Withdrawals & & & & & \\
\hline $\begin{array}{l}\text { From Gas Wells } \\
\text { From Oil Wells }\end{array}$ & 186,554 & $\begin{array}{r}194,262 \\
1,770,751\end{array}$ & $\begin{array}{r}204.093 \\
1.849 .231\end{array}$ & $\begin{array}{r}197.502 \\
\text { F } 2.181 .393\end{array}$ & $\begin{array}{r}198.603 \\
2.427 .110\end{array}$ \\
\hline & $1.146,493$ & & & ค 2378.996 & \\
\hline 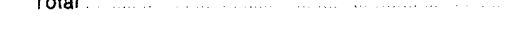 & $1,933,047$ & $1,965.013$ & $2,053,324$ & $2.378,896$ & $2,625.713$ \\
\hline Repressuring $\ldots$ & $1,545,391$ & 1.561 .498 & $1,639.689$ & ค 1930,290 & 2.168 .019 \\
\hline Nonhydrocarbon Gases Pemoved & 0 & 0 & 0 & 0 & 0 \\
\hline Wet Atter Lease Separation & 387,656 & 403.515 & 413,634 & 448,605 & 457.694 \\
\hline Vented and Flared $\ldots$ & 9.018 & 9,786 & 10,727 & 10.784 & $14.09 ?$ \\
\hline Markeled Production & 378.638 & 393.729 & 402.907 & ค 437.822 & 443,597 \\
\hline Extraction Loss & 23,240 & 19,932 & 21476 & 28.440 & 32.004 \\
\hline \multirow[t]{2}{*}{ Total Dry Production } & 355,398 & 373,797 & 381.431 & A 409.382 & 411.593 \\
\hline & \multicolumn{5}{|c|}{ Supply (million cubic feet) } \\
\hline Dry Production & 355,398 & 373.797 & 381,431 & A 409.382 & 411.593 \\
\hline \multicolumn{6}{|l|}{ Receipts at State Borders } \\
\hline Imports & 0 & 0 & 0 & 0 & 0 \\
\hline Intransit Receipts & 0 & 0 & 0 & 0 & 0 \\
\hline Interstate Receipts & 0 & 0 & 0 & 0 & 0 \\
\hline \multicolumn{6}{|l|}{ Withdrawals from Storage } \\
\hline Underground Slorage & 0 & 0 & 0 & 0 & 0 \\
\hline$\ldots \ldots \ldots$ & 0 & 0 & 0 & 0 & 0 \\
\hline Supplemental Gas Supplies & 0 & 0 & 0 & 0 & 0 \\
\hline Balancing ltem & $-16,178$ & -844 & 13.700 & 11.841 & 24,060 \\
\hline Total Supply & 339,220 & 372,353 & 395.131 & 421.223 & 4.35 .652 \\
\hline
\end{tabular}


Table 45. Surmmary Statistics for Natural Gas -- Alaska, 1988-1992 (Continued)

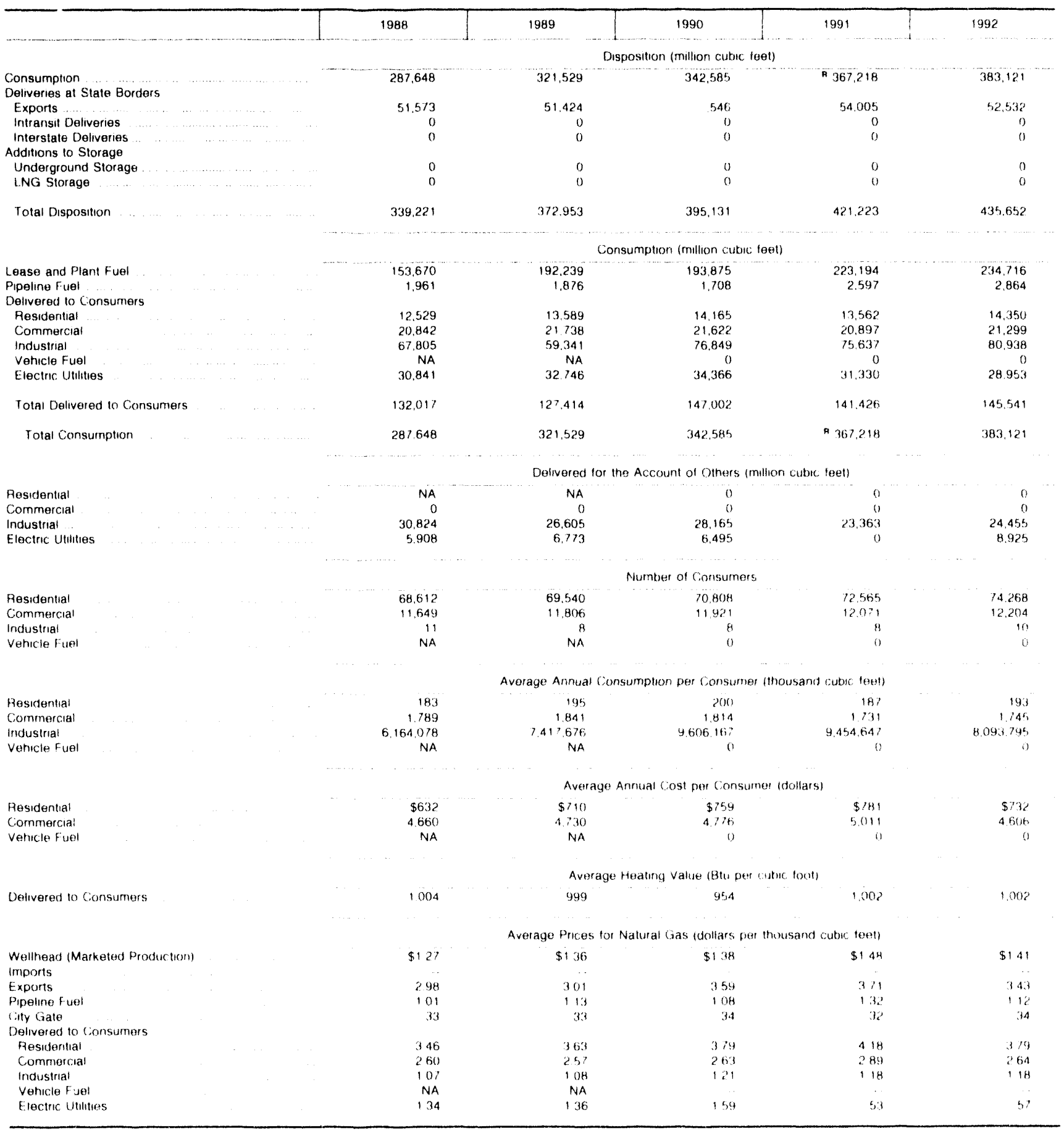

- Less than 500,000 cubic feel or 500 consumers

A Revised data

Not applicable

Na Not avallable

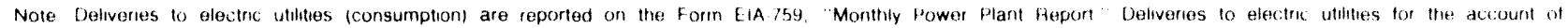
uthers are ceported on the Form FiA.176. "Annual Geport of Natural and Supplemental Gas Supply and Disposition" Sese the discussion on electnc uthity data and Tatile Al in Ap pendix A for a comparison of reporting to these two torms lotals may not add due to independent rounding

Sources Energy intormation Administration (EIA). Form EIA-176. "Annual Report ol Natural and Supplementat Gas Supply arid Disposition. "Form EIA 6? ? "Afinual (Juantity and Value of Natural Gas Report." Forn E1A.857. "Monthly Feport of Natural Gas Purchases and Detivenes to Consumers. "Form f. IA - 116 , Monthly Nalurai Gas Liquids Report. F urm E.A.759. "Monthly Power Plant Feport." Form F ERC.423. "Monthly Feport of Cost and Ouality of Fuels for Electric Plants "Form FiA 131. Underground Gas Storage He,port"

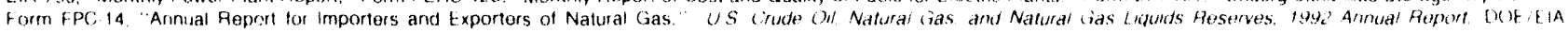
$0216(92)$, and the US Minerals Management Service 
Natural Gas 1992

Net Interstate Movements

Million

Marketed Production
Million Parcent of Cu. Feet National Total
$771 \quad .00$

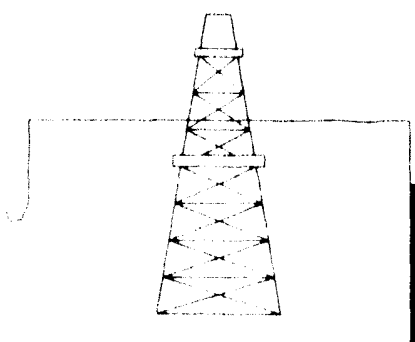

Deliveries to Consumers

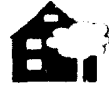

Residential:

28,386

.61

As ist

Commercial:

27,089

.97

(M)

Industrial:

19,774

.26

Vehicle Fuel:

46

9.00

$A$

Electric Utility:

30,939

Total:

106,234

1.12

.60

ARIZONA

Table 46. Summary Statistics for Natural Gas -- Arizona, 1988-1992

\begin{tabular}{|c|c|c|c|c|c|}
\hline & 1988 & 1989 & 1990 & 1991 & 1992 \\
\hline & \multicolumn{5}{|c|}{ Reserves (billion cubic feet) } \\
\hline \multirow[t]{2}{*}{$\begin{array}{l}\text { Estumated Proved Reserves }\{d r y\rangle \\
\text { as of December } 31\end{array}$} & NA & NA & NA & NA & NA \\
\hline & \multicolumn{5}{|c|}{ Number of Gas and Gas Condensate Wells } \\
\hline \multirow[t]{2}{*}{ Producing at End of Year } & 0 & 3 & 5 & 6 & 6 \\
\hline & \multicolumn{5}{|c|}{ Production (mition cubic teet) } \\
\hline $\begin{array}{l}\text { Gross Withdrawals } \\
\text { From Gas Wells } \\
\text { From Oll Wells }\end{array}$ & $\begin{array}{r}0 \\
179\end{array}$ & $\begin{array}{r}1.306 \\
149\end{array}$ & $\begin{array}{r}2,080 \\
67\end{array}$ & $\begin{array}{r}1.123 \\
1.58\end{array}$ & $\begin{array}{r}721 \\
72\end{array}$ \\
\hline Total & $1: 9$ & 1.455 & 2.147 & 1.280 & 794 \\
\hline Pepressuring & 0 & 0 & 0 & 0 & 0 \\
\hline Nonhydrocarbon Gases Removed & 0 & 0 & o & 0 & 0 \\
\hline Wet After Lease Separation & $1 / 9$ & 1.455 & $2.14 ?$ & 1.280 & 794 \\
\hline Vented and Flared & 123 & yt & 22 & 56 & 23 \\
\hline Marketed Production & 56 & 1.360 & 2.25 & 1.225 & 771 \\
\hline Extraction Loss & 0 & 0 & 0 & 0 & 0 \\
\hline \multirow[t]{2}{*}{ Total Dry Production } & 56 & 1,360 & 2.125 & 1.225 & 771 \\
\hline & \multicolumn{5}{|c|}{ Supply (rentition cubur, feet) } \\
\hline Dny Production & 56 & 360 & 2125 & 1225 & 771 \\
\hline $\begin{array}{l}\text { Receipts at State Borders } \\
\text { imports }\end{array}$ & 0 & 0 & ij & 0 & 0 \\
\hline $\begin{array}{l}\text { Imports } \\
\text { Intransit Recaipts }\end{array}$ & 0 & 0 & 0 & 0 & 0 \\
\hline Interstale Receipts & $1,287.035$ & 1.443015 & 1.428 .400 & 1.430 .709 & $1,244.223$ \\
\hline Withdrawais from Storage & & & & & \\
\hline Underground Storage & 0 & 0 & 0 & 0 & 0 \\
\hline LNG Siorage & 0 & ) & 0 & 0 & 0 \\
\hline Supplemental Gas Supples & o & 0 & $a$ & 0 & \\
\hline Balancing them & .9053 & $-21633^{\circ}$ & $-31,662$ & P. -25.332 & 4.718 \\
\hline Total Supply & 1268.034 & 1422802 & 1398.863 & $1.406,601$ & $1,249,712$ \\
\hline
\end{tabular}

See lootnotes at end of tabie 
Table 46. Summary Statistics for Natural Gas -- Arizona, 1988-1992 (Continued)

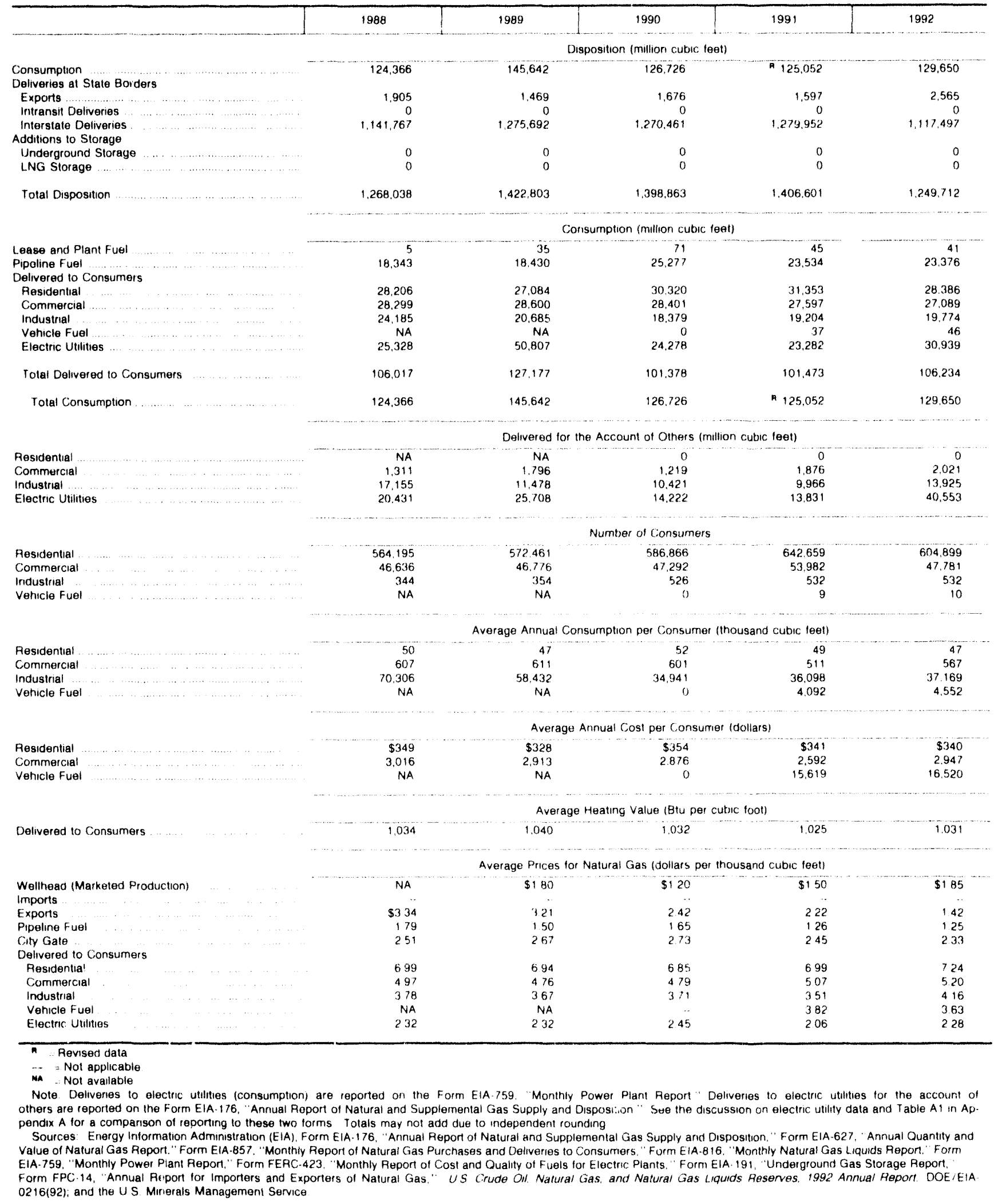


Net Interstate Movements

\section{Natural Gas}

1992

Marketed Production

Million

Cu. Feet

42,289

Million

Percent of

Cu. Feet National Totat

202,479

1.08

\section{Deliveries to Consumers}

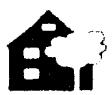

Residential:

39,474

Ain

Commercial:

25,314

ili

Industrial:

118,850

1.58

$\underset{6}{-6}$

Vehicle Fuel:

0

成

Electric Utility:

27.015

.84

.90

Total:

210,653

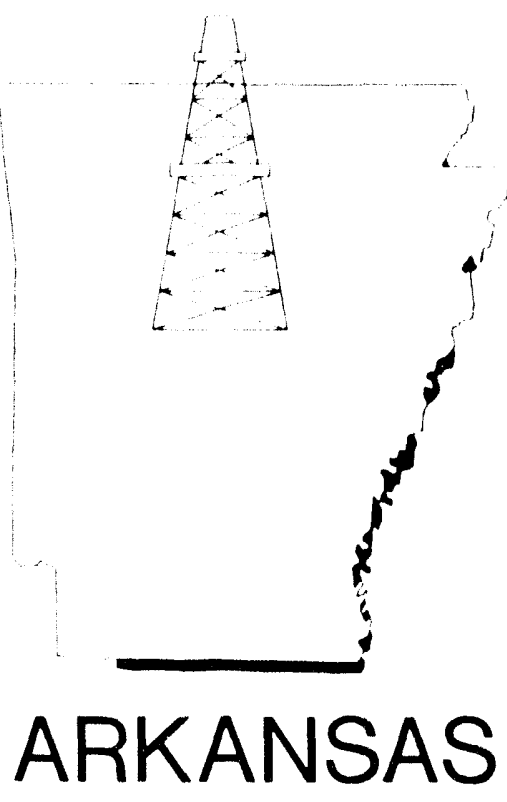

.98

1.18

Table 47. Summary Statistics for Natural Gas -- Arkansas, 1988-1992

\begin{tabular}{|c|c|c|c|c|c|}
\hline & 1988 & 1989 & 1990 & 1991 & 1992 \\
\hline & \multicolumn{5}{|c|}{ Reserves (bitlion cubr, feet) } \\
\hline \multirow[t]{2}{*}{$\begin{array}{l}\text { Estimated Proved Reserves (dry) } \\
\text { as of December } 31\end{array}$} & 1.986 & 1.772 & 1.731 & 1.669 & 1.750 \\
\hline & \multicolumn{5}{|c|}{ Number of Gas and Gas Condensate Wells } \\
\hline \multirow[t]{2}{*}{ Producing at End of Year } & 2996 & 2830 & 2.952 & 2.780 & 3.500 \\
\hline & \multicolumn{5}{|c|}{ Droduction (mithon cutsic teet) } \\
\hline Sross Withdrawals & & & & & \\
\hline From Gas Wells & 146898 & 155.740 & 161148 & 153,583 & 171.543 \\
\hline From Oil Wells & 43.780 & 43.365 & 34.256 & 16.049 & 39.364 \\
\hline Total & 190.678 & 199105 & 195.405 & 159,632 & 210,906 \\
\hline Repressuring & 22.994 & 23,837 & 20165 & 4722 & 8,056 \\
\hline Nonnydrocarton Gases Removed & 0 & 0 & 0 & 5 & 0 \\
\hline Wel Atter Lease Separation & 167.683 & 175.268 & 175.240 & ค 164,910 & 202.850 \\
\hline Vented and Flated & 1.110 & 1110 & 284 & 208 & 371 \\
\hline Marketed Produchion & 166.573 & 174.158 & 174,956 & 164.702 & 202.479 \\
\hline Extraction Loss & 1,061 & 849 & 800 & 290 & 413 \\
\hline \multirow[t]{2}{*}{ Tolal Dry Production } & 165.512 & 173309 & 174156 & 164.412 & 202.066 \\
\hline & \multicolumn{5}{|c|}{ Supply (million cubic feet) } \\
\hline Dry Production & 165512 & 173.309 & 174,156 & $1 6 4 4 \longdiv { 4 1 2 }$ & 202,066 \\
\hline Recelpls at State Borders & & & & & \\
\hline imports & 0 & 0 & 0 & 0 & 0 \\
\hline Intransit Peceipts & 0 & 0 & 0 & 0 & 0 \\
\hline Interstate Fieceipts & 2250.040 & 2.393 .404 & 2.223 .388 & 2.263 .622 & $2.235,546$ \\
\hline \multicolumn{6}{|l|}{ Withdrawals trom Storage } \\
\hline Underground Storage & 974 & 1.252 & 472 & 3,010 & 2.975 \\
\hline LNG Storage & 54 & 62 & 23 & 49 & 51 \\
\hline Supplementai Gas Supplies & 0 & 0 & 0 & 0 & 0 \\
\hline Balancing them & 525 & 17.704 & 16.237 & A $-21,688$ & $-20,293$ \\
\hline Total Suppiy & 2.417105 & 2.585 .731 & 2.414 .276 & 2409.405 & 2.420 .345 \\
\hline
\end{tabular}

See tootnotes at end of table 
Table 47. Summary Statistics for Natural Gas -- Arkansas, 1988-1992 (Continued)

\begin{tabular}{|c|c|c|c|c|c|}
\hline & 1988 & 1989 & 1990 & 1991 & 1992 \\
\hline & \multicolumn{5}{|c|}{ Disposition (million cubic teet) } \\
\hline Consumption & 216,836 & 249.641 & 232,374 & 209.124 & 224.576 \\
\hline \multicolumn{6}{|l|}{ Deliveries at State Borders } \\
\hline Exports $\ldots \ldots \ldots \ldots$ & 0 & 0 & 0 & 0 & 0 \\
\hline Intransit Deliveries $\ldots \ldots \ldots \ldots \ldots$ & 0 & 0 & 0 & 0 & 0 \\
\hline Interstate Deliveries $\ldots \ldots \ldots$ & $2,198,705$ & $2.334,761$ & $2,179.835$ & $2,199,198$ & $2,193.258$ \\
\hline \multicolumn{6}{|l|}{ Additions to Storage } \\
\hline 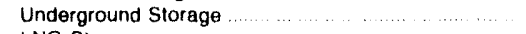 & 1.522 & 1.299 & 1.938 & 1.044 & 2.461 \\
\hline LNG Storage & 42 & 30 & 128 & 38 & 50 \\
\hline \multirow[t]{2}{*}{ Total Disposition } & $2,417,105$ & 2.585 .731 & $2.414,276$ & ค $2,409,405$ & 2.420 .345 \\
\hline & \multicolumn{5}{|c|}{ Consumption (million cutsic toot) } \\
\hline Lease and Plant Fuel. & 12.115 & 11,586 & -101 & 1.406 & 5,838 \\
\hline Pipeline Fuel ....... & 7.513 & 9,677 & 8,643 & 8,340 & 8.085 \\
\hline \multicolumn{6}{|l|}{ Delivered to Consumers } \\
\hline Pesidential $\ldots \ldots \ldots \ldots$ & 42,867 & 42,312 & 39,188 & 40.639 & 39.474 \\
\hline Commercial $\ldots \ldots \ldots \ldots$ & 27.457 & 27.271 & 25,129 & 25,986 & 25,314 \\
\hline Industrial $\ldots \ldots \ldots \ldots \ldots \ldots \ldots$ & 104,808 & 129.333 & 120.222 & 104.850 & 118,850 \\
\hline 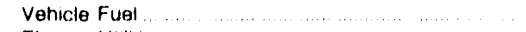 & NA & NA & 0 & 0 & 0 \\
\hline Electric Utilities & 22.075 & 29,462 & 32,090 & ค 27.903 & 27,015 \\
\hline Total Delivered to Consumers & 197.208 & 228.378 & 216.630 & ค 199.379 & 210.653 \\
\hline \multirow{3}{*}{ Total Consumption $\ldots \ldots \ldots$} & 216,836 & 249,641 & 2.32 .374 & A 209,124 & 224,576 \\
\hline & $\cdots+\ldots \ldots+\ldots$ & & 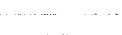 & $\ldots \ldots$ & $(2 \ldots \ldots \ldots \ldots$ \\
\hline & \multicolumn{5}{|c|}{ Deltvered for the Account of Others (million cubic teet) } \\
\hline Residential . . . . . . . . . . . & NA & NA & 0 & 0 & 0 \\
\hline 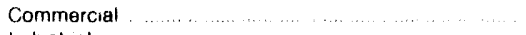 & 1.723 & 1,870 & 1,939 & 2,198 & 2,343 \\
\hline Industrial $\ldots \ldots \ldots$ & 79,343 & 104,237 & 93,332 & 84,515 & 102.468 \\
\hline \multirow[t]{3}{*}{ Electric Utilities $\ldots \ldots \ldots$} & 0 & 19.593 & 29,049 & 25.180 & 25.647 \\
\hline & r & $\cdots$ & $\cdot \ldots \ldots .$. & & ............ \\
\hline & \multicolumn{5}{|c|}{ Number of Consumers } \\
\hline Pesidential ...................... & 485,112 & 491.110 & 488,850 & 495,148 & 504,722 \\
\hline Commercial $\ldots \ldots . \quad \ldots \ldots . . . .$. & 61,630 & 61,848 & 61,530 & 61.731 & 62.221 \\
\hline 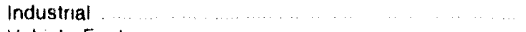 & 1,151 & 1,412 & 1,396 & 1,367 & 1,319 \\
\hline \multirow[t]{2}{*}{ Vehicle Fuel ..................... } & NA & NA & 0 & 0 & 0 \\
\hline & \multicolumn{5}{|c|}{ Average Annual Consumption per Consumer (thousand cubic foet) } \\
\hline$\ldots \ldots \ldots \ldots \ldots$ & Bis & 86 & $80^{\circ}$ & 82 & 78 \\
\hline Commercial $\quad$................. & 446 & 441 & 408 & 421 & 407 \\
\hline Industrial $\ldots \ldots \ldots$ & 91,059 & 91,596 & 86.119 & 76.701 & 90,106 \\
\hline \multirow[t]{2}{*}{ Vehicle Fuel ...................... } & NA & NA & 0 & 0 & 0 \\
\hline & \multicolumn{3}{|c|}{ Average Annual Cost per Consurner (dollars) } & & $\cdots \cdots$ \\
\hline Residential & $\$ 425$ & $\$ 418$ & $\$ 409$ & $\$ 408$ & $\$ 399$ \\
\hline Commercial & 1,935 & 1,931 & 1,821 & 1,831 & 1.783 \\
\hline \multirow[t]{2}{*}{ Vohicle Fuet } & NA & NA & 0 & 0 & 0 \\
\hline & \multicolumn{5}{|c|}{ Average Heating Values (Btu per cubsc toot) } \\
\hline \multirow[t]{3}{*}{ Delivered to Consumers } & 1.009 & 1,006 & 1.009 & 1,017 & 1,009 \\
\hline & & $\cdots \cdots \cdots$ & c........ & ......... & 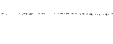 \\
\hline & & Average Prices & Gas Idollars I & nd cubc feet) & \\
\hline Wellhead (Marketed Production) & $\$ 194$ & $\$ 241$ & $\$ 206$ & $\$ 192$ & $\$ 215$ \\
\hline Imports $\ldots \ldots \ldots \ldots \ldots$ & & & & & $\cdots$ \\
\hline Exports $\ldots \ldots \ldots$ & $\cdots$ & & $\cdots$ & $\ldots$ & .. \\
\hline Pipeline Fuel $\ldots \ldots \ldots \ldots$ & 207 & 230 & 217 & 206 & 1.78 \\
\hline City Gate & 243 & 247 & 241 & 245 & 260 \\
\hline Delivered to Consumers & & & & & \\
\hline Residential ... . . . . . & 4.81 & 4.85 & 5.10 & 4.98 & 5.10 \\
\hline Cornmercial $\ldots \ldots \ldots$ & 434 & 4.38 & 446 & 435 & 438 \\
\hline Industrial $\ldots \ldots \ldots$ & 306 & 309 & 288 & 3.06 & 313 \\
\hline Vehicle Fuel $\ldots$ & NA & NA & -. & $\ldots$ & .. \\
\hline Electric Utilites & 1.39 & 169 & 157 & 144 & 1.57 \\
\hline
\end{tabular}

Revised data

Na Not applicable

Note: Deliveries to electric utlities (consumption) are reported on the Form EIA.759. "Monthly Power Plant Report" Deltveries to electric utitities for the account of others are reported on the Form ElA.176. "Arinual Report of Natural and Supplemental Gas Supply and Disposition" See the discussion on electric utlity data and Table A1 in Ap. pendix A for a comparison of reporting to these Iwo forms. Totals may not add due to independent rounding

Source Energy information Administration (EIA). Form EIA.176. "Annual Report of Natural and Supplemental Gas Supply and Disposition. "Forrn EIA-627, "Annual Ouantity and Value of Natural Gas Report, "Form EiA.857. "Monthly Report of Natural Gas Purchiases and Deliveries to Consurners," Form ElA.816. "Morithly Natural Gas Liquids Report," Form EIA-759, "Monthly Power Plant Report," Form FERC.423. "Monthly Report of Cost and Quality of Fuels for Electric Plants." Form EIA-191. "Underground Gas Storage Report," Form FPC-14. "Annual Peport for Importers and Exporters of Natural Gas," US. Crude Oil, Natural Gas, and Natural Gas Liquids Reserves, 1992 Annual Report, DOE.ElA. 0216(92), and the U.S. Minerals Management Survice 
Natural Gas 1992

Net Interstate Movements

Million

Cu. Feet

346,755

Marketed Production

Million
Cu. Feot
365,632

Percent of National Total

1.95

Deliveries to Consumers

a?

Residential:

479,537

10.22

A

asth

Commercial:

285,008

10.17

$\therefore \prod^{2}$

Industrial:

594,569

7.90

$\longrightarrow$ Vehicle Fuel:

27

5.28

国

Electric Utility:

564,432

20.41

Total:

$1,923,573$

10.82

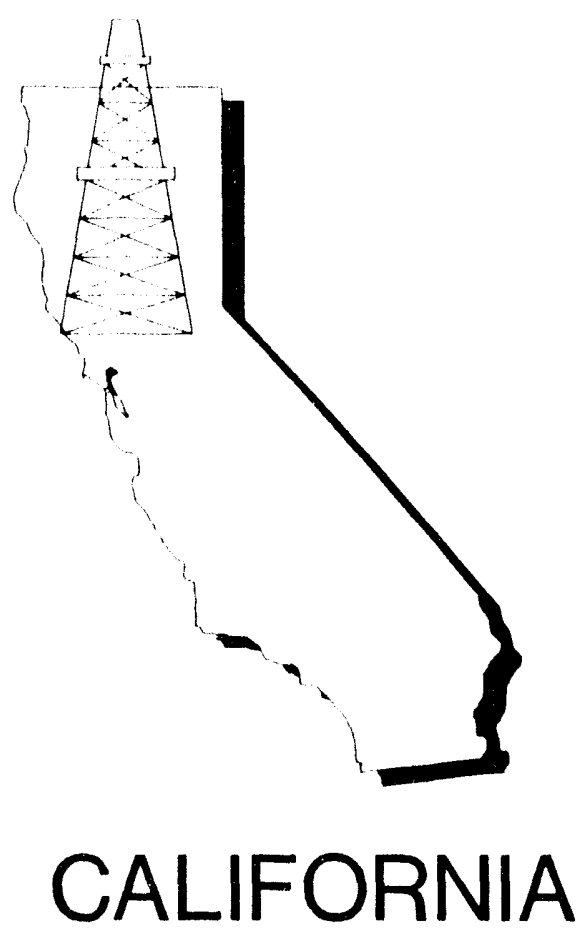

Table 48. Summary Statistics for Natural Gas -- California, 1988-1992

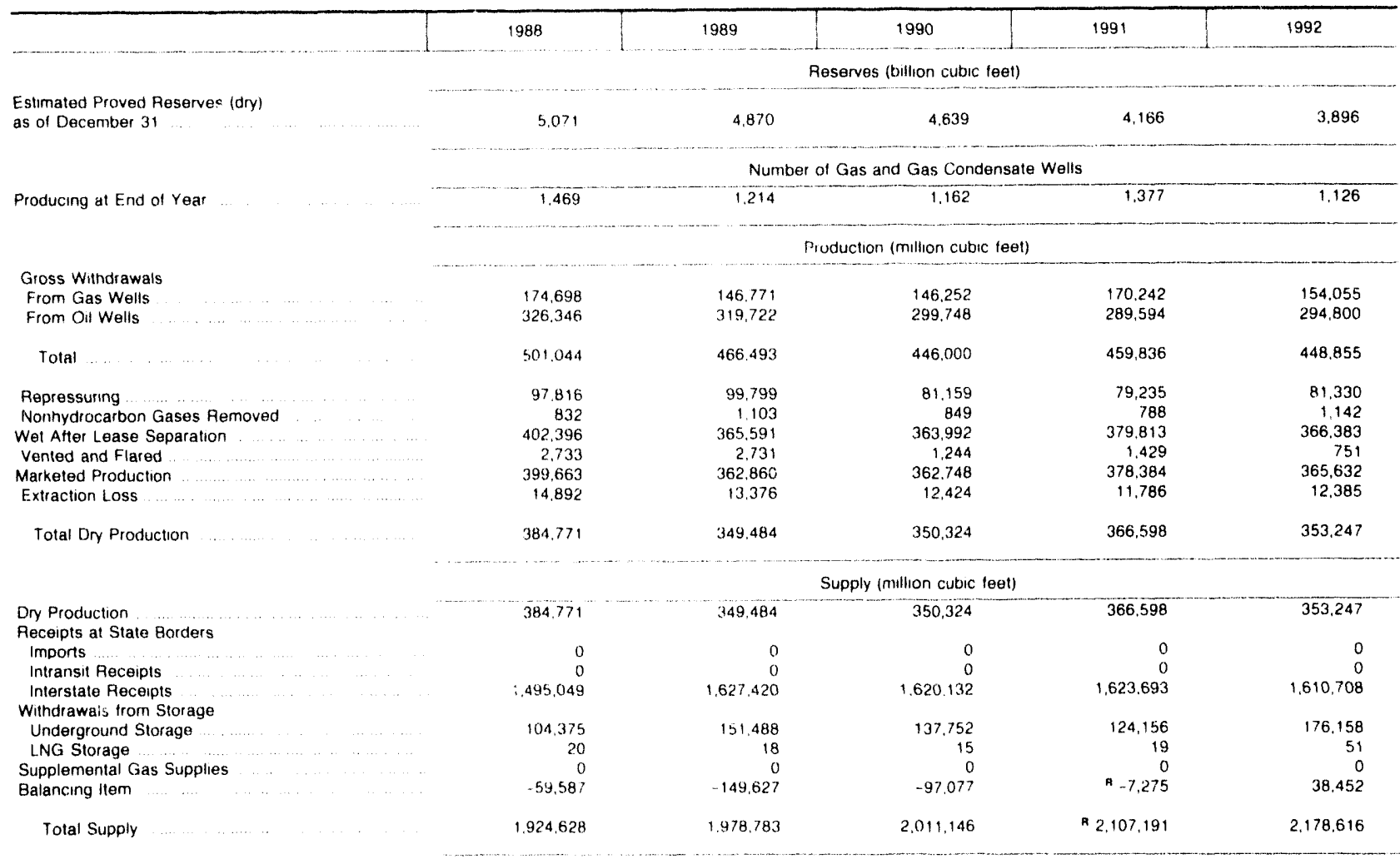

See footnotes at end of table. 
Table 48. Summary Statistics for Natural Gas -- California, 1988-1992 (Continued

\begin{tabular}{|c|c|c|c|c|c|}
\hline & 1988 & 1989 & 1990 & 1991 & 1992 \\
\hline & \multicolumn{5}{|c|}{ Disposition (million cubic feet) } \\
\hline Consumption & $1,804,452$ & $1,837.831$ & $1,864,057$ & A $1,970,709$ & $2,030,564$ \\
\hline \multicolumn{6}{|l|}{ Deliveries at State Borders } \\
\hline 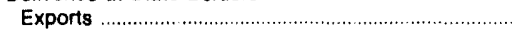 & 0 & 0 & 0 & 0 & 0 \\
\hline 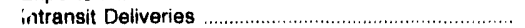 & 0 & 0 & 0 & 0 & 0 \\
\hline Interstate Deliveries & 0 & 0 & 0 & 0 & 0 \\
\hline \multicolumn{6}{|l|}{ Additions to Starage } \\
\hline 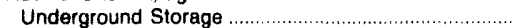 & 120,167 & 140,933 & 147,074 & 136,433 & 148,039 \\
\hline 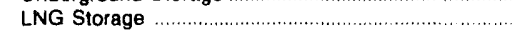 & 9 & 19 & 14 & 50 & 13 \\
\hline \multirow[t]{2}{*}{ Total Disposition } & $1,924,628$ & $1,978,783$ & $2,011,146$ & F $2,107,191$ & $2,178,616$ \\
\hline & \multicolumn{5}{|c|}{ Consumption (million cubic feet) } \\
\hline Lease and Plant Fuel .................. & 22,778 & 19,586 & 22.712 & 104.251 & 92,228 \\
\hline Pipeline Fuel ....................... & 19,194 & 19,203 & 20,132 & 18,509 & 14.763 \\
\hline \multicolumn{6}{|l|}{ Delivered to Consumers } \\
\hline 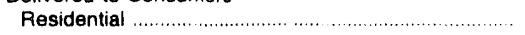 & 497,138 & 514,276 & 514,507 & 508,697 & 479,537 \\
\hline 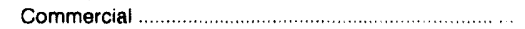 & 248,397 & 259,118 & 285,090 & 287,608 & 285,008 \\
\hline 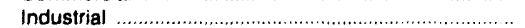 & 464,008 & 507,948 & 565,206 & 602,619 & 594,569 \\
\hline 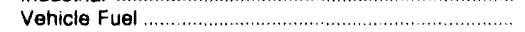 & NA & NA & 4 & 9 & 27 \\
\hline Electric Utilities & 552,938 & 517.700 & 456,406 & A 449,014 & 564,432 \\
\hline 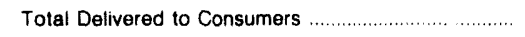 & $1,762,480$ & $1,799,042$ & $1,821,213$ & A $1.847,949$ & $1,923,573$ \\
\hline \multirow[t]{2}{*}{ Total Consumption . } & $1,804,452$ & $1,837,831$ & $1,864,057$ & A $1,970,709$ & $2,030,564$ \\
\hline & \multicolumn{5}{|c|}{ Delivered for the Account of Others (million cubic leet) } \\
\hline Residential ........................ & $N A$ & $\mathrm{NA}$ & 0 & 1,256 & 3,502 \\
\hline Commercial & 10,862 & 21,109 & 38,337 & 63,882 & 72,782 \\
\hline Industrial & 171,228 & 283,611 & 346,643 & 422.738 & 430,836 \\
\hline \multirow[t]{2}{*}{ 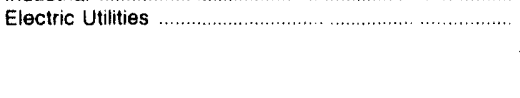 } & 55,488 & 87,126 & 114,142 & 225,773 & 406,235 \\
\hline & \multicolumn{5}{|c|}{ Number of Consurners } \\
\hline Residential & $8,113,034$ & $8,313,776$ & $8,497,848$ & $8,634,774$ & 8.680 .613 \\
\hline 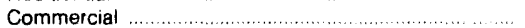 & 407.435 & 410,231 & 415,073 & 421,278 & 412,467 \\
\hline Industrial & 44,680 & 46,243 & 46,048 & 44,865 & 40,528 \\
\hline \multirow[t]{2}{*}{ Vehicle Fuel } & NA & NA & 1 & 17 & 65 \\
\hline & \multicolumn{5}{|c|}{ Average Annual Consumption per Consumer (thousand cubic teet) } \\
\hline Residential & 61 & 62 & 61 & 59 & 55 \\
\hline (2) & 610 & 632 & 687 & 683 & 691 \\
\hline 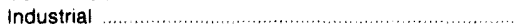 & 10,385 & 10,984 & 12,274 & 13,432 & 14,671 \\
\hline \multirow[t]{2}{*}{ Vehicle Fuel } & NA & NA & 4,342 & 539 & 420 \\
\hline & \multicolumn{5}{|c|}{ Average Annual Cost per Consurner (dollars) } \\
\hline Residential. & $\$ 346^{\circ}$ & $\$ 346$ & $\$ 350$ & $\$ 369$ & $\$ 330$ \\
\hline 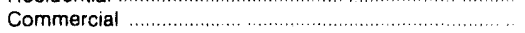 & 2.854 & 3,082 & 3,519 & 3,756 & 3,556 \\
\hline \multirow[t]{2}{*}{ 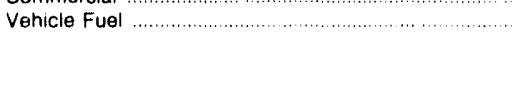 } & NA & NA & 21,031 & 3,105 & 2,698 \\
\hline & \multicolumn{5}{|c|}{ Average Heatıng Value (Btu per cubic fool) } \\
\hline \multirow[t]{2}{*}{ Delivered to Consumers } & 1,031 & 1,037 & 1,032 & 1.027 & 1.029 \\
\hline & \multicolumn{5}{|c|}{ Average Prices for Naturat Gas (dollara per thousand cubic feet) } \\
\hline Wellhead (Marketed Production) & $\$ 239$ & $\$ 2.32$ & $\$ 2.36$ & $\$ 2.46$ & $\$ 2.34$ \\
\hline Imports & -. & -. & ... & $\ldots$ & -. \\
\hline Exports & .. & .. & ... & -. & $\ldots$ \\
\hline Pipeline Fuel . & 2.55 & 2.39 & 2.40 & 2.19 & 1.40 \\
\hline City Gate & 2.60 & 2.75 & 290 & 2.80 & 272 \\
\hline \multicolumn{6}{|l|}{ Delivered to Consumers } \\
\hline (2 & 5.64 & 5.59 & 5.78 & 6.27 & 5.97 \\
\hline 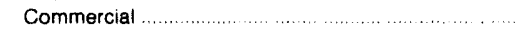 & 4.68 & 4.88 & 512 & 5.50 & 5.15 \\
\hline Industrial & 3.76 & 3.75 & 3.91 & 396 & 3.67 \\
\hline 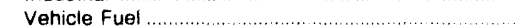 & NA & NA & 4.84 & 5.77 & 6.43 \\
\hline Electric Utilities & 293 & 304 & 3.13 & 2.95 & 2.81 \\
\hline
\end{tabular}

\section{A $=$ Revised data. \\ NA $\therefore$ Not available.}

-- Not applicable.

Note: Deliveries to electric utilities (consumption) are reported on the Form ElA.759, "Monthly Power Plant Report." Deliveries to electric utlities for the account of others are reported on the Form EIA.176. "Annual Report of Natural and Supplemental Gas Supply and Disposition " See the discussion on electric, utility data and Table A1 in Ap. pendix $A$ for a comparison of reporting to these two forms. Totals may not add due to independent rounding.

Sources: Energy Information Administration (EIA). Form EIA.176. "Annual Report of Natural and Supplemental Gas Supply and Disposition " Form EIA-627. "Annual Quantity and Value of Natural Gas Report" Form EIA-857 "Monthly Report of Natural Gas Purchases and Deliveries 10 Consumers " Form ElA.816 "Monthly Natural Gas Liquids Report." Form ElA.759, "Monthly Power Plant Report," Form FERC-423. "Monthly Poport of Cost and Quality of Fuels for Electric Plants," Form ElA-191, "Underground Gas Storage Report," Form FPC-14, "Annual Report for Importers and Exporters nf Natural Gas," U.S. Crude OIl. Natural Gas, and Natural Gas Liquids Resenves, 1992 Annual Report, DOE/EIA 0216(92); and the U.S. Minerals Management Service 


\section{Natural Gas 1992}

Net Interstate Movements

Million

Cu. Foet

Mlllion

Marketed Production

Cu. Feet

323,041

Deliveries to Consumers

हरे?

Residential:

94,614

A.

ast

Commercial:

66,420

57,579

Industrial:

Vehicle Fuel:

23

Percent of National Total

1.73

DIII

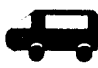

Electric Utility:

5,010

A

Total:

223,656
2.02

2.37

.76

4.50

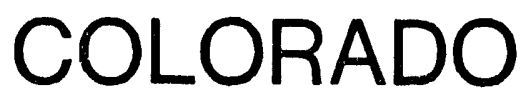

.18

1.26

Table 49. Summary Statistics for Natural Gas -- Colorado, 1988-1992

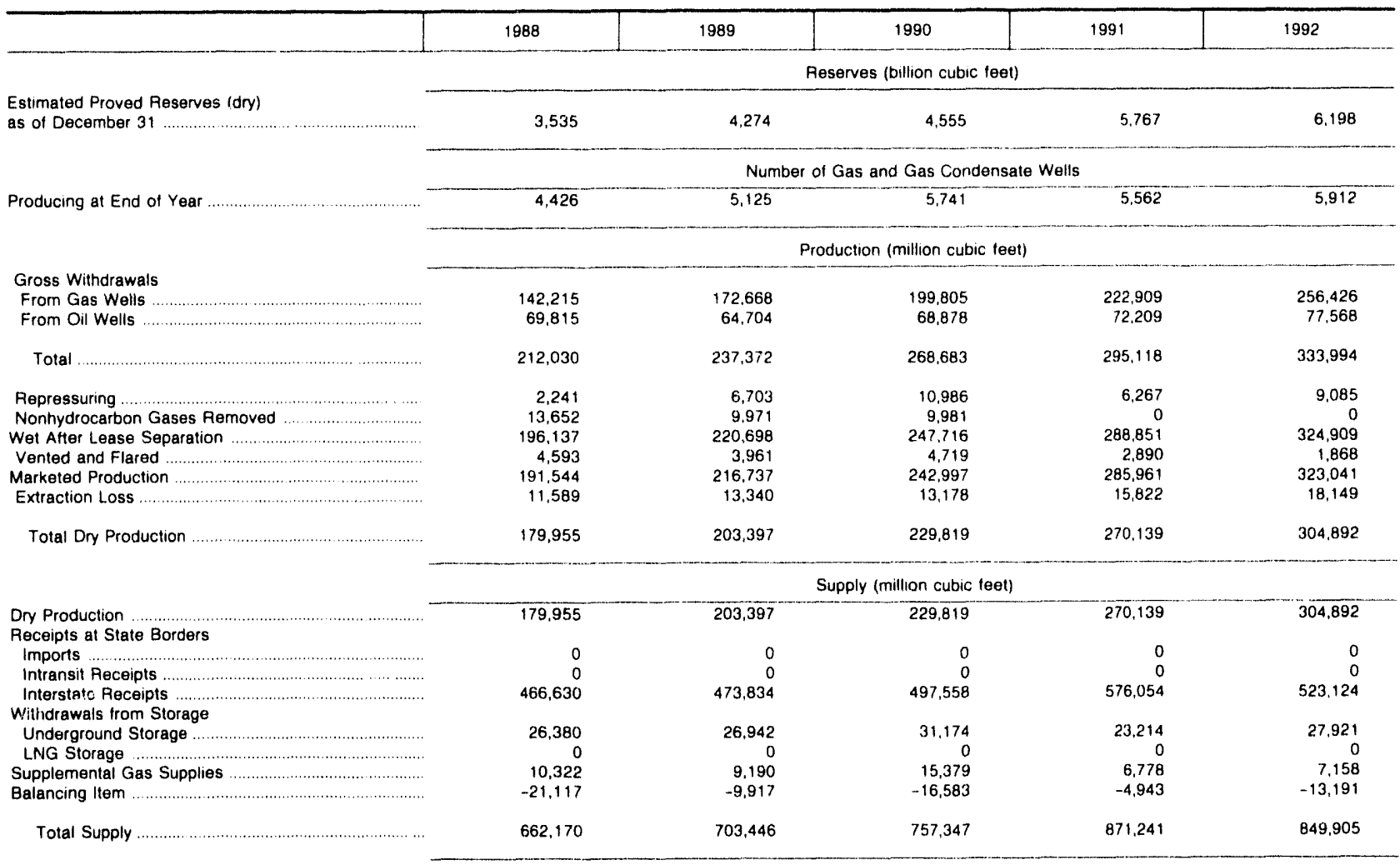

See footnotes at end of table. 
Table 49. Summary Statistics for Natural Gas -- Colorado, 1988-1992 (Continued)

\begin{tabular}{|c|c|c|c|c|c|}
\hline & 1988 & 1989 & 1990 & 1991 & 1992 \\
\hline & \multicolumn{5}{|c|}{ Disposition (million cubic feet) } \\
\hline Consumption . & 227.584 & 242,215 & 239,112 & 260,513 & 253,073 \\
\hline \multicolumn{6}{|l|}{ Deliveries at State Borders } \\
\hline Exports & 0 & 0 & 0 & 0 & 0 \\
\hline Intransit Deliveries & 0 & 0 & 0 & 0 & 0 \\
\hline Interstate Deliveries & 408,688 & 433,066 & 490.561 & 580,1 Ah & 573,771 \\
\hline \multicolumn{6}{|l|}{ Additions to Storage } \\
\hline Underground Storage & 25,898 & 28,165 & 27,674 & 30,584 & 23.061 \\
\hline 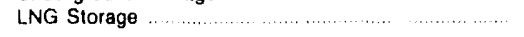 & 0 & 0 & 0 & 0 & 0 \\
\hline \multirow[t]{2}{*}{ Total Disposition } & 662,170 & 703,446 & 757,347 & 871.241 & 849.905 \\
\hline & \multicolumn{5}{|c|}{ Consumption (million cubic teet) } \\
\hline Lease and Plant Fuel .. & 11,622 & 12,221 & 17,343 & 23,883 & 21,169 \\
\hline Pipeline Fuel ................. & 7.875 & 11,228 & 9.114 & 8.346 & 8.248 \\
\hline \multicolumn{6}{|l|}{ Delivered to Consumers } \\
\hline Residential .................. & 92,888 & 91,567 & 91,916 & 97,440 & 94,614 \\
\hline 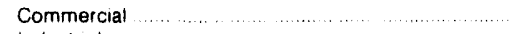 & 68.515 & 67.477 & 66,290 & 68.938 & 66.420 \\
\hline Industrial & 38,197 & 51,348 & 48,952 & 56.176 & 57,579 \\
\hline 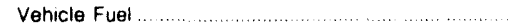 & NA & NA & 11 & 15 & 23 \\
\hline 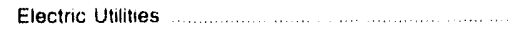 & 8,488 & 8.375 & 5,485 & 5,715 & 5.019 \\
\hline Total Delivered to Consumers & 208,087 & 218.766 & 212.655 & 228.283 & 223.656 \\
\hline \multirow[t]{2}{*}{ Total Consumption. } & 227.584 & 242,215 & 239,112 & 260,513 & 253.073 \\
\hline & \multicolumn{5}{|c|}{ Delivered for the Account of Others (million cubic teet) } \\
\hline Residential. & NA & NA & 163 & 335 & 0 \\
\hline (n) & 1,574 & 1,789 & 1.800 & 2.763 & 2,993 \\
\hline Industrial & 23.309 & 29,106 & 33,799 & 36,685 & 39.040 \\
\hline \multirow[t]{2}{*}{ Electric Utilities ............. } & 4.603 & 5,624 & 4,904 & 6,097 & 3,931 \\
\hline & \multicolumn{5}{|c|}{ Number of Consumers } \\
\hline Residential $\ldots \ldots \ldots \ldots \ldots$ & 955.810 & 970,512 & 983,592 & $1,002,154$ & $1.022,542$ \\
\hline Commerclat $\ldots \ldots \ldots \ldots$ & 110,769 & 112,004 & 112,661 & 113,945 & 114.898 \\
\hline$\ldots \ldots \ldots \ldots \ldots \ldots$ & 923 & 976 & 1,018 & 1.074 & 1,108 \\
\hline \multirow[t]{2}{*}{ Vehicle Fuel. } & NA & NA & 3 & 3 & 5 \\
\hline & \multicolumn{5}{|c|}{ Average Annual Consumption per Consumer (thousand cubic feet) } \\
\hline Residential & 97 & 94 & 93 & 97 & 93 \\
\hline Commercial $\ldots \ldots \ldots . . . . . . . . . .$. & 619 & 602 & 588 & 605 & 578 \\
\hline Industrial $\ldots \ldots \ldots$ & 41,383 & 52.610 & 48.087 & 52.305 & 51.967 \\
\hline \multirow[t]{2}{*}{ Vehicle Fuel } & NA & NA & 3,676 & 5.011 & 4.688 \\
\hline & \multicolumn{5}{|c|}{ Average Annual Cost per Consumer (dollars) } \\
\hline Residentıal & $\$ 429$ & $\$ 436$ & $\$ 427$ & $\$ 446$ & $\$ 422$ \\
\hline Commercial .............. & 2388 & 2,437 & 2,350 & 2.446 & 2,315 \\
\hline \multirow[t]{2}{*}{ Vehicle Fuel. } & NA & NA & 12,786 & 17.235 & 16.156 \\
\hline & \multicolumn{5}{|c|}{ Average Heating value (Blu per cubic fool) } \\
\hline \multirow[t]{2}{*}{ Delivered to Consumers } & 1,006 & 1,011 & 1,005 & 1.029 & 1.023 \\
\hline & \multicolumn{5}{|c|}{ Average Prices for Natural Gas (Jollars per thousand cubic feet) } \\
\hline Welihead (Marketed Production) & $\$ 159$ & $\$ 152$ & $\$ 155$ & $\$ 141$ & $\$ 137$ \\
\hline Imports $\ldots \ldots \ldots$ & $\cdots$ & $+\cdot$ & .. & $\cdots$ & $-\cdot$ \\
\hline 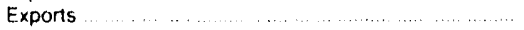 & .. & $\cdots$ & -... & $\ldots$ & -. \\
\hline Pipeline Fuel & 2.24 & 175 & 175 & 179 & 189 \\
\hline 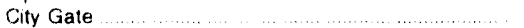 & 307 & 2.96 & 294 & 2.85 & 285 \\
\hline \multicolumn{6}{|l|}{ Delivered to Consumers } \\
\hline 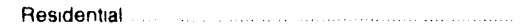 & 4.42 & 463 & 457 & 459 & 456 \\
\hline 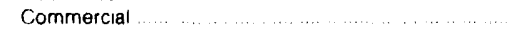 & 386 & 405 & 399 & 404 & 400 \\
\hline -. $\ldots \ldots \ldots, \ldots \ldots \ldots \ldots \ldots$ & 3.45 & 253 & 278 & 2.34 & 220 \\
\hline . & NA & NA & $34 \mathrm{G}$ & 344 & 3.45 \\
\hline Electric Utilities $\ldots \ldots \ldots \ldots \ldots \ldots \ldots$ & 225 & 2.23 & 215 & 214 & 214 \\
\hline
\end{tabular}

NA Not available

Note Deliveries 10 electric utilities (consumption) are reported on the Form ElA.759. "Monthly Power Plant Report" Deliveries to electric utilities for the account of others are reported on the Form EIA-176. "Annual Repon of Natural and Supplemental Gas Supply and Disposition." See the discussion on electric uttity data and Table At in Ap. pendix $A$ for a comparison of reporting to these two forms Totals may not add due to independent rounding

Sources Energy Information Administration (EIA). Form ElA.176. "Annual Repon of Natural and Supplemental Gas Supply and Disposition." Form EIA-627, "Annual Ouantity and Value of Natural Gas Report." Form ElA-857. "Monthly Report of Natural Gas Purchases and Deliveries to Consurners." Form EIA 816. "Monthly Natural Gas Liquids Report. "Form ElA-759, "Monthly Power Plant Pepon," Form FE.RC-423, "Monthly Peport of Cost and Quality or Fuels for Electric Plants, "Form ElA-191. "Underground Gas Storage Repor,," Form FPC.14. "Annual Report for importers and Exporters of Natural Gas," US Crude OIl Natural Gas, and Nalural Gas Liquids Reserves. 1992 Annual Report. DOE./EIA. $0216(92):$ and the US Minerals Management Service 


\section{Natural Gas 1992}

Net Interstate Movements

Million

Cu. Foot

118,601

Marketed Production

Mlllion

Percent of

National Total

.00

Deliveries to Consumers

aर

Residential:

42,394

.90

Aiti

ast

Commercial:

29,838

$\therefore$ Iㅔ

Industrial:

36,383

Vehicle Fuel:

0

.00

$A$

Electric Utility:

2,100

.08

Total:

110,716

.62

Table 50. Summary Statistics for Natural Gas -- Connecticut, 1988-1992

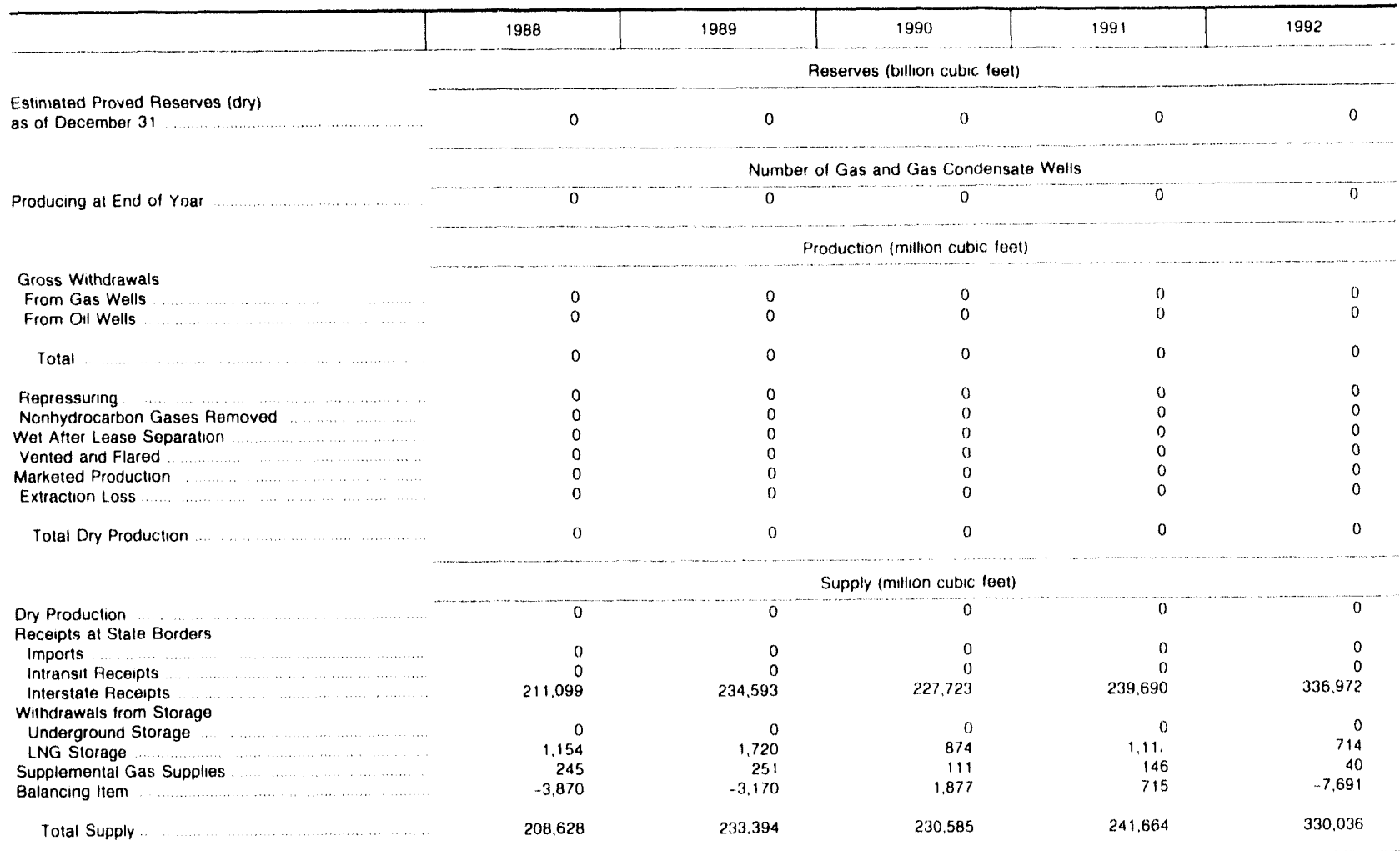

See footnotes at end of table 
Tabie 50. Summary Statistics for Natural Gas -- Connecticut, 1988-1992 (Continued)

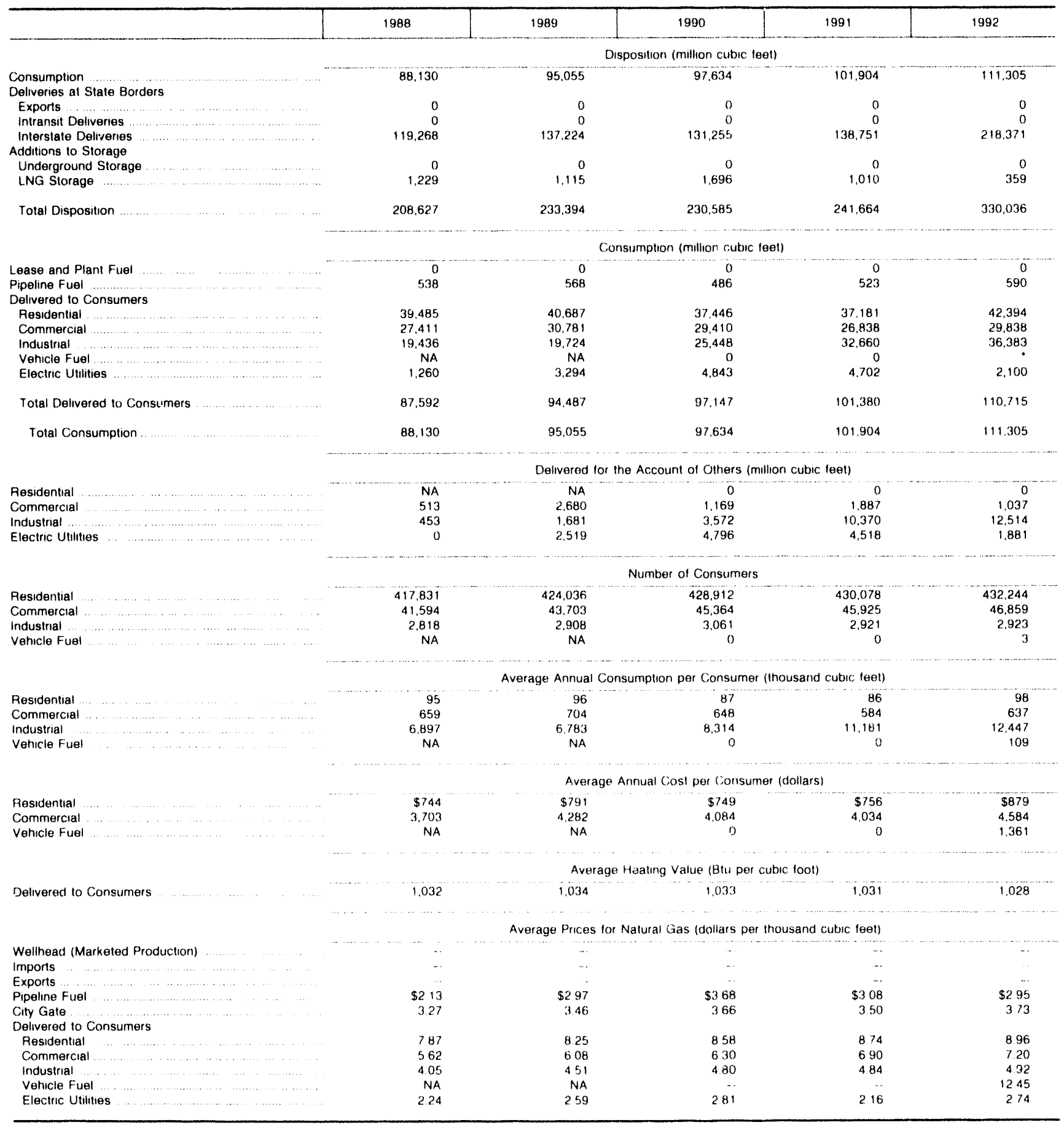

Less than 500,000 cubic feet

a Revised data

Na Not available

Note: Deliveries to electric utlities (consumption) are reported on the Form ElA.759 "Monthly Power Plant Report" Deiliveries 10 electric utilities tor the account of others are reported on the Form ElA-176. "Annual Report of Natural and Supplemental Gas Supply and Disposiltion" See ine discussion on electric utlity data and Table A1 in Ap. pendix A for a comparison of reporting to these two torms. Totals and supplemental Gas Supply and Dispositon

pendix A for a comparison of reporting to these two forms. Totals may not add due to independent rounding. Value of Natural Gas Report," Form EIA.857. "Monthly Report of Natural Gas Purchases and Deliveries to Consumers." Form EIA-B16. "Monthly Natural Gas Liquids Report," Form EIA.759. "Monthly Power Plant Peport," Form FERC-423. "Monthly Report of Cost and Quality of Fuels for Electric Plants. "Form ElA.191. "Underground Gas Storage Report." Form FPC-14. "Annual Feport tor Importers and Exporters of Natural Gas." US Crude OIl, Natural Gas, and Natural Gas Liquids Reserves. 1992 Annual Report. DOE/EIA. 0216(92): and the U.S Minerals Management Service 
Net Interstate Movements

\section{Natural Gas}

1992

Marketed Production

Million
Cu. Foel
0

Million

Cu. Foot

37.634

Percent of

National Total

.00

\section{Deliveries to Consumers}

$\hat{\theta}^{3}$

Residential:

8,194

.17

$A:$

int

Commercial:

4,965

.18

ind

Industrial:

18,060

.24

$\longrightarrow$ Vehicle Fuel:

0

.00

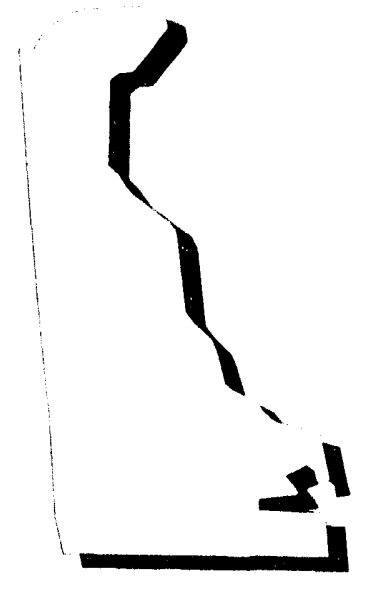

$A$

Electric Utility:

8,384

.30

Total:

39,604

.22

Table 51. Summary Statistics for Natural Gas -- Delaware, 1988-1992

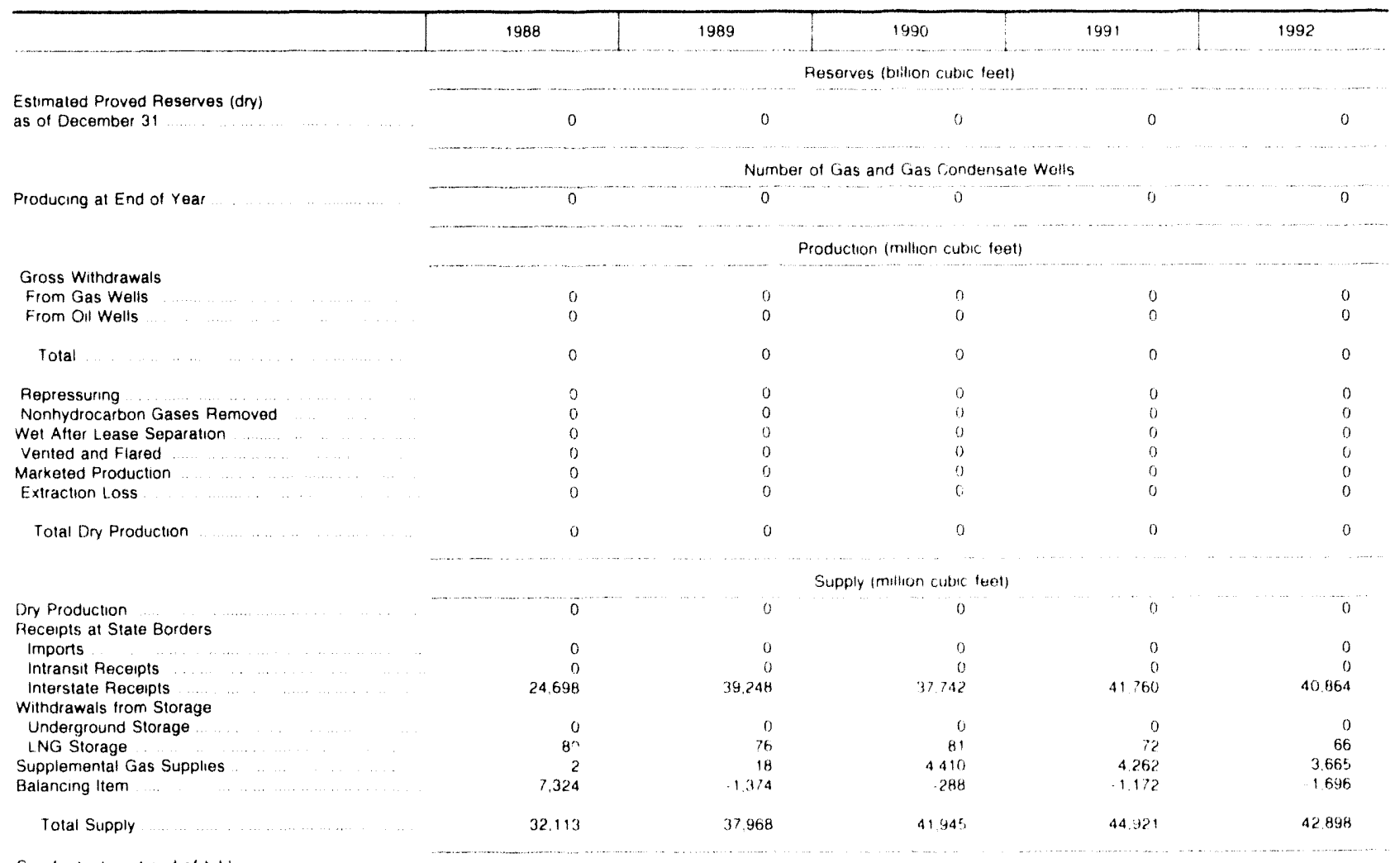

See toolnotes at end of tabie 
Table 51. Summary Statistics for Natural Gas -- Delaware, 1988-1992 (Continued)

\begin{tabular}{|c|c|c|c|c|c|}
\hline & 1988 & 1989 & 1990 & 1991 & 1992 \\
\hline & \multicolumn{5}{|c|}{ Disposition (million cubic teet) } \\
\hline Consumption & 29,258 & 34,924 & 39.127 & 41,948 & 39,608 \\
\hline \multicolumn{6}{|l|}{ Deliveries at State Borders } \\
\hline Exports & 0 & 0 & 0 & 0 & 0 \\
\hline Intransit Deliveries & 0 & 0 & 0 & 0 & 0 \\
\hline Interstate Deliveries & 2.762 & 3.005 & 2.730 & 2.894 & 3.230 \\
\hline \multicolumn{6}{|l|}{ Additions to Storage } \\
\hline Underground Storage. & 0 & 0 & 0 & 0 & 0 \\
\hline LNG Storage & 93 & 39 & 88 & 79 & 61 \\
\hline \multirow[t]{2}{*}{ Total Disposition } & 32.113 & 37.968 & 41,945 & 44,921 & 42.898 \\
\hline & \multicolumn{5}{|c|}{ Consumption (million cubic feet) } \\
\hline Lease and Plant Fuel & 0 & 0 & 0 & 0 & 0 \\
\hline Pipeline Fuel ....... & 4 & 4 & 4 & 4 & 4 \\
\hline \multicolumn{6}{|l|}{ Delivered to Consumers } \\
\hline Residential ... & 7,586 & 7,595 & 7,270 & 7.189 & 8.194 \\
\hline 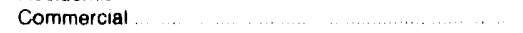 & 4.041 & 4.184 & 4,042 & 4.253 & 4,965 \\
\hline Industrial $\ldots \ldots \ldots$ & 14,803 & 15.141 & 17,036 & 16.147 & 18,060 \\
\hline Vehicle Fuel & NA & NA & 0 & 0 & 0 \\
\hline Eleciric Utilities & 2.824 & 7,999 & 10,776 & 14,354 & 8.384 \\
\hline Total Delivered to Consumers & 29.253 & 34,919 & 39.124 & 41,944 & 39,604 \\
\hline \multirow[t]{2}{*}{ Total Consumption } & 29.258 & 34.924 & 39,127 & 41.948 & 39.608 \\
\hline & \multicolumn{5}{|c|}{ Delivered for the Account of Others (million cubic teet) } \\
\hline …, $, \ldots \ldots, \ldots \ldots, \ldots, \quad \ldots \ldots \ldots \ldots \ldots$ & NA & NA & 0 & 0 & 0 \\
\hline Commercial $\ldots \ldots \ldots \ldots$ & 0 & 0 & 0 & 0 & 0 \\
\hline Industrial & 3,089 & 3.682 & 4.847 & 5.509 & 6,316 \\
\hline \multirow[t]{2}{*}{ Electric Unities ................ } & 409 & 313 & 35 & 39 & 48 \\
\hline & \multicolumn{5}{|c|}{ Number of Consumers } \\
\hline Residential. & 84,329 & 86,428 & 88.894 & 91467 & 94,027 \\
\hline Commercial $\ldots \ldots \ldots$. & 6.566 & 7.074 & 7.485 & 1895 & 8.173 \\
\hline$\ldots \ldots \ldots \ldots \ldots \ldots$ & 233 & 235 & 240 & 243 & 248 \\
\hline \multirow[t]{2}{*}{ Vehicle Fuel ........ } & NA & NA & 0 & 0 & 0 \\
\hline & \multicolumn{5}{|c|}{ Average Annual Consumption per Consumer (thousand cubuc teet) } \\
\hline Resıdentıal & 90 & 88 & 82 & 79 & 87 \\
\hline Commercial .......... & 615 & 591 & 540 & 539 & 607 \\
\hline Industrial $\ldots \ldots$ & b. 532 & 64.430 & 70.984 & 66.449 & 72.823 \\
\hline \multirow[t]{2}{*}{ Vehicle Fuel } & NA & NA & 0 & 0 & 0 \\
\hline & \multicolumn{5}{|c|}{ Average Annual Cost per Consurner (dollars) } \\
\hline Residentıal & $\$ 540$ & $\$ 564$ & $\$ 501$ & $\$ 460$ & $\$ 535$ \\
\hline Commercial & 3.035 & 3.189 & 2765 & 2591 & 2999 \\
\hline \multirow{3}{*}{ vehicie Fuel } & NA & NA & () & 0 & 0 \\
\hline & & $\cdots \cdots$ & (1) - . & & \\
\hline & \multicolumn{5}{|c|}{ Average Heating value (Btu per cubrc toot) } \\
\hline \multirow[t]{2}{*}{ Delivered to Consumers } & 1023 & 1,028 & 1.026 & 1034 & 1035 \\
\hline & \multicolumn{5}{|c|}{ Average Prices for Natural Gas (dollars per thousand cubic leet) } \\
\hline Wellhead (Marketed Production). & $\cdots$ & (n) & 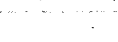 & & . \\
\hline Imports & $\ldots$ & - & $\cdots$ & & \\
\hline Exports & .. & $\ldots$ & & & - \\
\hline Pipeline Fuel & $\$ 295$ & $\$ 3.10$ & $\$ 310$ & $\$ 288$ & $\$ 301$ \\
\hline City Gate & 288 & 2.92 & 276 & 254 & 283 \\
\hline Delivered to Consumers & & & & & \\
\hline Residential & 600 & 642 & 613 & 586 & 613 \\
\hline Commercral & 493 & 539 & 512 & 481 & 494 \\
\hline Industrial & 322 & 345 & 344 & 309 & 325 \\
\hline Vehicle Fuel & NA & NA & $\cdots$ & & $\cdots$ \\
\hline Electric Utilities & 2.59 & 273 & 272 & 249 & 2.70 \\
\hline
\end{tabular}

MA $=$ Not available

Note Deliveries to electric utilties (consumption) are reported on the Form ElA.759. "Monthly Power Plant Report "Deliveries to electric utilities tor the account of others are reported on the Form ElA.176. "Annual Report of Natural and Supplemental Gas Supply and Disposition "See the discussion on electric utilty data and Table Al in Ap. pendix $A$ for a comparison of reporting to these two forms. Tolals may not add due to independent rounding

pendix A for a comparison of reporting to these two forms. Tolals may not add due to independent rounding

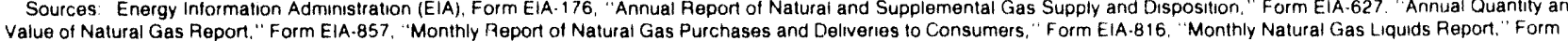

Value of Natural Gas Report," Form ElA.857, "Monthly Peport of Naturai Gas Purchases and Deliveries to Consumers, "Form ElA.816, "Monthly Natural Gas Liquids Report," Form
ElA.759. "Monthly Power Plant Peport," Form FERC.423. "Monthly Feport of Cost and Quality of Fuels for Electric Plants. "Form EIA-191, "Underground Gas Storage Report,"

Form FPC-14. "Annual Repor lor Importers and Exporters of Natural Gas." US Crude OIl, Natural Gas, and Natural Gas Liquids Resenes. 1992 Annual Report. DOE./EIA.

0216(92); and the US. Minerals Management Service 
Natural Gas 1992

Net Interstate Movements

Million

Cu. Fool

33,422

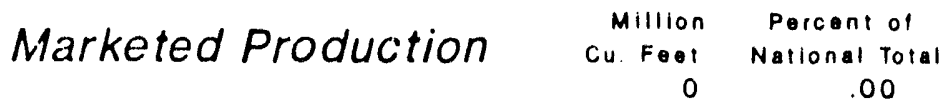

Deliveries to Consumers

â;

Residential:

16,587

$7:$

inst

Commercial:

16,103

ill

Industrial:

Vehicle Fuel:

A

Electric Utility:

Total:

32,690
.35

.57

0

.00

.00

.00

18

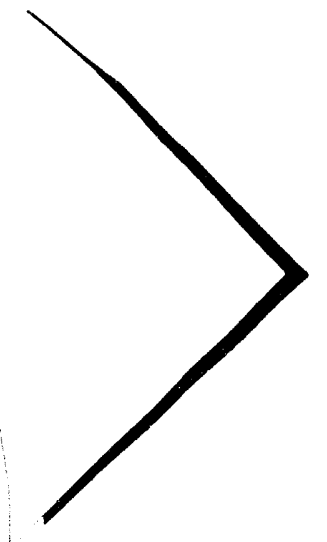

DISTRICT

OE

COLUMBIA

Table 52. Summary Statistics for Natural Gas -- District of Columbia, 1988-1992

\begin{tabular}{|c|c|c|c|c|c|}
\hline & 1988 & 1989 & 1990 & 1991 & 1992 \\
\hline & \multicolumn{5}{|c|}{ Reserves (billion cubic teet) } \\
\hline \multirow[t]{2}{*}{$\begin{array}{l}\text { Estimated Proved Reserves (dry) } \\
\text { as of December } 3 \text { ? }\end{array}$} & 0 & 0 & 0 & 0 & 0 \\
\hline & \multicolumn{5}{|c|}{ Number of Gas and Gas Condensate Wells } \\
\hline Producing at End of rear & 0 & 0 & 0 & 0 & 0 \\
\hline Gross Withdrawals & & & & & \\
\hline From Gas Wells & 0 & 0 & 0 & 0 & 0 \\
\hline From Oil Wells & 0 & 0 & 3 & 0 & 0 \\
\hline Total & 0 & 0 & 0 & 0 & 0 \\
\hline Hepressuring & 0 & 0 & 0 & 0 & 0 \\
\hline Nonnydiocartion Gases Femover & 0 & 0 & 0 & 0 & 0 \\
\hline Wet After Lease Separation & 0 & 0 & 0 & 0 & 0 \\
\hline vented and Flared & 0 & 0 & 0 & 0 & 0 \\
\hline \multirow[t]{2}{*}{ Total Dry Production } & 0 & 0 & 0 & 0 & 0 \\
\hline & \multicolumn{5}{|c|}{ Suppiy (million cubic leet) } \\
\hline Dry Pioduction & 0 & 0 & 0 & 0 & 0 \\
\hline \multicolumn{6}{|l|}{ Receipts at State Eorders } \\
\hline Imports & 0 & 0 & 0 & 0 & 0 \\
\hline Intransit Feceipts & 0 & 0 & 0 & 0 & 0 \\
\hline Interstate Flecelpts & 33.587 & 34.598 & 29.321 & 31872 & 33.422 \\
\hline \multicolumn{6}{|l|}{ Withdrawals toom Storage } \\
\hline Underground Storage: & 0 & 0 & 0 & 0 & 0 \\
\hline LNG Storage & 0 & 0 & 0 & 0 & 0 \\
\hline Supplemental Gas Supplies & 0 & 0 & 0 & 0 & 0 \\
\hline Balancing ttem & -868 & -1.175 & -457 & -771 & -465 \\
\hline Total Supply & 32.719 & 33.423 & 28864 & 31.101 & 32,957 \\
\hline
\end{tabular}

See footnotes at end of lable 
Table 52. Summary Statistics for Natural Gas -- District of Columbla, 1988-1992 (Continued)

\begin{tabular}{|c|c|c|c|c|c|}
\hline & 1988 & 1988 & 1890 & 1981 & 1992 \\
\hline & \multicolumn{5}{|c|}{ Disposition (million cubic feet) } \\
\hline Sonsumption & 32,719 & 33.422 & 28,864 & 31.101 & $32.95,7$ \\
\hline \multicolumn{6}{|l|}{ Deliveries at State Borders } \\
\hline Exports $\ldots \ldots \ldots \ldots$ & 0 & 0 & 0 & 0 & 0 \\
\hline Intransit Deliveries & 0 & 0 & 0 & 0 & 0 \\
\hline Interstate Deliveries ...... & 0 & 0 & 0 & 0 & 0 \\
\hline \multicolumn{6}{|l|}{ Additions to Storage } \\
\hline Underground Storage & 0 & 0 & 0 & 0 & 0 \\
\hline LNG Storage & 0 & 0 & 0 & 0 & 0 \\
\hline \multirow[t]{2}{*}{ Total Disposition } & 32,719 & 33.422 & 28,864 & 31.101 & 32.957 \\
\hline & \multicolumn{5}{|c|}{ Consumption (million cubic feet) } \\
\hline Lease and Plant Fuel ................ & 0 & 0 & 0 & 0 & 0 \\
\hline Pipeline Fuel ........... & 236 & 249 & 253 & 265 & 266 \\
\hline \multicolumn{6}{|l|}{ Delivered to Consumers } \\
\hline Residentiai $\ldots$ & 17,471 & 17,433 & 15,137 & 15,286 & 16587 \\
\hline Commercial & 15,012 & 15,741 & 13,473 & 15.550 & 16,103 \\
\hline Industrial $\quad \ldots \quad \ldots$ & 0 & 0 & 0 & 0 & 0 \\
\hline Venicle Fuel ... $\quad \ldots \ldots$ & NA & NA & 0 & 0 & 0 \\
\hline Electric Utilities. & 0 & 0 & 0 & 0 & 0 \\
\hline Total Delivered to Consumers & 32,483 & 33,174 & 28,611 & 30,836 & 32.690 \\
\hline \multirow[t]{2}{*}{ Total Consumption } & 32,719 & 33,422 & 28,864 & 31,101 & 32.957 \\
\hline & \multicolumn{5}{|c|}{ Detivered for the Account of Others (million cubic teet) } \\
\hline Residential & NA & NA & 0 & 0 & 0 \\
\hline Commercial & 0 & 0 & 0 & 417 & 155 \\
\hline Industrial & 0 & 0 & 0 & 0 & 0 \\
\hline \multirow[t]{2}{*}{ Electric Utities } & 0 & 0 & 0 & 0 & 0 \\
\hline & \multicolumn{5}{|c|}{ Number of Consumers } \\
\hline Residential & 134,758 & 134,837 & 136.183 & 136,629 & 136.438 \\
\hline Commercial & 11,370 & 11,354 & 11,322 & 11,318 & 11,206 \\
\hline industrial & 0 & 0 & 0 & 0 & 0 \\
\hline \multirow[t]{2}{*}{ Venicle Fuel } & NA & NA & 0 & 0 & 0 \\
\hline & \multicolumn{5}{|c|}{ Average Annual Consumption per Consumer (thousand cubic leet) } \\
\hline Residential & 130 & 129 & 111 & 112 & 122 \\
\hline Commercial & 1,320 & 1,386 & 1,190 & 1,374 & $: 437$ \\
\hline Industrial & 0 & 0 & 0 & 0 & 0 \\
\hline \multirow[t]{2}{*}{ Venicle Fuet } & NA & NA & 0 & 0 & 0 \\
\hline & \multicolumn{5}{|c|}{ Average Annual Cost per Consumer (dollars) } \\
\hline Residential & $\$ 902$ & $\$ 962$. & $\$ 798$ & $\$ 791$ & $\$ 925$ \\
\hline Commercial & 6.643 & 7.347 & 6,703 & 7,103 & 2.704 \\
\hline \multirow[t]{2}{*}{ Vehicie Fue: } & NA & NA & 0 & 0 & 0 \\
\hline & \multicolumn{5}{|c|}{ Average Heating Value (Btu per cubic toot) } \\
\hline \multirow[t]{2}{*}{ Delivered to Consumers } & 1.011 & 1.010 & 1.008 & 1,006 & 1,007 \\
\hline & \multicolumn{5}{|c|}{ Average Prices for Natural Gas (dollars per thousand cubic feet) } \\
\hline Wellhead (Marketed Production) & $\therefore$ & $\ldots$ & $\therefore$ & $\cdots$ & \\
\hline imports & -. & $\ldots$ & $\ldots$ &.- & \\
\hline Exports & .. & .. & $\ldots$ & .. & \\
\hline 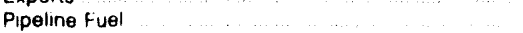 & $\$ 2.94$ & $\$ 303$ & $\$ 2.99$ & $\$ 278$ & $\$ 295$ \\
\hline City Gate. & $\ldots$ & -. & .. & -. & \\
\hline \multicolumn{6}{|l|}{ Delivered to Consumers } \\
\hline Residential & 6.96 & 744 & 718 & 707 & 761 \\
\hline$\ldots \ldots \ldots$ & 503 & 530 & 5.63 & 517 & 5.36 \\
\hline 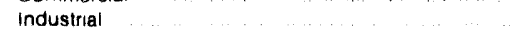 & .. & - & $\ldots$ & $\ldots$ & \\
\hline Venicio Fuel & NA & NA & $\cdots$ & $\cdots$ & \\
\hline Electric Utilities & .. & .. & .. & .. & \\
\hline
\end{tabular}

\section{MA $=$ Not avallable \\ - Not applicable}

Nole: Deliveries to electric utlities (consumption) are reported on the Form ElA.759, "Monthly Power Plant Report" Deliveries to electric utilities tor the account of others are reported on the Form EIA.176. "Annual Report of Natural and Supplemental Gas Supply and Disposition " See the discussion on electric utility data and Table A1 in Ap. pendix $A$ for a comparison of reporting to these two forms Totals may not add due to independent rounding.

Sources. Energy Information Administration (E.A). Form EIA. 176. "Annual Report of Natural and Supplemental Gas Supply and Disposition, "Form ElA.627, "Annual Quantity and Value of Natural Gas Report" "Form EIA.857 "Monthly Report of Natural Gas Purchases and Deliveries to Consumers, "Form EIA.816. "Monthiy Natural Gas L.iquids Report. "Form ElA.759 "Monthly Power Plant Report."Form FERC.423 "Monthly Report of Cost and Quality of Fuels for Electric Plants." Form EiA.191. "Underground Gas Storage Report."

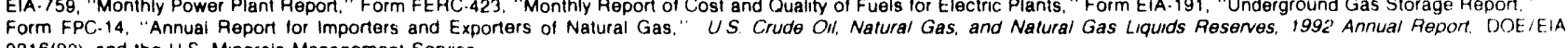
$0216(92)$, and the US Minerais Management Service 
Natural Gas 1992

Net Interstate Movements

Million

Cu. Foe

341.325

Marketed Production

Million

Cu Feot

Percent of

National Tolal

.04

Deliveries to Consumers

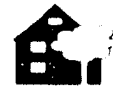

Residential:

14,380

.31

A.

insto

Commercial:

41.727

1.49

- IIII

Industrial:

84,829

1.13

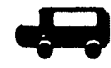

Vehicle Fuel:

9

1.76

策

Electric Utility:

202,576

7.32
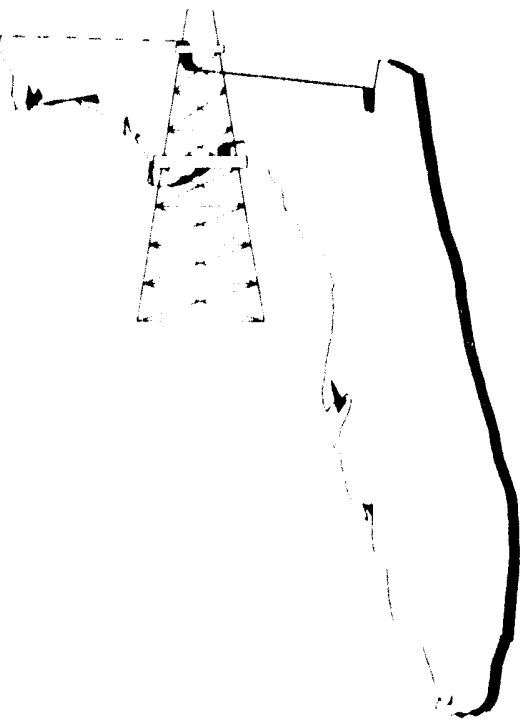

Total:

343,521

1.93

Table 53. Summary Statistics for Natural Gas .- Florida, 1988-1992

\begin{tabular}{|c|c|c|c|c|c|}
\hline & 1988 & 1989 & 1990 & 1991 & 1992 \\
\hline & \multicolumn{5}{|c|}{ Reserves (billon cubic teet) } \\
\hline \multirow[t]{2}{*}{$\begin{array}{l}\text { Estirnated Proved Heserves (dry) } \\
\text { as of Deceniber } 31\end{array}$} & 5,1 & 46 & $4^{5}$ & 38 & 47 \\
\hline & \multicolumn{5}{|c|}{ Number ot Gas and Gas Condensate Wells } \\
\hline \multirow[t]{2}{*}{ Producing at End of rear } & (1) & 0 & 6 & 0 & 0 \\
\hline & \multicolumn{5}{|c|}{ Production (mollion cutse teet) } \\
\hline Gross Withdianals & 0 & 0 & 0 & 0 & 8 \\
\hline From On Weills & 8.407 & $\begin{aligned} 0 \\
8.7 \% 3\end{aligned}$ & 2566 & 5.998 & 7.584 \\
\hline Total & 8.407 & s) & $1,5,66$ & 5898 & 1.584 \\
\hline Fepressiuning & 0 & 0 & 115 & 0 & 0 \\
\hline Nonhydrocarbon Gases Hemover & 157 & 990 & 681 & 531 & 682 \\
\hline Wet Aher L ease Separation & .650 & 7.984 & 6769 & 5.367 & 6.901 \\
\hline Vented and Flared & 166 & 450 & 286 & 482 & 245 \\
\hline Marketed Froduction & 7.484 & 7.534 & 6483 & 4.884 & $665 ?$ \\
\hline Extraction Loss & 3584 & 355,1 & 2831 & 1.893 & 2563 \\
\hline \multirow[t]{2}{*}{ Tolal Ury Production } & 3,900 & 3983 & 3652 & 2.991 & 4,094 \\
\hline & \multicolumn{5}{|c|}{ Supply (milion cutic leet) } \\
\hline Dry Production & 3900 & 3.983 & $3656^{\circ}$ & 2.991 & 4.094 \\
\hline Pecerpls al State Burders & & & & & \\
\hline Imports & 0 & 0 & 0 & 0 & a \\
\hline Intransit Receipts & 0 & 0 & 0 & 0 & 0 \\
\hline Interstate Peceipts & 290,973 & 322,798 & 325.847 & 335.163 & 341.354 \\
\hline Withurawals from Storage & & & & & \\
\hline Underground Storage & 0 & 0 & 0 & 0 & 0 \\
\hline LNG Storage & 0 & 0 & 0 & 0 & 0 \\
\hline Suppiemental (jas Supples & 0 & 0 & 0 & 0 & 0 \\
\hline Balancing Hem & 1.407 & 3.158 & .2492 & 45,391 & $1.5 \% 3$ \\
\hline Total Supply & 293.466 & 323,623 & $327,05 \%$ & A 344.145 & 353.021 \\
\hline
\end{tabular}

See tootnotes at end of table 
Table 53. Summary Statistics for Natural Gas ... Florida, 1988-1992 (Continued)

\begin{tabular}{|c|c|c|c|c|c|c|}
\hline & & 1988 & 1989 & 1990 & 1991 & 1992 \\
\hline & & \multicolumn{5}{|c|}{ Disposition (million cubic teet) } \\
\hline Consumption & & 293,433 & 323,591 & 327,023 & ค 344,116 & 352.992 \\
\hline \multicolumn{7}{|l|}{ Deliveries at State Borders } \\
\hline Exports & & 0 & 0 & 0 & 0 & 0 \\
\hline Intransit Deliveries & & 0 & 0 & 0 & 0 & 0 \\
\hline Interstate Deliveries & & 33 & 32 & 34 & 29 & 29 \\
\hline \multicolumn{7}{|l|}{ Additions to Storage } \\
\hline Underground Storage & & 0 & 0 & 0 & 0 & 0 \\
\hline ING Storago & & 0 & 0 & 0 & 0 & 0 \\
\hline \multirow[t]{2}{*}{ Total Disposition } & & 293.466 & 323.623 & 327,057 & ค 344,145 & 353.021 \\
\hline & & \multicolumn{5}{|c|}{ Consumption (million cubic teet) } \\
\hline Lease and Plant Fuel & & 7.275 & 8,942 & 1,716 & ค 3.751 & 5,134 \\
\hline Pipelirie Fuel & & 3.366 & 4,156 & 2,790 & 3.469 & 4337 \\
\hline \multicolumn{7}{|l|}{ Delivered to Consumers } \\
\hline Pesidential & & 14.891 & 13.089 & 12,976 & 12,908 & 14.380 \\
\hline Commercial & & 37,834 & 35.105 & 36,306 & 39,264 & 41,727 \\
\hline Industrial & & 75.518 & 75.485 & 84.941 & 83,398 & 84.829 \\
\hline Vehicle Fuel & & NA & NA & $\cdot$ & 7 & 9 \\
\hline Electric Utilities & & 154.550 & 186.814 & 188,293 & 201.319 & 202.576 \\
\hline Total Delivered to Consurners & & 282,792 & 310.493 & 322.516 & 336.895 & 343.52 .1 \\
\hline \multirow[t]{2}{*}{ Total Consumption } & & 293.433 & 323.591 & 327,023 & A 344.116 & 352.992 \\
\hline & & \multicolumn{5}{|c|}{ Delivered tor the Acciount of Others (million cubic teet) } \\
\hline Residential & & NA & NA & 87 & 81 & 82 \\
\hline Commercial & & 0 & 0 & 881 & 1,005 & 964 \\
\hline Industrial & & 18.054 & 19.078 & 34,996 & 49,468 & 56.893 \\
\hline \multirow[t]{2}{*}{ Electric Uthities } & & 16.059 & 11,526 & 68.783 & 168.412 & 186.524 \\
\hline & & \multicolumn{5}{|c|}{ Number of Consumers } \\
\hline Pesidential & & 446.690 & 452.544 & 457,648 & 467.221 & 471,863 \\
\hline Commercial & & 43.178 & 43,802 & 43,674 & 45,012 & 45,123 \\
\hline Industral & & $55 ?$ & 460 & 452 & F 377 & 388 \\
\hline \multirow[t]{2}{*}{ Vehicle Fuel } & & NA & NA & 1 & 4 & 6 \\
\hline & & \multicolumn{5}{|c|}{ Average Annual Consumption per Consumer (thousand cubic teet) } \\
\hline Residential & & 33 & 29 & 28 & 28 & 30 \\
\hline Commercial & & 876 & 801 & 831 & 872 & 925 \\
\hline Industrial & $\therefore \quad \therefore$ & 136,807 & 164,097 & 187.923 & 221,215 & 218.632 \\
\hline \multirow[t]{2}{*}{ Vehicle Fuel } & & NA & NA & 103 & 1,669 & 1.580 \\
\hline & & \multicolumn{5}{|c|}{ Average Annual Cost per Consumer (dollars) } \\
\hline Pesidential & & $\$ 250$ & $\$ 233$ & $\$ 240$ & $\$ 248$ & $\$ 277$ \\
\hline Commercial & & 3.980 & 3884 & 4.193 & 4.296 & 4.603 \\
\hline \multirow[t]{2}{*}{ Vehicle Fuet } & & NA & NA & 280 & 7,898 & 7.015 \\
\hline & & \multicolumn{5}{|c|}{ Average Heating Value (Btu per cubic toot) } \\
\hline \multirow[t]{2}{*}{ Delivered to Consumers } & & 1.042 & 1.042 & 1,043 & 1.049 & 1,049 \\
\hline & & \multicolumn{5}{|c|}{ Average Prices isr Natural Gas (dollars per thousand cubic teet) } \\
\hline Wellhead (Marketed Production) & & $\$ 153$ & $\$ 205$ & $\$ 225$ & $\$ 246$ & $\$ 251$ \\
\hline Imports & & & $\ldots$ & & -- & - \\
\hline Exports & & $\cdots$ & 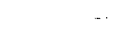 & .. & - & . \\
\hline Pipeline Fuel & & 185 & 200 & 217 & 211 & 206 \\
\hline & & 246 & 263 & 211 & 2.51 & 261 \\
\hline Delivered to Consumers & & & & & & \\
\hline Residential & & 749 & 806 & 847 & 898 & 908 \\
\hline Commercial & & 454 & 485 & 504 & 492 & 4.98 \\
\hline Industrial & & 284 & 313 & 358 & 311 & 322 \\
\hline Venicle Fuel & & NA & NA & 272 & 473 & 444 \\
\hline Electric Unilities & & 212 & 249 & 256 & 217 & 230 \\
\hline
\end{tabular}

\footnotetext{
- Less than 500.000 cubic leet

A Revised data.

NA Not avallable

Not applicable

Note Deliveries to electrir. utilties consumption) are reported on the Form FiA 759 "Monthly Power Plant Report "Deliveries 10 electric utilites for the account of others are reported on the Form E.IA.176. "Annual Report of Natural and Supplemental Gas Supply and Disposition" See the discussion on electric utility data and Iable Al in Appendix A for a comparison of reporting to these two forms Totals may not add due to independent rouriding

Sources Energy Information Administration (EIA). Form EIA. 176. "Annual Feport of Natural and Supplemental Gas Supply and Disposition. " Form EIA.627, "Annual Quantity and Value of Natural Gas Report," Form EIA.857. "Monthly Report or Natural Gas Purchases and Detivenes to Consumers, " Form ElA.816. "Monthly Natural Gas Liquids Report." Form EIA.759, "Monthly Power Plant Report," Form FE.RC-423. "Monthly Feport of Cost and Quatly of Fuels for Electric Plants. " Form E.A-191, "Underground Gas Storage Report." Form FPC. 14. "Annual Report tor Importers and Exporters of Natural Gas," "IS Crude Ol, Natural Gas, and Natural Gas Liquids Reserves, 19g2 Annual Report. DOE/EIA $0216(92)$. and the US Minerals Management Service
} 
Natural Gas 1992

Net Interstate Movements

Million

Cu. Fool

332,967

Marketed Production

Million
Cu. Fool
0

Percent of National Total .00

Deliveries to Consumers

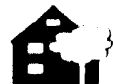

Residential:

108,214

2.31

Ai:

ist

Commercial:

53,861

172.227

III

Industrial:

0

.00

成

Electric Utility:

1.162

Total:

335,464

1.89

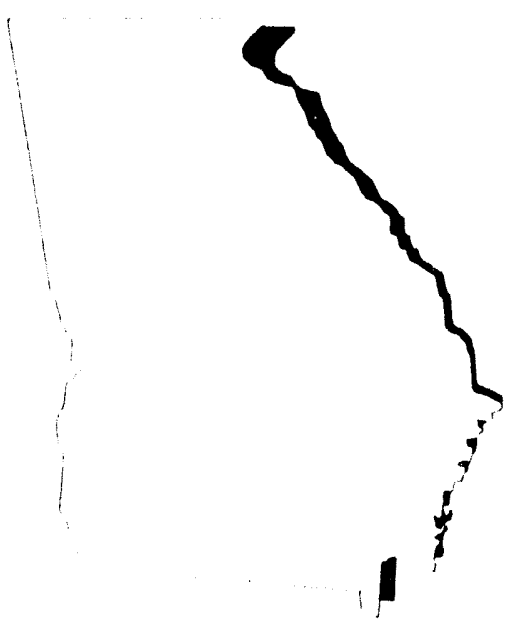

GEORGIA

Table 54. Summary Statistics for Natural Gas -- Georgia, 1988-1992

\begin{tabular}{|c|c|c|c|c|c|}
\hline & 1988 & 1989 & 1990 & 1991 & 1992 \\
\hline & \multicolumn{5}{|c|}{ Reserves (t) :hor cubic: teet) } \\
\hline \multirow[t]{2}{*}{$\begin{array}{l}\text { Estimated Proved Reserves (dry) } \\
\text { as of December } 34\end{array}$} & ) & (1) & () & 0 & 0 \\
\hline & \multicolumn{5}{|c|}{ Numter of Cias and fas Condensale Wells } \\
\hline \multirow[t]{2}{*}{ Producing at End of rear } & 0) & 0 & () & 0 & 0 \\
\hline & \multicolumn{5}{|c|}{ Proftluction (multion cuber faet) } \\
\hline Gross Withdrawals & & & & & \\
\hline From Gas Wells & 0 & () & 0 & 0 & 0 \\
\hline From Dit Weils & 0 & i) & o) & 0 & 0 \\
\hline rotal & 0 & 0) & () & 0 & 0 \\
\hline Fepressuring & 0 & 0 & 0 & 0 & 0 \\
\hline Norihydrocarbon Gases Aurnoved & 0 & 0 & 1) & 0 & 0 \\
\hline Wet Alter L gase Separation & c) & a) & 0 & (1) & 0 \\
\hline Vented and Flared & 0 & 0 & 0 & 0 & 0 \\
\hline Markeled Pruduction & 0 & 0 & 0 & 0) & 0 \\
\hline Extraction Loss & 0 & 0) & () & 0 & 0 \\
\hline \multirow[t]{2}{*}{ Total Dny Production } & 0 & () & () & 0 & 0 \\
\hline & \multicolumn{5}{|c|}{ Supply (mullion cubuc leet) } \\
\hline Dry Production & 0 & 0 & 0 & 0 & 0 \\
\hline Recerpts at State Borders & & & & & \\
\hline Imports & 0 & 0 & 0 & 0 & 0 \\
\hline Intransit Recelpts & D & 0 & () & 0 & 0 \\
\hline Interstate Feceipts & $1,303.174$ & 1320.6009 & $1,361.415_{2}$ & $1,397,050$ & $1,418,312$ \\
\hline Withdrawals trom Storage & 0 & 0 & 0 & 0 & 0 \\
\hline $\begin{array}{l}\text { Underground Storage } \\
\text { LNG Storage }\end{array}$ & 1,151 & $25+86$ & 1435 & 15,29 & 15,57 \\
\hline $\begin{array}{l}\text { LNG Storage } \\
\text { Supplemental Gas Suppliess }\end{array}$ & 241 & $\begin{array}{r}., 860 \\
292\end{array}$ & $\begin{array}{r}.433 \\
209\end{array}$ & $\begin{array}{l}3.95 \\
185\end{array}$ & 166 \\
\hline Balancing thern & 4,944 & 4.119 & 8,025 & 2.966 & 9.847 \\
\hline rotal Supply & $1,310,116$ & 1.121 .607 & 1.371 .083 & 1.395 .848 & $1,429,883$ \\
\hline
\end{tabular}

See footnotes at end of table 


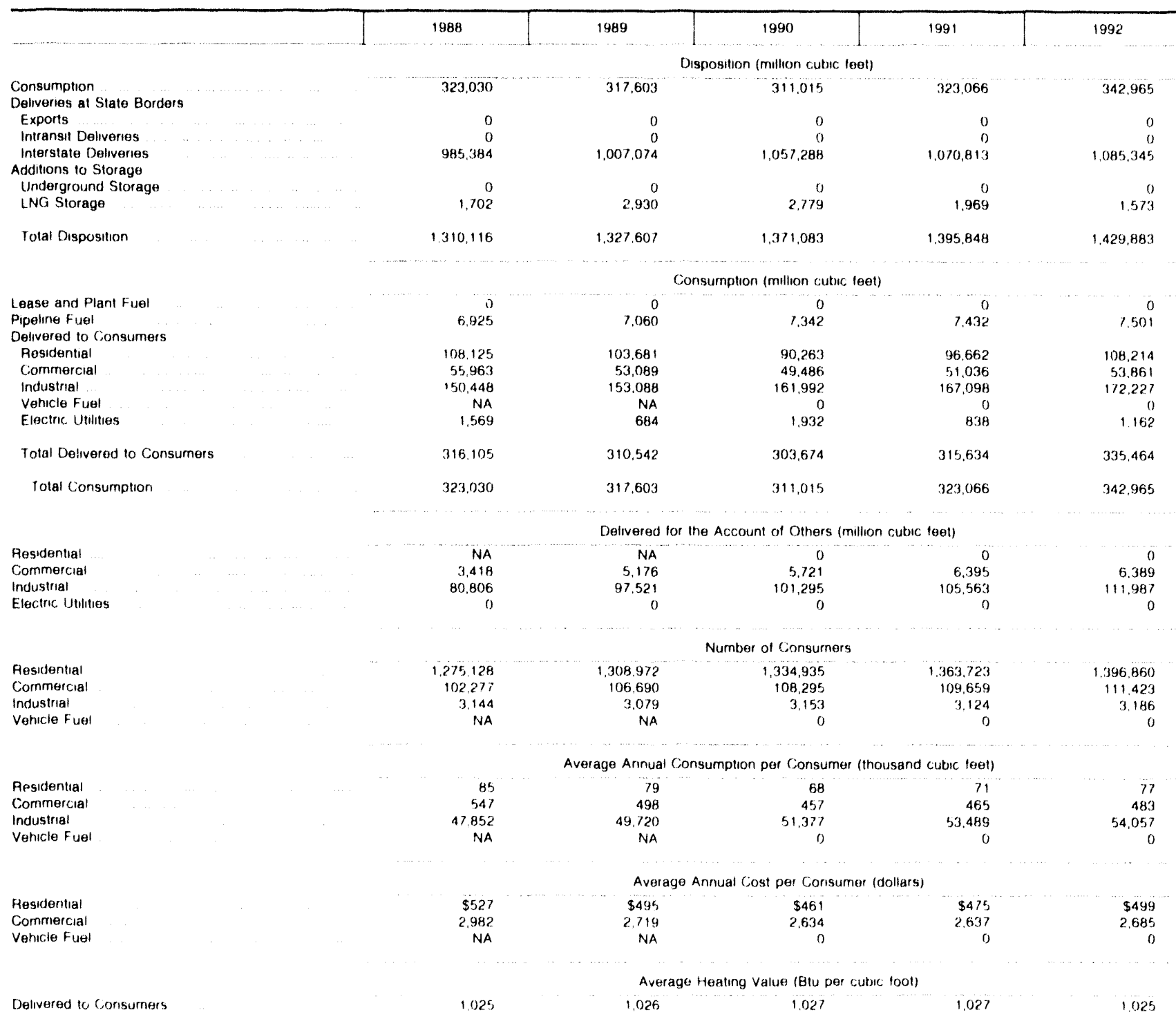

Welliread (Marketed Prorluction)

Average Prices for Natural Gas (doilars per thousand cubco teat)

Imports

Pipeline Fuel

City Gate

Delivered to Consumers

Residential

Commercial

Industrial

Venicie fuel

Electric Uilities

$\begin{array}{rrrr}\$ 269 & \$ 219 & \$ 209 & \$ 208 \\ 154 & 343 & 338 & 328 \\ 625 & 582 & 670 & \\ 547 & 576 & 567 & 544 \\ 373 & 359 & 334 & 350 \\ N A & & 59 & 289 \\ 323 & & 283 & \end{array}$

NA Not avalable

Not applicable

Note Deliveries to electric utlities (consumption) are reported on the Form ElA.759. Monthly Power Piant Report Deliveries 10 elecinc utilites tar the aciount of others are reported on the Form ElA-176. "Annual Report of Natural and Supplemental Gas Supply and Dispostion "See the discussion on eigctric uttity data and Tatie A1 in Ap. pendix A tor a comparison of reporting to these two torms Totals may not add due to indeperident rounding

Sources Energy Information Administration (E.IA). Form ElA.176. "Annual Report of Natural and Supplemental Gas Supply and Disposition," Form E.IA.627. "Arinual Ouantily and

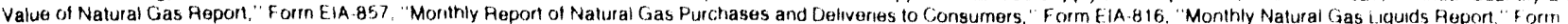

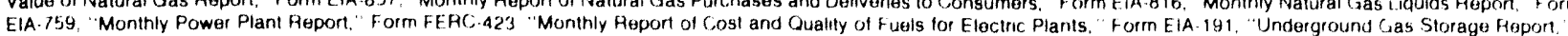

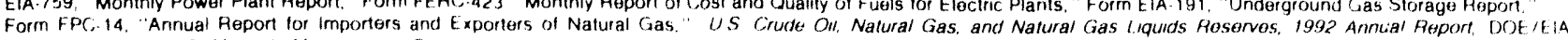
$0216(92)$, and the US Minerals Manayement Service 


\section{Natural Gas 1992}

Net Interstate Movements

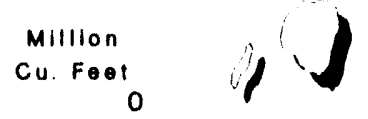

Marketed Production

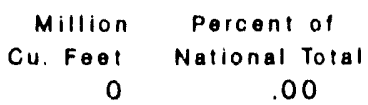

Deliveries to Consumers

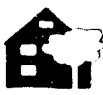

Residential:

551

.01

A.

Commercial:

2,144

.08

iII

Industrial:

0

.00

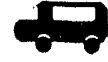

Vehicle Fuel:

0

.00

成

Electric Utility:

0

.00

Total:

2,695

.02
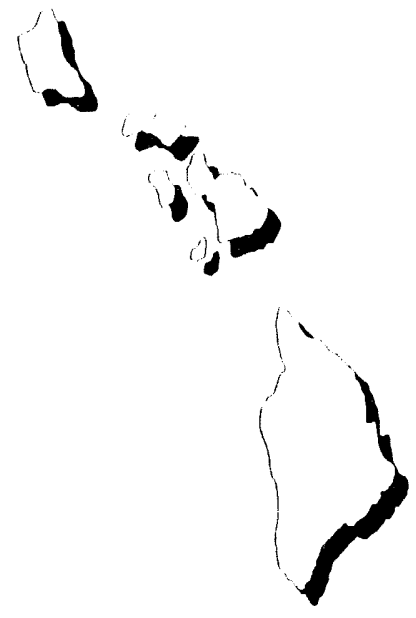

HAWAII

Table 55. Summary Statistics for Natural Gas -- Hawaii, 1988-1992

\begin{tabular}{|c|c|c|c|c|c|}
\hline & 1988 & 1989 & 1990 & 1991 & 1992 \\
\hline & \multicolumn{5}{|c|}{ Reserves (billion cubic feet) } \\
\hline \multirow[t]{2}{*}{$\begin{array}{l}\text { Estimated Proved Reserves (dry) } \\
\text { as of December } 31\end{array}$} & 0 & 0 & 0 & 0 & 0 \\
\hline & \multicolumn{5}{|c|}{ Number of Gas and Gas Condensate Welis } \\
\hline \multirow[t]{2}{*}{ Producing at End of Year. } & 0 & 0 & 0 & 0 & 0 \\
\hline & \multicolumn{5}{|c|}{ Production (million cubic feel) } \\
\hline Gross Withdrawals & & & & & \\
\hline From Gas Wells $\ldots \ldots \ldots \ldots$ & 0 & 0 & 0 & 0 & 0 \\
\hline From Oil Welss $\ldots \ldots$ & 0 & 0 & 0 & 0 & 0 \\
\hline Total $\ldots \ldots$ & 0 & 0 & 0 & 0 & 0 \\
\hline Repressuring & 0 & 0 & 0 & 0 & 0 \\
\hline Nonhydrocarbon Gases Removed & 0 & 0 & 0 & 0 & 0 \\
\hline 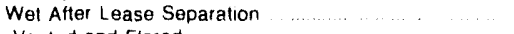 & 0 & 0 & 0 & 0 & 0 \\
\hline Vented and Flared $\ldots \ldots \ldots \ldots \ldots \ldots$ & 0 & 0 & 0 & 0 & 0 \\
\hline Marketed Production ............... & 0 & 0 & 0 & 0 & 0 \\
\hline 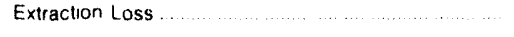 & 0 & 0 & 0 & 0 & 0 \\
\hline \multirow[t]{2}{*}{ Total Dry Production $\ldots \ldots \ldots \ldots \ldots \ldots$} & 0 & D & 0 & 0 & 0 \\
\hline & \multicolumn{5}{|c|}{ Supply (million cubic teet) } \\
\hline Dry Production & 0 & 0 & 0 & 0 & 0 \\
\hline \multicolumn{6}{|l|}{ Heceipts at State Borders } \\
\hline Imports & 0 & 0 & 0 & 0 & 0 \\
\hline Intransit Feceipts $\ldots \ldots . . .$. & 0 & 0 & 0 & 0 & 0 \\
\hline Interstate Receipts & 0 & 0 & 0 & 0 & 0 \\
\hline \multicolumn{6}{|l|}{ Withdrawals from Storage } \\
\hline Underground Storage $\ldots \ldots \ldots \ldots$ & 0 & 0 & 0 & 0 & 0 \\
\hline LNG Storage & 0 & 0 & 0 & 0 & 0 \\
\hline Supplemental Gas Supplies $\ldots \ldots \ldots$ & 2,801 & 2,844 & 2,817 & 2.725 & 2.711 \\
\hline Balancing Item $\ldots \ldots \ldots \ldots$ & -187 & -150 & 29 & -31 & -16 \\
\hline 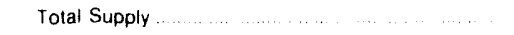 & 2.614 & 2.694 & 2.788 & 2,694 & 2.695 \\
\hline
\end{tabular}

See tootnotes at end of table. 
Table 55. Summary Statistics for Natural Gas -- Hawaii, 1988-1992 (Continued)

\begin{tabular}{|c|c|c|c|c|c|}
\hline & 1988 & 1989 & 1990 & 1991 & 1992 \\
\hline & \multicolumn{5}{|c|}{ Disposition (million cubic teet) } \\
\hline $\begin{array}{l}\text { Consumptic.n } \\
\text { Deliveries at State Borders }\end{array}$ & 2.614 & 2,694 & 2,788 & 2,684 & 2,695 \\
\hline 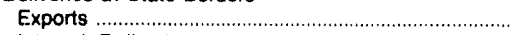 & 0 & 0 & 0 & 0 & 0 \\
\hline 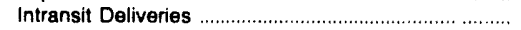 & 0 & 0 & 0 & 0 & 0 \\
\hline Interstate Deliveries & 0 & 0 & 0 & 0 & 0 \\
\hline \multicolumn{6}{|l|}{ Additions to Storage } \\
\hline 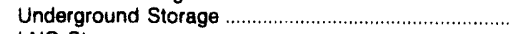 & 0 & 0 & 0 & 0 & 0 \\
\hline LNG Storage & 0 & 0 & 0 & 0 & 0 \\
\hline \multirow[t]{2}{*}{ 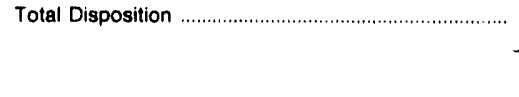 } & 2,614 & 2,694 & 2.788 & 2,694 & 2,695 \\
\hline & \multicolumn{5}{|c|}{ Consumption (million cubic feet) } \\
\hline Lease and Plant Fuel & 0 & 0 & 0 & 0 & 0 \\
\hline 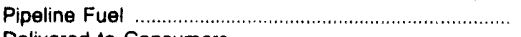 & 0 & 0 & 0 & 0 & 0 \\
\hline \multicolumn{6}{|l|}{ Delivered to Consumers } \\
\hline 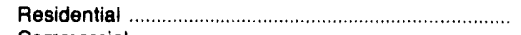 & 563 & 565 & 565 & 545 & 551 \\
\hline 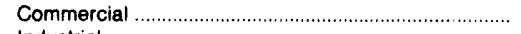 & 2,049 & 2,129 & 2,223 & 2,148 & 2,144 \\
\hline Industrial & 0 & 0 & 0 & 0 & 0 \\
\hline 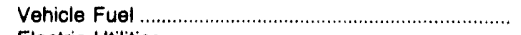 & NA & NA & 0 & 0 & 0 \\
\hline Electric Utilities & 2 & 0 & 0 & 0 & 0 \\
\hline Total Delivered to Consumers & 2,614 & 2,694 & 2,788 & 2,694 & 2,695 \\
\hline \multirow[t]{2}{*}{ Total Consumption } & 2,614 & 2,694 & 2,788 & 2,694 & 2,695 \\
\hline & \multicolumn{5}{|c|}{ Delivered for the Account of Others (million cubic feet) } \\
\hline Residential & NA & NA & 0 & 0 & 0 \\
\hline 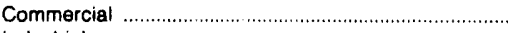 & 0 & 0 & 0 & 0 & 0 \\
\hline Industrial . & 0 & 0 & 0 & 0 & 0 \\
\hline \multirow[t]{2}{*}{ 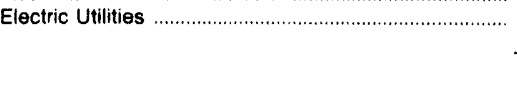 } & 0 & 0 & 0 & 0 & 0 \\
\hline & \multicolumn{5}{|c|}{ Number of Consumers } \\
\hline 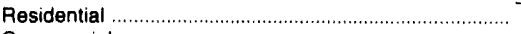 & 28,761 & 28,970 & 29,137 & 29,701 & 29,805 \\
\hline 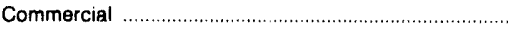 & 2,852 & 2,842 & 2,837 & 2,786 & 2,793 \\
\hline 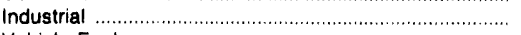 & 0 & 0 & 0 & 0 & 0 \\
\hline \multirow[t]{2}{*}{ 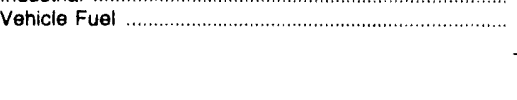 } & NA & NA & 0 & 0 & 0 \\
\hline & \multicolumn{5}{|c|}{ Average Annual Consumption per Consumer (thousand cubic teet) } \\
\hline 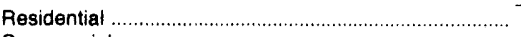 & 20 & 19 & 19 & 18 & 18 \\
\hline 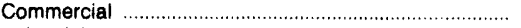 & 718 & 749 & 784 & 771 & 768 \\
\hline Industrial & 0 & 0 & 0 & 0 & 0 \\
\hline \multirow[t]{2}{*}{ 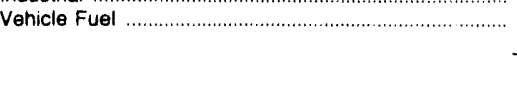 } & NA & NA & 0 & 0 & 0 \\
\hline & \multicolumn{5}{|c|}{ Average Annual Cost per Consumer (dollars) } \\
\hline 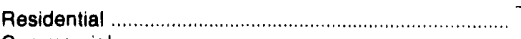 & $\$ 307$ & $\$ 305$ & $\$ 319$ & $\$ 421$ & 334 \\
\hline 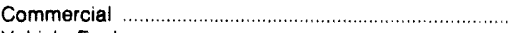 & 8,276 & 8,570 & 9.599 & 10,300 & 10,243 \\
\hline \multirow[t]{2}{*}{ 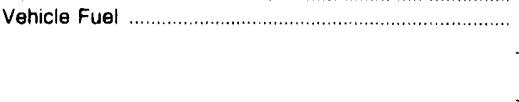 } & NA & NA & 0 & 0 & 0 \\
\hline & \multicolumn{5}{|c|}{ Average Heating Value (Btu per cubic foot) } \\
\hline \multirow[t]{2}{*}{ 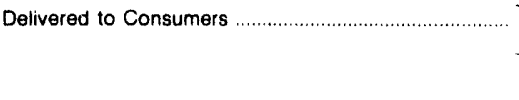 } & 1,078 & 1,080 & 1,070 & 1,080 & 1,073 \\
\hline & \multicolumn{5}{|c|}{ Average Prices for Natural Gas (dollars per thousand cubic feet) } \\
\hline Wellhead (Marketed Production) ................................... & $-\cdot$ & $\cdots$ & - & - & - \\
\hline 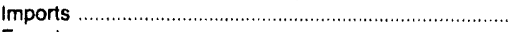 & $\cdots$ & - & - & - & - \\
\hline 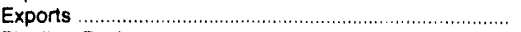 & -. & $\cdots$ & -. & -. & -. \\
\hline 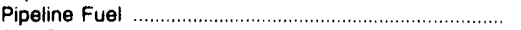 & - & - & - & -. & $\cdots$ \\
\hline 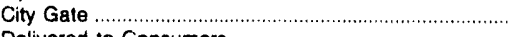 & $\$ 6.21$ & $\$ 6.49$ & $\$ 7.67$ & $\$ 8.74$ & $\$ 7.72$ \\
\hline Delivered to Consumers & & & & & \\
\hline 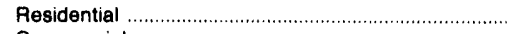 & 15.69 & 15.66 & 16.45 & 22.93 & 18.03 \\
\hline 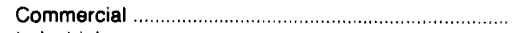 & 11.52 & 11.44 & 12.25 & 13.36 & 13.34 \\
\hline Industrial & -. & -. & -- & -- & -. \\
\hline 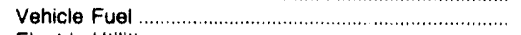 & NA & NA & - & -. & - \\
\hline 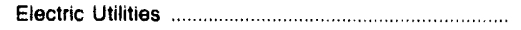 &.- & -- & $\cdots$ & -. & - \\
\hline
\end{tabular}

\section{MA $=$ Not available.}

- Not applicable

Note: Deliveries to electric utilities (consumption) are reported on the Form ElA-759, "Monthly Power Plant Report." Deliveries to electric utilities for the account of others are reported on the Form ElA-176. "Annual Report of Natural and Supplemental Gas Supply and Disposition." See the discussion on electric utility data and Table A1 in Appendix $A$ for a comparison of reporting to these two forms. Totals may not add due to independent rounding.

Sources: Energy information Administration (EIA), Form EIA-176, "Annual Report of Natural and Supplemental Gas Supply and Disposition, " Form ElA-627, "Annual Quantity and Value of Natural Gas Report," Form ElA-857, "Monthly Feport of Natural Gas Furchases and Deliveries to Consumers, "Form ElA-816, "Monthly Natural Gas Liquids Report," Form EIA.759, "Monthly Power Plant Report." Form FERC-423, "Monthly Report of Cost and Quality of Fuels for Electric Plants." Form EIA-191, "Underground Gas Storage Report,"

Form FPC-14, "Annual Report for Importers and Exporters of Natural Gas," U.S. Crude Oil, Natural Gas, and Natural Gas Liquids Reserves, 1992 Annual Report, DOE/EIA. Form FPC-14, "Annual Report for Importers and Exporis
$0216(92) ;$ and the U.S. Minerals Management Service. 


\section{Natural Gas 1992}

Net Interstate Movements

Million

Cu. Foot

$\begin{array}{ccc}\text { Marketed Production } & \begin{array}{c}\text { Million } \\ \text { cu. Foet }\end{array} & \begin{array}{c}\text { Percent of } \\ \text { National Total } \\ 0\end{array} \\ 0 & .00\end{array}$

Deliveries to Consumers

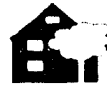

Residential:

9,659

.21

A.

inst

Commercial:

8,932

.32

(.). III

Industrial:

27,044

.36

$\longrightarrow$ Vehicle Fuel:

0

.00

$A$

Electric Utility:

0

.00

Total:

45,635

.26

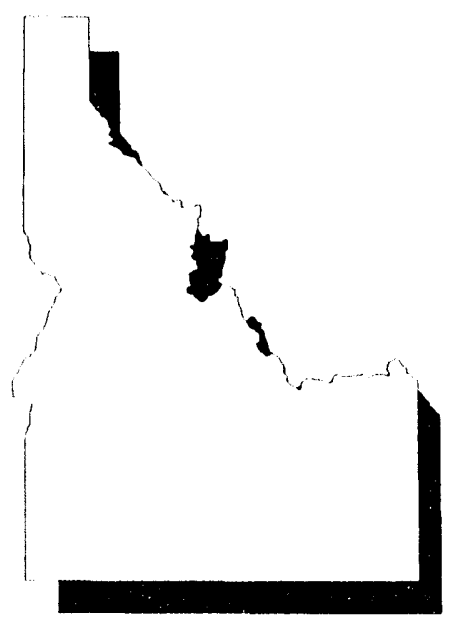

Table 56. Summary Statistics for Natural Gas -- Idaho, 1988-1992

\begin{tabular}{|c|c|c|c|c|c|}
\hline & 1988 & 1989 & 1990 & 1991 & 1992 \\
\hline & \multicolumn{5}{|c|}{ Reserves (billion cubic feet) } \\
\hline \multirow[t]{2}{*}{$\begin{array}{l}\text { Estimated Proved Reserves (dry) } \\
\text { as of December } 31\end{array}$} & 0 & 0 & 0 & 0 & 0 \\
\hline & \multicolumn{5}{|c|}{ Number of Gas and Gas Condensate Wells } \\
\hline \multirow[t]{2}{*}{ Producing at End of Year... } & 0 & 0 & 0 & 0 & 0 \\
\hline & \multicolumn{5}{|c|}{ Production (million cubic feet) } \\
\hline Gross Withdrawais & & & & & \\
\hline $\begin{array}{l}\text { From Gas Wells } \\
\text { From Oil Wells }\end{array}$ & $\begin{array}{l}0 \\
0\end{array}$ & $\begin{array}{l}0 \\
0\end{array}$ & $\begin{array}{l}0 \\
0\end{array}$ & $\begin{array}{l}0 \\
0\end{array}$ & $\begin{array}{l}0 \\
0\end{array}$ \\
\hline 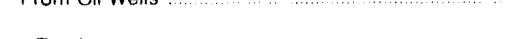 & & & & & \\
\hline 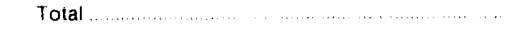 & 0 & 0 & 0 & 0 & 0 \\
\hline Repressuring & 0 & 0 & 0 & 0 & 0 \\
\hline Nonhydrocarbon Gases Removed $\ldots . . . . . . . . . . . . . .$. & 0 & 0 & 0 & 0 & 0 \\
\hline Wet After Lease Separation & 0 & 0 & 0 & 0 & 0 \\
\hline Vented and Flared & 0 & 0 & 0 & 0 & 0 \\
\hline Marketed Production . ..................... & 0 & 0 & 0 & 0 & 0 \\
\hline Extracion Loss & 0 & 0 & 0 & 0 & 0 \\
\hline \multirow[t]{2}{*}{ Total Dry Production } & 0 & 0 & 0 & 0 & 0 \\
\hline & \multicolumn{5}{|c|}{ Supply (miltion cubic feet) } \\
\hline Dry Production & 0 & 0 & 0 & 0 & 0 \\
\hline Receipts at State Borders & & & & & \\
\hline Imports & 503,451 & 501,477 & 514,597 & 496.967 & 496,451 \\
\hline Intransit Recerpts & 0 & 0 & 0 & 0 & 0 \\
\hline Interstate Receipts $\ldots \ldots \ldots \ldots \ldots \ldots \ldots$ & 60.696 & 78,911 & 80,926 & 87,575 & 103,589 \\
\hline \multicolumn{6}{|l|}{ Withdrawals from Storage } \\
\hline Underground Storage & 0 & 0 & 0 & 0 & 0 \\
\hline LNG Storage & 194 & 93 & 268 & 227 & 1,385 \\
\hline 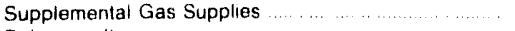 & 0 & 0 & 0 & 0 & 0 \\
\hline Balancing Item & -104 & -55 & $-3,644$ & $-1,097$ & $-7,330$ \\
\hline Total Supply & 564,237 & 580.426 & 592,142 & 583,673 & 594,096 \\
\hline
\end{tabular}

See footnotes at end of table. 
Table 56. Summary Statistics for Natural Gas -- Idaho, 1988-1992 (Continued)

\begin{tabular}{|c|c|c|c|c|c|}
\hline & 1988 & 1989 & 1990 & 1991 & 1992 \\
\hline & \multicolumn{5}{|c|}{ Disposition (million cubic feet) } \\
\hline Consumption . & 40,736 & 45,671 & 45,512 & 51,055 & 48.915 \\
\hline \multicolumn{6}{|l|}{ Deliveries at State Bordars } \\
\hline Exports & 0 & 0 & 0 & 0 & 0 \\
\hline 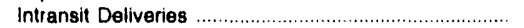 & 0 & 0 & 0 & 0 & 0 \\
\hline 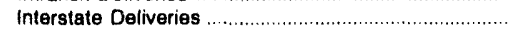 & 522,973 & $534,49 \%$ & 546,339 & 532,277 & 543,842 \\
\hline \multicolumn{6}{|l|}{ Additions to Storage } \\
\hline Underground Storage ................................ & 0 & 0 & 0 & 0 & 0 \\
\hline LNG Storage & 528 & 258 & 291 & 340 & 1,338 \\
\hline \multirow[t]{2}{*}{ Total Disposition ... } & 564,237 & 580,426 & 592,142 & 583,673 & 594,096 \\
\hline & \multicolumn{5}{|c|}{ Consumption (million cubic teet) } \\
\hline 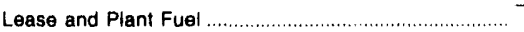 & 0 & 0 & 0 & 0 & 0 \\
\hline Pipeline Fuel & 4,091 & 4.961 & 5,081 & 4,589 & 3,280 \\
\hline \multicolumn{6}{|l|}{ Delivered to Consumers } \\
\hline 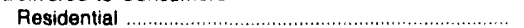 & 7,683 & 8,783 & 8,569 & 10,223 & 9.659 \\
\hline 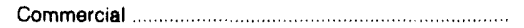 & 8,252 & 9,024 & 8,535 & 9,582 & 8,932 \\
\hline 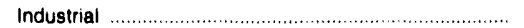 & 20,710 & 22,903 & 23,327 & 26,662 & 27,044 \\
\hline 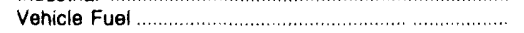 & NA & NA & 0 & 0 & 0 \\
\hline 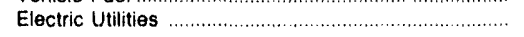 & 0 & 0 & 0 & 0 & 0 \\
\hline 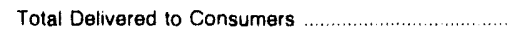 & 36,646 & 40,710 & 40,431 & 46,467 & 45,635 \\
\hline \multirow[t]{2}{*}{ Total Consumption . } & 40,736 & 45,671 & 45,512 & 51,055 & 48,915 \\
\hline & \multicolumn{5}{|c|}{ Delivered for the Account of Others (million cubic feet) } \\
\hline Residential. & $\mathrm{NA}$ & $\overline{N A}$ & 0 & 0 & 0 \\
\hline 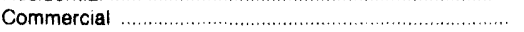 & 1,161 & 1,121 & 1,035 & 1.192 & 1,278 \\
\hline Industrial & 19,961 & 22,781 & 23,075 & 26,565 & 26.963 \\
\hline \multirow[t]{2}{*}{ 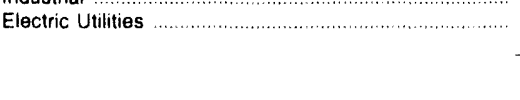 } & 0 & 0 & 0 & 0 & 0 \\
\hline & \multicolumn{5}{|c|}{ Number of Consumers } \\
\hline Residential. & 111,532 & 113,898 & 113,954 & 126,282 & 136,121 \\
\hline 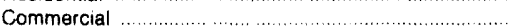 & 18,454 & 18,813 & 19.452 & 20,328 & 21,145 \\
\hline 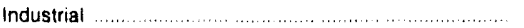 & 132 & 64 & 62 & 65 & 66 \\
\hline \multirow[t]{2}{*}{ Vehicie Fuel } & NA & NA & 0 & 0 & 0 \\
\hline & \multicolumn{5}{|c|}{ Average Annual Consumption per Consumer (thousand cubic feet) } \\
\hline Residential. & 69 & 77 & 75 & 81 & 71 \\
\hline Commercial. & 447 & 480 & 439 & $4 \% 1$ & 422 \\
\hline \multirow{3}{*}{$\begin{array}{l}\text { Industrial } \\
\text { Vehicle Fuel }\end{array}$} & 156,897 & 357.860 & 376,240 & 410.178 & 409,762 \\
\hline & NA & NA & 0 & 0 & 0 \\
\hline & \multicolumn{5}{|c|}{ Average Annual Cost per Consumer (dollars) } \\
\hline Residential. & $\$ 378$ & $\$ 389$ & $\$ 379$ & $\$ 420$ & $\$ 371$ \\
\hline 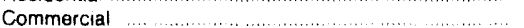 & 2.020 & 2.016 & 1.832 & 2.084 & 1.858 \\
\hline \multirow[t]{2}{*}{ 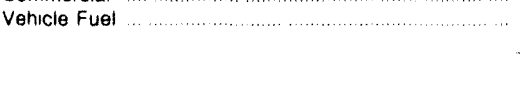 } & NA & NA & 0 & 0 & 0 \\
\hline & \multicolumn{5}{|c|}{ Average Heating Value (Btu per cubic foot) } \\
\hline \multirow[t]{2}{*}{ Detivered to Consumers } & 1,020 & 1,027 & 1.028 & 1,033 & 1,030 \\
\hline & \multicolumn{5}{|c|}{ Average Prices for Natural Gas (dollars per thousand cubic feet) } \\
\hline Wellhead (Marketed Production). &.- & -... & $\cdots$ & $\ldots$ & - \\
\hline Imports & $\$ 1.99$ & $\$ 2.04$ & $\$ 212$ & $\$ 2.01$ & $\$ 1.83$ \\
\hline Exports & -. & - & . & ... & -. \\
\hline (1) & 2.00 & 205 & 206 & 1.99 & 189 \\
\hline City Gate ........ & 2.14 & 2.17 & 208 & 2.14 & 2.18 \\
\hline \multicolumn{6}{|l|}{ Delivered to Consumers } \\
\hline Residential & 5.49 & 5.05 & 505 & 5.19 & 5.23 \\
\hline 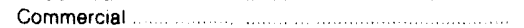 & 4.52 & 4.20 & 418 & 4.42 & 4.40 \\
\hline$(-1, \ldots$ & 426 & 2.92 & 2.72 & 2.94 & 297 \\
\hline 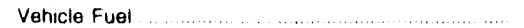 & NA & NA & -. & .. & -. \\
\hline 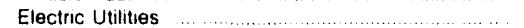 & .. & $\ldots$ & .. & $\ldots$ & .. \\
\hline
\end{tabular}

MA Not availeble

-. Not applicable

Note: Deliveries to electric utilities (consumption) are reported on the Form ElA-759. "Monthly Power Plant Repont" Deliveries to electric utilities for the account of others are reported on the Form ElA-176. "Annual Report of Natural and Suppiemental Gas Supply and Disposition." See the discussion on electric utitity data and Table A1 in Ap. pendix $A$ for a comparison of reporting to these two forms. Totals may not add due to independent rounding.

Sources: Energy Information Administration (EIA). Form E|A.176, "Annual Report of Natural and Supplemental Gas Supply and Disposition," Form ElA.627. "Annual Quantity and Value of Natural Gas Report," Form ElA.857. "Monthly Report of Natural Gas Purchases and Deliveries to Consumers." Form EiA-816, "Monthly Natural Gas Liquids Report," Form EIA.758. "Monthly Power Plant Report," Form FERC-423. "Monthly Report of Cost and Quality of Fuels for Electric Plants, "Form ElA-191. "Underground Gas Storage Report,"

Form FPC.14. "Annual Report for Imponters and Exporters of Natural Gas," U.S. Crude Oil. Natural Gas, and Natural Gas Liquids Reserves, 1992 Annual Report, DOE/EIA.

$0216(92)$; and the U.S. Minerals Management Service 
Natural Gas 1992

Net Interstate Movements

Million

Cu. Foot

Marketed Production
Million Percent of
Cu. Feat National Total
$347 \quad .00$

Deliveries to Consumers

है?

Residential:

475,360

10.14

Ais

Ants

Commercial:

196,964

7.03

(IM

Industrial:

300,366

3.99

$\longrightarrow$ Vehicle Fuel:

8

1.57

$A$

Electric Utility:

9,293

.34

Total:

981,991

5.52

Table 57. Summary Statistics for Natural Gas -- Illinois, 1988-1992

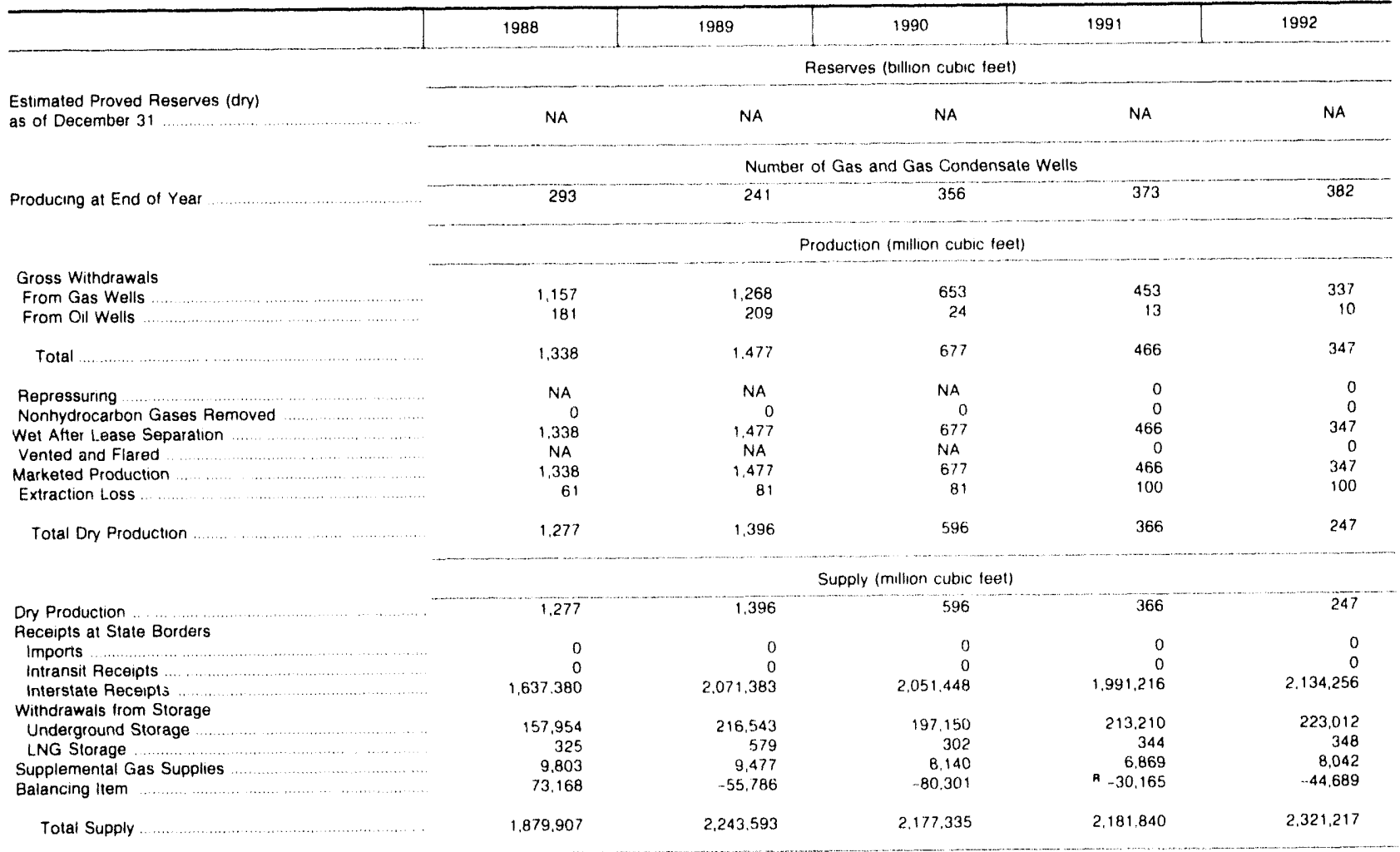

See footnotes at end of tabie 
Table 57. Summary Statistics for Natural Gas -- Illinois, 1988-1992 (Continued)

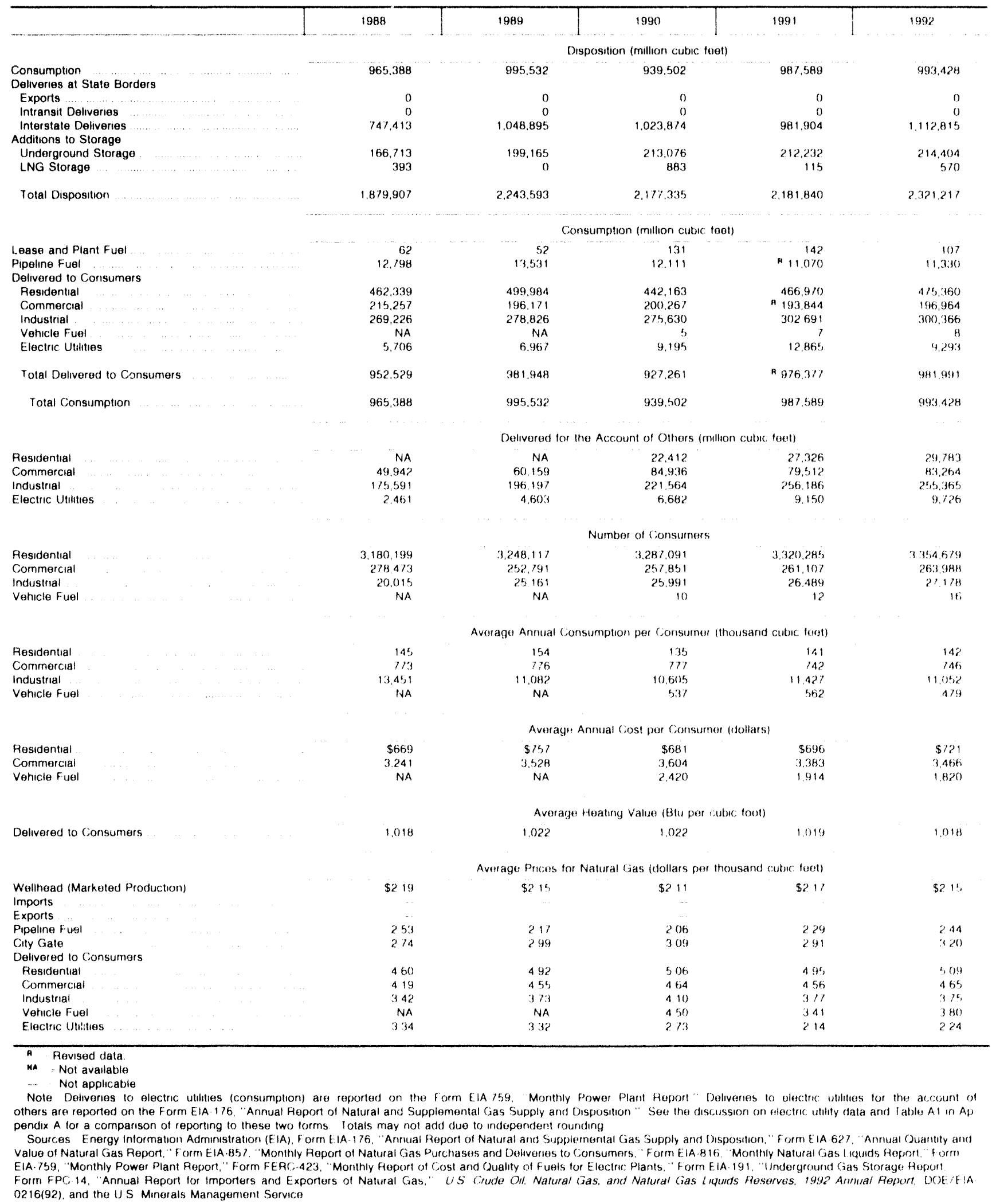


Natural Gas 1992

Net Interstate Movements

Million

Cu. Foel

480,369

\section{Marketed Production}

Million

Cu. Feel

Percent of

National Total

Deliveries to Consumers

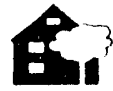

Residential:

152,692

3.26

A.

inth

Commercial:

72,720

2.59

$\prod_{x \rightarrow m}$

Industrial:

245,523

3.26

$\longrightarrow$ Vehicle Fuel:

59

11.55

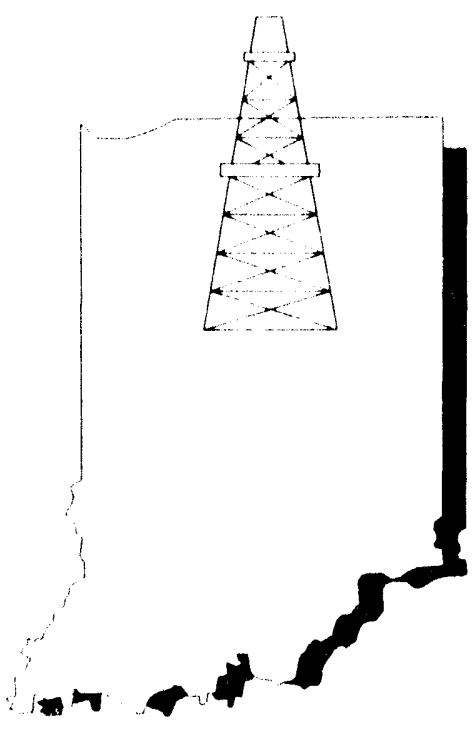

$A$

Electric Utility:

7.772

.28

Total:

478.765

2.69

Table 58. Summary Statistics for Natural Gas -- Indiana, 1988-1992

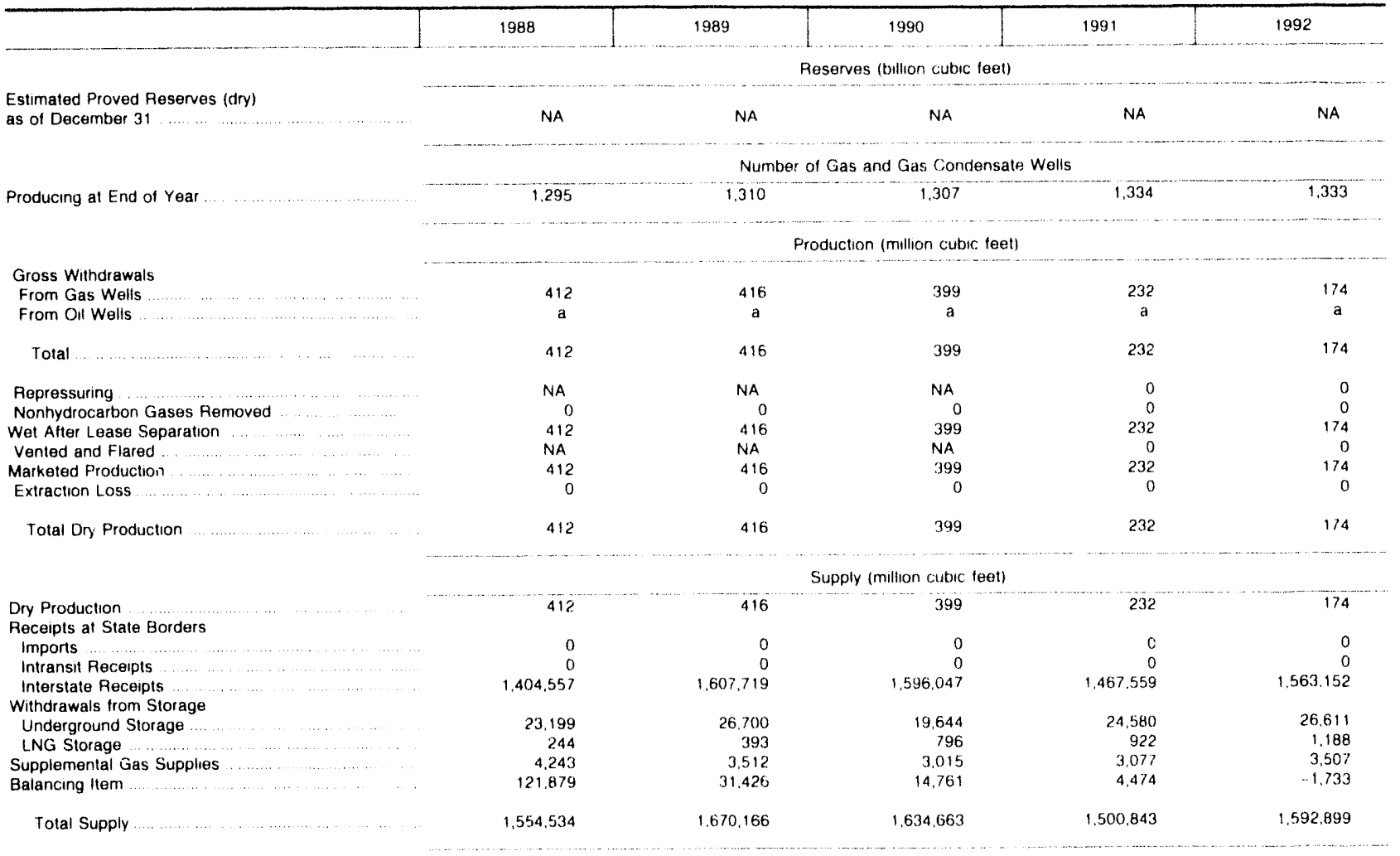

See footnotes at end of table 
Table 58. Summary Statistics for Natural Gas -- Indiana, 1988-1992 (Continued)

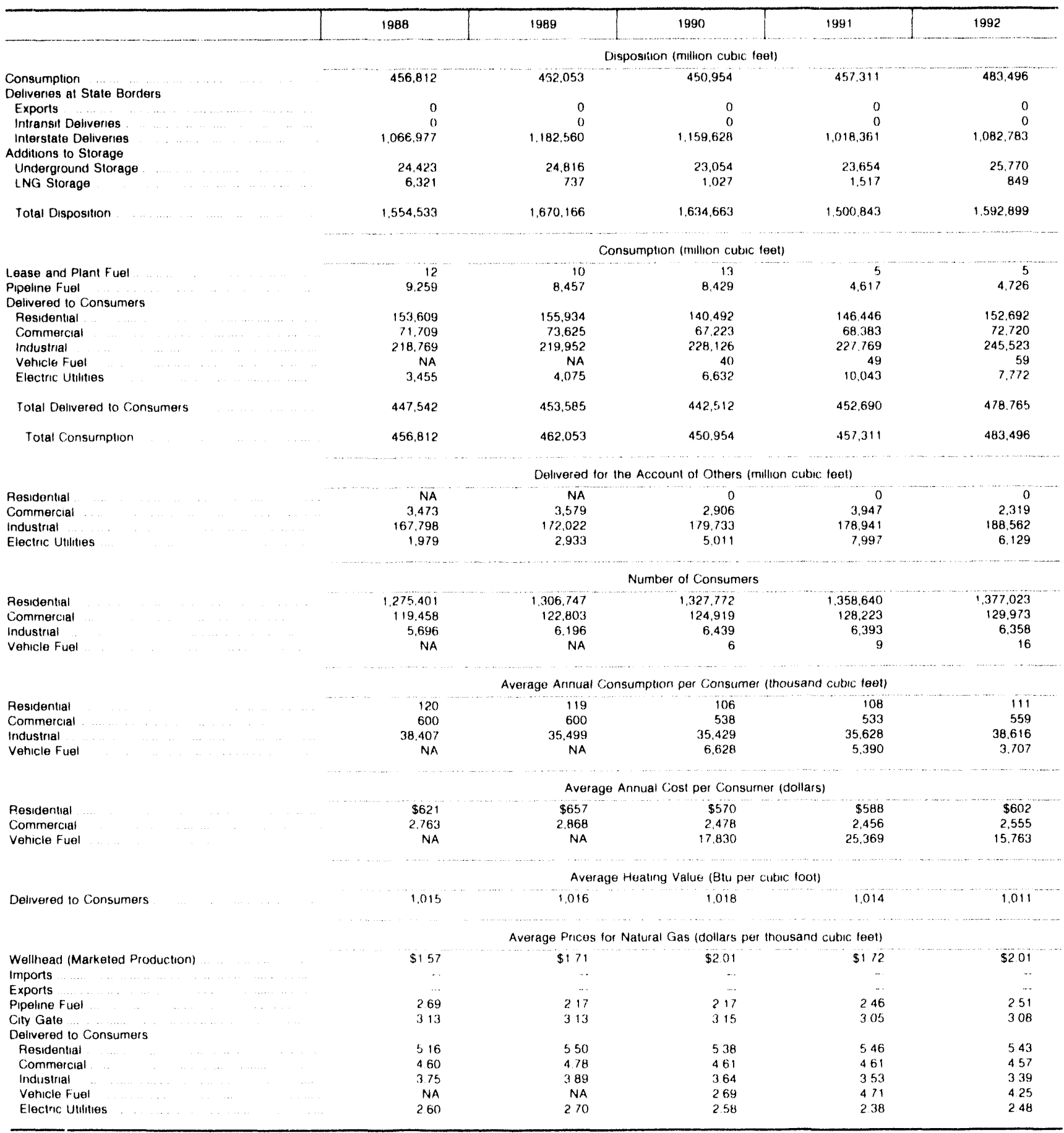

- Included in gross withdrawals from gas wells Breakdown not provided by State agency

A Revised data

Ma. Not available

Note Not applicable cthers are reported on the Form ElA.176. "Annual Report of Natural and Supplementai Gas Supply and Disposition "See the discussion on electric utitty data and Table A1 in Ap. cthers are reported on the Form ElA.176. "Annual Report of Natural and Supplemental Gas Supply and Disposing
pendix A for a comparison of reporting to these two torms Totals may not add due to independent rounding

Sources: Energy Information Administration (EIA). Form EIA-176. "Annual Repon of Natural and Supplemental Gas Supply and Disposition." Form EIA-627, "Annuai Quantity and Value of Natural Gas Report." Form EIA.857. "Monthly Feport ol Natural Gas Purchases and Deliveries to Consumers, "Form ElA.816. "Monthiy Natural Gas Liquids Report," Form EIA.759, "Monthly Power Plant Report," Form FERC-423, "Monthly Report of Cost and Quality of Fuels for Electric Plants, " Form EIA-191, "Underground Gas Storage Report," Form FPC-14. "Annual Feport lor Importers and Exporters of Natural Gas." U.S. Crude Oll, Natural Gas, and Natural Gas Liquids Reserves 1992 Annual Report. DOE/EIA. $0216(92)$; and the US Minerals Management Service 
Net Interstate Movements

Marketed Production

Million
Cu. Feot
0

Deliveries to Consumers

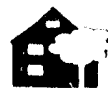

Residential:

74,879

in

insth

Commercial:

46,096

เ.

Industrial:

Vehicle Fuel:

100,752

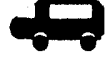

A

Electric Utility:

1

Mililion

Cu. Foot

242,676

Porcent of

National Total

.00

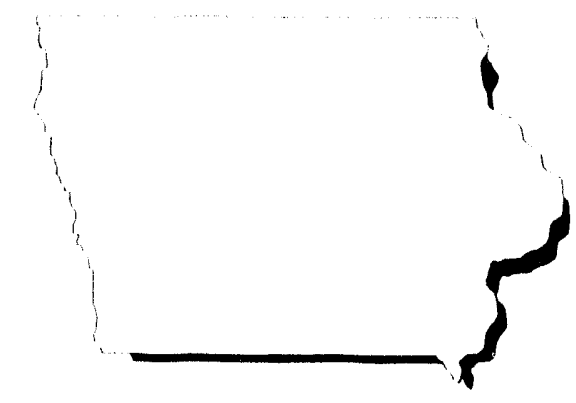

Total:

223,992

1.60

1.64

1.34

.20

$2.265 \quad .08$

1.20

Table 59. Summary Statistics for Natural Gas -- lowa, 1988-1992

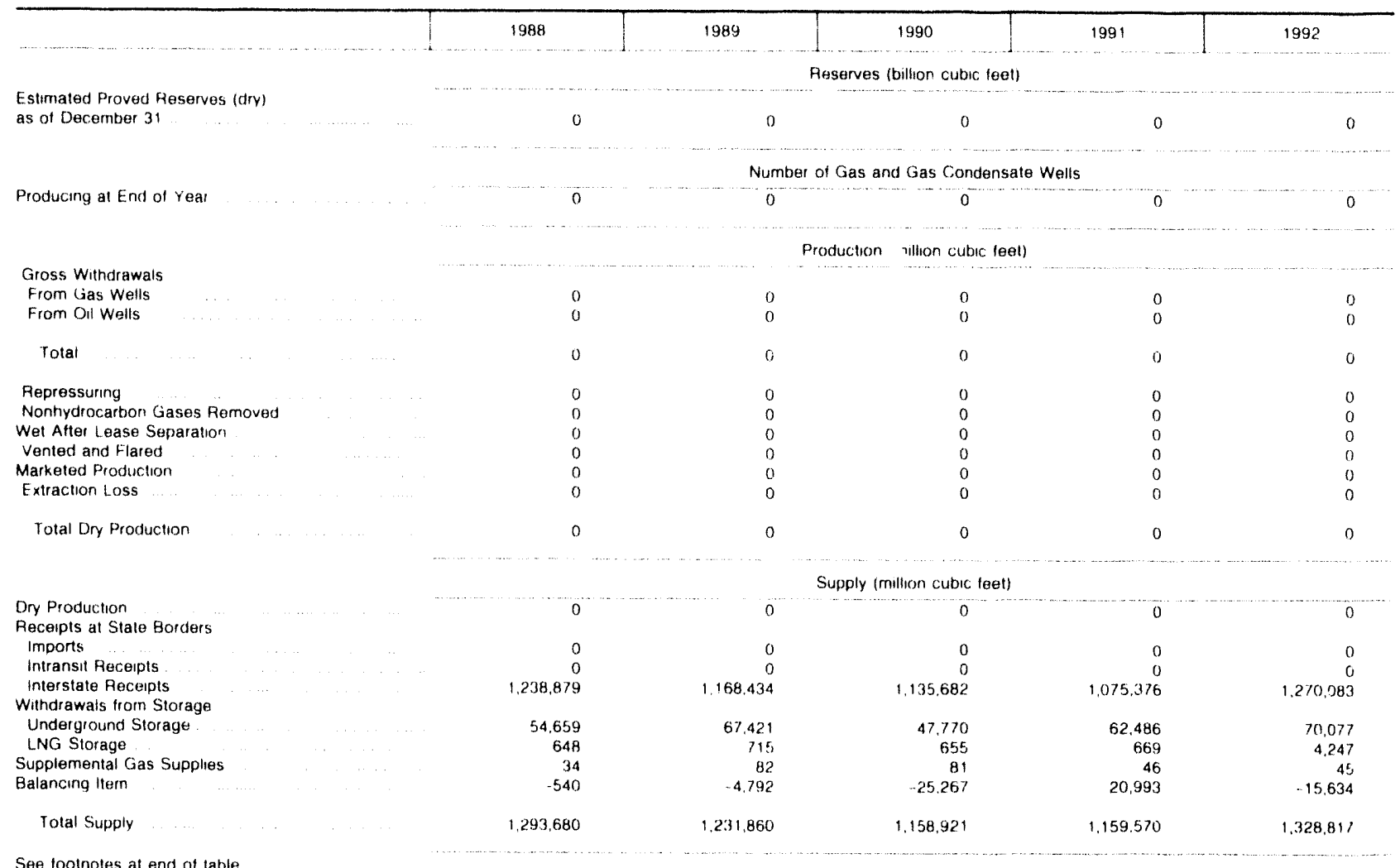

See tootnotes at end of table 
Table 59. Summary Statistics for Natural Gas -- lowa, 1988-1992 (Continued)

\begin{tabular}{|c|c|c|c|c|c|}
\hline & 1988 & 1989 & 1980 & 1991 & 1992 \\
\hline & \multicolumn{5}{|c|}{ Disposition (million cubic leet) } \\
\hline Consumption & 239,127 & 225,739 & 218,201 & 233.182 & 230.932 \\
\hline \multicolumn{6}{|l|}{ Deliveries at State Borders } \\
\hline 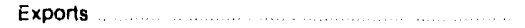 & 0 & 0 & 0 & 0 & 0 \\
\hline Intransit Deliveries $\ldots \ldots \ldots \ldots \ldots \ldots \ldots \ldots \ldots \ldots \ldots$ & 0 & 0 & 0 & 0 & 0 \\
\hline Interstate Deliveries $\ldots \ldots \ldots \ldots$ & 999,000 & 946.728 & 895,053 & 867,098 & $1,027,408$ \\
\hline \multicolumn{6}{|l|}{ Additions to Storage } \\
\hline Underground Storage & 55,076 & 58,386 & 44,471 & 57.278 & 65.818 \\
\hline LNG Storage & 477 & 1,008 & 1,196 & 2,012 & 4.659 \\
\hline \multirow[t]{2}{*}{ Total Disposition } & $1,293.680$ & 1.231 .861 & $1.158,921$ & 1.159 .570 & 1.328 .817 \\
\hline & \multicolumn{5}{|c|}{ Consumption (million cubic leet) } \\
\hline Lease and Plant Fuel & 0 & 0 & 0 & 0 & 0 \\
\hline Pipeline Fuel ........ & 10.589 & 10,446 & 9.150 & ${ }^{\text {R }} 6,648$ & 6,940 \\
\hline \multicolumn{6}{|l|}{ Delivered to Consumers } \\
\hline Residential $\ldots \ldots \ldots \ldots$ & 76,111 & 77.403 & 71,380 & 18,801 & 74,879 \\
\hline Commercial . . . . . & 44,955 & 46,142 & 43,953 & 46.615 & 46,095 \\
\hline Industrial & 102,013 & 89,347 & 90.240 & 97.446 & 100.752 \\
\hline Vehicle Fuel & NA & NA & $\cdot$ & 1 & 1 \\
\hline Electıc Utilities & 5,459 & 2,402 & 3.478 & 3,671 & 2,265 \\
\hline Total Delivered to Consumers $\ldots . . . .$. & 228.538 & 215.294 & 209,051 & ค 226,533 & 223,992 \\
\hline \multirow[t]{2}{*}{ Total Consumption } & 239,127 & 225,739 & 218.201 & 233.182 & 230.932 \\
\hline & \multicolumn{5}{|c|}{ Delivered for the Account of Others (million cubic feet) } \\
\hline Residential. & NA & NA & 0 & 0 & 0 \\
\hline$\ldots \ldots \ldots+\ldots+\ldots$ & 774 & 980 & 1.068 & 1,097 & 1.974 \\
\hline$\ldots \ldots \ldots, \ldots, \quad \ldots, \quad \ldots$ & 60.931 & 49,800 & 58,222 & 70,066 & 83,004 \\
\hline \multirow[t]{2}{*}{ Electric Utilities } & 1.784 & 1,183 & 1.137 & 1,256 & 2.163 \\
\hline & \multicolumn{5}{|c|}{ Number of Consumers } \\
\hline$(\ldots \ldots \ldots \ldots \ldots \ldots \ldots \ldots \ldots \ldots \ldots \ldots \ldots \ldots$ & 689.655 & 701.687 & 706.842 & 716,088 & 729,081 \\
\hline Commercial $\quad \ldots \ldots \ldots \ldots \ldots$ & 81,294 & 82.549 & 83.047 & 84,387 & 85.325 \\
\hline Industrai $\ldots \ldots \ldots$ & 1.937 & 1.895 & 1,883 & 1866 & 1,835 \\
\hline \multirow[t]{2}{*}{$\ldots+\ldots+\ldots, \quad \ldots+\ldots$} & NA & NA & 2 & 2 & 3 \\
\hline & \multicolumn{5}{|c|}{ Average Annual Consumption per Consumer (thousand cubic feet) } \\
\hline$\ldots \ldots \ldots \ldots$ & 110 & 110 & 101 & 110 & 103 \\
\hline Commerclal $\ldots \ldots$ & 553 & 559 & 529 & 552 & 540 \\
\hline Industral $\quad \ldots \ldots$ & 52,665 & 47,149 & 47.923 & 52.222 & 54.905 \\
\hline \multirow[t]{2}{*}{$\begin{array}{llllll}\ldots & \ldots & \ldots \ldots & \ldots & \ldots & \ldots\end{array}$} & NA & NA & 24 & 487 & 442 \\
\hline & \multicolumn{5}{|c|}{ Average Annual Cost per Consumer (dollars) } \\
\hline Fesidential & $\$ 529$ & $\$ 519$ & $\$ 504$ & $\$ 530$ & 537 \\
\hline Commercial & 2,229 & 2.183 & $2,1,35$ & ค 2,205 & 2,306 \\
\hline \multirow[t]{2}{*}{ Venicle Fuel } & NA & NA & 156 & 1,512 & 1.761 \\
\hline & \multicolumn{5}{|c|}{ Average Heating Value (Blu per cubic loot) } \\
\hline \multirow[t]{2}{*}{ Delivered to Consumers } & 1.007 & 1.011 & 1,007 & 1,008 & 1,004 \\
\hline & \multicolumn{5}{|c|}{ Average Prices for Natural Gas (dollars per thousand cubic feet) } \\
\hline Wellhead (Marketed Production) & $\therefore$ & $\therefore$ &.- & $\cdots$ & $\cdots$ \\
\hline imports $\ldots \ldots \ldots$ & .. & $\ldots$ & $\cdots$ & -. & . \\
\hline Exports & -. &.- & . & $\ldots$ & .. \\
\hline Pipeline Fuel $\quad \ldots \ldots \ldots \ldots \ldots \ldots \ldots \ldots$ & $\$ 201$ & $\$ 202$ & $\$ 15 ?$ & ค $\$ 154$ & $\$ 171$ \\
\hline$\ldots \ldots \ldots \ldots, \ldots \ldots, \ldots, \quad \ldots \ldots \ldots$ & $2 . \ni 2$ & 280 & 286 & 273 & 320 \\
\hline \multicolumn{6}{|l|}{ Delivered to Consumers } \\
\hline Residential ......... ... & 479 & 4.70 & 499 & 481 & 523 \\
\hline Commercial $\ldots . . . . . . . \ldots \ldots \ldots$ & 403 & 390 & 403 & 399 & 4.27 \\
\hline$(1 \ldots \ldots+\ldots, \ldots \ldots$ & 3.11 & 2.54 & 287 & 265 & 3.55 \\
\hline$\cdots \quad \ldots \ldots \ldots \ldots \ldots$ & NA & NA & 648 & 311 & 399 \\
\hline 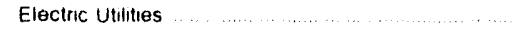 & 204 & 269 & 306 & 270 & 308 \\
\hline
\end{tabular}

- Less than 500,000 cubic feet

a Revised data.

NA Not avallable

-.- Not applicable

Note Deliveries to electric utlities (consumption) are reported on the Form ElA.759, "Monthiy Power Plant Report "Deliveries to electric utlities for the account of others are reported on the Form ElA-176, "Annual Report of Natural and Supplemental Gas Supply and Disposition "See the discussion on electric utility data and Tabie A1 in Ap. pendix $A$ for a comparison of reporting to these two forms. Totals may not add due to independent rounding

Sources: Energy Information Administration (EIA). Form ElA-176. "Annual Report of Natural and Supplemental Gas Supply and Disposition," Form EIA-627. "Annual Quantity and Value of Natural Gas Report, "Form ElA-857. "Monthly Report of Natural Gas Purchases and Deliveries to Consumers, " Form EiA-816. "Monthly Natural Gas Liquids Report," Form EIA-759, "Monthly Power Plant Fieport," Form FERC-423. "Monthly Peport of Cost and Quality of Fueis for Electric Plants." Form ElA-191, "Underground Gas Storage Report." Form FPC.14. "Annual Report for Importers and Exporters of Natural Gas," US Crude Oil. Natural Gas, and Natural Gas Liquids Reserves, 1992 Annual Report. DOE. ElA. Form FPC-14, Annual Repon tor Importers and Export 


\section{Natural Gas 1992}

Net Interstate Movements $\quad-257.668$

Million

Cu. Feot

Marketed Production

Million

Percent of Cu. Feet National Tolal 658.007

3.52

\section{Deliveries to Consumers}

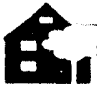

Residential:

71,522

1.52

7.:

asts

Commercial:

53,973

1.93

c. M

Industrial:

130,807

1.74

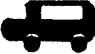

Vehicle Fuel:

0

.00

$A$

Electric Utility:

13,981

.51

Total:

270,284

1.52

Table 60. Summary Statistics for Natural Gas -- Kansas, 1988-1992

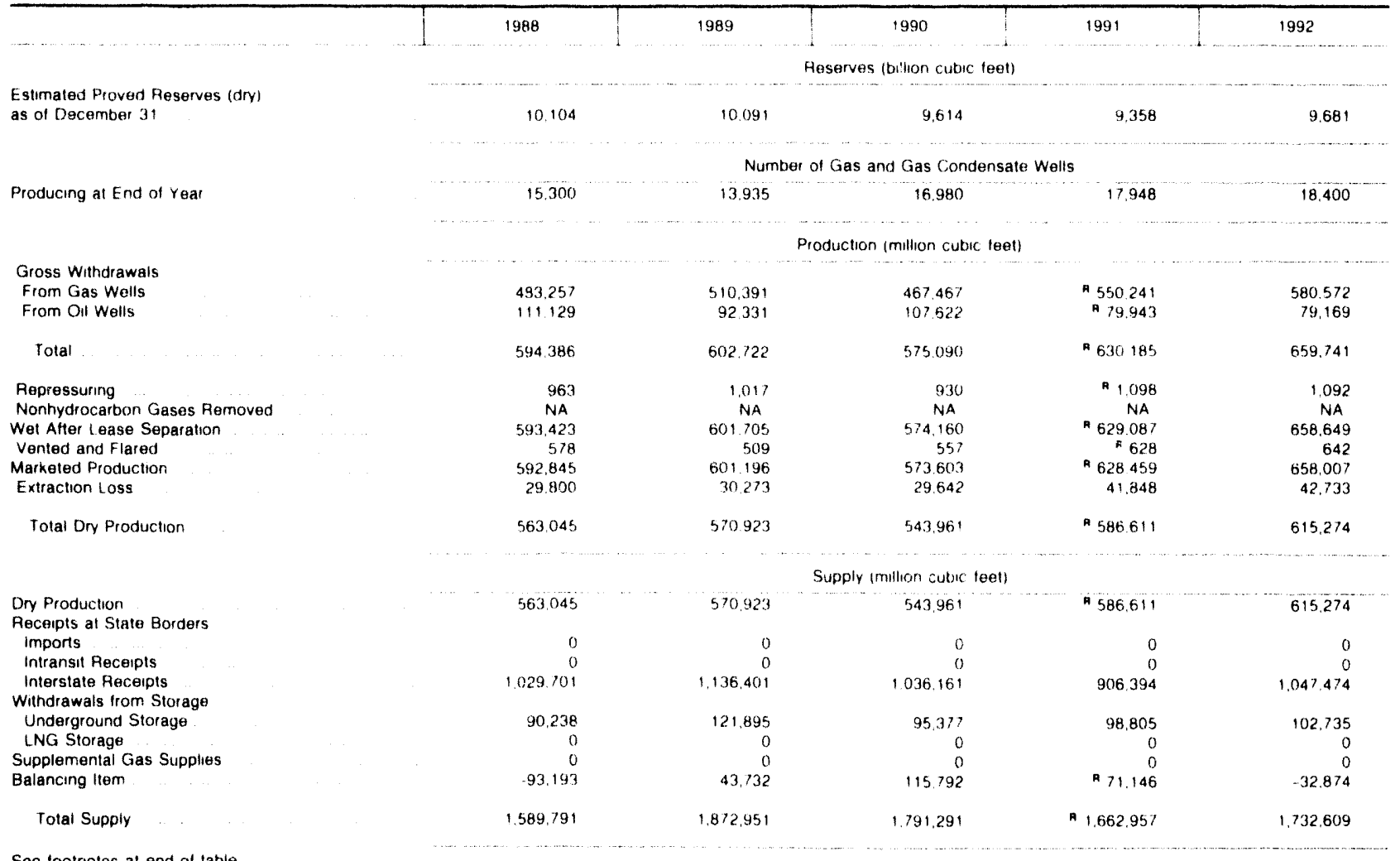


Table 60. Summary Statistics for Natural Gas -- Kansas, 1988-1992 (Continued)

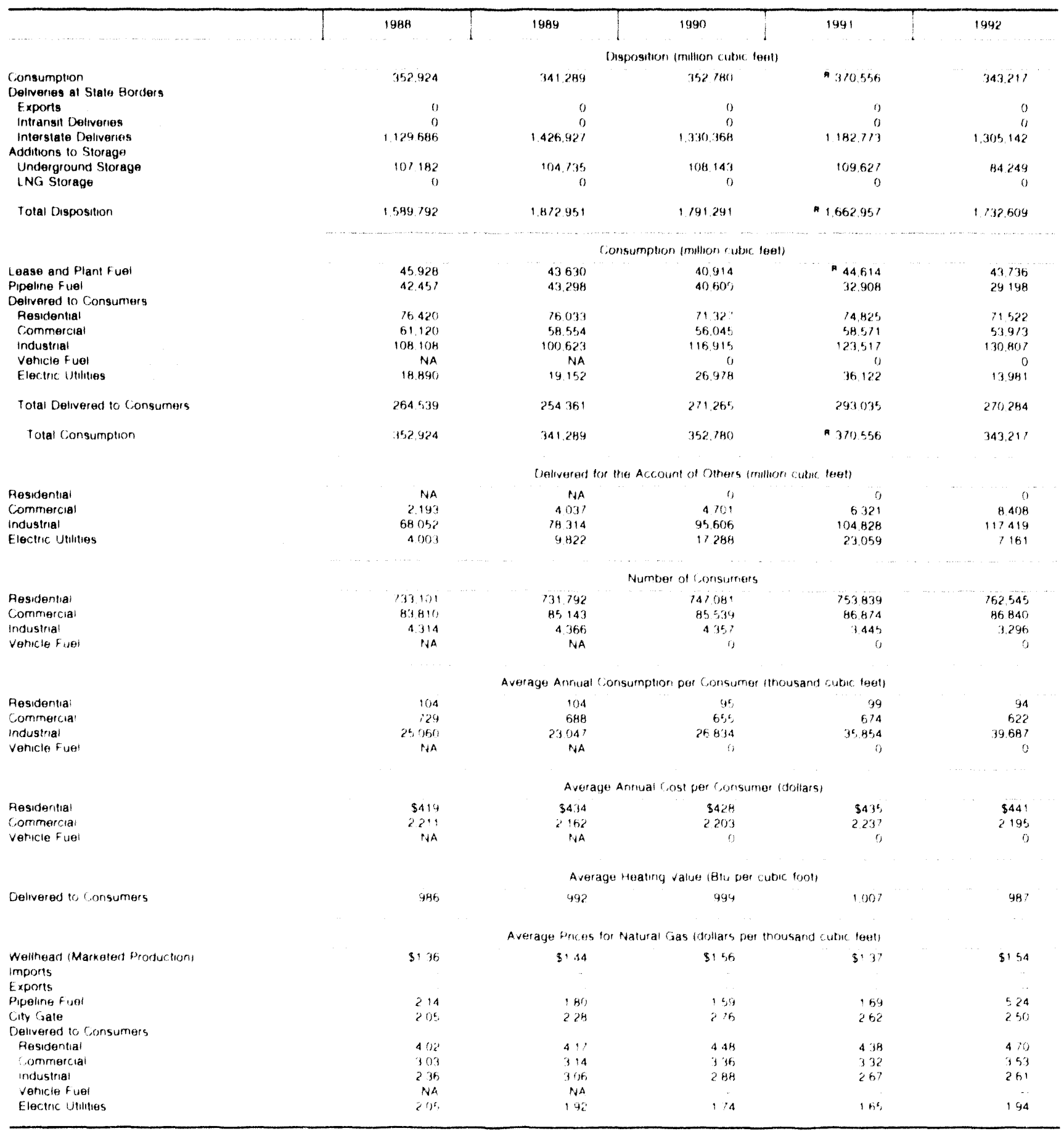

\section{Pevised dala}

Not applic abie

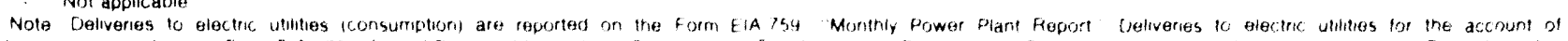
others are reported on the Form ElA 176 . Annual Report of Natural and Supplemental Gas Supply and Orspositicn Set the discussion on electric, utity data and Table At in Ad Dendix A to a comparison of reprorting to these two torms Totals may not add due to indeperdent rounding

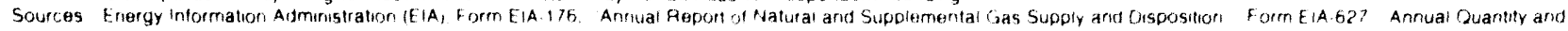

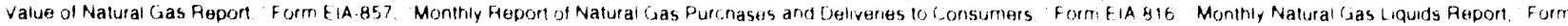

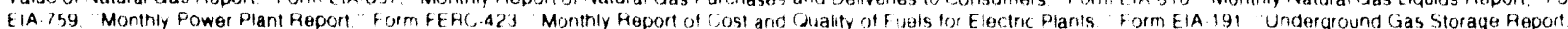

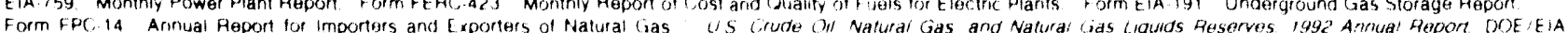

$0216(92)$ and the US Minerals Management Service 


\section{Natural Gas 1992}

Net Interstate Movements

Million

Cu F०01

174,733

Marketed Production

Million

Percent of

National Total

Cu. Foet National Tola
79,690

Deliveries to Consumers

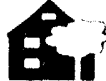

Residential:

61,911

1.32

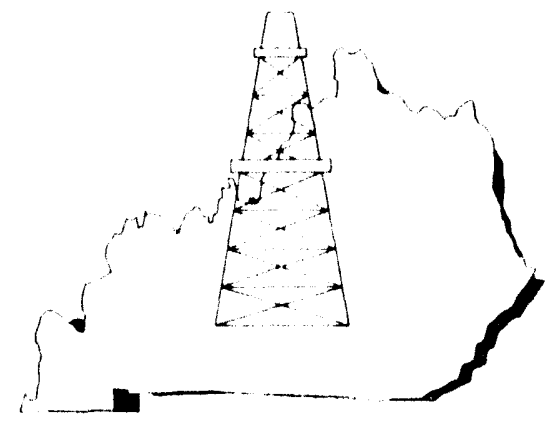

A

nsth

Commercial:

35,419

1.26

i. M

Industrial:

73,619

.98

KENTUCKY

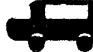

Vehicle Fuel:

0

.00

$A$

Electric Utility:

268

.01

Total:

171,218

.96

Table 61. Summary Statistics for Natural Gas -- Kentucky, 1988-1992

\begin{tabular}{|c|c|c|c|c|c|}
\hline & 1988 & 1989 & 1990 & 1991 & 1992 \\
\hline & \multicolumn{5}{|c|}{ Reserves (bitlion cubic leet) } \\
\hline \multirow[t]{2}{*}{$\begin{array}{l}\text { Estimated Proved Heserves (dry) } \\
\text { as of December } 31\end{array}$} & 923 & 992 & 1.016 & 1155 & 1,084 \\
\hline & \multicolumn{5}{|c|}{ Number of Gas and Gas Condensate Wells } \\
\hline \multirow[t]{2}{*}{ Producing al End of Year } & 10,777 & 11.248 & 11,713 & 12.169 & 12.483 \\
\hline & \multicolumn{5}{|c|}{ Production (million cubic feet) } \\
\hline $\begin{array}{l}\text { Gross Withdrawals } \\
\text { From Gas Wells }\end{array}$ & 73.629 & 72.417 & 75,333 & 78.904 & 79,690 \\
\hline From OIl Wells & a & a & a & a & a \\
\hline Total & 73.629 & 72,417 & 75,333 & 78.904 & 79.690 \\
\hline Repressuring & - & - & - & . & - \\
\hline Nonhydrocarbon Gases Removed & & 70 & 25. & 200 &. \\
\hline $\begin{array}{l}\text { Wet After Lease Separation } \\
\text { Vented and Flared }\end{array}$ & 73.629 & 72.417 & 75.333 & 78.904 & 79.690 \\
\hline Marketed Production & 73.629 & 72.417 & 75,333 & 78.904 & 79.690 \\
\hline Extrartion Loss & 2.142 & 1,444 & 1.899 & 2.181 & 2.342 \\
\hline \multirow[t]{2}{*}{ Total Dry Production } & 21.487 & 70.973 & 73.434 & 76.723 & 77.348 \\
\hline & \multicolumn{5}{|c|}{ Supply (milion cubic teet) } \\
\hline $\begin{array}{l}\text { Dry Production } \\
\text { Recelpts at State Bordars }\end{array}$ & 71487 & 70.973 & 73.434 & 76.723 & 77.348 \\
\hline $\begin{array}{l}\text { Imports } \\
\text { Imstale boroars }\end{array}$ & 0 & 0 & 0 & 0 & 0 \\
\hline Intransit Peceipls & 0 & 0 & 0 & 0 & 0 \\
\hline Interstate Receipts & 3.055 .726 & $3,208.031$ & 3.303 .547 & $3.030,350$ & $3,197.882$ \\
\hline $\begin{array}{l}\text { Withdrawals Irom Storage } \\
\text { Underaround Storaue }\end{array}$ & & & & & \\
\hline $\begin{array}{l}\text { Underground Storage } \\
\text { ING Storage }\end{array}$ & 68.676 & $\begin{array}{r}69.423 \\
0\end{array}$ & $\begin{array}{r}45,078 \\
0\end{array}$ & 48.822 & 42.795 \\
\hline $\begin{array}{l}\text { LNG Storage } \\
\text { Supplementai Gas Supplies }\end{array}$ & 6 & 44 & $\begin{array}{l}0 \\
2\end{array}$ & $\begin{array}{l}0 \\
2 \\
2\end{array}$ & $\begin{array}{l}0 \\
5\end{array}$ \\
\hline Balancing ltem & $-102,981$ & -156.157 & -207.989 & $-94,227$ & -55.636 \\
\hline Total Supply & $3,092,914$ & $3,192,314$ & 3.214 .073 & 3.061 .670 & 3.262 .394 \\
\hline
\end{tabular}

See footriotes al end of table 
Table 61. Summary Statistics for Natural Gas -- Kentucky, 1988-1992 (Continued)

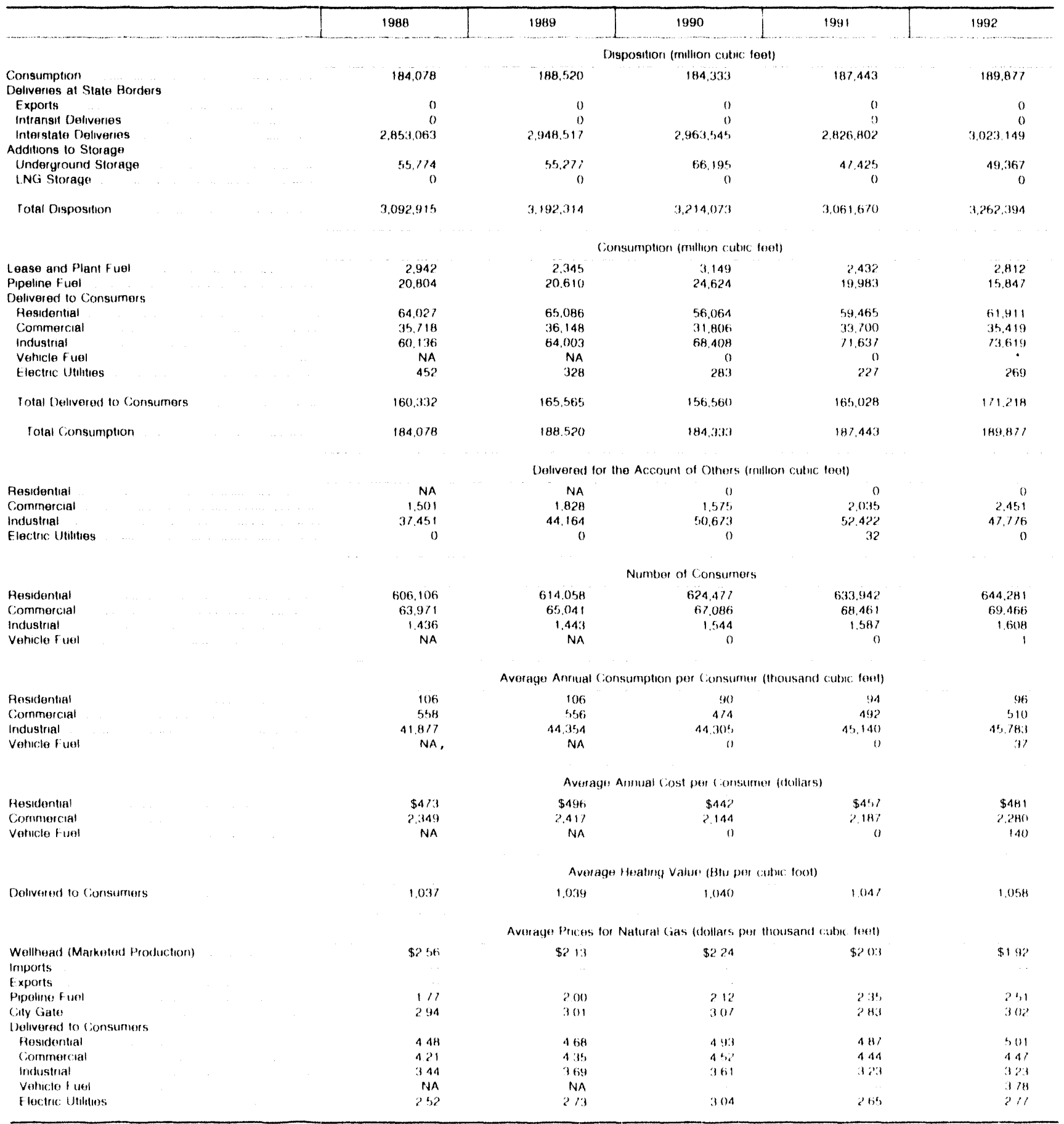

- Inclended in gross withde awals liom gas wells Breakdown nol provided by State agency

- less than 500,000 cutuc feet

Not avalables

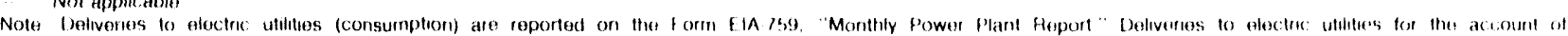

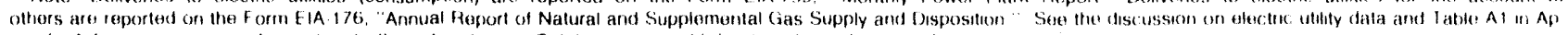
pendix $A$ for a comparison of teporting to these Iwo torms Tolats may not add due to independent rounding

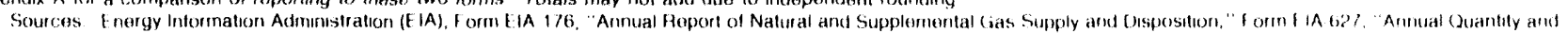

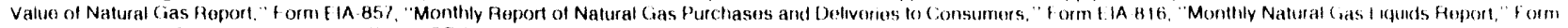

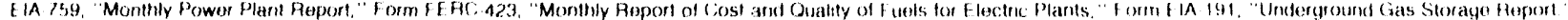

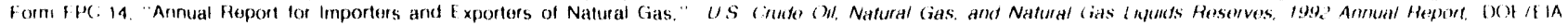
$0216(92)$. and the US Minorals Management Service 


\section{Natural Gas 1992}

Net Interstate Movements

Cu. Feet

Marketed Production

Millian Percent of

Cu. Feer

$4,914,300$

National Total

26.26

Deliveries to Consumers

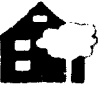

Residential:

55,221

1.18

A.

nsth

Commercial:

28,445

1.01

IIII

Industrial:

932,467

12.39

$\longrightarrow$ Venicle Fuel:

9

1.76

成

Electric Utility:

254,922

9.22

LOUISIANA

Total:

$1,271,064$

7.15

Table 62. Summary Statistics for Natural Gas -- Louisiana, 1988-1992

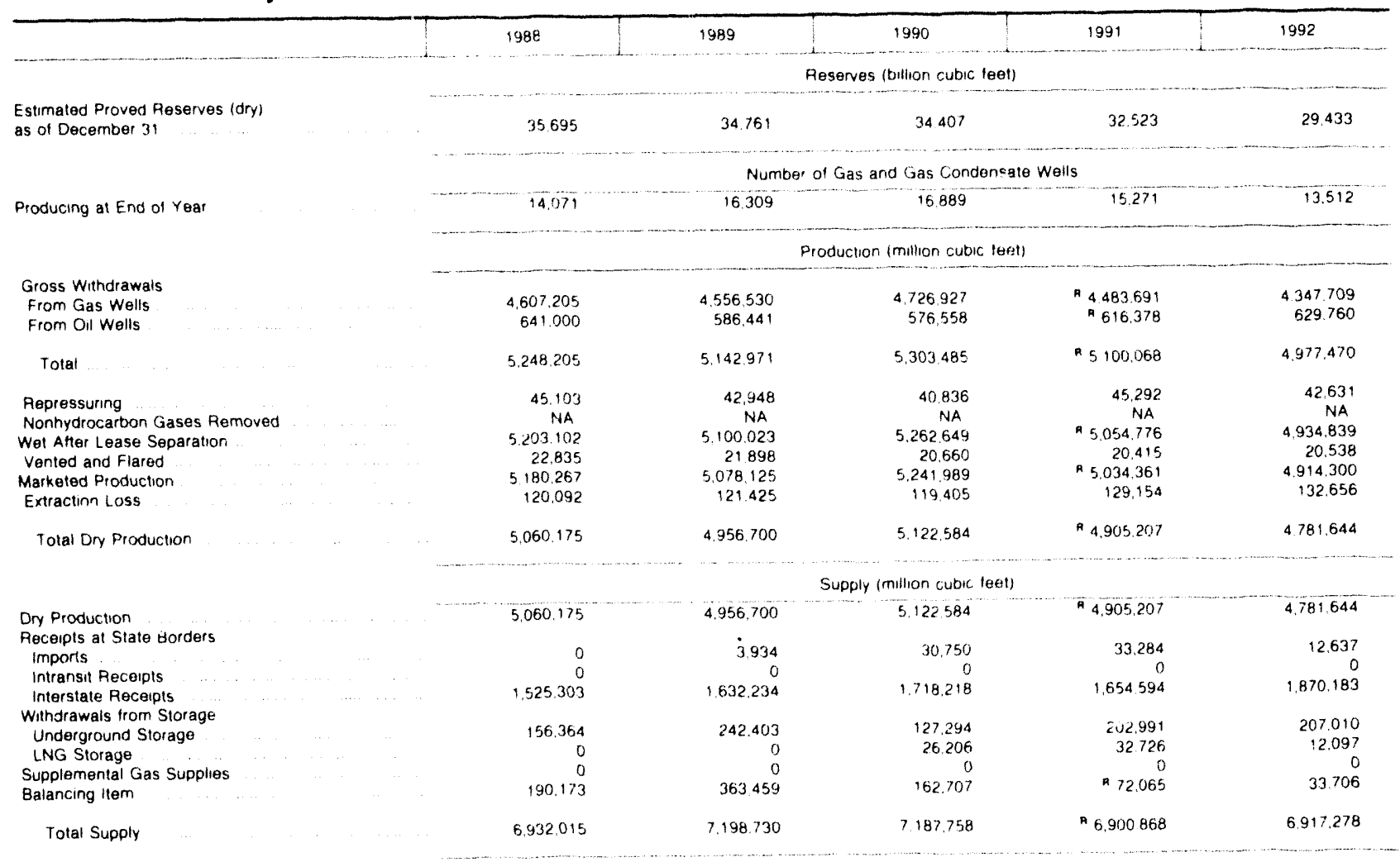


Table 62. Summary Statistics for Natural Gas -- Louisiana, 1988-1992 (Continued)

\begin{tabular}{|c|c|c|c|c|c|}
\hline & 1988 & 1989 & 1990 & 1991 & 1992 \\
\hline & \multicolumn{5}{|c|}{ Disposition (million cubic feet) } \\
\hline Consumption ........................ & $1,445,703$ & $1,538,481$ & $1,570,991$ & ค $1,508,108$ & $1,545,804$ \\
\hline \multicolumn{6}{|l|}{ Deliveries at State Borders } \\
\hline Exports & 0 & 0 & 0 & 0 & 0 \\
\hline 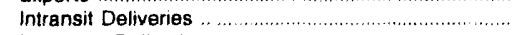 & 0 & 0 & 0 & 0 & 0 \\
\hline Interstate Deliveries & $5,292,062$ & $5,482.027$ & $5,388,681$ & $5,181,474$ & $5,165,877$ \\
\hline \multicolumn{6}{|l|}{ Additions to Storage } \\
\hline Underground Storage & 194,251 & 178,222 & 200,183 & 178,002 & 193,051 \\
\hline LNG Storage & 0 & 0 & 27,903 & 33,284 & 12,545 \\
\hline \multirow[t]{2}{*}{ Total Disposition } & $6,932,016$ & $7,198,730$ & $7.187,758$ & ${ }^{\text {* }} 6,900,868$ & $6.917,278$ \\
\hline & \multicolumn{5}{|c|}{ Consumption (million cubic feet) } \\
\hline Lease and Plant Fuel & 272,455 & 256,123 & 258,267 & 195,526 & 220,711 \\
\hline Pipeline Fuel & 56,573 & 49,847 & 55,736 & 53,622 & 54,029 \\
\hline \multicolumn{6}{|l|}{ Delivered to Consumers } \\
\hline 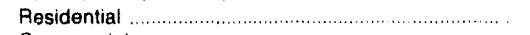 & 59,707 & 57,705 & 53,392 & 54,593 & 55,221 \\
\hline 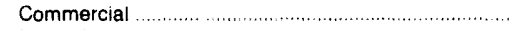 & 27.475 & 27.156 & 24.937 & 25,452 & 28,445 \\
\hline 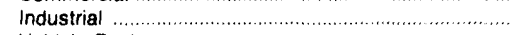 & 779,171 & 902,666 & 909,828 & F 924,661 & 932,467 \\
\hline Vehicle Fuel & NA & NA & 34 & 9 & 9 \\
\hline 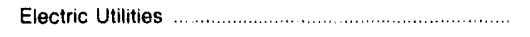 & 250,323 & 244,984 & 268,797 & 254,245 & 254,922 \\
\hline 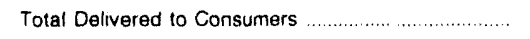 & 1.116 .676 & $1,232,511$ & $1,256,987$ & ค $1,258,960$ & $1,271,064$ \\
\hline \multirow[t]{2}{*}{ Total Consurnption... } & $1,445,703$ & $1,538,481$ & $1,570,991$ & A $1,508,108$ & $1,545,804$ \\
\hline & \multicolumn{5}{|c|}{ Delivered for the Account of Others (million cubic feet) } \\
\hline Residential ... & NA & NA & 0 & 0 & 0 \\
\hline 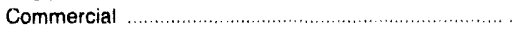 & & 16 & 0 & 233 & 3,552 \\
\hline industrial & 331,658 & 476,295 & 483,858 & 505,590 & 582,295 \\
\hline \multirow[t]{2}{*}{ 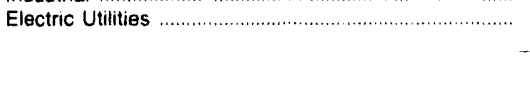 } & 181,223 & 170,098 & 231,753 & 209,258 & 208,847 \\
\hline & \multicolumn{5}{|c|}{ Number of Consumers } \\
\hline 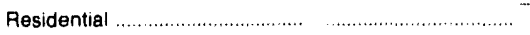 & 946,970 & 934,472 & 934,007 & 936,423 & 940,403 \\
\hline Commercial . & 66.472 & 64,114 & 62,770 & ค 61,574 & 61,030 \\
\hline 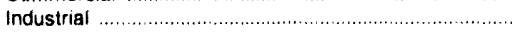 & 1,503 & 1,531 & 1,504 & ค 1,469 & 1,452 \\
\hline \multirow[t]{2}{*}{ 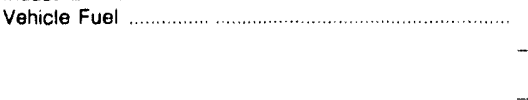 } & NA & NA & 1 & 3 & 2 \\
\hline & \multicolumn{5}{|c|}{ Average Annual Consumption per Consumer (thousand cubic feet) } \\
\hline Residential .. & 63 & 62 & 57 & 58 & 59 \\
\hline Commercial & 413 & 424 & 397 & 413 & 466 \\
\hline \multirow{3}{*}{ 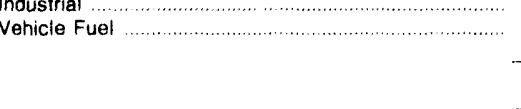 } & 518,410 & 589,592 & 604,939 & ค 629,449 & 642,195 \\
\hline & NA & NA & 34,282 & 2,961 & 4,270 \\
\hline & \multicolumn{5}{|c|}{ Average Annual Cost per Consumer (dollars) } \\
\hline 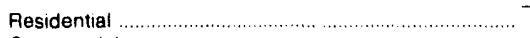 & $\$ 362$ & $\$ 369$ & $\$ 348$ & $\$ 336$ & $\$ 329$ \\
\hline Commercial & 2,125 & 2,197 & 2,088 & 2,024 & 2,234 \\
\hline \multirow[t]{2}{*}{ 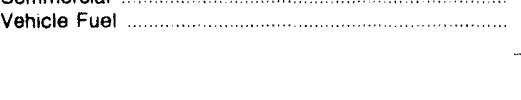 } & NA & NA & 111,000 & 10,539 & 18,361 \\
\hline & \multicolumn{5}{|c|}{ Average Heating Value (Btu per cubic toot) } \\
\hline \multirow[t]{2}{*}{ Delivered to Consumers } & 1.042 & 1,043 & 1,042 & 1,047 & 1,044 \\
\hline & \multicolumn{5}{|c|}{ Average Prices for Natural Gas (dollars per thousand cubic feet) } \\
\hline Wellhead (Marketed Production) & $\$ 1.81$ & $\$ 1.82$ & $\$ 1.83$ & $\$ 1.73$ & $\$ 1.73$ \\
\hline Imports & - & 1.74 & 1.88 & 1.70 & 1.73 \\
\hline 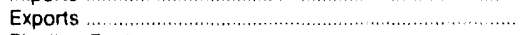 &.- & $\cdots$ & $-\cdot$ & - & $\cdots$ \\
\hline Pipeline Fuel & 196 & 2.07 & 1.98 & 2.25 & 2.25 \\
\hline City Gate & 3.09 & 2.98 & 2.97 & 2.56 & 2.48 \\
\hline \multicolumn{6}{|l|}{ Delivered to Consumers } \\
\hline 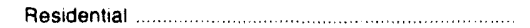 & 5.74 & 5.97 & 6.09 & 5.77 & 5.60 \\
\hline Commercial & 5.14 & 5.19 & 5.26 & 4.90 & 4.79 \\
\hline Industrial & 1.99 & 1.97 & 2.00 & 1.74 & 1.93 \\
\hline 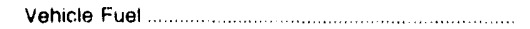 & NA & NA & 3.24 & 3.56 & 4.30 \\
\hline Electric Utilities & 1.70 & 1.78 & 1.73 & 1.59 & 1.91 \\
\hline
\end{tabular}

- Includes Ofishore Federal Domain

A $=$ Revised data.

NA - Not available.

-- Not applicable. others are reported on the Form EIA.176, "Annual Report of Natural and Supplemental Gas Supply and Disposition." See the discussion on electric utility data and Table A1 in Appendix $A$ for a comparison of reporting to these two forms. Totals may not add due to independent rounding.

Sources: Energy Information Administration (EIA), Form ElA-176. "Annual Report of Natural and Supplemental Gas Supply and Disposition, "Form ElA-627, "Annual Quantity and Value of Natural Gas Report," Form ElA-857. "Monthly Feport ol Natural Gas Purchases and Deliveries to Consumers, " Form ElA-816, "Monthly Natural Gas Liquids Repo: " "Form EIA-759, "Monthly Power Plant Report," Form FERC-423, "Monthly Report of Cost and Quality of Fuels for Electric Plants," Form EiA-192, "Underground Gas Storage Repo,"

Form FPC-14. "Annual Report for Importers and Exporters of Natural Gas," U.S. Crude Oil, Natural Gas, and Natural Gas Liquids Reserves, 1992 Annual Report, DOE/ElA. $0216(92) ;$ and the U.S. Minerals Management Service. 


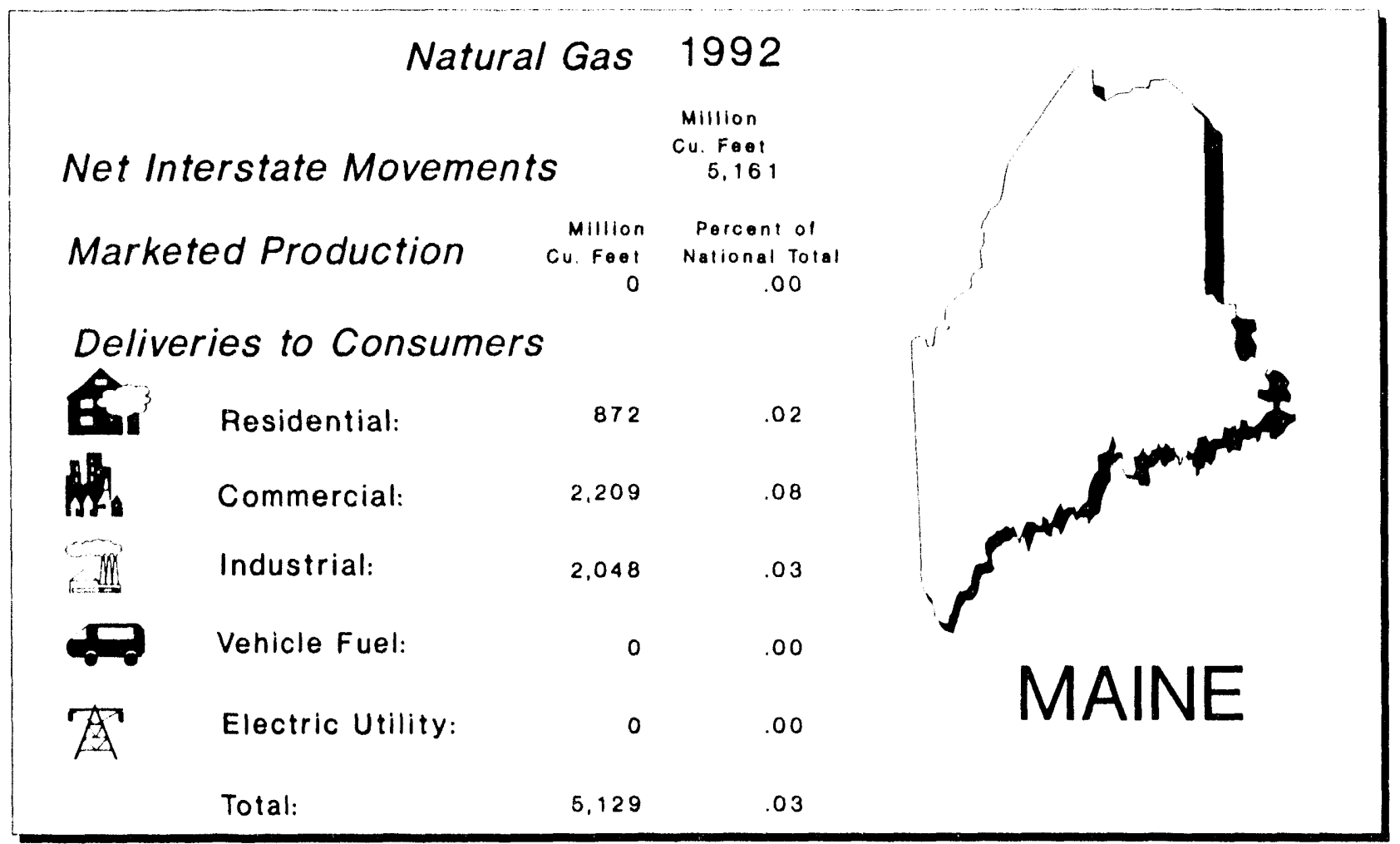

Table 63. Summary Statistics for Natural Gas -- Maine, 1988-1992

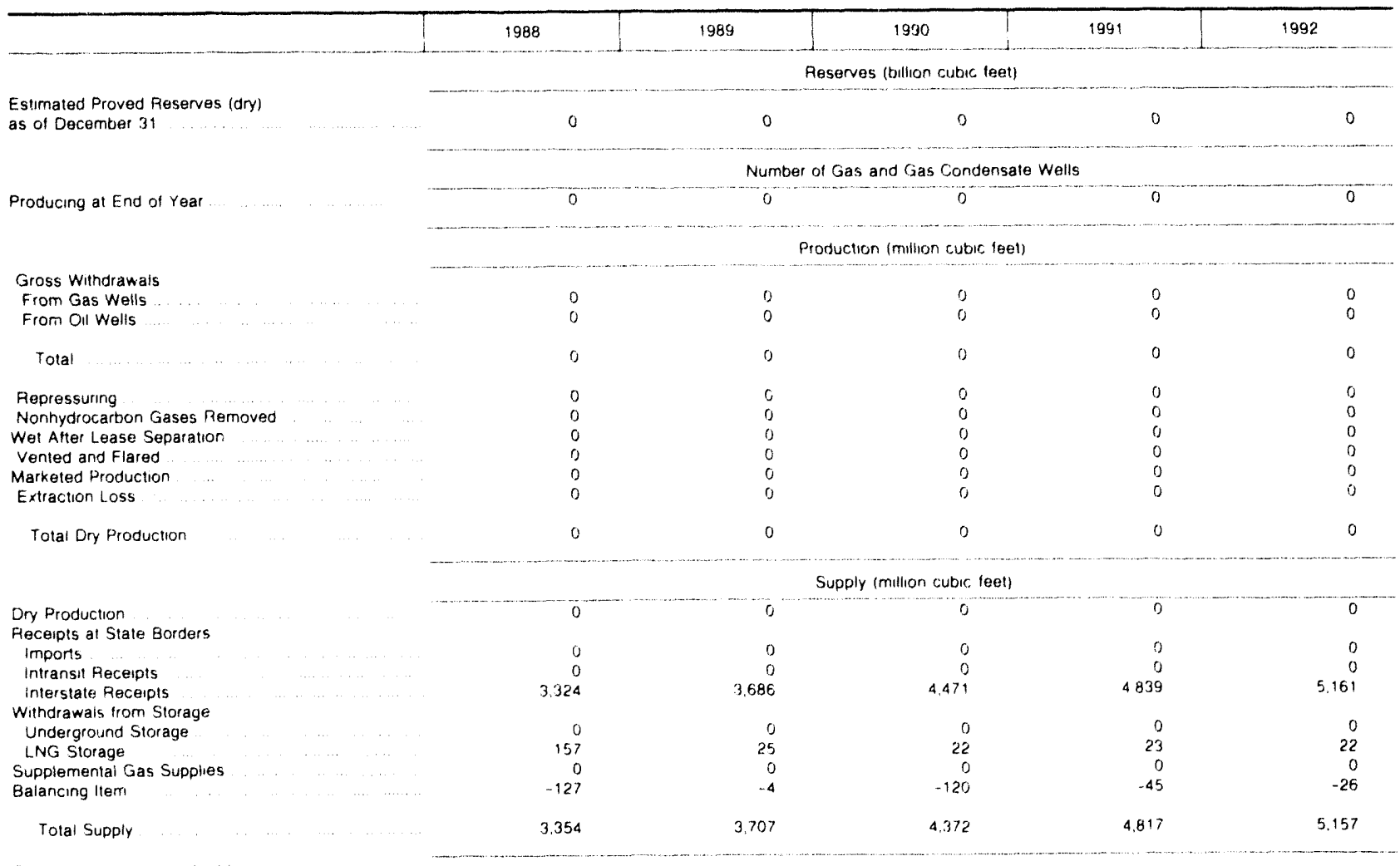

See tootnotes at end of table 
Table 63. Summary Statistics for Natural Gas -- Maine, 1988-1992 (Continued)

\begin{tabular}{|c|c|c|c|c|c|}
\hline & 1988 & 1989 & 1990 & 1991 & 1992 \\
\hline & \multicolumn{5}{|c|}{ Disposition (million cubic feet) } \\
\hline 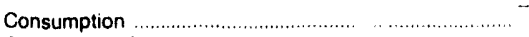 & 3,197 & 3,678 & 4,354 & 4,792 & 5,131 \\
\hline \multicolumn{6}{|l|}{ Deliveries at State Borders } \\
\hline Exports & 0 & 0 & 0 & 0 & 0 \\
\hline intransit Deliveries & 0 & 0 & 0 & 0 & 0 \\
\hline 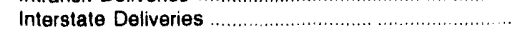 & 0 & 0 & 0 & 0 & 0 \\
\hline \multicolumn{6}{|l|}{ Additions to Storage } \\
\hline Underground Storage & 0 & 0 & 0 & 0 & 0 \\
\hline 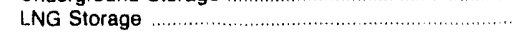 & 157 & 29 & 18 & 25 & 26 \\
\hline \multirow[t]{2}{*}{ 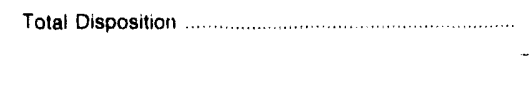 } & 3.354 & 3,707 & 4,372 & 4,817 & 5.157 \\
\hline & \multicolumn{5}{|c|}{ Consumption (million cubic teet) } \\
\hline Lease and Plant Fuel & 0 & 0 & 0 & 0 & 0 \\
\hline 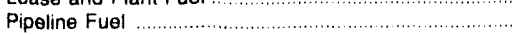 & 6 & 6 & 5 & 3 & 2 \\
\hline \multicolumn{6}{|l|}{ Delivered to Consumers } \\
\hline Rosidential .................... & 568 & 638 & 648 & 722 & 872 \\
\hline Commercial & 1,461 & 1,660 & 1,678 & 1,860 & 2,209 \\
\hline Industrial & 1.162 & 1,374 & 2,024 & 2.207 & 2,048 \\
\hline 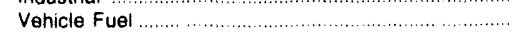 & NA & NA & 0 & 0 & 0 \\
\hline 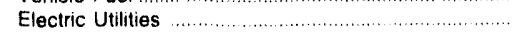 & 0 & 0 & 0 & 0 & 0 \\
\hline Total Delivered to Consumers & 3,191 & 3.672 & 4,350 & 4,789 & 5.129 \\
\hline \multirow[t]{2}{*}{ 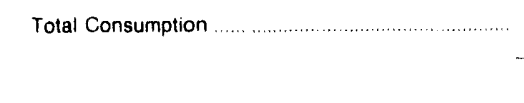 } & 3,197 & 3,678 & 4.354 & 4,792 & 5,131 \\
\hline & \multicolumn{5}{|c|}{ Delivered for the Account of Others (million cubic teet) } \\
\hline Residential ........... & NA & NA & 0 & 0 & 0 \\
\hline 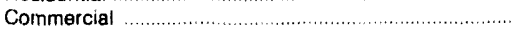 & 0 & 0 & 0 & 0 & 0 \\
\hline Industrial & 0 & 0 & 70 & 91 & 0 \\
\hline \multirow[t]{2}{*}{ Electric Utilities } & 0 & 0 & 0 & 0 & 0 \\
\hline & \multicolumn{5}{|c|}{ Number of Consumers } \\
\hline Residential ........... & 11,933 & 11,902 & 12,000 & 12,424 & 13,766 \\
\hline 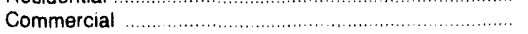 & 3,731 & 3,986 & 4,250 & 4.455 & 4,838 \\
\hline Industrial & 73 & 74 & 80 & 81 & 80 \\
\hline \multirow[t]{2}{*}{ Vehicle Fuel } & NA & NA & 0 & 0 & 0 \\
\hline & \multicolumn{5}{|c|}{ Average Annual Consumption per Consumer (thousand cubic feet) } \\
\hline Residential .................. & 48 & 54 & 54 & 58 & 63 \\
\hline Commercial & 392 & 416 & 395 & 418 & 457 \\
\hline \multirow{3}{*}{$\begin{array}{l}\text { Industrial } \\
\text { Venicle Fuel }\end{array}$} & 15,919 & 18,564 & 25,297 & 27.248 & 25,595 \\
\hline & NA & NA & 0 & 0 & 0 \\
\hline & \multicolumn{5}{|c|}{ Average Annual Cost per Consumer (dollars) } \\
\hline Residential & $\$ 345$ & $\$ 384$ & $\$ 411$ & $\$ 399$ & $\$ 440$ \\
\hline Commercial & 2.448 & 2,625 & 2,653 & 2.513 & 2,825 \\
\hline \multirow[t]{2}{*}{ Vehicle Fuel } & NA & NA & 0 & 0 & 0 \\
\hline & \multicolumn{5}{|c|}{ Average Heating Value (Blu per cubic foot) } \\
\hline \multirow[t]{2}{*}{ Delivered to Consumers. } & 1.027 & 1,003 & 1,005 & 1,006 & 1.013 \\
\hline & \multicolumn{5}{|c|}{ Average Prices for Natural Gas (dollars per thousand cubic feet) } \\
\hline Wollhead (Marketed Production) ................................ & - & $\cdots$ & - & -. &.- \\
\hline Imports & $\ldots$ & - & $\ldots$ & $\cdots$ & $\cdots$ \\
\hline Exports & -. & -. & $\cdot \cdot$ & $-\cdot$ & $\cdots$ \\
\hline Pipeline Fuet & $\$ 4.60$ & $\$ 3.41$ & $\$ 3.73$ & $\$ 3.59$ & $\$ 3.97$ \\
\hline City Gate & 3.00 & 3.23 & 3.06 & 3.00 & 3.17 \\
\hline \multicolumn{6}{|l|}{ Delivered to Consumers } \\
\hline 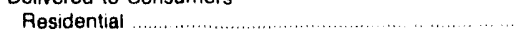 & 7.26 & 7.16 & 7.61 & 6.86 & 6.95 \\
\hline 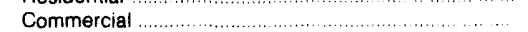 & 6.25 & 6.30 & 6.72 & 6.02 & 6.19 \\
\hline Industrial & 4.51 & 4.57 & 5.06 & 4.69 & 4.14 \\
\hline Vehicle Fuel & NA & NA & .. & - & $\ldots$ \\
\hline Electric Utilities & .. & n. & -. & -. & - \\
\hline
\end{tabular}

\section{NA $=$ Not available}

N... Not applicable

Note: Deliveries to electric utilities (consumption) are reported on the Form ElA-759. "Monthly Power Plant Report" Deliveries to electric utilities tor the account of others are reported on the Form EIA-176. "Annual Report of Natural and Supplemental Gas Supply and Disposition." See the discussion on electric utility data and Table A1 in Ap. pendix $\mathrm{A}$ for a comparison of reporting to these two forms. Totals may not add due to independent rounding.

Sources: Energy Intormation Administration (EIA), Form ElA-176. "Annuai Report of Natural and Supplemental Gas Supply and Disposition." Form ElA-627, "Annual Quantity and

Value of Natural Gas Report," Form ElA-857, "Monthly Report of Natural Gas Purchases and Deliveries to Consumers," Form ElA-B16, "Monthly Natural Gas Liquids Report,"

Form ElA.759." "Mas port," Form FPC.14. "Annual Report for Importers and Exporters of Natural Gas;" "ElA report. US. Crude Oit. Natural Gas, and Natural Gas Liquids Reserves. 1992 Annual Report DOE/EIA-0216(92) and the U.S. Minerals Management Service. 


\section{Natural Gas}

Net Interstate Movements

Marketed Production
Million Cu. Feet

33

\section{2}

Mllition

Cu. Feel

192,423

Percent of National Total .00

\section{Deliveries to Consumers}

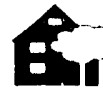

Residential:

75,122

1.60

7.:

ins

Commercial:

42,464

Industrial:

49,720

Vehicle Fuel:

0

11,576

178,881
Electric Utility

Total:
1.52

.66

成

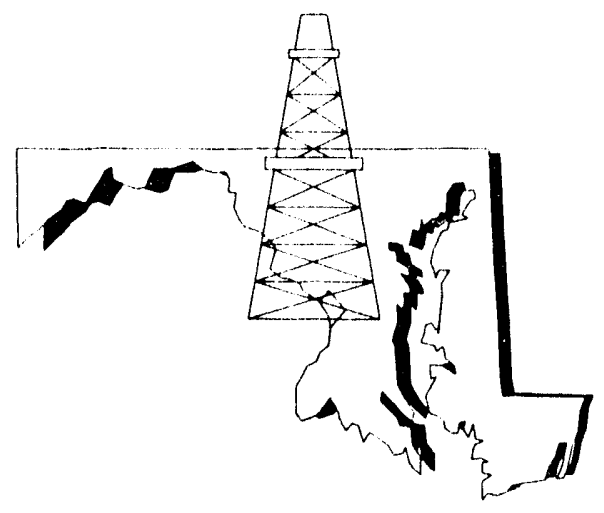

MARYLAND

Table 64. Summary Statistics for Natural Gas -- Maryland, 1988-1992

\begin{tabular}{|c|c|c|c|c|c|}
\hline & 1988 & 1989 & 1990 & 1991 & 1992 \\
\hline & \multicolumn{5}{|c|}{ Reserves (billion cubic leet) } \\
\hline \multirow[t]{2}{*}{$\begin{array}{l}\text { Estimated Proved Reserves (dry) } \\
\text { as of December } 31\end{array}$} & NA & NA & NA & NA & NA \\
\hline & \multicolumn{5}{|c|}{ Number of Gas and Gas Condensate Wells } \\
\hline \multirow[t]{2}{*}{ Producing at End of Year. } & 8 & 8 & 7 & 7 & 9 \\
\hline & \multicolumn{5}{|c|}{ Production (million cubic teet) } \\
\hline Gross Withdrawals & & & & & \\
\hline From Gas Wells & 29 & 34 & 22 & 29 & 33 \\
\hline From Oll Wells & 0 & 0 & 0 & 0 & 0 \\
\hline Total & 29 & 34 & 22 & 29 & 33 \\
\hline Repressuring & 0 & 0 & 0 & 0 & 0 \\
\hline Nonhydrocarbon Gases Removed ......... & 0 & 0 & 0 & 0 & 0 \\
\hline Wel After Lease Separation & 29 & 34 & 22 & 29 & 33 \\
\hline Vented and Flared & 0 & 0 & 0 & 0 & 0 \\
\hline 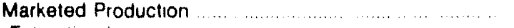 & 29 & 34 & 22 & 29 & 33 \\
\hline 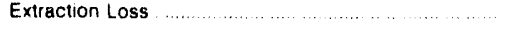 & 0 & 0 & 0 & 0 & 0 \\
\hline \multirow[t]{2}{*}{ Total Dry Production } & 29 & 34 & 22 & 29 & 33 \\
\hline & \multicolumn{5}{|c|}{ Supply (million cubic feet) } \\
\hline $\begin{array}{l}\text { Dry Production } \\
\text { Receipts at State Borders }\end{array}$ & 29 & 34 & 22 & 29 & 33 \\
\hline Imports & 0 & 0 & 0 & 0 & 0 \\
\hline Inttansit Receipts $\ldots . . . . . .$. & 0 & 0 & 0 & 0 & 0 \\
\hline Interstate Receipts ........ & 857,050 & 893.124 & 831.632 & 931,110 & 959,084 \\
\hline \multicolumn{6}{|l|}{ Withdrawals from Storage } \\
\hline Underground Storage & 19,397 & 19.166 & 14,074 & 20,656 & 19.169 \\
\hline LNG Storage & 771 & 760 & 377 & 531 & 715 \\
\hline Supplemental Gas Supplies ................ & 743 & 899 & 24 & 72 & 126 \\
\hline Balancing ltem .......................... & -7.224 & -23.332 & $-3,827$ & $-17,242$ & $-10,859$ \\
\hline Total Supply $\ldots \ldots \ldots \ldots \ldots \ldots$ & 870.766 & 890.651 & 942,303 & 935.157 & 968,267 \\
\hline
\end{tabular}


Table 64. Summary Statistics for Natural Gas -- Maryland, 1988-1992 (Continued)

\begin{tabular}{|c|c|c|c|c|c|}
\hline & 1988 & 1989 & 1990 & 1991 & 1992 \\
\hline & \multicolumn{5}{|c|}{ Disposition (miltion cubic teet) } \\
\hline$\ldots$ & 172,901 & 189,706 & 172,267 & 173.081 & 181,300 \\
\hline \multicolumn{6}{|l|}{ Deliveries at State Borders } \\
\hline 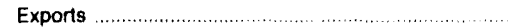 & 0 & 0 & 0 & 0 & 0 \\
\hline Intransit Deiiveries . & 0 & 0 & 0 & 0 & 0 \\
\hline Interstate Deliveries & 682,447 & 681,700 & 749,836 & 738.910 & 766,661 \\
\hline \multicolumn{6}{|l|}{ Additions to Storage } \\
\hline Underground Storage & 14,653 & 18,548 & 19,431 & 22,508 & 19,502 \\
\hline LNG Storage & 764 & 697 & 769 & 657 & 804 \\
\hline \multirow[t]{2}{*}{ 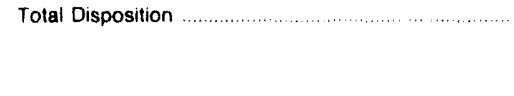 } & 870.765 & 890.651 & 942,303 & 935.157 & 968.267 \\
\hline & \multicolumn{5}{|c|}{ Consumption (million cubic teet) } \\
\hline Lease and Plant Fuel ...... & 1 & 1 & 1 & 0 & 0 \\
\hline 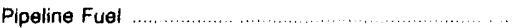 & 2.573 & 2.193 & 2,403 & 2,519 & 2,419 \\
\hline \multicolumn{6}{|l|}{ Delivered to Consumers } \\
\hline 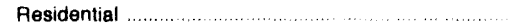 & 74.918 & 75,138 & 66,428 & 69,235 & 75,122 \\
\hline 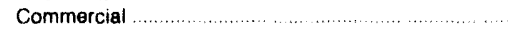 & 25,879 & 26,920 & 24,051 & 38,117 & 42.464 \\
\hline Industrial & 64.194 & 66.271 & 61,848 & 47.150 & 49,720 \\
\hline 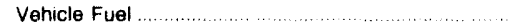 & NA & NA & 0 & 0 & 0 \\
\hline Electric Utilities & 5,336 & 19,184 & 17.536 & 16,059 & 11.575 \\
\hline Total Detivered to Consumers & 170,326 & 187.512 & 169,863 & 170,561 & 178,881 \\
\hline \multirow[t]{2}{*}{ 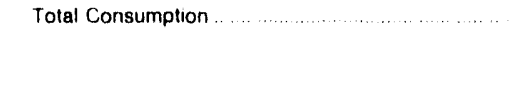 } & 172.901 & 189.706 & 172.267 & 173,081 & 181.300 \\
\hline & \multicolumn{5}{|c|}{ Delivered for the Account of Others (miltion cubic teel) } \\
\hline 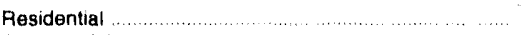 & NA & NA & 0 & 0 & 0 \\
\hline Commercial & 800 & 1.010 & 1.052 & 1,308 & 1,692 \\
\hline Industrial & 39,873 & 44.669 & 39,245 & 39,686 & 39.740 \\
\hline \multirow[t]{2}{*}{ Electric Utilities ........... } & 0 & 0 & 8.483 & 6.430 & 3.691 \\
\hline & \multicolumn{5}{|c|}{ Number of Consumers } \\
\hline Residential & 760,754 & 767.219 & 774.707 & 782.373 & 894,677 \\
\hline 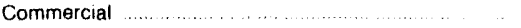 & 53,045 & 54740 & 55,576 & 61,878 & 62.858 \\
\hline Industrial & 5.397 & 5,570 & 5.646 & 520 & 514 \\
\hline \multirow[t]{2}{*}{ 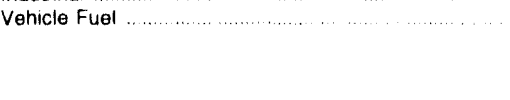 } & NA & NA & () & 0 & 0 \\
\hline & \multicolumn{5}{|c|}{ Average Arinual Consumption per Consumer (thousand cubic teel) } \\
\hline Residential. & 98 & 98 & 86 & 88 & 84 \\
\hline Commercial & 488 & 492 & 433 & 616 & 676 \\
\hline 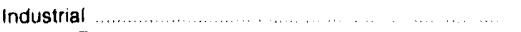 & 11,894 & 11,898 & 10.954 & 90,673 & 96.731 \\
\hline \multirow{2}{*}{ Vehicle Fuel } & NA & NA & 0 & 0 & 0 \\
\hline & \multicolumn{5}{|c|}{ Average Annual Cost per Consumer (doliars) } \\
\hline Residential $\ldots \ldots \ldots \ldots \ldots$ & $\$ 581$ & $\$ 617$ & $\$ 553$ & $\$ 545$ & $\$ 540$ \\
\hline Commercial $\ldots \ldots \ldots$ & 2.483 & 2,668 & 2,316 & 3,107 & 3.537 \\
\hline \multirow[t]{2}{*}{ 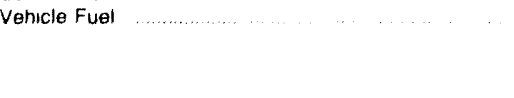 } & NA & NA & 0 & 0 & 0 \\
\hline & \multicolumn{5}{|c|}{ Average Heating Value (Btu per cubic fool) } \\
\hline \multirow[t]{2}{*}{ Delivered to Consurners } & $1,03 \%$ & 1,032 & 1.028 & 1.027 & 1,028 \\
\hline & \multicolumn{5}{|c|}{ Average Prices for Natural Gas (doliars per thousand cubic feet) } \\
\hline Wellhead (Marketed Production) & $\$ 093$ & $\$ 085$ & $\$ 114$ & $\$ 155$ & $\$ 1.91$ \\
\hline Imports & $\ldots$ & 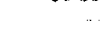 & $\ldots$ & .. & . \\
\hline Exports $\ldots \ldots \ldots \ldots$ & & - & $\ldots$ & & .. \\
\hline Pipeline Fuer & 227 & 272 & 215 & 194 & 194 \\
\hline City Gate $\ldots \ldots \ldots \ldots \ldots$ & 3.15 & 320 & 316 & 305 & 320 \\
\hline \multicolumn{6}{|l|}{ Delivered to Consumers } \\
\hline Residential ................. & 590 & 6.30 & 645 & 616 & 643 \\
\hline Commercial . . . . & 509 & 543 & 5.35 & 504 & 524 \\
\hline Industrial $\ldots \ldots \ldots, \ldots$ & 430 & 481 & 4.57 & 3.51 & 3.56 \\
\hline 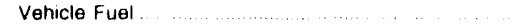 & NA & NA & $\cdots$ & $\ldots$ & $\cdots$ \\
\hline Electric Utilities $\ldots \ldots$ & 2.71 & 272 & 255 & 2.36 & 2.66 \\
\hline
\end{tabular}

MA Not available

Note Deliventies to electric utilities (consumption) are reported on the Form F.IA.759. "Monthly Power Plant Report "Deliveries to electric utilties for the account of others are reported on the Form ElA.176. "Annual Report of Natural and Supplemental Gas Supply and Disposition" See the discussion on electric utility data and Table At in Ap. pendix A for a comparison of reporting to these two forms Totals may not add due to independent rounding.

Sources. Energy Information Administration (EIA), Form ElA-176. "Anrual Report of Natural and Supplemental Gas Supply and Disposition." Form ElA-627, "Annual Quantity and Value of Natural Gas Feport." Form ElA-857. "Monthly Report of Natural Gas Purchases and Delivertes to Consumers, "Form ElA.816, "Monthly Natural Gas t.quids Feport." Form EIA-759, "Monthly Power Plant Report, " Form FERC.423, "Monthly Report of Cost and Quality of Fuels for Flectric Plants." Form ElA-191. "Underground Gas Storage Report."

Form FPC.14. "Annual Feport for Importers and Exporters of Natural Gas," U.S Cruite Oil. Natural Gas. and Natural Gas l.quids Feserves, 1992 Annual Report. DOE. EIA.

$0216(92)$, and the US Minerals Management Service. 


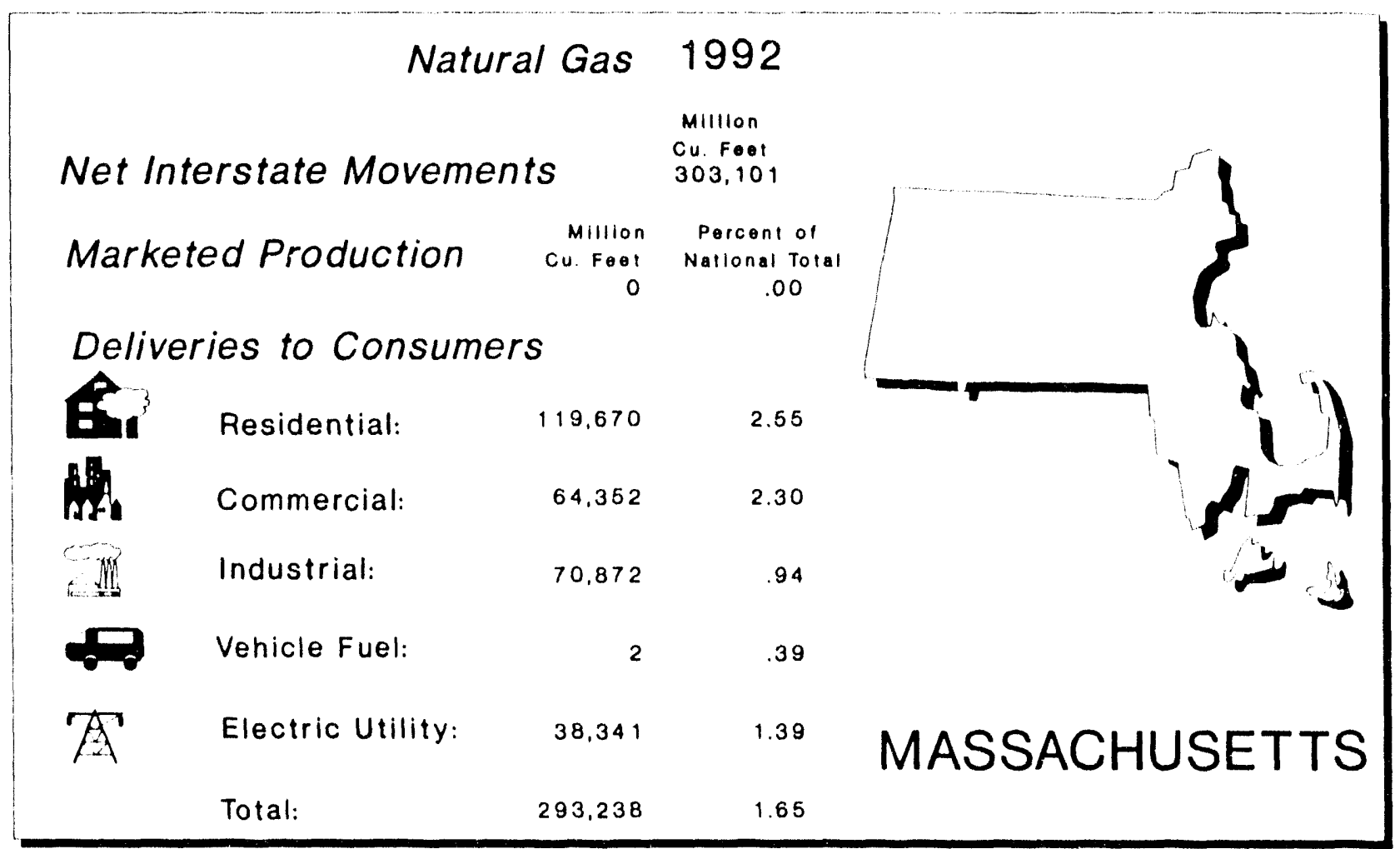

Table 65. Summary Statistics for Natural Gas -- Massachusetts, 1988-1992

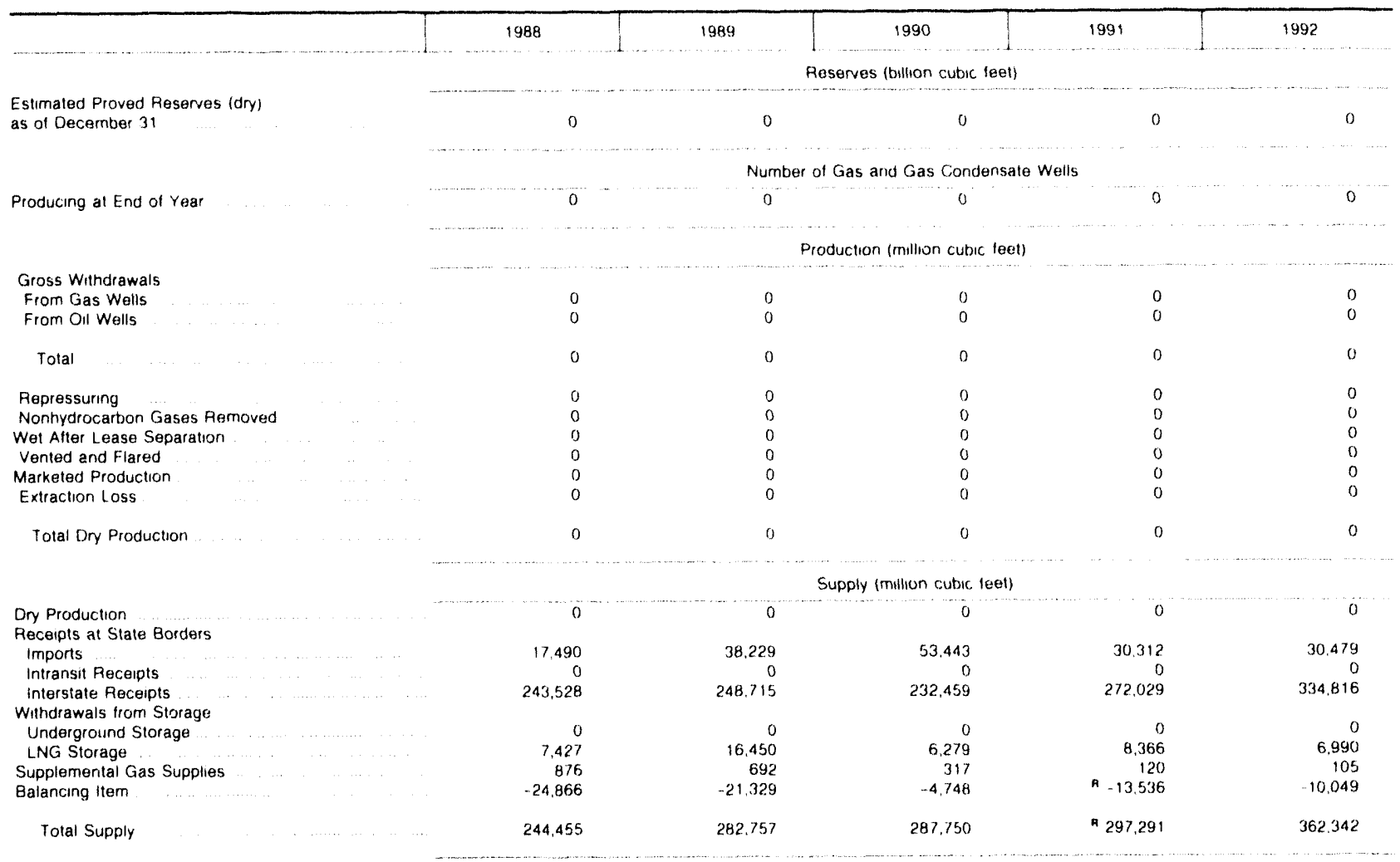

See footnotes at end of table 
Table 65. Summary Statistics for Natural Gas -- Massachusetts, 1988-1992 (Continued)

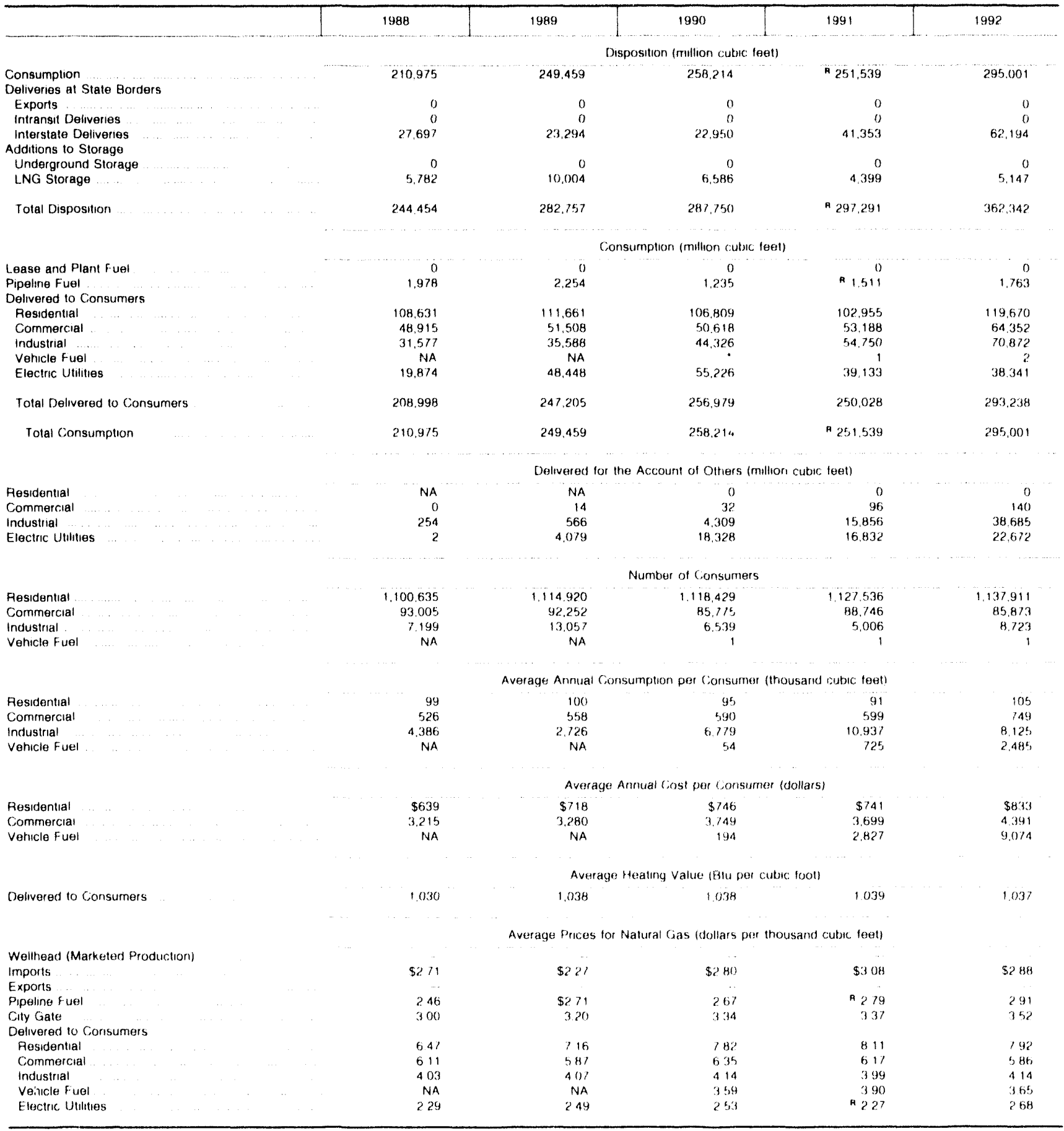

- Less than 500.000 cubic teet

P Revised data

Na Not available

Nol applicable

Note Deliveries to electric utilites (consumption) are teponted on the Form ElA 759. "Monthly Power Plant Feport Delivenies to electric utilities for the accuunt of others are reported on the Form EIA-176. "Annual Report of Natural and Supplementat Gas Supply and Disposition "See the discussion on etectric utility data and Tatile A1 in Ap. pendix $A$ for a comprarison of reporing to these two forms. Totals may not add due to independent rounding

Sources: Energy Intormation Adrninistration (EIA). Form EIA-176. "Annual Report of Natural and Supplernental Gas Supply and Disposition." Form EIA-62\%, "Annual Guantity and Value of Natural Gas Report." Form E1A.857. "Monthly Feport of Natural Gas Purchases and Deliveries to Consumers. "Form E.1A-816. "Monthly Natural Gas Liquids Report," Furm ElA.759. "Monthly Power Plant Report, "Form FERC-423, "Monthly Feport of Cost and Quality of Fueis for Flectric Plants." Form EIA. 191 . "Inderground Gas Storage Fieport."

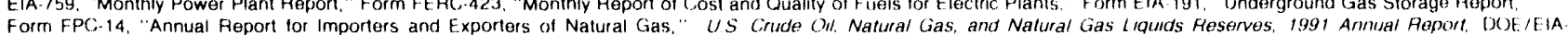
$0216(91)$, and the US. Minerals Management Service 


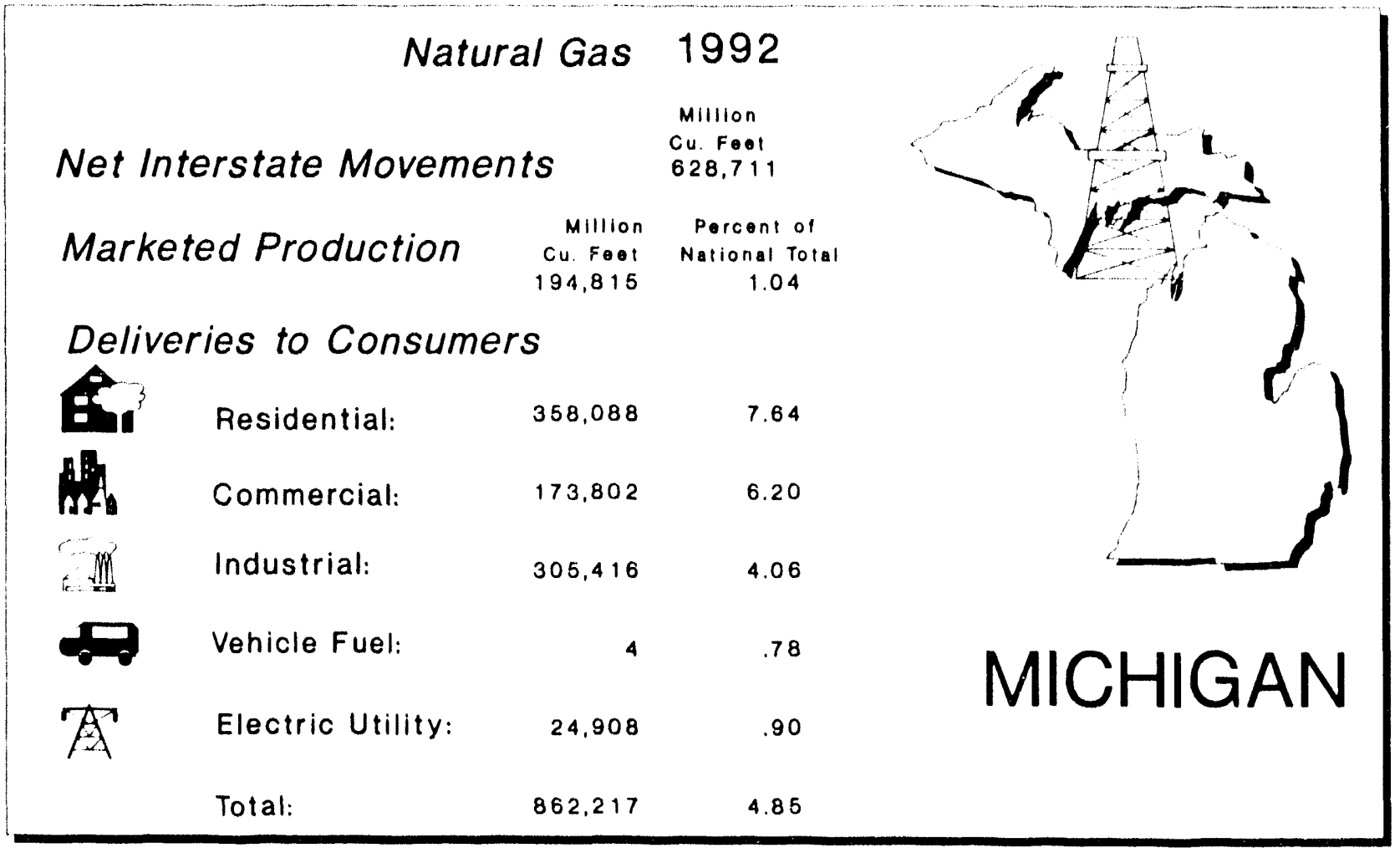

Table 66. Summary Statistics for Natural Gas -- Michigan, i988-1992

\begin{tabular}{|c|c|c|c|c|c|}
\hline & 1988 & 1989 & 1990 & 1991 & 1992 \\
\hline & \multicolumn{5}{|c|}{ Reserves (billion cubic leet) } \\
\hline \multirow[t]{2}{*}{$\begin{array}{l}\text { Estimated Proved Reserves (dry) } \\
\text { as of December } 31\end{array}$} & 1,323 & 1,342 & 1.243 & 1.334 & 1223 \\
\hline & \multicolumn{5}{|c|}{ Number of Gas and Gas Condensate Wells } \\
\hline \multirow[t]{2}{*}{ Producing at End of Year } & 988 & 1.207 & 1.438 & 2620 & 3257 \\
\hline & \multicolumn{5}{|c|}{ Production (million cubsic teet) } \\
\hline Gross Withdrawals & & & & & \\
\hline $\begin{array}{l}\text { From Gas Wells } \\
\text { From Oll Wells }\end{array}$ & 85,013 & 94,439 & 106.689 & 120848 & 120.287 \\
\hline From Oll Wells & 66.796 & 68,387 & 71.126 & B0. 565 & A0) 192 \\
\hline Total & 151,809 & $: 62.826$ & 177.815 & 201,413 & 200,479 \\
\hline Repressuring & 2.340 & 2768 & 2,340 & 2.340 & 2.740 \\
\hline Nonhydrocarton Gases Removerd & NA & NA & NA & NA & NA \\
\hline Wet Atter Lease Separation & 149.469 & 150.056 & 175.475 & 199.073 & 198139 \\
\hline Vented and Flared & 3,324 & 4,070 & 3,324 & 3.324 & 3.324 \\
\hline Extraction Loss & 10.483 & 9.886 & 8.317 & 8,103 & 8.093 \\
\hline \multirow[t]{2}{*}{ Total Dry Production } & 135,562 & 146.102 & 163,834 & 187,646 & 186.722 \\
\hline & \multicolumn{5}{|c|}{ Supply (million cubic terel) } \\
\hline Dry Production & 135,662 & 146.102 & 163.834 & 197646 & 186722 \\
\hline \multicolumn{6}{|l|}{ Receipts al State Borders } \\
\hline Intransit Receipts & 0 & ) & 0 & 0 & 0 \\
\hline interstate Feceipls & $975.99^{\prime} 3$ & 972.991 & 993.264 & 942159 & $1,135,780$ \\
\hline \multicolumn{6}{|l|}{ Withdrawals from Storage } \\
\hline Unnerground Storage & 342,472 & 436.508 & 314.451 & 394.196 & 392,716 \\
\hline LNG Siorage & 0 & 0 & 0 & 0 & 0 \\
\hline Supplemental Gas Supplies & 2.402 & 2.402 & 19106 & 15,016 & 14.694 \\
\hline Balancing Item & -16.298 & 3.568 & 94.341 & 6.050 & 58.803 \\
\hline Total Supply & $1.441,228$ & $1,554,435$ & 1.585 .006 & $1,546,217$ & 1.827 .283 \\
\hline
\end{tabular}


Table 66. Summary Statistics for Natural Gas -- Michigan, 1988-1992 (Continued)

\begin{tabular}{|c|c|c|c|c|c|}
\hline & 1988 & 1989 & 1990 & 1991 & 1992 \\
\hline & \multicolumn{5}{|c|}{ Disposition (million cubic feet) } \\
\hline Consumption & 749.225 & 774,439 & 817.463 & 827.674 & 891.181 \\
\hline \multicolumn{6}{|l|}{ Deliveries at State Borders } \\
\hline$\ldots \ldots \ldots$ & 17,900 & 38.361 & 17,284 & 14.751 & 67.763 \\
\hline$\ldots \ldots, \ldots \ldots \ldots$ & 331155 & 325,320 & 331.862 & 346.290 & 471,606 \\
\hline Interstate Deliveries & 1,300 & 1.495 & 3,088 & 2.506 & 6,268 \\
\hline \multicolumn{6}{|l|}{ Additions to Storage } \\
\hline Underground Storage & 341,649 & 414,819 & 415,309 & 354996 & 390.465 \\
\hline LNG Storago & 0 & 0 & 0 & 0 & 0 \\
\hline \multirow[t]{2}{*}{ Total Disposition. } & 1.441 .229 & $1,554,435$ & $1,585,006$ & 1.546 .217 & $1,827,283$ \\
\hline & \multicolumn{5}{|c|}{ Consumption (million cubic feet) } \\
\hline Lease and Plant Fuel & $\theta, 250$ & 8,003 & 9.094 & 9.595 & 7.274 \\
\hline Pipeline Fuel $\ldots$ & 18.377 & 16.824 & 17.928 & 19,590 & 21,690 \\
\hline \multicolumn{6}{|l|}{ Delivered to Consumers } \\
\hline Residential & 348.512 & 361,667 & 327,396 & 337.205 & 358.088 \\
\hline Commercial & 167.900 & 176.182 & 159.429 & 165,558 & 173,802 \\
\hline Industrial & 191.159 & 192.981 & 280,615 & 271.987 & 305.416 \\
\hline Vehicle Fuel & NA & NA & 2 & 3 & 4 \\
\hline Electric Utilities $\ldots \ldots \ldots \ldots$ & 15,027 & 18.182 & 22.999 & 23.736 & 24.908 \\
\hline Total Delivered to Consumers & 722,598 & 749,613 & 790,441 & 198,489 & 862.217 \\
\hline \multirow[t]{3}{*}{ Total Consumption } & 749.225 & 774,439 & $817,46.3$ & 827.674 & 891.181 \\
\hline & $(-\ldots \ldots \ldots+\cdots$ & $\ldots \ldots \ldots \ldots$ & & & \\
\hline & \multicolumn{5}{|c|}{ Delivered for the Account of Others (million cubic feel) } \\
\hline$\ldots \ldots \ldots \ldots$ & NA & NA & 2.997 & 3,627 & 4.121 \\
\hline$\ldots \ldots \ldots \ldots$ & 47,678 & 52.120 & 48,061 & 52.444 & 54,248 \\
\hline$\ldots \ldots$ & 153,051 & 158.992 & 247,139 & 242.652 & 277.506 \\
\hline \multirow[t]{2}{*}{ Electric Utilities $\ldots$} & 1,934 & 885 & 23,015 & 20,960 & 19,162 \\
\hline & \multicolumn{5}{|c|}{ Number of Consumers } \\
\hline Residentıal & 2.491 .149 & $2.531,304$ & $2,573.570$ & 2.609 .561 & 2.640 .579 \\
\hline$\cdots \quad \ldots$ & 185.961 & 191.474 & 195.766 & 198,890 & $201,56 \dagger$ \\
\hline$\ldots \ldots$ & 11.117 & 11.452 & 11,500 & 11.446 & 11460 \\
\hline \multirow[t]{2}{*}{ Vericle Fuel } & NA & NA & 1 & 1 & 1 \\
\hline & \multicolumn{4}{|c|}{ Average Annual Consumption per Consumer (thousand cutse teet) } & . \\
\hline Residential & 140 & 143 & 127 & 129 & 136 \\
\hline Commercial & 903 & 920 & 814 & 832 & 862 \\
\hline industrial & 17.195 & 16,851 & 24,401 & 23.763 & 26.651 \\
\hline \multirow[t]{2}{*}{ Vehicle Fuel } & NA & NA & 2.028 & 2,813 & 3,603 \\
\hline & \multicolumn{5}{|c|}{ Average Annual Cost per Consumer (dollars) } \\
\hline Residential & $\$ 747$ & $\$ 742$ & $\$ 639$ & $\$ 655$ & $\$ 686$ \\
\hline Commercial & 4.511 & 4462 & 3.773 & 3,911 & 4,008 \\
\hline \multirow[t]{2}{*}{ Venicle Fuel } & NA & NA & 4.116 & 6,041 & 3.555 \\
\hline & \multicolumn{5}{|c|}{ Average Heating Value (Btu per cubic toot) } \\
\hline \multirow[t]{2}{*}{ Delivered to Consumers } & 1.022 & 1.029 & 1,022 & 1020 & 1.020 \\
\hline & \multicolumn{5}{|c|}{ Average Prices for Natural Gas (dollars per thousand cubic leel) } \\
\hline Wellhead (Marketed Production) & $\$ 318$ & $\$ 316$ & $\$ 300$ & $\$ 279$ & $\$ 271$ \\
\hline Imports & 1.59 & .. & .. & 170 & 160 \\
\hline$\ldots \ldots \ldots$ & 201 & 200 & 270 & 191 & 183 \\
\hline$\ldots$ & 239 & 203 & 1.86 & 50 & 57 \\
\hline City Gate & 341 & 324 & 312 & 308 & 304 \\
\hline Delivered to Consumers & & & & & \\
\hline Residential & 534 & s 19 & 502 & 507 & 506 \\
\hline Commercial & 500 & 485 & 463 & 470 & 465 \\
\hline Industral & 436 & 4.22 & 389 & 400 & 392 \\
\hline Vehicie Fuel & NA & NA & 203 & 215 & 99 \\
\hline Electric Utilties & 41 & 19 & 47 & 76 & 81 \\
\hline
\end{tabular}

Hevised dala

MA Not available

Not appicable

Note Deliveries to electric utilities (consumption) are reported on the Form EiA 759. "Monthly Power Plant Report" Detiveries to electric utilities tor the account of others are reported on the Form EIA-176. "Annual Peport of Naturai and Supplemental Gas Supply and Disposition "See the discussion on electric utilty data and Table A1 in AP. pendix $A$ for a companson of reporting to these two forms. Totals may not add due to independent rounding

Sources Energy intormation Administration (ElA). Form ElA-176. "Annual Report of Nalural and Supplemental Gas Supply and Disposition. "Form ElA-627. "Annual Quantity and Value ol Natural Gas Report," Form ElA-857. "Monthly Report of Natural Gas Purchases and Deliveries to Consumers. " Form ElA.816. "Monthly Natural Gas Liquids Report," Form! EIA-759 "Monthly Power Plant Report," Form FERC.423. "Monthly Feport of Cost and Quality of Fuels for Electric Plants." Form ElA.191 "Underground Gas Storage Report"

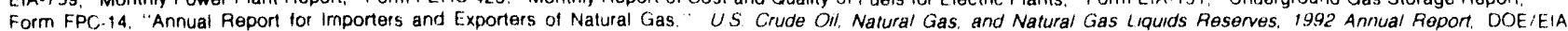
$0216(92)$, and the US Minerals Management Service. 


\section{Natural Gas 1992}

Net Interstate Movements

Million

Cu. Foot

273,537

Marketed Production

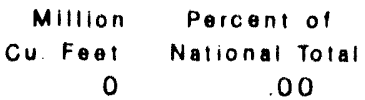

\section{Deliveries to Consumers}

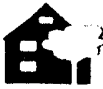

Residential:

113,560

2.42

A:

istes

Commercial:

82,381

2.94

$\ldots$

Industrial:

93.025

1.24

Vehicle Fuel:

0

.00

A

Electric Utility:

4,806

18

MINNESOTA

Total:

293,873

1.65

Table 67. Summary Statistics for Natural Gas -- Minnesota, 1988-1992

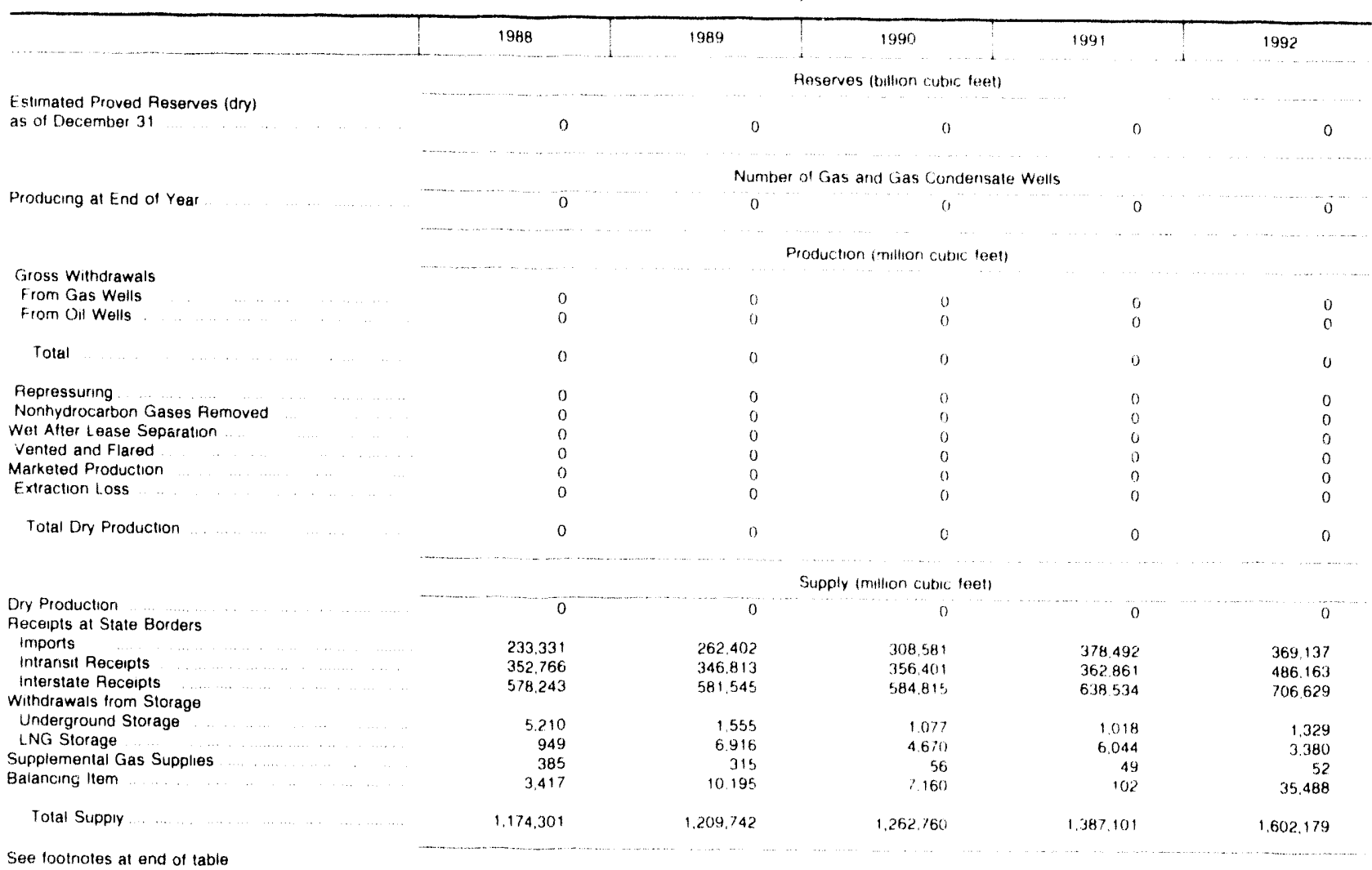


Table 67. Summary Statistics for Natural Gas .. Minnesota, 1988-1992 (Continued)

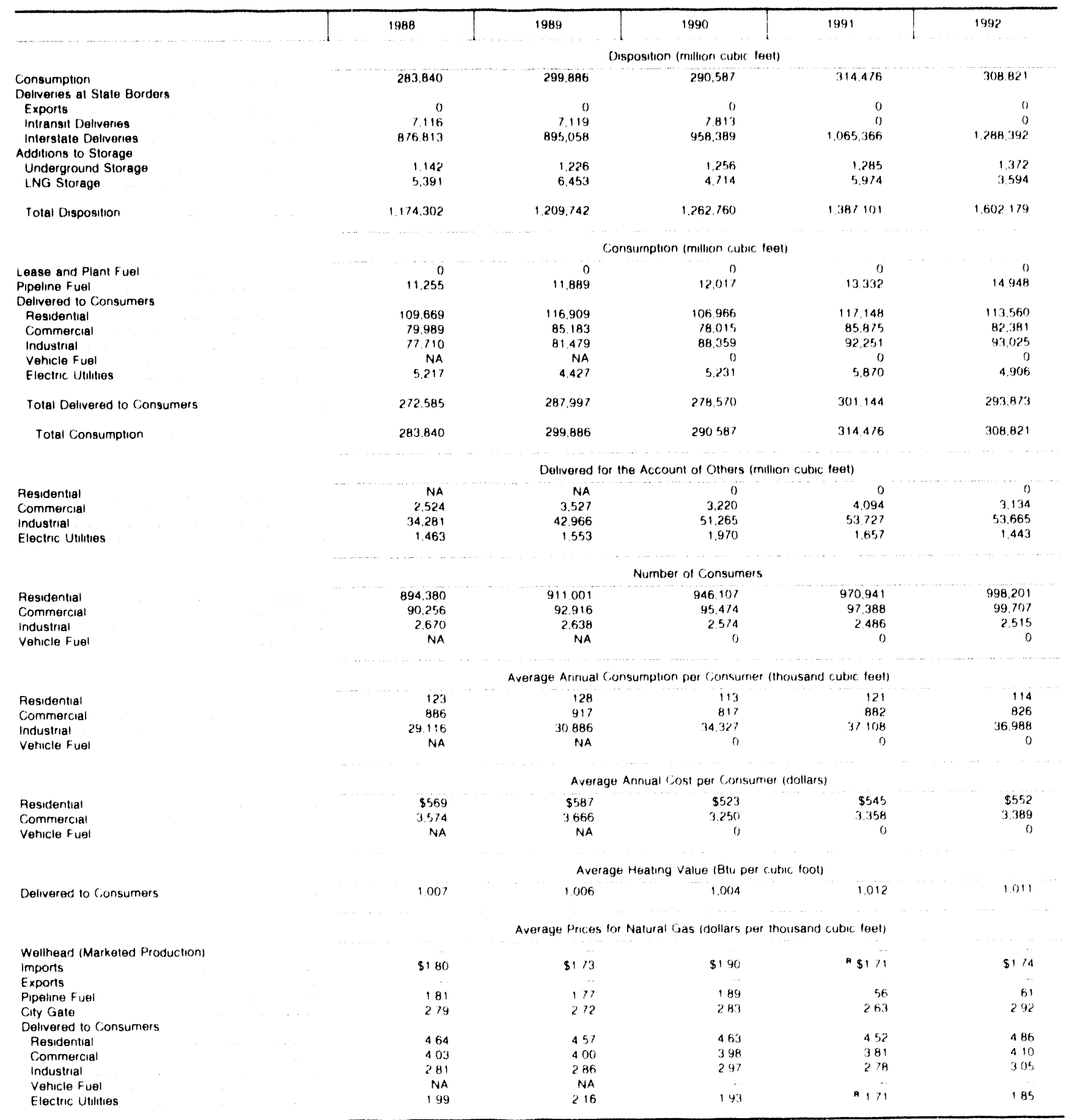

h Hevised data

Not available

Note Deliveries to electric utlities (consumption) are reported on the Form EIA.759. Monthly Power Plant Feport Deliveries to eloctric utilties for the account of others are reported on the Form EIA-176. "Annual Report of Natural and Supplemental Gas Supply and Disposition" See the discussion on electic utilitv data and Tabie A1 in Ap pendix $A$ for a comparison of reporting to these two forms Totals may not add due to independent roundirig

Sources Energy Information Administration (EIA), Form EIA.176. "Arinual Feport of Natural and Supplemental Gas Supply and Disposition, " Form FiA.627. Annual Quantity and Value of Natural Gas Report. "Form EIA.857. "Monthly Report of Natural Gas Purchases and Deliveries to Consumers." Form ElA.816. "Monthly Natural Gas L.quids Feport." Form ElA.759 "Mon Form FPC.14. "Annual Report lor Importers and Exporters of Natural Gas," US Crude Oll. Natural Gas. and Nalural Gas Liquids Reserves. 1992 Anrual Report. DOE/EIA. $0216(92)$. and the US Minerals Management Service 
Natural Gas 1992

Net Interstate Movements

Million

Cu. Fool

Marketed Production Million parcent of

Deliveries to Consumers

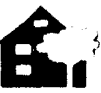

Residential:

A.

inst

Commercial:

17,942

i.

Industrial

102,612

1.36

$\longrightarrow$ Vehicle Fuel:

0

.00

A

Electric Utility:

64,180

1.96

Total:

201,221

1.13

Tabee 68. Summary Statistics for Natural Gas -- Mississippi, 1988-1992

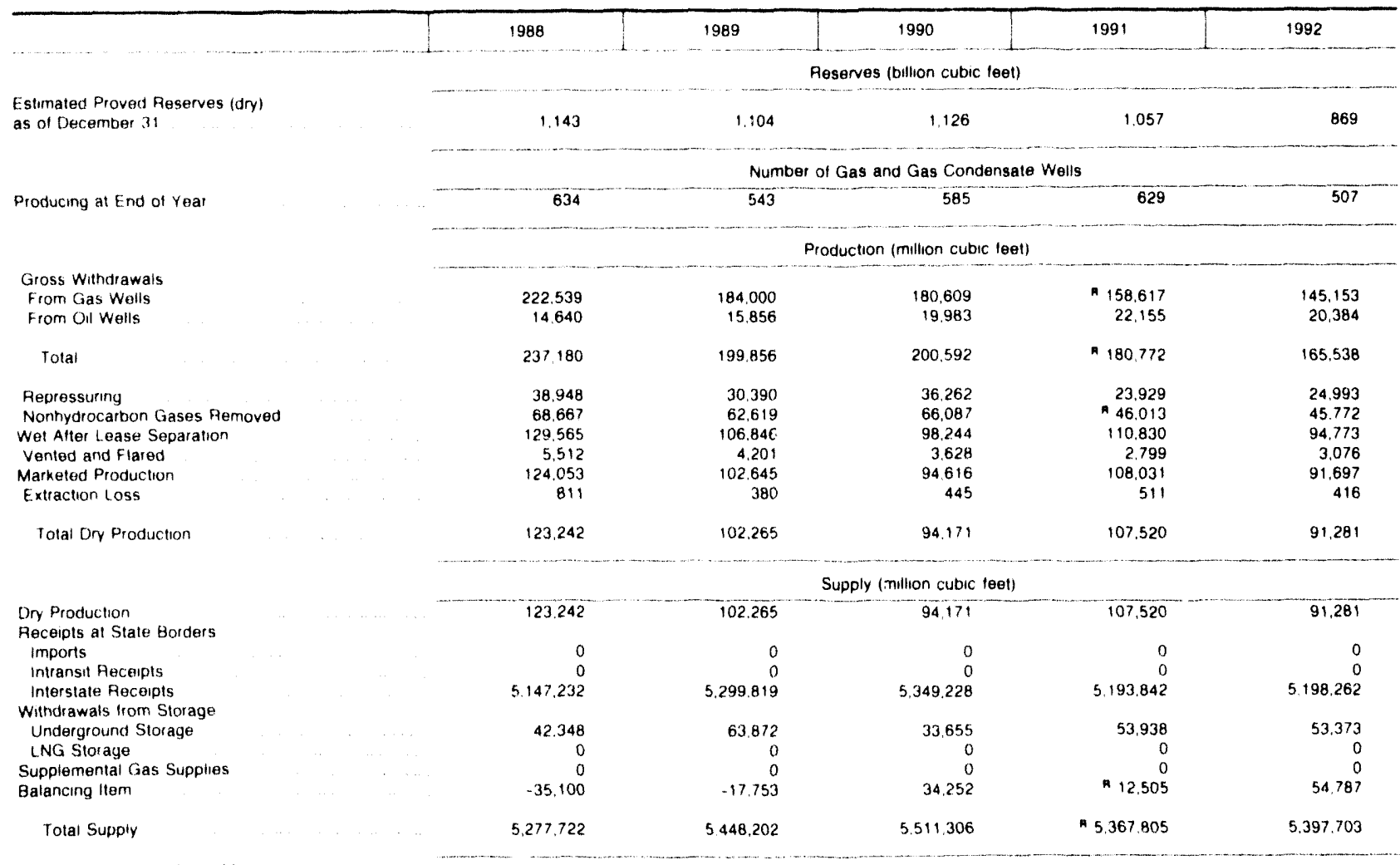

See footnotes al end of table 
Tabee 68. Summary Statistics for Natural Gas -- Mississippl, 1988-1992 (Continued)

\begin{tabular}{|c|c|c|c|c|c|}
\hline & 1988 & 1989 & 1990 & 1991 & 1992 \\
\hline & \multicolumn{5}{|c|}{ Disposition (million cubic foet) } \\
\hline $\begin{array}{l}\text { Consumption } \\
\text { Deliveries at State Borders }\end{array}$ & 212,779 & 225,625 & 253,690 & 249,761 & 239.442 \\
\hline Exports $\ldots . . . . . . .$. & 0 & 0 & 0 & 0 & 0 \\
\hline Intransit Deliveries & 0 & 0 & 0 & 0 & 0 \\
\hline Interstate Deliveries & $5,023,162$ & $5,172,100$ & $5,204,455$ & 5.069 .990 & $5,103,156$ \\
\hline Additions to Storage & & & & & \\
\hline Underground Storage & 41,780 & 50,478 & 53.161 & 48,054 & 55.105 \\
\hline LNG Storage & 0 & 0 & 0 & 0 & 0 \\
\hline \multirow[t]{2}{*}{ Total Disposition } & 5.277 .721 & $5,448.202$ & $5,511,306$ & ค $5,367,805$ & 5.397 .703 \\
\hline & \multicolumn{5}{|c|}{ Consumption (million cubic teet) } \\
\hline Lease and Plant Fuel. & 7.100 & 5.021 & 7.257 & 4,585 & 4.945 \\
\hline Pipeline Fuel $\ldots$ & 34.511 & 34,007 & 37,735 & 34,645 & 33.276 \\
\hline Delivered to Consumers & & & & & \\
\hline Residential & 26.889 & 26.312 & 25.045 & 25,756 & 26.487 \\
\hline$\ldots \quad \ldots \quad \ldots \quad \ldots$ & 18.108 & 17.568 & 17548 & 17.743 & 17942 \\
\hline$\therefore \quad \ldots \quad \ldots$ & 92.910 & 97.790 & 100.801 & 104,622 & 102612 \\
\hline . $: \quad+\ldots$, & NA & NA & 0 & 0 & 0 \\
\hline Electric Utilities & 33,261 & 44.927 & 65,304 & A 62,409 & 54.180 \\
\hline Total Delivered to Consumers & 171.168 & 186.597 & 208.699 & ค 210,531 & 201,221 \\
\hline \multirow[t]{2}{*}{ Total Consumption } & 212.779 & 225,625 & 253,690 & ค 249.761 & 239.442 \\
\hline & \multicolumn{5}{|c|}{ Delivered for the Account of Others (miltion cubic leet) } \\
\hline Pesidentiat & NA & NA & 0 & 0 & 0 \\
\hline Commercial & 0 & 0 & 777 & 731 & 645 \\
\hline Industrial & 40,868 & 47.098 & 51,694 & 54.398 & 55.973 \\
\hline \multirow[t]{2}{*}{ Electric Utilities } & 26.010 & 45,785 & 62.412 & 57.297 & 41.304 \\
\hline & \multicolumn{5}{|c|}{ Number of Consumers } \\
\hline Residential & 372.238 & 376.353 & 382.251 & 386.264 & $392+55$ \\
\hline Commercial & 44.170 & 44.253 & 43.184 & 43.693 & 44313 \\
\hline Industrial & 1.263 & 1.282 & 1.317 & 1,314 & 1,32 ? \\
\hline \multirow[t]{2}{*}{ Venicle Fuel } & NA & NA & 0 & 0 & n \\
\hline & \multicolumn{5}{|c|}{ Average Annual Consumption per Consumer (thousand cubic teet) } \\
\hline Residential & 72 & 70 & 66 & 67 & 68 \\
\hline$\ldots \ldots \ldots$ & 410 & 397 & 406 & 406 & 405 \\
\hline $2, \ldots \ldots \ldots+\ldots$ & 73.563 & 76,279 & 76.539 & 79.621 & 77326 \\
\hline \multirow[t]{2}{*}{ Vehicle Fuel } & NA & NA & 0 & 0 & 0 \\
\hline & \multicolumn{5}{|c|}{ Average Annual Cost per Consumer (dollars) } \\
\hline Residential & $\$ 423$ & $\$ 357$ & $\$ 349$ & $\$ 348$ & $\$ 335$ \\
\hline Commercial & 2.057 & 1,880 & 1,820 & 1.739 & 1672 \\
\hline \multirow[t]{2}{*}{ Vehicle Fuel } & NA & NA & 0 & 0 & a \\
\hline & \multicolumn{5}{|c|}{ Average Heating Value (Blu per cubic foot) } \\
\hline \multirow[t]{2}{*}{ Delivered to Consumers. } & 1.017 & 1.030 & 1.033 & 1.029 & 1.047 \\
\hline & \multicolumn{5}{|c|}{ Average Prices for Natural Gas (dollars per thousand cubic feet) } \\
\hline Wellhead (Marketed Production) & $\$ 1.86$ & $\$ 197$ & $\$ 176$ & $\$ 166$ & $\$ 164$ \\
\hline Imports & -. & $\cdots$ & ... & .. & $\ldots$ \\
\hline Exports & $\ldots$ & $\ldots$ & $\ldots$ & .. & \\
\hline Pipeline Fuel & 187 & 209 & 211 & 233 & 234 \\
\hline City Gate & 329 & 308 & 289 & 255 & 262 \\
\hline \multicolumn{6}{|l|}{ Delivered to Consumers } \\
\hline Residential & 585 & 510 & 533 & 521 & 495 \\
\hline Commercial & 502 & 473 & 448 & 428 & 413 \\
\hline Industrial & 254 & 254 & 257 & 235 & 253 \\
\hline Vehicle Fuel & NA & NA & $\ldots$ & .. & \\
\hline Electric Utilities & 190 & 188 & 183 & 161 & 185 \\
\hline
\end{tabular}

\section{a : Revised data}

ma $\because$ Not avallabie

Not applicable

Note Deliveries to electric utilities iconsumption) are reported on the Form EtA.759. "Monthly Power Piant Feport "Deliveries to eluutr. utilties for the account of others are reported on the Form EIA.176. "Annual Report of Natural and Supptemental Gas Supply and Disposition" See the discussion on electric utility data and 7 atite A1 in Ap pendix A for a comparison of reporting to these two forms Totals may not add due to independent rounding.

Sources Energy Intormation Administration (EIA). Form E.IA.176. "Annual Report of Natural and Supplemental Gas Supply and Dispositson," Form EiA.627. "Annual Ouantity and Value of Natural Gas Report," Form ElA-857. "Monthly Report of Natural Gas Purchases and Deliveries to Consumers. "Form ElA.816. "Monthly Natural Gas Liquids Repor!." Forn ElA.759. "Monthly Power Plant Report." Form FERC-423, "Monthly Report of Cost and Quality of Fuels for Electric Plants. "Form ElA-191. "Underground Gas Storage Feport. Form FPC-14 "Annual Report for Importers and Exporters of Naiurat Gas." US Crude Oil. Natural Gas. and Natural Gas Liquits Reserves. 1992 Annuat Report. DOE . EIA $0216(92)$, and the US Minerals Management Service. 
Natural Gas 1992

Net Interstate Movements

Million

Cu. Foot

Marketed Production

Millton Porcont of Cu. Foet National Total

\section{Deliveries to Consumers}

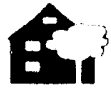

Residential:

A.

insth

Commercial:

III

Industrial:

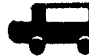

Vehicle Fuel:

A Electric Utility:

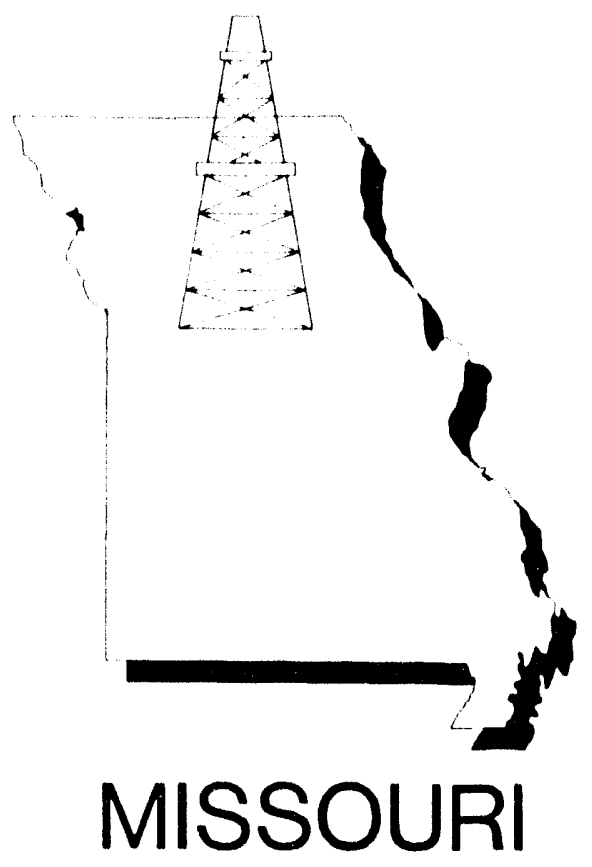

Total:

Table 69. Summary Statistics for Natural Gas -- Missouri, 1988-1992

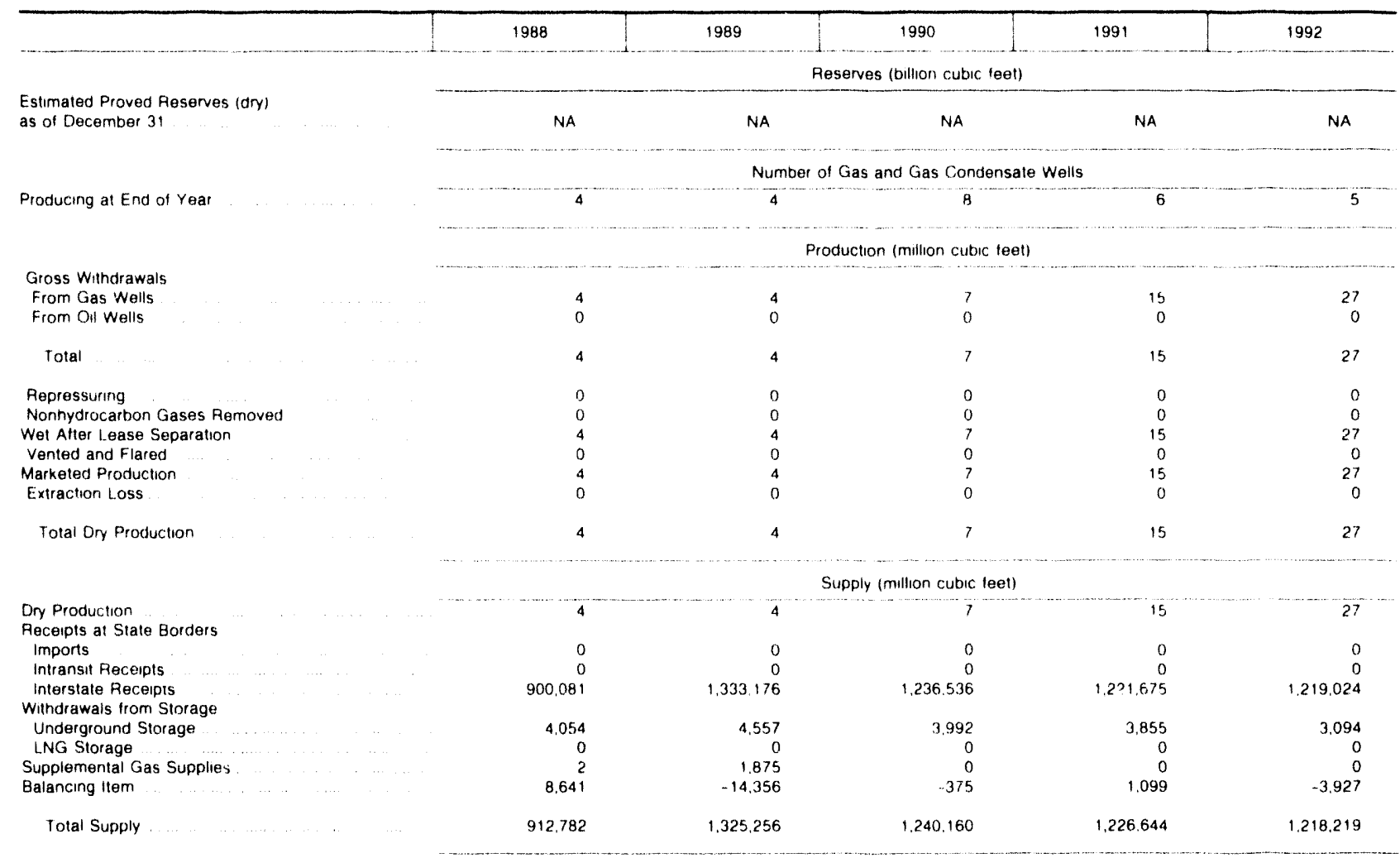

See footnotes at end of table 
Table 69. Summary Statistics for Natural Gas -- Missouri, 1988-1992 (Continued)

\begin{tabular}{|c|c|c|c|c|c|}
\hline & 1988 & 1989 & 1990 & 1991 & 1992 \\
\hline & \multicolumn{4}{|c|}{ Disposition (million cubic feet) } & \\
\hline $\begin{array}{l}\text { Consumption } \\
\text { Deliveries at State Borders }\end{array}$ & 252,923 & 252,527 & 238,709 & 256,328 & 240.745 \\
\hline \multicolumn{6}{|l|}{ Deliveries at State Borders } \\
\hline Exports & 0 & 0 & 0 & 0 & 0 \\
\hline Intransit Deliveries & 0 & 0 & 0 & 0 & 0 \\
\hline Interstate Deliveries & 655,619 & $1,069,819$ & 996,135 & 965,344 & 974.394 \\
\hline \multicolumn{6}{|l|}{ Additions to Storage } \\
\hline Underground Storage & 4,240 & 2.911 & 5,316 & 4,972 & 3,080 \\
\hline LNG Storage & 0 & 0 & 0 & 0 & 0 \\
\hline \multirow[t]{2}{*}{ 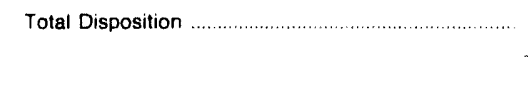 } & 912,782 & $1,325,256$ & $1,240,160$ & $1,226,644$ & $1,218,219$ \\
\hline & \multicolumn{5}{|c|}{ Consumption (million cubic feet) } \\
\hline Lease and Plant Fuel .... & 0 & 0 & 0 & 0 & $\overrightarrow{1}$ \\
\hline Pipeline Fuel & 4.901 & 5,164 & 5,302 & 2,563 & 2,309 \\
\hline \multicolumn{6}{|l|}{ Delivered to Consumers } \\
\hline 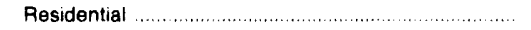 & 128,317 & 129,144 & 115,950 & 120,680 & 116,655 \\
\hline Commercial & 63,839 & 63,039 & 59,387 & 63.191 & 60.963 \\
\hline Industrial & 54.243 & 53,938 & 54,538 & 57,186 & 58,466 \\
\hline Vehicle Fuel & NA & NA & 0 & 0 & 0 \\
\hline 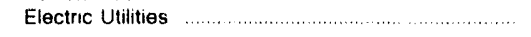 & 1,623 & 1,242 & 3,532 & 12,709 & 2,351 \\
\hline Total Delivered to Consumers & 248,022 & 247,363 & 233,408 & 253,765 & 238,435 \\
\hline \multirow[t]{2}{*}{ Total Consumption $\ldots \ldots \ldots \ldots \ldots \ldots \ldots$} & 252,923 & 252,527 & 238,709 & 256,328 & 240,745 \\
\hline & \multicolumn{5}{|c|}{ Delivered for the Account of Others (million cubic feet) } \\
\hline Residential. & NA & NA & 1 & 0 & 0 \\
\hline 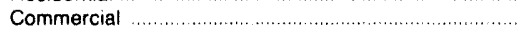 & 2,400 & 4,851 & 8,306 & 8,910 & 8,817 \\
\hline Industrial & 16,101 & 24,219 & 36,711 & 42,745 & 44.131 \\
\hline \multirow[t]{2}{*}{ 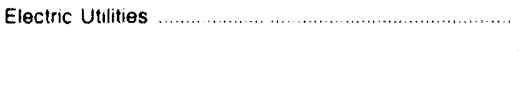 } & 1,879 & 2,485 & 2,015 & 2,869 & 1.418 \\
\hline & \multicolumn{5}{|c|}{ Number of Consurners } \\
\hline Residential & $1,194,985$ & $1,208,523$ & $1,213,305$ & $1,211,342$ & $1,220,203$ \\
\hline Commercial & 97.939 & 99,721 & 105,164 & 117,675 & 125,174 \\
\hline Industrial & 2,880 & 3,063 & 3,140 & 3,096 & 2,989 \\
\hline \multirow[t]{2}{*}{ 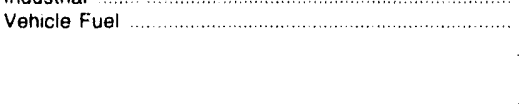 } & NA & NA & 0 & 0 & 0 \\
\hline & \multicolumn{5}{|c|}{ Average Annual Consumption per Consumer (thousand cubic leet) } \\
\hline Residential. & 107 & 107 & 96 & 100 & 96 \\
\hline 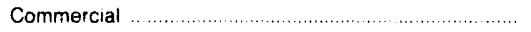 & 652 & 632 & 565 & 537 & 487 \\
\hline Industrial & 18,834 & 17610 & 17.369 & 18,471 & 19,560 \\
\hline \multirow[t]{2}{*}{ 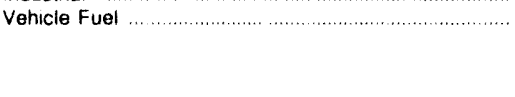 } & NA & NA & 0 & 0 & 0 \\
\hline & \multicolumn{5}{|c|}{ Average Annual Cost per Consumer (dollars) } \\
\hline Residential. & $\$ 5: 1$ & $\$ 517$ & $\$ 498$ & $\$ 512$ & $\$ 488$ \\
\hline 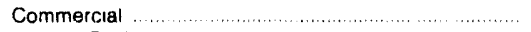 & 2,739 & 2,745 & 2,557 & 2,418 & 2,179 \\
\hline \multirow[t]{2}{*}{ (n) } & NA & NA & 0 & 0 & 0 \\
\hline & \multicolumn{5}{|c|}{ Average Heating Value (Btu per cubic toot) } \\
\hline \multirow[t]{2}{*}{ Delivered to Consumers } & 1.006 & 1.008 & 1.011 & 1,009 & 1,002 \\
\hline & \multicolumn{5}{|c|}{ Average Prices for Natural Gas (dollars per thousand cubic feet) } \\
\hline 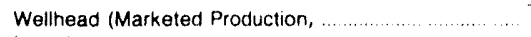 & $\$ 3.75$ & $\$ 3.50$ & $\$ 1.57$ & $\$ 1,32$ & $\$ 1.56$ \\
\hline Imports & - & - & $-\cdot$ & $-\cdot$ & -. \\
\hline Exports & -. & $\cdots$ & $-\cdot$ & $-\cdot$ & - \\
\hline 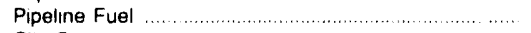 & 2.78 & 1.94 & 1.77 & 2.05 & 2.31 \\
\hline City Gate & 2.87 & 3.00 & 3.14 & 2.92 & 2.86 \\
\hline \multicolumn{6}{|l|}{ Delivered to Consumers } \\
\hline 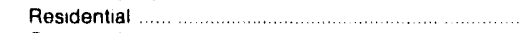 & 4.76 & 484 & 5.21 & 5.14 & 5.11 \\
\hline 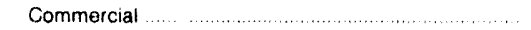 & 4.20 & 4.34 & 4.53 & 4.50 & 4.47 \\
\hline … & 3.81 & 4.13 & 419 & 4.08 & 3.87 \\
\hline 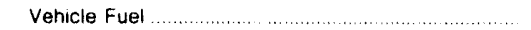 & NA & NA & $\ldots$ & -. & $\ldots$ \\
\hline Electric Utilities & 2.75 & 2.50 & 1.75 & 1.51 & 1.89 \\
\hline
\end{tabular}

MA $=$ Not available.

Note: Deliveries to electric utilities (consumption, are reported on the Form ElA.759 "Monthly Power Plant Repon." Deliveries to electric utilities for the account of Note: Deliveries to electric utilities (consumption) are reported on the Form EiA-759, "Montinly Power Plant Repor." Deliveries to electric utifies for the account of
others are reported on the Form ElA-176. "Annual Report of Natural and Supplemental Gas Supply and Disposition." See the discussion on electric utility data and Table A1 in Ap.

pendix $A$ for a comparison of teporting to these two forms. Totals may not add due to independent rounding

Source: Energy Information Administration (EIA), Form EIA-176. "Annual Report of Natural and Supplemental Gas Supply and Disposition," Form EIA.627, "Annual Quantity and Value of Natural Gas Report." Form ElA-857, "Monthly Peport of Natural Gas Purchases and Deliveries to Consumers." Form ElA-816, "Monthly Natural Gas Liquids Repon," Form EIA.759, "Monthly Power Plant Repont," Form FERC-423, "Monthly Report of Cost and Quality of Fuels for Electric Plants, " Form ElA-191, "Underground Gas Storage Report," Form FPC.14, "Annual Report for Importers and Exponers of Natural Gas." U.S. Crude Oil. Natural Gas, and Natural Gas Liquids Reserves, 1992 Annual Report. DOE/EIA. 0216(92); and the U.S. Minerals Management Service. 


\section{Natural Gas 1992}

Net Interstate Movements

Million
Cu. Feot
53,867

Marketed Production

Mililon

Cu. Feet

$-4,567$

Percent of

National Total

.29

\section{Deliveries to Consumers}

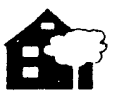

Residential:

16,673

.36

Nis.

nath

Commercial:

11,557

$\rightarrow$

Industrial:

12,218

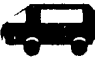

Vehicle Fuel:

2

.39

A

Electric Utility:

220

.41

.16

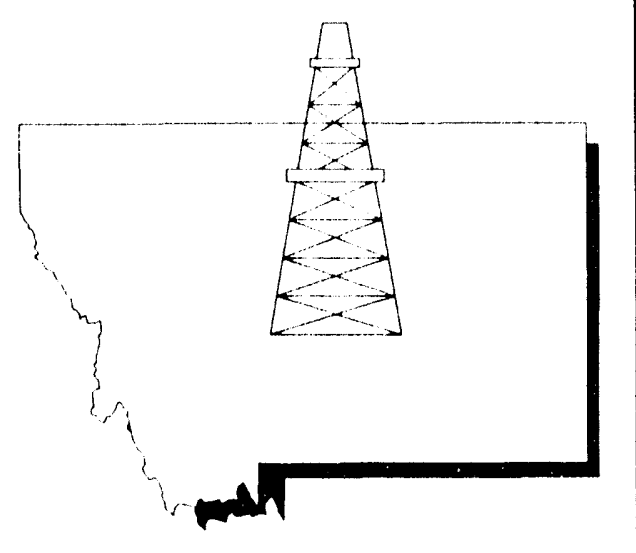

Total:

40,671

.23

Table 70. Summary Statistics for Natural Gas -- Montana, 1988-1992

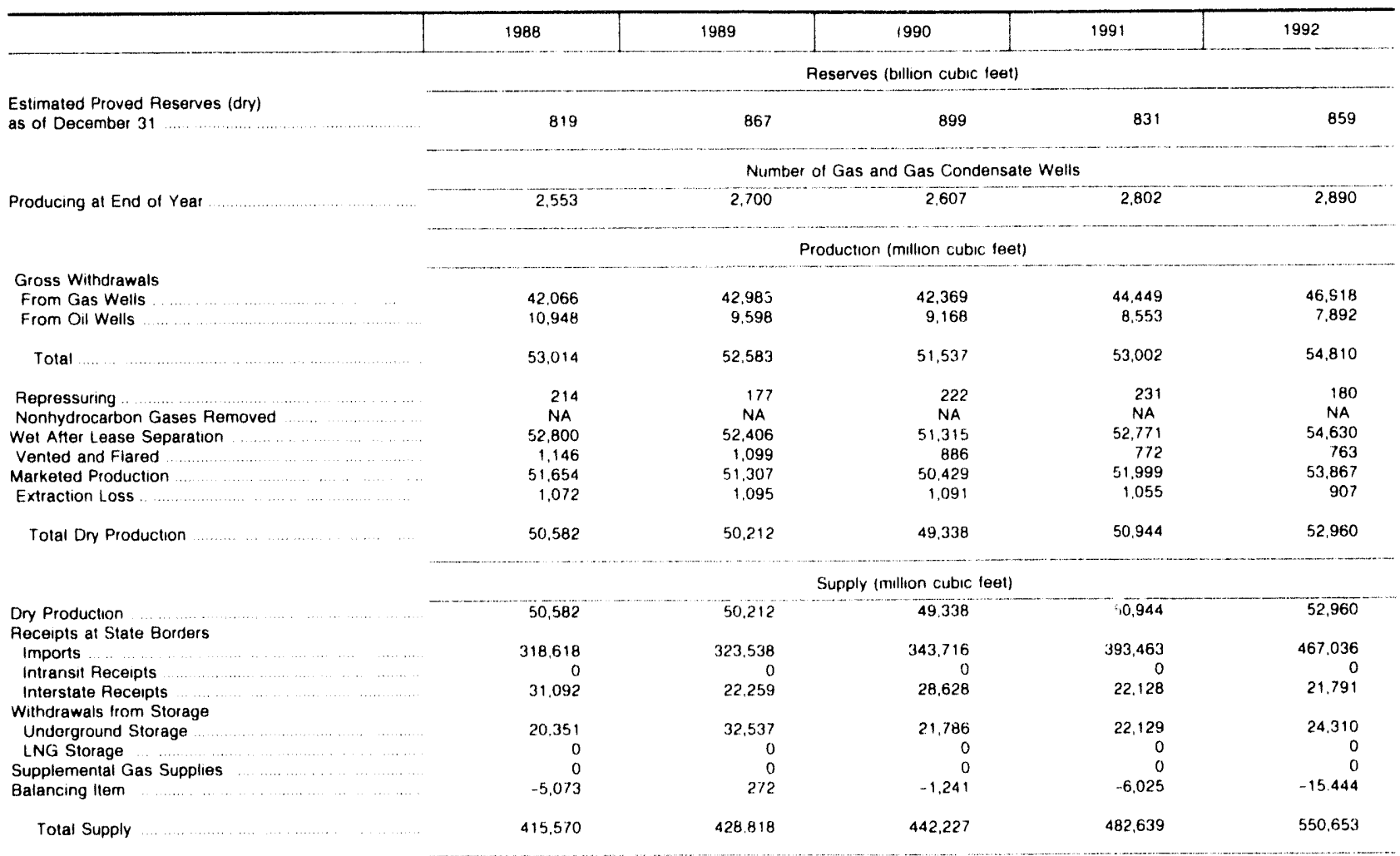

See tootnotes at end of table. 
Table 70. Summary Statistics for Natural Gas -- Montana, 1988-1992 (Continued)

\begin{tabular}{|c|c|c|c|c|c|}
\hline & 1988 & 1989 & 1990 & 1991 & 1992 \\
\hline & \multicolumn{5}{|c|}{ Disposition (million cubic feet) } \\
\hline Consumption . & 41,825 & 45,756 & 43,169 & 45,402 & 45,561 \\
\hline \multicolumn{6}{|l|}{ Deliveries at State Borders } \\
\hline Exports & 39 & 82 & 75 & 41 & 14 \\
\hline Intransit Deliveries & 15,080 & 14,372 & 16.013 & 16,298 & 14.554 \\
\hline 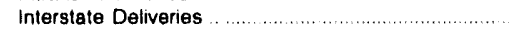 & 344,845 & 358,128 & 368,321 & 408,507 & 478,815 \\
\hline \multicolumn{6}{|l|}{ Additions to Storage } \\
\hline Underground Storage & 13,782 & 10,479 & 14,648 & 12,392 & 11,708 \\
\hline LNG Storage & 0 & 0 & 0 & 0 & 0 \\
\hline \multirow[t]{2}{*}{ Total Disposition } & 415,571 & 428,818 & 442,227 & 482,639 & 550,653 \\
\hline & \multicolumn{5}{|c|}{ Consumption (million cubic feet) } \\
\hline Lease and Plant Fuel & 1,994 & 1,766 & 2.262 & 1,680 & 1,871 \\
\hline Pipeline Fuel & 2,245 & 2,415 & 2,051 & 2,321 & 3,019 \\
\hline \multicolumn{6}{|l|}{ Delivered to Consumers } \\
\hline Residential .................. & 16,900 & 18,195 & 16,850 & 18,413 & $16,6,3$ \\
\hline Commercial . & 12,041 & 13.141 & 12,164 & 12,846 & $11,55 i$ \\
\hline Industrial & 8,360 & 9,903 & 9.424 & 9,873 & 12,218 \\
\hline 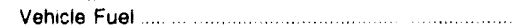 & NA & NA & . & 2 & 2 \\
\hline Electric Utilities & 286 & 336 & 418 & 268 & 220 \\
\hline 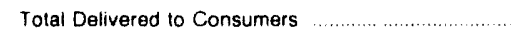 & 37,587 & 41,575 & 38,856 & 41,401 & 40,671 \\
\hline \multirow[t]{2}{*}{ Total Consumption } & 41,825 & 45,756 & 43,169 & 45,402 & 45,561 \\
\hline & \multicolumn{5}{|c|}{ Delivered for the Account of Others (million cubic teet) } \\
\hline Residential & NA & NA & 0 & 0 & 0 \\
\hline 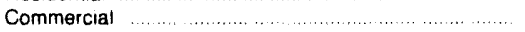 & 13 & 242 & 261 & 327 & 533 \\
\hline Industrial & 1,101 & 2,600 & 3,306 & 4.493 & 10.078 \\
\hline \multirow[t]{2}{*}{ 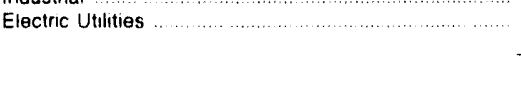 } & 0 & 0 & 118 & 178 & 99 \\
\hline & \multicolumn{5}{|c|}{ Number of Consumers } \\
\hline Residential. & 171.785 & 171,156 & $174, \overline{384}$ & 177,726 & 182,641 \\
\hline Commercial & 22,246 & 22.219 & 23.331 & 23,185 & 23,610 \\
\hline Industria! & 435 & 428 & 457 & 452 & 459 \\
\hline \multirow[t]{2}{*}{ Vehicle Fuel $\ldots \ldots \ldots \ldots \ldots$} & NA & NA & 1 & 1 & 2 \\
\hline & \multicolumn{5}{|c|}{ Average Annual Consumption per Consumer (thousand cubic feet) } \\
\hline Rezidentiai. & 98 & 106 & 97 & 104 & 91 \\
\hline Commercial & 541 & 591 & 521 & 554 & 490 \\
\hline Industrial & 19,219 & 23.138 & 20,622 & 21,842 & 26,620 \\
\hline \multirow[t]{2}{*}{ 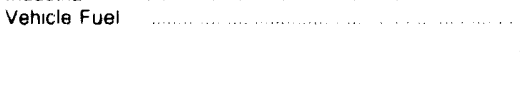 } & NA & NA & 82 & 1,936 & 1,054 \\
\hline & \multicolumn{5}{|c|}{ Average Annual Cost per Consumer (dollars) } \\
\hline Residentiai & $\$ 423$ & $\$ 464$ & $\$ 444$ & $\$ 468$ & $\$ 439$ \\
\hline$\ldots \ldots \ldots$ & 2.329 & 2.579 & 2.419 & 2.411 & 2,185 \\
\hline \multirow[t]{2}{*}{ Venicle Fuel } & NA & NA & 376 & 8,718 & 4.749 \\
\hline & \multicolumn{5}{|c|}{ Average Heating Value (Btu per cubic foot) } \\
\hline \multirow[t]{2}{*}{ Delivered to Consumers } & 1,025 & 1.020 & 1.028 & 1.029 & 1,023 \\
\hline & \multicolumn{5}{|c|}{ Average Prices for Natural Gas (dollars per thousand cubic leet) } \\
\hline Wellhead (Marketed Production) .................... & $\$ 1.70$ & $\$ 1.55$ & $\$ 179$ & $\$ 166$ & $\$ 162$ \\
\hline Imports & 1.56 & 148 & 144 & 1.38 & 152 \\
\hline Exports $\ldots$ & 1.33 & 1.45 & 169 & 172 & 1.66 \\
\hline Pipeline Fuel & 1.65 & 1.57 & 1.75 & 176 & 163 \\
\hline \multirow{2}{*}{\multicolumn{6}{|c|}{ Delivered to Consumers }} \\
\hline & & & & & \\
\hline Residential ... & 4.30 & 4.37 & 459 & 452 & 4.80 \\
\hline . & 4.30 & 4.36 & 4.64 & 4.35 & 4.46 \\
\hline Industral & 3.08 & 298 & 3.27 & 3.22 & 4.19 \\
\hline$\ldots \ldots \ldots \ldots \ldots \ldots \ldots \ldots \ldots$ & NA & NA & 4.59 & 450 & 4.51 \\
\hline Electric Utilities & 1.53 & 138 & 1.77 & 433 & 3.30 \\
\hline
\end{tabular}

- Less than 500,000 cubic feet or 500 consumers

wa Not available

Note. Deliveries to electric utilities (consumption) are reported on the Form ElA.759. "Monthly Power Plant Report" Deliveries to electric utlities for the account of others are reporteu on the Form EIA.176. "Annual Report of Natural and Supplemental Gas Supply and Disposition." See the discussion on electric utility data and Table A1 in Ap pendix $A$ for a comparison of reporting to these two forms. Totals may not add due to independent rounding.

Sources: Energy Information Administration (EIA). Form EIA.176. "Annual Report of Natural and Supplemental Gas Supply and Disposition." Form EIA.627. "Annual Quantity and Value of Natural Gas Report." Form ElA.857. "Monthly Report of Natural Gas Purchases and Deliveries to Consumers," Form EIA-816, "Monthly Natural Gas Liquids Report," Form ElA-759. "Monthly Power Plant Repon,." Form FERC-423. "Monthly Report of Cost and Quality of Fuels for Electric Plants, " Form ElA-191. "Underground Gas Storage Report." Form FPC-14, "Annual Report tor Importers and Exporters of Natural Gas." US. Crude OIl, Natural Gas, and Natural Gas Liquids Reserves, 1992 Annual Report. DOE/EIA. 0216(92): and the U.S Minerals Management Service. 
Natural Gas 1992

Net Interstate Movements

Million

Cu. Foet

123,182

Marketed Production

Million

Percent of

National Total

1,177

.01

Deliveries to Consumers

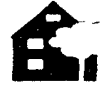

Residential:

41,414

A.

insth

Commercial:

34,490

1.23

i. M

Industrial:

26,451

.35

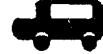

Vehicle Fuel:

.00

NEBRASKA

成

Electric Utility:

1,803

.07

Total:

104,258

.59

Table 71. Summary Statistics for Natural Gas -- Nebraska, 1988-1992

\begin{tabular}{|c|c|c|c|c|c|}
\hline & 1988 & 1989 & 1990 & 1991 & 1992 \\
\hline & \multicolumn{5}{|c|}{ Reserves (tutlion cubic feet) } \\
\hline \multirow[t]{2}{*}{$\begin{array}{l}\text { Estmated Proved Peserves (dry) } \\
\text { as of December } 31\end{array}$} & NA & NA & NA & NA & NA \\
\hline & \multicolumn{5}{|c|}{ Number of Gas and Gas Condensate Wells } \\
\hline \multirow[t]{2}{*}{ Producing at End of Year } & 18 & 15 & 11 & 12 & 22 \\
\hline & \multicolumn{5}{|c|}{ Produclion (million cutic feel) } \\
\hline \multicolumn{6}{|l|}{ Gross Withdrawais } \\
\hline rrom Gas Weils & 322 & 285 & 114 & 126 & 486 \\
\hline From Oll Wells & 588 & 593 & 679 & 657 & 691 \\
\hline Total & 910 & 878 & 793 & 784 & 1.177 \\
\hline Repressuring & $\cdot$ & $\cdot$ & $\cdot$ & $\cdot$ & $\cdot$ \\
\hline Nonhydrocarbon Gases Removed & • & - & $\cdot$ & $\cdot$ & $\cdot$ \\
\hline Wet After Lease Separation & 910 & 878 & 793 & 784 & 1,177 \\
\hline Vented and Flared & $\cdot$ & • & & $\cdot$ & 0 \\
\hline Marketed Production & 910 & 878 & 793 & 784 & 1,177 \\
\hline Extraction Loss & 59 & 29 & $\cdot$ & 13 & 3 \\
\hline \multirow[t]{2}{*}{ Tolal Dry Production } & 851 & 849 & 793 & 771 & 1.174 \\
\hline & \multicolumn{5}{|c|}{ Supply (miltion cubic teet) } \\
\hline Dry Production & 851 & 849 & 793 & 771 & 1,174 \\
\hline \multicolumn{6}{|l|}{ Receipts at State Borders } \\
\hline imports & 0 & 0 & 0 & 0 & 0 \\
\hline$\ldots, \quad \ldots, \ldots \ldots \ldots$ & 0 & 0 & 0 & 0 & 0 \\
\hline$\ldots \ldots \ldots \ldots \ldots$ & $1,091,860$ & $1,011.038$ & 970,896 & 924.993 & $1,021,817$ \\
\hline \multicolumn{6}{|l|}{ Withdrawals trom Storage } \\
\hline Underground Storage $\quad \ldots \quad \begin{array}{lllll} & \ldots & \ldots & \ldots\end{array}$ & 7.567 & 8.309 & 9,772 & 8.687 & 9,848 \\
\hline LNG Storage $\ldots \ldots$ & 167 & 414 & 155 & 211 & 173 \\
\hline Supplemental Gas Supplies $\ldots . . \ldots \ldots \ldots \ldots$ & 1,948 & 2.088 & 2,361 & 2,032 & 1.437 \\
\hline Balancing Item $\ldots$ & -10.441 & $-6,998$ & $-19,191$ & $-25,32.3$ & $-18,422$ \\
\hline 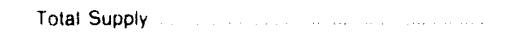 & $1,091,952$ & $1,015,700$ & 964,786 & ค 911,371 & $1,016.025$ \\
\hline
\end{tabular}


Table 71. Summary Statistics for Natural Gas -- Nebraska, 1988-1992 (Continued)

\begin{tabular}{|c|c|c|c|c|c|}
\hline & 1988 & 1989 & 1990 & 1991 & 1992 \\
\hline & \multicolumn{5}{|c|}{ Disposition (million cubic leet) } \\
\hline Consumption $\ldots . . . . . . . . . . .$. & 121,979 & 120,235 & 111,063 & 115.808 & 106.853 \\
\hline \multicolumn{6}{|l|}{ Deliveries at State Borders } \\
\hline Exports & 0 & 0 & 0 & 0 & 0 \\
\hline Intransit Deliveries ............ & 0 & 0 & 0 & 0 & 0 \\
\hline Interstate Deliveries. & 962,058 & 888,303 & 845,834 & 786,554 & 898,635 \\
\hline \multicolumn{6}{|l|}{ Additions to Storage } \\
\hline Underground Storage & 7,615 & 6,952 & 7,395 & 8,916 & 10.254 \\
\hline LNG Storage & 299 & 210 & 493 & 92 & 283 \\
\hline \multirow[t]{2}{*}{ Total Disposition } & $1,091,951$ & $1,015,700$ & 964,786 & A 911,371 & $1.016,025$ \\
\hline & \multicolumn{5}{|c|}{ Consumption (million cubic feet) } \\
\hline Lease and Plant Fuel.. & 47 & 34 & 26 & 31 & 40 \\
\hline Pipeline Fuel ................ & 4,698 & 4,909 & 3,536 & 2,368 & 2,555 \\
\hline \multicolumn{6}{|l|}{ Delivered to Consumers } \\
\hline Residential ............... & 43,502 & 44,804 & 41,499 & 44,671 & 41,414 \\
\hline Commercial & 39,388 & 37,351 & 36,489 & 40.291 & 34,490 \\
\hline Industrial & 32,299 & 30,545 & 25,746 & 24,758 & 26,451 \\
\hline 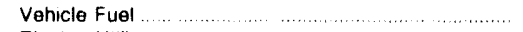 & NA & NA & 0 & 0 & $\cdot$ \\
\hline 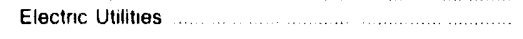 & $2 \cap A 6$ & 2,593 & 3,766 & 3,689 & 1,903 \\
\hline Total Delivered to Consumers. & 117,234 & 115,293 & 107,500 & 113,409 & 104,258 \\
\hline \multirow[t]{2}{*}{ Total Consumption } & 121,979 & 120,235 & 111,063 & 115,808 & 106,853 \\
\hline & \multicolumn{5}{|c|}{ Delivered for the Account of Others (million cubic feel) } \\
\hline 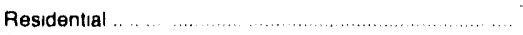 & NA & NA & 0 & 0 & 0 \\
\hline Commercial & 894 & 571 & 2,231 & 3,294 & 4,063 \\
\hline Industral & 15,783 & 17,311 & 14,304 & 13,266 & 15,558 \\
\hline \multirow[t]{2}{*}{ Electric Utilities } & 2 & 679 & 2,793 & 2,612 & 1,038 \\
\hline & \multicolumn{5}{|c|}{ Number of Consumers } \\
\hline Residential ................. & 403,657 & 406,723 & 407.094 & 413.354 & 418.611 \\
\hline Cornmercial & 61,365 & 60.377 & 60,405 & 60,947 & 61,319 \\
\hline Industrial $\ldots \ldots \ldots$ & 684 & 702 & 712 & 718 & 696 \\
\hline \multirow[t]{2}{*}{ Vehicle Fuel } & NA & NA & 0 & 0 & 1 \\
\hline & \multicolumn{5}{|c|}{ Average Annual Consumption per Consumer (thousand cubic leet) } \\
\hline Residential. & 108 & 110 & 102 & 108 & 99 \\
\hline Commercial & 642 & 619 & 604 & 661 & 562 \\
\hline Industrial .... & 47,221 & 43,511 & 36,160 & 34,482 & 38,005 \\
\hline \multirow[t]{2}{*}{ Vehicle Fuel } & NA & NA & 0 & 0 & 363 \\
\hline & \multicolumn{5}{|c|}{ Average Annual Cost per Consumer (dollars) } \\
\hline Residential. & $\$ 481$ & $\$ 493$ & $\$ 469$ & $\$ 502$ & $\$ 477$ \\
\hline 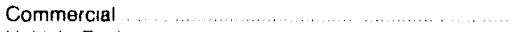 & 2,404 & 2.331 & 2.330 & 2,562 & 2,247 \\
\hline \multirow[t]{2}{*}{ Vehicle Fuel $\ldots \ldots \ldots \ldots$} & NA & NA & 0 & 0 & 0 \\
\hline & \multicolumn{5}{|c|}{ Average Heating Value (Btu per cubic foot) } \\
\hline \multirow[t]{2}{*}{ Delivered to Consumers } & 983 & 987 & 983 & 984 & 979 \\
\hline & \multicolumn{5}{|c|}{ Average Prices for Natural Gas (dollars per thousand cubic feet) } \\
\hline Wellhead (Marketed Production) & $\$ 2.66$ & $\$ 2.23$ & $\$ 2.26$ & $\$ 2.06$ & $\$ 178$ \\
\hline Imports & $\ldots$ & $\cdots$ & .. & $\ldots$ & .. \\
\hline 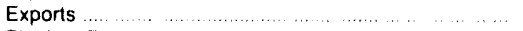 & -. & $\cdots$ & $\ldots$ & $\cdots$ & $\cdots$ \\
\hline Pipeline Fuel & 177 & 186 & 1.70 & 1.43 & 1.54 \\
\hline 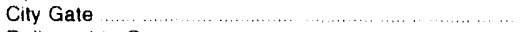 & 3.03 & 291 & 2.95 & 2.75 & 291 \\
\hline \multicolumn{6}{|l|}{ Delivered to Consumers } \\
\hline Residentiai ............... & 4.46 & 4.48 & 4.60 & 4.64 & 4.82 \\
\hline 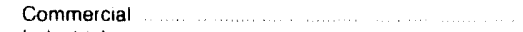 & 375 & 377 & 3.86 & 387 & 3.99 \\
\hline Industrial & 2.85 & 2.92 & 297 & 276 & 2.92 \\
\hline Vehicle Fuel & NA & NA & $\cdots$ & - & -. \\
\hline Electric Utulities $\ldots \ldots \ldots$ & 256 & 2.26 & 190 & 1.85 & 2.28 \\
\hline
\end{tabular}

\footnotetext{
- Less than 500,000 cubic feet

A - Revised data

NA Not available

Not applicable

Note Deliveries to electric utilites (consumption) are reported on the Form ElA-759 "Monthiy Power Plant Report" Deliveries to electric utilities tor the account of others are reported on the Form EIA.176, "Annual Report of Natural and Supplemental Gas Supply and Disposition." See Ihe discussion on electric utlity data and Table A In Ap. pendix $A$ for a comparison of reporting to these two forms. Tolals may not add due to iridependent rounding.

Sources: Energy Information Administration (EIA). Form ElA-176. "Annual Report of Natural and Supplemental Gas Supply and Disposition," Form ElA-627. "Annual Quantity and Value of Natural Gas Report." Form ElA-857. "Monthly Report of Natural Gas Purchases and Deliveries to Consumers," Form ElA.816. "Monthly Natural Gas Liquids Report," Form ElA-759, "Monthly Power Plant Report," Form FERC-423, "Monthly Report of Cost and Quality of Fuels for Electric Plants." Form ElA-191, "Underground Ges Storage Report," Form FPC-14. "Annual Report for Importers and Exporters of Natural Gas," U.S. Crude Otl. Natural Gas, and Natural Gas Liquids Reserves, 1992 Annual Report, DOE/ElA. 0216(92); and the U S Minerals Management Service.
} 
Natural Gas 1992

Net Interstate Movements

Million

Marketed Production
Million Percent of
Cu. Feel Nalional Total
30
.00

\section{Deliveries to Consumers}

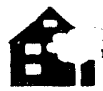

Residential:

18,184

.39

A.

ist

Commercial:

16,101

.57

Industrial:

9,259

.12

$\square$ Vehicle Fuel:

12

2.35

$A$

Electric Utility:

24,355

.88

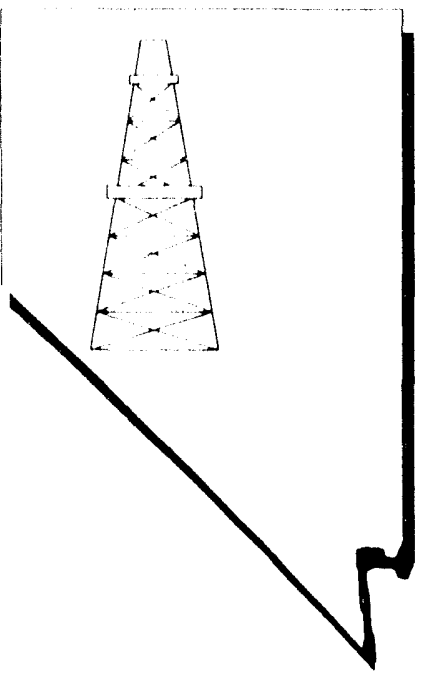

NEVADA

Total:

67,912

.38

Table 72. Summary Statistics for Natural Gas -- Nevada, 1988-1992

\begin{tabular}{|c|c|c|c|c|c|c|}
\hline & & 1988 & 1989 & 1990 & 1991 & 1992 \\
\hline & & \multicolumn{5}{|c|}{ Reserves (bullion cubic feel) } \\
\hline \multirow{2}{*}{\multicolumn{2}{|c|}{$\begin{array}{l}\text { Estimated Proved Reserves (dry) } \\
\text { as of December } 31\end{array}$}} & 0 & 0 & 0 & 0 & 0 \\
\hline & & \multicolumn{5}{|c|}{ Number of Gas and Gas Condensate Wells } \\
\hline \multirow{2}{*}{\multicolumn{2}{|c|}{ Producing at End of Year }} & 0 & 0 & 0 & 0 & 0 \\
\hline & & \multicolumn{5}{|c|}{ Production (million cubic teet) } \\
\hline Gross Withdrawals & & & & & & \\
\hline From Gas Wells & & 0 & 0 & 0 & 0 & 0 \\
\hline From Oll Wells & & 0 & 0 & 0 & 53 & 30 \\
\hline Total $\ldots$ & & 0 & 0 & 0 & 53 & 30 \\
\hline Hepressurng & & 0 & 0 & 0 & 0 & 0 \\
\hline Nonhydrocarbon Gases Removed & & 0 & 0 & 0 & 0 & 0 \\
\hline Wet After Lease Separation & & 0 & 0 & 0 & 53 & 30 \\
\hline Vented and Flared & & 0 & 0 & 0 & 0 & 0 \\
\hline Marketed Production & & 0 & 0 & 0 & 53 & 30 \\
\hline Extraction Loss & & 0 & 0 & 0 & 0 & 0 \\
\hline \multirow{3}{*}{\multicolumn{2}{|c|}{ Total Dry Production }} & 0 & 0 & 0 & 53 & 30 \\
\hline & & & & & $\cdots$ & ( \\
\hline & & \multicolumn{5}{|c|}{ Supply (million cubic teet) } \\
\hline Dry Production & & 0 & 0 & 0 & 5.3 & 30 \\
\hline Heceipts at State Borders & & & & & & \\
\hline Imports & & 0 & 0 & 0 & 0 & 0 \\
\hline Intransit Heceipts & & 0 & 0 & 0 & 0 & 0 \\
\hline Interstate Receipts & & 45.301 & 65.715 & 68,994 & 69,164 & 259.899 \\
\hline \multicolumn{7}{|l|}{ Withdrawals from Slorage } \\
\hline Underground Storage & & 0 & 0 & 0 & 0 & 0 \\
\hline L.NG Storage & & 383 & 491 & 904 & 39 & 155 \\
\hline Supplemental Gas Supplies & & 32 & 37 & 125 & 0 & 30 \\
\hline Balancing Itern & & 5.145 & $6 / 6$ & 2.243 & -1.400 & $-10,782$ \\
\hline Total Supply $\ldots \ldots \ldots$ & & 50,861 & 66.919 & 67,780 & 67.856 & 249,332 \\
\hline
\end{tabular}


Table 72. Summary Statistics for Natural Gas -- Nevada, 1988-1992 (Continued)

\begin{tabular}{|c|c|c|c|c|c|}
\hline & 1988 & 1989 & 1990 & 1991 & $199 ?$ \\
\hline & \multicolumn{5}{|c|}{ Disposition (million cubic feet) } \\
\hline Consumption & 48,226 & 63,667 & 64.876 & 64.859 & 68,416 \\
\hline \multicolumn{6}{|l|}{ Deliveries at State Borders } \\
\hline Exports & 0 & 0 & 0 & 0 & 0 \\
\hline Intransit Deliveries & 0 & 0 & 0 & 0 & 0 \\
\hline Interstate Deliveries & 2.422 & 2,556 & 2.548 & 2,230 & 180,832 \\
\hline \multicolumn{6}{|l|}{ Additions to Storage } \\
\hline Underground Storage & 0 & 0 & 0 & 0 & 0 \\
\hline LNG Storage ............ & 213 & 696 & 356 & 767 & 83 \\
\hline \multirow[t]{2}{*}{ Total Disposition } & 50,861 & 66,919 & 67,780 & 67.856 & 249,332 \\
\hline & \multicolumn{5}{|c|}{ Consumption (million cubic feet) } \\
\hline Lease and Plant Fuel .................. & 0 & 0 & 0 & 53 & 30 \\
\hline Pipeline Fuel & 195 & 717 & 791 & 341 & 474 \\
\hline \multicolumn{6}{|l|}{ Delivered to Consumers } \\
\hline Residential ................... & 15,275 & 16.765 & 17.153 & 19.135 & 18,184 \\
\hline Commercial & 14,879 & 15.116 & 15,073 & 16.960 & 16,101 \\
\hline Industrial . . . . . . . . . & 7.218 & 7.859 & 7.511 & 6,624 & 9.259 \\
\hline 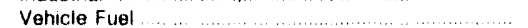 & NA & NA & 0 & в & 12 \\
\hline 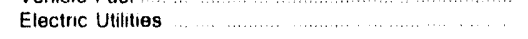 & 10.658 & 23,210 & 24,348 & 21,738 & 24355 \\
\hline Total Delivered to Consumers & 48,031 & 62.950 & 64,086 & 64.465 & 67.912 \\
\hline \multirow[t]{2}{*}{ Total Consumption .. } & 48,226 & 63,667 & 64,876 & 64,859 & 68,416 \\
\hline & \multicolumn{5}{|c|}{ Delivered for the Account of Others (million cubic feet) } \\
\hline Pesidential. & NA & NA & 0 & 0 & 0 \\
\hline Commercial & 725 & 575 & 346 & 1.563 & 1,889 \\
\hline$\ldots \ldots \ldots \ldots+\ldots$ & 4.964 & 6.966 & 6,457 & 5.687 & 8,569 \\
\hline \multirow[t]{2}{*}{ Electric Utilties } & 6.903 & 22.374 & 23,193 & 21,403 & 28,675 \\
\hline & \multicolumn{5}{|c|}{ Number of Consumers } \\
\hline$\ldots \ldots \ldots$ & 219.981 & 236.237 & 256.119 & 283,307 & 295,714 \\
\hline Commercial & 18,921 & 19,924 & 20,694 & 22,124 & 22,799 \\
\hline Industrial & 98 & 100 & 100 & 113 & 114 \\
\hline \multirow[t]{2}{*}{ Vehicie Fuel } & NA & NA & 0 & 1 & 2 \\
\hline & \multicolumn{5}{|c|}{ Average Annual Consumption per Consumer (thousand cubic leet) } \\
\hline Pesidentia $\ldots . . . .$. & 69 & 71 & 67 & 68 & 61 \\
\hline 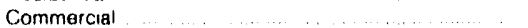 & 786 & 159 & 728 & 767 & 706 \\
\hline Industrial $\ldots$ & 73.657 & 78.590 & 75.114 & 58,621 & 81,222 \\
\hline \multirow[t]{2}{*}{ Vehicle Fuel $\ldots$} & NA & NA & 0 & 8.152 & 6.008 \\
\hline & \multicolumn{5}{|c|}{ Average Annual Cost per Consurner (dollars) } \\
\hline$\ldots$ & $\$ 407$ & $\$ 394$ & $\$ 379$ & $\$ 379$ & $\$ 344$ \\
\hline Commercial & 3,635 & 3,369 & 3,188 & 3,328 & 3.055 \\
\hline \multirow[t]{3}{*}{ Venicle Fuel $\ldots$} & NA & NA & 0 & 30.349 & 20.713 \\
\hline & \multirow{2}{*}{\multicolumn{5}{|c|}{ Average Heating Value (Btu per cubic loot) }} \\
\hline & & & & & \\
\hline \multirow[t]{2}{*}{ Delivered to Consurners } & 1,003 & 1.030 & 1,031 & 1,032 & 1,031 \\
\hline & \multicolumn{5}{|c|}{ Average Prices for Natural Gas (dollars per thousand cubic feet) } \\
\hline & & ....... & 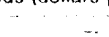 & 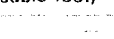 & ... \\
\hline $\begin{array}{l}\text { Wellhead (Marketed Production) } \\
\text { imports }\end{array}$ & $\cdots$ & $\cdots$ & $\cdots$ & $\cdots$ & $\cdots$ \\
\hline Exports & .. & $\ldots$ & $\ldots$ & .. & $\ldots$ \\
\hline Pipeline Fuel & $\$ 2.14$ & $\$ 214$ & $\$ 1.70$ & $\$ 174$ & $\$ 1.77$ \\
\hline$\ldots+\ldots$ & 287 & 3.33 & 2.75 & 2.33 & 2.37 \\
\hline Delivered to Consumers & & & & & \\
\hline Residential & 587 & 555 & 566 & 5.61 & 5.59 \\
\hline$\ldots+\ldots-a-1$ & 4.62 & 4.44 & 438 & 4.34 & 433 \\
\hline Inciustrial & 383 & 498 & 410 & 421 & 4.07 \\
\hline Vehicle Fual & NA & $\mathrm{NA}$ & ... & 3.72 & 345 \\
\hline 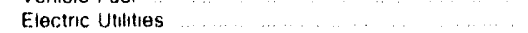 & 2.79 & 217 & 2.02 & 178 & 191 \\
\hline
\end{tabular}

\section{NA Not available.}

Not applicable others are reported on the Form ElA.176. "Annual Peport of Natural and Supplemental Gas Supply and Disposition." See the discussion on eleciric utilty data and Table A1 in Ap. others are reported on the Form ElA-176. "Annual Feport of Natural and Supplemental Gias Supply and Dispositor
pendix A for a comparison of reporting to these two forms. Totals may not add due 10 independent rounding

Sources. Energy Intormation Auministration (EIA). Form EIA-176. "Annual Report of Natural and Supplemental Gas Supply and Disposition." Form ElA-627. "Annual Quantity and Velue of Natural Gas Report." Form E.IA.857. "Monthly Report of Natural Gas Purchases and Deliveries to Consumers." Form EIA-816. "Monthly Natural Gas Liquids Report," Form E.IA.759. "Monthly Power Plant Report," Form FERC-423, "Monthly Report of Cost and Quality of Fuels tor Electric Plants, "Form ElA.191, "Underground Gas Storage Report," Form FPC.14, "Annual Report for Importers and Exporters of Natural Gas," US Crude Oil, Natural Gas, and Natural Gas Liquids Reserves. 1992 Annual Report, DOE. 0216(92); and the US Minerals Mariagement Service. 
Natural Gas 1992

Net Interstate Movements

Million

Cu Feet

18,975

$\begin{array}{ccc}\text { Marketed Production } & \text { Million } & \text { Percent of } \\ \text { Cu. Feol } & \text { National Total } \\ 0 & 00\end{array}$

Deliveries to Consumers

:i?

Residential:

6,449

.14

A.

inst

Commercial:

5,862

.21

WII

Industrial:

3,828

.05

Vehicle Fuel:

0

.00

$A$

Electric Utility:

633

.02

Total:

16,771

.09

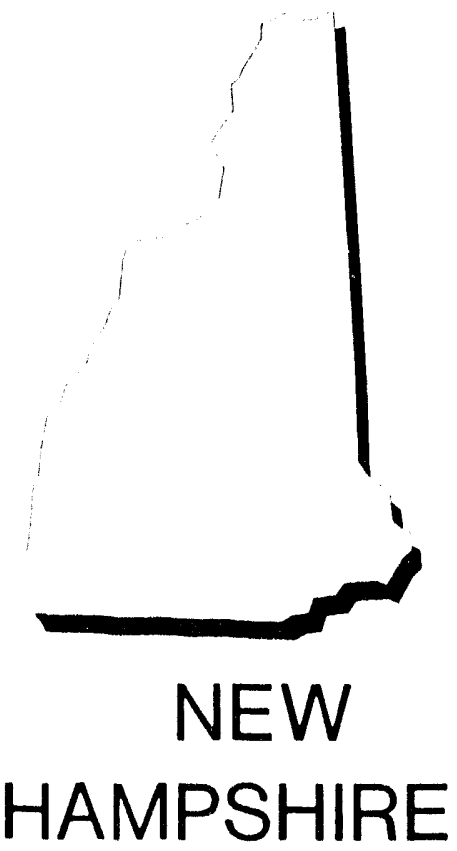

Table 73. Summary Statistics for Natural Gas -- New Hampshire, 1988-1992

\begin{tabular}{|c|c|c|c|c|c|}
\hline & 1988 & 1989 & 1990 & 1991 & 1992 \\
\hline & \multicolumn{5}{|c|}{ Reserves (billion cubic feet) } \\
\hline \multirow[t]{2}{*}{$\begin{array}{l}\text { Estimated Proved Feserves (dry) } \\
\text { as of December } 31\end{array}$} & 0 & 0 & 0 & 0 & 0 \\
\hline & \multicolumn{5}{|c|}{ Number of Gas and Gas Condensate Wells } \\
\hline \multirow[t]{3}{*}{ Producing at End of Year. } & 0 & 0 & ) & $\ddot{0}$ & 0 \\
\hline & & & (2) & & \\
\hline & \multicolumn{5}{|c|}{ Prorluction (millior cutic teet) } \\
\hline Gross Withdrawais & & & & & \\
\hline From Gas Wells & a & 0 & 0 & i) & 0 \\
\hline From OII Wells & i) & 0 & D & 0 & 0 \\
\hline Total & 0 & c) & 0 & 0 & 0 \\
\hline Repressuring & 0 & 0 & 0) & 0 & 0 \\
\hline Nonhydrocarbon Gases Removed & 0 & 0 & () & 0 & 0 \\
\hline Wet After Lease Separation & i) & 0 & 0 & 0 & 0 \\
\hline Vented and Flared & 0 & 0 & 0 & 0 & 0 \\
\hline \multirow[t]{3}{*}{ Total Dry Production } & 0 & 0 & 2 & 0 & 0 \\
\hline & & & & & \\
\hline & \multicolumn{5}{|c|}{ Supply (multion cutur teen) } \\
\hline Dry Production & 0 & 0 & 0 & 0 & 0 \\
\hline \multicolumn{6}{|l|}{ Receipts al State Borders } \\
\hline imports & 0 & 0 & 0 & 0 & 0 \\
\hline Intransı Feceipts & 0 & (j) & 0 & 0 & 0 \\
\hline Interslate Receipts & 16.711 & 17.736 & 18,090 & 19.494 & 24.110 \\
\hline \multicolumn{6}{|l|}{ Withdrawals trom Storage } \\
\hline Underground Storage & 0 & D & ) & 0 & 0 \\
\hline LNG Storagge & 142 & 213 & 0 & 0 & 0 \\
\hline Supplemental Gas Supplies & 492 & 592 & 205 & 128 & 96 \\
\hline Balancing Item & $1.1 \%$ & 939 & 435 & 681 & -2.219 \\
\hline Total Supply & 16.175 & 17.602 & 18.131 & 18.942 & 21.987 \\
\hline
\end{tabular}

See footnotes at end of table 
Table 73. Summary Statistics for Natural Gas -- New Hampshire, 1988-1992 (Continued)

\begin{tabular}{|c|c|c|c|c|c|}
\hline & 1988 & 1989 & 1990 & 1991 & 1992 \\
\hline & \multicolumn{5}{|c|}{ Disposition (million cubic feet) } \\
\hline Consumption ... & 13,009 & 13.945 & 14,274 & 14,127 & 16.852 \\
\hline \multicolumn{6}{|l|}{ Deliveries at State Borders } \\
\hline 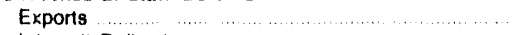 & 0 & 0 & 0 & 0 & 0 \\
\hline Intransit Deliveries .............. & 0 & 0 & 0 & 0 & 0 \\
\hline 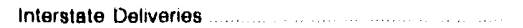 & 3,167 & 3,657 & 4,457 & 4,815 & 5,135 \\
\hline \multicolumn{6}{|l|}{ Additions to Storage } \\
\hline Underground Storage & 0 & 0 & 0 & 0 & 0 \\
\hline 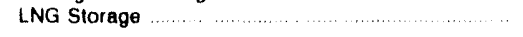 & 0 & 0 & 0 & 0 & D \\
\hline \multirow[t]{2}{*}{ Total Disposition } & 16,176 & 17,602 & 18,731 & 18,942 & 21,987 \\
\hline & \multicolumn{5}{|c|}{ Consumption (million cubic feet) } \\
\hline Lease and Plant Fuel & 0 & 0 & 0 & 0 & 0 \\
\hline Pipeline Fuel & 22 & 19 & 22 & 33 & 81 \\
\hline \multicolumn{6}{|l|}{ Delivered to Consumers } \\
\hline Residential ....................... & 5.927 & 6.290 & 5,903 & 5,609 & 6.449 \\
\hline 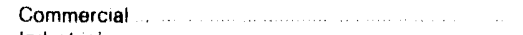 & 5,034 & 5,371 & 5,073 & 5.028 & 5,862 \\
\hline Industrial & 1,971 & $2.24 !$ & 3.276 & 3,457 & 3,828 \\
\hline 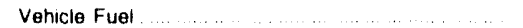 & NA & NA & 0 & 0 & 0 \\
\hline$\ldots \ldots \ldots \ldots \ldots \ldots \ldots$ & 55 & 23 & 0 & 0 & 633 \\
\hline Total Delivered to Consumers .............. & 12.987 & 13,925 & $14,25,2$ & 14,094 & 16.771 \\
\hline \multirow[t]{3}{*}{ Total Consumption } & 13,009 & 13,945 & 14.274 & 14.127 & 16,852 \\
\hline & & & & $\cdots+\cdots$ & \\
\hline & \multicolumn{5}{|c|}{ Delivered tor the Account of Others (million cubic teet) } \\
\hline$\ldots \ldots \ldots \ldots \ldots$ & NA & NA & 0 & 0 & 0 \\
\hline$\ldots \ldots \ldots$ & 0 & 0 & 0 & 0 & 0 \\
\hline industrial ... & () & 0 & 52 & 202 & 0 \\
\hline \multirow[t]{2}{*}{ Electric Utilities } & 0 & 0 & 0 & $\ddot{u}$ & 0 \\
\hline & \multicolumn{5}{|c|}{ Number of Consumers } \\
\hline Residential & 61,969 & 64.059 & 65,310 & 67.991 & 69,356 \\
\hline$\ldots \ldots \ldots .$. & 9,159 & 10,237 & 10,521 & 11.088 & 11.383 \\
\hline$\ldots$ & 295 & 376 & 364 & 361 & 344 \\
\hline \multirow[t]{2}{*}{ Vehicle Fuel } & NA & NA & 0 & 0 & 0 \\
\hline & \multicolumn{5}{|c|}{ Average Anriual Consumption per Consumer (thousand cubrc leet) } \\
\hline$\ldots \ldots \ldots+\ldots-\ldots$ & 96 & 98 & 90 & 82 & 93 \\
\hline Commercial ..................... & 550 & 525 & 482 & 454 & 515 \\
\hline Industrial $\ldots \ldots \ldots$ & 6,681 & 5.960 & 9.001 & 9.575 & 11.128 \\
\hline \multirow{2}{*}{ Vehicle Fuel } & NA & NA & 0 & 0 & 0 \\
\hline & \multicolumn{5}{|c|}{ Average Annual Cost per Consumer (dollars) } \\
\hline 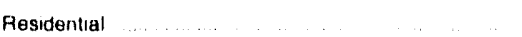 & $\$ 601$ & $\$ 672$ & $\$ 670$ & $\$ 589$ & 702 \\
\hline 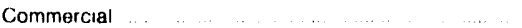 & 3,111 & 3,269 & 3.246 & 2,884 & 3,469 \\
\hline \multirow[t]{3}{*}{ Vehicle Fuel ............. } & NA & NA & 0 & 0 & 0 \\
\hline & $\cdots$ & & $\ldots \ldots . . . .$. & & $\cdots \cdots$ \\
\hline & \multicolumn{5}{|c|}{ Average Heating value (Btu per cubic fool) } \\
\hline \multirow[t]{2}{*}{ Delivered to Consumers. } & 1.025 & 1.019 & 1,014 & 1,007 & 1.009 \\
\hline & \multicolumn{5}{|c|}{ Average Prices for Natural Gas (dollars per thousand cubic feet) } \\
\hline Wellhead (Marketed Production) & ... & ?.. & $\ldots$ & -. & \\
\hline Imports $\ldots$ & $\ldots$ & -. & .. & .. & . \\
\hline Exports $\ldots \ldots \ldots \ldots$ & .. & $\ldots$ & $\ldots$ & .. & .. \\
\hline$\ldots \ldots \ldots \ldots \ldots \ldots \ldots \ldots$ & $\$ 333$ & $\$ 3.26$ & $\$ 367$ & $\$ 3.40$ & $\$ 381$ \\
\hline$\ldots \ldots \ldots \ldots \ldots$ & 3.04 & 3.28 & 351 & 3.40 & 358 \\
\hline Delivered to Consumers & & & & & \\
\hline Residential & 628 & 685 & 741 & 714 & 755 \\
\hline$\ldots \quad \ldots \ldots \ldots \ldots$ & 5.66 & 623 & 673 & 6.35 & 674 \\
\hline$\ldots \ldots \ldots \ldots \ldots \ldots$ & 372 & 420 & 436 & 431 & 449 \\
\hline Vehicle Fuel. & NA & NA & $\ldots$ & . & $\ldots$ \\
\hline Electric Utilities & 2.48 & 3.16 & ... & -. & 220 \\
\hline
\end{tabular}

\footnotetext{
NA Not available
}

Note: Deliveries to electric utilities (consumption) are reported on the Form ElA.759. "Monthly Power Plant ReFort" Deliveries to electric utilities for the account of others are reported on the Form EiA.176. "Annual Report of Natural and Supplemental Gas Supply and Disposition." See thic discussion on electric uthity data and Table At in Appendix $A$ for a comparison of reporting to these two torms Totals may not add due to independent rounding

Sources Energy Intormation Adrninistration (EIA). Form EIA-176. "Annual Report of Natural and Supplemental Gas Supply and Disposition. "Form EIA-627, "Annual Quanity and Value of Natural Gas Feport." Form EIA-857. "Monthly Report of Natural Gas Purchases and Deliveries to Consumers, "Form ElA-816, "Moninly Natural Gas Liquids Feport," Form EIA.759, "Monthly Power Plant Feport," Form FERC-423. "Monthly Report of Cost and Quality of Fuels tor Electric Plants," Form EIA.191, "Underground Gas Storage Report," Form FPC-14. "Annual Feport for Importers and Exporters of Natural Gas." U.S Crude Oil. Nalural Gas, and Natural Gas Liquids Reserves, 1992 Annual Report. DOE./ElA. 0216(92), and the US Minerals Management Service. 
Natural Gas 1992

Net Interstate Movements

Mililion

Marketed Production

480,627

Million Percent of

Marketed Production Cu. Feet Natlonal Total

Deliveries to Consumers

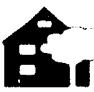

Residential:

198,462

4.23

A:

ist

Commercial:

130,891

4.67

c. MII

Industrial:

174,569

2.32

$\longrightarrow$ Vehicle Fuel:

0

.00

$A$

Electric Utility:

38,772

1.40

Total:

542,695

3.05

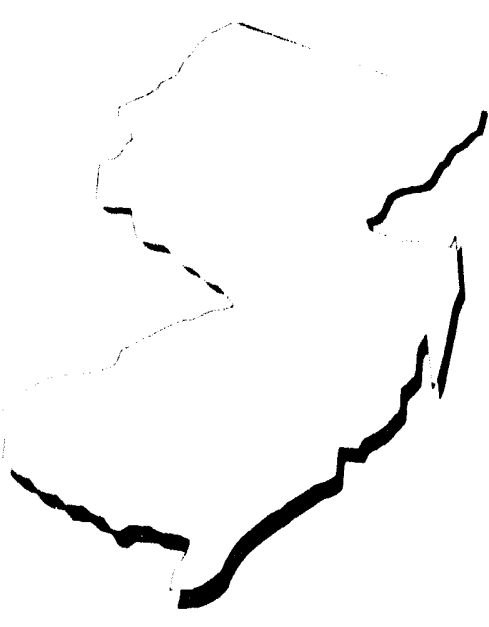

NEW

JERSEY

Table 74. Summary Statistics for Natural Gas -- New Jersey, 1988-1992

\begin{tabular}{|c|c|c|c|c|c|c|}
\hline & & 1988 & 1989 & 1990 & 1991 & 1992 \\
\hline & & \multicolumn{5}{|c|}{ Reserves (billion cubic feet) } \\
\hline \multirow[t]{2}{*}{$\begin{array}{l}\text { Estimated Proved Reserves (dry) } \\
\text { as of December } 31\end{array}$} & & 0 & 0 & ) & 0 & 0 \\
\hline & & \multicolumn{5}{|c|}{ Number of Gas and Gas Condensate Wells } \\
\hline \multicolumn{2}{|l|}{ Producing at End of Yoar } & 0 & 0 & 0 & ) & ) \\
\hline \multicolumn{7}{|l|}{ Gross Withdrawals } \\
\hline From Gas Wells & & 0 & 0 & i) & 0 & 0 \\
\hline From Oll Wells & & 0 & 0 & o & 0 & 0 \\
\hline Total ... & & 0 & 0 & 0 & D & 0 \\
\hline Repressuring & & 0 & 0 & 0 & 0 & 0) \\
\hline Nothydrocarbon Gases Removed & & o & 0 & 0 & 0 & 0 \\
\hline Wet After Lease Separation & & i) & 0 & 0 & 0 & 0 \\
\hline Vented and Flared & & 0 & 0 & c) & 0 & 0 \\
\hline Extraction Loss & & 0 & 0 & ) & 0 & 0 \\
\hline \multirow[t]{2}{*}{ Totat Dry Production } & & 0 & 0 & 0 & 0 & 0 \\
\hline & & \multicolumn{5}{|c|}{ Supply (million cubic teet) } \\
\hline Dry Production & & 0 & 0 & 0 & 0 & c) \\
\hline \multicolumn{7}{|l|}{ Receipts at State Borders } \\
\hline Imports & & 0 & 0 & oj & 0 & 0 \\
\hline Intransit Recelpts & & 0 & 0 & 0 & 0 & 0 \\
\hline Interstate Receipts & & 1.009 .154 & 1.039 .568 & $1,036,85.3$ & 1.049018 & $1,108,758$ \\
\hline \multicolumn{7}{|l|}{ Withdiawals from Storage } \\
\hline Underground Storage & & 0 & 0 & 0 & 0 & 0) \\
\hline LNG Storage & & 3.202 & 2.444 & 2.298 & $2.22 !$ & 2.471 \\
\hline Supplemental Gas Supplies & & 14.846 & 14,539 & 9.962 & A 14,789 & 14.362 \\
\hline Balancing Item & & -1.933 & 17.084 & 13.939 & ${ }^{9} 62468$ & 51,223 \\
\hline Total Supply & & 1.025 .269 & $1,073,635$ & $1,063,053$ & 1.128 .497 & $1,176.813$ \\
\hline
\end{tabular}

See footnotes at end t table 
Table 74. Summary Statistics for Natural Gas -- New Jersey, 1988-1992 (Continued)

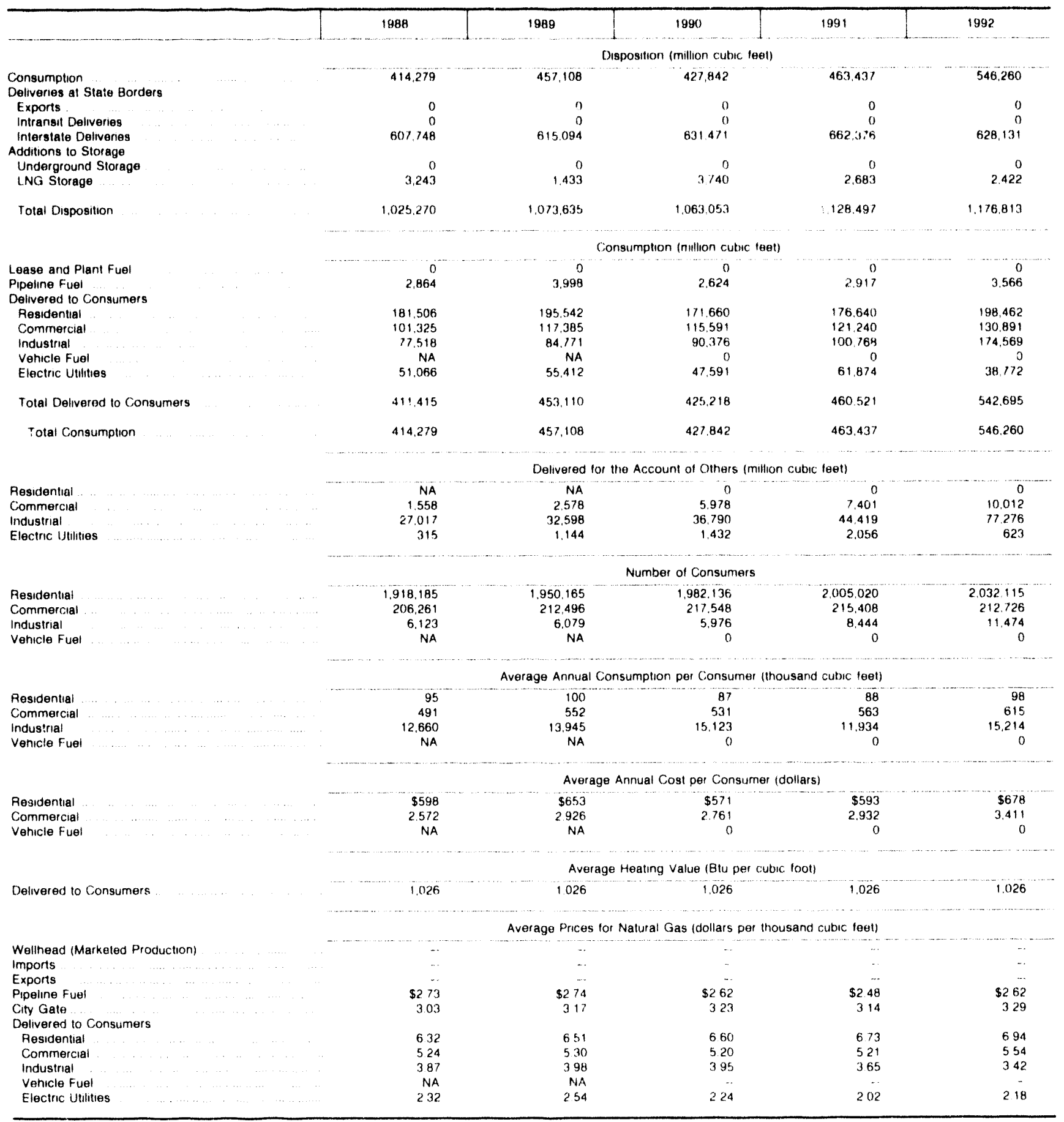

A Revised dala

wa ... Not available

...... Not applicable

Note Deliveries to electric utitites (consumption) are reported on the Form ElA-759. "Monthly Power Plant Report" Deliveries to electic utilties tor the account of others are reported on the Form EIA-176. "Annual Report of Natural and Supplemental Gas Supply and Disposition." See the discussion on electric utility data and Table A1 in Ap. pendix $A$ for a comparison of reporting to these two forms Totals may not add due to independent rounding

Sources. Energy intormation Administration (EIA). Form EIA.176. "Annual Report of Natural and Supplemental Gas Supply and Disposition," Form EiA.627, "Annual Quantity and Value of Natural Gas Report." Form ElA-857. "Monthly Peport of Natural Gas Purchases and Deliveries to Consumers." Form ElA-816, "Monthly Natural Gas Liquids Report," Form ElA.759. "Monthly Power Plant Report." Form FERC-423. "Monthiy Report of Cost and Quality of Fuels for Electric Plants, " Form EIA.191. "Underground Gas Storage Report." Form FPC.14. "Annual Report for Importers and Exporters of Natural Gas," US Crude Oil, Natural Gas. and Nalural Gas liquids Reserves, I992 Annual Report. DOE/EIA. 0216(92), and the U S Minerals Management Service 
Natural Gas 1992

Net Interstate Movements

Million

Cu. FeOt

.911 .733

Marketed Production

Porcont of National Talal 6.78

\section{Deliveries to Consumers}

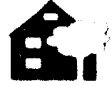

Residential:

31,433

67

A.

Commercial:

27.884

.99

$\therefore$

Industrial:

17.070

Vehicle Fuel:

7

1.37

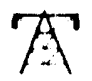

Electric Utility:

22,486

Total:

88,881

.81

NEW MEXICO .56

Table 75. Summary Statistics for Natural Gas -- New Mexico, 1988-1992

\begin{tabular}{|c|c|c|c|c|c|}
\hline & 1984 & 1969 & 14905 & 1991 & 1992 \\
\hline & \multicolumn{5}{|c|}{ Raserves itrillon cutic teatl } \\
\hline \multirow{3}{*}{$\begin{array}{l}\text { Estimated Proved Heserves (dry) } \\
\text { as of December } 31\end{array}$} & 17956 & & & & \\
\hline & & & & & . \\
\hline & \multicolumn{5}{|c|}{ Number of Gas and Jas Conderisate Walls } \\
\hline \multirow[t]{2}{*}{ Producing at End of rear } & 15909 & 17087 & +124 & 20021 & 180.040 \\
\hline & \multicolumn{5}{|c|}{ Production (nrithion cutic leet) } \\
\hline Gross Withdrawals & & & & & \\
\hline $\begin{array}{l}\text { From Gas Welis } \\
\text { From Ol Wells }\end{array}$ & $60274 f_{j}$ & $685,36 \%$ & 143953 & 9. 840751 & 1067477 \\
\hline From Oll Wells & 2012.53 & 192119 & $2(x)>16$ & ค $21785 x_{i}$ & 222.303 \\
\hline Total & 51.994 & 878285 & $9,46,79$ & 91.054619 & 1.289780 \\
\hline Repressuring & 15,94 & 17104 & $1612^{2}$ & 17094 & 165,40 \\
\hline Nonhydrocartion Gases Removed & 4118 & 1942 & 1772 & $\begin{array}{l}1.876 \\
\text { a }\end{array}$ & 2751 \\
\hline Wet After Lease Separation & 795,4131 & 8590334 & 356.743 & A 1039649 & 12114489 \\
\hline Ver,ed and Fiared & $358 \%$ & 4419 & $1.5 / 4$ & 1365 & 1.626 \\
\hline Marketed Production & 791.819 & $85,46,15$ & $355,1,14$ & ค : $1,38,284$ & 1264.853 \\
\hline Extractior Loss & 63.35 .5 & 51.594 & 56.626 & $7046 \%$ & 15,520 \\
\hline \multirow[t]{3}{*}{ Total Dey Production } & 728454 & 193621 & $8984 / 4$ & 935,821 & 193343 \\
\hline & & & $\cdots$ & & \\
\hline & \multicolumn{5}{|c|}{ 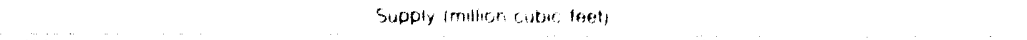 } \\
\hline $\begin{array}{l}\text { Ony Production } \\
\text { Aecelpers a State Borders }\end{array}$ & 728.454 & 79321 & B9A 4/A & a 95,792 & 1.9354 \\
\hline Imports & o & o & 3 & ") & $s$ \\
\hline Intransit Ruceripts & & 3 & $r_{i}$ & $r_{i}$ & is \\
\hline $\begin{array}{l}\text { Interstate Fecelpts } \\
\text { Withdtamals trom Slorage }\end{array}$ & 879379 & 846,451 & (7b) 74 ! & $m, 7 n$ & A3t, $/ B>$ \\
\hline $\begin{array}{l}\text { Withdra wals from Storage } \\
\text { Underground Storages }\end{array}$ & $144 ! 1$ & 17774 & $13+26$ & 17864 & \\
\hline LNG Sturage & 0 & 0 & is & 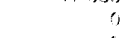 & 2599 \\
\hline Supplemental 'aas Sudphies & is & $\therefore$ & 3 & ${ }^{5}$ & \\
\hline Balancing llem & 6) 813 & 76421 & $88 \mathrm{lig}_{0}$ & a 64843 & .51.142 \\
\hline Total Supply & 15,61441 & 1733.66 .7 & $170044 t$ & $1,15,3,320$ & $15,0,95,5$ \\
\hline
\end{tabular}

See tootnotes at end of at:le 
Table 75. Summary Statistics for Natural Gas -- New Mexico, 1988-1992 (Continued)

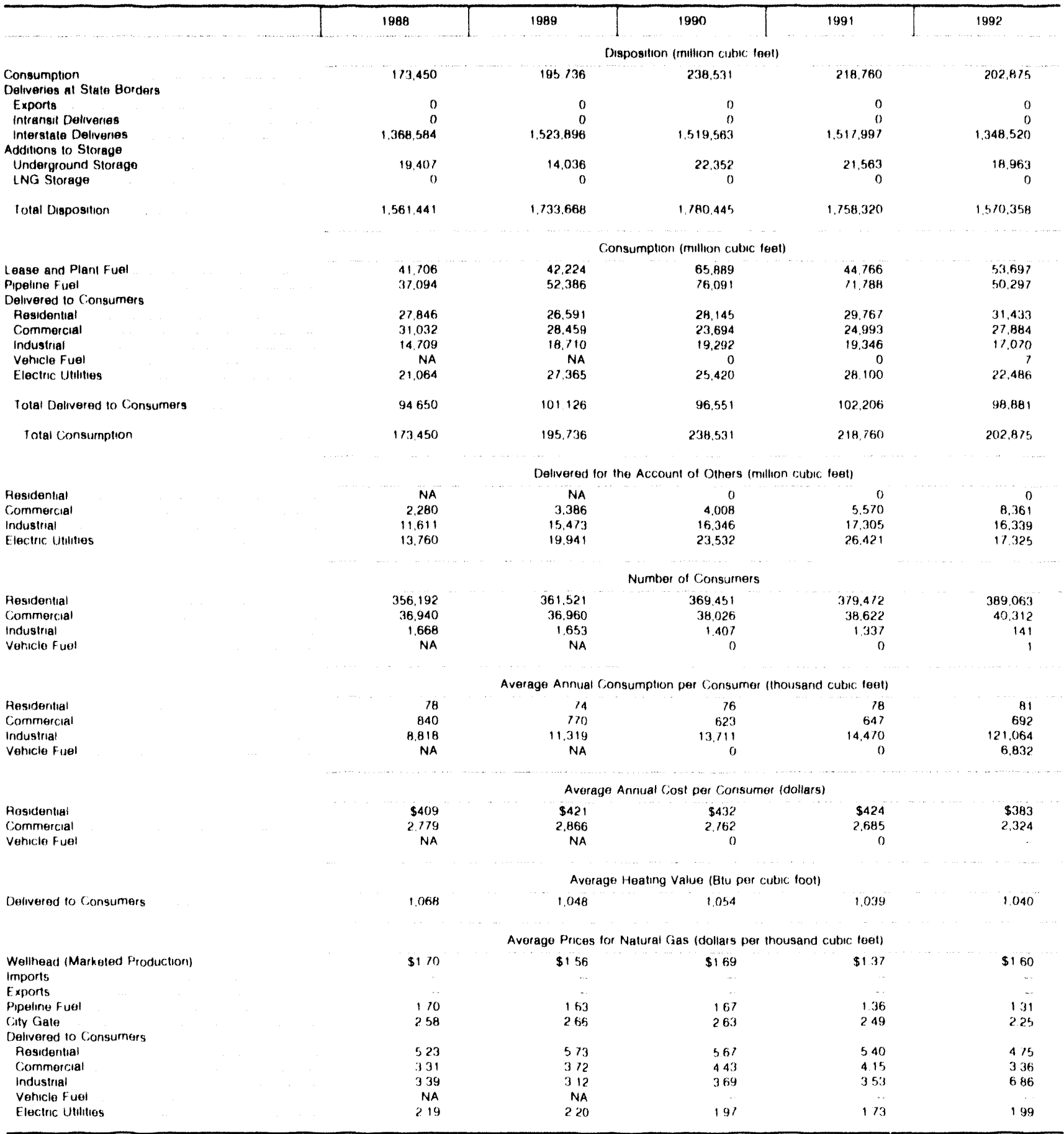

\section{Revised data}

Not avallable Not applicable

Note Deliveries to electric utilties (consumption) are reported on the Form ElA-759. "Monthly Power Plant Report Deliveries to electric utities for the account of others are reported on the Form ElA 176. "Annual Peport of Natural and Supplemental Gas Supply and Disposition" See the discussion on Glectric uthity data and Tatile A1 in Ap pendix $A$ tor a comparison of reporting to these two torms Totals may not add due to independent rounding

Sources Energy Intormation Administration (EIA). Form EIA-176, "Annual Repont of Natural and Supplemental Gas Supply and Disposition. "Form EIA 627, "Annual Duantity and Value ol Natural Gas Report," Form EIA 857. "Monthly Feport of Natural Gas Purchases and Deliveries to Consumers. "Form EIA .816. "Monthly Natural Gas Liquids Report." Form EIA. 759. "Monthly Power Plant Feport." Form FERC.423. "Monthly Report of Cost and Quality of Fuels for Electric Plants. "Form EIA.191. "Underyround Gas Sturage Report." Form FPC 14. "Annual Roport for importers and Exporters of Natural Gas." UIS Crude Ot,. Natural Gas, and Natural Gas Liquids Fieserves, I992 Annual Report. DOE IEIA $0216(92)$ and the US Minerals Management Service 
Natural Gas 1992

Net Interstate Movements

Million

Cu. Foet

996,803

Marketed Production

Million

Percent of

Cu. Feet National Total

23,508

.13

Deliveries to Consumers

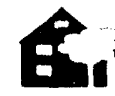

Residential:

378,689

8.07

A.

inst

Commercial:

217,214

7.75

6. MI

Industrial:

147,520

1.96

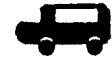

Vehicle Fuel:

6

1.17

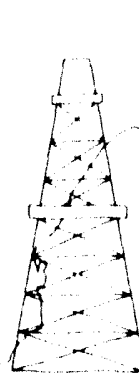

咸

Electric Utility:

208,731

7.56

Total:

952,161

5.35

Table 76. Summary Statistics for Natural Gas -- New York, 1988-1992

\begin{tabular}{|c|c|c|c|c|c|}
\hline & 1988 & 1989 & 1990 & 1991 & 1992 \\
\hline & \multicolumn{5}{|c|}{ Reserves (billion cubic teet) } \\
\hline \multirow[t]{2}{*}{$\begin{array}{l}\text { Estimaled Proved Reserves (dry) } \\
\text { as of December } 31\end{array}$} & 351 & 368 & 354 & 331 & 329 \\
\hline & \multicolumn{5}{|c|}{ Number of Gas and Gas Condensate Wells } \\
\hline \multirow[t]{2}{*}{ Producing at End of Year } & 5.090 & 5,304 & 5.525 & 5.737 & 5.906 \\
\hline & \multicolumn{5}{|c|}{ Production (million cubic teet) } \\
\hline $\begin{array}{l}\text { Gross Withdrawals } \\
\text { From Gas Wells } \\
\text { From Oil Wells }\end{array}$ & $\begin{array}{r}26.423 \\
1.044\end{array}$ & $\begin{array}{r}24.343 \\
1.126\end{array}$ & $\begin{array}{r}24,010 \\
1388\end{array}$ & $\begin{array}{r}21.877 \\
901\end{array}$ & $\begin{array}{r}22.697 \\
824\end{array}$ \\
\hline Total & 27.467 & 25.469 & 25.398 & 22,778 & 23.521 \\
\hline Repressuring & 0 & 0 & 0 & 0 & 0 \\
\hline Nonhydrocarbon Gases Pemoved & 0 & 0 & 0 & 0 & 0 \\
\hline Wet After Lease Separation & 27.467 & 25.469 & 25.398 & 22.778 & 23.521 \\
\hline Vented and Flared & 4.012 & 5.036 & 375 & 1 & 13 \\
\hline Marketed Production & 23.455 & 20.433 & 25.023 & 22.777 & 23,508 \\
\hline Extraction Loss & 0 & 0 & 0 & 0 & 0 \\
\hline \multirow[t]{2}{*}{ Total Dry Production } & 23.455 & 20.433 & 25.023 & 22.777 & 23.508 \\
\hline & \multicolumn{5}{|c|}{ Supply (million cubic teet) } \\
\hline $\begin{array}{l}\text { Dry Production } \\
\text { Receipts at State Borders }\end{array}$ & 23.455 & 20.433 & 25.023 & 22.777 & 23.508 \\
\hline Imports & 70.993 & 67.956 & 98.217 & 188.233 & 435.470 \\
\hline Intransit Receipls & 0 & 0 & 0 & 0 & 0 \\
\hline Interstate Recerpts & 1.075 .859 & $1.066,665$ & 1.039 .598 & 1.105 .278 & 1.121 .178 \\
\hline \multicolumn{6}{|l|}{ Withdrawals from Storage } \\
\hline Underground Storage & 52.735 & 64.708 & 49.842 & 51.792 & 60.693 \\
\hline LNG Storage & 370 & 595 & 303 & 309 & 363 \\
\hline Supplemental Gas Supplies & 728 & 1.239 & 385 & 678 & 1.190 \\
\hline Balancing Item & -13.098 & 54.006 & 75.309 & $-15,759$ & -60.556 \\
\hline Total Supply & $1.2+1.042$ & 1.275 .602 & $1.288,678$ & 1.353 .309 & 1.581 .846 \\
\hline
\end{tabular}


Table 76. Summary Statistics for Natural Gas -- New York, 1988-1992 (Continued)

\begin{tabular}{|c|c|c|c|c|c|}
\hline & 1988 & 1989 & 1990 & 1991 & 1992 \\
\hline & \multicolumn{5}{|c|}{ Disposition (million cubic feet) } \\
\hline Consumption & 790.218 & 845,853 & 863,090 & 875,184 & 959.004 \\
\hline \multicolumn{6}{|l|}{ Deliveries at State Borders } \\
\hline 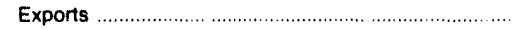 & 1,800 & 0 & 0 & 0 & 0 \\
\hline Intransit Deliveries & 0 & 0 & 0 & 0 & 0 \\
\hline Interstate Deliveries & 362,242 & 375,695 & 360,693 & 414.155 & 559.844 \\
\hline \multicolumn{6}{|l|}{ Additions to Storage } \\
\hline Underground Storage & 56.332 & 53,490 & 63,690 & 63,411 & 62,265 \\
\hline LNG Storage & 449 & 564 & 1,205 & 559 & 732 \\
\hline \multirow[t]{2}{*}{ Total Disposition . ............................................... } & $1,211,041$ & $1.275,602$ & $1,288,678$ & $1,353,309$ & $1,581,846$ \\
\hline & \multicolumn{5}{|c|}{ Consumption (million cubic leet) } \\
\hline Lease and Plant Fuel & 788 & 604 & 840 & 1,073 & 965 \\
\hline 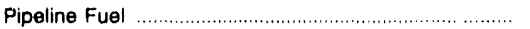 & 4.757 & 5,292 & 4,733 & 5.011 & 5,878 \\
\hline \multicolumn{6}{|l|}{ Delivered to Consumers } \\
\hline 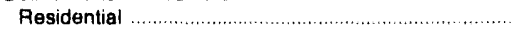 & 357,260 & 364,713 & 337,988 & 338,892 & 378,689 \\
\hline 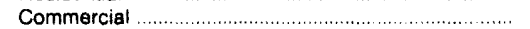 & 188.037 & 196,380 & 194,990 & 199,598 & 217.214 \\
\hline 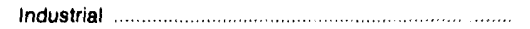 & 90,883 & 96,864 & 101.285 & 118.944 & 147,520 \\
\hline 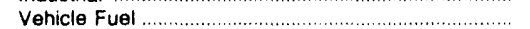 & NA & NA & 2 & 25 & 6 \\
\hline Electric Utilities & 148,493 & 182,000 & 223,253 & 211,640 & 208,731 \\
\hline Total Delivered to Consumers & 784,673 & 839,957 & 857.517 & 869,100 & 952,161 \\
\hline \multirow[t]{2}{*}{ 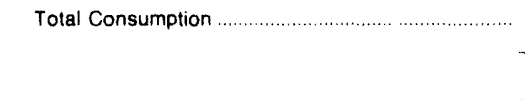 } & 790,218 & 845,853 & 863,090 & 875,184 & 959,004 \\
\hline & \multicolumn{5}{|c|}{ Delivered for the Account of Others (million cubic feet) } \\
\hline Residentiai .. & NA & NA & 2,660 & 2,631 & 2,413 \\
\hline 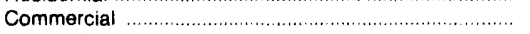 & 19,944 & 28,376 & 31,904 & 38,556 & 48,552 \\
\hline 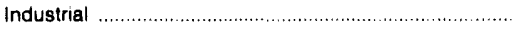 & 47,259 & 58.333 & 60,359 & 83,934 & 113,074 \\
\hline \multirow[t]{2}{*}{ Electric Utilities } & 10,511 & 16,216 & 21,280 & 23,485 & 19,893 \\
\hline & \multicolumn{5}{|c|}{ Number of Consumers } \\
\hline Residential ........................ & $3,839,952$ & $3,859,413$ & $3,917,354$ & $4,472,005$ & $4,522,274$ \\
\hline 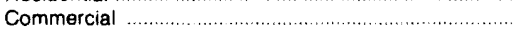 & 270,218 & 285,031 & 281,717 & 310,941 & 315,974 \\
\hline 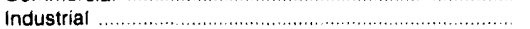 & 24.654 & 27,426 & 25,008 & 28,837 & 28,198 \\
\hline \multirow[t]{2}{*}{ 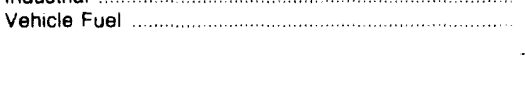 } & NA & NA & 3 & 8 & 10 \\
\hline & \multicolumn{5}{|c|}{ Average Annual Consumption per Consumer (thousand cubic leet) } \\
\hline Residential. & 93 & 94 & 86 & 76 & 84 \\
\hline Commercial ................ & 696 & 689 & 692 & 642 & 687 \\
\hline \multirow{3}{*}{ Vehicle Fuel } & 3,686 & 3,532 & 4,050 & 4,125 & $5, \therefore:$ \\
\hline & NA & NA & 575 & 3,098 & 600 \\
\hline & \multicolumn{5}{|c|}{ Average Annual Cost per Consumer (dollars) } \\
\hline 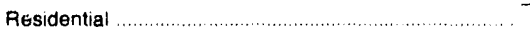 & $\$ 605$ & $\$ 682$ & $\$ 639$ & $\$ 557$ & $\$ 635$ \\
\hline Commercial & 3.752 & 3,874 & 3,868 & 3.510 & 3,954 \\
\hline \multirow[t]{2}{*}{ 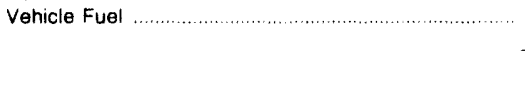 } & NA & NA & 2,699 & 14,500 & 3,279 \\
\hline & \multicolumn{5}{|c|}{ Average Heating Value (Btu per cubic foot) } \\
\hline \multirow[t]{2}{*}{ Delivered to Consumers. } & 1,029 & 1.029 & 1,030 & 1,028 & 1,029 \\
\hline & \multicolumn{5}{|c|}{ Average Prices for Natural Gas (dollars per thousand ini leet) } \\
\hline Wellhead (Marketed Production) & $\$ 2.30$ & $\$ 2.20$ & $\$ 2.20$ & $\$ 2.15$ & $\$ 2.25$ \\
\hline 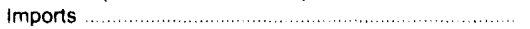 & 2.18 & 2.52 & 2.83 & 2.63 & 2.48 \\
\hline Exports & 2.12 & - & - & -. & -. \\
\hline 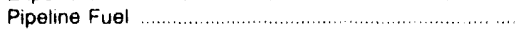 & 2.33 & 2.64 & 2.59 & 2.71 & 2.86 \\
\hline City Gate & 2.91 & 3.07 & 3.05 & 2.92 & 301 \\
\hline \multicolumn{6}{|l|}{ Delivered to Consumers } \\
\hline 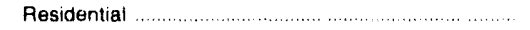 & 6.50 & 7.22 & 7.40 & 7.35 & 758 \\
\hline 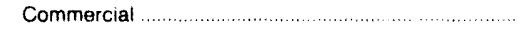 & 5.39 & 5.62 & 5.59 & 5.47 & 5.75 \\
\hline Industrial & 4.69 & 4.83 & 4.86 & 4.72 & 4.93 \\
\hline 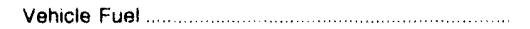 & NA & NA & 4.70 & 4.68 & 5.47 \\
\hline 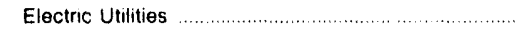 & 2.30 & 2.42 & 2.46 & 2.30 & 2.48 \\
\hline
\end{tabular}

MA $=$ Not available

Note: Deliveries to electric utilities (consumption) are reported on the Form ElA.759, "Monthly Power Plant Report" Deliveries to electric utilities for the account of others are reported on the Form ElA.176. "Annual Report of Natural and Supplemental Gas Supply and Disposition "See the discussion on electric utility data and Table A1 in Ap. others an repored

Sources. Energy Information Administration (EIA" Eorm EIA-176. "Annual Report of Natural and Supplementai Gas Supply and Disposition," Form EIA-627, "Annual Quantity and Value of Natural Gas Report," Form ElA.857. "Monthly Peport of Natural Gas Purchases and Deliveries to Consumers, "Form EIA-816. "Monthly Natural Gas Liquids Report," Form EIA-759. "Monthly Power Plant Report," Form FEAC-423, "Monthly Report of Cost and Quality of Fuels for Electric Plants," Form EIA.191. "Underground Gas Siorage Report,"

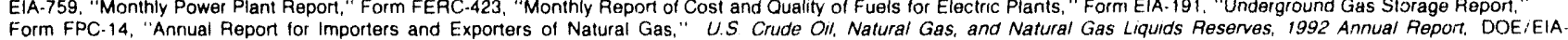
Form FPC-14, "Annual Report for Importers and Expo
0216(92); and the U.S. Minerals Management Service 
Natural Gas 1992

Net Interstate Movements

Million

Marketed Production

$\begin{array}{cc}\text { Million } & \text { Percent of } \\ \text { Cu. Feet } & \text { National Tolal } \\ 0 & .00\end{array}$

Deliveries to Consumers

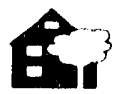

Residential:

42,588

.91

A.

inst

Commercial:

36,418

1.30

C.M

Industrial:

90,984

1.21

$\longrightarrow$ Vehicle Fuel:

7

1.37

$A$

Electric Utility:

3,169

.11

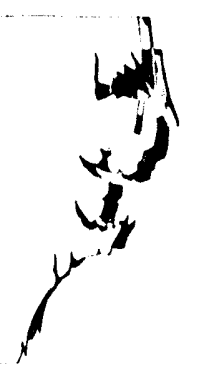

Total:

173,156

.97

Table 77. Summary Statistics for Natural Gas -- North Carolina, 1988-1992

\begin{tabular}{|c|c|c|c|c|c|}
\hline & 1988 & 1989 & 1990 & 1091 & 1992 \\
\hline & \multicolumn{5}{|c|}{ Reserves (billion cubic leet) } \\
\hline \multirow[t]{2}{*}{$\begin{array}{l}\text { Estımated Proved Reserves (dry) } \\
\text { as of December } 31\end{array}$} & 0 & 0 & 0 & 0 & 0 \\
\hline & \multicolumn{5}{|c|}{ Number of Gas and Gas Condensate Wells } \\
\hline \multirow[t]{2}{*}{ Producing at End of Yaar } & 0 & 0 & $\ddot{0}$ & 0 & 0 \\
\hline & \multicolumn{5}{|c|}{ Production (million cubic leet) } \\
\hline Gross Withdrawals & & & & & \\
\hline From Gas Welis & 0 & 0 & 0 & 0 & 0 \\
\hline From Oil Wells & 0 & 0 & 0 & 0 & 0 \\
\hline Total & 0 & 0 & 0 & 0 & 0 \\
\hline Repressuring & 0 & 0 & 0 & 0 & 0 \\
\hline Nont, drocartion Gases Removed & 0 & 0 & ()) & 0 & 0 \\
\hline Wet Atier Lease Separation & 0 & 0 & 0 & 0 & 0 \\
\hline Vented and Flared & 0 & 0 & 0 & 0 & 0 \\
\hline Marketed Production & 0 & 0 & D & 0 & 0 \\
\hline Extraction Loss & 0 & 0 & 0 & 0 & 0 \\
\hline \multirow[t]{3}{*}{ Total Dry Production } & 0 & 0 & 0 & 0 & 0 \\
\hline & & & & & \\
\hline & \multicolumn{5}{|c|}{ Supply (million cubic feet) } \\
\hline Ory Production & 0 & 0 & 0 & 0 & ) \\
\hline \multicolumn{6}{|l|}{ Peceipts at Slate Borders } \\
\hline Imports & 0 & 0 & 0 & 0 & 0 \\
\hline Intransit Receipts & 0 & 0 & 0 & 0 & 0 \\
\hline Interstate Receipts & 863.186 & 878.416 & 931.485 & 928.505 & $94372 \%$ \\
\hline \multicolumn{6}{|l|}{ Withdrawals trom Storage } \\
\hline Underground Storage & 0 & 0 & 0 & 0 & 0 \\
\hline LNG Storage & 1.890 & 2.803 & 578 & 1232 & 1.22 \\
\hline Supplementai Gas Suppties & 0 & (1) & 0 & 0 & 2 \\
\hline Balancing Hem & $-3,48$ & 6.0 .23 & 3.141 & 10,276 & 11.985 \\
\hline Total Supply & 861.928 & $875 \quad 186$ & 928.922 & $9: 94 C:$ & $93286 ?$ \\
\hline
\end{tabular}

See footnotes at end of table 
Table 77. Summary Statistics for Natural Gas -- North Carolina, 1988-1992 (Continued)

\begin{tabular}{|c|c|c|c|c|c|}
\hline & 1988 & 1989 & 1990 & 1991 & 1992 \\
\hline & \multicolumn{5}{|c|}{ Dispesisition (miflion cubic feel) } \\
\hline Consumption $\ldots . . . . . . . .$. & $\$ 51,990$ & 161.788 & 161,208 & 166,380 & 179,595 \\
\hline \multicolumn{6}{|l|}{ Deliveries at State Borders } \\
\hline Exports & 0 & 0 & 0 & 0 & 0 \\
\hline intransit Deliveries & 0 & 0 & 0 & 0 & 0 \\
\hline Interstate Deliveries & 707.786 & 711.800 & 765.691 & 751,862 & 752.237 \\
\hline \multicolumn{6}{|l|}{ Additions to Storage } \\
\hline Underground Storage & 0 & 0 & 0 & 0 & 0 \\
\hline LNG Storage & 2.151 & 1,597 & 2.023 & 1,219 & 1,030 \\
\hline \multirow[t]{2}{*}{ Total Disposition .... } & 861,927 & 875.185 & 928,922 & 919.461 & 932.862 \\
\hline & \multicolumn{5}{|c|}{ Consumption (million cubic feet) } \\
\hline Lease and Flant Fuel & 0 & 0 & 0 & 0 & 0 \\
\hline Pipeline Fuel .... & 5.200 & 5.683 & 6.281 & 6.207 & 6.439 \\
\hline \multicolumn{6}{|l|}{ Delivered to Consumers } \\
\hline Residential & 38.384 & 38.658 & 35,003 & 37,976 & 42,588 \\
\hline Commercial & 32.464 & 33.145 & $31,27 ?$ & 34,313 & 36,418 \\
\hline Industria! & 74.874 & 82.629 & 86.184 & 84,863 & 90,984 \\
\hline Total Delivered to Consumers & 146.790 & 156.105 & 154.927 & 160.172 & 173,156 \\
\hline \multirow[t]{2}{*}{ Total Consumption } & 151.990 & 161,788 & 161.208 & 166,380 & 179.595 \\
\hline & \multicolumn{5}{|c|}{ Delivered for the Account of Dthers (million cubic feet) } \\
\hline Residential & NA & NA & 0 & 0 & 0 \\
\hline Commercial & 1.424 & 2.126 & 1.696 & 1.725 & 1.497 \\
\hline Industrial & 13.263 & 24.687 & 24.962 & 23.348 & 17,302 \\
\hline \multirow[t]{2}{*}{ Electric Unilites } & 840 & 1.593 & 2.149 & 2,106 & 461 \\
\hline & \multicolumn{5}{|c|}{ Number of Consumers } \\
\hline Fiesidentiat & 472.928 & 492,821 & 520,140 & 539.321 & 575.096 \\
\hline Cornmercial & 60.663 & 63.562 & 68.088 & 70.207 & 72,647 \\
\hline Industrial & 3,196 & 3.381 & 2.802 & 3.506 & 3.119 \\
\hline \multirow{2}{*}{ Vehicle Fuel } & NA & NA & 1 & 1 & 2 \\
\hline & \multicolumn{5}{|c|}{ Average Annual Consumption per Consumer (thousand cubic feet) } \\
\hline Residential & 81 & 78 & 67 & 70 & 74 \\
\hline \multirow[t]{2}{*}{ Vehicle fuel } & NA & NA & 1.824 & 1.040 & 3.321 \\
\hline & \multicolumn{5}{|c|}{ Average Annual Cost per Consumer (dollars) } \\
\hline Residential & $\$ 507$ & $\$ 514$ & $\$ 415$ & $\$ 439$ & $\$ 489$ \\
\hline Commercial & 2.644 & 2.680 & 2.126 & 2.213 & 2.399 \\
\hline \multirow[t]{2}{*}{ Vehicle Fuet } & NA & NA & 8.326 & 4,836 & 16.871 \\
\hline & \multicolumn{5}{|c|}{ Average Heating value (Btu per cubtc fool) } \\
\hline \multirow[t]{2}{*}{ Delivered to Consumers } & $1030^{\circ}$ & 1.031 & 1032 & 1.032 & 1.034 \\
\hline & \multicolumn{5}{|c|}{ Average Prices for Naturai Gas Idollars per thousand cubic feell } \\
\hline Wellnead (Markeien Production) & & . & & $\therefore$ & $\therefore$ \\
\hline imports & & .. & . & . & . \\
\hline Exports & & & $\ldots$ & & .. \\
\hline Pipeline Fuei & $\$ 236$ & $\$<74$ & $5<03$ & \$1 83 & $\$: 86$ \\
\hline City Gate & 287 & 301 & 248 & 269 & 288 \\
\hline \multicolumn{6}{|l|}{ Delivered to Consumers } \\
\hline Residential & 625 & 655 & $6: 7$ & 624 & 650 \\
\hline Commercial & 494 & 514 & 463 & $\lfloor 53$ & 479 \\
\hline Industria: & 357 & 364 & 347 & 324 & 334 \\
\hline venicle fuei & NA & NA & 456 & 465 & $50 \mathrm{OB}$ \\
\hline Electric Unimites & 348 & 357 & 320 & 276 & 296 \\
\hline
\end{tabular}

\section{Ma Not avallable}

Not applicabie

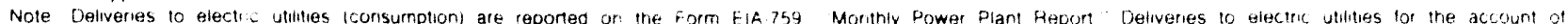
others are reported on the Form ElA.176. Annual Feport of Natura: and Supplemental Gas Supply and Disposition See the discussion on electric uthity data and Table A. in A.P pendix A for a comparison of reporting 10 these two torms lotals may nol add due to independent rounding

Sources Energy intormation: Administration IEIA). Form E:A.176. Annual Report of Naturai and Supplemental Gas Supply and Disposition Form EIA.62? Annual Cuantity arid value of Naturai Gas Report Form EIA.857 Monthiy Report of Natural Gas Purchases and Detiveries to Consumeis. Form ElA B:E. Monthly Natural Gas Liquids Report. Form

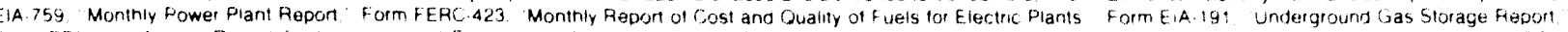

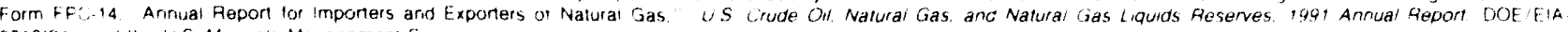
02161911 . and the US Minerais Management Service 
Natural Gas 1992

Net Interstate Movements

Mllilion

Marketed Production

$\begin{array}{cc}\text { Million } & \text { Percent of } \\ \text { Cu. Feet } & \text { National Total } \\ 54,883 & .29\end{array}$

Deliveries to Consumers

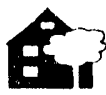

Residential:

9,693

.21

inst

Commercial:

9,759

C.MIII

Industrial:

5,940

.08

Vehicle Fuel:

3

.59

A

Electric Utility:

.00

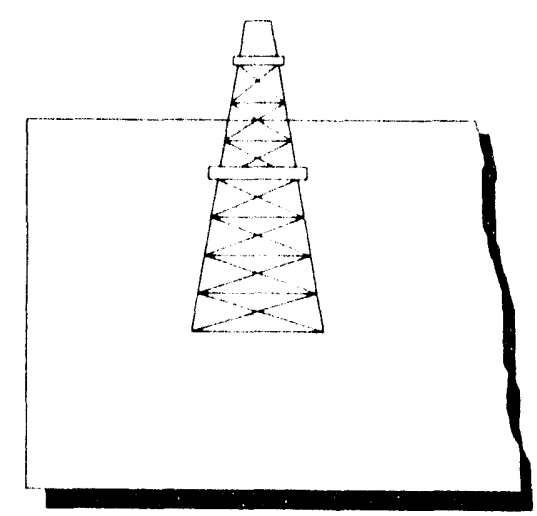

NORTH

Total:

25.397

.14

Table 78. Summary Statistics for Natural Gas -- North Dakota, 1988-1992

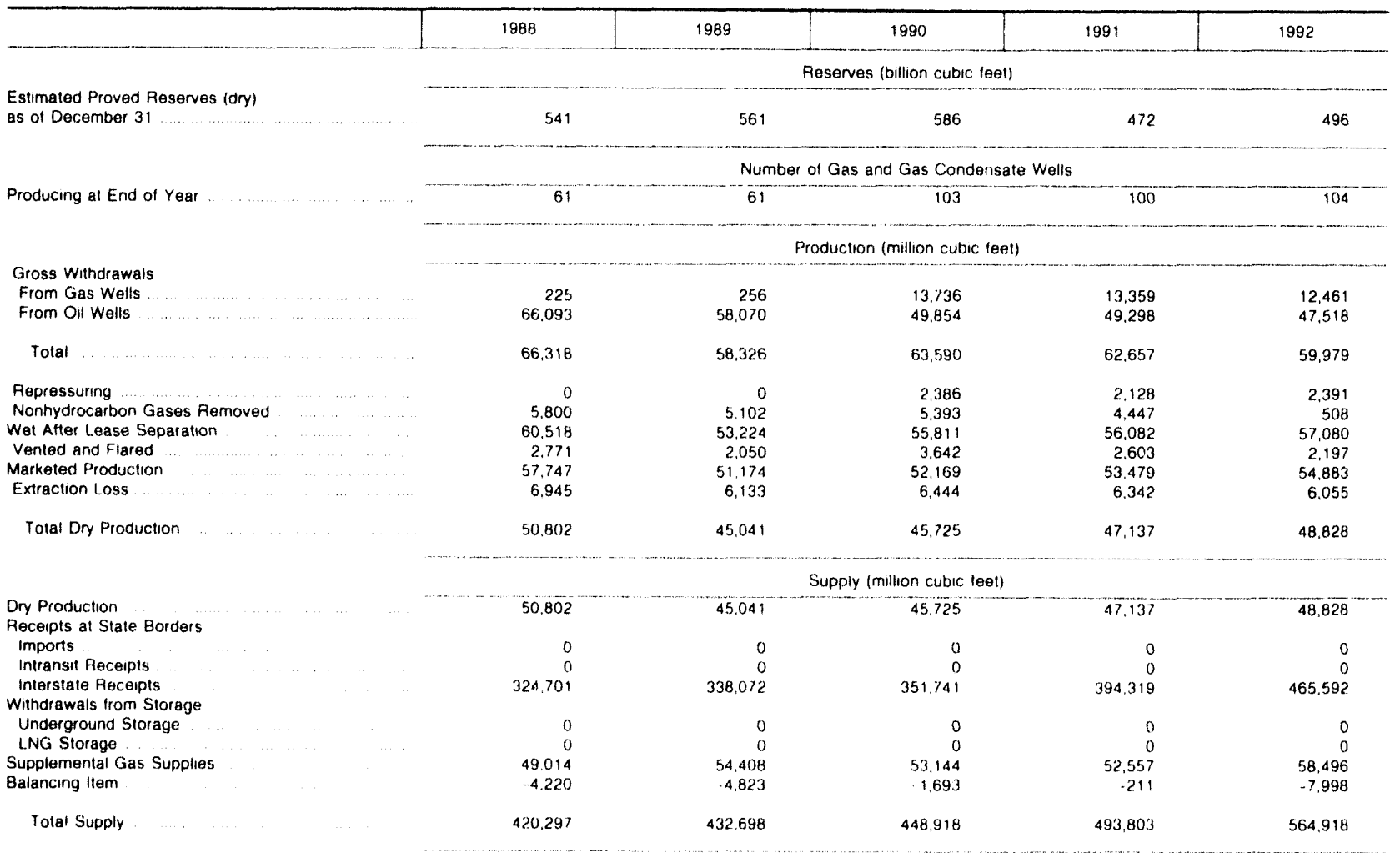

See footnotes at end of table 
Table 78. Summary Statistics for Natural Gas -- North Dakota, 1988-1992 (Continued)

\begin{tabular}{|c|c|c|c|c|c|}
\hline & 1988 & 1989 & 1990 & 1991 & 1992 \\
\hline & \multicolumn{5}{|c|}{ Disposition (million cubic feet) } \\
\hline Consumption .................... & 28,614 & 30,152 & 32,490 & 39.789 & 36,588 \\
\hline $\begin{array}{l}\text { Deliveries at State Borders } \\
\text { Exports }\end{array}$ & 0 & 0 & 0 & 0 & 0 \\
\hline Intransit Deliveries & 0 & 0 & 0 & 0 & 0 \\
\hline Interstate Deliveries & 391,683 & 402,546 & 416,428 & 454,014 & 528,330 \\
\hline \multicolumn{6}{|l|}{ Additions to Storage } \\
\hline Underground Storage & 0 & 0 & 0 & 0 & 0 \\
\hline L.NG Storage & 0 & 0 & 0 & 0 & 0 \\
\hline \multirow[t]{2}{*}{ Total Disposition . } & 420,297 & 432,698 & 448.918 & 493,803 & 564.918 \\
\hline & \multicolumn{5}{|c|}{ Consumption (million cubic teet) } \\
\hline Lease and Plant Fuel .... & 4,014 & 3,388 & 6,939 & 11,583 & 8.462 \\
\hline 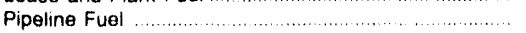 & 1.724 & 1.805 & 1,771 & 2.011 & 2,729 \\
\hline \multicolumn{6}{|l|}{ Delivered to Consumers } \\
\hline Residential & 9,147 & 9,825 & 9,183 & 10,338 & 9,693 \\
\hline 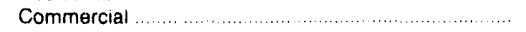 & 9,827 & 10,609 & 10,236 & 10,732 & 9,759 \\
\hline Industrial & 3.901 & 4,525 & 4,359 & 5,123 & 5.940 \\
\hline 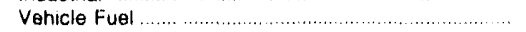 & NA & NA & $\cdot$ & 1 & 3 \\
\hline Electric Utilities & 2 & 1 & 2 & 1 & 1 \\
\hline Total Delivered to Consumers & 22,876 & 24,959 & 23,779 & 26,195 & 25,397 \\
\hline \multirow[t]{2}{*}{ Total Consumption } & 28,614 & 30,152 & 32,490 & 39,789 & 36,588 \\
\hline & \multicolumn{5}{|c|}{ Delivered for the Account of Others (million cubic feet) } \\
\hline Residential & NA & NA & 0 & 0 & 0 \\
\hline Commercial ........................... & 716 & 2,082 & 2.585 & 3,223 & 3.035 \\
\hline 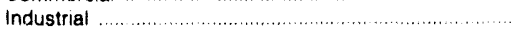 & 2,206 & 3.336 & 3.296 & 3,901 & 4,656 \\
\hline \multirow[t]{2}{*}{ 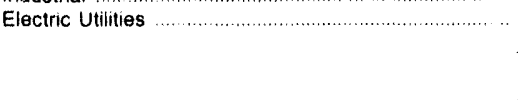 } & 0 & 0 & 0 & 0 & 0 \\
\hline & \multicolumn{5}{|c|}{ Number of Consumers } \\
\hline Residential & 84,059 & 84,643 & 85,646 & 87,880 & 89,522 \\
\hline Cornmercial & 12,104 & 12,454 & 12,742 & 12,082 & 12,353 \\
\hline \multirow{3}{*}{ 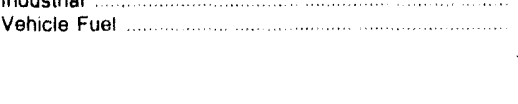 } & 148 & 151 & 165 & 170 & 171 \\
\hline & NA & NA & 1 & 1 & 4 \\
\hline & \multicolumn{5}{|c|}{ Average Annual Consumption per Consumer (thousand cubic feet) } \\
\hline Residential & 109 & 116 & 107 & 118 & 108 \\
\hline Commercial ……………………… & 812 & 852 & 803 & 888 & 790 \\
\hline \multirow{3}{*}{$\begin{array}{l}\text { Industrial } \\
\text { Vehicle Fuel }\end{array}$} & 26,359 & 29,964 & 26.416 & 30,134 & 34,739 \\
\hline & NA & NA & 29 & 1,408 & 856 \\
\hline & \multicolumn{5}{|c|}{ Average Annual Cost per Consumer (dollars) } \\
\hline 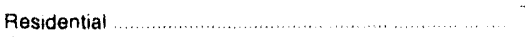 & $\$ 561$ & $\$ 543$ & $\$ 504$ & $\$ 568$ & $\$ 541$ \\
\hline 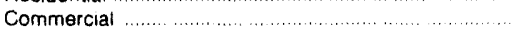 & 3,640 & 3.565 & 3,368 & 3,851 & 3,567 \\
\hline \multirow[t]{2}{*}{ 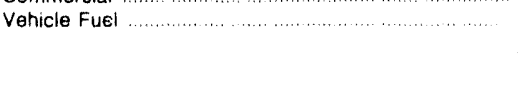 } & NA & NA & 125 & 4.697 & 3,636 \\
\hline & \multicolumn{5}{|c|}{ Average Heating Value (Btu per cubic foot) } \\
\hline \multirow[t]{2}{*}{ Delivered to Consumers } & 1.055 & 1,049 & 1,032 & 1,046 & 1,045 \\
\hline & \multicolumn{5}{|c|}{ Average Prices for Natural Gas (dollars per thousand cubic feet) } \\
\hline Wellhead (Marketed Production) $\ldots . . . . . . . . . . . . . .$. & $\$ 2.00$ & $\$ 178$ & $\$ 1.79$ & $\$ 1.67$ & $\$ 1.97$ \\
\hline 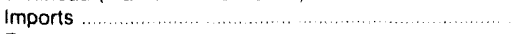 & $m$ & $\cdots$ & $\cdots$ & - & $\cdots$ \\
\hline Exports & - . & $\cdots$ & + & -- & -. \\
\hline Pipeline Fuel & 2.49 & 203 & 161 & 1.35 & 1.28 \\
\hline City Gate & 3.42 & 312 & 307 & 3.49 & 3.28 \\
\hline \multicolumn{6}{|l|}{ Delivered to Consumers } \\
\hline Residential . & 515 & 468 & 4.70 & 4.82 & 5.00 \\
\hline Commercial & 448 & 4.19 & 4.19 & 4.34 & 4.52 \\
\hline Industrial & 341 & 355 & 334 & 3.19 & 3.25 \\
\hline Vehicle Fuel & NA & NA & 431 & 3.34 & 4.25 \\
\hline Electric Utilities & 4.56 & 4.61 & 4.01 & 436 & 4.18 \\
\hline
\end{tabular}

- Less than 500,000 cubic feet

NA Not available.

Not applicable Note: Deliveries to electric utilities (consumption) are reported on the Form ElA.759, "Monthly Power Plant Report" Deliveries to electric utilities for the account of
others are reported on the Form EiA.176, "Annual Report of Natural and Supplemental Gas Supply and Disposition." See the discussion on electric utility data and Table Ai in Ap. pendix $A$ for a comparison of ceporting to these two forms Totals may not add due to independent rounding.

Sources: Energy Intormation Administration (EIA). Form EIA-176. "Annual Report of Natural and Supplemental Gas Supply and Disposition, " Form EIA-627. "Annual Quanity and Value of Naturai Gas Report." Form EIA-B57. "Monthly Report or Natural Gas Purchases and Deliverles to Consumers." Form EIA.816. "Monthly Natural Gas Liquids Report." Form EIA.759, "Monthly Power Plant Report." Form FERC.423, "Monthly Report of Cost and Quality of Fueis for Electric Plants." Form ElA-191. "Underground Gas Storage Report." Form FPC-14. "Annual Report for Importers and Exporters of Natural Gas," US Crude Oil. Natural Gas, and Natural Gas Liquids Reserves. 1992 Annual Report, DOE/EiA. 0216(92): and the US Minerals Management Service. 


\section{Natural Gas 1992}

Net Interstate Movements

Million

Marketed Production

Million

643,869

144,815

Percent of

National Total

.77

Deliveries to Consumers

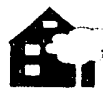

Residential:

340,628

7.26

A.

ints

Commercial:

160,645

c.

Industrial:

294,805

$\square$ Vehicle Fuel:

69

5.73

3.92

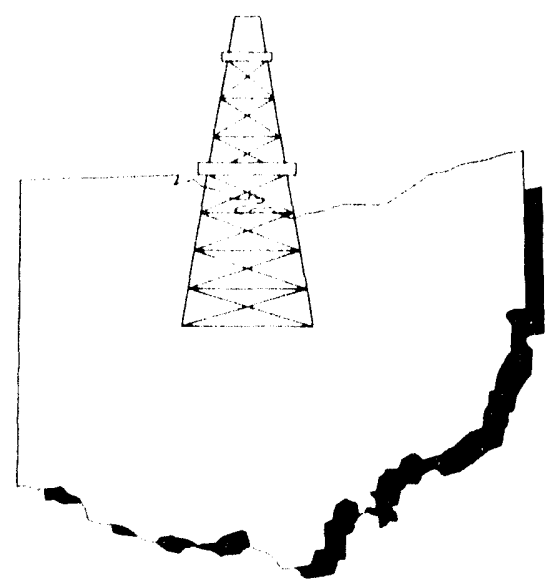

A

Electric Utility:

2,966

.11

$\mathrm{OHIO}$

Total:

799,093

4.49

Table 79. Summary Statistics for Natural Gas -- Ohio, 1988-1992

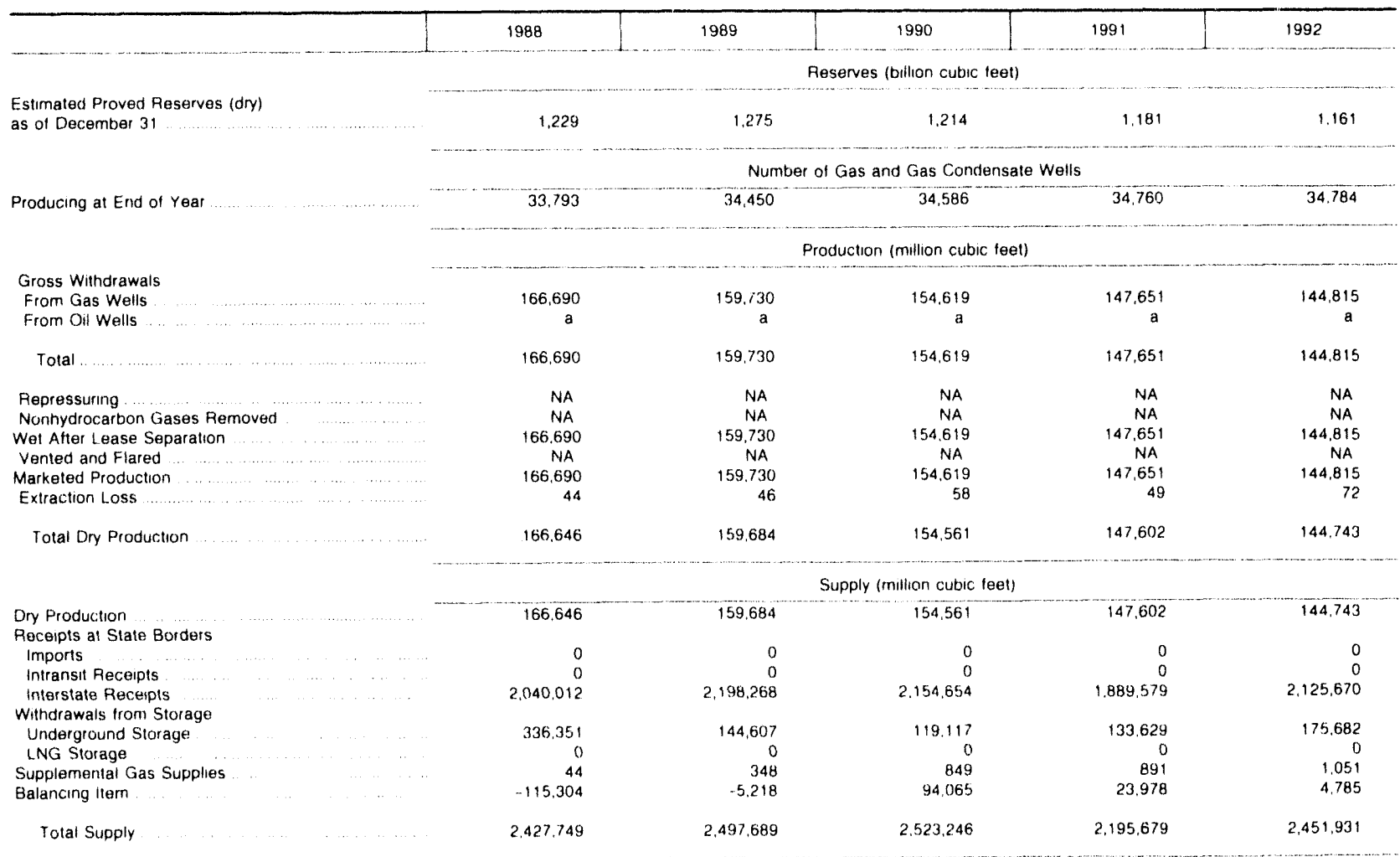

See tootnotes at end of table 
Table 79. Summary Statistics for Natural Gas -- Ohio, 1988-1992 (Continued)

\begin{tabular}{|c|c|c|c|c|c|}
\hline & 1988 & 1989 & 1990 & 1991 & 1992 \\
\hline & \multicolumn{5}{|c|}{ Disposition (million cubic feel) } \\
\hline Consumption ....................... & 805,309 & 814,123 & 746.719 & 765,639 & 810.121 \\
\hline \multicolumn{6}{|l|}{ Deliveries at State Borders } \\
\hline 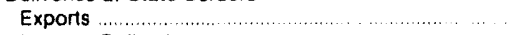 & 0 & 0 & 0 & 0 & 0 \\
\hline 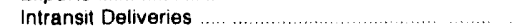 & 0 & 0 & 0 & 0 & 0 \\
\hline 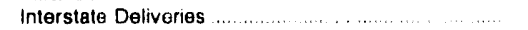 & $1,459,639$ & $1,550.668$ & $1,622,075$ & $1,295,980$ & $1,481,800$ \\
\hline \multicolumn{6}{|l|}{ Additions to Storayg } \\
\hline Underground Storage & 162,801 & 132.898 & 154,452 & 134,060 & 160,009 \\
\hline LNG Storage & 0 & 0 & 0 & 0 & 0 \\
\hline \multirow[t]{2}{*}{ 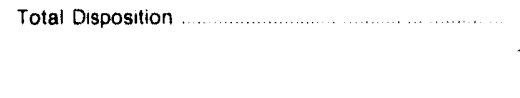 } & $2,427,749$ & $2,497,689$ & $2,523,246$ & $2,195,679$ & $2,451,931$ \\
\hline & \multicolumn{5}{|c|}{ Consumption (million cubic leet) } \\
\hline Lease and Plant Fuel. & 4.869 & 3,876 & 5,129 & 1.476 & 1,450 \\
\hline Pipeline Fuel ............... & 10,004 & 10,395 & 9.981 & 9.046 & 9,578 \\
\hline \multicolumn{6}{|l|}{ Delivered to Consumers } \\
\hline Residential ..................... & 350,612 & 359,148 & 308,321 & 321.724 & 340,628 \\
\hline 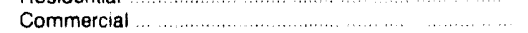 & 158,790 & 161,516 & 143.503 & 150,339 & 160,645 \\
\hline Industrial & 280,059 & 278,205 & 278.459 & 279.750 & 294,805 \\
\hline Vehicle Fuel & NA & NA & 73 & 67 & 59 \\
\hline 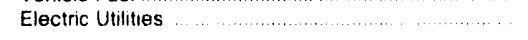 & 974 & 983 & 1.254 & 3.237 & 2,956 \\
\hline Total Delivered to Consumers & 790,436 & 799,852 & 731.609 & 755,118 & 799,093 \\
\hline \multirow[t]{2}{*}{ Total Consumption } & 805,309 & 814,123 & 746,719 & 765,639 & 810.121 \\
\hline & \multicolumn{5}{|c|}{ Delivered for the Account of Others (million cubic feet) } \\
\hline Residential & NA & NA & 0 & 0 & 81 \\
\hline Commercial & 20,433 & 21,903 & 18,258 & 20,033 & 23,188 \\
\hline Industrial & 227.745 & 233,517 & 239,551 & 246,062 & 260.609 \\
\hline \multirow[t]{2}{*}{ 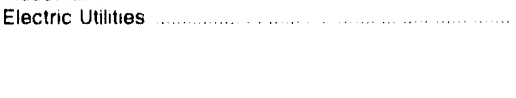 } & 0 & 301 & 656 & 2.695 & 2.147 \\
\hline & \multicolumn{5}{|c|}{ Number of Consumers } \\
\hline Residential ............ & 2.678 .838 & $2,714,839$ & 2,766912 & 2.801 .716 & $2,826,713$ \\
\hline Commercial & 219,257 & 225.347 & 233,075 & 236.519 & 237,861 \\
\hline Industrial $\ldots \ldots$ & 8,163 & 8,356 & 8,301 & 8,479 & 8.573 \\
\hline \multirow[t]{2}{*}{ Vehicle Fuel } & NA & NA & 850 & 850 & 675 \\
\hline & \multicolumn{5}{|c|}{ Average Annual Consumption per Consumer (thousand cubic feet) } \\
\hline Residential ........ & 131 & 132 & 111 & 115 & 121 \\
\hline Commercial & 724 & 717 & 616 & 636 & 675 \\
\hline Industrial $\ldots \ldots \ldots$ & 34,308 & 33,294 & 33,545 & 32,993 & 34,388 \\
\hline \multirow[t]{2}{*}{ 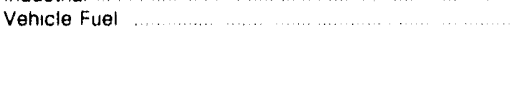 } & NA & NA & 85 & 79 & 87 \\
\hline & \multicolumn{5}{|c|}{ Average Annual Cost per Consumer (dollars) } \\
\hline Residential : & $\$ 682$ & $\$ 704$ & $\$ 590$ & $\$ 606$ & $\$ 627$ \\
\hline Commercial $\quad \ldots . \ldots \ldots \ldots \ldots$ & 3.440 & 3,513 & 2.880 & 3.027 & 3,187 \\
\hline \multirow[t]{2}{*}{ Venicle Fuel $\ldots \ldots \ldots \ldots \ldots$} & NA & NA & 270 & 236 & 272 \\
\hline & \multicolumn{5}{|c|}{ Average Heating Value (Btu per cubic fool) } \\
\hline \multirow[t]{2}{*}{ Delivered to Consumers } & 1.040 & 1.042 & 1,040 & 1,044 & 1.036 \\
\hline & \multicolumn{5}{|c|}{ Average Prices for Natural Gas (dollars per thousand cubic feet) } \\
\hline Wellhead (Marketed Production) & $\$ 255$ & $\$ 255$ & $\$ 254$ & $\$ 2.38$ & $\$ 2.35$ \\
\hline Imports & $\cdots$ & $\ldots$ & $\ldots$ &.- & - \\
\hline Exports $\ldots \ldots \ldots \ldots$ & . & -. & -. & $\cdots$ & -. \\
\hline Pipeline Fuel & 243 & 254 & 261 & 266 & 2.83 \\
\hline City Gate & 326 & 331 & 309 & 305 & 326 \\
\hline \multicolumn{6}{|l|}{ Delivered to Consumers } \\
\hline 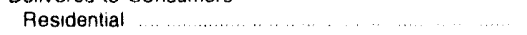 & 5.21 & 532 & 5.29 & 5.28 & 5.20 \\
\hline Commercial & 475 & 490 & 468 & 4.76 & 472 \\
\hline Industrial & 410 & 4.19 & 4.08 & 409 & 4.15 \\
\hline Vehicle Fuel & NA & NA & 316 & 297 & 3.12 \\
\hline Electric Utilities & 351 & 3.15 & 257 & F 2.19 & 2.31 \\
\hline
\end{tabular}

- Included in gross withdrawals from gas wells. Breakdown not provided by State agency

Ra Revised data.

Na. Not available.

Note. Not applicable others are reported on the Form ElA-176. "Annual Report of Natural and Supplernental Gas Supply and Disposition "See the discussion on electric utlity data and Table A1 in Ap. others are reported on the Form ElA.176. "Annual Report of Natural and Supplemental Gas Supply and Disposit
pendix $t$ tor a comparison of reporting to these two forms Totais may not add due to independent rounding.

Sources: Energy intormation Administration (EIA). Form E.IA-176. "Annual Report of Natural and Supplemental Gas Supply and Disposition," Form EIA.627, "Annual Ouantity and Value of Natural Gas Fedort," Form ElA.857. "Monthly Report of Natural Gas Purchases and Deliveries to Consumers." Form EiA 816 . "Monthly Natural Gas Liquids Report." Form EIA-759. "Monthly Power Plant Report," Form FERC-423. "Monthly Report of Cost and Quality of Fuels for Electric Plants. "Form EIA.191. "Underground Gas Storage Report," Form FPC-14, "Annual Report for Importers and Exporters of Natural Gas," US Crude OII, Natural Gas, and Natural Gas Liquids Reserves. 1992 Annual Report, DOE/EtA0216(92), and the U.S Minerals Managernent Service 


\section{Natural Gas 1992}

Net Interstate Movements $\begin{gathered}\text { Million } \\ \text { Cu. Feot } \\ -1,266,616\end{gathered}$

Marketed Production

Million
Cu. Foet
$2,017.356$

Percent of National Total

10.78

\section{Deliveries to Consumers}

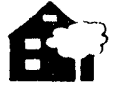

Residential:

65,811

1.40

A.

ind

Commercial:

35,190

1.26

c. III

Industrial:

175,168

2.33

$\longrightarrow$ Vehicle Fuel:

45

8.81

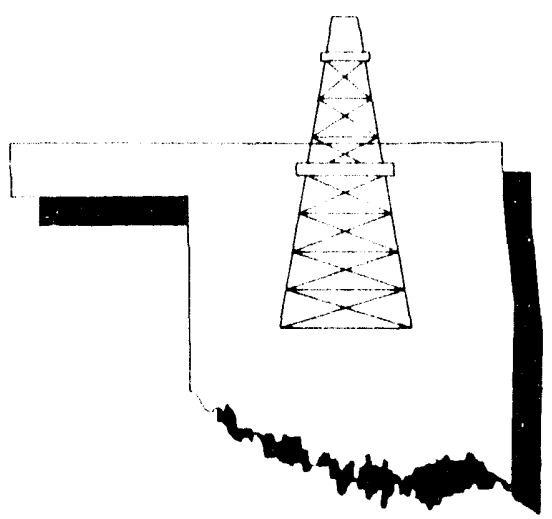

PT

Electric Utility:

148,980

5.39

Total:

425,195

2.39

Table 80. Summary Statistics for Natural Gas -- Oklahoma, 1988-1992

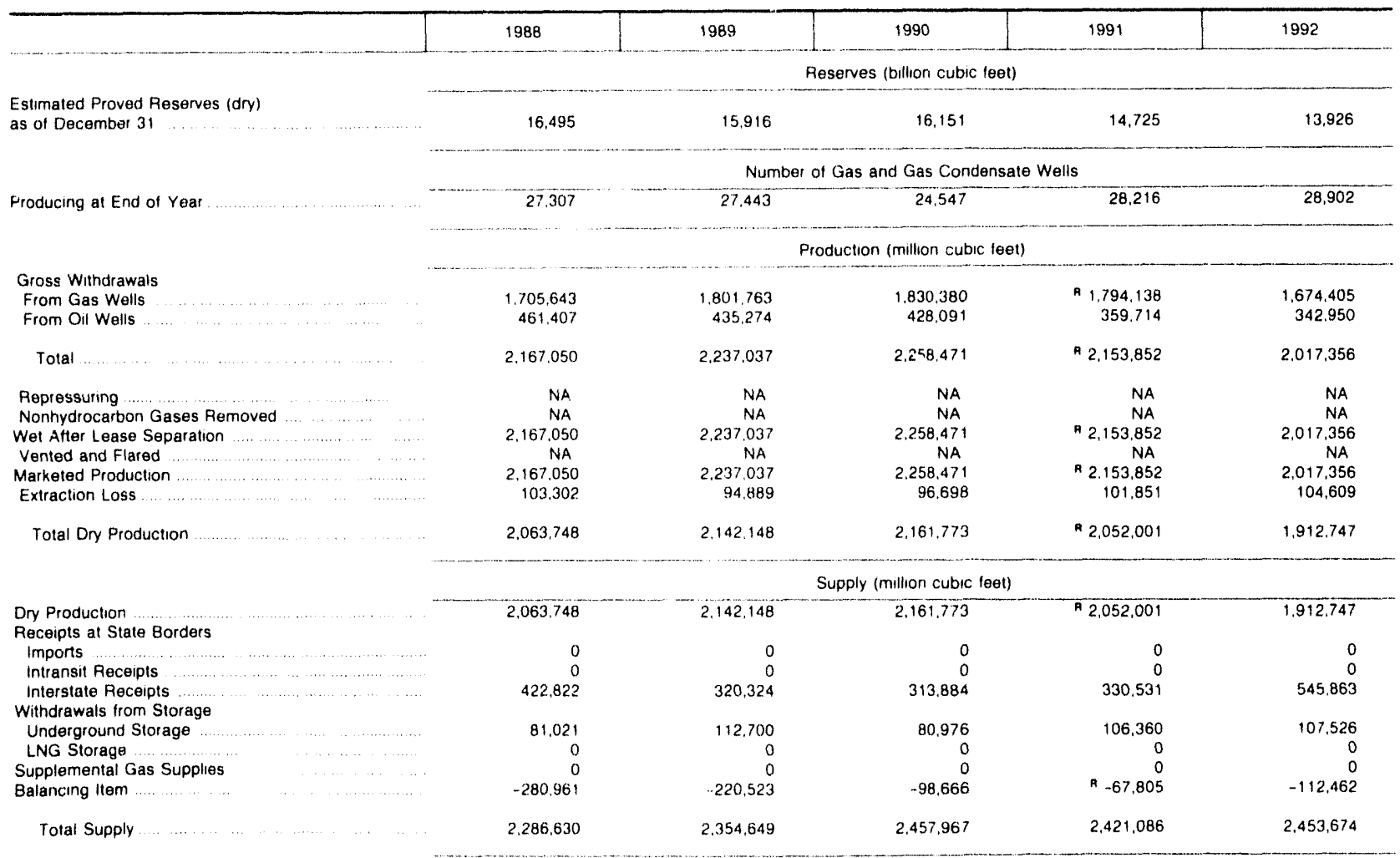

See lootnoles at end of table 
Table 80. Summary Statistics for Natural Gas -- Oklahoma, 1988-1992 (Continued)

\begin{tabular}{|c|c|c|c|c|c|}
\hline & 1988 & 1989 & 1990 & 1991 & 1992 \\
\hline & \multicolumn{5}{|c|}{ Disposition (million cubic leet) } \\
\hline Consumption & 588.796 & 600,824 & 604,423 & 570.154 & 543,827 \\
\hline \multicolumn{6}{|l|}{ Deliveries at State Borders } \\
\hline Exports & 0 & 0 & 0 & 0 & 0 \\
\hline Intransit Deliveries & 0 & 0 & 0 & 0 & 0 \\
\hline Interstate Deliveries & $1,602.593$ & $1,655,455$ & $1,758,270$ & $1,756,711$ & $1,812,379$ \\
\hline \multicolumn{6}{|l|}{ Additions to Storage } \\
\hline Underground Storage & 95,241 & 98.370 & 95,274 & 94,221 & 97,468 \\
\hline LNG Storage & 0 & 0 & 0 & 0 & 0 \\
\hline \multirow[t]{2}{*}{ Total Disposition } & $2,286,630$ & $2,354,649$ & $2.457,967$ & $2,421,086$ & $2,453,674$ \\
\hline & \multicolumn{5}{|c|}{ Consumption (million cubic feet) } \\
\hline Lease and Plant Fuel & 100,926 & 90.225 & 111,567 & 88,366 & 92,978 \\
\hline Pipeline Fuel .............. & 27.740 & 36,482 & 26,030 & 25.083 & 25,654 \\
\hline \multicolumn{6}{|l|}{ Delivered to Consumers } \\
\hline Residential .................... & 71.970 & 71,793 & 65,618 & 69.200 & 65,811 \\
\hline Commercial & 47,870 & 38,509 & 37,208 & 39,588 & 35,190 \\
\hline Industrial $\ldots \ldots \ldots \ldots$ & 163,069 & 185,796 & 195,042 & 180,695 & 175.168 \\
\hline 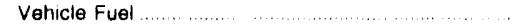 & NA & NA & 0 & 8 & 45 \\
\hline 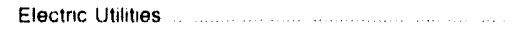 & 177.222 & 178,021 & 168,960 & 167.214 & 148,980 \\
\hline 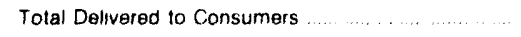 & 460,130 & 474.118 & 460,827 & 456,705 & 425,195 \\
\hline \multirow[t]{2}{*}{ Total Consumption } & 588,796 & 600,824 & 604,423 & 570.154 & 543.827 \\
\hline & \multicolumn{5}{|c|}{ Delivered for the Account of Cthers (million cubic feet) } \\
\hline Residential & NA & NA & 0 & 0 & 0 \\
\hline Commercial $\ldots \ldots \ldots$ & 12,217 & 3,988 & 2.944 & 3.445 & 4,052 \\
\hline Industral & 97,836 & 89.950 & 78,309 & 104.773 & 133,643 \\
\hline \multirow[t]{2}{*}{ 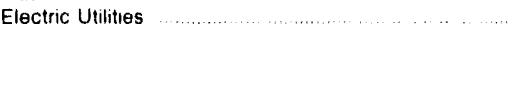 } & 163.015 & 166.455 & 160,721 & 131,393 & 137.019 \\
\hline & \multicolumn{5}{|c|}{ Number of Consumers } \\
\hline Residential. & 805,107 & 806,875 & 814,296 & 824,172 & 832,677 \\
\hline 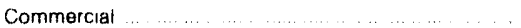 & 86,666 & 86,172 & 85,790 & 86.744 & 87,120 \\
\hline Industrial & 2,689 & 2,877 & 2.889 & 2,840 & 2,859 \\
\hline \multirow[t]{2}{*}{ Vehicle Fuel } & NA & NA & 0 & 5 & 13 \\
\hline & \multicolumn{5}{|c|}{ Average Annual Consumption per Consumer (thousand cubic feet) } \\
\hline Residential & 89 & 89 & 81 & 84 & $\overline{79}$ \\
\hline$-\ldots \ldots \ldots \ldots+\ldots \ldots+\ldots$ & 552 & 447 & 434 & 456 & 404 \\
\hline$\ldots \ldots \ldots \ldots \ldots \ldots$ & 60,643 & 64,580 & 67,512 & 63,625 & 61,269 \\
\hline \multirow[t]{2}{*}{ Vehicle Fuel } & NA & NA & 0 & 1,629 & 3,485 \\
\hline & \multicolumn{5}{|c|}{ Average Annual Cost per Consumer (dollars) } \\
\hline Residential & $\$ 404$ & $\$ 401$ & $\$ 387$ & $\$ 396$ & $\$ 392$ \\
\hline Commercial & 2,247 & 1,762 & 1,700 & 1,784 & 1,709 \\
\hline \multirow[t]{2}{*}{ Vehicie Fuel } & NA & NA & 0 & 6,236 & 10,672 \\
\hline & \multicolumn{5}{|c|}{ Average Heating Value (Btu per cub,c foot) } \\
\hline \multirow[t]{2}{*}{ Delivered to Consumers } & 1.038 & 1.028 & 1.027 & 1.021 & 1.026 \\
\hline & \multicolumn{5}{|c|}{ Average Prices for Natural Gas (dollars per thousand cubic feat) } \\
\hline Wellhead (Marketed Production) ...................... & $\$ 1.55$ & $\$ 159$ & $\$ 157$ & $\$ 1.47$ & $\$ 170$ \\
\hline Imports & $\cdots$ & -. & $\ldots$ & -. & - \\
\hline Exports & & -. & .. & -. & - \\
\hline Pipeline Fuel & 2.10 & 183 & 185 & 1.62 & 179 \\
\hline City Gate $\ldots \ldots \ldots \ldots$ & 224 & 207 & 203 & 2.04 & 222 \\
\hline \multicolumn{6}{|l|}{ Delivered to Consumers } \\
\hline Residential .................... & 4.52 & 450 & 4.80 & 4.72 & 4.96 \\
\hline 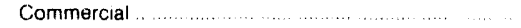 & 407 & 394 & 3.92 & 3.91 & 4.23 \\
\hline Industrial & 176 & 1.97 & 1.74 & 169 & 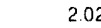 \\
\hline 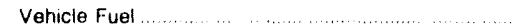 & NA & NA & $\ldots$ & 3.83 & 306 \\
\hline Electric Utilittes & 292 & 305 & 314 & 2.98 & 3.20 \\
\hline
\end{tabular}

R Revised data

MA - Not available

-- Not applicabie.

Note: Deliveries to electric utlities (consumpt!on) are reported on the Form ElA.759. "Monthly Power Plant Report" Deliveries to electric uttities for the account of others are reported on the Form ElA.176. "Annual Report of Natural and Supplemental Gas Supply and Disposition " See the discussion on electric uttlity data and Table Al in Ap. pendix A for a comparison of reporting to these two forms Totals may not add due to independent rounding

Sources: Energy information Administration (E.IA) Form EIA-176, "Annual Report of Natural and Supplemental Gias Supply and Disposition." Form EIA-627, "Annual Quantity and Value of Natural Gas Report, "Form EiA-857. "Monthly Report of Natural Gas Purchases and Deliveries to Consumers. "Form EIA-816. "Monthly Natural Gas Liquids Report." Form EIA-759. "Monthly Power Plant Report," Form FEAC-423. "Monthly Report ol Cost and Ouality of Fuels for Electric Plants. "Form EIA-191. "Underground Gas Storage Report," Form FPC-14. "Annual Report for Importers and Exporters of Natural Gas," US Crude Oil. Natural Gas, and Natural Gas Liquids Reserves, 1992 Annual Report. DOE/EIA. $0216(92)$; and the U.S. Minerals Management Service 
Natural Gas 1992

Net Interstate Movements

Mlllion

Cu. Foer

90,940

Marketed Production

Million

Percent of

Cu. Feei National Total

2,580

Deliveries to Consumers

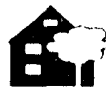

Residential:

23.109

A.

inst

Commercial:

19,570

$\rightarrow \prod_{i \infty}$

Industrial:

58.519

Vehicle Fuel:

6

成

Electric Utility:

14,264

Total:

116,469

.01

.49

.70

.78

1.17

.62

OREGON

Table 81. Summary Statistics for Natural Gas -- Oregon, 1988-1992

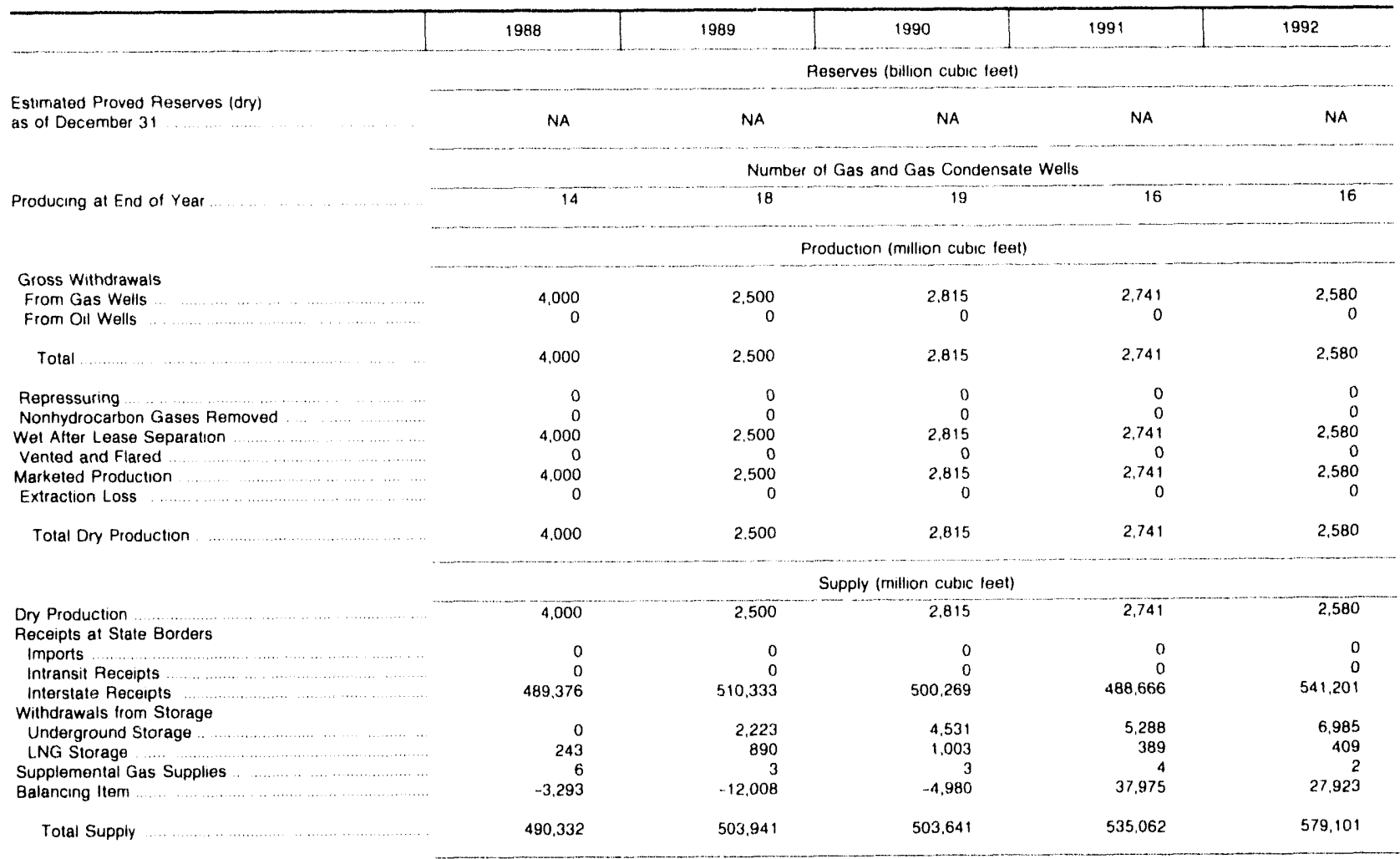

See footnotes at end of table. 
Table 81. Summary Statistics for Natural Gas -- Oregon, 1988-1992 (Continued)

\begin{tabular}{|c|c|c|c|c|c|}
\hline & 1988 & 1989 & 1990 & 1991 & 1992 \\
\hline & \multicolumn{5}{|c|}{ Disposition (million cubic teet) } \\
\hline Consumption & 87,163 & 108.028 & 109,215 & 123,436 & 122,350 \\
\hline \multicolumn{6}{|l|}{ Deliveries at State Borders } \\
\hline Exports $\ldots \ldots \ldots \ldots$ & 0 & 0 & 0 & 0 & 0 \\
\hline Intransil Deliveries .......... & 0 & 0 & 0 & 0 & 0 \\
\hline Interstate Deliveries ... & 402,366 & 390,029 & 387.778 & 405,163 & 450,261 \\
\hline \multicolumn{6}{|l|}{ Additions to Storage } \\
\hline Underground Storage & 0 & 4,944 & 5,894 & 5,853 & 6,114 \\
\hline LNG Storage & 803 & 940 & 754 & 609 & 376 \\
\hline \multirow[t]{2}{*}{ Total Disposition } & 490,332 & 503,941 & 503,641 & 535,062 & 579,101 \\
\hline & \multicolumn{5}{|c|}{ Consumption (miltion cubic teet) } \\
\hline Lease and Plant Fuel & 115 & 59 & 93 & 60 & 68 \\
\hline Pipeline Fuel & 8.052 & 8.522 & 9,014 & 8,819 & 6,812 \\
\hline \multicolumn{6}{|l|}{ Delivered to Consumers } \\
\hline Residential & 20,819 & 22.504 & 23,383 & 26.324 & 23,109 \\
\hline Commercial $\ldots \ldots \ldots \ldots \ldots$ & 18.400 & 20.249 & 20.449 & 22,328 & 19.570 \\
\hline Industrat $\ldots \ldots \ldots \ldots$ & $39,7 ? 1$ & 43,752 & 48,890 & 55.049 & 58,519 \\
\hline Vehicle Fuel $\ldots \ldots \ldots$ & NA & NA & 0 & 0 & 6 \\
\hline Electric Utilities $\ldots \ldots \ldots$ & 0 & 12.942 & 7,386 & 10,856 & 14,264 \\
\hline Total Delivered to Consumers & 78,996 & 99.448 & 100.108 & 114,557 & 115.469 \\
\hline \multirow[t]{2}{*}{ Total Consumption } & 87.163 & 108.028 & 109,215 & 123,436 & 122.350 \\
\hline & \multicolumn{5}{|c|}{ Delivered for the Account of Others (million cubtc feet) } \\
\hline Residential & NA & NA & 0 & 0 & 0 \\
\hline Commercial & 221 & 353 & 464 & 477 & 433 \\
\hline Industrial & 26,019 & 34,133 & 38,128 & 44.521 & 46.434 \\
\hline \multirow[t]{2}{*}{ Electric Utihties } & 0 & 13,148 & 7.458 & 10.798 & 12,818 \\
\hline & \multicolumn{5}{|c|}{ Number of Consumers } \\
\hline $\begin{array}{c}\ldots \\
\ldots \ldots\end{array}$ & 288,066 & 302.156 & 326.177 & 376,166 & 354,256 \\
\hline Commercial & 41,998 & 43,997 & 47,175 & 55.374 & 50,251 \\
\hline Industrial $\ldots \ldots \ldots \ldots \ldots$ & 1.034 & 738 & 699 & 787 & 740 \\
\hline \multirow[t]{2}{*}{ Vehicle Fuel $\quad \ldots \ldots \ldots \ldots \ldots$} & NA & NA & 0 & 0 & 13 \\
\hline & \multicolumn{5}{|c|}{ Average Annual Consumption per Consumer (thousand cubic teet) } \\
\hline Residential & 72 & 74 & 72 & 70 & 65 \\
\hline 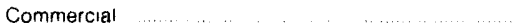 & 438 & 460 & 433 & 403 & 389 \\
\hline Industral & 38,463 & 59,285 & 69.943 & 69,949 & 79,080 \\
\hline \multirow[t]{2}{*}{ Vehicle Fuel ........... } & NA & NA & 0 & 0 & 469 \\
\hline & \multicolumn{5}{|c|}{ Average Annual Cost per Consumer (dollars) } \\
\hline Residential & $\$ 491$ & $\$ 461$ & $\$ 449$ & $\$ 429$ & $\$ 403$ \\
\hline 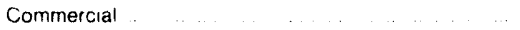 & 2,349 & 2.211 & 2,101 & 1.917 & 1,841 \\
\hline \multirow[t]{2}{*}{ Venicle Fuel } & NA & NA & 0 & 0 & 1.017 \\
\hline & \multicolumn{5}{|c|}{ Average Heating Value (Btu per cubic foot) } \\
\hline \multirow[t]{2}{*}{ Delivered to Consumers } & 1,023 & 1.035 & 1.023 & 1.029 & 1.035 \\
\hline & \multicolumn{5}{|c|}{ Average Prices for Natural Gas (dollars per thousand cubic feet) } \\
\hline Wellhead (Marketed Production) & $\$ 160$ & $\$ 140$ & $\$ 1.39$ & $\$ 142$ & $\$ 129$ \\
\hline Imports $\ldots \ldots$ & w. & -. & -- & $\ldots$ & -. \\
\hline Exports $\ldots . . . .$. & .. & .. & .. & .. & .. \\
\hline Pipeline Fuel & 190 & 2.09 & 216 & 2.32 & 216 \\
\hline$\ldots \ldots \ldots \ldots \ldots \ldots \ldots$ & 301 & 2.67 & 247 & 239 & 2.34 \\
\hline \multicolumn{6}{|l|}{ Delivered to Consumers } \\
\hline Residential & 679 & 619 & 627 & 6.13 & 6.17 \\
\hline 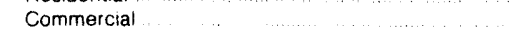 & 536 & 4.80 & 485 & 475 & 473 \\
\hline$\ldots \ldots \ldots$ & 372 & 3.52 & 347 & 341 & $33 \epsilon$ \\
\hline$\ldots \ldots+\ldots \ldots \ldots \ldots$ & NA & NA & -. & .. & 217 \\
\hline Electric Utilities & ... & $\ldots$ & $\ldots$ & 159 & 1.97 \\
\hline
\end{tabular}

NA $=$ Not avallable

Note. Deliveries to electric utilties (consumption) are reponted on the Form ElA.759. "Monthly Power Plant Report." Deliveries to electric utilities for the account of others are reported on the Form ElA.176. "Annual Report of Natural and Supplemental Gas Supply and Disposition "See the discussion on electric utlity data and Table A1 in Ap. pendix A for a comparison of reporting to these two forms Totals may not add due to independent rounding

Sources: Energy Intormation Administration (EIA). Form EIA-176. "Annual Report of Natural and Supplemental Gas Supply and Disposition." Form EIA.627, "Annual Ouantity and Value of Natural Gas Report, "Form ElA.857. "Monthly Report of Natural Gas Purchases and Deliveries to Consumers, "Form ElA.816. "Monthly Natural Gas Liquids Report," Form EIA.759, "Monthly Power Plant Report," Form FE.RC-423. "Monthly Report of Cost and Quality of Fuels for Electric Plants. "Form ElA.191. "Underground Gas Storage Fiepor " Form FPC-14. "Annual Report for Importers and Exporters of Natural Gas." US Crude Ot. Nalural Gas. and Natural Gas Liquids Reserves. 1992 Annual Report. DOE; ElA. 0216(92): and the U.S. Minerals Management Service 
Natural Gas 1992

Net Interstate Movements

Million

Cu. Fool

Million

Marketed Production

Cu. Foot

138,675

Deliveries to Consumers

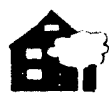

Residential:

266,528

A.

ast

Commercial:

134,254

$\therefore$ II

Industrial:

236,708

$\longrightarrow$ Vehicle Fuel:

3

$A$

Electric Utility:

3,100

6.68

Percent of National Tolal

.74

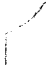

4.79

3.14

.59

PENNSYLVANIA

Total:

640,593

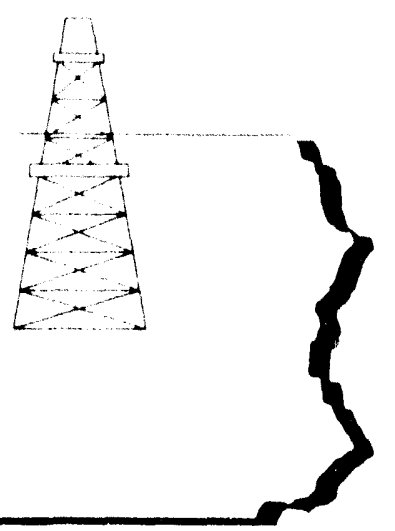

3.60

Table 82. Summary Statistics for Natural Gas -- Pennsylvania, 1988-1992

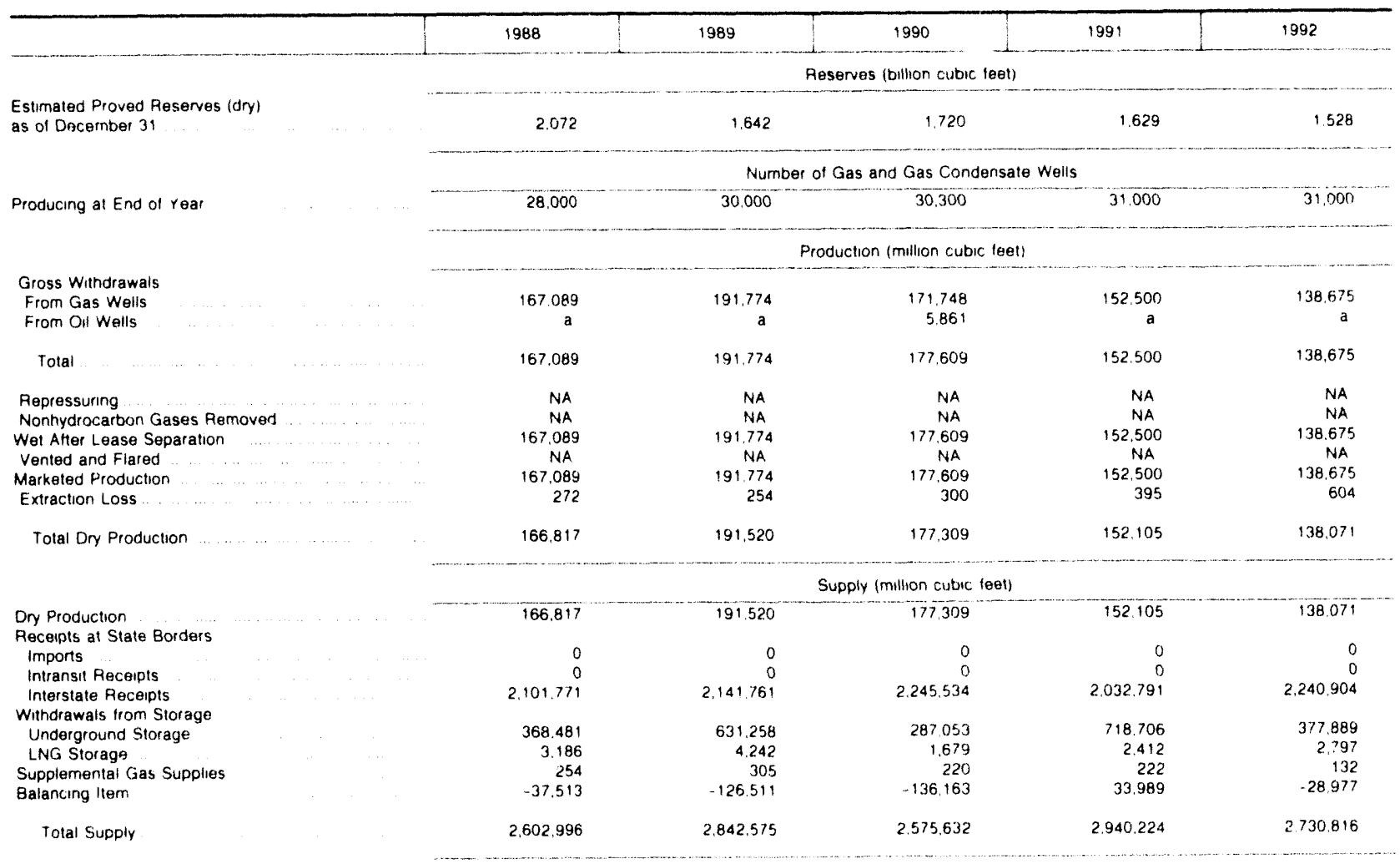

See footnotes at end of table 
Table 82. Summary Statistics for Natural Gas -- Pennsylvania, 1988-1992 (Continued)

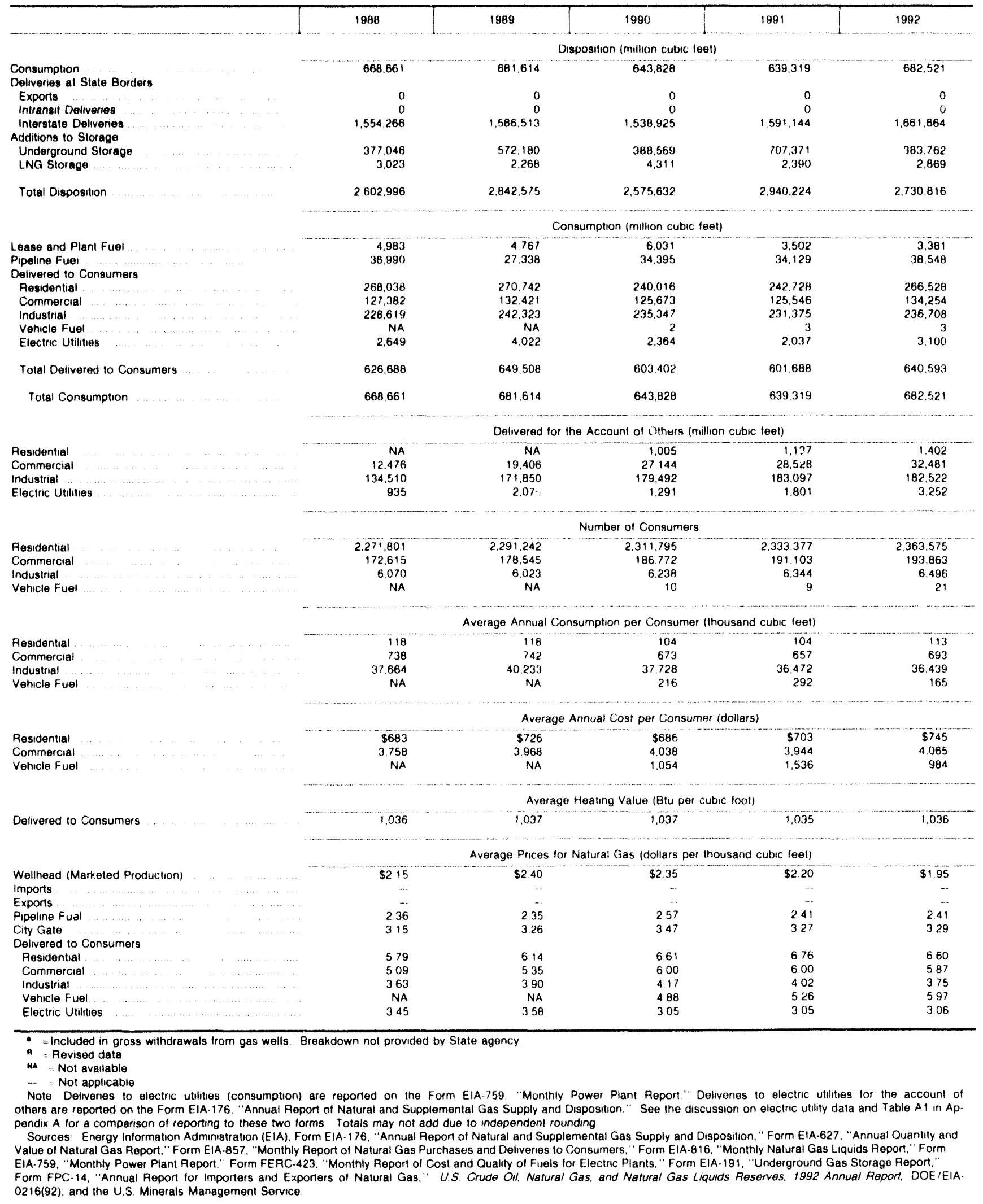


Natural Gas 1992

Net Interstate Movements

Million

Cu. Fool

73,322

Marketed Production

Million Percent of

Cu. Foet National Total

0
0

Deliveries to Consumers

- Residential:

20,000

A.

ast

Commercial:

9,080

.

Industrial:

47.917

.43

$\because$ Vehicle Fuel:

Vehicle Fuel: $\quad 9$

等

Electric Utility:

468

.32

.64

1

Total:

77.476

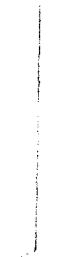

1.76

.02

RHODE

ISLAND

Table 83. Summary Statistics for Natural Gas -- Rhode Island, 1988-1992

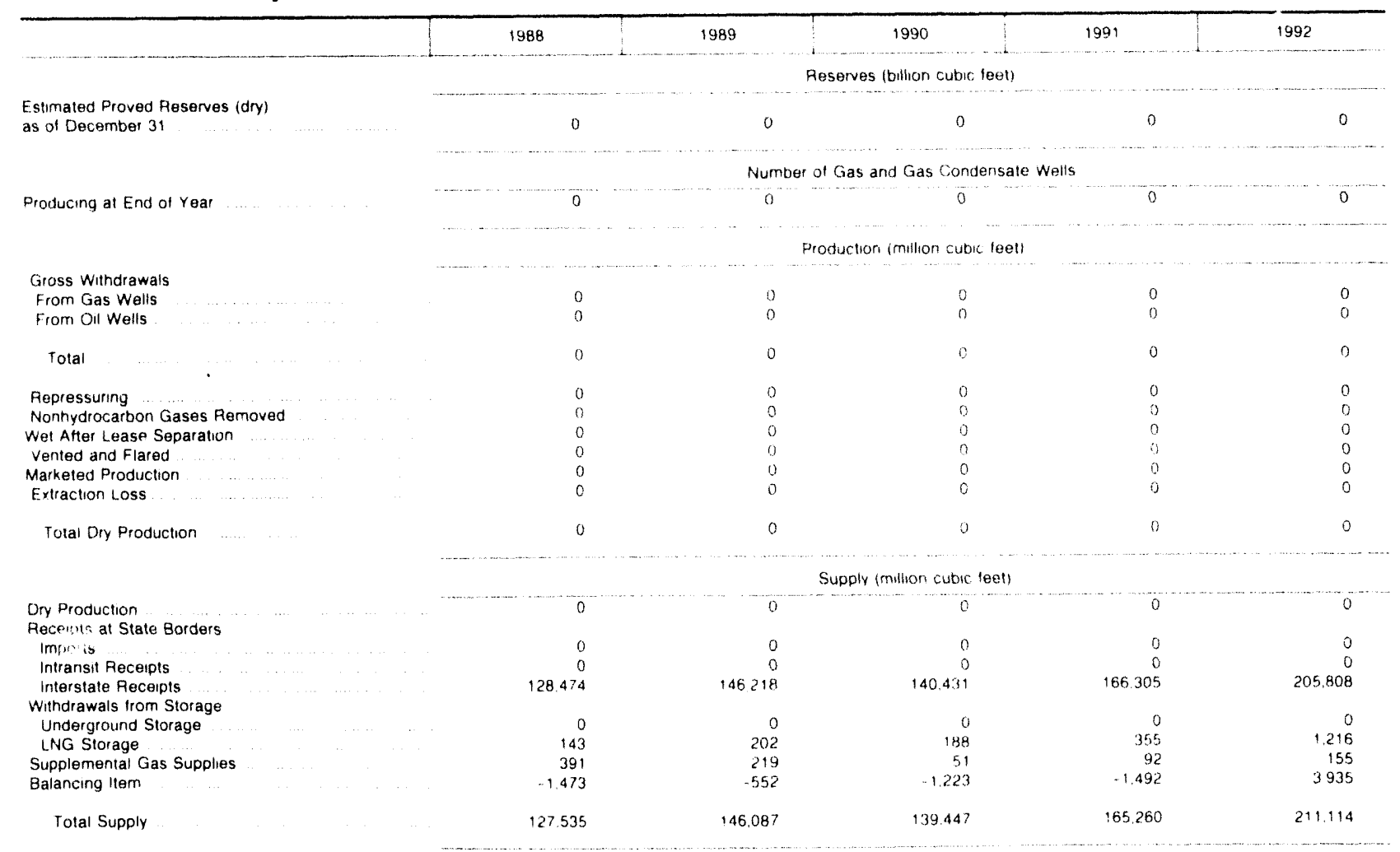




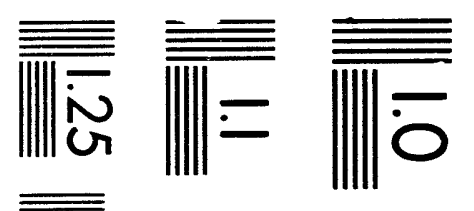

$$
\begin{aligned}
& \overline{\underline{\underline{\underline{\underline{\underline{W}}}}}}
\end{aligned}
$$

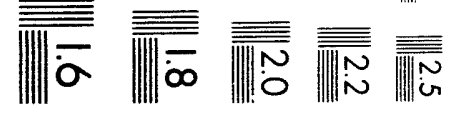



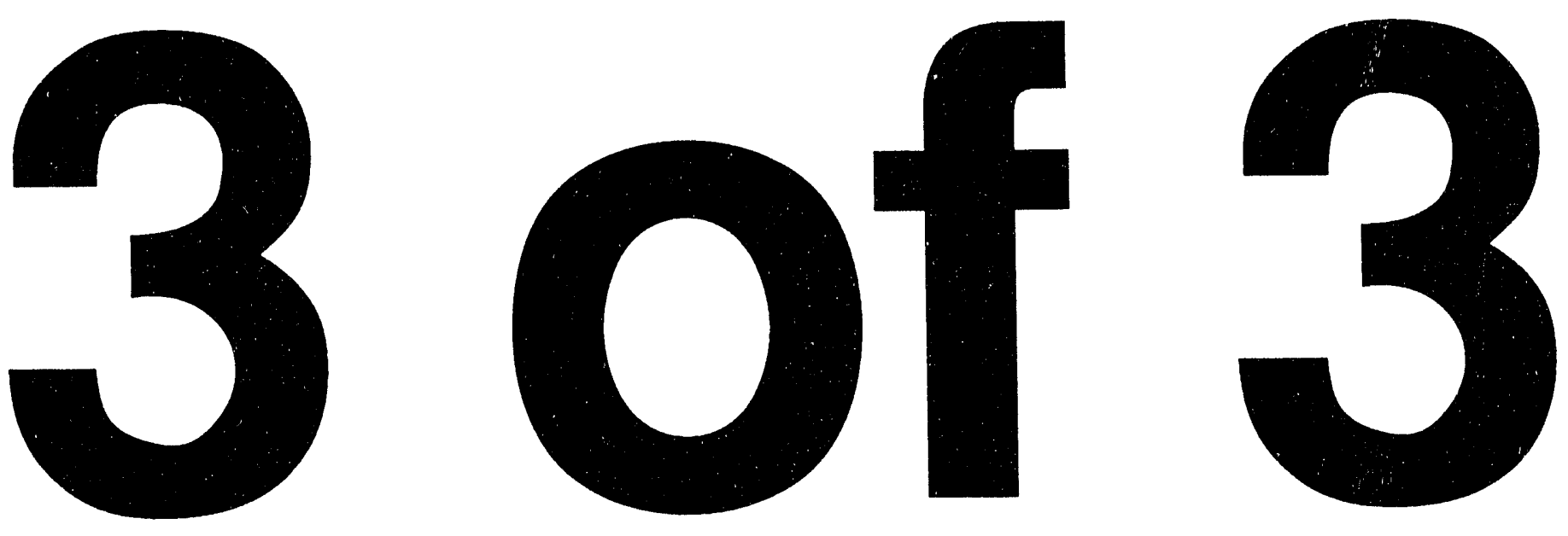
Table 83. Summary Statistics for Natural Gas -- Rhode Island, 1988-1992 (Continued)

\begin{tabular}{|c|c|c|c|c|c|}
\hline & 1988 & 1989 & 1990 & 1991 & 1992 \\
\hline & \multicolumn{5}{|c|}{ Disposition (million cubic feet) } \\
\hline Consumption ...................... & 30.787 & 33,938 & 35,787 & 54,310 & 77,833 \\
\hline $\begin{array}{l}\text { Deliveries at State Borders } \\
\text { Exports }\end{array}$ & \multicolumn{5}{|c|}{ Deliveries at State Borders } \\
\hline $\begin{array}{l}\text { Exports } \\
\text { Intransit Deliveries }\end{array}$ & $\begin{array}{l}0 \\
0\end{array}$ & $\begin{array}{l}0 \\
0\end{array}$ & $\begin{array}{l}0 \\
0\end{array}$ & $\begin{array}{l}0 \\
0\end{array}$ & $\begin{array}{l}0 \\
0\end{array}$ \\
\hline Interstate Deliveries & 96,574 & 111.986 & 103,518 & 110,202 & 132,486 \\
\hline \multicolumn{6}{|l|}{ Additions to Storage } \\
\hline Underground Storage & 0 & 0 & 0 & 0 & 0 \\
\hline LNG Storage & 174 & 164 & 142 & 749 & 796 \\
\hline \multirow[t]{2}{*}{ Total Disposition } & 127.535 & 146,087 & 139,447 & 165,260 & 211,114 \\
\hline & \multicolumn{5}{|c|}{ Consumption (Inillion cubic feet) } \\
\hline 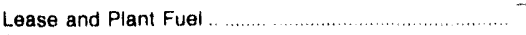 & 0 & 0 & 0 & 0 & 0 \\
\hline 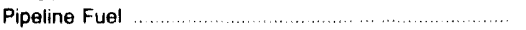 & 119 & 116 & 118 & 161 & 357 \\
\hline \multicolumn{6}{|l|}{ Delivered to Consumers } \\
\hline Residential .................... & 17.678 & 18,283 & 17.724 & 17,366 & 20.000 \\
\hline 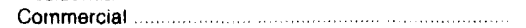 & 8,352 & 8.767 & 8.071 & 8,269 & 9.080 \\
\hline Industrial & 4.453 & 4,624 & 4,381 & 26,867 & 47.917 \\
\hline 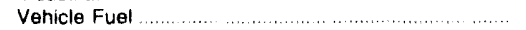 & NA & NA & 8 & 9 & 9 \\
\hline 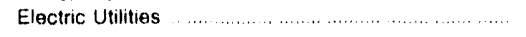 & 185 & 2.147 & 5,484 & 1.638 & 469 \\
\hline 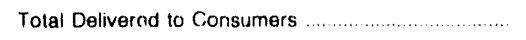 & 30,668 & 33,821 & 35.668 & 54,148 & 77.476 \\
\hline \multirow[t]{2}{*}{ Total Consumption } & 30,787 & 33,938 & 35,787 & 54.310 & 77.833 \\
\hline & \multicolumn{5}{|c|}{ Delivered for the Account of Others (million cubic feet) } \\
\hline Residential. & NA & $\overline{N A}$ & 0 & 0 & 0 \\
\hline 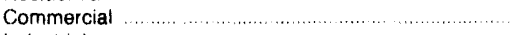 & 1,080 & 1.411 & 330 & 0 & 0 \\
\hline Industrial & 660 & 815 & 583 & 23.032 & 42,457 \\
\hline \multirow[t]{2}{*}{ Electric Utilities } & 0 & 342 & 1,033 & 1.771 & 466 \\
\hline & \multicolumn{5}{|c|}{ Number of Consumers } \\
\hline Fesidential. & 185,861 & 190,796 & 195,100 & 196,438 & 197,926 \\
\hline Commercial & 16,096 & 16,924 & 17.765 & 18.430 & 18,607 \\
\hline Industrial & 1,152 & 1,122 & 1,135 & 1,107 & 1,096 \\
\hline \multirow[t]{2}{*}{ Vehicle Fuel } & NA & NA & 84 & 95 & 96 \\
\hline & \multicolumn{5}{|c|}{ Average Annual Consumption per Consumer (thousand cubic feet) } \\
\hline Residential ............... & 95 & 96 & 91 & 88 & 101 \\
\hline 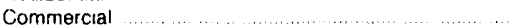 & 519 & 518 & 454 & 449 & 488 \\
\hline industrial . . . . & 3.866 & 4.122 & 3,860 & 24,270 & 43,720 \\
\hline \multirow[t]{2}{*}{ Vehicle Fuel } & NA & NA & 91 & 91 & 97 \\
\hline & \multicolumn{5}{|c|}{ Average Annual Cost per Consumer (dollars) } \\
\hline Residential.. & $\$ 628$ & $\$ 683$ & $\$ 656$ & $\$ 675$ & $\$ 776$ \\
\hline 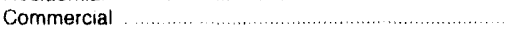 & 3,007 & 3,321 & 2,819 & 2.704 & 3,083 \\
\hline \multirow[t]{2}{*}{ Vehicle Fuel } & NA & NA & 351 & 344 & 375 \\
\hline & \multicolumn{5}{|c|}{ Average Heating Value (Btu per cubic foot) } \\
\hline \multirow{2}{*}{ 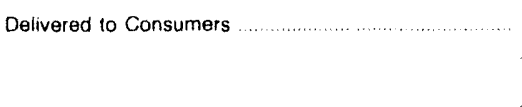 } & 1.027 & 1,027 & 1,028 & 1,028 & 1,018 \\
\hline & \multicolumn{5}{|c|}{ Average Prices for Natural Gas (dollars per thousand cubic feet) } \\
\hline Wellhead (Marketed Production) ........ & $\cdots$ & $\cdots$ & $\cdots$ & - & $\cdots$ \\
\hline Imports & -. & $\cdots$ & .. & $\cdots$ & $\cdots$ \\
\hline Exports & $\ldots$ & -. &.- & -. & -. \\
\hline Pipeline Fuel ....... & $\$ 2.20$ & $\$ 4.19$ & $\$ 3.74$ & $\$ 3.41$ & $\$ 2.94$ \\
\hline City Gate & 3.43 & 368 & 3.71 & 3.68 & 3.82 \\
\hline \multicolumn{6}{|l|}{ Delivered to Consumers } \\
\hline Pesidential … . . & 6.60 & 7.13 & 7.22 & 7.63 & 7.68 \\
\hline Commercial & 5.80 & 6.41 & 6.20 & 6.03 & 6.32 \\
\hline Industrial & 4.83 & 5.16 & 5.32 & 5.40 & 466 \\
\hline Vehicle Fuel & NA & NA & 3.87 & 3.77 & 388 \\
\hline Electric Utilities & $\$ 2.15$ & $\$ 2.49$ & $\$ 2.24$ & ค 2.04 & 2.20 \\
\hline
\end{tabular}

\section{R $=$ Revised data.
NA $=$ Not available \\ NA $\quad$ Not available}

Na) Not applicable. Note: Deliveries to electric utilities (consumption) are reported on the Form ElA.759, "Monthly Power Plant Peport." Deliveries to electric utlities for the account of
others are reported on the Form ElA.176, "Annual Report of Natural and Supplemental Gas Supply and Disposition." See the discussion on electric utility data and Table A1 in Appendix A for a comparison of reporting to these two forms. Totals may not add due to independent rounding.

Sources Energy Intormation Administration (EIA). Form ElA-176, "Annual Report of Natural and Supplemental Gas Supply and Disposition," Form ElA.627, "Annual Ouantity and Value or Natural Gas Report," Form EIA-857. "Monthly Report of Natural Gas Purchases and Deliveries to Consumers, " Form ElA-816. "Monthly Natural Gas Liquids Report," Form ElA-759 "Monthly Power Plant Report," Form FERC-423, "Monthly Report of Cost and Quality of Fuels tor Electric Plants. "Form EIA-191, "Underground Gas Storage Peport,"

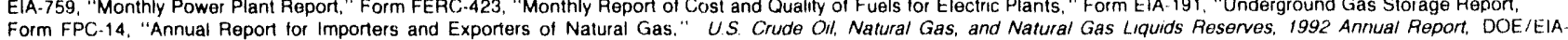
$0216(92)$; and the U.S. Minerals Management Service. 


\section{Natural Gas 1992}

Net Interstate Movements $\quad$ 128,868
Marketed Production
Million
Percent of
National Total
.00

\section{Deliveries to Consumers}

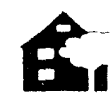

Residential:

22,392

.48

A.

Ast

Commercial:

16,644

i.

Industrial:

94,327

1.25

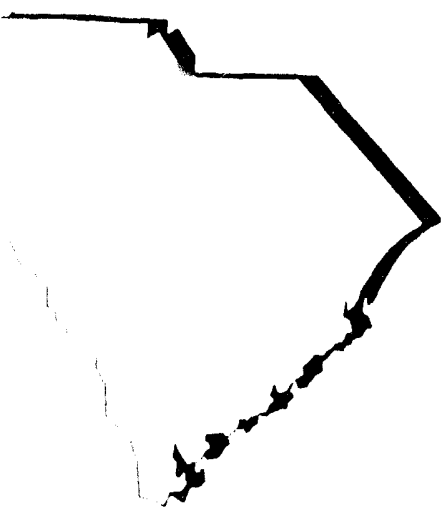

$\longrightarrow$ Vehicle Fuel:

0

.00

FI

Electric Utility:

1,795

.06

Total:

135,157

.76

\section{SOUTH CAROLINA}

Table 84. Summary Statistics for Natural Gas -- South Carolina, 1988-1992

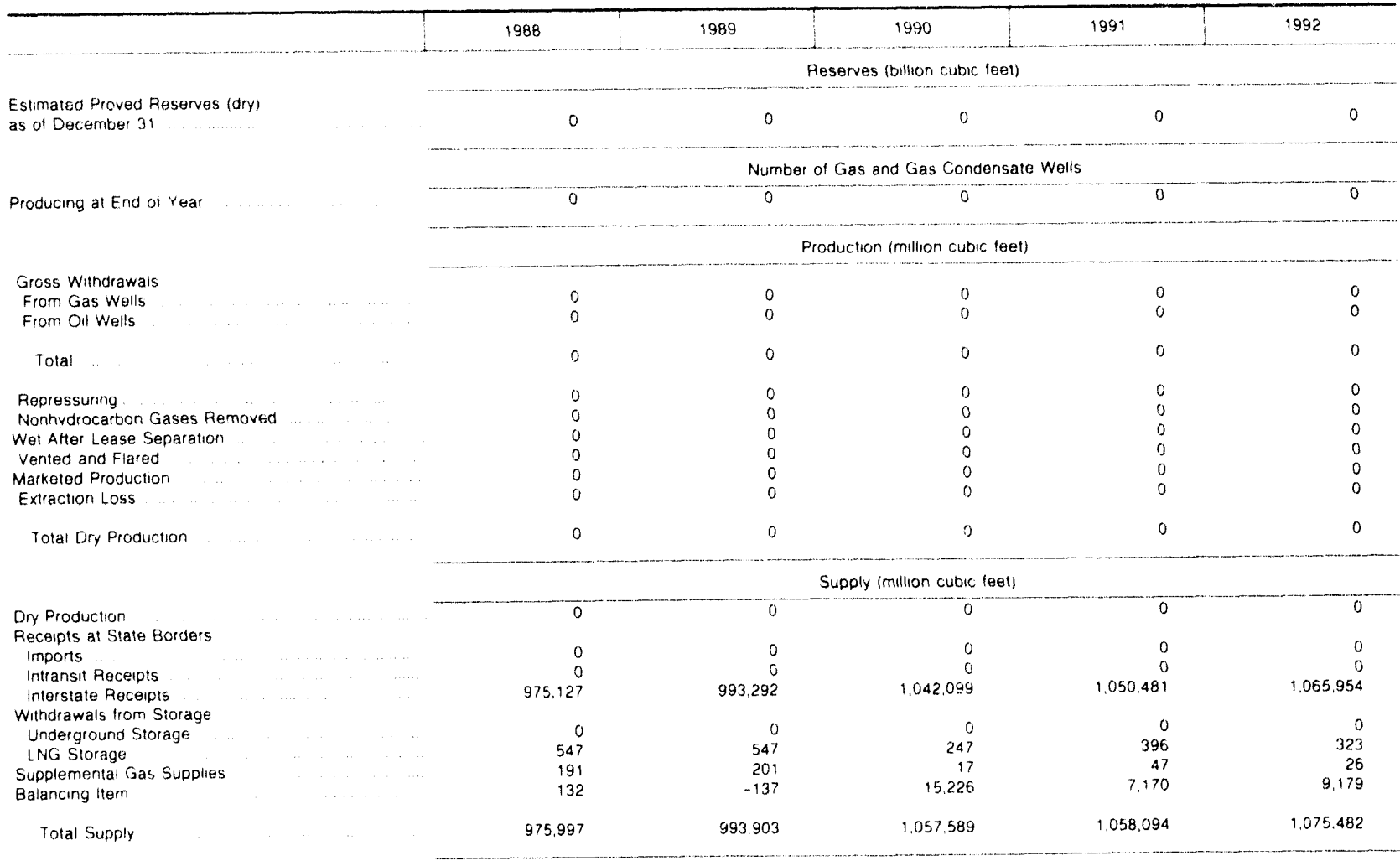

See lootnotes at end of table 
Table 84. Summary Statistics for Natural Gas -- South Carolina, 1988-1992 (Continued)

\begin{tabular}{|c|c|c|c|c|c|}
\hline & 1988 & 1989 & 1990 & 1991 & 1992 \\
\hline & \multicolumn{5}{|c|}{ Disposition (mution cubic teet) } \\
\hline Consumption & 112,309 & 116.818 & 130,453 & 133,828 & 138,057 \\
\hline \multicolumn{6}{|l|}{ Deliveries at State Borders } \\
\hline Exports & 0 & 0 & 0 & 0 & 0 \\
\hline Intransit Deliveries & 0 & 0 & 0 & 0 & () \\
\hline Interstate Deliveries & 863,186 & 876,596 & 926,742 & 923.920 & 937,086 \\
\hline \multicolumn{6}{|l|}{ Additions to Storage } \\
\hline Underground Storage & 0 & 0 & 0 & 0 & 0 \\
\hline LNG Storage & 503 & 490 & 394 & 346 & 339 \\
\hline \multirow[t]{2}{*}{ Total Disposition } & 975,998 & 993,904 & 1.057 .589 & $1.058,094$ & $1,075,482$ \\
\hline & \multicolumn{5}{|c|}{ Consumption (million rubic feet) } \\
\hline Lease and Plant Fuel. & 0 & 0 & 0 & 0 & 0 \\
\hline Pipelıne Fuel ................... & 2.493 & 2,581 & 2.858 & 2,808 & 2,900 \\
\hline \multicolumn{6}{|l|}{ Delivered to Consumers } \\
\hline Residential .................. & 20,790 & 20.472 & 18,396 & 19.612 & 22,392 \\
\hline 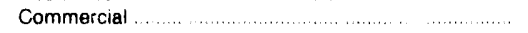 & 17,472 & 16.525 & 15,394 & 15,796 & 16,644 \\
\hline Industrial . . & 69,177 & 74,534 & 86,831 & 85,790 & 94,327 \\
\hline Vehicle Fuel & NA & NA & 0 & 0 & 0 \\
\hline Electric Utilities & 2,378 & 2.705 & 6,975 & 9,823 & 1,795 \\
\hline Total Delivered to Consumers & 109.817 & 114,237 & 127,595 & 131.020 & 135,157 \\
\hline \multirow[t]{2}{*}{ Total Consumption. } & 112,309 & 116,818 & 130.453 & 133,828 & 138,057 \\
\hline & \multicolumn{5}{|c|}{ Delivered for the Account of Others (million cubic feet) } \\
\hline Residential .......... & NA & NA & 0 & 0 & 0 \\
\hline 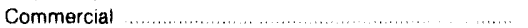 & 153 & 302 & 341 & 278 & 239 \\
\hline Indust'ial & 13,667 & 15,959 & 20,817 & 25,368 & 31,176 \\
\hline \multirow[t]{2}{*}{ Electric Utilities } & 0 & 0 & 0 & 0 & 0 \\
\hline & \multicolumn{5}{|c|}{ Number of Consumers } \\
\hline Residential & 313,831 & 327.527 & 339,486 & 344.763 & 357.818 \\
\hline ㄷ. & 37,075 & 38,856 & 39,904 & 39,999 & 40.968 \\
\hline Industrial & 1.273 & 1,307 & 1,384 & 1,400 & 1,568 \\
\hline \multirow[t]{2}{*}{ 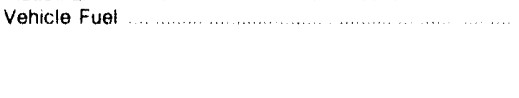 } & NA & NA & 0 & 0 & 0 \\
\hline & \multicolumn{5}{|c|}{ Average Annual Consumption per Consumer (thousand cubic feet) } \\
\hline 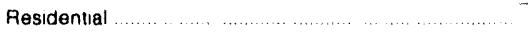 & 66 & 63 & 54 & 57 & 63 \\
\hline Commercial & 471 & 425 & 386 & 395 & 406 \\
\hline Industrial & 54,342 & 57.027 & 62,739 & 61.279 & 60.158 \\
\hline \multirow[t]{2}{*}{ 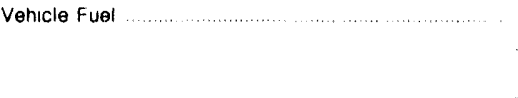 } & NA & NA & 0 & 0 & 0 \\
\hline & \multicolumn{5}{|c|}{ Average Annual Cost per Consumer (dollars) } \\
\hline Residential . & $\$ 446$ & $\$ 421$ & $\$ 388$ & $\$ 397$ & $\$ 440$ \\
\hline Commercial & 2,632 & 2,402 & 2,275 & 2.197 & 2.294 \\
\hline \multirow[t]{2}{*}{ Vehicle Fuel ........................ } & NA & NA & 0 & 0 & 0 \\
\hline & \multicolumn{5}{|c|}{ Average Heating Value (Btu per cubic loot) } \\
\hline \multirow[t]{2}{*}{ Delivered to Consumers } & 1,027 & 1,026 & 1,028 & 1,027 & 1.027 \\
\hline & \multicolumn{5}{|c|}{ Average Prices lor Natural Gas (dollars per thousand cubic feet) } \\
\hline Wellhead (Marketed Production) ............................. & $\cdots$ & $\ldots$ & $\cdots$ & $\cdots$ & \\
\hline Imports & $\ldots$ & $\ldots$ & $\ldots$ & $\ldots$ & \\
\hline Exports $\ldots \ldots \ldots$ & .. & $\ldots$ & $\ldots$ & & \\
\hline Pipeline Fuel & $\$ 2.40$ & $\$ 2.75$ & $\$ 2.06$ & $\$ 18 \%$ & $\$ 194$ \\
\hline City Gate & 3.46 & 346 & 314 & 2.95 & 3.23 \\
\hline \multicolumn{6}{|l|}{ Delivered to Consumers } \\
\hline 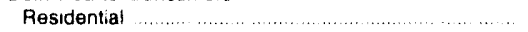 & 673 & 673 & 7.17 & 698 & 703 \\
\hline Commercial $\ldots \ldots \ldots$ & 5.59 & 5.65 & 5.90 & 556 & 565 \\
\hline Industrial & 343 & 3.45 & 3.35 & 2.95 & 313 \\
\hline 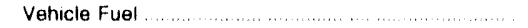 & NA & NA & $\ldots$ & $\ldots$ & \\
\hline Electric Utlities & 1.86 & $2.2 r$ & 176 & 153 & 173 \\
\hline
\end{tabular}

MA $=$ Not available.

-- Not applicable

Note: Deliveries to electric utilities (consumption) are reported on the Form ElA.759. "Monthly Power Plant Report" Deliveries to electric utlities for the accounl of others are reported on the Form ElA. : 76, "Annual Report of Natural and Supplemental Gas Supply and Disposition." See the discussion on electric utility data and Iable: Al in Ap pendix $A$ for a comparison of reporting to these two forms. Totals may thot add due to independent rounding

Sources. Energy information Administration (EIA). Form ElA.176. "Annual Report of Natural and Suppiemental Gas Supply and Disposition." Form EIA.627, "Annual Quantity and Value of Natural Gas Report." Form EIA-857. "Monthly Report of Natural Gas Purchases and Deliveries to Consumers." Form EIA-B16, "Monthly Natural Gas Liquirds Report." Form EIA.759. "Monthly Power Plant Report." Form FERC-423. "Monthly Report of Cost and Quality of Fuels for Electric Plants. " Form ElA-191, "Underground Gas Storage Report." Form FPC-14. "Annual Report for Importers and Exporters ol Natural Gas," U.S. Crude Oil. Natural Gas, and Natural Gas Liquids Reserves, 1992 Annual Report. DOE /F.IA. 0216(92); and the U.S. Minerals Management Service 
Natural Gas 1992

Net Interstate Movements

Mililion

Million

Cu. Foot

26,225

Marketed Production

Cu. Feet

1,456

Deliveries to Consumers

है?

Residential:

10,791

Percent of

Netional Total

.01

A.

issto

Commercial:

9,122

. III

Industrial:

4,488

.06

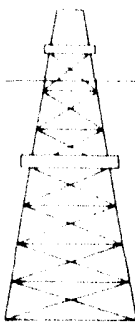

$\longrightarrow$ Vehicle Fuel:

6

$A$

Electric Utility:

48

.33

SOUTH

.98

.00

DAKOTA

Total:

24,454

.14

Table 85. Summary Statistics for Natural Gas -- South Dakota, 1988-1992

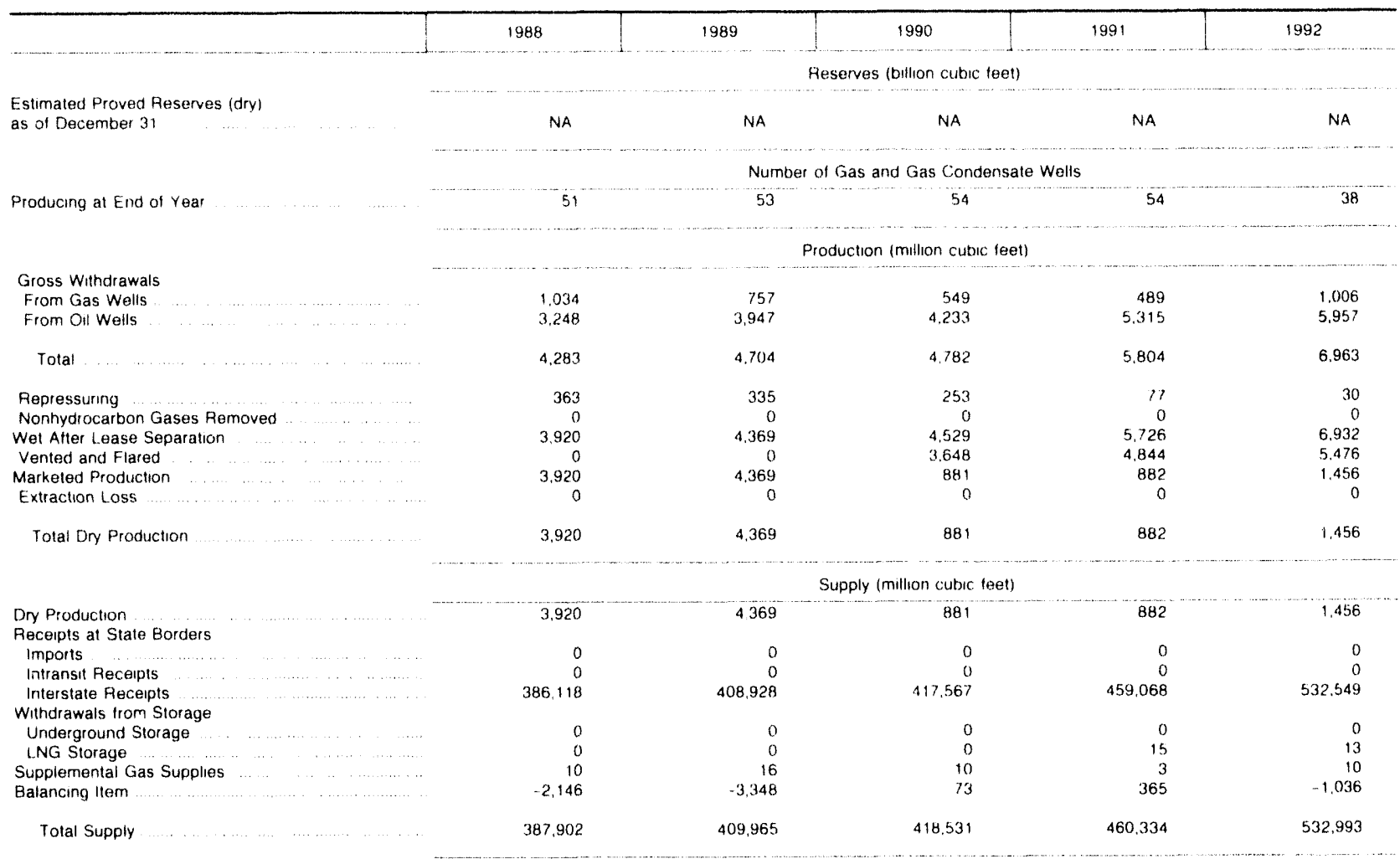

See foolnotes at end of table. 
Table 85. Summary Statistics for Natural Gas -- South Dakota, 1988-1992 (Continued)

\begin{tabular}{|c|c|c|c|c|c|}
\hline & 1988 & 1989 & 1990 & 1991 & 1992 \\
\hline & \multicolumn{5}{|c|}{ Osposition (million cubs feet) } \\
\hline Consumption & 24,227 & 25,504 & 25.056 & 26,260 & 26,645 \\
\hline \multicolumn{6}{|l|}{ Deliveries at State Borders } \\
\hline Exports $\ldots \ldots \ldots$ & 0 & 0 & 0 & 0 & 0 \\
\hline 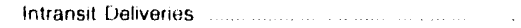 & 0 & 0 & 0 & 0 & 0 \\
\hline 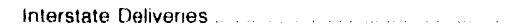 & 363,676 & 384,461 & 393,476 & 434.073 & 506,324 \\
\hline \multicolumn{6}{|l|}{ Additions to Storage } \\
\hline Underground Storage. & 0 & 0 & 0 & 0 & 0 \\
\hline LNG Storage $\ldots$ & 0 & 0 & 0 & 0 & 24 \\
\hline \multirow[t]{2}{*}{ Total Disposituon } & 387,903 & 409,965 & 418,531 & 460,334 & 532.993 \\
\hline & \multicolumn{5}{|c|}{ Consumption (million cubic teet) } \\
\hline Lease and Plant Fuel & 123 & 112 & 158 & 393 & 451 \\
\hline Pupeline Fuel ....... & 130 & 130 & 110 & 338 & 1,741 \\
\hline \multicolumn{6}{|l|}{ Delivered to Consumers } \\
\hline Residential ............ & 10,687 & 11,342 & 10,204 & 11.218 & 10,791 \\
\hline$\ldots \quad \ldots \ldots+\ldots \ldots \ldots \ldots \ldots$ & 8,396 & 8.826 & 8,555 & 9.473 & 9.122 \\
\hline Industrial & 4,668 & 4,962 & 5,793 & 4,658 & 4,488 \\
\hline Vehicle Fuel .... & NA & NA & 0 & 2 & 5 \\
\hline Electric Untities $\ldots \ldots . \quad \ldots \ldots$. & 223 & 132 & 235 & 177 & 48 \\
\hline Total Delivered to Consumers & 23.974 & 25.263 & 24,787 & 25.529 & 24.454 \\
\hline \multirow[t]{2}{*}{ Total Consumption } & 24,227 & 25,504 & 25,056 & 26,260 & 26,645 \\
\hline & \multicolumn{5}{|c|}{ Delivered for the Account of Others (million cubic feet) } \\
\hline Residential & NA & NA & 0 & 0 & 0 \\
\hline Commercial & 321 & 695 & 1.161 & 1,723 & 1.603 \\
\hline Industıal & 1.425 & 1,954 & 3,124 & 2,090 & 2.129 \\
\hline \multirow[t]{2}{*}{ Electric, Utilities } & 0 & 41 & 1.39 & 151 & 714 \\
\hline & \multicolumn{5}{|c|}{ Number of Consumers } \\
\hline Hesidentıal & 102,084 & 103,538 & 105,436 & 107,846 & 110,291 \\
\hline Commercal .. & 12,438 & 12,771 & 13.443 & 13,692 & 14.133 \\
\hline$\ldots \quad \ldots \ldots+\ldots . . \ldots$ & 267 & 270 & 275 & 283 & 319 \\
\hline \multirow[t]{2}{*}{ 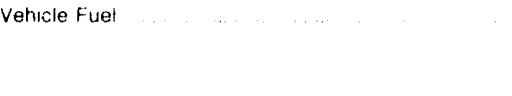 } & NA & NA & 0 & 1 & 2 \\
\hline & \multicolumn{5}{|c|}{ Average Annual Consumption per Consumer (thousand cubic feet) } \\
\hline Residential. & 105 & 110 & 97 & 104 & 98 \\
\hline Commercial & 675 & 691 & 636 & 692 & 645 \\
\hline$\ldots \ldots \ldots$ & 17,484 & $18.3 / 6$ & 21,067 & 16,459 & 14,068 \\
\hline \multirow[t]{2}{*}{ Vehicle Fuel } & NA & NA & 0 & 2.433 & 2.403 \\
\hline & \multicolumn{5}{|c|}{ Average Annuat Cost per Consumer (dollars) } \\
\hline$\ldots \ldots \ldots$ & $\$ 515$ & $\$ 531$ & $\$ 498$ & $\$ 514$ & $\$ 503$ \\
\hline Commercial $\ldots \ldots$ & 2.765 & 2.757 & 2.674 & 2.795 & $2,7 \cup 7$ \\
\hline \multirow[t]{2}{*}{ Vehicle Fuel } & NA & NA & 0 & 10,051 & 9,810 \\
\hline & \multicolumn{5}{|c|}{ Average Heating value (Blu per cubic toot) } \\
\hline \multirow[t]{2}{*}{ Delivered to Consumers } & 1.020 & 1,017 & 1.016 & 1,018 & 1,015 \\
\hline & \multicolumn{5}{|c|}{ Average Prices for Natural Gas (dollars per thousand cubic feet) } \\
\hline Wellhead (Marketed roduction) & $\$ 145$ & $\$ 111$ & $\$ 156$ & $\$ 112$ & $\$ 179$ \\
\hline 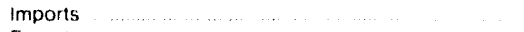 & & $\cdots$ & -. &.- & $\ldots$ \\
\hline Exports & $\cdots$ & ... & $\cdots$ & -. & .. \\
\hline 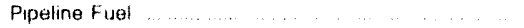 & 205 & 191 & 2.13 & 142 & 122 \\
\hline City Gate $\ldots \ldots \ldots \ldots \ldots$ & 318 & 304 & 3.12 & 311 & 310 \\
\hline \multicolumn{6}{|l|}{ Delivered to Consumers } \\
\hline Residential ..... & $4+1$ & 486 & 514 & 4.94 & 5.15 \\
\hline Commercial .......... & 410 & 399 & 4.20 & 4.04 & 419 \\
\hline$\ldots \ldots$ & 318 & 309 & 379 & 3.31 & 3.63 \\
\hline Vehicle Fuel & NA & NA & . & 413 & 408 \\
\hline Electric Utinties & 233 & 2.62 & 2.64 & ค 1.77 & 2.88 \\
\hline
\end{tabular}

\section{A Revised data}

Na Not available

Not available

Note Deliveries to electric ultities (consumption) are reported on the Form EtA.759. "Monthly Power Plant Report" Deiveries 10 electric utlities to the account of others are reported on the Form EIA 176. "Annual Heport of Natural and Supplemental Gas Supply and Disposition "See the discussion on electric utility data and Table A1 in Appendix $A$ for a comparison of repoiting to these two torms rotals may not add due to independent rounding

Sources Energy Intormation Admistration (E:IA). Form E.1A 176. "Annual Report of Natural and Supplemental Gas Supply and Disposition,."Form ElA-627, "Annual Quantity and Value of Naturat Gas Report," Form E:IA-857. "Monthly Report of Natural Gas Purchases and Deliveries to Consumers. "Form ElA-816. "Monthly Natural Gas L.iquids Report," Form ElA.759. "Morthly Power Plant Report, "Form FE AC 423. "Monthly Report of Cost and Quality of Fuels tor Electric Plants "Form ElA.191 "Underground Gas Storage Report."

Form FPC. 14. "Annual Report tor importers and Exporters of Natural Gas." US Crude OH. Natural Gas. and Natural Gas Ltouids Reserves, 1992 Annual Report. DOE/ElA. $0216(92)$, and the U.S Minerals Management Service 
Natural Gas 1992

Net Interstate Movements

Million

Marketed Production

Million
Cu Feet

1,770

Deliveries to Consumers

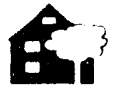

Residential:

52,220

Cu. Feet

168,860

A.

Ast

Commercial:

46,532

Percent of National Total .01

政

Industrial:

126,230

1.68

Vehicle Fuel:

2

.39

$A$

Electric Utility:

291

.01

Total:

225,276

1.27

Table 86. Summary Statistics for Natural Gas -- Tennessee, 1988-1992

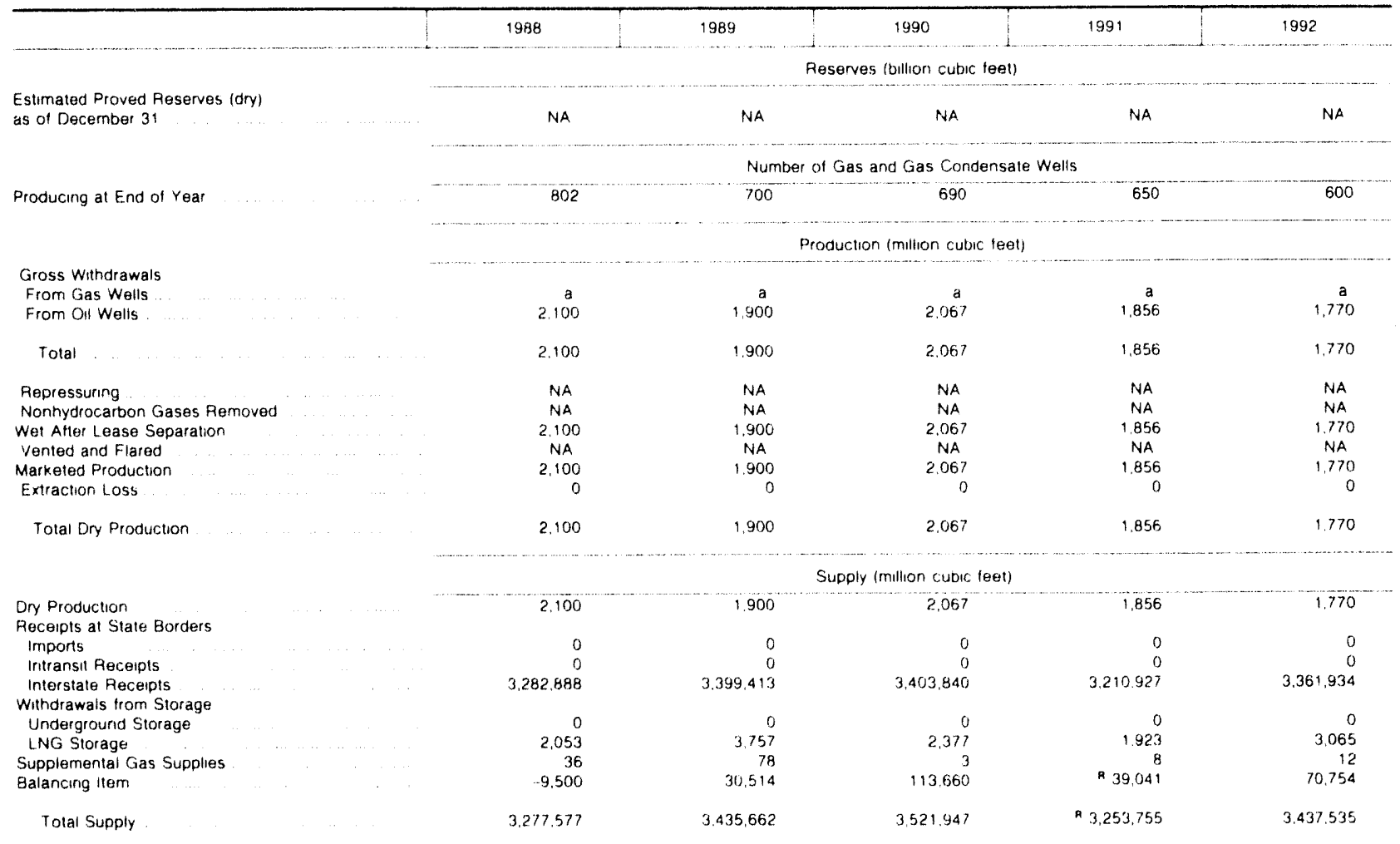

See footnotes at end of table. 
Table 86. Summary Statistics for Natural Gas -- Tennessee, 1988-1992 (Continued)

\begin{tabular}{|c|c|c|c|c|c|}
\hline & 1988 & 1989 & 1990 & 1991 & 1992 \\
\hline & \multicolumn{5}{|c|}{ Disposition (million cubic fert) } \\
\hline Consumption & 214,244 & 221,482 & 219,831 & ค 227108 & 241,702 \\
\hline \multicolumn{6}{|l|}{ Deliveries at State Borders } \\
\hline Exports & 0 & 0 & 0 & 0 & 0 \\
\hline Intransil Deliveries & 0 & 0 & 0 & 0 & 0 \\
\hline Interstate Deliveries & $3,061,224$ & $3,212,302$ & $3,299,107$ & $3,025,125$ & $3,193,074$ \\
\hline \multicolumn{6}{|l|}{ Additions to Storage } \\
\hline Underground Storage & 0 & 0 & 0 & 0 & 0 \\
\hline LNG Storage & 2.109 & 1.879 & 3.008 & 1.522 & 2.759 \\
\hline \multirow[t]{2}{*}{ Total Disposition } & $3,277,577$ & $3,435,662$ & $3.521,947$ & * $3,253,755$ & $3.437,535$ \\
\hline & \multicolumn{5}{|c|}{ Consumption (million cubiri leel) } \\
\hline Lease and Plant Fuel & 60 & 45 & 74 & 14 & 39 \\
\hline$\ldots+\ldots \ldots$ & 17.089 & 17.810 & 19,596 & 15,756 & 16.388 \\
\hline \multicolumn{6}{|l|}{ Deliverad to Consumers } \\
\hline Fiesidential & 47.668 & 49,196 & 46,340 & ค 49.357 & 52,220 \\
\hline Commercial & 45,852 & 47,513 & 43.552 & A 45,953 & 46,532 \\
\hline 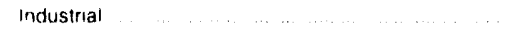 & 103,349 & 106.898 & 109.703 & 115.786 & 126,230 \\
\hline Vehicle fuel $\ldots \ldots$ & NA & NA & 2 & 1 & ? \\
\hline Electric Utilities & 225 & 18 & 565 & 211 & 291 \\
\hline Tolal Delivered to Consumers & 197.095 & 203,626 & 200,161 & A $2 \$ 1,309$ & 225,275 \\
\hline \multirow[t]{2}{*}{ Total Consumption } & 214.244 & 221,482 & 219.831 & ค 227.108 & 241,702 \\
\hline & \multicolumn{5}{|c|}{ Delivered tor the Account of Others (million cubrc leet) } \\
\hline Residential & NA & NA & 0 & 0 & i) \\
\hline Commercial & 1.191 & 864 & 1.092 & 1,961 & 1.680 \\
\hline Industrial. & 33.249 & 40.190 & 43,605 & 51,462 & 63.566 \\
\hline \multirow[t]{2}{*}{ Electric Utilities } & 0 & D & 563 & .43 & 219 \\
\hline & \multicolumn{5}{|c|}{ Number of Consumers } \\
\hline Resıdential & 565,856 & 599042 & 627.031 & 661.105 & 696.140 \\
\hline Commercial & 81.159 & 84,040 & 88.753 & 89.863 & 91.999 \\
\hline Industrial & 2.151 & 2.555 & 2.361 & 2,369 & 2.425 \\
\hline \multirow[t]{2}{*}{ Vehucle Fuel } & NAA & NA & 2 & & 2 \\
\hline & \multicolumn{5}{|c|}{ Average Annual Consumption per Consumer (thousand cubsc leet) } \\
\hline Residential & 84 & 82 & 74 & 75 & 75 \\
\hline Commercia! & 565 & 565 & 491 & 511 & 506 \\
\hline Industrial & 48,047 & 41,839 & 46,465 & 48.876 & 52,054 \\
\hline \multirow[t]{3}{*}{ Vehicle Fuel } & NA & NA & 928 & 741 & 951 \\
\hline & . & $\ldots . \quad \cdots$ & & $\ldots \ldots \ldots$ & \\
\hline & \multicolumn{5}{|c|}{ Average Annual Cost per Consurner (dollars) } \\
\hline Pesidential & $\$ 392$ & $\$ 397^{\circ}$ & $\$ 378$ & $\$ 388$ & $\$ 412$ \\
\hline Commercial & 2.474 & 2.538 & 2,351 & 2,432 & $256 \%$ \\
\hline \multirow[t]{2}{*}{ Vehicle Fuel } & NA & NA & 3.980 & 3048 & 4,139 \\
\hline & \multicolumn{5}{|c|}{ Average Heating Value (Btu per cubic toot) } \\
\hline \multirow[t]{2}{*}{ Delivered to Consumers } & 1,031 & 1,032 & 1.035 & 1.033 & 1.031 \\
\hline & \multicolumn{5}{|c|}{ Average Prices for Natural Gas (dollars per thousa id cubic leet) } \\
\hline Wellhead (Marketer Production) & $\$ 150$ & $\$ 165$ & $\$ \div 65$ & $\$ 172$ & $\$ 175$ \\
\hline imports & & .. & & $\ldots$ & \\
\hline 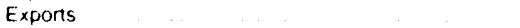 & & $\ldots$ & ... & . & \\
\hline Pipeline Fuel & 178 & 197 & 194 & 261 & 244 \\
\hline City Gate & 277 & 281 & 288 & 273 & 290 \\
\hline Delivered to Conisurners & & & & & \\
\hline Residential & 465 & 483 & 511 & 519 & 550 \\
\hline Commercial & 438 & 449 & 480 & 476 & 506 \\
\hline Industrial & 326 & 337 & 341 & 322 & 344 \\
\hline Venicle Fuel & NA & NA & 429 & 411 & 435 \\
\hline Electric Utilties & 246 & 283 & 282 & 252 & 249 \\
\hline
\end{tabular}

- Inctuded in gross withdrawals from oll wells Breakdown not provided by Slate agency

R Revised data

MA Not avallable

Not applicabie

Note. Deliveries 10 electric uthties (consumption) are reprorted on the form ElA.759, "Monthly Power Plant Repon." Deliveries to electric utilties for the account of

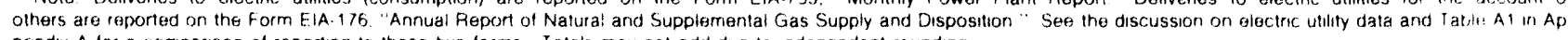
pendix A lor a companson of reporting to these two forms Totals may not add due to independent rounding

Sources Energy Intormation Adrninistration (EIA), Form EIA-176. "Annuat Report of Natural and Supplemental Gas Supply and Disposition." Form EIA.627. "Annual Ouantity and Value of Natural Gas Report." Form ElA-857. "Monthly Report of Natural Gas Furchases and Delivertes to Consumers. "Form EiA-816. "IWonthly Natural Gas tiquids Heport." Form ElA.759. Monthly Power Plant Report."Form FEAC.423. "Monthly Fieport of Cost and Oualty of Fuels for Electric Plants. "Form EIA.191. "Underground Gas Storage Report. Form FPC.14. Annual Report tor Importers and Exporters of Natural Gas," US Crude Oll. Natural Gas, and Natural Gas Llquids Resenves, 1992 Annual Report. DOE/ElA $0216(92)$ and the US Minerals Management Service 
Natural Gas 1992

Net Interstate Movements $\begin{gathered}\text { Milllon } \\ \text { Cu. Fo日t } \\ -2,274,705\end{gathered}$

Marketed Production

Million Percent of

Cu. Feel National Tolal

$6,145,862 \quad 32.84$

Deliveries to Consumers

ấ.

Residential:

214,682

4.58

Af:

AS

Commercial:

184,673

6.59

M

Industrial:

$1,734,001$

23.04

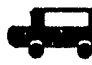

Vehicle Fuel:

4

.78

A

Electric Utility:

968,165

35.01

Total:

$3,101,526$

17.44

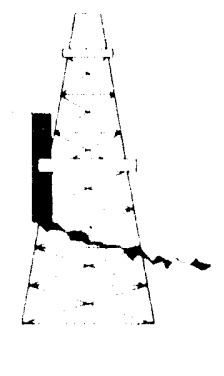

Table 87. Summary Statistics for Natural Gas -- Texas, 1988-1992

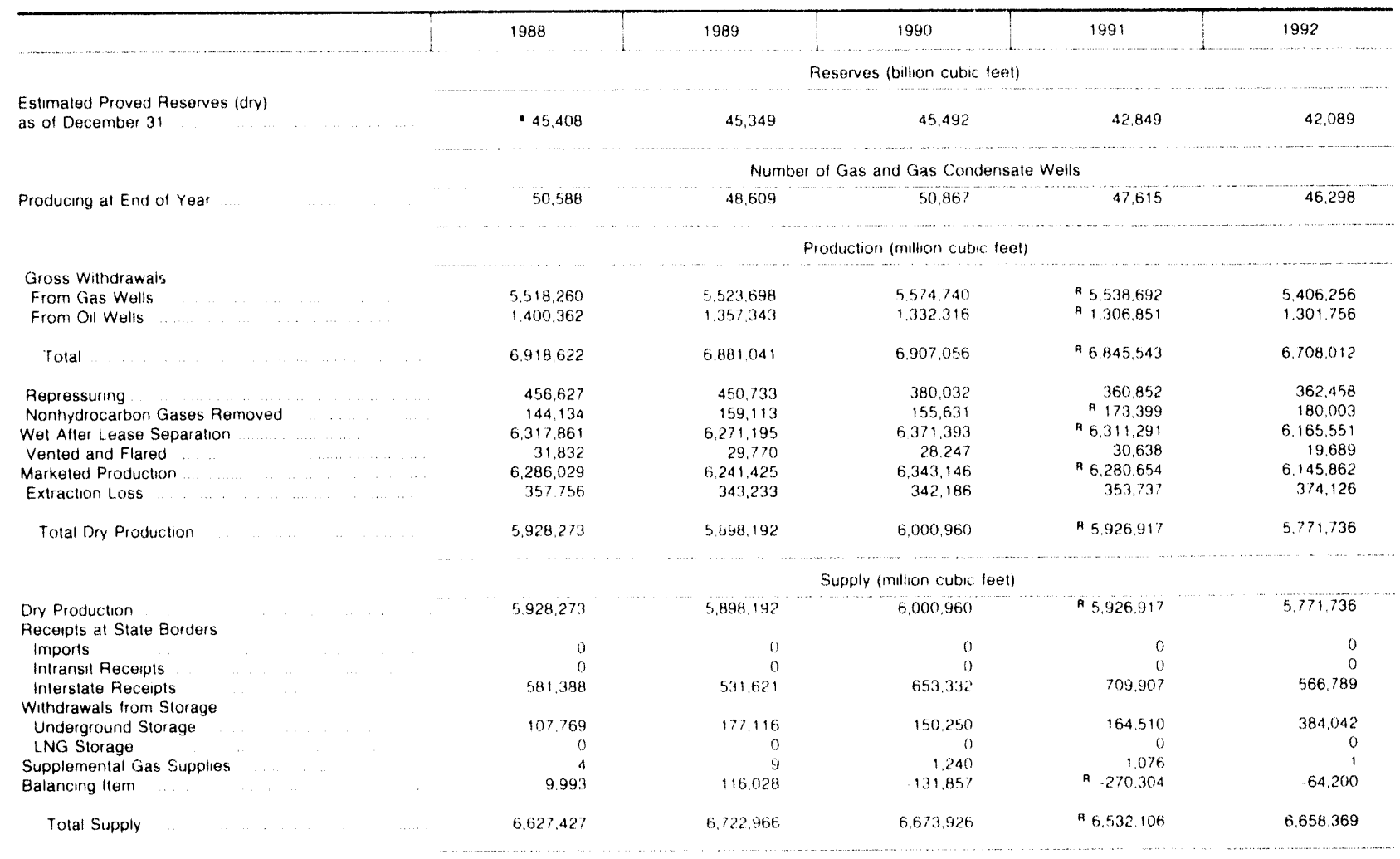


Table 87. Summary Statistics for Natural Gas -- Texas, 1988-1992 (Continued)

\begin{tabular}{|c|c|c|c|c|c|}
\hline & 1988 & 1989 & 1990 & 1991 & 1992 \\
\hline & \multicolumn{5}{|c|}{ Disposition (million cubic: leet) } \\
\hline Consumption & $3.531,008$ & $3.623,618$ & 3.601 .828 & ค $3,560,113$ & $3.476,274$ \\
\hline \multicolumn{6}{|l|}{ Deliveries at State Borders } \\
\hline Exports $\ldots \ldots \ldots \ldots \ldots$ & 422. & 15.535 & 13,983 & 58.851 & 93,408 \\
\hline … & 0 & 0 & 0 & 0 & 0 \\
\hline Interstate Deliveries. & $2,949,238$ & $2,922,632$ & $2,883,075$ & $2,742,234$ & $2,749.086$ \\
\hline \multicolumn{6}{|l|}{ Additions to Storage } \\
\hline Underground Storage & 146.758 & 161,181 & 175.039 & 170,908 & 340,602 \\
\hline L.NG Storage & 0 & 0 & 0 & 0 & is \\
\hline \multirow[t]{2}{*}{ Total Disposition } & $6,627.426$ & 6.722 .966 & $6,673,926$ & ค $6,532,106$ & $6,658,369$ \\
\hline & \multicolumn{5}{|c|}{ Consumption (million cubic feet) } \\
\hline Lease and Plant Fuel ... & 318,922 & 291,977 & 394,605 & ค 297,233 & 293,845 \\
\hline Pipeline Fuel ........... & 107,527 & 107,190 & 106,046 & 81,963 & 80,903 \\
\hline \multicolumn{6}{|l|}{ Delivered to Consumers } \\
\hline Residential .................... & 209,957 & 230.099 & 210.655 & 222,200 & 214,682 \\
\hline Commercial $\ldots \ldots \ldots \ldots$ & 175,368 & 182,670 & 172,333 & ค 180,973 & 164,673 \\
\hline Industrial $\ldots \ldots \ldots \ldots \ldots \ldots$ & 1.675 .324 & $1,787,888$ & 1,710798 & 1.772 .691 & $1,734,001$ \\
\hline Vehicle Fuel $\ldots \ldots \ldots$ & NA & NA & 10 & 2 & 4 \\
\hline 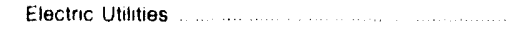 & $1.043,910$ & $1,023,793$ & $1,007,381$ & $1,005,05 !$ & 968.165 \\
\hline Total Delivered to Consumers .......... & $3,104,559$ & $3,224,451$ & $3.101,177$ & A 3.180 .917 & $3,101,526$ \\
\hline \multirow[t]{2}{*}{ Total Consumption . } & $3,531,008$ & $3,623,618$ & $3,601,828$ & $3,560.113$ & 3.476 .274 \\
\hline & \multicolumn{5}{|c|}{ Uelivered for the Account of Others (millton cubic feet) } \\
\hline$\ldots \ldots \ldots \ldots \ldots$ & NA & NA & 1.951 & 43 & 43 \\
\hline Commerciał $\ldots \ldots \ldots \ldots \ldots \ldots \ldots$ & 21,863 & 16,935 & 17,645 & A 19.287 & 37,443 \\
\hline Industrial $\ldots \ldots \ldots$ & $1,176.854$ & $1,298,541$ & $1,231,679$ & $1.227,979$ & $1,190,677$ \\
\hline \multirow[t]{2}{*}{ Electric Utilities } & 551,078 & 493.095 & 515,120 & 534,110 & 449.615 \\
\hline & \multicolumn{5}{|c|}{ Number of Consumers } \\
\hline Resıdential & $3.166,168$ & $3,201,316$ & $3,232,849$ & $3,274,482$ & $3,285,025$ \\
\hline Commercial & 284,013 & 270.227 & 268.181 & 269.411 & 292.990 \\
\hline Industrial & 4.427 & 13,383 & 13,659 & 13.770 & 5,481 \\
\hline \multirow[t]{2}{*}{ Vehicle Fuel } & NA & NA & 3 & 5 & 2 \\
\hline & \multicolumn{5}{|c|}{ Average Annual Consumption per Consumer (thousand cutic feel) } \\
\hline Residentia\} & 66 & 72 & 65 & 68 & 65 \\
\hline Commercial & 617 & 676 & 643 & A 672 & 630 \\
\hline$\ldots \ldots$ & 378,433 & 133,594 & 125,251 & 128.736 & 316,366 \\
\hline \multirow[t]{2}{*}{ Vehicie Fuel } & NA & NA & 3,286 & 394 & 2,190 \\
\hline & \multicolumn{5}{|c|}{ Average Annual Cos! per Consumer (dollars) } \\
\hline Residential & $\$ 356$ & $\$ 399$ & $\$ 376$ & $\$ 388$ & $\$ 377$ \\
\hline Commercial & 2,590 & 2,779 & $2.66^{1}$ & 2,695 & 2,578 \\
\hline \multirow[t]{2}{*}{ Vehicle Fuel } & NA & NA & 10,155 & 2,160 & 9,927 \\
\hline & \multicolumn{5}{|c|}{ Average Heating Value (Btu per cubic foot) } \\
\hline \multirow[t]{2}{*}{ Delivered to Consumers } & 1.038 & 1,038 & 1.040 & 1.037 & 1.043 \\
\hline & \multicolumn{5}{|c|}{ Average Prices for Natural Cas (dollars per thousand cubic teet) } \\
\hline Welliead (Marketed Production) & $\$ 151$ & $\$ 153$ & $\$ 157$ & $\$ 150$ & $\$ 177$ \\
\hline imports $\ldots . .$. & & $\ldots$ & $\ldots$ & -. & . \\
\hline Exports $\ldots \ldots \ldots$ & 262 & 204 & 182 & 175 & $19 \%$ \\
\hline Pipeline Fuel & 198 & 189 & 174 & 162 & 166 \\
\hline City Gate & 305 & 333 & 314 & 288 & 306 \\
\hline \multicolumn{6}{|l|}{ Delivered to Consumers } \\
\hline Residential & 537 & 555 & 578 & 571 & 5.78 \\
\hline$\ldots \ldots$ & 419 & 411 & 414 & 401 & 400 \\
\hline$\ldots+\ldots+\ldots+\ldots$ & 219 & 2.24 & 218 & 193 & 212 \\
\hline 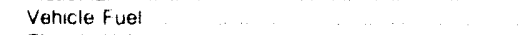 & NA & NA & 3.09 & 5,49 & 453 \\
\hline$\ldots \ldots \ldots$ & 216 & 223 & 217 & 203 & 225 \\
\hline
\end{tabular}

- Includes Ottshore Federal Domatn

A Revised data

wa. Not avallable

-- Not applicable

Note Deliveries 10 electric utilties (consumption) are reported on the Form Ela 759 . "Monthly Power Plant Report "Deliveries to electric utlities lor the account of others are reported on the Form EIA.176. "Annual Report of Natural and Supplementat Gas Supply and Disposition." See the discussion on electnc utlity data and Tatile Al in Ap. pendix $A$ for a comparison of reporting to these two forms Totals may not add due to independent rounding

Sources Energy Information Administration (EIA). Form EIA-176, "Annual Report of Natural and Supplemental Gas Supply and Disposition, "Form EIA.627, "Annual Quantity and value of Natural Gas Report," Form EIA-B57. "Monthly Report of Natural Gas Purchases and Deliveries to Consumers "Form EIA-816 "Monthly Natural Gas Liquids Report." Form EIA.759. "Monthly Power Plant Report," Form FERC-423. "Monthly Report of Cost and Ouality of Fuels for Electric Plants, "Form EIA-191, "Underground Gas Storage Feport." Form r HL.14. "Annual Report for Importers and Exporters of Natural Gas." US Crude Oll. Natural Gas, and Natural Gas liquids Reserves. 1992 Annual Report. DOE /EIA. 0216(92): and the US Minerals Management Service 
Natural Gas 1992

Net Interstate Movements

Million

$\mathrm{Cu}$ Foel

60,343

Marketed Production

Million

Percent of

Met National Total

$171.293 \quad .92$

\section{Deliveries to Consumers}

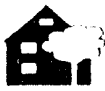

Residential:

44,701

.95

Ait.

nots

Commercial:

16,584

r. M

Industrial:

40,878

.54

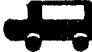

Vehicle Fuel:

15

2.94

A'

Electric Utility:

6,576

.24

Total:

108,755

.61

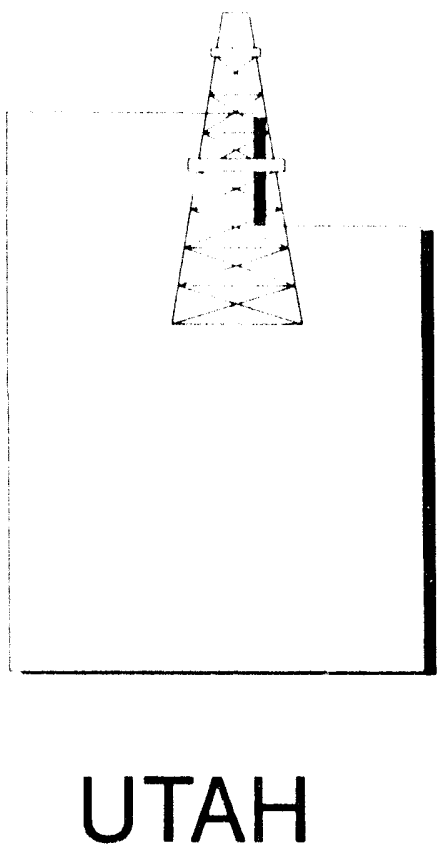

Table 88. Summary Statistics for Natural Gas -- Utah, 1988-1992

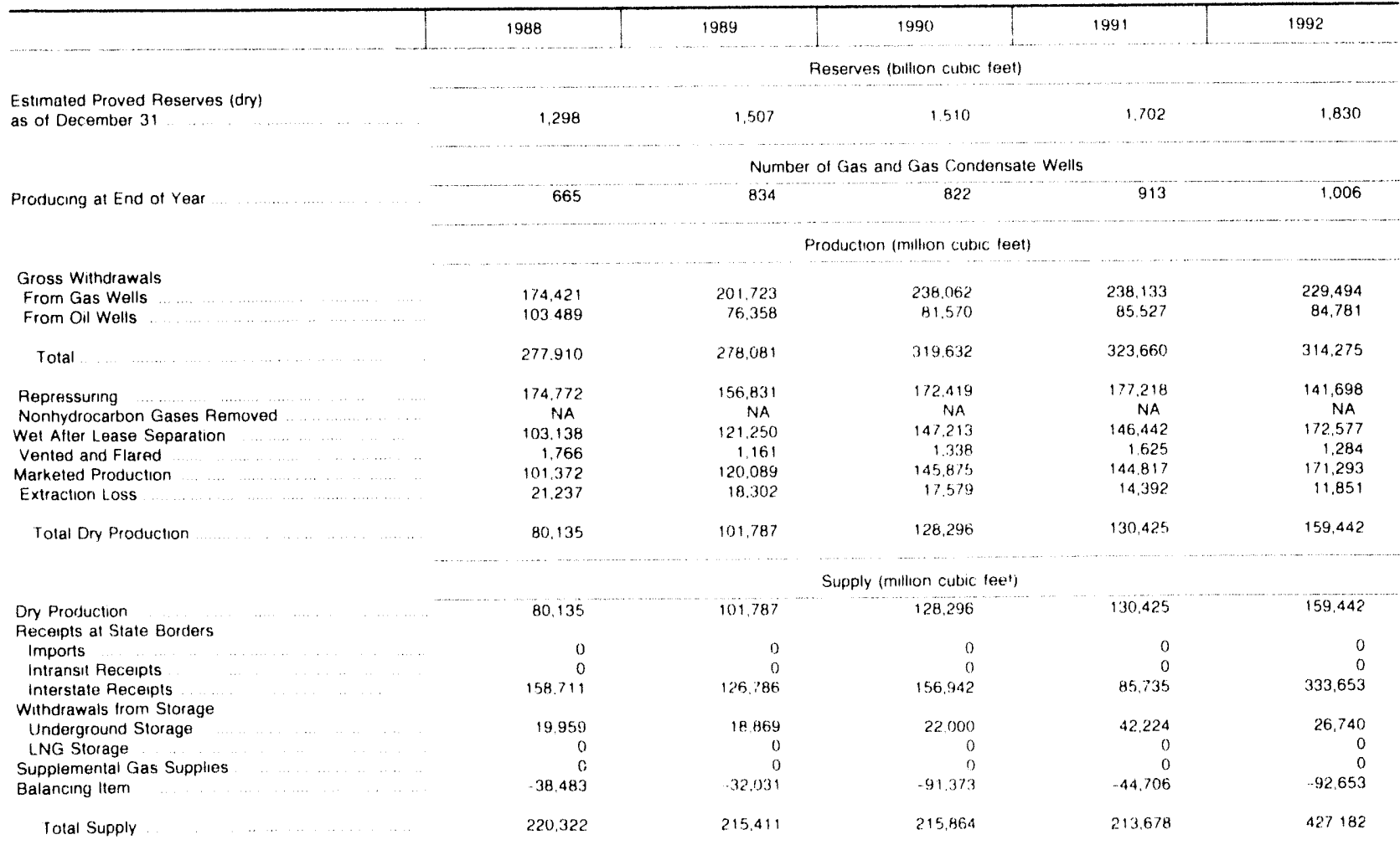

See rootnoles at end of table 
Table 88. Summary Statistics for Natural Gas -- Utah, 1988-1992 (Continued)

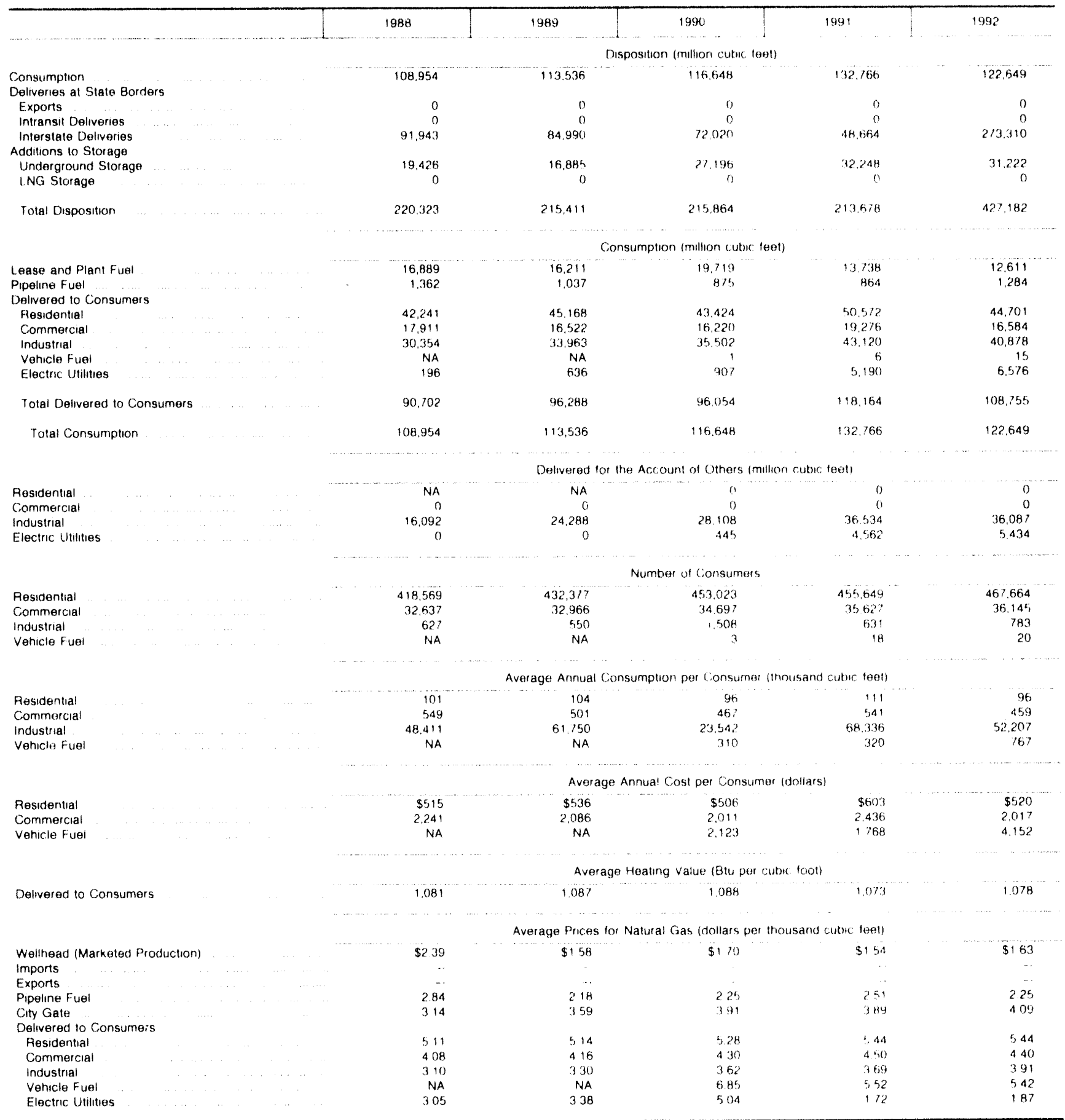

MA Not avallable

Note Deliveries to electric utilities (consumption) are reported on the Form ElA.759. "Monthly Power Plant Fepon' Deliveries to electric utitites tor the account of others are reported on the Form ElA.176. "Annual Report of Natural and Supplemental Gas Supply and Disposition "See the discussion on electric utilty data arid Iatje Al in Ap. pendix A for a comparison of teporting to these two forms Totals may not add due to independent rounding

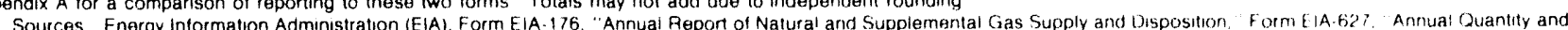

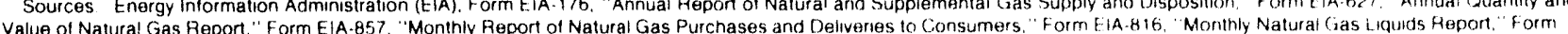

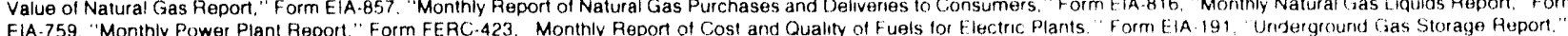

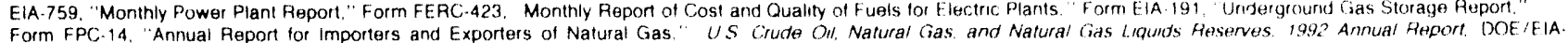
$0216(92)$, and the U S Minerals Managemenit Service 
Natural Gas 1992

Net Interstate Movements

Million

Cu. Feet

7,695

Marketed Production

Million Percent of

Cu. Feot National Total

$0 \quad .00$

Deliveries to Consumers

ar

Residential:

2,520

.05

Ai.

ints

Commercial:

2,319

.08

$=\sqrt{m}$

Industrial:

1.958

.03

Venicle Fuel:

0

.00

$A$

Electric Utility:

801

.03

Total:

$? .598$

.04

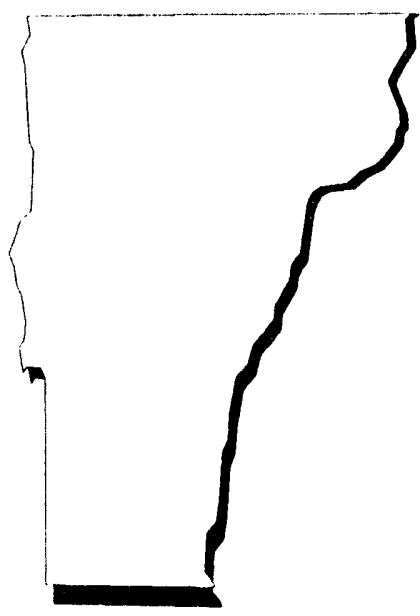

VERMONT

Table 89. Summary Statistics for Natural Gas -- Vermont, 1988-1992

\begin{tabular}{|c|c|c|c|c|c|}
\hline & 1988 & 1989 & 1990 & 1991 & 1992 \\
\hline & \multicolumn{5}{|c|}{ Reserves (billion cubic feet) } \\
\hline \multirow[t]{2}{*}{$\begin{array}{l}\text { Estimated Proved Reserves (dry) } \\
\text { as of December } 31\end{array}$} & 0 & 0 & 0 & 0 & 0 \\
\hline & \multicolumn{5}{|c|}{ Number of Gas and Gas Condensate Wells } \\
\hline \multirow[t]{2}{*}{ Producing at End of Year } & 0 & 0 & 0 & 0 & 0 \\
\hline & \multicolumn{5}{|c|}{ Production (million cubic feet) } \\
\hline $\begin{array}{l}\text { Gross Withdrawais } \\
\text { From Gas Wells } \\
\text { From Oil Wells }\end{array}$ & $\begin{array}{l}0 \\
0\end{array}$ & $\begin{array}{l}0 \\
0\end{array}$ & $\begin{array}{l}0 \\
0\end{array}$ & $\begin{array}{l}0 \\
0\end{array}$ & $\begin{array}{l}0 \\
0\end{array}$ \\
\hline Total & 0 & 0 & 0 & 0 & 0 \\
\hline Repressuring & 0 & 0 & 0 & 0 & 0 \\
\hline Nonhydrocarbon Gases Removed $\ldots . . . .$. & 0 & 0 & 0 & 0 & 0 \\
\hline Wet After Lease Separation & 0 & 0 & 0 & 0 & 0 \\
\hline Vented and Flared $\ldots \ldots \ldots \ldots \ldots$ & 0 & 0 & 0 & 0 & 0 \\
\hline Marketed Production & 0 & 0 & 0 & 0 & 0 \\
\hline Extraction Loss $\ldots \ldots \ldots \ldots$ & 0 & 0 & 0 & 0 & 0 \\
\hline \multirow[t]{2}{*}{ Total Dry Production } & 0 & 0 & 0 & 0 & 0 \\
\hline & \multicolumn{5}{|c|}{ Supply (million cubic lee!) } \\
\hline 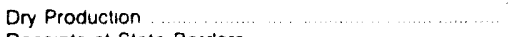 & 0 & 0 & 0 & 0 & 0 \\
\hline Receipts at State Borders & & & & & \\
\hline 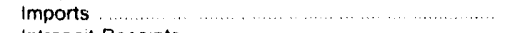 & 8.105 & 13,152 & 14.512 & 15.796 & 17,248 \\
\hline 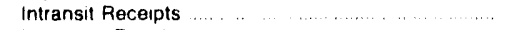 & 0 & 0 & 0 & 0 & 0 \\
\hline Interstate Receipts & 0 & 0 & 0 & 0 & 0 \\
\hline \multicolumn{6}{|l|}{ Withdrawals from Storage } \\
\hline Underground Storage ..... & 0 & 0 & 0 & 0 & 0 \\
\hline LNG Storage $\ldots \ldots \ldots \ldots$ & , & 0 & 0 & 0 & 0 \\
\hline Supplementai Gas Supplies & 0 & 0 & 0 & 0 & 3 \\
\hline 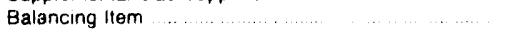 & -314 & -129 & 141 & -78 & 3 \\
\hline Total Supply. & 7,791 & 13,023 & 14.654 & 15,223 & 17,254 \\
\hline
\end{tabular}

See footnotes at end of table 
Table 89. Summary Statistics for Natural Gas -- Vermont, 1988-1992 (Continued)

\begin{tabular}{|c|c|c|c|c|c|}
\hline & 1988 & 1989 & 1990 & 1991 & 1992 \\
\hline & \multicolumn{5}{|c|}{ Disposition (million cubic feet) } \\
\hline Consumption . & 5,551 & 6.151 & 6.766 & 7,073 & 7,601 \\
\hline \multicolumn{6}{|l|}{ Deliveries at State Borders } \\
\hline Exports & 0 & 0 & 0 & 0 & 0 \\
\hline 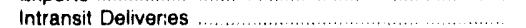 & 0 & 0 & 0 & 0 & 0 \\
\hline Interstate Deliveries & 2.240 & 6,872 & 7,887 & 8,651 & 9.653 \\
\hline \multicolumn{6}{|l|}{ Additions to Storage } \\
\hline Underground Storage & 0 & 0 & 0 & 0 & 0 \\
\hline LNG Storage & 0 & 0 & 0 & 0 & 0 \\
\hline \multirow[t]{2}{*}{ Total Disposition . } & 7,791 & 13,023 & 14,654 & 15,723 & 17,254 \\
\hline & \multicolumn{5}{|c|}{ Consumption (million cubic feet) } \\
\hline Lease and Plant Fuel. & 0 & 0 & 0 & 0 & 0 \\
\hline Pipeline Fuel ................ & 0 & 5 & 5 & 3 & 3 \\
\hline \multicolumn{6}{|l|}{ Delivered to Consumers } \\
\hline Residential & 1,868 & 2.126 & 2,150 & 2.203 & 2.520 \\
\hline 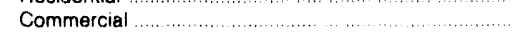 & 1,941 & 2,081 & 2,049 & 2,058 & 2,319 \\
\hline Industrial & 1,741 & 1,901 & 1,878 & 1,717 & 1,958 \\
\hline Vehicle Fuet & NA & NA & 0 & 0 & 0 \\
\hline Electric Utilities & 0 & 37 & 685 & 1,091 & 801 \\
\hline Total Delivered to Consumers & 5,551 & 6.145 & 6,761 & 7.069 & 7.598 \\
\hline \multirow[t]{2}{*}{ Total Consumption. } & 5,551 & 6,151 & 6.766 & 7.073 & 7,601 \\
\hline & \multicolumn{5}{|c|}{ Delivered for the Account of Others (miltion cubic teet) } \\
\hline Residential. & NA & NA & 0 & 0 & 0 \\
\hline Commercial & 0 & 0 & 0 & 0 & 0 \\
\hline 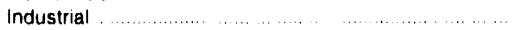 & 0 & 0 & 0 & 0 & 0 \\
\hline \multirow[t]{2}{*}{ 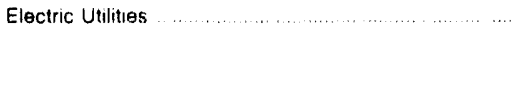 } & 0 & 0 & 0 & 0 & 0 \\
\hline & \multicolumn{5}{|c|}{ Number at Consumers } \\
\hline Residential. & 16,616 & 16,920 & 18.300 & 19.879 & 20,468 \\
\hline Commercial & 2.698 & 2,768 & 2.949 & 3,154 & 3,198 \\
\hline Industrial & 21 & 14 & 15 & 13 & 18 \\
\hline \multirow[t]{2}{*}{ Vehicle Fuel } & NA & NA & 0 & 0 & 0 \\
\hline & \multicolumn{5}{|c|}{ Average Annual Consumption per Consumer (thousand cubic teet) } \\
\hline Residential. & 112 & 126 & 117 & 111 & 123 \\
\hline 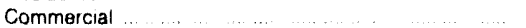 & 720 & 752 & 695 & 652 & 725 \\
\hline Industrial & 82,920 & 135.779 & 125.194 & 132,070 & 108,751 \\
\hline \multirow[t]{2}{*}{ 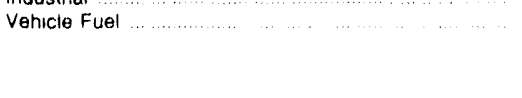 } & NA & NA & 0 & 0 & 0 \\
\hline & \multicolumn{5}{|c|}{ Average Annual Cost per Consumer (dollars) } \\
\hline$\ldots \ldots \ldots+\ldots, \ldots \ldots \ldots, \ldots$ & $\$ 636$ & $\$ 707$ & $\$ 680$ & $\$ 691$ & $\$ 825$ \\
\hline Cornmercial $\ldots \ldots \ldots \ldots$ & 3,358 & 3.564 & 3,509 & 3.421 & 4,110 \\
\hline \multirow[t]{2}{*}{ 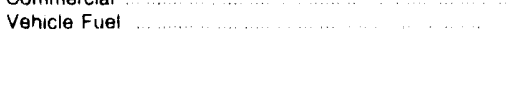 } & NA & NA & () & 0 & 0 \\
\hline & \multicolumn{5}{|c|}{ Average Heating Value (Btu per cubic foot) } \\
\hline \multirow[t]{2}{*}{ Delivered to Consumers . . . . . . . . } & $990^{\circ}$ & 986 & 987 & 988 & 995 \\
\hline & \multicolumn{5}{|c|}{ Average Prices for Natural Gas (dollars per thousand cubic teet) } \\
\hline Wellhead (Marketed Production) & $\cdots$ & $\cdots$ & $\cdots$ & $\cdots$ & $\cdots$ \\
\hline Imports & $\$ 243$ & $\$ 270$ & $\$ 304$ & $\$ 2.80$ & $\$ 2.86$ \\
\hline Exports & & $\ldots$ & .. & $\ldots$ & .. \\
\hline Pipeline Fuel $\ldots$ & $\cdots$ & 264 & 2.85 & 286 & 2.96 \\
\hline City Gale & 259 & 259 & 288 & 287 & 293 \\
\hline \multicolumn{6}{|l|}{ Delivered to Consumers } \\
\hline Residential & 5.65 & 5.62 & 579 & 6.23 & 670 \\
\hline Commercial $\ldots$ & 4.67 & 474 & 505 & 5.24 & 5.67 \\
\hline Industrial & 297 & 3.01 & 3.51 & 2.99 & 328 \\
\hline Vehicle Fuel & NA & NA & -.. & ... & - \\
\hline Electric Utilites & $\therefore$ & 2.64 & 242 & ค 172 & 200 \\
\hline
\end{tabular}

navised data

wA $\because$ Not avallable.

- Not applicabie.

Note: Deliveries to electric utlities (consumption) are reported on the Form ElA.759. "Monthly Power Plant Report." Detiveries to electric utilities tor the account of others are reported on the Form E.A.176. "Annual Report of Natural and Supplemental Gas Supply and Disposition." See the discussion on electric utlity data and Table A1 in Ap. pendix $A$ for a comparison of reporting to these two forms. Totals may not add due to independent rounding

Sources. Energy Intormation Administration (EIA). Form EIA-176. "Annual Report of Natural and Supplemental Gas Supply and Disposition." Form ElA .627, "Annual Ouantity and Value of Natural Gas Report." Form EiA. B57. "Monthly Heport of Natural Gas Purchases and Deitiveries to Consumers, "Form EiA.816. "Monthly Natural Gas Liquids Report." Form ElA.759, "Monthly Power Plant Report," Form FERC.423, "Monthly Report of Cost and Ouality of Fuels for Electric Plants," Form ElA.191, "Uniderground Gas Storage Report." Form FPC.14. "Annual Report for Importers and Exporters of Natural Gas." U.S Crude Otl. Natural Gas, and Natural Gas LIquids Reserves. 1992 Annual Report, DOE/ElA0216(92): and the U.S. Minerals Management Service 
Natural Gas 1992

Net Interstate Movements

Million

Cu. Foot

189,401

Marketed Production

Million Percent of

Cu. Feat National Total

$24,733 \quad .13$

Deliveries to Consumers

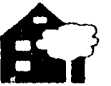

Residential:

62,431

1.33

A.

ast

Commercial:

50.757

Gim

Industrial:

68,808

$\rightarrow$ Venicle Fuel:

0

.00

A

Electric Utility:

10,936

.40

Total:

192,932

1.08

Table 90. Summary Statistics for Natural Gas -- Virginia, 1988-1992

\begin{tabular}{|c|c|c|c|c|c|}
\hline & 1988 & 1989 & 1990 & 1991 & 1992 \\
\hline & \multicolumn{5}{|c|}{ Reserves (billion cubic feet) } \\
\hline \multirow[t]{2}{*}{$\begin{array}{l}\text { Estimated Proved Reserves (dry) } \\
\text { as of December } 31\end{array}$} & 230 & 217 & 138 & 225 & 904 \\
\hline & \multicolumn{5}{|c|}{ Number of Gas and Gas Condensate Wells } \\
\hline \multirow[t]{2}{*}{ Producing at End of Year } & 728 & 752 & 819 & 886 & 1.153 \\
\hline & \multicolumn{5}{|c|}{ Production (million cubic lest) } \\
\hline Gross Withdrawals & & & & & \\
\hline From Gas Wells ................. & 18,682 & 17,935 & 14,774 & 14,906 & 24,733 \\
\hline 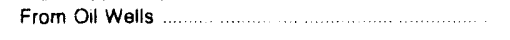 & 0 & 0 & 0 & 0 & 0 \\
\hline Total ................ & 18.682 & 17.935 & 14,774 & 14,906 & 24,733 \\
\hline Pepressuring ..... & 0 & 0 & 0 & 0 & 0 \\
\hline Nonhydrocarbon Gases Removed & 0 & 0 & 0 & 0 & 0 \\
\hline Wet After Lease Separation .......... & 18,682 & 17,935 & 14,774 & 14,906 & 24.733 \\
\hline Vented and Flared & 258 & 0 & 0 & 0 & 0 \\
\hline \multirow[t]{2}{*}{ Total Dry Production } & 18,424 & 17.935 & 14.774 & 14,906 & 24,733 \\
\hline & \multicolumn{5}{|c|}{ Supply (million cutic feel) } \\
\hline 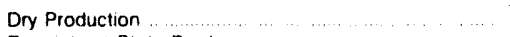 & 18,424 & 17.935 & 14,774 & 14,906 & 24,733 \\
\hline Receipts at State Borders & & & & & \\
\hline Imports & 0 & 0 & 0 & 0 & 0 \\
\hline Intransit Receipts & 0 & 0 & 0 & J & 0 \\
\hline Interstale Receipts & 994,838 & $1,029,161$ & $1,059,259$ & $1,071,858$ & $1,119,418$ \\
\hline \multicolumn{6}{|l|}{ Withdrawals from Storage } \\
\hline Underground Storage & 0 & 0 & 0 & 0 & 0 \\
\hline LNG Storage & 260 & 2,173 & 142 & 243 & 168 \\
\hline Supplemental Gas Supples $\ldots \ldots \ldots$ & 643 & 428 & 59 & 240 & 245 \\
\hline 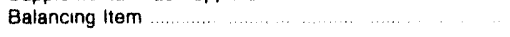 & $-2,082$ & 7.026 & 21.047 & P -1.941 & $-14,334$ \\
\hline$\ldots \ldots \ldots \ldots \ldots$ & $1,012,083$ & $1,056,723$ & $1,095.281$ & $1,091,307$ & 1.130 .230 \\
\hline
\end{tabular}

See footnotes at end of table 
Table 90. Summary Statistics for Natural Gas .- Virginia, 1988-1992 (Continued)

\begin{tabular}{|c|c|c|c|c|c|}
\hline & 1988 & 1989 & 1990 & 1991 & 1992 \\
\hline & \multicolumn{5}{|c|}{ Disposition (million cubic teet) } \\
\hline 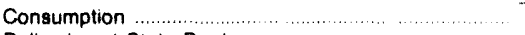 & 163,529 & 173,725 & 180,868 & 174.671 & 200.039 \\
\hline \multicolumn{6}{|l|}{ Deliveries at State Borders } \\
\hline Exports & 0 & 0 & 0 & 0 & 0 \\
\hline 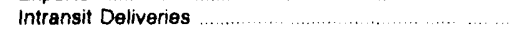 & 0 & 0 & 0 & 0 & 0 \\
\hline Interstate Deliveries & 848.322 & 880,831 & 914,223 & 916.463 & 930,018 \\
\hline \multicolumn{6}{|l|}{ Additions to Storage } \\
\hline 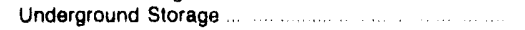 & 0 & 0 & 0 & 0 & 0 \\
\hline LNG Storage & 231 & 2.167 & 190 & 173 & 173 \\
\hline \multirow[t]{2}{*}{ Total Disposition } & $1,012,082$ & $1,056,723$ & $1,095,281$ & $1.091,307$ & $1,130,230$ \\
\hline & \multicolumn{5}{|c|}{ Consumption (million cubic teet) } \\
\hline Lease and Plant Fuel. & 536 & 425 & 489 & 327 & 653 \\
\hline Pipeline Fuel ................... & 8,238 & 5,850 & 6,943 & 6,636 & 6.454 \\
\hline \multicolumn{6}{|l|}{ Delivered to Consumers } \\
\hline Residential .................... & 58,539 & 61.712 & 51,438 & 54,199 & 62,431 \\
\hline 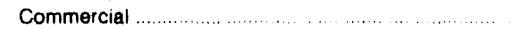 & 42,013 & 44,181 & 41,038 & 44.077 & 50.757 \\
\hline Industrial & 53,107 & 57,761 & 74,661 & 59,962 & 68,808 \\
\hline Vehicle Fuel & NA & NA & 0 & 0 & 0 \\
\hline 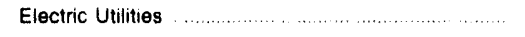 & 1.096 & 3.796 & 6,299 & 9,471 & 10.936 \\
\hline Total Delivered to Consumers. & 154,756 & 167.450 & $173,4.37$ & 167,709 & 192,932 \\
\hline \multirow[t]{2}{*}{ Total Consumption } & 163,529 & 173.725 & 180,868 & 174,671 & 200.039 \\
\hline & \multicolumn{5}{|c|}{ Delivered tor the Account of Others (million cubic teet) } \\
\hline Residential & NA & NA & 0 & 0 & 0 \\
\hline Commercial & 997 & 1,274 & 2.804 & 2.826 & 4,719 \\
\hline Industrial & 25,852 & 36.779 & 53,144 & 42.709 & 51,223 \\
\hline \multirow[t]{2}{*}{ Electric Utilities } & 654 & 3,062 & 4.945 & 9.441 & 11,669 \\
\hline & \multicolumn{5}{|c|}{ Number of Consumers } \\
\hline Residentıal $\ldots \ldots \ldots$ & 573.731 & 601.906 & 622,883 & 651,203 & 664,500 \\
\hline Commercial & 54,892 & 61.012 & 63,751 & 67,997 & 69,629 \\
\hline Industrial $\ldots \ldots \ldots \ldots \ldots$ & 895 & 895 & 929 & 1.156 & 1.101 \\
\hline \multirow[t]{2}{*}{ Vehicle Fuel } & NA & NA & 0 & 0 & 0 \\
\hline & \multicolumn{5}{|c|}{ Average Annual Consumption per Consumer (thousand cubic teet) } \\
\hline Residential $\ldots \ldots \ldots \ldots$ & 102 & 103 & 03 & 83 & 94 \\
\hline 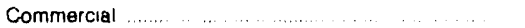 & 765 & 724 & 644 & 648 & 729 \\
\hline 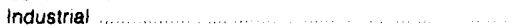 & 59,337 & 64.537 & 80.367 & 51,870 & 62.496 \\
\hline \multirow[t]{2}{*}{ 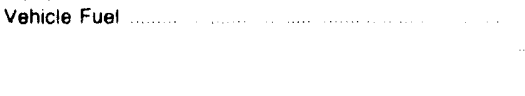 } & NA & NA & 0 & 0 & 0 \\
\hline & \multicolumn{5}{|c|}{ Average Arinual Cost per Consumer (dollars) } \\
\hline 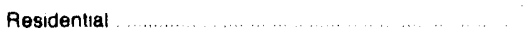 & $\$ 593$ & $\$ 675$ & $\$ 557$ & $\$ 566$ & $\$ 628$ \\
\hline 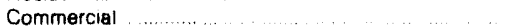 & 3,408 & 3.567 & 3.171 & 3.146 & 3,626 \\
\hline \multirow[t]{2}{*}{ Venicle Fuel $\ldots \ldots \ldots \ldots \ldots$} & NA & NA & 0 & 0 & 0 \\
\hline & \multicolumn{5}{|c|}{ Average Heating Value (Btu per cubic fool) } \\
\hline \multirow[t]{2}{*}{ Delivered to Consumers ........ } & 1.041 & 1,041 & 1,042 & 1,042 & 1.039 \\
\hline & \multicolumn{5}{|c|}{ Average Prices for Naturat Gas (dollars per thousand cubic teet) } \\
\hline Wellhead (Marketed Production) & $\$ 2.08$ & $\$ 219$ & $\$ 230^{\circ}$ & $\$ 188$ & $\$ 1.85$ \\
\hline Imports & $\cdots$ & $\ldots$ & & $-\cdot$ & $\cdots$ \\
\hline Exports .................. & $\ldots$ & $\ldots$ & & $\ldots$ & .. \\
\hline Pipeline Fuel ............... & 2.59 & 263 & $200^{5}$ & 186 & 193 \\
\hline City Gate ....................... & 287 & 313 & 309 & $2 \% 6$ & 291 \\
\hline \multicolumn{6}{|l|}{ Delivered to Consumers } \\
\hline Residential .... & 581 & 659 & 675 & 680 & 6.69 \\
\hline Commercial & 4.45 & 493 & 493 & 485 & 497 \\
\hline Industrial & 335 & 391 & 367 & 381 & 372 \\
\hline Venicle Fuel ...... & NA & NA & $\ldots$ & .. & ... \\
\hline Electric Utilities $\ldots \ldots \ldots \ldots$ & 216 & 257 & 2.69 & 190 & 247 \\
\hline
\end{tabular}

A $=$ Revised data

Ma $=$ Not available.

Note: Deliveries to electric utilities (consumption) are reported on the form Ela.759. "Monthly Power Plant Report" Deliveries to electric uttities tor the account of others are reported on the Form EIA.176. "Annual Report of Natural and Supplementai Gas Supply and Disposition "See the discussion on electric uttlity data and Table A1 in AP. pendix $A$ for a comparison of reporting to these two forms Totals may not add due to independent rounding

Sources: Energy Information Administration (EIA). Form EIA-176. "Annual Report of Natural and Supplemental Gas Supply and Disposition," Form ElA-627, "Annual Quantity and Value of Natural Gas Report, "Form EIA-857, "Monthly Report of Natural Gas Purchases and Deliveries to Consumers, " Form EiA-816. "Monthiy Natural Gas Liquids Report, " Form ElA.759, "Monthly Power Plant Report," Form FERC-423. "Monthly Report of Cost and Quality of Fuels for Electric Plants. "Form ElA-191. "Underground Gas Storage Report." Form FPC-14. "Annual Report lor Importers and Exporters of Natural Gas." US Crude Ott Natural Gas, and Natural Gas Liqurds Reserves. 1992 Annual Report. DOE/ElA 0216(92); and the U.S. Minerals Management Service. 


\section{Natural Gas 1992}

Net Interstate Movements

Marketed Production

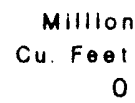

Deliveries to Consumers

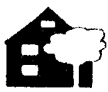

Residential:

43,048

98

ast

Commercial:

37,800

III

Industrial:

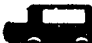

Vehicle Fuel:

8
Electric Utility:

Total:
Million

Cu. Foot

218,706

Percent of National Total .00

1.35

1.06

18.40

.19

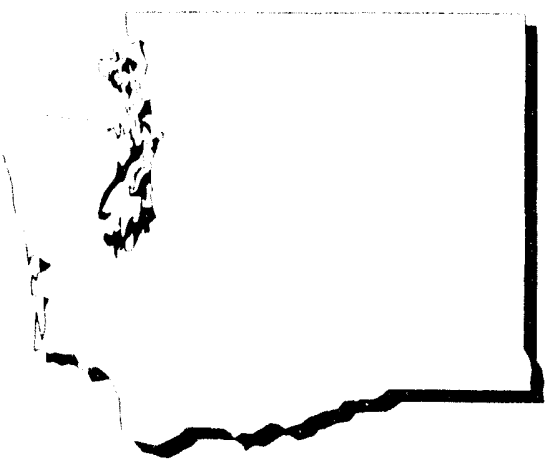

WASHINGTON

Table 91. Summary Statistics for Natural Gas -- Washington, 1988-1992

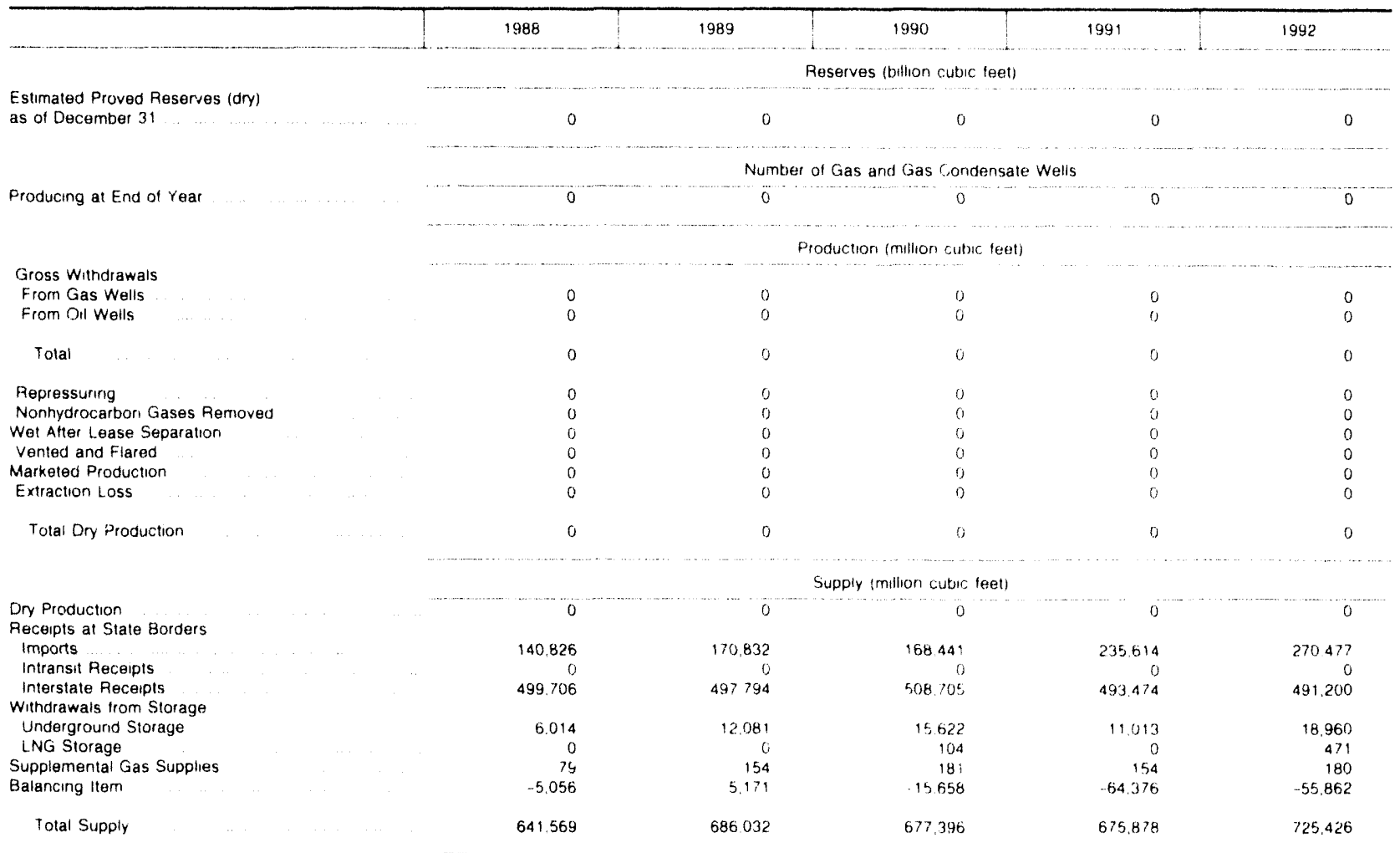

See foolnotes at end of table 
Table 91. Summary Statistics for Natural Gas -- Washington, 1988-1992 (Continued)

\begin{tabular}{|c|c|c|c|c|c|}
\hline & 1988 & 1989 & 1990 & 1991 & 1992 \\
\hline & \multicolumn{5}{|c|}{ Disposition (multion cubic feet) } \\
\hline Consumption & 146,778 & 162.779 & 162,735 & 172,996 & 169.161 \\
\hline \multicolumn{6}{|l|}{ Deliveries at State Borders } \\
\hline Exports $\ldots \ldots \ldots \ldots \ldots \ldots$ & 0 & 0 & 0 & 0 & 0 \\
\hline Intransit Deliveries & 0 & 0 & r & 0 & 0 \\
\hline Interstate Deliveries $\ldots \ldots \ldots \ldots$ & 489,376 & 510,333 & 500,26 & 488,666 & 542.972 \\
\hline \multicolumn{6}{|l|}{ Additions to Storage } \\
\hline Underground Storage & 5,415 & 12,921 & 14,296 & 14,214 & 13.294 \\
\hline LNG Storage & 0 & 0 & 96 & 2 & 0 \\
\hline \multirow[t]{2}{*}{ Total Disposition } & 641,569 & 686,033 & 677,396 & 675,878 & 725,426 \\
\hline & \multicolumn{5}{|c|}{ Consumption (million cutic teet) } \\
\hline Lease and Plant Fuel & 0 & 0 & 0 & 0 & 0 \\
\hline Pipeline Fuel ...... & 3.953 & 4,359 & 5,053 & 5.094 & 3.069 \\
\hline \multicolumn{6}{|l|}{ Delivered to Consumers } \\
\hline$\ldots \ldots \ldots \ldots . . . .$. & 34.981 & 38,359 & 40,346 & $46,2 a^{2} 2$ & 43.048 \\
\hline 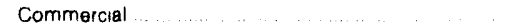 & 36,674 & 38,502 & 38.671 & 41,738 & 37.800 \\
\hline 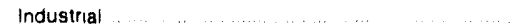 & 69,418 & 73,239 & 78,424 & 79,735 & 79,766 \\
\hline Vehicle Fuel ......... . . . . . & NA & NA & 50 & 66 & 94 \\
\hline Electric Utilities $\quad \ldots \quad \ldots \quad \ldots$ & 1.753 & 8,320 & 191 & 139 & 5.385 \\
\hline Total Delivered to Consumers & 142,825 & 158,420 & 157.682 & 167.901 & 166,092 \\
\hline \multirow[t]{2}{*}{ Total Consumption } & 146.778 & 162,779 & 162.735 & 172.996 & 169.161 \\
\hline & \multicolumn{5}{|c|}{ Delivered for the Account of Others (million cuble teet) } \\
\hline Residential & NA & NA & 0 & 0 & c \\
\hline Commercial & 1.022 & 2.291 & 2,462 & 3.247 & 4.831 \\
\hline Industrial. & 21,620 & 30.274 & 36.929 & 44.526 & 49.911 \\
\hline \multirow[t]{2}{*}{ Electric Utihties } & 877 & 7.035 & 48 & 88 & 3.597 \\
\hline & \multicolumn{5}{|c|}{ Number of Consumers } \\
\hline Residential & 413.008 & 425.624 & 458.013 & 492189 & 528.913 \\
\hline Commercial & 56.487 & 55.231 & 58,148 & 60.887 & 63.391 \\
\hline Industrial & 3.564 & 3.365 & 3.428 & 3.495 & 3.490 \\
\hline \multirow[t]{2}{*}{ Vehicle Fuel } & NA & NA & 14 & 32 & 19 \\
\hline & \multicolumn{5}{|c|}{ Average Annual Consumntion per Consumer (thousand cubic teet) } \\
\hline Residentia! & 85 & 90. & $8 B$ & 94 & 81 \\
\hline Commercial & 649 & 697 & 665 & 686 & 596 \\
\hline Industrial & 19.478 & 21.765 & 22.878 & 22.814 & 22.856 \\
\hline \multirow[t]{2}{*}{ Vehicle Fuel } & NA & NA & 3.563 & 2.078 & 4.921 \\
\hline & \multicolumn{5}{|c|}{ Average Annual Cost per Consumer (dollars) } \\
\hline Residential & $\$ 466$ & $\$ 495$ & $\$ 442$ & $\$ 440$ & $\$ 407$ \\
\hline Commercral & 2.980 & 3259 & 2.752 & 2.783 & 2.575 \\
\hline \multirow[t]{2}{*}{ Vehicie Fuel } & NA & NA & 14417 & 8.437 & 20.679 \\
\hline & \multicolumn{5}{|c|}{ Average Heating Value (Blu per cubic fool) } \\
\hline \multirow[t]{3}{*}{ Deliveriad to Consumers } & 1026 & 1.032 & 1.030 & 1,031 & 1033 \\
\hline & \multirow{2}{*}{\multicolumn{5}{|c|}{ Average Prices for Natural Gas (dollars per thousand cubce leet) }} \\
\hline & & & & & \\
\hline Wellinead (Markeled Production) & NA & NA & NA & NA & NA \\
\hline imports & & & & $\$ 151$ & $\$ 47$ \\
\hline Exports & $\ldots$ & -. & & & $\ldots$ \\
\hline Pipeline Fuel & 199 & 206 & 204 & 198 & 189 \\
\hline City Gale & 232 & 220 & $19 t$ & 191 & 190 \\
\hline Delivered to Consumers & & & & & \\
\hline Residential & 550 & 5,49 & 502 & 468 & 500 \\
\hline Commercial & 459 & 468 & 414 & 406 & 432 \\
\hline Industrial & 297 & 293 & 276 & 279 & 291 \\
\hline Vericle Fuel & NA & NA & 405 & 406 & 420 \\
\hline Electric Utilities & 315 & 519 & $\cdot 2232$ & 402 & 331 \\
\hline
\end{tabular}

- includes fixed minimum charges

Na Not avaliable

-... Not applicable

Note. Deliveries to electric utilties (consumption) are reported on the Form ElA.759 Monthiy Power Ptant Feport Deliveries 10 electric utiltes tor the accourit of others are reported on the Form EIA 176. "Annual Peport of Natural and Suppiemental Gas Supply and Uisposition See the discussion on electric utility data and Table A. in Ap. pendix A tor a comparison of reporting to these two forrns Totals may not add due to independent rounding

Sources Energy Intormation Administration (EIA). Form ElA.176. "Annual Report of Natural and Supplemental Gas Suppty and Disposition. Form fiA.62? Annual Ouantity and value of Naturar Gas Feport. "Form EIA.857. "Monthly Report of Natural Gas Purchases and Deliventes to Consurners." Form. EIA.816. Monthly Nalural Gas Liquids Report."Form EIA.759, "Monthly Power Plant Report." Form FEAC.423 "Munthly Report ol Cost and Quality of Fuels for Electric Plants. "Form ElA.191 "Underground Gas Storage Repon Form FPC-14. "Annual Report lor Imponters and Exponters of Naturai Gas." US. Crude Oll Natural Gas, and Natural Gas Lquids Resenes. 1992 Annual Repon, DOE: EIA $0216(92)$, and the US Minerals Maragement Service 
Natural Gas 1992

Net Interstate Movements

Milition

Marketed Production

\section{Million \\ Cu. Feat}

$-76,901$

Percent of

National Total

$182,000 \quad .97$

\section{Deliveries to Consumers}

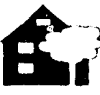

Residential:

35,291

.75

A

nsth

Commercial:

24,419

s.

Industrial:

44,178

$$
.97
$$

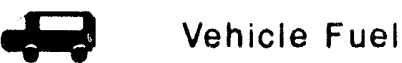

0

.00

$A$

Electric Utility:

201

Total:

104,089

.01

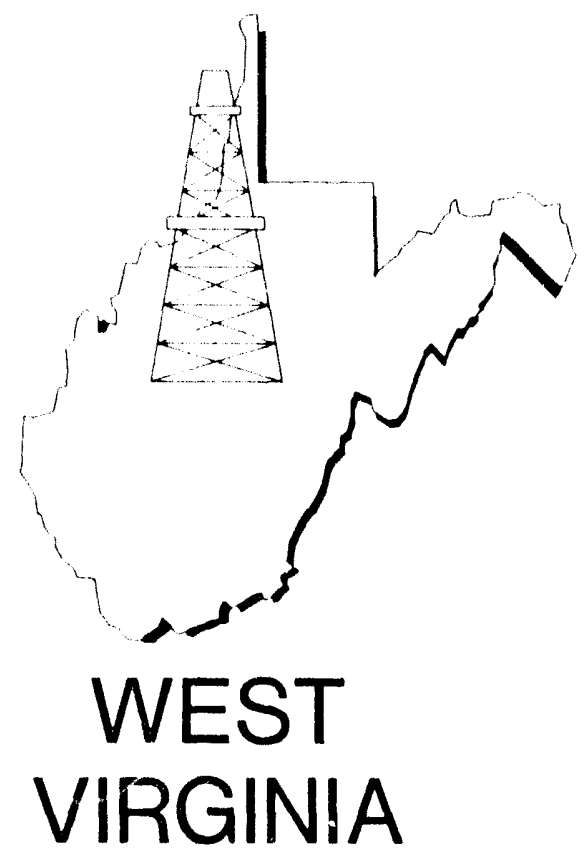

Table 92. Summary Statistics for Natural Gas -- West Virginia, 1988-1992

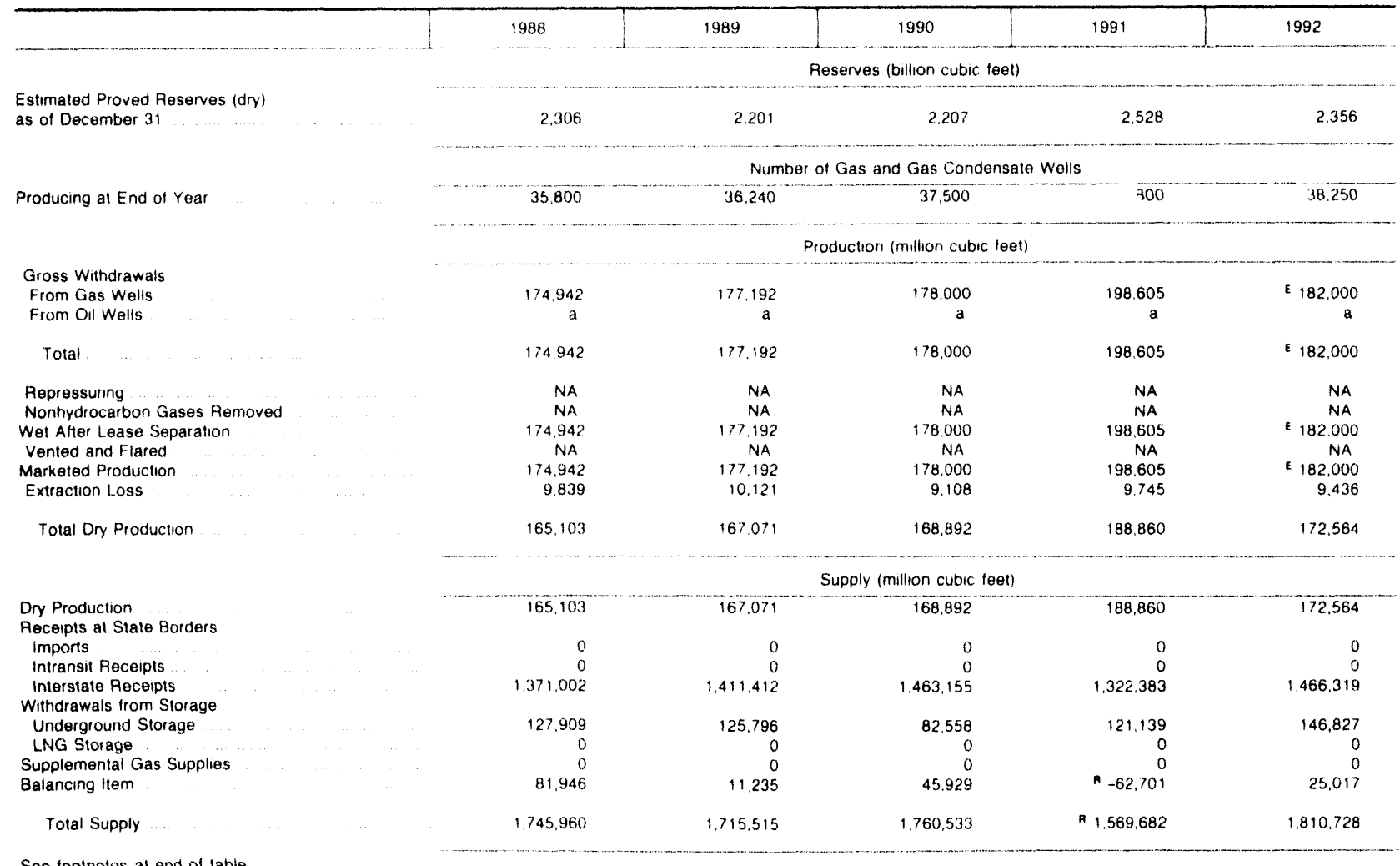

See footnotes al end of table 
Table 92. Summary Statistics for Natural Gas -- West Virginia, 1988-1992 (Continued)

\begin{tabular}{|c|c|c|c|c|c|}
\hline & 1988 & 1989 & 1990 & 1991 & 1992 \\
\hline & \multicolumn{5}{|c|}{ Disposition (million cubic feet) } \\
\hline Consumption . & 122,140 & 129.460 & 120.453 & 110,708 & 128,861 \\
\hline \multicolumn{6}{|l|}{ Deliveries at State Borders } \\
\hline Exports & 0 & 0 & 0 & 0 & 0 \\
\hline Intransit Deliveries $\ldots \ldots \ldots \ldots$ & 0 & 0 & 0 & 0 & 0 \\
\hline Interstate Deliveries $\ldots . . . \ldots \ldots$ & $1,517,502$ & $1,470,635$ & 1.513 .864 & $i, 354,722$ & $1,543,220$ \\
\hline \multicolumn{6}{|l|}{ Additions to Storage } \\
\hline Underground Storage & 106.318 & 115,421 & 126,217 & 104.251 & 138,647 \\
\hline L.NG Storage $\ldots \ldots \ldots \ldots$ & 0 & 0 & 0 & 0 & 0 \\
\hline \multirow[t]{2}{*}{ Tolal Disposition } & $1,745,960$ & $1,715,515$ & $1,760,533$ & A $1,569,682$ & $1,810,728$ \\
\hline & \multicolumn{5}{|c|}{ Consumption (million cubic feet) } \\
\hline Lease and Plant Fuel & 8,343 & 7.882 & 9.631 & 7.744 & 8,097 \\
\hline Pipeline Fuel & 13,202 & 11,250 & 8.698 & 8,305 & 16,675 \\
\hline \multicolumn{6}{|l|}{ Delivered to Consumers } \\
\hline Residential $\ldots \ldots \ldots$ & 37,690 & 37,128 & 32,600 & ค 32,587 & 35,291 \\
\hline Commercial ............ & 22,416 & 23,258 & 21,391 & A 21,043 & 24.419 \\
\hline industrial $\ldots \ldots$ & 40,415 & 49,816 & 47.993 & 40,889 & 44,178 \\
\hline$\ldots \ldots \ldots \ldots$ & NA & NA & 0 & 0 & • \\
\hline Electric Utilities & 73 & 124 & 139 & 140 & 201 \\
\hline Total Delivered to Corisumers & 100,595 & 110,327 & 102.124 & A 94.659 & 104,089 \\
\hline \multirow[t]{2}{*}{ Total Consumption } & 122.140 & 129,460 & 120.453 & R 110,708 & 128,861 \\
\hline & \multicolumn{5}{|c|}{ Delivered tor the Account of Others (mition cubic feet) } \\
\hline Residential & NA & NA & $i$ & 3 & 7 \\
\hline Commercial & 8.904 & 8.952 & 8.955 & 9.496 & 10.536 \\
\hline \multirow{3}{*}{ Electric Utilities } & 33,433 & 35.992 & 36.632 & 32.142 & 37,034 \\
\hline & 0 & 0 & 0 & 159 & 204 \\
\hline & \multicolumn{5}{|c|}{ Number of Consumers } \\
\hline Residential & 349.765 & 349.347 & 349,673 & ค 350,489 & 352,463 \\
\hline Commercial & 33.192 & 33.880 & 32.785 & A 32.755 & 33.289 \\
\hline Industriai & 208 & 211 & 182 & 198 & 159 \\
\hline \multirow[t]{2}{*}{ Venicle Fuel } & NA & NA & 0 & 0 & 1 \\
\hline & \multicolumn{5}{|c|}{ Average Annual Consumption per Consumer (thousand cubic feet) } \\
\hline Residential & 108 & 106 & 93 & 93 & 100 \\
\hline Comrnercial & 675 & 686 & 652 & A 642 & 734 \\
\hline Industrial & 194.301 & 236.096 & 263.697 & 206.509 & 277.850 \\
\hline \multirow[t]{2}{*}{ Vehicle Fisel } & NA & NA & 0 & 0 & 310 \\
\hline & \multicolumn{5}{|c|}{ Average Annual Cos! per Consumer (dollars) } \\
\hline Residential & $\$ 593$ & $\$ 611$ & $\$ 60 ?$ & $\$ 605$ & $\$ 632$ \\
\hline Commercial & 3,496 & 3.608 & 3.806 & ค 3,924 & 4.017 \\
\hline \multirow[t]{2}{*}{ Vehicie Fuel } & NA & NA & $\theta$ & 0 & 899 \\
\hline & \multicolumn{5}{|c|}{ Average Heating Value (Btu per cubic locil) } \\
\hline \multirow[t]{2}{*}{ Delivered to Consumers } & 1,077 & 1.077 & 1071 & 1.073 & 1.065 \\
\hline & \multicolumn{5}{|c|}{ Average Prices for Natural Gas (dollats per thousand Cubic leet) } \\
\hline Wellhead (Marketed Production) & $\$ 305$ & $\$ 311$ & $\$ 319$ & $\$ 29 ?$ & $\$ 3.01$ \\
\hline Imports & - & $\cdots$ & & & $\cdots$ \\
\hline . $\ldots$ & & & & & $\cdots$ \\
\hline Pipeline Fuel & 289 & 297 & 266 & 249 & 293 \\
\hline City Gate & 343 & 375 & 354 & 358 & 3.23 \\
\hline \multicolumn{6}{|l|}{ Delivered to Consumers } \\
\hline Residential & 550 & $5 / 5$ & 646 & 650 & 631 \\
\hline Commercial & 518 & 526 & 583 & 611 & 548 \\
\hline Industrial & 286 & 292 & 295 & 295 & 2.89 \\
\hline Vehicle Fuel & NA & NA & & ... & 290 \\
\hline Electric Utitites & 389 & 459 & 513 & 363 & 353 \\
\hline
\end{tabular}

- Included in gross withdrawals from gas wells Breakdown nol provided by State agency

- Less than 500.000 cubic teet

- Estimated data

a Fevised data

Na Not avaslable

Na Not avalable

Note Deliveries to electric utities (consumption) are reported on the Form ElA 759. "Monthly Power Ptant Report" Deliveries to electric utilities tor the account of others are reported on the form EIA.176. "Annual Feport of Natural and Supplemental Gas Supply and Dispostion " See the discussion on eieciric utilty data and Table At in Ap pendix $A$ for a comparisori of reporting to these two lorms Totals may nol add due to independent rounding

Sources Energy triformation Administration (EIA). Form EIA-176. "Annual Report of Natural and Supplemental Gas Supply and Disposition. Form E. A.627. "Annual Quantity and

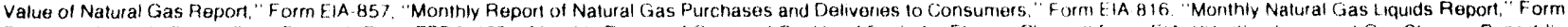
EIA.759. "Monthiy Power Plant Report. Form FFRC -423. "Monthly Fleport of Cost and Quality of Fuets for Electric Plants . Form EiA 191. "Underground Cas Storage Report."

Form FPC.14 "Annual Report for Importers and Exporters of Natural Gas." US Crude Ot. Natural Gas. and Natural Gias liqunds Reserves 1992 Annual Report. DOE/EIA

0216(92), and the: US Minerals Management Service 


\section{Natural Gas 1992}

Net Interstate Movements

Million

351,672

$\begin{array}{ccc}\text { Marketed Production } & \begin{array}{c}\text { Million } \\ \text { Cuil Feat }\end{array} & \begin{array}{c}\text { Percent } \\ \text { National Total } \\ 0\end{array} \\ 0 & 00\end{array}$

Deliveries to Consumers

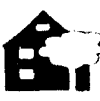

Residential:

123.405

2.63

A.

inst

Commercial:

71,314

2.54

씼

Industrial:

130,267

1.73

Vehicle Fuel:

28

5.48

A

Electric Utility:

2.584

.09

Total:

327,599

1.84

Table 93. Summary Statistics for Natural Gas -- Wisconsin, 1988-1992

\begin{tabular}{|c|c|c|c|c|c|}
\hline & 1988 & 1989 & 1990 & 1991 & 1992 \\
\hline & \multicolumn{5}{|c|}{ Feserves (tullion cutuc (een) } \\
\hline \multirow[t]{2}{*}{$\begin{array}{l}\text { Estimated Proved Reserves (dry) } \\
\text { as of December } 31\end{array}$} & 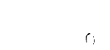 & 0 & 0 & 8 & 0 \\
\hline & \multicolumn{5}{|c|}{ Number of Gas and Gas Condensate Wells } \\
\hline \multirow[t]{2}{*}{ Producing at End of Year } & $i$ & a & 0 & () & n \\
\hline & \multicolumn{5}{|c|}{ Productun (mullion cubic teetl } \\
\hline \multicolumn{6}{|l|}{ Gross Withdrawals } \\
\hline From Gas Wells & a & 0 & 0 & 0 & 0 \\
\hline From Oll Wells & 1 & 0 & 0 & 0 & $\theta$ \\
\hline Total & u & $\theta$ & 0 & 0 & i) \\
\hline Repressuring & is & 0 & is & 0 & 0) \\
\hline Nonhydrocarbor, Gases Rernoved & 0 & 0 & 0 & 0 & 0 \\
\hline Wet After Lease Separation & $\because$ & 0 & 0 & 0 & D \\
\hline Verited and Flared & 6 & 0 & 0 & 0 & 0 \\
\hline Marketed Production & 0 & 0 & 0 & i) & 0 \\
\hline Extraction Loss & 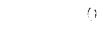 & 0 & $r$ & (1) & 0 \\
\hline \multirow[t]{3}{*}{ Total Dry Production } & 0 & 0 & 0 & 0 & 0 \\
\hline & & $\ldots .$. & & & \\
\hline & \multicolumn{5}{|c|}{ Supply (millon cutsc teet) } \\
\hline Dry Production & 0 & 0 & 0 & n) & 0 \\
\hline Peceipts at State Borders & & & & & \\
\hline Imports & (i) & 0 & ") & i) & (j) \\
\hline Intransit Recoipts & a & 0 & 0 & 0 & 0 \\
\hline Interstate Receipts & 355,85 & 775,925 & 788.509 & 872520 & 1057,942 \\
\hline \multicolumn{6}{|l|}{ Withdrawals from Storage } \\
\hline Underground Storage. & 0 & 0 & 0 & 0 & $a$ \\
\hline LNG Storage & $1 / 2$ & $1 / 4$ & 126 & 131 & 117 \\
\hline Supplemental Gas Supplies & 2 & 5 & 1 & 1 & 1 \\
\hline Balancing ttem & $4 \div 122$ & 20.314 & 9.464 & $B 118$ & 263.151 \\
\hline Total Supply & 199049 & 796.418 & 398391 & $840.7 \%$ & $103: 909$ \\
\hline
\end{tabular}

See footnotes at end of table 
Table 93. Summary Statistics for Natural Gas -- Wisconsin, 1988-1992 (Continued)

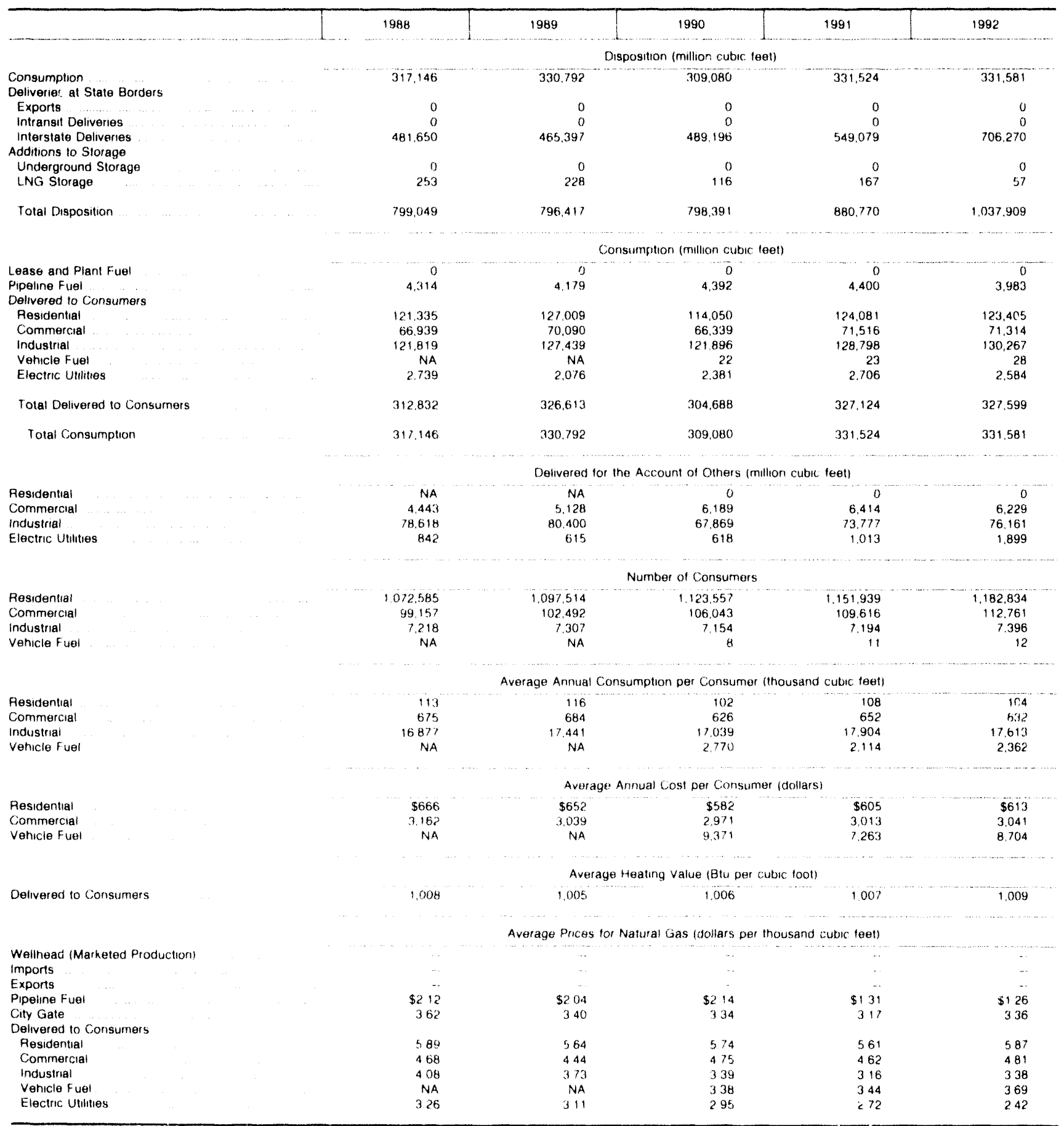

Na Not availabie

Note Deliveries to electric utilities (Consumption) are reported on the Form ElA.759. "Monthly Power Plant Report" Deliveries to electric utilities for the account of others are reported on the Form EIA.176. "Anrmua! Feport of Natural and Supplemental Gas Supply and Disposition" See the discussion on electric utility data and Table A1 in Ap.

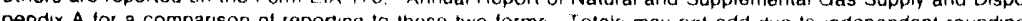

Six A for a comparison of reporting to these two torms totals may not add due to independent rounding

Sources Energy intormation Administration (E/A). Form ElA.176. "Annual Feport of Natural and Supplementat Gas Supply and Disposition." Form ElA.627, "Annual Ouantiy and Value of Natural Gas Report." Form E.1A-857. "Monthly Reporl of Natural Gas Purchases and Deliveries to Consumers. "Form ElA .816. "Munthly Natural Gas $L$ Iquids Report. "Form ElA.759, "Monthly Power Plant Report." Form FEAC.423, "Monthly Feport of Cost and Quality of Fuels for Electhic Plants. "Form ElA 191. "Underground Gas Storage Peport." Form FPC-14. "Annual Report for importers and Exporters of Natural Gas." US Crude Oil. Nature rias, and Natural Gas Liquids Reserves. 1992 Annual Report. DOE/ElA. 0216(92); and the US Minerals Management Service 


\section{Natural Gas 1992}

Net Interstate Movements

Million

Marketed Production

Mlllion
Cu. Foot

$-586,561$

842,576

Parcent of

National Total

4. 50

\section{Deliveries to Consumers}

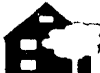

Residential:

10,895

.23

A.

nsty

Commercial:

8,009

m

Industrial:

56,046

$\longrightarrow$ Vehicle Fuel:

10

1.96

$A$

Electric Utility:

83

.00

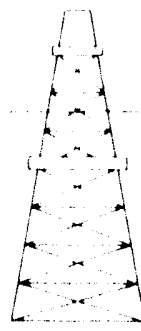

Total:

75,044

.42

Table 94. Summary Statistics for Natural Gas -- Wyoming, 1988-1992

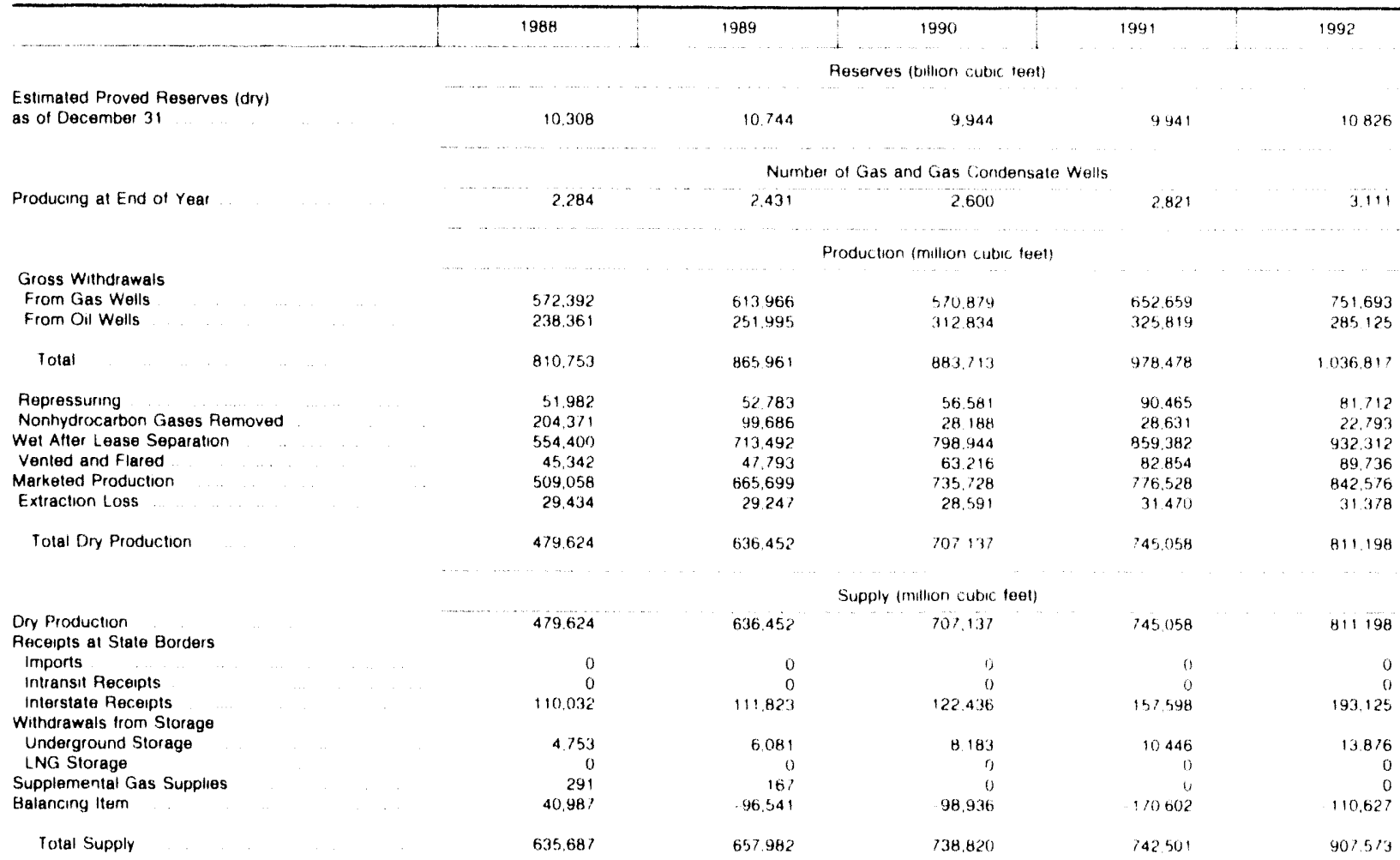

See footnotes at end of table 
Table 94. Summary Statistics for Natural Gas -- Wyoming, 1988-1992 (Continued)

\begin{tabular}{|c|c|c|c|c|c|}
\hline & 1988 & 1989 & 1990 & 1991 & 1992 \\
\hline & \multicolumn{5}{|c|}{ Disposition (million cubic teet) } \\
\hline 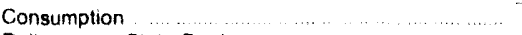 & 82,363 & 82,362 & 92,190 & 97,291 & 123,547 \\
\hline \multicolumn{6}{|l|}{ Deliveries at State Borders } \\
\hline Exports & 0 & 0 & 0 & 0 & 0 \\
\hline Intransit Deliveries $\ldots \ldots \ldots \ldots \ldots \ldots$ & 0 & 0 & 0 & 0 & 0 \\
\hline 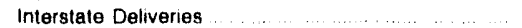 & 543,606 & 563,073 & 634,485 & 634,337 & 778,686 \\
\hline \multicolumn{6}{|l|}{ Adcuitorls to Storage } \\
\hline Underground Storage $\ldots . . . . .$. & 9.719 & 12,546 & 12.146 & 10,872 & 5.340 \\
\hline LNG Storage & 0 & 0 & 0 & 0 & 0 \\
\hline \multirow[t]{2}{*}{ Total Disposition } & 635,688 & 657,981 & 738,820 & 742.501 & 907,573 \\
\hline & \multicolumn{5}{|c|}{ Consumption (million cubic feet) } \\
\hline Lease and Plant Fuel $\ldots \ldots \ldots$ & 40,698 & 40.361 & 41,415 & 35,142 & 40,599 \\
\hline Pipeline Fuel & 5,660 & 5,368 & 5,059 & 7,802 & 7,904 \\
\hline \multicolumn{6}{|l|}{ Delivered to Consumers } \\
\hline Residential & 11,650 & 11,780 & 11.485 & 11,992 & 10,895 \\
\hline Commercial & 8,700 & 8,551 & 8,440 & 9,101 & 8,009 \\
\hline Industrial $\ldots \ldots \ldots$ & 15,472 & 16,217 & 25,722 & 33,174 & 56,046 \\
\hline Vehicle Fuel $\ldots \ldots \ldots$ & NA & NA & 0 & 5 & 10 \\
\hline Electric Utilities $\ldots \ldots \ldots$ & 183 & 85 & 69 & 76 & 83 \\
\hline Total Delivered to Consumers & 36,005 & 36.633 & 45,715 & 54,348 & 75,044 \\
\hline \multirow[t]{2}{*}{ Total Consumption } & 82,363 & 82,362 & 92.190 & 97.291 & 123.547 \\
\hline & \multicolumn{5}{|c|}{ Delivered for the Account of Others (million cubic feet) } \\
\hline Residential & NA & NA & 0 & 0 & 0 \\
\hline$\ldots+\ldots+\ldots+\ldots$ & 0 & 7 & 21 & 89 & 160 \\
\hline$\ldots \ldots \ldots \ldots$ & 12.051 & 13,496 & 23,569 & 31,093 & 54,053 \\
\hline \multirow[t]{2}{*}{$\begin{array}{llll}\cdots & \ldots \ldots & \ldots \ldots & \end{array}$} & 0 & 0 & 0 & 0 & 0 \\
\hline & \multicolumn{5}{|c|}{ Number of Consumers } \\
\hline Residential & 112.126 & 113,129 & 113,598 & 113,463 & 114.793 \\
\hline$\ldots \ldots \ldots$ & 15.093 & 14.012 & 13.767 & 14.931 & 15,064 \\
\hline Industrial $\ldots \ldots \ldots$ & 200 & 230 & 284 & 228 & 244 \\
\hline \multirow[t]{2}{*}{ Vehicle Fuel } & NA & NA & 0 & 5 & 5 \\
\hline & \multicolumn{5}{|c|}{ Average Annual Consumption per Consumer (thousand cubic teet) } \\
\hline Residential. & 104 & 104 & 101 & 106 & 95 \\
\hline Commercial & 576 & 610 & 613 & 610 & 532 \\
\hline$\ldots$ & 77,360 & 70,509 & 90,570 & 145,499 & 229,698 \\
\hline \multirow[t]{2}{*}{ Venicie Fuel. } & NA & NA & 0 & 949 & 2.006 \\
\hline & \multicolumn{5}{|c|}{ Average Annual Cost per Consumer (doliars) } \\
\hline Residentiat & $\$ 465$ & $\$ 490$ & $\$ 489$ & $\$ 501$ & $\$ 448$ \\
\hline Commercial & 2.371 & 2.645 & 2.741 & 2,628 & 2,263 \\
\hline \multirow[t]{2}{*}{ Vehicle Fuel } & NA & NA & 0 & 5,370 & 11.516 \\
\hline & \multicolumn{5}{|c|}{ Average Heating Value (Btu per cubic foot) } \\
\hline \multirow[t]{2}{*}{ Delivered to Consumers } & 1.053 & 1.055 & 1.099 & 1.060 & 1,058 \\
\hline & \multicolumn{5}{|c|}{ Average Prices for Natural Gas (dollars per thousand cubic feet) } \\
\hline Wellhead (Marketed Production) & $\$ 15.3$ & $\$ 124$ & $\$ 116$ & $\$ 1.06$ & $\$ 113$ \\
\hline Imports & & $\ldots$ & -. & -. & -. \\
\hline Exports & $\cdots$ & $\cdots$ & $\cdots$ & $\ldots$ & - \\
\hline Pipeline Fuel & 206 & 188 & 1.95 & 1.85 & 2.48 \\
\hline City Gate & 315 & 299 & 300 & 304 & 2.90 \\
\hline \multicolumn{6}{|l|}{ Delivered to Consumers } \\
\hline Residential & 448 & 471 & 484 & 4.74 & 4.72 \\
\hline.... & 4.11 & 4.33 & 447 & 431 & 4.26 \\
\hline 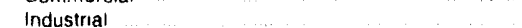 & 336 & 323 & 3.23 & 3.03 & 2.91 \\
\hline$\ldots$ & NA & NA & .. & 5.66 & 5.74 \\
\hline Electric Uthities & 378 & 361 & 326 & 3.51 & 333 \\
\hline
\end{tabular}

\section{Na - Not avarlable}

Not applicabie

Note Deliveries to electric utilies (consumption) are reported on the Form ElA-759, "Monthly Power Plant Report "Deliveries to electric utilities for the account of others are reported on the Form EIA.176. "Annual Report of Natural and Supplemental Gas Supply and Disposition." See the discussion on electric utility data and Table A1 in Ap. pendix $A$ for a comparison of reporting to these two forms. Totals may not add due to independent rounding

Sources Energy Intormation Administration (EIA). Form EIA-176, "Annual Feport of Natural and Supplemental Gas Supply and Disposition," Form EIA-627, "Annual Quantity and Value of Natural Gas Report." Form ElA-857. "Monthly Report of Natural Gas Purchases and Deliveries to Consurners," Form ElA.816. "Monthly Natural Gas Liquids Report," Form EIA.759. "Monthly Power Plant Report. "Form FERC.423. "Monthly Report of Cost and Ouality of Fuels for Electric Plants." Form ElA.191. "Underground Gas Storage Report,"

Form FPC.14. "Arnual Report tor Importers and Exporters of Natural Gas," US Crude OI, Natural Gas. and Natural Gas Liquids Reserves, 1992 Annual Report. DOE/ElA.

0216(92): and the US Minerals Management Service 


\section{Historical Data}

Dry production of natural gas continues to be a large contributor to the Nation's domestic energy supply. In 1973, the drop in oil imports due to the oil embargo by OPEC nations resulted in natural gas production reaching an all-time high of 21.7 trillion cubic feet. During 1992, dry production was 17.8 trillion cubic feet, 1 percent above the 1991 level (Table 95).

The early 1970's brought record levels in the total U.S. consumption with a peak level of 22.1 trillion cubic feet in 1972. Deliveries of natural gas to the residential and electric utility sectors set record levels that same year, and deliveries to industrials peaked in 1973. Between 1982 and 1991 total U.S. consumption of natural gas remained in the range of 16 to 19 trillion cubic feet (Table 97). It rose to 19.5 trillion cubic feet in 1992.

Industrial users are the leading consumers of natural gas. Industrial consumption reached 7.5 trillion cubic feet in 1992, up 4 percent from the 1991 level and the highest level since 1974. Much of the increase can be attributed to natural gas consumption by monutility generators (NUG's). NUG's generate electricity for their own use and for sale to electric utilities, which in turn distribute it to consumers.

Natural gas consumption in the residential sector, the second leading consuming sector, responds largely to weather-related home-heating requirements. Although the last 3 years were warmer than normal, residential comsumption in 1992 was 3 percent higher than in 1991 and 7 percent higher than in 1990. Severe weather conditions in December 1989 resulted in great demand for natural gas by residential customers. During 1989, residential consumption was 4.8 trillion cubic feet, the highest level since 1979. Residential consumption in 1992 was 2 percent less than the 1989 level

Commercial consumption, which also responds to variations in the weather, reached a record 2.8 trillion cubic feet in 1992, surpassing the previous record set in 1979. Historically, the electric utility sector has had the third largest amount of consumption. However, in 1992 and in 1988 it was surpassed by the commercial sector. Consumption in the electric utility sector decreased 1 percent from 1991 to 1992

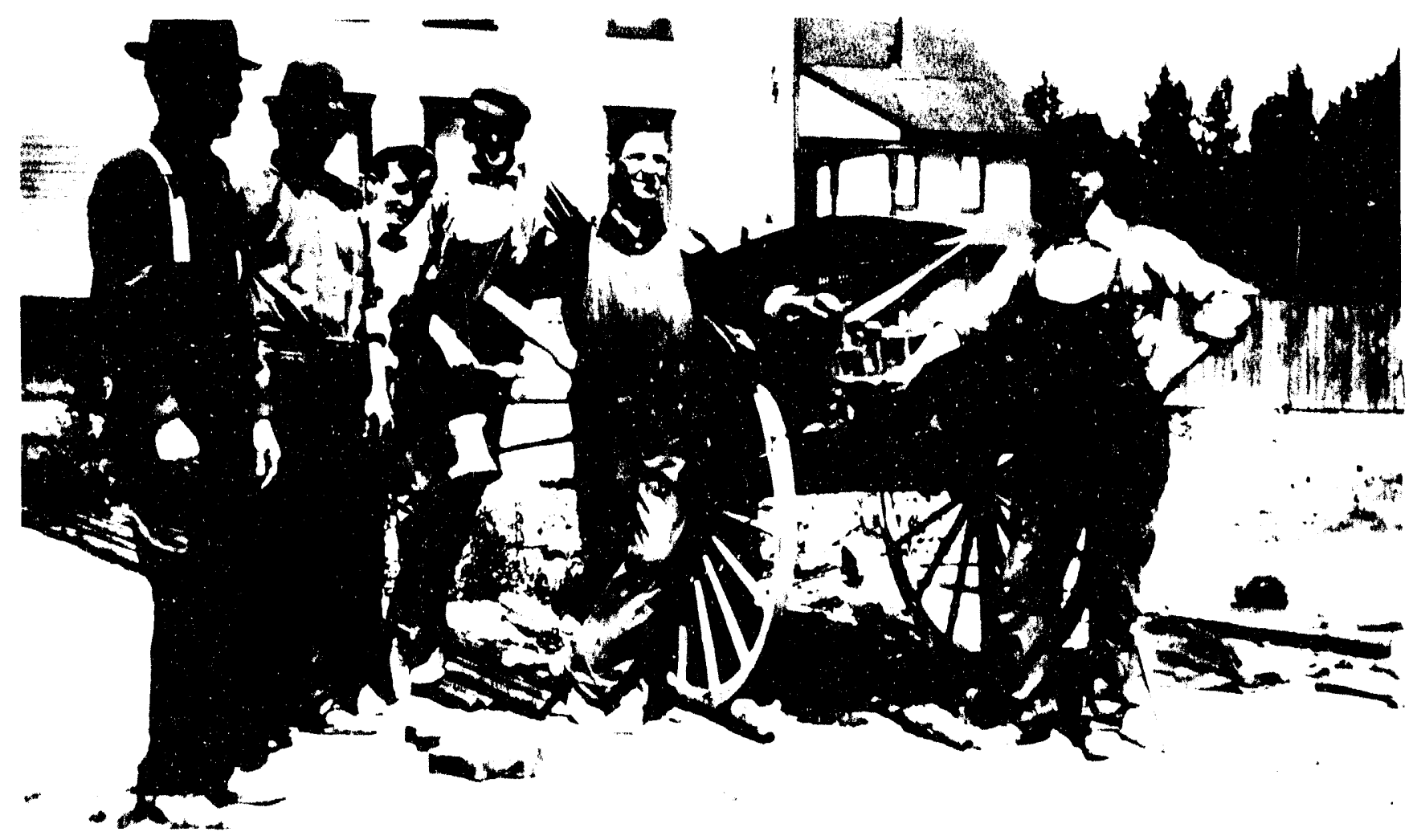

An early natural gas utility work crew poses for a picture in the pre-hard-hat ira. 


\section{Revisions to Historical Data}

Since the publication of the Natural Gas Annual 1991, some revisions have been made to 1991 data. These data were revised due to an ongoing program of quality assurance conducted by the R.serves and Natural Gas Division for the monthly Form EIA-857, "Monthly Report of Natural Gas Purchases and Deliveries to Consumers," and the annual Form EIA-176 data collection programs. This effort resulted in the refiling of Form EIA-176 for 1991 for several respondents.

The 1991 Form EIA-627, "Annual Quantity and Value of Natural Gas Report" began collecting data on volumes of natural gas used on leases as a separate item. This item was revised for three States for their 1991 filings. In some instances, gross withdrawals and/or marketed production were revised.

Revisions were also made in the consumption sector. The 1990 and 1991 commercial consumption volumes and prices of natural gas previously included natural gas delivered for use as vehicle fuel. These vehicle fuel volumes and prices, beginning with 1990 data, now appear as a separate sector under U.S. consumption. The commercial sector has been revised where appropriate.

\section{Changes to Data Collection Programs}

The Bureau of Mines, U.S. Department of the Interior, conducted surveys of the natural gas industry until 1977 , when this function was transferred to the newly formed U.S. Department of Energy (DOE). Since that time the Energy Information Administration (EIA) within the DOE has collected informa. in on natural gas production, transmission, consumption, and prices. Some of the data are collected on behalf of the Federal Energy Regulatory Commission (FERC), an independent commission within the DOE, which has jurisdiction primarily in the regulation of electric utilities and the interstate natural gas industry.
The EIA made many changes to data collection forms and procedures that became effective for the collection of 1980 data. These changes provided more complete natural gas information with minimal changes in respondent burden. In some instances voluntary data collection efforts were changed to mandatory surveys. The Form EIA-176 combined and expanded two voluntary predecessor forms from the Bureau of Mines (BOM-1340-A and BOM-1341-A) into a new mandatory form.

Also in 1980, the Form EIA-627, "Annual Quantity and Value of Natural Gas Report," was introduced to collect data, previously collected on an informal basis, from the appropriate agencies of the producing States. In addition to volumes of gas produced from gas and oil wells, the form requested data on the quantities of nonhydrocarbon gases removed in treating or processing operations, quantities of gas used for repressuring as well as gas vented and flared, and marketed production. In 1991, the Form EIA-627 was revised to also collect quantities of fuel used on the lease.

The United States Geological Survey provided supplemental production data, including production data for the Outer Continental Shelf, until 1982, when this function was transferred to the United States Minerals Management Service.

In 1982, the Form EIA-176 was revised and expanded into the version that was used for data collection through 1986. The Form EIA-176 was reapproved in 1988 for the collection of 1987 through 1989 data. The form was changed to include collection of data on the transportation of gas to commercial consumers for the account of others and to add a short form of the EIA- 176 to be filed by small companies with limited activities. In 1991, the Form EIA-176 was reapproved for the collection of 1990 through 1992 data. The major changes to the form were: deliveries of gas to be used as vehicle fuel are reported and the data reported on the form are no longer considered confidential. See Appendix A for further information about the history of data collection. 
Table 95. Quantity and Average Price of Natural Gas Production in the United States, 1930-1992 (Volumes in Million Cubic Feet, Prices in Dollars per Thousand Cubic Feet)

\begin{tabular}{|c|c|c|c|c|c|c|c|c|}
\hline Year & $\begin{array}{c}\text { Gross } \\
\text { Withdrawals }\end{array}$ & $\begin{array}{l}\text { Used for } \\
\text { Repressuring }\end{array}$ & $\begin{array}{l}\text { Nonhydro- } \\
\text { carbon } \\
\text { Gases } \\
\text { Removed }\end{array}$ & $\begin{array}{l}\text { Vented and } \\
\text { Flared }\end{array}$ & $\begin{array}{l}\text { Marketed } \\
\text { Production }\end{array}$ & $\begin{array}{l}\text { Extraction } \\
\text { Loss }\end{array}$ & $\begin{array}{c}\text { Dry } \\
\text { Production }\end{array}$ & $\begin{array}{l}\text { Average } \\
\text { Wellhead } \\
\text { Price of } \\
\text { Marketed } \\
\text { Production }\end{array}$ \\
\hline 1930. & NA & NA & NA & NA & $1,978,91 i$ & 75,140 & $1,903.771$ & $\$ 0.08$ \\
\hline 1931 & NA & NA & NA & NA & $1,721,902$ & 62,288 & $1,659, \div 14$ & .07 \\
\hline 1932 & NA & NA & NA & NA & $1,593,798$ & 51,816 & $1,44,982$ & .06 \\
\hline $1933 \ldots \ldots \ldots \ldots \ldots \ldots \ldots$ & NA & NA & NA & NA & $1,596,673$ & 48,280 & $1,48,393$ & .06 \\
\hline 1934 & NA & NA & NA & NA & $1,815,796$ & 52,190 & $1,763,606$ & 06 \\
\hline 1935 & NA & NA & NA & NA & $1,968,963$ & 55,488 & $1,913,475$ & .06 \\
\hline 1936 & $2,691,512$ & 73,507 & NA & 392,528 & $2,225,477$ & 61,064 & $2,164,413$ & .06 \\
\hline 1937 & $3,084,567$ & 84,925 & NA & 526,159 & $2,473,483$ & 70,210 & $2,403,273$ & .05 \\
\hline 1938 & $3,108,858$ & $10 t, 551$ & NA & 649,106 & $2,358,201$ & 73,338 & $2,284,86.3$ & .05 \\
\hline 1939 & 3.387 .095 & 171,401 & NA & 677,311 & $2,538,383$ & 73,746 & $2,464,637$ & 05 \\
\hline 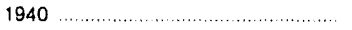 & $3,752,702$ & 362,916 & NA & 655,967 & $2,733,819$ & 79,526 & $2,654,293$ & 05 \\
\hline $1941 \ldots$ & $4,168,116$ & 644,379 & NA & 630,212 & $2,893,525$ & 115,464 & $2,778,061$ & .05 \\
\hline 1942 & $4,525,095$ & 752,619 & NA & 626,782 & $3,145,694$ & 119,000 & $3,026,694$ & .05 \\
\hline 1943 & $5,024,449$ & 824,803 & NA & 684,115 & $3,515,531$ & 121,788 & $3,393,743$ & .05 \\
\hline 1944 & $5,708,288$ & 882,979 & NA & $1,010,285$ & $3,81^{r}, 024$ & 142,868 & $3,672,156$ & 05 \\
\hline 1945 & $6,000,161$ & $1,061,951$ & NA & 896,208 & $4,042,002$ & 159,936 & $3,882,066$ & .05 \\
\hline 1946 & $6.293,037$ & $1,038,242$ & NA & $1,102,033$ & $4,152,762$ & 165,274 & $3,987,488$ & 05 \\
\hline $1947 \ldots$ & $6,733,230$ & $1,083,119$ & NA & $1,067,938$ & $4,582,173$ & 188.734 & $4,393,439$ & .06 \\
\hline 1948 & $7, i 78,777$ & $1,220,579$ & NA & 810,178 & $5,148,020$ & 209,508 & $4,938,512$ & 06 \\
\hline 1949 & $7,546,825$ & $1,273,205$ & NA & 853,884 & $5,419,736$ & 224,332 & $5,195,404$ & 06 \\
\hline 1950 & $8,479,650$ & $1,396,546$ & NA & 801.044 & $6,282,060$ & 259,862 & $6.022,198$ & .07 \\
\hline 1951 & $9,689,372$ & $1,438,827$ & NA & 793,186 & $7,457,359$ & 292,400 & $7,164,959$ & 07 \\
\hline 1952 & $10,272,566$ & $1,410.501$ & NA & 848,608 & $8,013,457$ & 319,158 & $7,694,299$ & .08 \\
\hline 1953 & $10,645,798$ & $1,438,606$ & NA & 810,276 & $8,396,916$ & 340.068 & $8,056,848$ & .09 \\
\hline 1954 & $10.984,850$ & $1,518,737$ & NA & 723,567 & $8,742,546$ & 354,348 & $8,388,198$ & 10 \\
\hline 1955 & $11,719,794$ & $1,540,804$ & NA & 773,639 & $9,405,351$ & 376,686 & $9,028,665$ & 10 \\
\hline 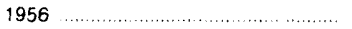 & $12,372,905$ & $1,426,648$ & NA & 864,334 & $10,081,923$ & 418.013 & $9,663,910$ & 11 \\
\hline 1957 & $12,906,669$ & $1,417,263$ & NA & 809,148 & $10,680,258$ & 433,636 & $10,246,622$ & 11 \\
\hline 1958 & $13,146,635$ & 1.482 .975 & NA & 633,412 & $11,030,248$ & 458,040 & $10,572,208$ & .12 \\
\hline 1959 & $14,229,272$ & $1,612,109$ & NA & 571,048 & $12,046,115$ & 498,457 & 11.547 .658 & .13 \\
\hline 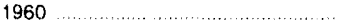 & $15,087,911$ & $1.753,996$ & NA & 562,877 & $12,771,038$ & 542,890 & $12,228,148$ & .14 \\
\hline 1961 & $15,460,312$ & $1,682,754$ & NA & 523,533 & $13,254,025$ & 592,446 & $12,661,579$ & 15 \\
\hline 1962 & $16,038,973$ & $1,736,722$ & NA & 425,629 & $13,876,622$ & 623,616 & $13,253,006$ & 16 \\
\hline 1963 & $16,973,368$ & $1,843,297$ & NA & 383.408 & $14,746,663$ & $670.25 !$ & $14,076.412$ & .16 \\
\hline 1964 & $17,535,553$ & $1,647,108$ & NA & 341.853 & $15.546,592$ & 722,565 & $14,824,027$ & .15 \\
\hline 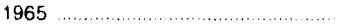 & $17,963,100$ & $1,604,204$ & NA & 319,143 & $16,039,753$ & 753,473 & $15,286,280$ & .16 \\
\hline 1966 & $19,033,839$ & $1,451,516$ & NA & 375,695 & $17,206,628$ & 739,308 & $16,467,320$ & 16 \\
\hline $1967 \ldots \ldots \ldots$ & $20,251,776$ & $1,590,574$ & NA & 489,877 & $18,171,325$ & 784,534 & $17,386,791$ & 96 \\
\hline 1968 & $21,325,000$ & $1,486,092$ & NA & 516,508 & $19,322,400$ & 827,877 & $18,494,523$ & .16 \\
\hline 1969 & $22,679,195$ & $1,455,205$ & NA & 525,750 & $20,698,240$ & 866,560 & $19,831,680$ & 17 \\
\hline 1970. & $23.786,453$ & $1,376.351$ & NA & 489,460 & $21,920,642$ & 906,413 & $21,014,229$ & 17 \\
\hline 1971. & $24,088,031$ & $1,310.458$ & NA & 284,561 & $22.493,012$ & 883.127 & $21,609,885$ & 18 \\
\hline 1972 & $24,016,109$ & $1,236,292$ & NA & 248,119 & $22,531,698$ & 907.993 & $21,623,705$ & .19 \\
\hline 1973. & $24,067,202$ & $1,171,361$ & NA & 248,292 & $22,647,549$ & 916,551 & $21,730,998$ & 22 \\
\hline 1974 & $22,849,793$ & $1,079,890$ & NA & 169,381 & $21,600,522$ & 887,490 & $20,713,032$ & 30 \\
\hline ................. & $21,103,530$ & 860,956 & NA & 133,913 & $20,108,661$ & 872,282 & $19,236,379$ & 44 \\
\hline … & $20,943,778$ & 859,410 & NA & 131,930 & $19,952,438$ & 854,086 & $19,098,352$ & 58 \\
\hline (2.1. & $21,097,071$ & 934,801 & NA & 136,807 & $20,025,463$ & 862,563 & $19,162,900$ & .79 \\
\hline 1978 & $21,308,815$ & $1,181,432$ & NA & 153,350 & $19,974,033$ & 852,130 & $19,121,903$ & .91 \\
\hline 1979 & $21,883,353$ & $1,245,074$ & NA & 167,019 & $20,471,260$ & 807,845 & $19,663,415$ & 1.18 \\
\hline 1980 & $21,869,692$ & $1,365,454$ & 199,063 & 125,451 & $20,179,724$ & 776.605 & $19,403.119$ & 159 \\
\hline $198 \mathrm{t}$. & $21,587,453$ & $1.311,735$ & 221,878 & 98,017 & $19,955,823$ & 774,562 & $19,181,261$ & 1.98 \\
\hline 1982 & $20,272,254$ & $1,388,392$ & 208,492 & 93,365 & $18,582,005$ & 761,942 & $17,820,063$ & 2.46 \\
\hline 1983 & $18,659,046$ & $1,458,054$ & 221,937 & 94,962 & $16,884,093$ & 789,632 & $16,094,461$ & 259 \\
\hline 1984 & $20,266,522$ & $1,630,152$ & 224,118 & 107.913 & $18,304,339$ & 837,867 & $17.466,472$ & 2.66 \\
\hline 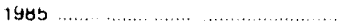 & $19,606,699$ & $1,915,197$ & 326.497 & 94,778 & $17,270,227$ & 816.370 & 16.453 .857 & 251 \\
\hline 1986 & $19,130,711$ & $1,837,552$ & 336,851 & 97,633 & $16,858,675$ & 799,645 & $16,059,030$ & 1.94 \\
\hline 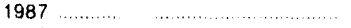 & $20,140,200$ & $2,207,559$ & 376,033 & 123,707 & $17,432,901$ & 812,320 & $16.620,581$ & 167 \\
\hline 1988 & $20,999,255$ & $2,478,382$ & 459,883 & 142,525 & $17,918,465$ & 815,844 & $17,102,621$ & 169 \\
\hline 1989 & $21,074,425$ & $2,475.179$ & $362,45 ?$ & 141,642 & $18,095,147$ & 784,502 & $17,310,645$ & 169 \\
\hline 1990. & $21,522,622$ & $2,489,040$ & 289,374 & 150,415 & 18.593 .792 & 784,118 & $17,809,674$ & 1.71 \\
\hline 1991 & A $21,750,108$ & ค $2,771,928$ & A 275,831 & A 169,909 & ค $18,532,439$ & 834,637 & ค $17,697,802$ & 164 \\
\hline $1992 \ldots \ldots$ & $22,132,249$ & $2,972,552$ & 280,370 & 167,519 & $18,711,808$ & 871,905 & $17,839,903$ & 174 \\
\hline
\end{tabular}

A Revised data.

Nole: Beginning with 1965 data, all volumes are shown on a pressure base of 14.73 psia at 60 degrees Fahrenhelt For prior years, the pressure base is 1465 psia at 60 de. grees Fahrenhelt

Sources: 1930-1975: Bureau of Mines. Minerals Yearbook. "Natural Gas" chapter. 1976-1978 Energy Information Administration (ElA). Energy Data Reports. Natural Gas An. nual. 1979: ElA, Natural Gas Production and Consumption, 1979. 1980-1992. EIA, Form EIA-627, "Annual Quantity and Value of Natural Gas Report," Form EIA-176, "Annual Fie. port of Natural and Supplemental Gas Supply and Disposition." Form ElA.64A. "Annual Report of the Origin of Natural Gas L.quids Production," and Form EIA.816. "Monthiy Natural Gas Liquids Report." 
Figure 16. Natural Gas Supply and Disposition in the United States, 1965-1992

Dry Production

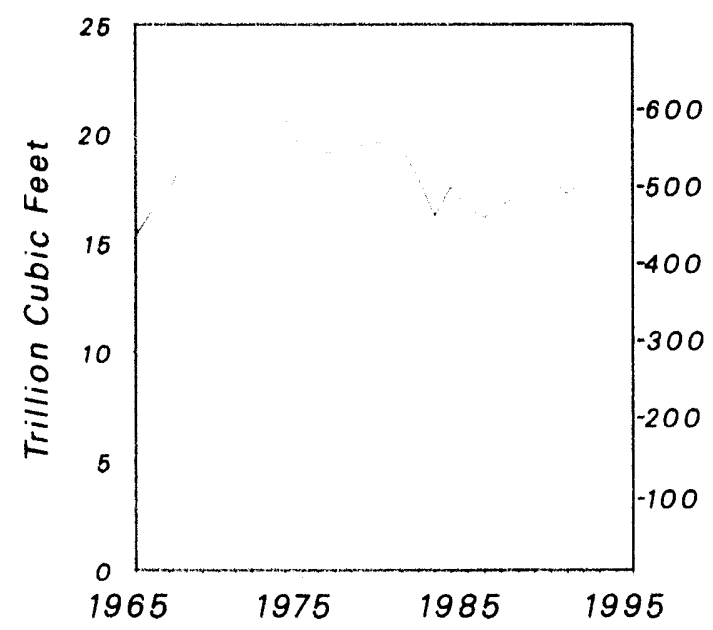

Net Additions to Storage

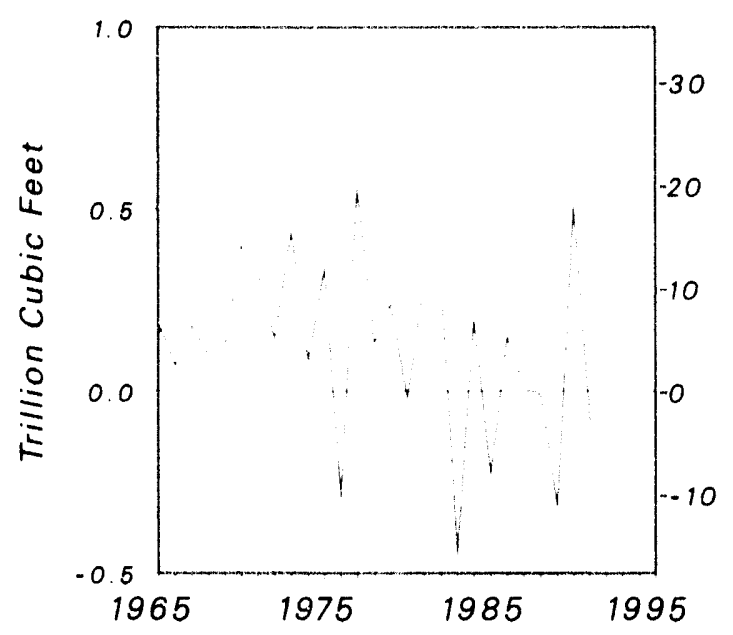

Wellhead Price

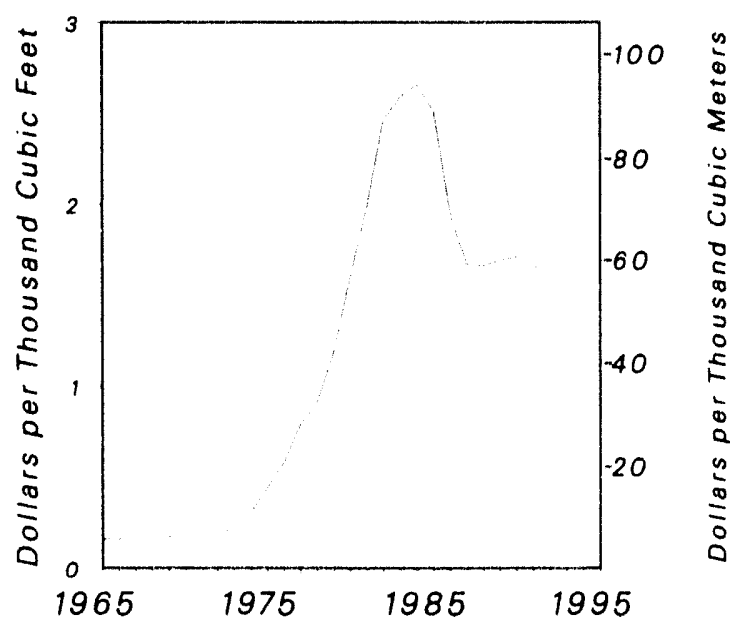

Net Imports

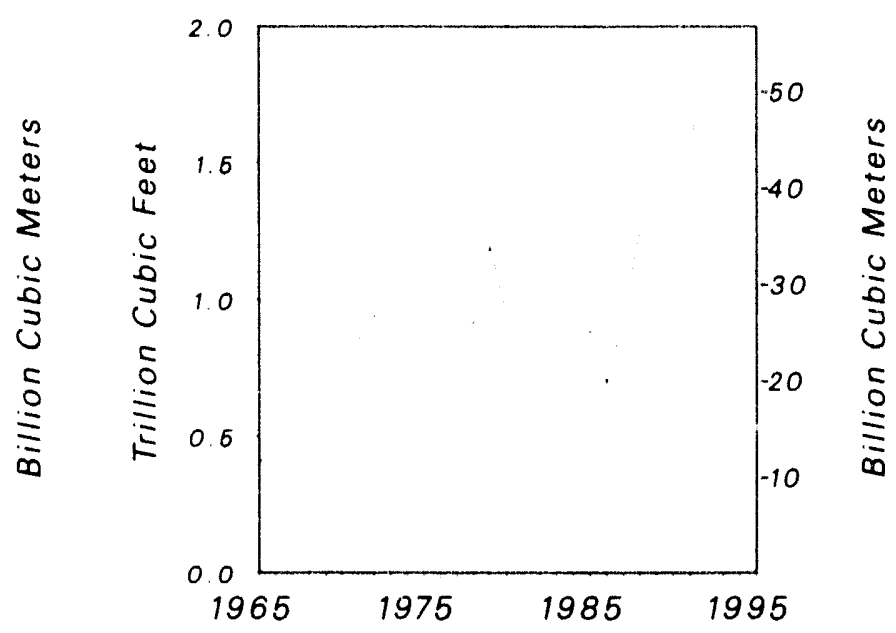

Sources: 1960-1975: Bureau of Mines. Minerals Yearbook. "Natural Gas"chepter. 1976-1978: Energy Information Administration (EIA). Energy Data Reports, Natural Gas Annual. 1979: ElA. Natural Gas Information Administration Supplemental Gas Supply and Disposition. "Forms ElA-191/FERC-8. "Underground Gas Storage Report. and Value of Natural Gas Report"; and Form FPC-14. Annual Report for Importers and Exporters of Natural Gas. 
Table 96. Supply and Disposition of Natural Gas in the United States, 1930-1992 (Million Cubic Feet)

\begin{tabular}{|c|c|c|c|c|c|c|c|c|c|}
\hline \multirow[b]{2}{*}{ Year } & \multicolumn{5}{|c|}{ Supply } & \multicolumn{4}{|c|}{ Disposition } \\
\hline & $\begin{array}{c}\text { Dry } \\
\text { Production }\end{array}$ & $\begin{array}{c}\text { Withdrawals } \\
\text { from } \\
\text { Storage }\end{array}$ & Imports & $\begin{array}{c}\text { Balancing } \\
\text { Item }\end{array}$ & Total & $\begin{array}{c}\text { Additions } \\
\text { to } \\
\text { Storage }\end{array}$ & Exports & Consumption & Total \\
\hline $1930 \ldots \ldots . .$. & $1,903.771$ & NA & 21 & $-35,490$ & $1,868,302$ & 0 & 1,198 & $1,866,504$ & 1.868 .302 \\
\hline $1931 \ldots \ldots \ldots$ & $1,659.614$ & NA & 44 & $-35,466$ & $1,624,192$ & 0 & 2,231 & $1,621,961$ & $1,624.192$ \\
\hline $1932 \ldots$ & $1,541,982$ & NA & 38 & $-37,808$ & $1,504,212$ & 0 & 1,693 & $1,502,519$ & $1,504,212$ \\
\hline $1933 \ldots \ldots$. & $1,548.393$ & NA & 83 & $-41,199$ & $1.507,277$ & 0 & 2.158 & $1,505,119$ & $1.507,277$ \\
\hline $1934 \ldots \ldots \ldots$ & $1,763,606$ & NA & 68 & $-45,075$ & $1,718,599$ & 0 & 5,801 & $1,712,798$ & $1,718,599$ \\
\hline $1935 \ldots \ldots$ & $1,913,475$ & NA & 106 & $-41,074$ & $1,872,507$ & 11,294 & 6,800 & $1,854,413$ & $1.872,507$ \\
\hline $1936 \ldots \ldots .$. & $2,164,413$ & NA & 152 & $-46,677$ & $2,117,888$ & 10,998 & 7,436 & $2,099,454$ & $2,117,888$ \\
\hline $1937 \ldots \ldots \ldots$ & $2,403,273$ & NA & 289 & $-52,157$ & $2,351,405$ & 13.706 & 4,868 & $2,332,831$ & $2,351,405$ \\
\hline $1938 \ldots \ldots$ & $2,284,863$ & NA & 372 & $-47,658$ & $2,237,577$ & 14,981 & 1,837 & $2,220,759$ & $2,2977.577$ \\
\hline 1939 & $2,464,637$ & NA & 131 & $-53,595$ & 2.411 .173 & 8,032 & 3.122 & $2,400,019$ & 2.411 .173 \\
\hline 1940 & $2.654,293$ & NA & 0 & $-58,602$ & $2,595.691$ & 14,995 & 5.563 & $2,575,133$ & $2,595,691$ \\
\hline $1941 \ldots$ & $2,778,061$ & NA & 0 & $-64,616$ & $2,713,445$ & 16,251 & 7.466 & $2,689,728$ & $2,713,445$ \\
\hline $1942 \ldots \ldots \ldots$ & $3,026,694$ & NA & 0 & $-71,195$ & $2,955.499$ & 21,024 & 8,702 & $2,925,773$ & 2.955 .499 \\
\hline $1943 \ldots \ldots \ldots$ & $3,393,743$ & NA & 0 & $-81,889$ & $3,311,854$ & 18,953 & 11,210 & $3,281,691$ & $3,311,854$ \\
\hline $1944 \ldots \ldots .$. & $3,672,156$ & 33,585 & 0 & $-94,068$ & $3.611,673$ & 43,502 & 14,576 & $3,553,595$ & $3,611,673$ \\
\hline 1945 & $3,882,066$ & 36.167 & 0 & $-97,981$ & $3,820,252$ & 61.502 & 18,207 & $3.740,543$ & $3,820,252$ \\
\hline $1946 \ldots$ & $3.987,488$ & 56,138 & 0 & $-102,837$ & $3,940,789$ & 75.458 & 17.675 & $3,847,656$ & $3,940,789$ \\
\hline $1947 \ldots$ & $4,393,439$ & 86,643 & 0 & $-127,807$ & $4,352,275$ & 96,316 & 18.149 & $4,237,810$ & 4.352 .275 \\
\hline $1948 \ldots \ldots \ldots$ & $4,938,512$ & 79.035 & 0 & $-126,796$ & $4,890,751$ & 136,406 & 18,704 & $4,735,641$ & $4,890,751$ \\
\hline $1949 \ldots \ldots$. & $5.195,404$ & 106,368 & 0 & $-1.38,515$ & $5,163,257$ & 172,051 & 20,054 & $4,971,152$ & $5,163,257$ \\
\hline $1950 \ldots \ldots$ & $6,022,198$ & 175,260 & 0 & $-175,437$ & $6,022,021$ & 229.752 & 25.727 & 5.766 .542 & $6,022,021$ \\
\hline $1951 \ldots \ldots$ & $7.164,959$ & 209,428 & 0 & $-192,372$ & $7,182.015$ & 347.690 & 24,163 & $6,810,162$ & 7.182 .015 \\
\hline 1952 & $7,694,299$ & 221,909 & 7,807 & $-203,646$ & 7.720 .369 & 398,593 & 27,456 & $7,294.320$ & $7,720.369$ \\
\hline $1953 \ldots \ldots$ & $8,056,848$ & 246,802 & 9,225 & -240.445 & 8.072 .430 & 404,838 & 28,322 & $7,639.270$ & $8,072,430$ \\
\hline $1954 \ldots \ldots$ & $8,388,198$ & 330.177 & 6.847 & $-215,709$ & $8.509,513$ & 432,283 & 28.726 & $8,048,504$ & $8,509,513$ \\
\hline $1955 \ldots \ldots$ & $9.028,665$ & 437.251 & 10,888 & $-246,933$ & $9,229,871$ & 505,185 & 31,029 & $8,693,657$ & $9,229,871$ \\
\hline 1956 & $9,663,910$ & 452,762 & 10,380 & $.212,992$ & $9,914,060$ & 589,232 & 35,963 & $9,288,865$ & $9,914,060$ \\
\hline $1957 \ldots \ldots$ & $10,246,622$ & 480,981 & 37,941 & $-205,373$ & 10.560 .171 & 672,377 & 41,655 & 9.846 .139 & $10,560.171$ \\
\hline $1958 \ldots \ldots$ & $10,572,208$ & 621,091 & 135,797 & 283,597 & $11,045,499$ & 704.172 & 38,719 & $10.302,608$ & $11,045,499$ \\
\hline $1959 \ldots$ & $11,547,658$ & 668.743 & 133,990 & -223.312 & 12.127 .079 & 787,485 & 18.413 & $11,321,181$ & $12,127,079$ \\
\hline $1960 \ldots$ & $12,228,148$ & 712.658 & 155,646 & -274.231 & $12,822,221$ & 844,352 & 11,332 & $11,966,537$ & $12,822,221$ \\
\hline 1961 & $12,661.579$ & 698.050 & 218.860 & $\sim 234,808$ & $13,343,681$ & 843.666 & 10,747 & $12,489,268$ & $13,343,681$ \\
\hline $1962 \ldots \ldots$ & $13,253,006$ & 854,336 & 401.534 & $-285,726$ & $14,223,150$ & 940,823 & 15,814 & $13,266,513$ & $14,223,150$ \\
\hline $1963 \ldots \ldots$ & $14,076,412$ & 916,720 & 406.204 & $-364,658$ & $15,034,678$ & $1,047,492$ & 16.957 & $13,970,229$ & $15,034,678$ \\
\hline $1964 \ldots \ldots$ & $14,824,027$ & 885,307 & 443,326 & $-304,435$ & $15,848,225$ & $1,014,814$ & 19,603 & $14,813,808$ & $15,848,225$ \\
\hline 1965 & $15,286,280$ & 959,865 & 456,394 & $-318,711$ & $16,383,828$ & $1,077,980$ & 26,132 & 15.279 .716 & $16,383,828$ \\
\hline 1966 & $16,467,320$ & $1,141,614$ & 479.780 & -401.203 & 17.687 .511 & $1,210,469$ & 24.639 & $16,452,403$ & $17,687,511$ \\
\hline $1967 \ldots \ldots$ & $17,386,791$ & 1.132 .534 & 564.226 & $-296,214$ & 18.787 .337 & $1,317,363$ & 81,614 & $17,388,360$ & $18,787,337$ \\
\hline $1968 \ldots \ldots$ & $18,494,523$ & $1,329,536$ & 651,885 & -325.062 & $20,150.882$ & $1.425,075$ & 93,745 & 18.632 .062 & $20,150,882$ \\
\hline 1969 & $19,831,680$ & $1,379,488$ & $T 26.951$ & $-334,168$ & $21,603,951$ & $1,498,988$ & 51,304 & 20.056 .240 & $21,606.532$ \\
\hline $1970 \ldots$ & $21,014.229$ & $1,458,607$ & 820,780 & $-227,650$ & $23.065,966$ & $1,856,767$ & 69.813 & $21,139,386$ & $23,065.966$ \\
\hline 1971 & $21,609,885$ & $1,507,630$ & 934,548 & $-338,999$ & 23.713 .064 & $1,839,398$ & 80,212 & $21,793,454$ & $23,713,064$ \\
\hline 1972 & $21,623,705$ & $1,757.218$ & $1,019,496$ & $-328,002$ & $24,072,417$ & $1,892,952$ & 78.013 & $22,101,452$ & $24,072,417$ \\
\hline $1973 \ldots$ & $21,730,998$ & $1,532.820$ & $1,032,901$ & $-195,863$ & $24,100,856$ & $1.974,324$ & 77.169 & $22,049,363$ & $24,100,856$ \\
\hline $1974 \ldots \ldots$ & $20,713,032$ & 1.700 .546 & 959.284 & .288 .731 & 23.084 .131 & $1,784,209$ & 76,789 & $21,223,133$ & $23,084,131$ \\
\hline $1975 \ldots$ & $19,236.379$ & $1,759.565$ & 953,008 & $-235,065$ & $21.713,887$ & 2.103 .619 & 72.675 & 19.537 .593 & $21,713,887$ \\
\hline $1976 \ldots$ & $19,098.352$ & $2,059,898$ & 963,768 & -216.240 & $21,905,778$ & $1.755,690$ & 64.711 & $19,946,496$ & $21,766,897$ \\
\hline $1977 \ldots$ & $19,162,900$ & $1,735,868$ & $1.011,002$ & $-41,063$ & $21,868,707$ & $2,306,515$ & 55,626 & $19,520,581$ & $21,882,722$ \\
\hline $1978 \ldots$ & $19,121,903$ & $2,150,928$ & 965,545 & $-287,201$ & $21.951,175$ & $2,278,002$ & 52,532 & $19,627,478$ & $21,958,012$ \\
\hline $1979 \ldots \ldots$ & $19,663,415$ & $2,057,020$ & 1.253 .383 & -372.330 & $22,601,488$ & $2,295,034$ & 55,673 & $20.240,161$ & $22,591,468$ \\
\hline $1980 \ldots \ldots$ & $19,557,709$ & $1,972,333$ & 984,767 & -639.721 & $21,875,088$ & $1,949,064$ & 48,731 & $19,877,293$ & $21,875,088$ \\
\hline $1981 \ldots \ldots . .$. & $19,356,963$ & $1,930,092$ & 903,949 & $-500,444$ & $21,690,560$ & $2,227.522$ & 59,372 & $19,403,858$ & 21.690 .752 \\
\hline $1982 \ldots \ldots$ & $17,964,874$ & $2,164.184$ & 933,336 & $-537,061$ & 20.525 .333 & $2,472.383$ & 51,728 & $18,001,055$ & $20,525,166$ \\
\hline $1983 \ldots \ldots \ldots$ & $16,226,355$ & $2,269,654$ & 918,407 & $-703,342$ & $18.711,074$ & $1,822.354$ & 54,639 & $16,834,914$ & $18,711,907$ \\
\hline $1984 \ldots \ldots$ & $17,576,449$ & $2,098,303$ & 843,060 & $-217,308$ & $20,300,504$ & $2,295,138$ & 54,753 & $17,950,524$ & $20,300,415$ \\
\hline 1985 & $16,580,220$ & $2,397,359$ & 949,715 & $-428,120$ & $19,499,174$ & 2.162 .603 & 55,268 & $17,280,943$ & $19,498,814$ \\
\hline $1986 \ldots \ldots$ & $16,172,219$ & $1,836,693$ & 750,449 & -494.491 & $18,264,870$ & $1,983,603$ & 61,271 & $16,221,296$ & $18,266,170$ \\
\hline $1987 \ldots \ldots$ & $16,721,963$ & $1,905,419$ & 992,532 & -443231 & $19.176,683$ & $1,911,489$ & 54,020 & $17,210,809$ & $19.176,318$ \\
\hline $1988 \ldots \ldots . .$. & $17,203,755$ & $2,270,011$ & $1,293,812$ & $-452,492$ & $20,315,086$ & $2,211,277$ & 73,638 & $18,029,588$ & $20,314,503$ \\
\hline 1989 & $17,417,390$ & $2,854,061$ & $1,381,520$ & -217.526 & $21,435,445$ & $2.527,7,50$ & 106,871 & $18,800,826$ & $21,435,447$ \\
\hline $1990 \ldots \ldots . .$. & $17,932,480$ & $1,986.330$ & $1,532,259$ & $-151,863$ & $21,299,206$ & $2,499,264$ & 85,565 & $18,715,090$ & $21,299,919$ \\
\hline $1991 \ldots \ldots . . .$. & $17,810,408$ & $2,751,818$ & $1,773,313$ & A $-499,779$ & $21,835,760$ & $2,671,632$ & 129,244 & R $19,035,156$ & A $21,836,032$ \\
\hline 1992 & $17,957,822$ & $2,772,308$ & $2.137,504$ & $-507,565$ & $22,360,069$ & $2,599,426$ & 216,282 & $19,544,364$ & $22,360,072$ \\
\hline
\end{tabular}

A Revised dala.

Note: Prior to 1980 dry production and consumption volumes did not include supplemental gas supplies. and storage volumes did not include liquelied natural gas (LNG) Begin ning with 1976 data. total supply and disposition do not balance on equivalent data in Table 1 due to the exclusion of intransit receipts and deliveries. Beginning with 1965 data. all volumes are shown on a pressure base of 1473 psia at 60 degrees Fahrenheit. For prior years, the pressure base is 14.65 psia at 60 degrees Fahrenheit

Sources: 1930-1975: Bureau of Mines, Minerals Yearbook. "Natural Gas" chapter. 1976-1978: Energy Intormation Administration, ElA), Energy Data Reports, Natural Gas Annual 1979: ElA, Natural Gas Production and Consumption 1979. 1980-1992. ElA, Form ElA-176. "Annual Report of Natural and Supplemental Gas Supply and Disposition," Form EIA-191. "Underground Gas Storage Report," Form EIA-64A, "Annual Feport of the Origin of Natural Gas Liquids Production," Form ElA-627, "Annual Ouantity and Value of Naturat Gas Report," Form ElA-191, "Underground Gas Storage Feport," and the Form FPC-14, "Annual Heport for Importers and Exporters of Natural Gas." 
Figure 17. Natural Gas Delivered to Consumers in the United States, 1930-1992

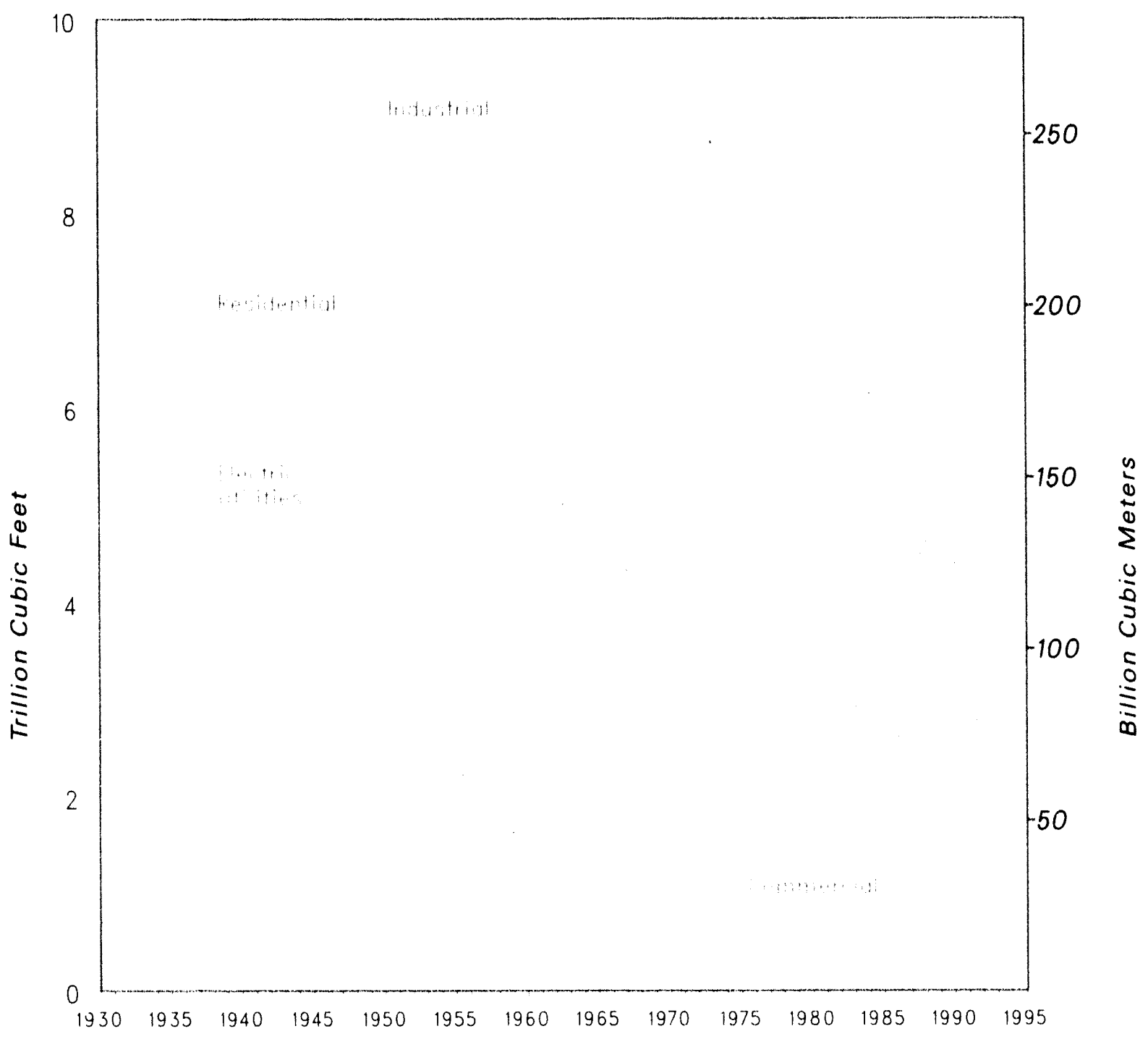

Sources: 1930-1975: Bureau of Mines, Minerals Yearbook. "Natural Gas" chapter. 1976-1978: Energy Information Administration (E|A). Energy Data Reports, Natural Gas Annual. 1979: ElA, Natural Gas

Production and Consumption, 1979. 1980-1992: Form ElA-176. "Annual Report of Natural and

Supplemental Gas Supply and Disposition," and Form ElA-759. "Monthly Power Plant Report." 
Table 97. Natural Gas Consumption in the United States, 1930-1992 (Million Cubic Feet)

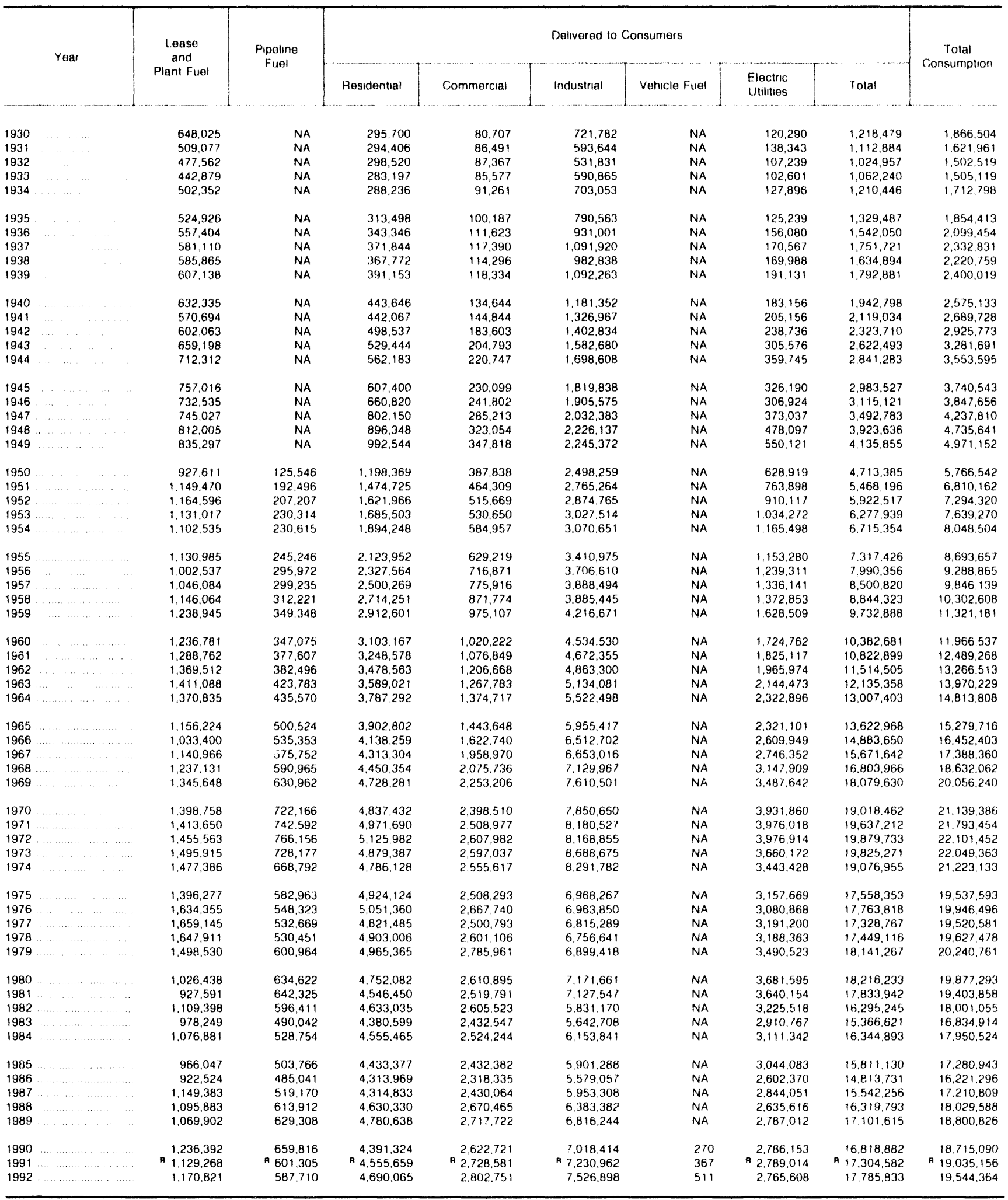

R. Revised data.

Note: Beginning with 1965 data, all volumes are shown on a pressure base of 14.73 psia at 60 degrees Fahrenheit. For prior years. the pressure base is 1465 psia at 60 de grees Fahrenheit. Number of vehicle tuel consumers generally reters to the number of fueling stations

Sources: 1930-1975: Bureau of Mines. Minerals Yearbook, "Natural Gas" chapter. 1976-1978. Energy Intormation Administration (ElA), Energy Data Reports. Natural Gas An. nual 1979. ElA, Natural Gas Production and Consumption, 1979. 1980-1992. ElA, Form EIA-176, "Annual Report of Natural and Supplemental Gas Supply and Disposition," and the Form EIA.759. "Monthly Power Plant Report." 
Figure 18. Average Price of Natural Gas Delivered to U.S. Consumers, 1967-1992

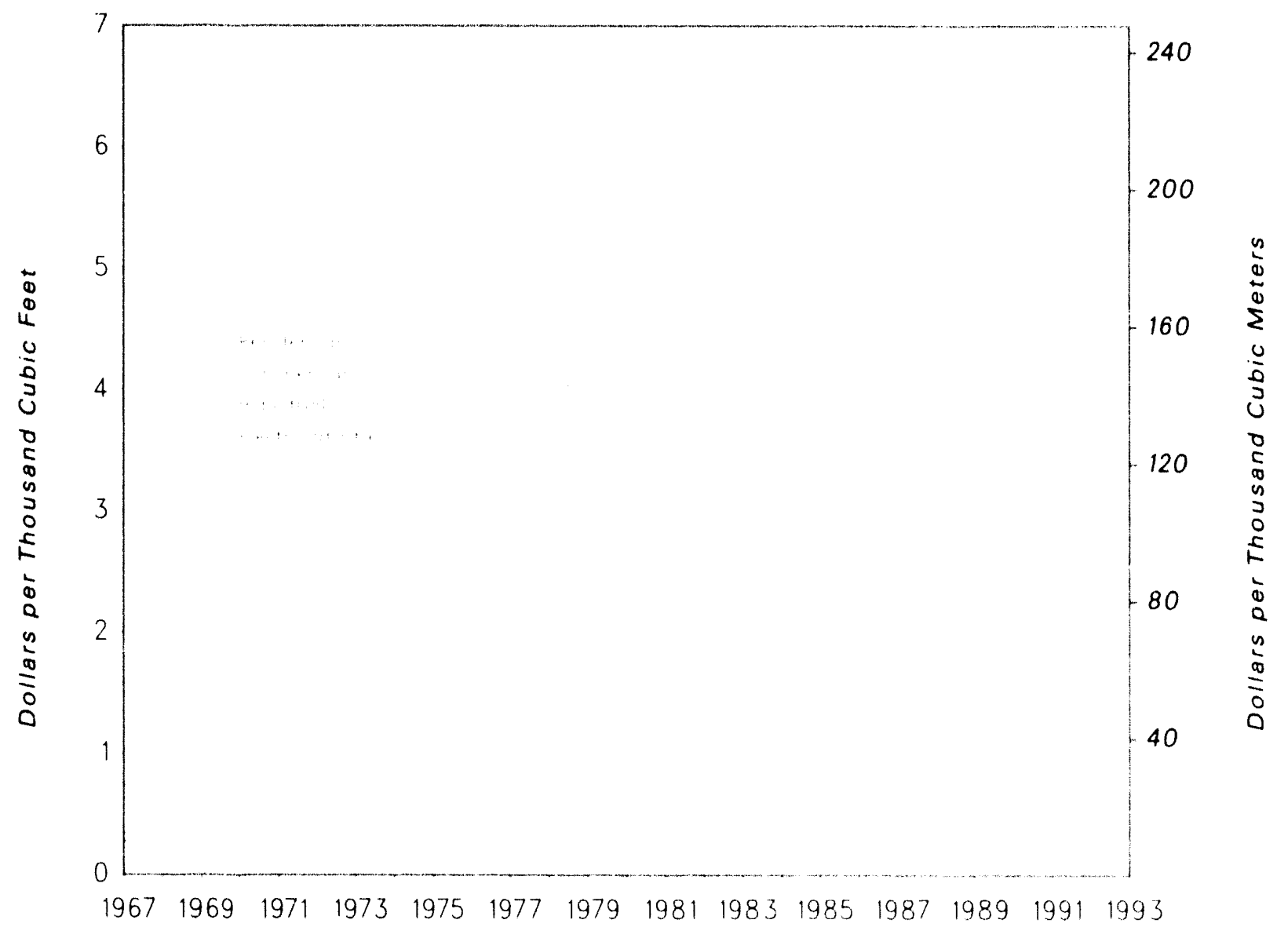

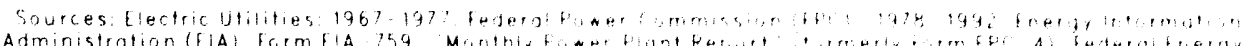

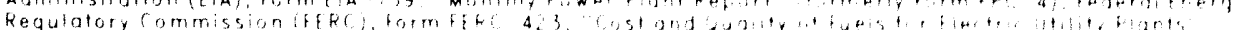

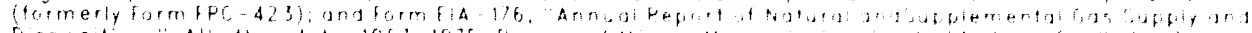

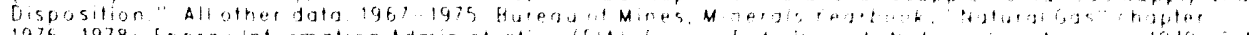

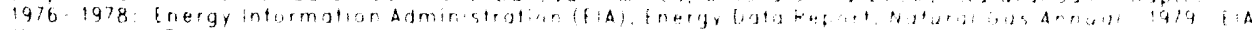

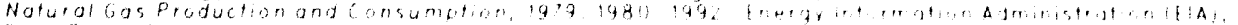

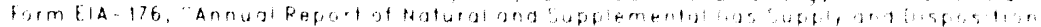


Table 98. Average Price of Natural Gas Consumption in the United States, 1967-1992 (Dollars per Thousand Cubic Feet)

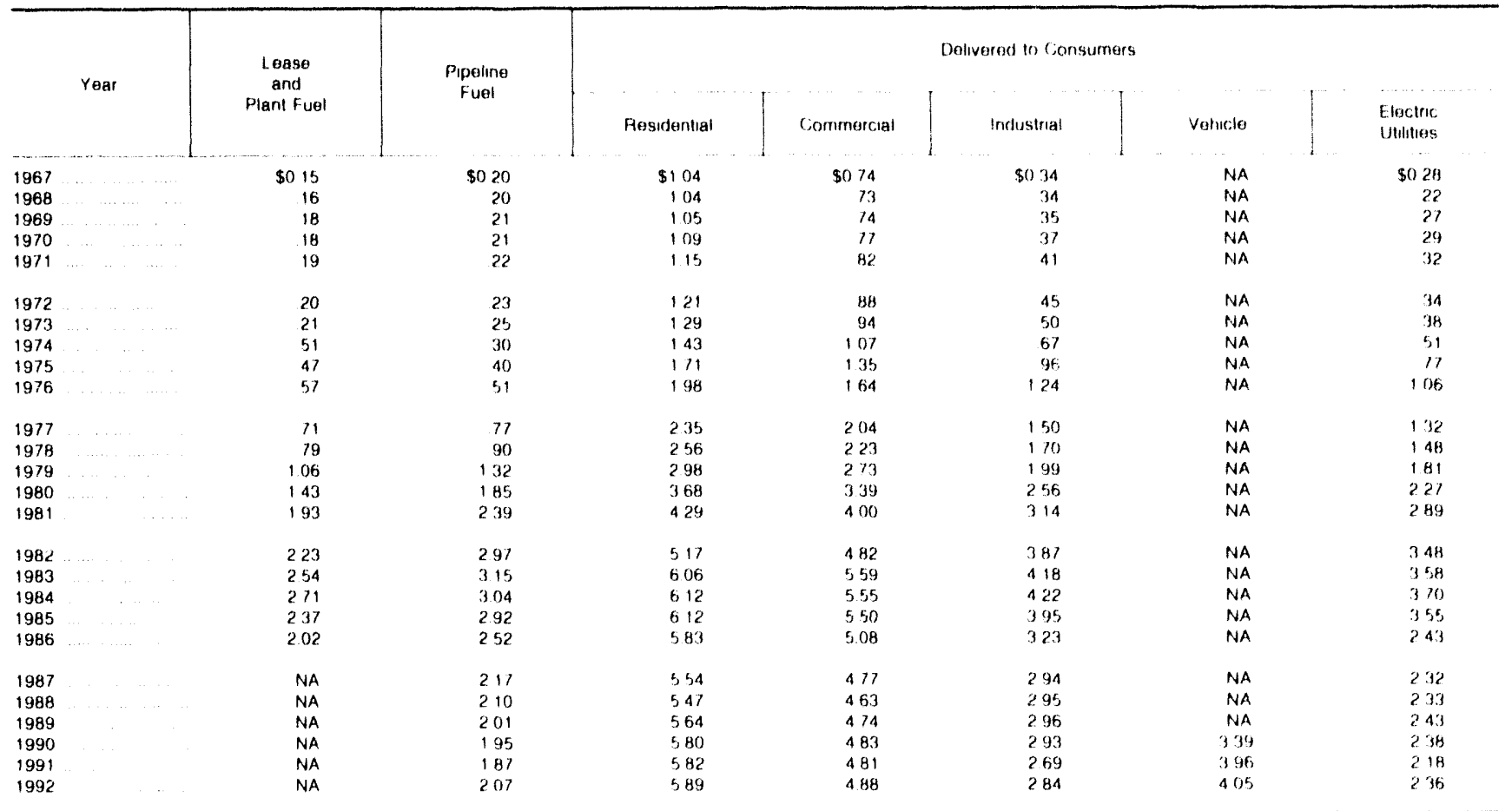

Revised data

Note Beginning in 1987. prices for deliveries to consumers are calculated using only onsystem sales data Dug to large amounts of missiric data for values of leases and plant fuel since 1987. prices are not estimated in previous years. imputations were made for missing dala and a price was calculated using reported and imputed data to derive a total value for gas consumed Since total consumption value estumates were not made since 1987 no lease and plant fuel value estimate was made

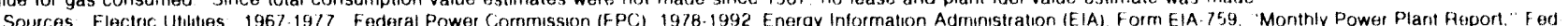
erai Energy Regulatory Commission (FEAC). Form FEAC.423. "Cost and Quality of Fuels lor Electric Uthty Plants." and Form EIA 176 , "Anrual Report of Natural and Supplemental Gas Supply and Disposition" All other data 1967.1975 Bureau of Mines, Minela/s Yearbook. "Natural Gas" chapter 1976.1978. Energy intormation Arjministration, Energy Data Report. Natural Gas Annual 1979 Energy Intormation Administration. Natural Gas Production and Consumption 197919801992 Energy Information Adrministration (E.IA). Form ElA-176. "Annual Report of Nalural and Supplemental Gas Supply and Disposition 


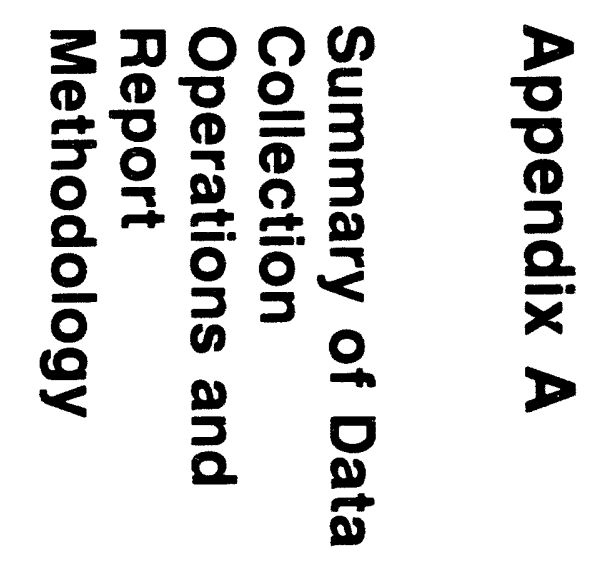




\section{Summary of Data Collection Operations and Report Methodology}

The 1992 data for the Vatural Gas Annual are taken primarily from Form EIA-176, "Annual Report of Natural and Supplemental Gas Supply and Disposition," and Form EIA-627, "Annual Quantity and Value: of Natural Cias Report." Fach of these surveys and all other sources of data for this report are discussed separately in the following sections

\section{Form EIA-176}

\section{Survey Design}

The original version of Form EIA-176 was approved in 1980 with a mandatory response requirement. Prior (1) 1980, published data were hased on voluntary responses to Bureau of Mines, U.S. Department of the Interior predecessor Forms B(3)-6-1341)-A and BO( )M-6-1341-A of the same title.

In 1982, the scope of the revised EIA-176 survey was expanded to collect the number of electric utility consumers in each State, volumes of gas transported to industral and electric utility consumers, detailed information on volumes transported across State horders by the respondent for others and for the responding company, and detailed information on other disposition. These changes were incorporated to provide more complete survey information with a minimal change in respondent burden. The 1982 revision of the Form EIA-176 continues lo be the basis for the current version of this form.

In 1988. the Form EIA-176 was revised to include data collection for deliveries of natural gas 10 commercial consumers for the accotent of others. The revised form was approved for use during reporl years 1987 through 1989. A short version of Form EIA-176 was also approved in 1988. Companies engaged in purchase and delivery activities but not in transportation and storage activities may file the short form. Ustally, these companies are municipals handling small volumes of gas
In 1990, the form 1:IA-176 was revised (1) include more detailed information for gas withdrawn from storage facilities, gas added to storage facilities, deliveries of company-owned natural gas and natural gas transported for the account of others. The revised form was approved for use beginning with report year 1990 . Data reported on this form are no longer considered proprietary. Response to the form continues to be mandatory

In February 1993, forms for report year 1992 were mailed to all identafied interstate natural gas pipeline companies; intrastate natural gas pipeline companies; investor and municipally owned natural gas distributors; underground natural gas storage operators; synthetic natural gas plant operators; field, well, or processing plant operators that deliver natural gas directly fo consumers (including their own industrial facilities) other than for lease or plant use or processing; and field, well, or processing-plant operators that transport gas (o, across, or from a State border through field or gathering facilities. Detailed instructions for completing the form were included in each survey package. Completed forms were returned to the Data (Operations Branch of the Reserves and Natural Gas Division, where each was checked for errors, corrected as necessary, and processed into computer-generated State and national data summaries.

\section{Response Statistics}

Each company and its parent company or subsidiaries were required to file if they met the survey specifications. The original mailing totaled 2,104 questionnaire packages. To this original mailing, six names were added and forty six were deleted as a result of the survey processing. Additions were the result of eomparisons of the mailing list to other survey mailing lists. Deletions result from post oflice returns and determinations that companies were out of husiness, sold, or not within the scope of the survey. After all updates, the survey universe was 2,064 responses from approximately $1,8(x)$ companies. 
Following the original mailing, second request mailing, and nomrespondents followup, 2,056 respenses were entered inte the data base. There were elght nonrespondents.

\section{Summary of Form EIA-176 Data Reporting Requirements}

The Form E:IA-17t is a five-page form comsisting of seven parts. Part I of the form contans identifying information including the company identification number, the company name and address, the State for which the report is filed, and address correction information. Part 11 is certification information. The body of the form ('arts III-VII) is a multiline schedule for reporting all supplies of natural gas and supplemental gaseous fuels and their disposition withen the State indicalcil.

Respondents filed completed forms with the lis in Washinglon, D.( Data for the year 1992 were due April 1.1903

Computer edit programs verified the report sear, State code. and arithenctic telats. Further tests were made to ensure that all necessary data elements were present and that the data were reasonable and intermally consistent. The computerized edit system produced error listings with messages for each failed edit test. To resolve problems, respondents were contacted by telephone and were required to file amended forms with corrected datat.

All natural gas and supplemental gaseous fuels volumes were reporfed on a physical custody hasis in thousand cubic leet, and dollar values were reported to the nearest whole dollar. All volumes were reported at 14.73 pounds per square inch absolute (psia) pressure and o() degrees Fahrenkeit. Other minor report standards were specified in the instructions booklet to assure that the filed data were consistent and could be readily proecessed

\section{Comparison of the Form EIA-176 with Other Lata Sources}

Comparison of the E IA - 176 data with data from similar series is another method of ensuring the validity of the data published in this report. This comparison on a company - by -company hasis showed signilicant differ. ences that respondents were required to reconcile.

Data on imports and exports of natural gas, as collecled by the VIA-176 survey, were checked by comparing individual responses with the mandatory submissions of Form lil' - 14 , "Anmual Report for Importers and Exporters of Natural (ias." Where discrepancies were noted, respondents were required an file corrected reports.

Similarly, dala on the underground storage of natural gas were compared with submissions of form I:IA- I91. "Inderground (ias Storage Report." If significant differences were noted, companies were contacted to rece oncile the discrepancies. During 1992, the 92 companies filing the form IIA-IUI reported fotal injections of 2.479 billion cubic feet and total withdrawals of 2,256 billion cubic fect. This compares 102,555 billion cubic feet of injections and 2,724 billion cubic feed of withdrawak, as reported on the form 1:IA-176

Data on deliveries to residential, commercial, and industrial ensumers were compared with data submitled (n) Form VIA-857, "Monthly Report of Natural Cias Purchases and Deliveries lo Consumers." Where discrepances were noted, respondents were required to file corrected reports for cither and sometimes both surveys. Numerous telephone calls were made fo clarify any misunderstandings concerning the correct filing of both forms. lypical errors included electric utility volumes combined with industrial volumes, sale for resale volumes reported as industrial consumption, cogeneration volumes not reported on Form I:IA-857, and misinferpedation of general instructions.

A discussion of the eomparisen of the data on deliveries (1) electric utilities filed on form 1:IA-176 and that reported in the I IA publication, Electric Power Annual, is included in this Appendix under "Flectric Utility Datia."

\section{Routine Form ElA-176 Edit Checks}

A series of manual and computerized edit checks was used loscreen the Iorm EIA-176. The edits performed included validity, arithmetic, and analytical checks. A computerized check was also made for comsistency with previous lilings.

The incoming forms for the survey were reviewed prior 10 keying. This prescan determined if the respondent identification (II)) number and the company name and address were correct, if the data on the form appeared complete and reasonable, and if the certifying information were complete

Mantalchecks on the data were also made. Lach form was prescanned to determine that data were reported on the correct lines. The how of gas through interstate pipelines was checked at the company level to assure that each delivery from a state was matched with a corresponding recoipt in an adjoming Stale. 
Figure A1. Form EIA-176

ElA 176 \{Revised 1991)

U.S. DEPARTMENT OF ENERGY

Form Approvers OMB No, 19050115 ENERGY INFOHMATION ADMINISTRATION

Expres $12 / 31: 93$

ANNUAL REPORT OF NATURAL AND SUPPLEMENTAL GAS SUPPLY AND DISPOSITION, $19 \square$

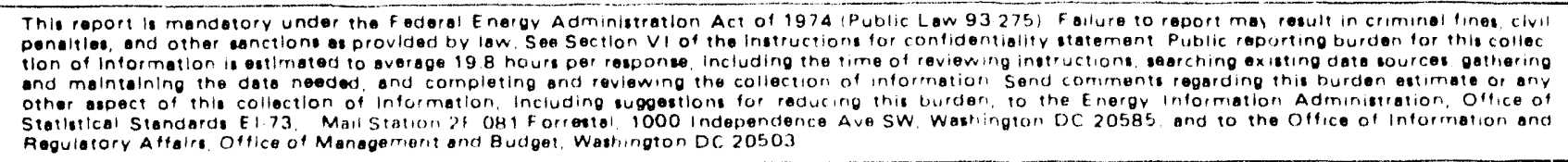

EIA USE

RESPONDENT COPY.

Retain for your files

Alfix maling latel or enter mall address

Control (10) No

Name

Operations in (State)

Street or Post Office Box

Cily. State, Zip Code

Altention

PART I IDENTIFICATION

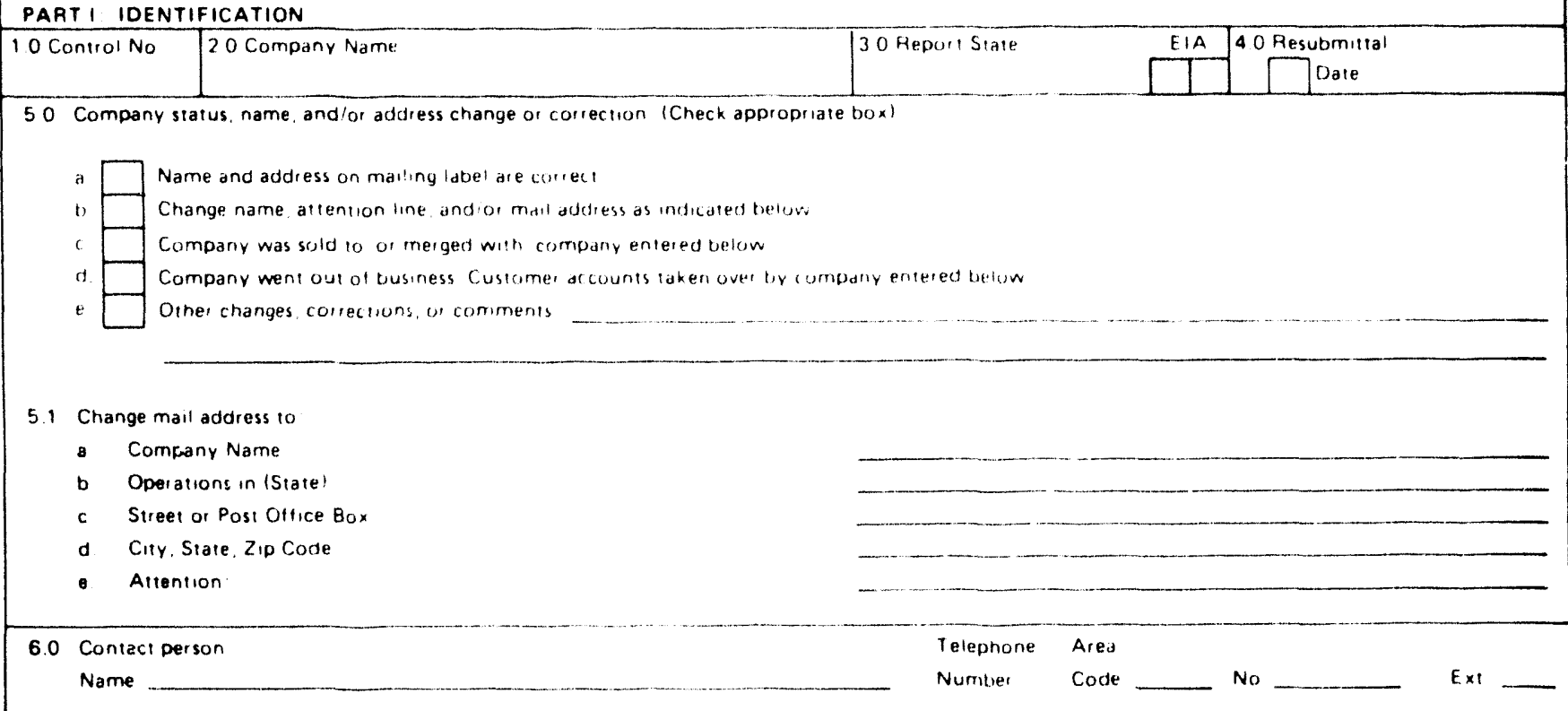

PART II: CERTIFICATION AND DISCLOSURE STATEMENT

1.0 I certify that (Check appropriate box)

a. The information provided herein and appended hereto is true and accurate or, where indicated on the form. reasonable estimates to the best of my knowledge

b. My company does not meet any of the criteria set forth in Section II. "Who must submit," of the instructions and is therefore not required to complete and submit a Form EIA-176 for the repon State.

\begin{tabular}{|l|l|}
\hline 2.0 Name & 3.0 Title \\
\hline 4.0 Signature & 5.0 Date
\end{tabular}

Title 18, USC 1001, makes it a crime for any person knowingly and willingly to make to any agency or department of the United States any false, fictitious or traudulent statements as to any matter within its jurisdiction. 
EIA.176, ANNUAL REPORT OF NATURAL AND SUPPLEMENTAL GAS SUPPLY AND DISPOSITION, 19

\begin{tabular}{|l|l|l|l|}
\hline 1.0 Control No. & 2.0 Company Nome & 3.0 Report State & Ela Resubmittal \\
\hline
\end{tabular}

\begin{tabular}{|c|c|c|c|c|c|c|}
\hline $1.0 \mathrm{~T}$ & Type of Company (check one) & \multirow{2}{*}{\multicolumn{2}{|c|}{$\begin{array}{r}2.0 \\
0 \\
\end{array}$}} & \multicolumn{3}{|c|}{$\begin{array}{l}\text { Gas Activities Operated On-system Within the Report State } \\
\text { (check all that apply) }\end{array}$} \\
\hline - & Investor owned distributor & & a & Produced Natural Gas & $m$ & Delivered for Ressale \\
\hline b & Municipally owned distributor & & $\mathrm{b}$ & Gathered & $n$ & Delivered directiy \\
\hline c & Interstate pipeline & & c & Processed & & 10 consumers \\
\hline d & Intrastate pipeline & & d & Purchased & 0 & Other (specify) \\
\hline - & Storege operator & & e & Transported Interstate & & \\
\hline 1 & SNG plent operator & & 1 & Transported Intrastate & & \\
\hline 0 & Integrated oil and gas & & g & Stored Underground & & \\
\hline n & Producer & & h & Stored LNG & & \\
\hline i & Gutherer & & 1 & Injected Propane-air & & \\
\hline i & Procossor & & 1 & Produced SNG & & \\
\hline$k$ & Other (specify) & & k & Imported & & \\
\hline & & & 1 & Exported & & \\
\hline
\end{tabular}

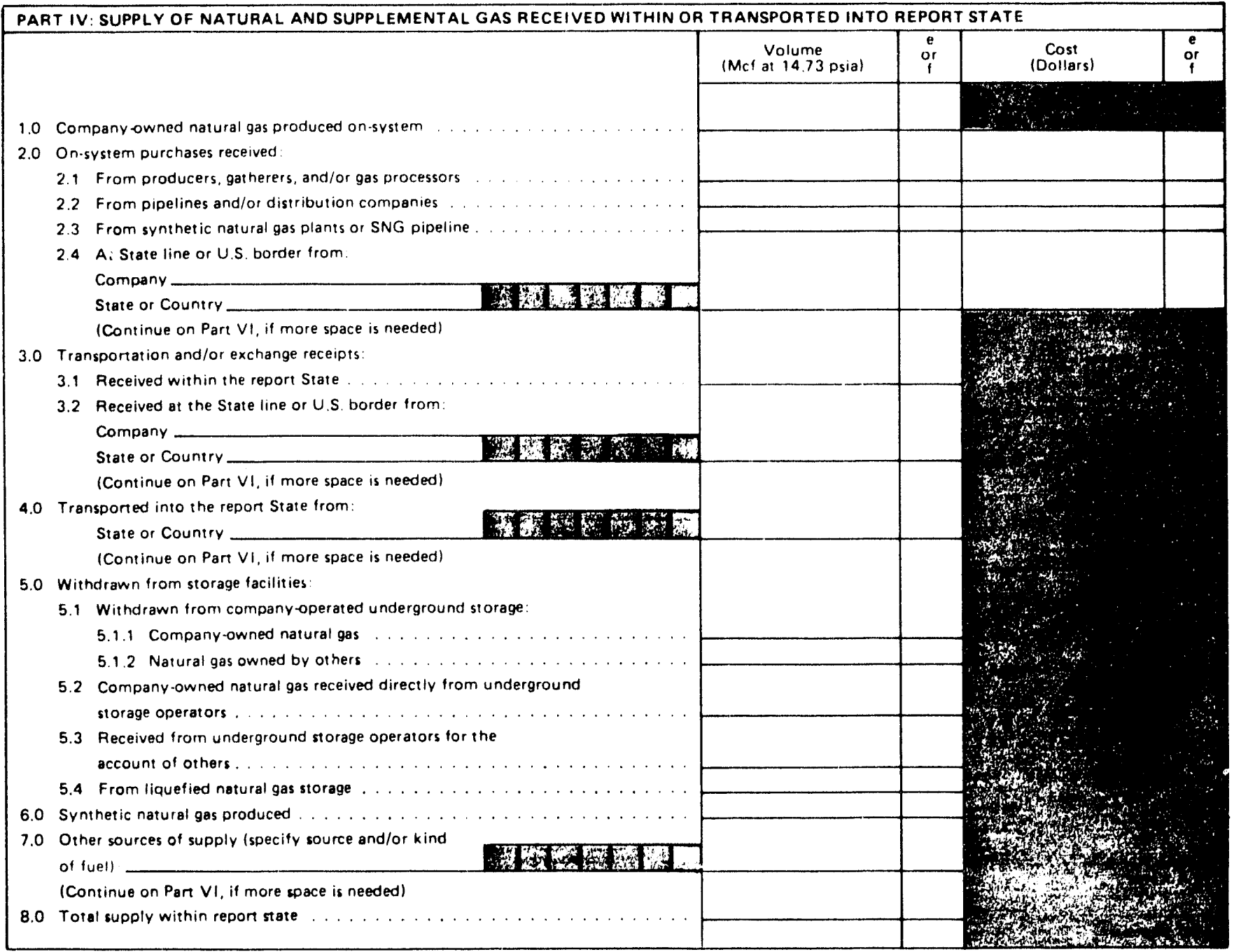


EIA-176, ANNUAL REPORT OF NATURAL AND SUPPLEMENTAL GAS SUPPLY AND DISPOSITION, 19

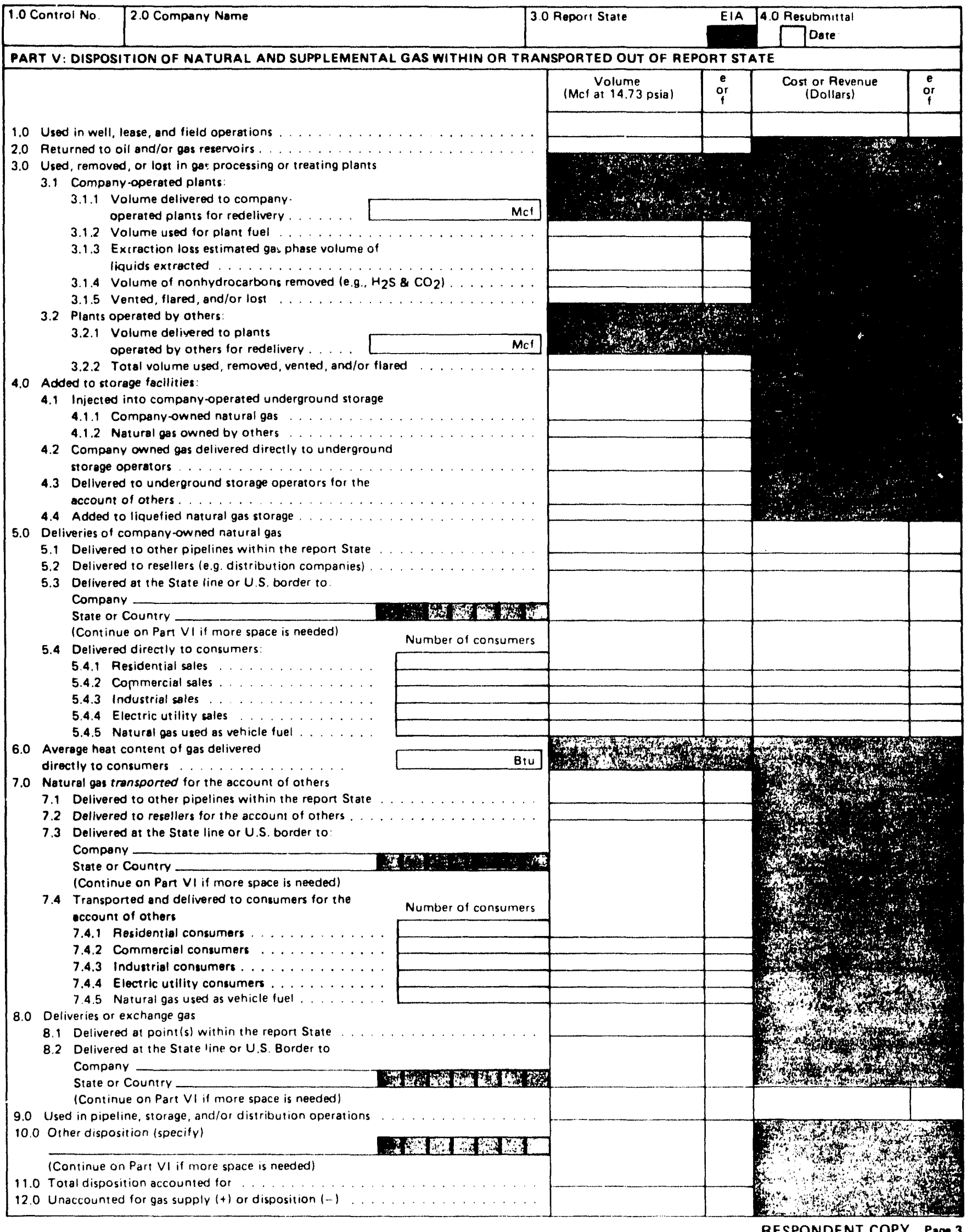


EIA.176, ANNUAL REPORT OF NATURAL AND SUPPLEMENTAL GAS SUPPLY AND DISPOSITION, 19

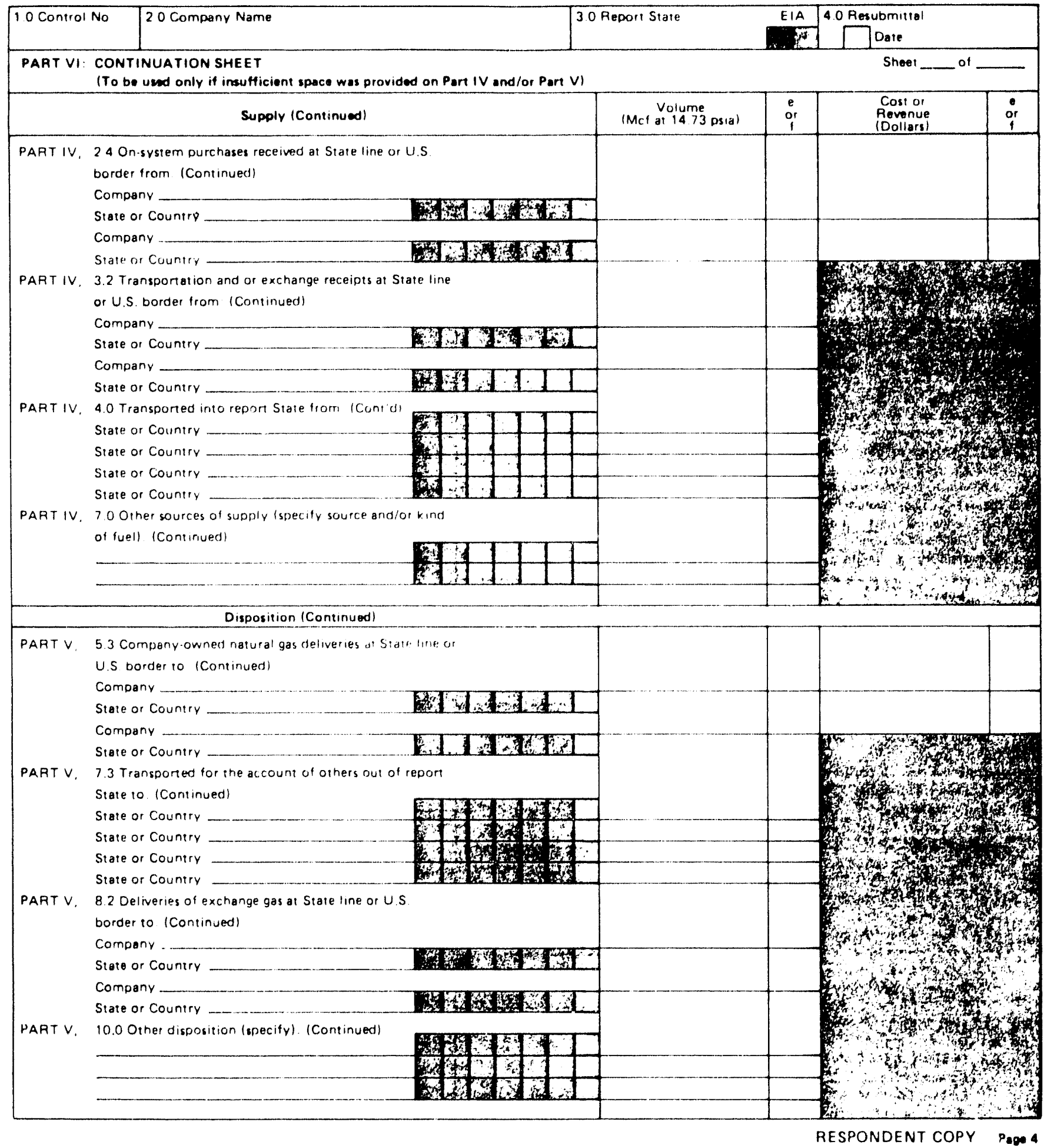


EIA-176, ANNUAL REPORT OF NATURAL AND SUPPLEMENTAL GAS SUPPLY AND DISPOSITION, 19 प

\begin{tabular}{|c|c|c|c|c|}
\hline 1.0 Control No. & 2.0 Compeny Nems & 3.0 Report Stote & $E \mid A$ & $\begin{array}{l}\text { 4.0 Resubmittal } \\
\text { DDate: }\end{array}$ \\
\hline
\end{tabular}

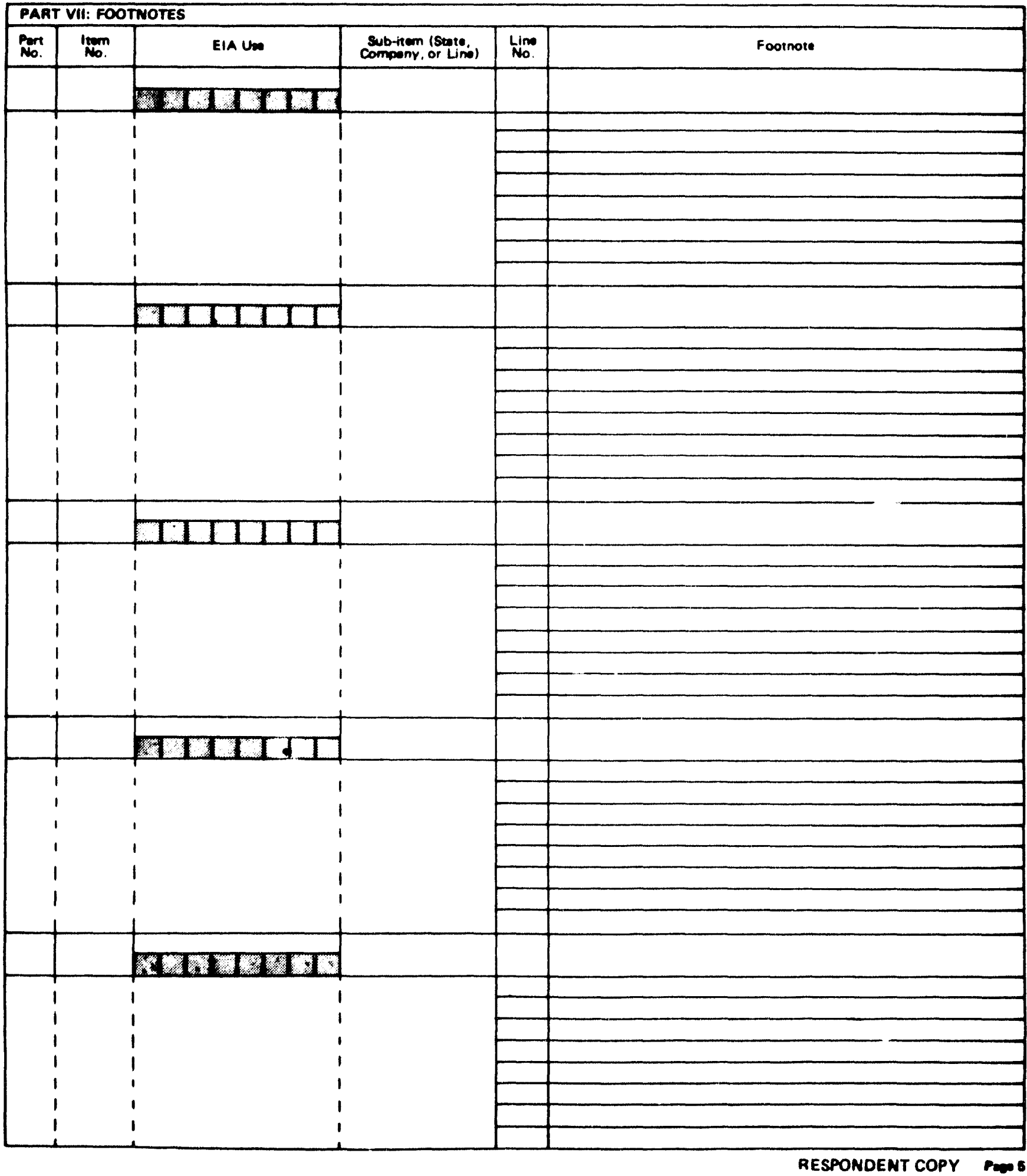




\section{ANNUAL REPORT OF NATURAL AND SUPPLEMENTAL GAS SUPPLY AND DISPOSITION, $19 \square$}

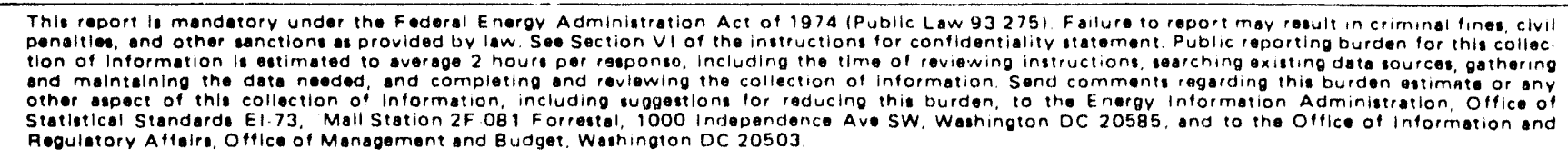
Regulatory Affolrt. Offlce of Management and Budget. Washington DC 20503

\section{EIA USE}

RESPONDENT COPY

Retain for your files.
Control 110 i No

Affix malling label or enter mall address

Name:

Operations in (State)

Street or Post OHfice Box:

City, State, Zip Code

Attention:

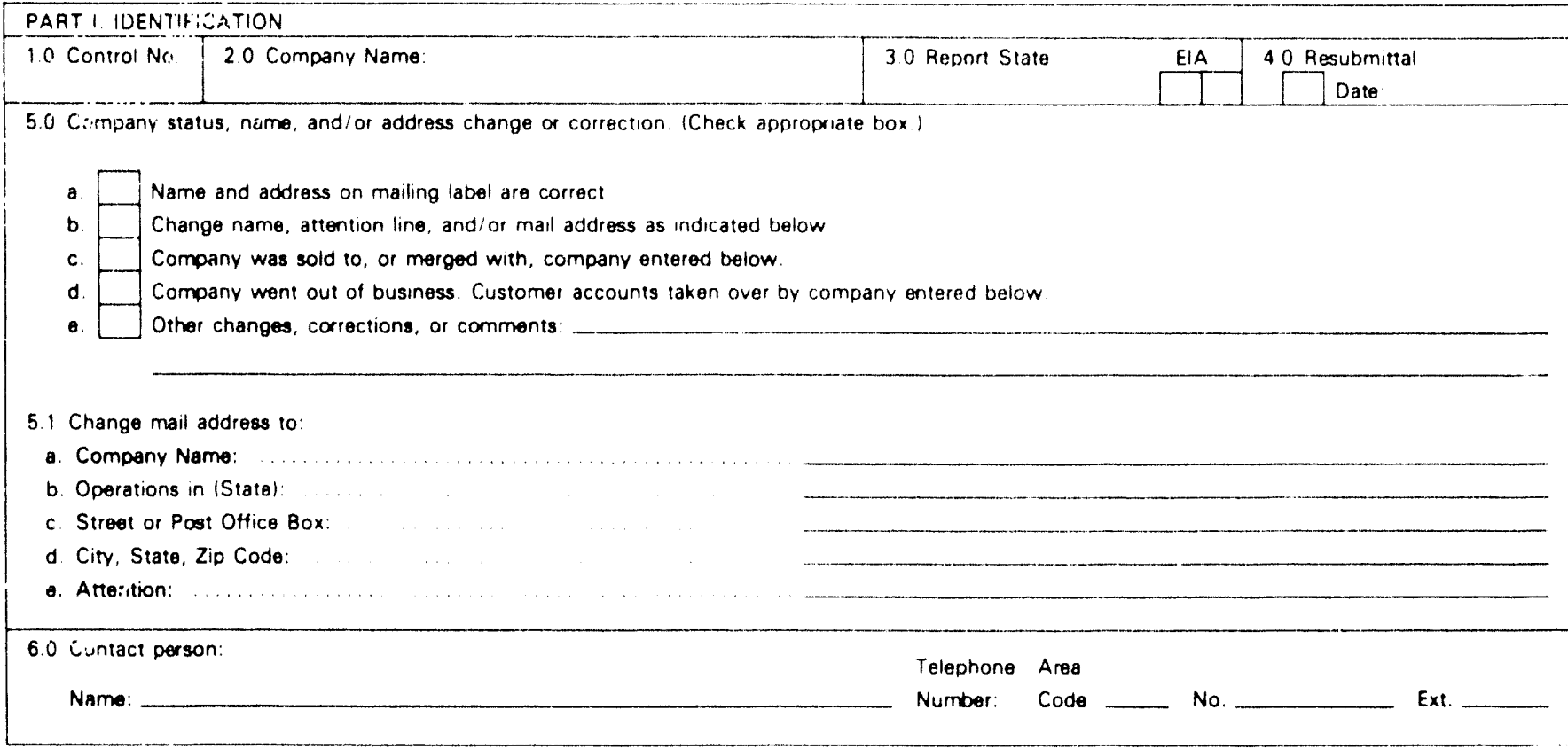

PART II: CERTIFICATION AND DISCLOSURE STATEMENT

1.0 I certity that (Chock appropriate box)

a. The information provided herein and appended hereto is true and accurate or, where indicated (x) the form, reasonahle usitiniates to the best of my knowledge

b. My company does not meet any of the criteria set forth in Section II, "Who must submit," of the instrustions and is theiviore not required to complete and submit a Form EIA. 176 for the report State

\begin{tabular}{|l|l|}
\hline 2.0 Name & 3.0 Titte \\
\hline 4.0 Signature & 5.0 Date \\
\hline $\begin{array}{l}\text { Title 18, USC 1001, makes it a crime for any person knowingly and willingty to make to amy agency or department of the United States ally fateo, fictitious } \\
\text { of traudulent statements as to any matter within its jurisdiction. }\end{array}$ \\
\hline
\end{tabular}

or traudulent statements as to any matter within its jurisdiction. 
EIA.176, ANNUAL REPORT OF NATURAL AND SUPPLEMENTAL GAS SUPPLY AND DISPOSITION, 19

\begin{tabular}{|l|l|l|l|l|l|}
\hline 1.0 Control No & 2.0 Company Name & 30 Report State & ElA & 40 Resubmitial \\
\hline
\end{tabular}

PART III TYPE OF COMFANY AND GAS ACTIVITIES OPERATED IN THE REPOHT STATE

1.0 Type of Company (check one)

a.
b.
c.
d.
e.
f.
Municipally owned distributor
Interstate pipeline
Intrastate pipeline
Storage operator
SNG plant operator
integrated oil and gas
i.
i.
Producer
Gatherer
Processor
Other (specity)

20 Gas Actwities Operated On system Within the Report State (check all that apply)

\begin{tabular}{|c|c|}
\hline a & Produced Natural Gas \\
\hline b. & Gathered \\
\hline c. & Processed \\
\hline$d$ & Purchased \\
\hline$\theta$ & Transported Interstate \\
\hline 1. & Transported Intrastate \\
\hline$g$ & Stored Underground \\
\hline h & Stored LNG \\
\hline$i$ & Injected Propane sir \\
\hline 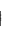 & Produced SNG \\
\hline$k$ & Imported \\
\hline 1 & Exported \\
\hline
\end{tabular}

$m\left[\begin{array}{l}\text { Delivered for Resale } \\ \text { Delivered directly }\end{array}\right.$ to consumers

- Other (specify)

PART IV SUPPLY OF NATURAL AND SUPPIEMENTAI GAS RECEIVED WITHIN OR TRANSPORTED INTO REPORT STATE

2.0 On system purchases received:

21 From producers, gatherers, and/or gas processors

2.2 From pipeline, distribution, and a storage operators

2.3 From synthetic natural gas plants or SNG pipeline

7.0 Other sources of supply (specily)

(Source and/orkind of fuel)

(Continue on Pan VI. if more space is needed)

8.0 Total supply withm report Stat:

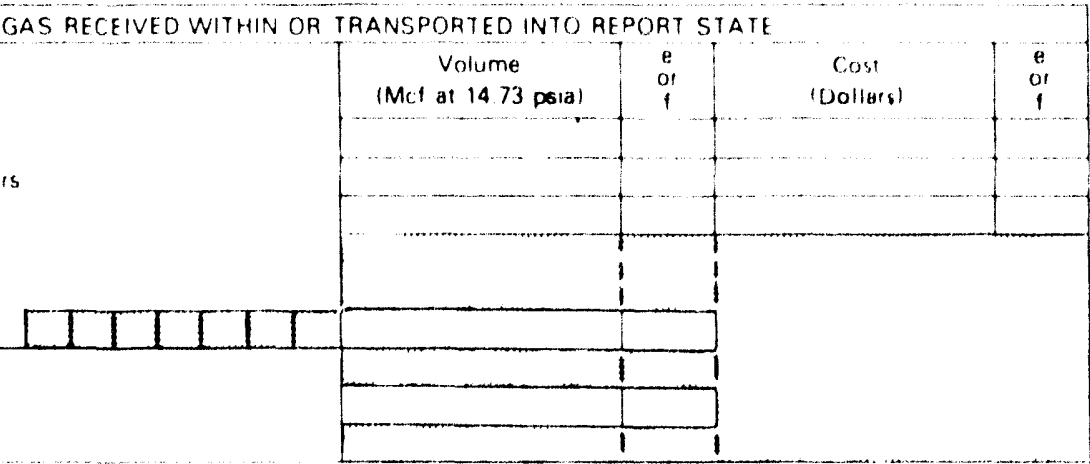

PART $V$ DISPOSITION OF NATURAL AND SUPPLEMENTAL GAS WITHIN OR TRANSPORTED OUT OF HEPORT STATE

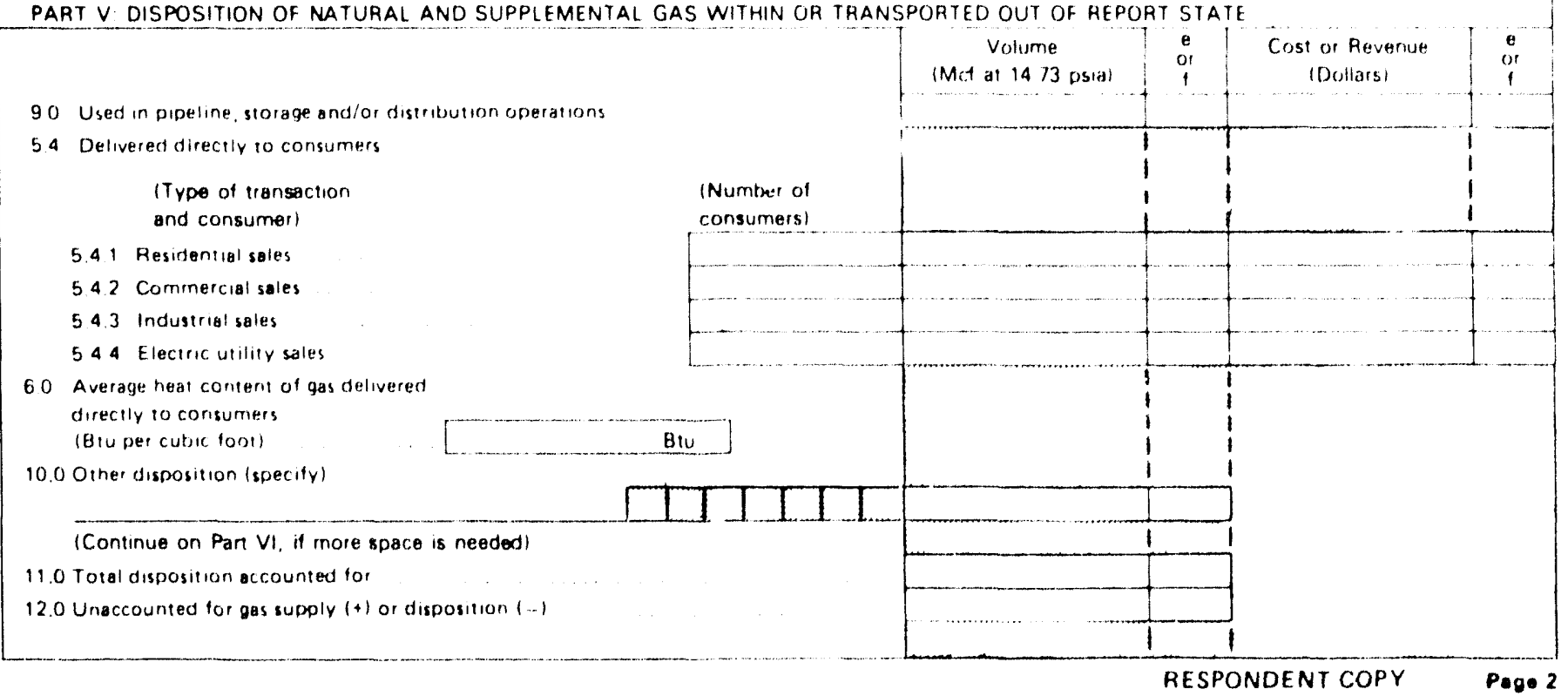


EIA.176, ANNUAL REPORT OF NATURAL. AND SUPPLEMENTAL GAS SUPPLY AND DISPOSITION, $19 \square$

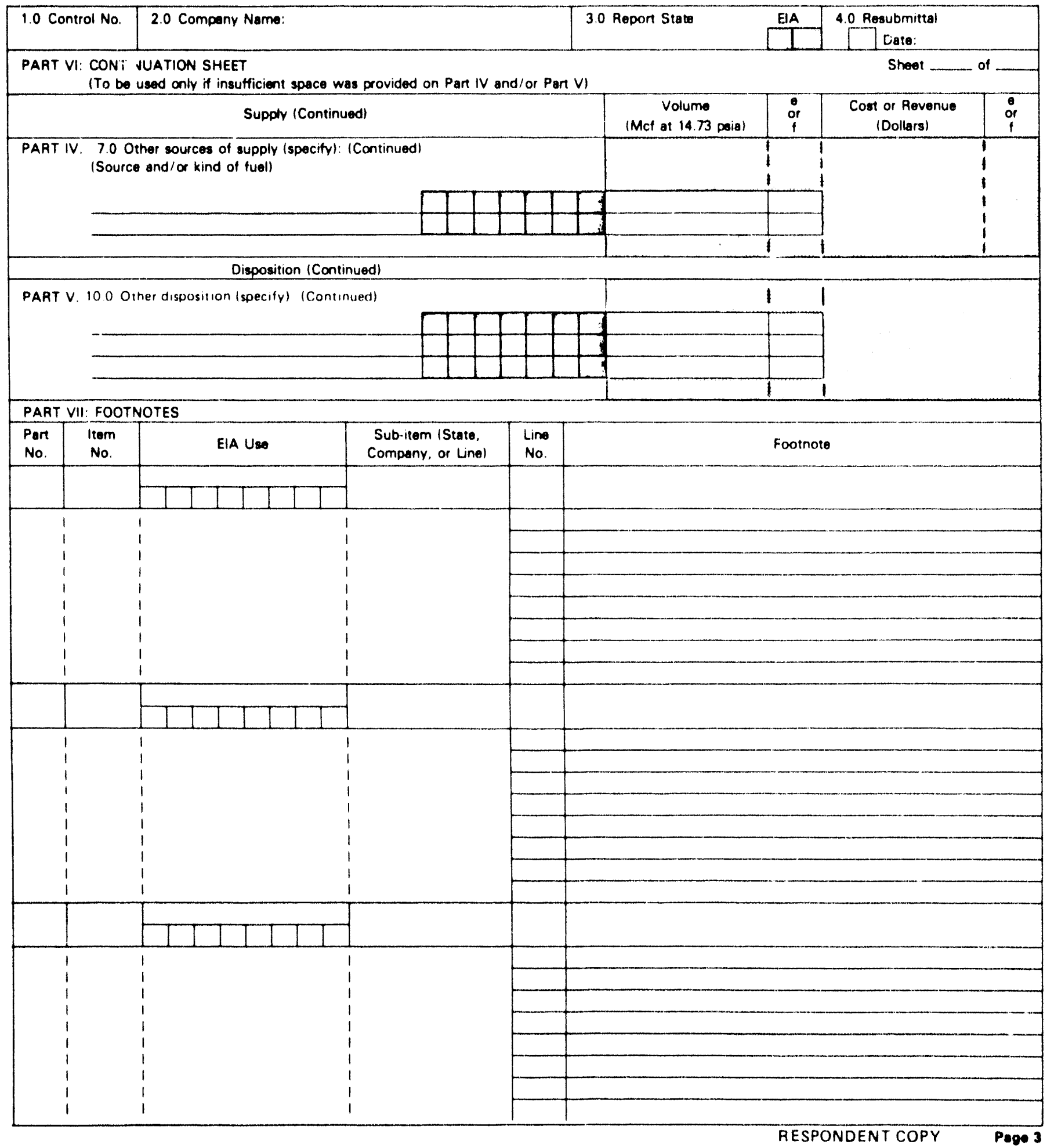


Form EIA-627

\section{Survey Design}

Beginnmg with loge (data, natural gats production datat previously obtamed all an informal base from appropriate Slate agencies Were collected on form I:IA -6.27 (Figure A 3) This form was designed by the EIA to collect anmual natural gas production data from the approprate State agencies under a standard data re porting system within the limits imposed by the diver sity of data collection systems of the varusus prodecung States. It was also destgened to atvold duplicatom of the efforts involved in the collectorn of production and

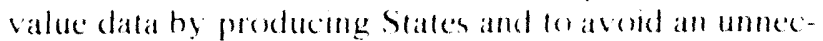
essary respondent hurden on gas and oil well operators.

In 1991. the (office of Management and Budget approved the lorm LIA-627 for use in report years log() through 1992. In May 1993, forms for report year 1992 were mailed to the appropriate agenceses in 3.3 States Completed forms wererefurned to the Datal Operations Branch of the Reserves and Natural (ias I Diveson for review, processing, and complation

\section{Response Statistics}

All of the 3.3 natural gas producme sialces pirticipated In the voluntary $1: 1 \mathrm{~A}-027$ surves by filing the com. pleted form on by responding to telephome contaces Data on the quantuties of mombydroxarbon gases re. moved in 1902 were repurted by the approprate agese. cies of 23 af the 33 producing States The 23 s ites accounted for 01 percent of total ly92 gross withdraw als lo addeton, the gross withdrawal data from Kansats, Ioustana, Montanta and (Oklahoma, in hich together

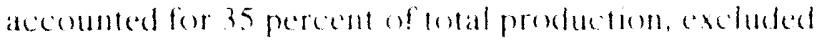
all or most of the nombedrecartone gases removed on

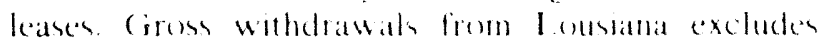
most quantries of monhydrocarbon gases remowed on leases. Nombydrocarbon gases removed have been as. cluded from gerose wathdrawals an Missouri

The commercial recovery of methane from enal beds

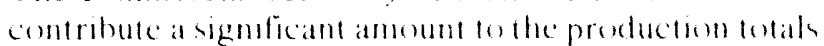
in a number of states. (inal bed methane seams pore duction yountiles (on million cubse feet) are included in groms withdrawats otals for the followmg states: Alahama (9)1,925), Colorate(8) (83,762), Illmons (82), and New Mexicon $(36,5,219)$

\section{Summary of EIA-627 Data Reporting Requirements}

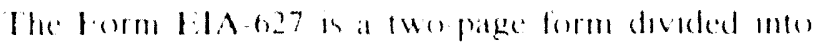
four parts. Part I repuest elentifyng informathen in. cluding the batme and focathen of the responding state agerey and the name and telephence number of a contact person within the agency Part Il collecets data on the number of producing gas wells, the productoon of natural gas includeng gerose willdrawals from both gats and anl wells; volumes returned to formation for repressurmg. pressure maintenance, and cycling quanfilles rented and flared, quathlates of nomhydrocarbon gases removed. quantules of fuel used on lease; and markeled producteon Pat 111 of the form is for reporting the value of marketed production. Part IV is space to be used by the respondent lo explatu data elements reported that may be hased on defintions differing from those applied to data in previons years.

\section{Routine Form EIA-627 Edit Checks}

Iatch filing of the Iorm 1:IA-6.27 is mamually checked for reasomablentes and mathematical accuracy. Volumes are comberted, ats necessary, fo a standard 14.73 psia pressure base. Value data are compared to the

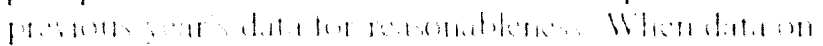

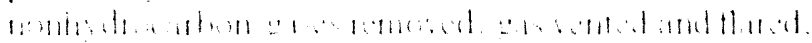

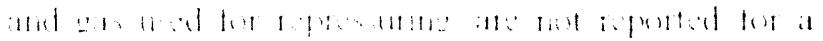

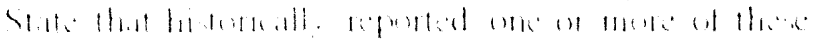

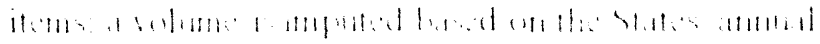

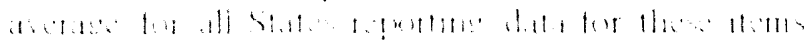

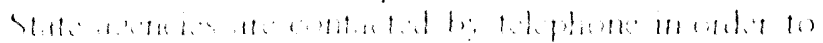

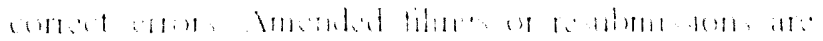

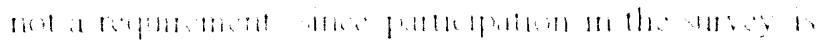
bitmitis

\section{Comparison of the Form ElA-627 with Other Data Sources}

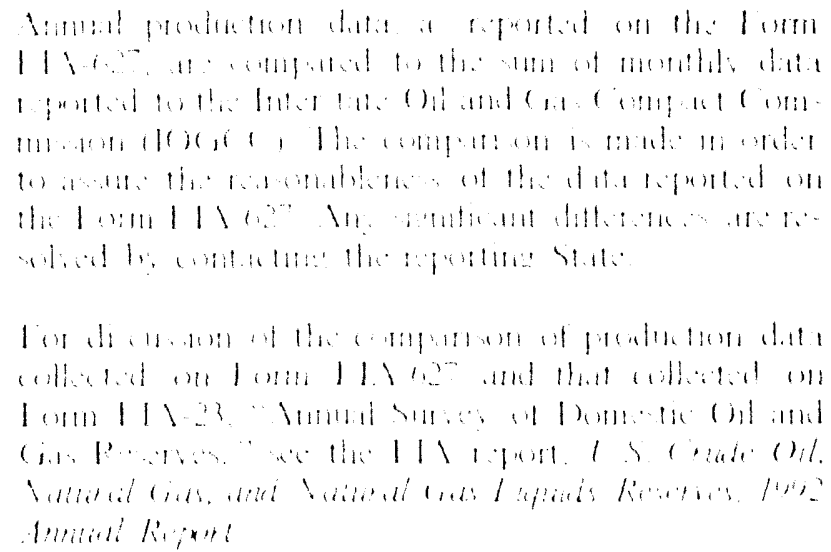




\section{ANVAL QL ANTITY ANI VALLF OF NATLRAL GAS REPORT}

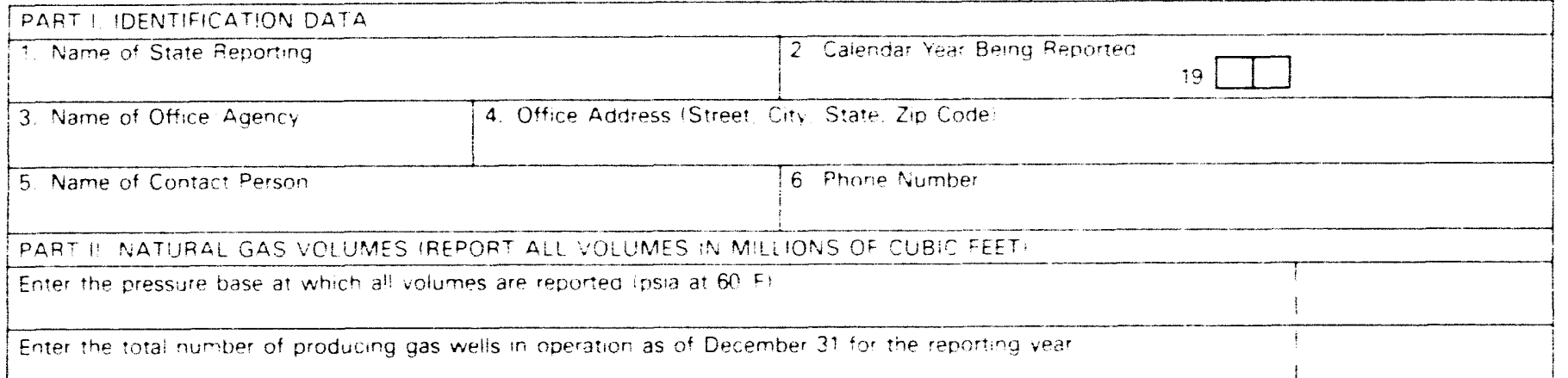

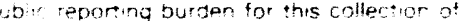
intormation is estmated to average 4 ? hout Det respmnse including the time of revirwing instertons searching extsting data sources gant rempioting and reviewing the rollecton th intirmation Send comments tegarting this burden estimate or any other asper. of this collection of "iformation inciading sugagstions for reducing this burden to the Ena

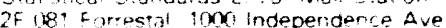
SW Washington. DC 2 n5s 55 and to the Otthe of intmatimn and Reguiatory Attars Hice of Maragement and Budge Wastington DC 20503

\begin{tabular}{|c|c|c|c|c|c|c|c|c|}
\hline \multirow[b]{2}{*}{ Month } & \multicolumn{3}{|c|}{ Gross Withdrawals } & \multirow{2}{*}{$\begin{array}{l}\text { Used for } \\
\text { Repressuring } \\
\text { Etc. }\end{array}$} & \multirow{2}{*}{ Vented and Flared } & \multirow{2}{*}{$\begin{array}{c}\text { Nonhydrocarbon } \\
\text { Gases } \\
\text { Removed }\end{array}$} & \multirow{2}{*}{$\begin{array}{c}\text { Natura! Gas } \\
\text { Used as Fue' } \\
\text { on Leases }\end{array}$} & \multirow{2}{*}{$\begin{array}{l}\text { Marketed } \\
\text { Production }\end{array}$} \\
\hline & $\begin{array}{c}\text { Gas and } \\
\text { Condensate Wells }\end{array}$ & $\begin{array}{c}\text { Oit Weils } \\
\text { (Casinghead) }\end{array}$ & Total & & & & & \\
\hline \multicolumn{9}{|l|}{ January } \\
\hline \multicolumn{9}{|l|}{ February } \\
\hline \multicolumn{9}{|l|}{ March } \\
\hline \multicolumn{9}{|l|}{ April } \\
\hline \multicolumn{9}{|l|}{ May } \\
\hline \multicolumn{9}{|l|}{ June } \\
\hline \multicolumn{9}{|l|}{ July } \\
\hline \multicolumn{9}{|l|}{ August } \\
\hline \multicolumn{9}{|l|}{ September } \\
\hline \multicolumn{9}{|l|}{ October } \\
\hline \multicolumn{9}{|l|}{ November } \\
\hline \multicolumn{9}{|l|}{ Decemher } \\
\hline TOTAL & & & & & & & & \\
\hline
\end{tabular}




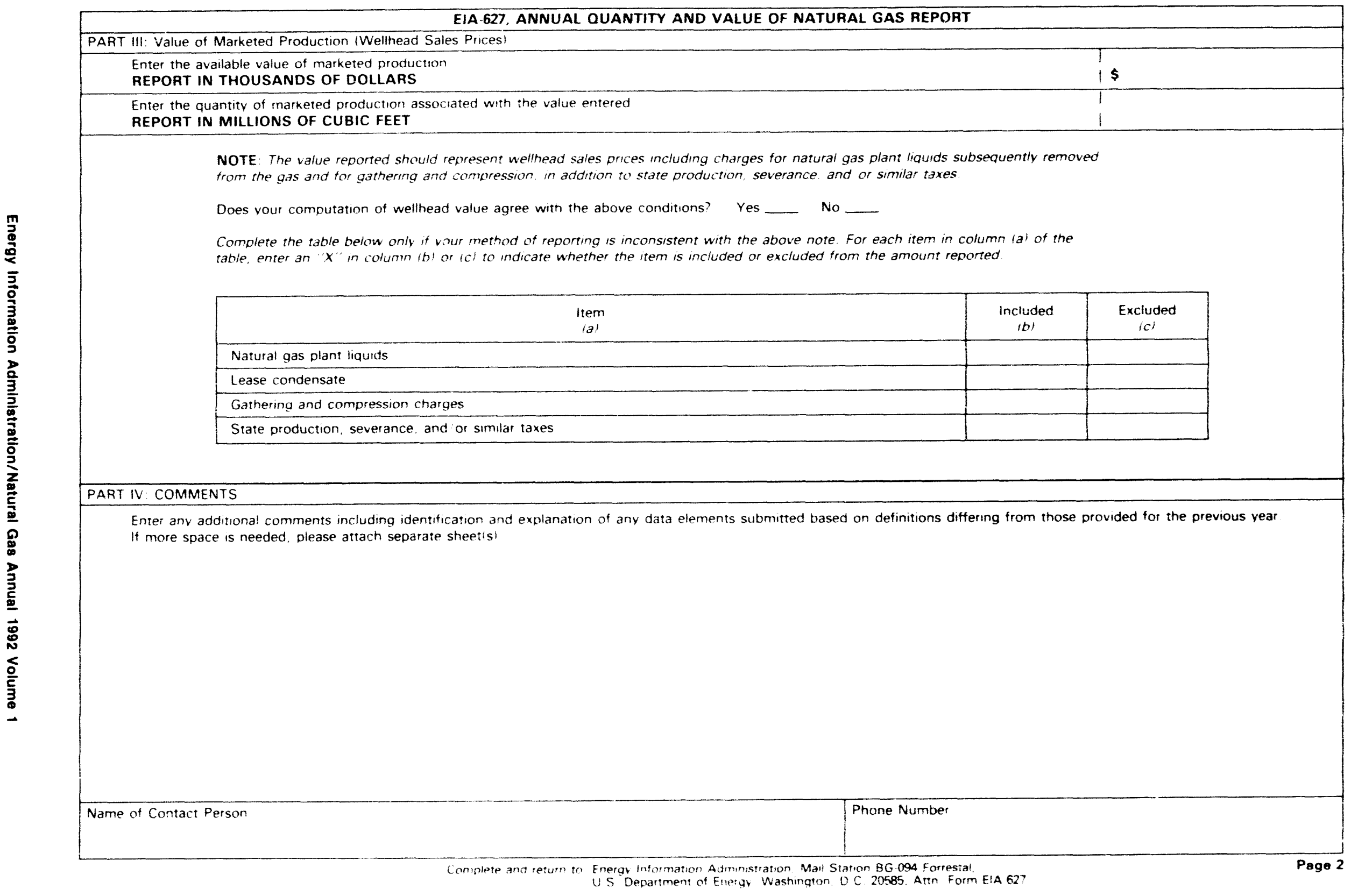




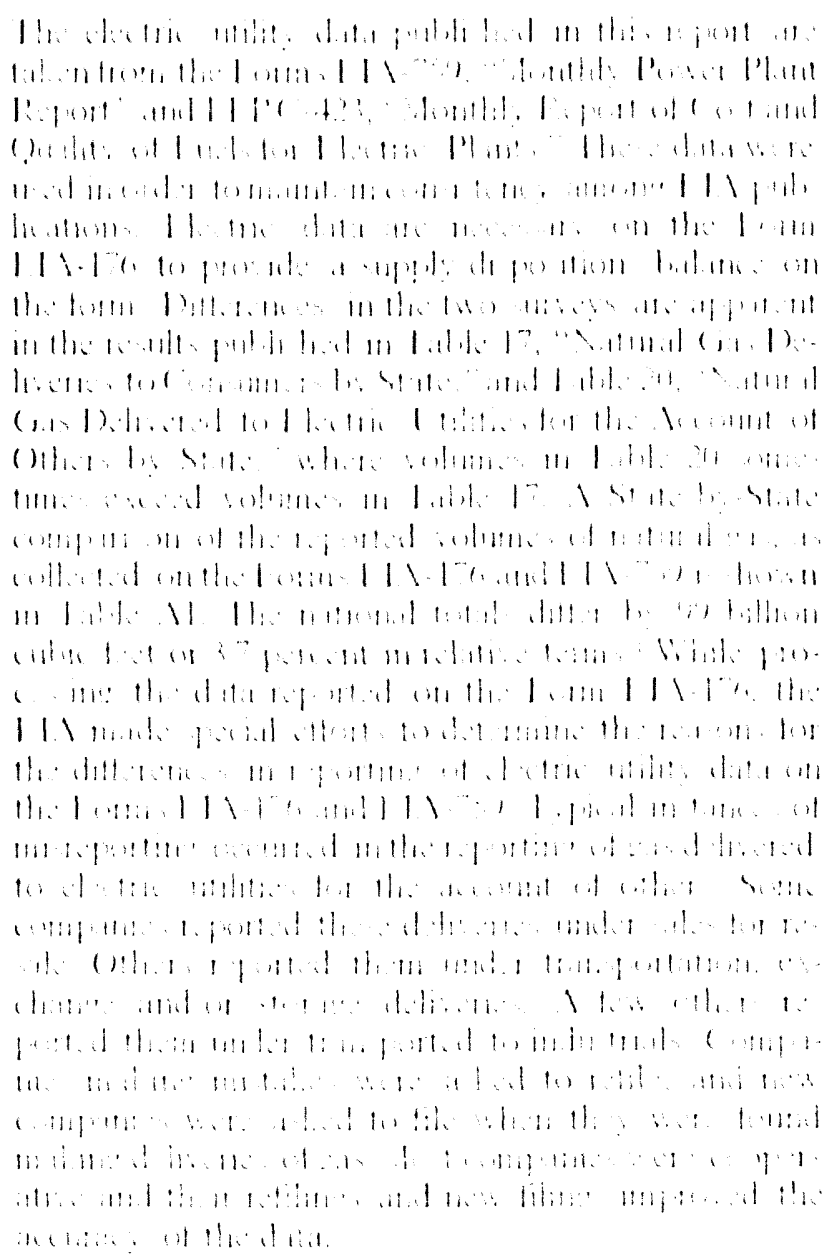

\section{Other Data Sources}

The U.S. Minerals Management Service (LSMMSisupplied data on the quantity and value of natural gas production and the number of producing wells in the Gulf of Mexico (Outer Contmental Shelf. Monthly reports to the IOCiCC were the source of information for gross withdrawals from gas and onl wells in Wyoming. Volumes of extraction losses were reported on Form ElA-64A, "Annual Report of the ()rigin of Natural Gas Liquids Production." Heat (Btu) content ex. traction loss was estimated from data reported on form EIA-64A and Form EIA-816, "Monthly Natural Gas Liquids Report." Volumes and prices of natural gas imports and exports were reported on the Form FPC-14, "Annual Report for Importers and Exporters of Natural Gas." These data are nomproprietary and are filed annually by each individual or organization having authorization to import and export natural gas.

\section{Natural Gas Consumed as a Vehicle Fuel}

Data on delueres of natural gas delivered for use as a velucle firel were collected for the first fime in loge In log() and lonl deleserses of nalural gas for vehicle fuel use were alle haded with volumes delivered to commercial comsumes. Begmmmg with the Vatural Gas finnal. 1902 vehick fuel whlumes are no knger included wilh commeretal volumes, except in Table 18

\section{Natural Gas Balancing Item}

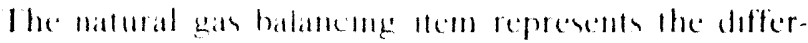
ence between the sum of the compenemes of natural gas supply and the sum of the compoments of nallural gas depomitum If in calculated fin cach state as the result of a companson belween toral reported supply

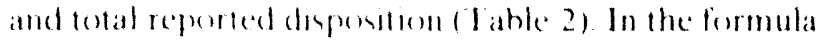

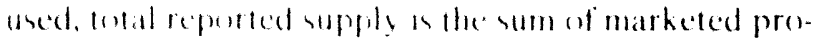
ductorn. net internate monements, net movements across 1 s borders, and supplemental gascous fucels supply Ietal reported dispostom is the stum of extrac-

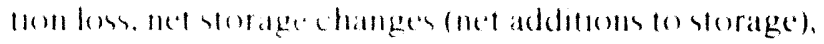
and comsumplom When the catculation results in a

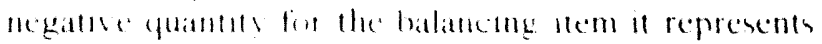
an excess at reperted supply in relation to reported dispestsom. and postive quantmes molicate the opposite stltatlom

The differences betwedn supply and demand represent quamentes low. the net result at gas company comver-

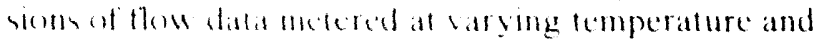
pressure cendeteme lo al slandard lemperature and pressure base, metermg matecurateses the effece of variations in compant aceountung and billing practices, differences between hillmg crele and calendar perted time

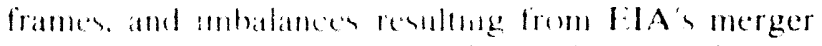
of data reportme systems. wheh a aty in scope, format, definitions. and lype of respondents The balancing Hems in indertual states maty also reflect the

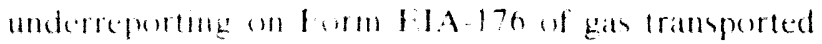
acroms state berders for the aceoum af enthers by some interstate pipelines

\section{Natural Gas Processed and Extraction Loss}

Lxtractum low in the reduethon in the volume of natural gar avalable fiof disposilum resultumg from the removal of nalural gas liquad comblotuents al natural gas processing plants. It represents that portion of the "raw" gas

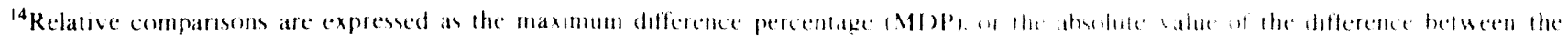
two volumes dovided by the smallet of the two volumes, multapled by f(x)
} 
stream that is transferred from the natural gas supply

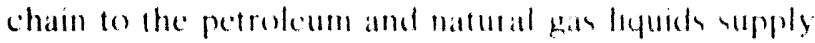
chain. Extraction loss does net indelede the redectum in volume resulteng from the removal of nonbydrocarbon comblituents al gas userl as fuel. vented, hared, of onhermbe disponed of withm natural gas processing plants. Extratetion loms alser resulte in a reduction in the total heat (Btul) entlent of the natural

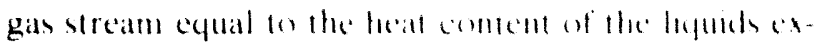
tracted

The Form EIA-64A. "Anmual Repurt of the ()tgin of Natural Gas I iquids Production," collects data (int the volume of natural gas recerved for processing. the toral quantity of natural gats leyuids produced, and the resulting shrinkage (defined as extraction lass in this report) from all natural gas processing-and eycling-plant operators. The quantity of matural gas recened and liquids produced are reported hy state of origin of the natural gas Shrinkage volumes are calculated and reported by plant operators based upon the chemical composition of the liquids extracted using standard conversion factors specified in the form instructions. A description of the Form I: IA-64A survey is presented in the EIA publicatom, L'S (rude ()il. Natural (ias.

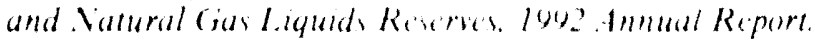

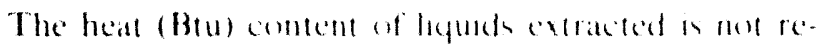

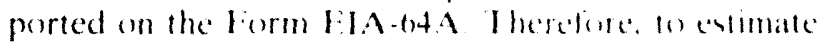
the extraction loss heat conlent. dattat reported on the Form FIA-816, "Monthly Naltural (ian and liguld Report." were used to determine the andevidual prodlicts contained in the wat liquids reported on Form E1A-64A. A description of the Form I:IA-816 survey is presented in the EIA publication. Petrolewm Supply Annual 1992. Lolume II.

To estimate the quantutes of molumbal prestucts ex tracted in each State, data from thic form LIA.htA survey were used to determme the follal leqund pro. duction, and data from the Form IA 1 - klo sures were used to estimate the quantitien of the modidual prode ucts contained in those total liquich

The Form FIA - 816 captures information on the quan. tity of individual components (i ce ethane. propane. normal butane. isobutanes and pentanes plus produced or contaned in mixes of plant lequal as determined by chemical analysis. The sofumetre rathes of the andividual components to the lotal liquide, as colloulated from the 12 monthly form 1.1A-816 1eports for sach State. were applied to the anmual totat licumid produse

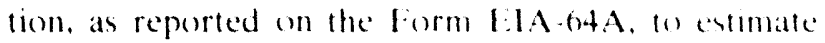
the quantities of individual components remoned at gas-processing plants (Table A 3 ).

The heat (Btu) content of extracted hquids Wats entimated by applying comversion factors to the entmated quantities of products extracted in each State. These conversion factors, in million Btu per harrel of liqual produced, were: ethane, 3.082, propane, 3.836, mormal butane, 4.326: isobutane, 3.974: and pentane plus, 4.620)
It should be noted that, at the State level, extraction losses are not necessarily related to State production. All gas processed in 11 States originated, or was produced in those States; but part of the gas processed in the other 12 States originated outside of the State in which the gas was processed. Cias produced from 9 States (Arizona, Indiana, Maryland, Missouri, New lork, ()regon, South I akota, Tennessee, and Virginia) was not processed.

For comparative purposes, the quantities of natural gas delivered $t 1$ processing plants, total liquids extracted, and estimaled volumetric and heat content extraction losses by State or origm of the gas (i.e., the State in which the gas was produced) are shown in Table $\mathrm{A} 4$.

\section{Lease and Plant Fuel}

l.ease and plant fuel represent those quantities of natural gas used in well, field, and/or lease operations (such as gas used in drilling operations, heaters, dehydrators, and field compressors) and as fuel in natural gas processing plants.

l.ease fuel data were collected for report year 1992. (n) the Form EIA-627. "Annual Quantity and Value of Natural Cias Report." Of the 33 States reporting on the form EIA-627, 26 States reported quantities of natural gas used as lease fuel. (iross withdrawals from Kansas (14,042 million cubic feet) and Oklahoma (43,05.3 million cubic feet) include gas used for fuel on leases hased on tiling of the EIA-176. Most of Nevada's marketed production is consumed as lease fuel, $30 \mathrm{mil}$ lion cubic feet. In the absence of reporting quantities on the Form EIA-627, the Form EIA-176 was used to chtimate lease fuel quantities. Although EIA recognizes that lease data collected on the Form E:IA-176 do not constitute a census or result from a statistically selected sample, the data collected in the survey provide the bost information available to the EIA for estimating such urage. To estimate lease use during 1992 (Table A(). several simplifying assumptions were made:

- The quantity of gas used for lease fuel was assumed to be a function of gross withdrawals of natural gas from gas and oil wells.

- The average proportion of company-owned onystem production reported as used in lease operations by respondents to the Form EIA-176 was assumed to be typical of the average use by all operators as a proportion of gross withdrawals.

- Average usage was calculated separately for Alaska and for the lower 48 States to reflect the distinctive field operations in Alaska. particularly on the North Slope.

Form L:IA-176 respondents reported volumes of company-owned onsystem production amounting 10 13 percent of 1992 gross withdrawals $(32$ percent of withdrawals in Alaska and 11 percent of withdrawals 
in the lower fis states) I eaxe use reported by respontdents averaged 010.345 thousand cubic feet per thousand cubic teet of reported production in Alaskat and 1).(1)2192 thousind cubic feet per thousand cubic feet of reported production in the lower 48 states. The fuel. use estimates shown in liable 16 were calculated by applying the atoreve rattos to the gross withdrawals from the varuss States (lable 3), not reporting lease use on the $1: 11-627$.

Begmning with the 1990 survey, datat on natural gats used as processing plant fuel were collected from the

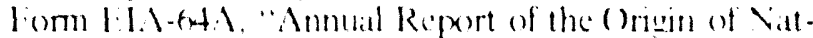

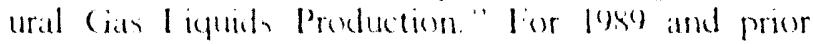
years the quantity of gas uxed an plant fied was assumed is be at tanction of the quantity of natural gats delivered to matural gats processteg platsts. The average proportion of gets delivered to compans-operated onsystem

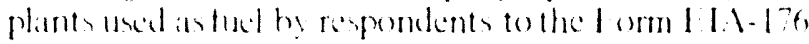
wats astumed to be typical of the aberage use by all plant operators as a proportion of total gats delivered to all plants withon each state

\section{Marketed Production}

Hatketed production of natural gats is taken from responses to Pant II of the form | 1.1-6.27. It is the quantity of notural gar prodened that is atralable for marketing and is reported in linhles 3 and 7 . It refers to

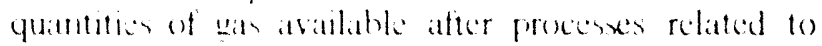
provinetion are complite the proceses are: repressurnale, prosure mantenatnce. cyling, renting

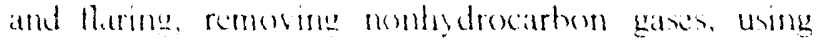
fucl on the kiax

Average wellheid prices are calculated from wolumes and saleses reported in Pant 111 of the form 1.1.1-6.27. ltase data are shown as "Reported Hellhead balle" in lahk 7. The wolumes in thas wetion reter to the atcual amount of matural gas reported to the Statles as soll.

In many states, the matheded prodection volumes are

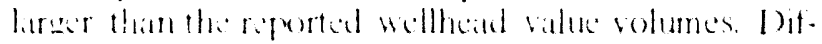
ferences in these volumes esenerally restat from difter. ences in definition and reporting requirements for separrate datat sytems in the Statte. For example, while production quantities of federal. tribal, and State royalty gas are included in mitrketed production, some State reperting rules exclude these quantities trom reported wellheinl value volumes.

\section{Census Divisions}

The Burealle of the (emsus, I s Department of commeres, has grouped the in States and the Destrict of

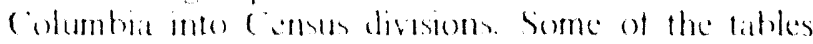
and graphs in this report show data by Census division. These groupines are

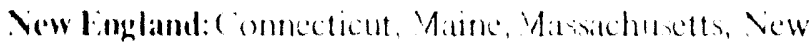
Hamphine, Rhode Stand, and Vermont.

Midalle Mantia: Vow Jerey, Vew York, and Ponnsylvaniat

Fast Vorth (entral: Illinols, Indiana, Michigan, ()hio. and llixomsin

West Vorth (emtral: lowa, Kamsas. Minneyola, Mis-

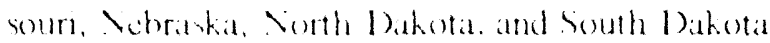

South Atlantic: 1) latware. District of (olumbia Itor-

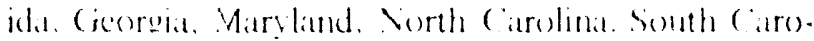
lina, Viremia, and West Viremia

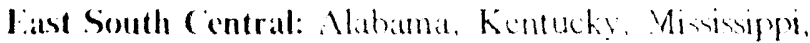
and lenturese.

Wist Somth (intral: Arkansats, I onistana, ()klahoma. and loxal.

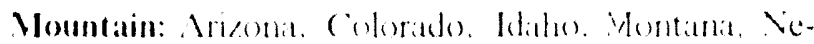

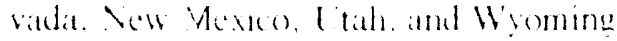

Pacific (ontiguons: Callembia, Oregon, and Wishington.

Pacific Voncontiguons: Maska and Ilawaii. 
Table A1. Comparison of Electric Utility Natural Gas Consumption Data by State, 1992 (Million Cubic Feet)

\begin{tabular}{|c|c|c|c|c|}
\hline State & $\begin{array}{c}\text { Form } \\
\text { E.A-176 }\end{array}$ & $\begin{array}{c}\text { Form } \\
\text { ElA.759 }\end{array}$ & Difterencs & MDPः \\
\hline Alabama & 3,642 & 3,368 & -274 & 8.1 \\
\hline Alaska .... & 28,693 & 28,953 & 260 & .9 \\
\hline 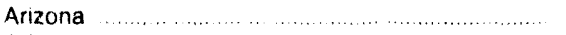 & 40,580 & 30,939 & $-9,641$ & 31.2 \\
\hline Arkansas & 26,523 & 27.015 & 492 & 1.9 \\
\hline Californa & 582,604 & 564.432 & $-18,171$ & 3.2 \\
\hline Colorado & 5,713 & 5,019 & -694 & 13.8 \\
\hline Connecticut & 1.881 & 2,100 & 2.19 & 11.6 \\
\hline Delaware & 9,389 & 8,384 & $-1,004$ & 12.0 \\
\hline Florida & 200,096 & 202,576 & 2,480 & 12 \\
\hline Georgia & 1,217 & 1,162 & -55 & 47 \\
\hline$\ldots \ldots \ldots \ldots \ldots . .$. & 10,610 & 9,293 & $-1,317$ & 14.2 \\
\hline Indiana & 7,567 & 7,772 & 205 & 2.7 \\
\hline lowa & 3,295 & 2,265 & $-1,030$ & 45.5 \\
\hline Kansas & 13,110 & 13,981 & 872 & 6.6 \\
\hline Kentucky & 217 & 269 & 52 & 23.9 \\
\hline 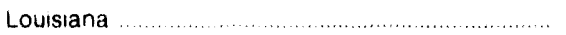 & 240,733 & 254,922 & 14,189 & 5.9 \\
\hline Maryland & 10,416 & 11.575 & 1,159 & 11.1 \\
\hline 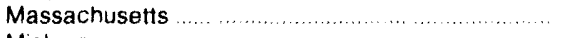 & 34,899 & 38,341 & 3.442 & 9.9 \\
\hline Michigan & 19.537 & 24.908 & 5,370 & 27.5 \\
\hline Minnesota $\ldots \ldots \ldots \ldots$ & 5,133 & 4,906 & -227 & 46 \\
\hline 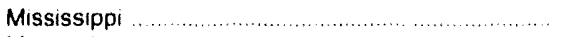 & 51,888 & 54,180 & 2,293 & 4.4 \\
\hline Missouri & 2,710 & 2.351 & -359 & 15.3 \\
\hline Montana & 222 & 220 & -2 & 1.1 \\
\hline Nebraska & 1,793 & 1.903 & 109 & 6.1 \\
\hline Nevada & 28,902 & 24,355 & $-4,546$ & 18.7 \\
\hline New Jersey & 38,293 & 38,772 & 478 & 1.2 \\
\hline New Mexico & 18,072 & 22,486 & 4.414 & 244 \\
\hline 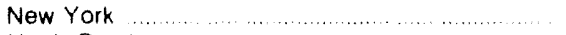 & 200.579 & 208,73 & 8.152 & 4.1 \\
\hline North Carolina & 2,994 & 3,159 & 166 & 5.5 \\
\hline North Dakota & 5 & 1 & -3 & 244.9 \\
\hline Ohio & 2,549 & 2,956 & 407 & 16.0 \\
\hline Oklahoma & 157,680 & 148,980 & $-8,700$ & 5.8 \\
\hline Oregon & 12,818 & 14,264 & 1,447 & 11.3 \\
\hline Pennsylvania & 3.954 & 3.100 & -855 & 276 \\
\hline Rhode Island $\ldots \ldots \ldots \ldots$ & 466 & 469 & 3 & 6 \\
\hline South Carolina & 1,524 & 1,795 & 270 & 17.7 \\
\hline South Dakota & 771 & 48 & .723 & 1509.9 \\
\hline Tennessee & 295 & 291 & .5 & 17 \\
\hline Texas & 868,758 & 968,165 & 99.407 & 11.4 \\
\hline Utah & 5.463 & 6,576 & 1.113 & 20.4 \\
\hline Vermont & 801 & 801 & 0 & 0 \\
\hline Virginia & 11,669 & 10.936 & -733 & 67 \\
\hline$(-1 \ldots \ldots \ldots \ldots \ldots$ & 4,514 & 5.385 & 870 & 19.3 \\
\hline West Virginia & 204 & 201 & -3 & 1.5 \\
\hline$(-\ldots \ldots+\ldots \ldots \ldots+\ldots$ & 2,697 & 2.584 & -113 & 44 \\
\hline Wyoming & 83 & 83 & 0 & 1 \\
\hline Total. & $2.666,507$ & $2,765,608$ & 99,101 & 37 \\
\hline
\end{tabular}

- : Relative comparisons are expressed as the maximum difference percentage (MDP), or the absolute value of the difference between two volumes divided by the smaller of the two volumes, multiplied by 100

Note: Totals may not equal sum of components due to independent rounding

Sources: Energy Information Administration (EIA), Form EIA.176, "Annual Peport of Natural and Suppiemental Gas Supply and Disposition," and Form ElA-759، "Monthly Power Plant Report." 
Table A2. Natural Gas Unaccounted for by State, 1988-1992 (Million Cubic Feet)

\begin{tabular}{|c|c|c|c|c|c|}
\hline State & 1988 & 1989 & 1990 & 1991 & 1992 \\
\hline Alabama & 3,029 & 4,035 & 67 & 1,908 & 3,062 \\
\hline Alaska & 1,661 & 1,471 & 2,397 & 114 & -14 \\
\hline Arizona & 57,804 & 21,579 & 17,347 & 23,029 & 53,366 \\
\hline Arkansas & 470 & 2,174 & 4,177 & 13,145 & 4,424 \\
\hline 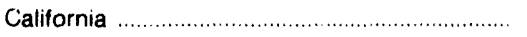 & 43,475 & 40,927 & 4,341 & 80,522 & 11,493 \\
\hline Colorado & $-5,332$ & 5,746 & 9.499 & 10,580 & 9,372 \\
\hline 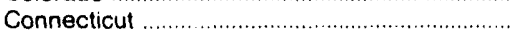 & 2,719 & 3,243 & -441 & 2,284 & 946 \\
\hline Delaware & $-16,089$ & 788 & -132 & 1,527 & 170 \\
\hline District of Columbia & 866 & 1,175 & 457 & 771 & 620 \\
\hline 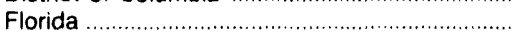 & 7,715 & 1,752 & $-1,006$ & 402 & -275 \\
\hline (2, & -132 & 8,170 & $-2,313$ & 7,039 & 6,624 \\
\hline 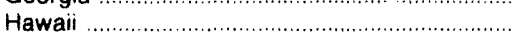 & 189 & 150 & 29 & 31 & 16 \\
\hline Idaho & 163 & -466 & 3,379 & -415 & 5,755 \\
\hline 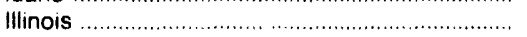 & 13,355 & 4,174 & $-2,391$ & $-16,276$ & 17,107 \\
\hline Indiana & 1,088 & 5,588 & $-2,394$ & 2,261 & 8,676 \\
\hline lowa & 15,028 & $-2,924$ & 18,357 & 9,222 & 9,307 \\
\hline Kansas & 23,566 & 10,501 & -473 & 11,288 & 17,699 \\
\hline 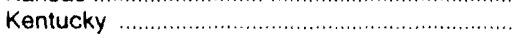 & 36,100 & 11,827 & 2,769 & -836 & 6,660 \\
\hline 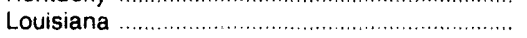 & 12,427 & 36,763 & $-3,929$ & $-4,957$ & 14,770 \\
\hline Maine & 127 & 4 & 120 & 45 & 26 \\
\hline Maryland & 4,324 & 8,836 & $-3,484$ & 13,400 & 6,019 \\
\hline Massachusetts & 15,256 & 365 & -447 & $-3,225$ & 331 \\
\hline Michigan & $-20,210$ & 1,606 & 1,249 & 16,865 & 8,913 \\
\hline 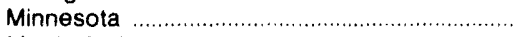 & 10,491 & 5,834 & $-14,294$ & -17.472 & $-62,450$ \\
\hline 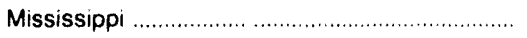 & 1.240 & 12,211 & $-6,959$ & $-5,013$ & 8,000 \\
\hline 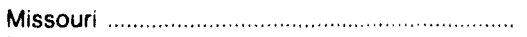 & 8,683 & 78,489 & 1,271 & 4,142 & 13,773 \\
\hline 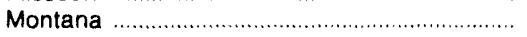 & 1.669 & $-25,444$ & $-26,971$ & 1,872 & 1,491 \\
\hline 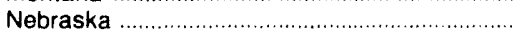 & 11,691 & 3,242 & 6,150 & 4,546 & 2,292 \\
\hline Nevada & $-5,234$ & -269 & 2,095 & 22 & 2,111 \\
\hline 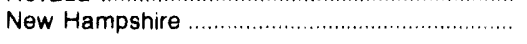 & 1,366 & 1,245 & -219 & 6 & 678 \\
\hline 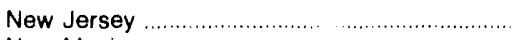 & $-7,478$ & 2,018 & 723 & 6,120 & 39,471 \\
\hline New Mexico & 4,790 & 2,175 & 10 & 2,095 & 813 \\
\hline New York & 42,740 & 20,364 & $-3,003$ & 11,958 & 28,140 \\
\hline 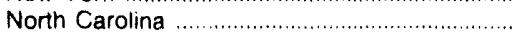 & 2,895 & 3,654 & -246 & 2,906 & 2,414 \\
\hline 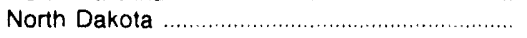 & -647 & -254 & -53 & -976 & -233 \\
\hline Ohio & 63,480 & 20,427 & 12,381 & 9,636 & 8.537 \\
\hline Oklahoma & 733 & 11,460 & 13,234 & 7,913 & 16,062 \\
\hline 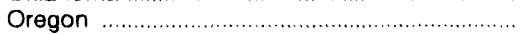 & 1,145 & 452 & 3,062 & $-2,395$ & -764 \\
\hline Pennsylvania & 60,954 & 23,438 & $-2,571$ & 13,505 & 11,380 \\
\hline 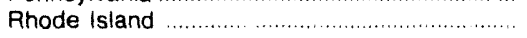 & $-1,521$ & 2,928 & 6,164 & 2,092 & -1.100 \\
\hline South Carolina & 3,477 & 2,699 & $-1,878$ & 746 & 1,110 \\
\hline South Dakota & -708 & -139 & -62 & -518 & 413 \\
\hline 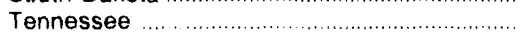 & 5,558 & 11.433 & $-2,376$ & 38,691 & 6,920 \\
\hline Texas & 28,716 & 25,292 & $-1,640$ & 12,298 & 17,553 \\
\hline Utah & 1,948 & 1,475 & 4,507 & $-2,949$ & $-6,193$ \\
\hline 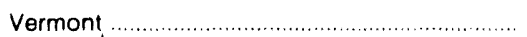 & 314 & 97 & -151 & 76 & -3 \\
\hline Virgınia $\Lambda$ & $-13,925$ & 1,672 & -613 & 1,383 & 963 \\
\hline Washinglion & 6.949 & 3,005 & 5,778 & $-1,735$ & 247 \\
\hline 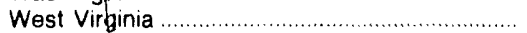 & $-59,927$ & 1,372 & $-6,101$ & 10,295 & 10,233 \\
\hline Wisconsin & -109 & $-1,852$ & -671 & 926 & 3,614 \\
\hline 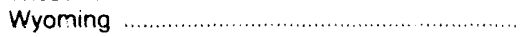 & -179 & 5,907 & 4,903 & 3,050 & 3,234 \\
\hline Total & 366,709 & 380,419 & 39,650 & 271,946 & 293,768 \\
\hline
\end{tabular}

Source: Energy Information Administration (EIA), Form E|A-176, "Annual Report of Natural and Supplemental Gas Supply and Disposition." 
Table A3. Natural Gas Processed and Liquids Extracted at Natural Gas Processing Plants by State, 1992

\begin{tabular}{|c|c|c|c|c|c|}
\hline \multirow{2}{*}{$\begin{array}{c}\text { Plant } \\
\text { Location }\end{array}$} & \multicolumn{3}{|c|}{$\begin{array}{l}\text { Volume of Natural Gas } \\
\text { Delivered to Processing Plants } \\
\text { (million cubic feet) }\end{array}$} & \multirow{2}{*}{$\begin{array}{c}\text { Total } \\
\text { Liquids } \\
\text { Extracted } \\
\text { (thousand } \\
\text { barrels) }\end{array}$} & \multirow{2}{*}{$\begin{array}{l}\text { Extraction } \\
\text { Loss } \\
\text { (million } \\
\text { cubic } \\
\text { feet) }\end{array}$} \\
\hline & $\begin{array}{c}\text { State } \\
\text { Production }\end{array}$ & $\begin{array}{l}\text { Out of State } \\
\text { Production }\end{array}$ & $\begin{array}{l}\text { Natural } \\
\text { Gas } \\
\text { Processed }\end{array}$ & & \\
\hline 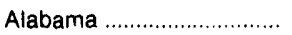 & 126,222 & 688 & 126,910 & 4,121 & 5,490 \\
\hline 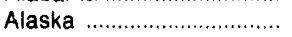 & $2,121,838$ & 0 & $2,121,838$ & 27,056 & 32,004 \\
\hline 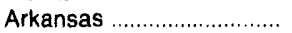 & 151,644 & 4,929 & 156,573 & 332 & 413 \\
\hline California & 243,692 & 0 & 243,692 & 10,171 & 12,385 \\
\hline 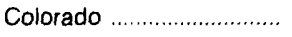 & 256,019 & 0 & 256,019 & 13,169 & 18,149 \\
\hline 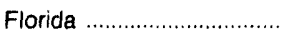 & 8,769 & 217,485 & $2.26,254$ & 2,317 & 2,563 \\
\hline 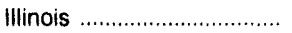 & 942 & 0 & 942 & 88 & 100 \\
\hline 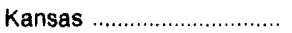 & 799,871 & 144,052 & 943,923 & 30,359 & 42,733 \\
\hline 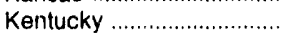 & 47,174 & 251 & 47,425 & 1,795 & 2,342 \\
\hline 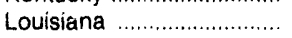 & $4,273,899$ & 192,526 & $4,466,425$ & 93,744 & 132,656 \\
\hline 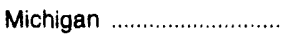 & 186,144 & 0 & 186,144 & 6,207 & 8,093 \\
\hline 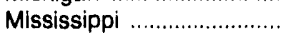 & 4,800 & 22 & 4,822 & 319 & 416 \\
\hline Montana & 12,581 & 116 & 12,697 & 698 & 907 \\
\hline 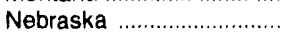 & 65 & 0 & 65 & 3 & 3 \\
\hline 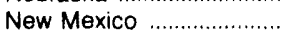 & 714,780 & 7,653 & 722,433 & 53,543 & 75,520 \\
\hline North Dakota ...................... & 50,462 & 0 & 50,462 & 4,675 & 6,055 \\
\hline Ohio & 2,730 & 0 & 2,730 & 55 & 72 \\
\hline Oklahoma & $1,066,390$ & 5,036 & $1,071,426$ & 73,518 & 104,609 \\
\hline 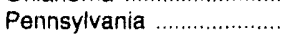 & 8,636 & 2,904 & 11,540 & 436 & 604 \\
\hline Tennessee & 0 & 0 & 0 & 0 & 0 \\
\hline Texas & $4,197,248$ & 33,897 & $4,231,145$ & 264,766 & 374,126 \\
\hline Utah & 306,217 & 12,800 & 319,017 & 8,513 & 11,851 \\
\hline 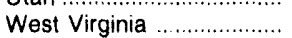 & 115,260 & 0 & 115,260 & 6,657 & 9,436 \\
\hline 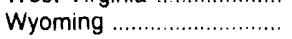 & 727,730 & 383 & 728,113 & 23,778 & 31,378 \\
\hline 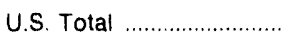 & $15,423,113$ & 622,742 & $16,045,855$ & 626,320 & 871,905 \\
\hline
\end{tabular}

- = "State Production" refers to gas delivered to processing plants located in the same State in which the gas was produced. "Out of State Production" refers to gas produced in other States and delivered to plants located in the State listed for processing.

b = "Total Liquids Extracted" represents the total quantity of liquids extracted from natural gas at natural gas processing plants located in the State.

Note: Totals may not equal sum of components due to independent rounding.

Source: Energy Information Administration (EIA), Form ElA.64A, "Annual Report of the Origin of Natural Gas Liquids Production." 
Table A4. Estimated Composition of Liquids Extracted at Natural Gas Processing Plants and the Resulting Heat Content Extraction Loss by State, 1992

(Liquid Volumes in Thousand Barrels, Heat Content in Billion Btu)

\begin{tabular}{|c|c|c|c|c|c|c|}
\hline \multirow{2}{*}{ State } & \multicolumn{5}{|c|}{ Estimated Components and Products in Liquids Extractedo } & \multirow{2}{*}{$\begin{array}{c}\text { Estimated Heat } \\
\text { Content } \\
\text { Extraction Loss }\end{array}$} \\
\hline & Ethane & Propane & Isobutane & N-Butane & Pentanes Plus & \\
\hline Alabama .......................... & 7 & 1,617 & 216 & 1,212 & 1,070 & 17,265 \\
\hline Alaska ............................... & 0 & 547 & 2,585 & 8,293 & 15,630 & 120,461 \\
\hline Arkansas $\ldots \ldots \ldots \ldots \ldots \ldots \ldots$ & 33 & 58 & 35 & 55 & 151 & 1,399 \\
\hline California ......................... & 18 & 2,850 & 1,994 & 1,596 & 3,713 & 42,970 \\
\hline Colorado ........................... & 3.774 & 4,192 & 676 & 1,912 & 2,615 & 50,752 \\
\hline Florida $\ldots \ldots \ldots \ldots \ldots$ & 617 & 764 & 61 & 478 & 397 & 8,976 \\
\hline 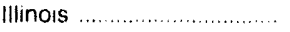 & 0 & 32 & 0 & 0 & 56 & 382 \\
\hline 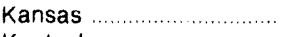 & 4,661 & 12,547 & 3,855 & 4,873 & 4,423 & 119,330 \\
\hline 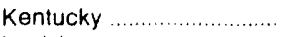 & 188 & 989 & 90 & 320 & 208 & 7,076 \\
\hline Louisiana ............................ & 34,158 & 25,085 & 9,308 & 8,687 & 16,505 & 352,328 \\
\hline 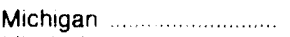 & 916 & 2,148 & 951 & 938 & 1,253 & 24,692 \\
\hline Mississippi .......................... & 0 & 111 & 0 & 95 & 112 & 1,358 \\
\hline 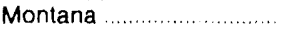 & 0 & 294 & 28 & 177 & 200 & 2,925 \\
\hline 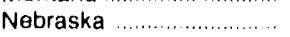 & 0 & 0 & 0 & 0 & 0 & 0 \\
\hline New Mexico ........................ & 22,506 & 15,590 & 3,102 & 5,716 & 6,629 & 196,848 \\
\hline North Dakota ....................... & 12 & 2,141 & 0 & 1,349 & 1,173 & 19,505 \\
\hline Ohio & 1 & 20 & 3 & 14 & 17 & 231 \\
\hline Oklahoma ............................ & 29,537 & 22,887 & 3,500 & 8,141 & 9,452 & 271,626 \\
\hline 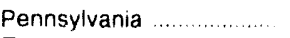 & 0 & 196 & 30 & 89 & 120 & 1,815 \\
\hline Ternessee .......................... & 0 & 0 & 0 & 0 & 0 & 0 \\
\hline 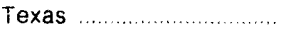 & 84,338 & 70,219 & 35,707 & 29,139 & 45,364 & $1,006,822$ \\
\hline 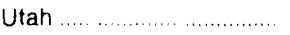 & 105 & 3,264 & 231 & 1,653 & 3,260 & 35,974 \\
\hline 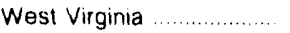 & 1,915 & 2,735 & 377 & 853 & 777 & 25,171 \\
\hline Wyoming. & 6,068 & 7,378 & 2,310 & 3,232 & 4,789 & 92,294 \\
\hline U.S. Total & 188,854 & 175.664 & 65,059 & 78,822 & 117,914 & $2,400,203$ \\
\hline
\end{tabular}

- The liquid quantities shown are the estimated quantities of individual components and products contained in the liquids at the point at which the liquids were extracted from the natural gas. The estimates are based upon the assumption that the liquids extracted in each State were composed of natural gas components and products in the same proportions as those ultimately fractionated at processing and tractionating plants within the State. The quantities ultimately extracted in each State were obtained from unpublished summaries of the 12 monthly reports on Form ElA-816. For each State, ratios of the quantities of each component and product ultimately fractionated to the total quantity of liquids fractionated were developed. Those ratios were applied to the total liquids quantities extracted from natural gas in each State (see Table A2) to derive the estimated component and product quantities shown.

- Extraction loss represents that portion of the natural gas stream which was transferred to the petroleum and natural gas liquids supply chain as a re. sult of the removal of part of the natural gas constituents in the form of natural gas liquids at natural gas processing plants. Estimates of the heat content extraction loss, i.e., the heat content of the extracted liquids, were computed using the following average heat content conversion factors (million Btu per barrel): ethane, 3.082 ; propane, 3.836; normal butane, 4.326; isobutane, 3.974; and pentanes plus, 4.620 .

Sources: Estımated Components and Products in Liquids Extracted: Total liquids from Form ElA.64A. "Annual Report of the Origin of Natural Gas Liquids Production," apportioned to components and products based upon quantities of components and products fractionated as reported on Energy Informa. tion Administration (EIA). Form EIA-816. "Monthly Natural Gas L.iquids Report" (see footnote a above) Heat Content extraction loss conversion factors (see footnote b above): Energy Information Administration, Annual Energy Review 1992. 
Table A5. Natural Gas Processed, Liquids Extracted, and Estimated Extraction Loss by State of Origin (Production) of Natural Gas, 1992

\begin{tabular}{|c|c|c|c|c|c|c|}
\hline \multirow{2}{*}{ State } & \multicolumn{3}{|c|}{$\begin{array}{l}\text { Volume of Natural Gas Delivered } \\
\text { to Processing Plants } \\
\text { (million cubic feet) }\end{array}$} & \multirow{2}{*}{$\begin{array}{l}\text { Total } \\
\text { Liquids } \\
\text { Extracted } \\
\text { (thousand } \\
\text { barreis) }\end{array}$} & \multicolumn{2}{|c|}{ Extraction Loss } \\
\hline & $\begin{array}{l}\text { Located Within } \\
\text { the State }\end{array}$ & $\begin{array}{l}\text { Located Outside } \\
\text { of the State }\end{array}$ & $\begin{array}{c}\text { Total } \\
\text { Processed }\end{array}$ & & $\begin{array}{l}\text { Volume } \\
\text { (million cubic } \\
\text { feet) }\end{array}$ & $\begin{array}{l}\text { Estimated } \\
\text { Heat } \\
\text { Content } \\
\text { (billion Btu) }\end{array}$ \\
\hline Alabama $\ldots \ldots \ldots \ldots \ldots$ & 126,222 & 8,396 & 134,618 & 4,574 & 5,555 & 19,016 \\
\hline Alaska $\ldots \ldots \ldots \ldots \ldots \ldots \ldots \ldots \ldots \ldots$ & $2,121,838$ & 0 & $2,121,838$ & 27,056 & 32,004 & 120,461 \\
\hline 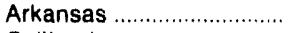 & 151,644 & 9 & 151,653 & 183 & 401 & 771 \\
\hline California $\ldots \ldots \ldots \ldots \ldots \ldots \ldots$ & 243,692 & 0 & 243,692 & 10,171 & 12,385 & 42,970 \\
\hline Colorado ................................ & 256,019 & 324 & 256,343 & 13,176 & 18,164 & 50,779 \\
\hline Florida & 8,769 & 0 & 8,769 & 1,168 & 99 & 4,525 \\
\hline 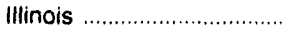 & 942 & 0 & 942 & 88 & 100 & 382 \\
\hline 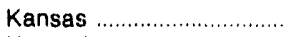 & 799,871 & 2,187 & 802,058 & 26,923 & 36,425 & 105,812 \\
\hline 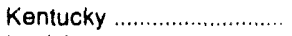 & 47,174 & 0 & 47,174 & 1.792 & 2,330 & 7,064 \\
\hline Louisiana ............................ & $4,273,899$ & 142,292 & $4.416,191$ & 90,159 & 128,722 & 338,911 \\
\hline 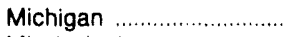 & 186,144 & 0 & 186.144 & 6,207 & 8,093 & 24,692 \\
\hline 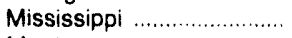 & 4,800 & 13,285 & 18,085 & 374 & 587 & 1,576 \\
\hline Montana .............................. & 12,581 & 383 & 12,964 & 734 & 915 & 3,060 \\
\hline 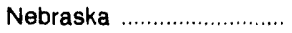 & 65 & 0 & 65 & 3 & 3 & 0 \\
\hline New Mexico ...................... & 714,780 & 1,045 & 715.825 & 53,052 & 74,812 & 195,061 \\
\hline 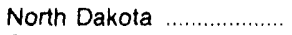 & 50,462 & 116 & 50,578 & 4,690 & 6,063 & 19,568 \\
\hline 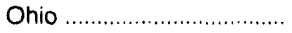 & 2,730 & 0 & 2,730 & 55 & 72 & 231 \\
\hline Oklahoma ........................... & $1,066,390$ & 88,331 & $1,154,721$ & 77,064 & 109,438 & 285,314 \\
\hline Pennsylvania ........................ & 8,636 & 0 & 8,636 & 345 & 452 & 1,436 \\
\hline 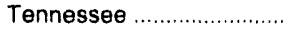 & 0 & 251 & 251 & 3 & 12 & 12 \\
\hline 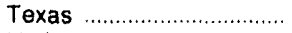 & $4,197,248$ & 350,419 & $4,547,667$ & 269,515 & 382,472 & $1,024,941$ \\
\hline 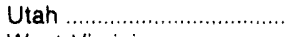 & 306,217 & 0 & 306,217 & 8,172 & 11,375 & 34,533 \\
\hline 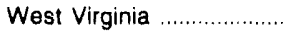 & 115,260 & 6,684 & 121,944 & 6.901 & 9,728 & 26.197 \\
\hline 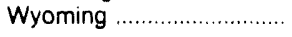 & 727.730 & 9,020 & 736,750 & 23,915 & 31,697 & 92,891 \\
\hline 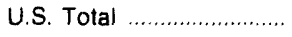 & $15,423,113$ & 622,742 & $16,045,855$ & 626,320 & 871.905 & $2,400,203$ \\
\hline
\end{tabular}

Note: This table shows the volume of natural gas delivered to processing plants, the quantity of natural gas liquids extracted, and the estimated volumetric and heat content extraction losses traced back to the State of origin of the gas, i.e., to the State from which the gas was produced whether processed within or outside of the producing State. Totals may not equal sum of components due to independent rounding.

Sources: Natural gas delivered to plants, and total liquids extracted: Energy Information Administration (EIA), Form ElA-64A. "Annual Report of the Origin of Natural Gas Liquids Production." Extraction Loss: Extraction loss volumes (Table A2) and estimated heat contents (Table A3) apportioned to state of origin based upon the origin of gas processed as reported on Form EIA.64A. 
Table A6. Quantity of Natural Gas Used as Lease and Plant Fuei by State, 1992 (Million Cubic Feet)

\begin{tabular}{|c|c|c|c|}
\hline State & Lease Fuel & Plant Fuel & Total Lease and Plant Fuel \\
\hline Alabama. & 8,391 & 4,477 & 12,868 \\
\hline 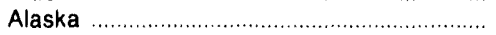 & 197,975 & 36,741 & 234,716 \\
\hline Arizona & 41 & 0 & 41 \\
\hline Arkansas & 5,570 & 268 & 5,838 \\
\hline 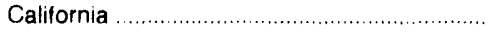 & 84,220 & 8,008 & 92,228 \\
\hline 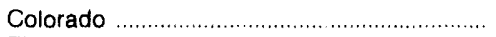 & 8,936 & 12,233 & 21,169 \\
\hline Florida & 3,819 & 1,315 & 5,134 \\
\hline Illinois & 9 & 98 & 107 \\
\hline Indiana & 5 & 0 & 5 \\
\hline 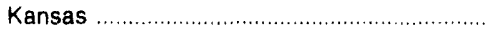 & - 17,424 & 26,312 & 43,736 \\
\hline Kentucky & - 2,105 & 707 & 2,812 \\
\hline 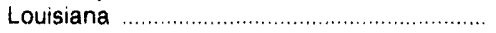 & - 134,088 & 86,623 & 220,711 \\
\hline Michigan & 4,178 & 3,096 & 7,274 \\
\hline 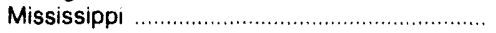 & 4,372 & 573 & 4,945 \\
\hline 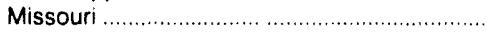 & 1 & 0 & 1 \\
\hline Montana & a 1,448 & 423 & 1,871 \\
\hline 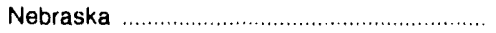 & 31 & 9 & 40 \\
\hline Nevada & 30 & 0 & 30 \\
\hline 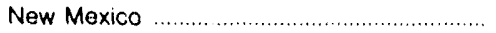 & 14,805 & 38,892 & 53,697 \\
\hline 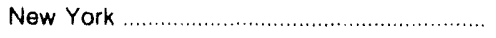 & 965 & 0 & 965 \\
\hline North Dakota & 3,709 & 4,753 & 8,462 \\
\hline Ohio & 1,434 & 16 & 1,450 \\
\hline Oklahoma & - 53,278 & 39,700 & 92,978 \\
\hline Oregon & 68 & 0 & 68 \\
\hline 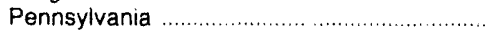 & 3,040 & 341 & 3,381 \\
\hline South Dakota & 451 & 0 & 451 \\
\hline 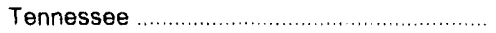 & 39 & 0 & 39 \\
\hline Texas & 123,111 & 170,734 & 293,845 \\
\hline Utah & 3,866 & 8,745 & 12,611 \\
\hline 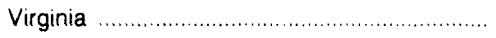 & 653 & 0 & 653 \\
\hline West Virginia & 4,807 & 3,290 & 8,097 \\
\hline 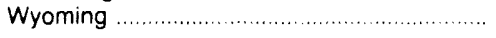 & - 27,382 & 13,217 & 40,599 \\
\hline . & 710,250 & 460,571 & $1,170,821$ \\
\hline
\end{tabular}

- Lease fuel quantities were estimated by assuming that the proportions of on-system production used as lease fuel by respondents to the Form ElA. 176, "Annual Report of Natural and Supplemental Gas Supply and Disposition," were the same as the proportions of gross withdrawals as reported on Form ElA-627. "Annual Quantity and Value of Natural Gas Report," used as lease by all operators. Form ElA-176 respondents reported on-system production totaling 31.9 percent of gross withdrawals in Alaska and 11.0 percent of gross withdrawals in the lower 48 States. The average ratios of volumes "Used in well, lease, and field operations" to "Company-owned natural gas produced on-system" computed from Form ElA-176 responses were 0.03485 for Alaska and 0.02192 for the lower 48 States. Those ratios were applied to gross withdrawals from all States, where lease fuel use was applicable, that did not report lease fuel use on the Form EIA.627.

Sources: Energy Intormation Administration (ElA), Form ElA-627. "Annual Quantity and Value of Natural Gas Report," estimates based upon Form ElA. 176, "Annual Report of Natural and Supplemental Gas Supply and Disposition," and Form ElA-64A, "Annual Feport of the Origin of Natural Gas Liquids Production." 
Appendix B

Metric and

Thermal

Conversion Tables 


\section{Metric and Thermal Conversion Tables}

\section{Metric Conversions}

Table B1 presents Summary Statistics for Natural Gas in the United States for 1988 through 1992 in metric units of measure. Volumes are shown in cubic meters instead of cubic feet. Prices are shown in dollars per thousand cubic meters instead of dollars per thousand cubic feet. The data in this table have been converted from the data that appear in Table 1 of this report.

\section{Thermal Conversions}

Table $B 2$ presents the thermal (Btu) conversion factors and the converted data for natural gas supply and disposition from 1988 through 1992. A brief documentation for the thermal conversion factors follows:

- Marketed Production. The conversion factor is calculated by adding the total heat content of dry production to the total heat content of extraction loss and dividing the resulting sum by the total quantity of dry production and extraction loss (see below).

- Extraction Loss. The conversion factor is obtained from Appendix A of this publication.

- Dry Production. The conversion factor is assumed to be the same as the thermal conversion factors for consumption (see below).

- Receipts at U.S. Borders. The conversion factors for imports are obtained from Form FPC.14, "Annual Report for Importers and Exporters of Natural Gas." Intransit receipts are assumed to have the same average heat content as imports.
- Withdrawals from Storage. Both underground and LNG storage withdrawals are assumed to have the same heat content as consumption (see helow).

- Supplemental Gas Supplies. This conversion factor is assumed to be the same as that for consumption (see below).

- Balancing ltem. This conversion factor is calculated by subtracting the total heat content of all other items of supply from the heat content of total disposition (from Table B2) and dividing the difference by the balancing item quantity.

- Consumption. The thermal conversion factor for total consumption (lease and plant fuel, pipeline fuel, and deliveries to consumers) is the average heat content for deliveries to end users as reported on Form EIA-176, "Annual Report of Natural and Supplemental Gas Supply and Disposition." Average heat content of electric utility consumption is obtained from EIA's Electric Power Annual. The factor for nonutility consumption is calculated by subtracting the total heat content of electric utility consumption from the heat content of total consumption and dividing the difference by the quantity of nonutility consumption (total consumption less electric utility consumption).

- Deliveries at U.S. Borders. The conversion facior for exports is obtained from Form FPC-14. Intransit deliveries are assumed to have the same average heat content as exports.

- Additions to Storage. Additions to both underground and I.NG storage are assumed to have the same heat content as consumption (see above). 
Table B1. Summary Statistics for Natural Gas in the United States, Metric Equivalents, 1988-1992

\begin{tabular}{|c|c|c|c|c|c|}
\hline & 1988 & 1989 & 1990 & 1991 & 1992 \\
\hline & \multicolumn{5}{|c|}{ Reserves (billion cubic meters) } \\
\hline \multirow[t]{2}{*}{$\begin{array}{l}\text { Estimaled Proved Pleserves (dry) } \\
\text { as of December } 31\end{array}$} & 4.758 & 4.732 & 4,795 & 4,731 & 4.673 \\
\hline & \multicolumn{5}{|c|}{ Number of Gas and Gas Condensate Wells } \\
\hline \multirow[t]{2}{*}{ Producing at End of Year. } & 257.279 & 262.483 & 269.790 & 276,987 & 276,014 \\
\hline & \multicolumn{5}{|c|}{ Production (million cubic meters) } \\
\hline Gross Withdrawals & & & & & \\
\hline From Gas Wells & 437.977 & 444,825 & 454,586 & ค $45: 568$ & 457,738 \\
\hline$+\ldots \ldots \ldots \ldots \ldots \ldots \ldots \ldots \ldots$ & 156.655 & 151.936 & 154.866 & ค 162,326 & 168,977 \\
\hline Total & 594,632 & 596,760 & 609,452 & A 615893 & 626.714 \\
\hline Repressuring & $-70,180$ & $-70,089$ & $.70,482$ & A. -78.492 & $.84,173$ \\
\hline Nonhydrocarbon Gases Removed & $-13,022$ & -10.264 & -8.194 & ค. -7.311 & $-7,939$ \\
\hline Wet After Lease Separation $\ldots \ldots \ldots$ & 511,429 & 516,408 & 530.776 & A 529,591 & 534.602 \\
\hline Vented and Flared & $-4,036$ & $-4,011$ & $-4,259$ & ค $-4,811$ & -4.744 \\
\hline Marketed Production & 507.394 & 512,397 & 526,517 & ค 524.779 & 529,859 \\
\hline 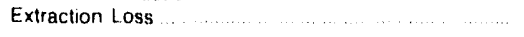 & $-23,102$ & $-22,215$ & $-22,204$ & -23.634 & $-24,690$ \\
\hline \multirow[t]{2}{*}{ Total Dry Production } & 484,291 & 490,182 & 504.313 & A $50 ! 145$ & 505,169 \\
\hline & \multicolumn{5}{|c|}{ Supply (million cubic meters) } \\
\hline Dry Production & 484,291 & 490.182 & 504,313 & ค 501,145 & 505,169 \\
\hline Receipts at US Borders & (1) & 400.106 & & & 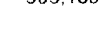 \\
\hline Imports & 36,637 & 39,120 & 43,389 & 50,215 & 60.527 \\
\hline Intransit Recelpts $\ldots \ldots \ldots \ldots$ & 9.989 & 9.821 & 10,092 & 10.275 & 13,767 \\
\hline Withdrawals from Storage & & & & & \\
\hline Underground Storage ...... & 63.532 & 79,394 & 54,759 & 76.136 & 77.129 \\
\hline LNG Storage & 747 & 1,424 & 1,488 & 1,787 & 1.374 \\
\hline Supplemental Gas Supplies & 2,864 & 3.023 & 3,477 & R 3189 & 3,339 \\
\hline Balancing ltem & -12.813 & -6.160 & $.4,300$ & A $-14,152$ & $-14,373$ \\
\hline \multirow[t]{2}{*}{ Total Supply } & 585.247 & 616.804 & 613,217 & ' 628,594 & 646,932 \\
\hline & \multicolumn{5}{|c|}{ Disposition (millon cubic meters) } \\
\hline Consumption $\ldots \ldots \ldots \ldots$ & 510,540 & 532.379 & 529.951 & R 539,015 & 553,434 \\
\hline Deliveries at US Borders & & & & & \\
\hline Exports & 2,085 & 3,026 & 2.423 & 3.660 & 6.124 \\
\hline$\ldots \ldots \ldots \ldots \ldots \ldots \ldots$ & 10,006 & 9.821 & 10.072 & 10,267 & 13.767 \\
\hline Additions to Storage & & & & & \\
\hline Underground Storage & 61,570 & 70,545 & 68,908 & 73,861 & 72.361 \\
\hline 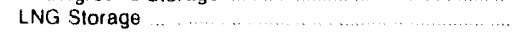 & 1.046 & 1.033 & 1,864 & 1,791 & 1,247 \\
\hline \multirow[t]{2}{*}{ Total Disposition } & 585,247 & 616.804 & 613,217 & A 628.594 & 646,932 \\
\hline & \multicolumn{5}{|c|}{ Consumption (millon cubic meters) } \\
\hline Lease and Plant Fuel & 31,032 & 30,296 & 35,011 & 31.977 & 33,154 \\
\hline$\ldots \ldots \ldots \ldots \ldots \ldots$ & 17,384 & 17,820 & $\$ 8,684$ & A 17,027 & 16,642 \\
\hline Delivered to Consumers & & & & & \\
\hline Residential & 131.116 & 135.372 & 124,348 & A 129,002 & 132.808 \\
\hline Commercial & 75.619 & 76.957 & 74,267 & ค 77,265 & 79.365 \\
\hline Industrial & 180,757 & 193.014 & 198,739 & A 204.758 & 213.138 \\
\hline Vahicle Fuel & NA & NA & 8 & 16 & 14 \\
\hline Electric Untitites & 74.632 & 78.919 & 78.895 & ค 78,976 & 78.313 \\
\hline Total Delivered to Consumers & 462,124 & 484,263 & 476,257 & $490,0: 0$ & 503,638 \\
\hline \multirow[t]{2}{*}{ Total Consumption. } & 510,540 & 532.379 & 529.951 & A 539.015 & 553,434 \\
\hline & \multicolumn{5}{|c|}{ Delivered tor the Account of Others (million cubic meters) } \\
\hline Residential & NA & NA & 886 & 1,032 & 1,173 \\
\hline Commercial & 6,996 & 8.371 & 9.982 & ค 11,494 & 13.337 \\
\hline Industrial & 103,730 & 121,697 & 128,687 & 137.731 & 148,624 \\
\hline Electric Utillties & 30,476 & 32.626 & 39.370 & 44.743 & 48,064 \\
\hline
\end{tabular}


Table B1. Summary Statistics for Natural Gas in the United States, Metric Equivalents, 1988-1992 (Continued)

\begin{tabular}{|c|c|c|c|c|c|}
\hline & 1989 & 1989 & 1990 & 1991 & 1992 \\
\hline & \multicolumn{5}{|c|}{ Number of Consumers } \\
\hline Residential. & 48.474 .449 & $49,309.593$ & $50,187,178$ & ค $51,593,206$ & 52.331 .397 \\
\hline Commercial ............ & 4124,745 & 4.168 .048 & $4,236,286$ & A $4.357,252$ & $4,409,699$ \\
\hline Industrial ............ & 199,041 & 225,346 & 218.341 & ค 216.529 & 209,616 \\
\hline \multirow[t]{2}{*}{ Venicle Fuel } & NA & NA & 1.007 & 1.106 & 1.033 \\
\hline & \multicolumn{5}{|c|}{ Average Annual Consumption per Consumer (thousand cubic meters) } \\
\hline Residential. & 3 & 3 & 2 & 2 & 3 \\
\hline Commercial & 18 & 18 & 18 & 18 & 18 \\
\hline Industrial $\ldots \ldots \ldots \ldots \ldots \ldots$ & 908 & 857 & 910 & 946 & 1,017 \\
\hline \multirow[t]{2}{*}{ Vehicle Fuel .......... } & NA & NA & 8 & 9 & 14 \\
\hline & \multicolumn{5}{|c|}{ Average Annual Cost per Consurner (dollars) } \\
\hline Residential. & 523 & 547 & 507 & 514 & 528 \\
\hline Commercial & 3.001 & 3.092 & 2,989 & 3,013 & 3.103 \\
\hline \multirow[t]{2}{*}{ Vehicle Fuel } & NA & NA & 910 & 1,314 & 2.002 \\
\hline & \multicolumn{5}{|c|}{ Average Heating Value (Kilopoules per cubic meter) } \\
\hline \multirow[t]{2}{*}{ Delivered to Consumers } & 38,330 & 38.405 & 38.405 & 38.368 & 38.368 \\
\hline & \multicolumn{5}{|c|}{ Average Prices for Natural Gas (dollars per thousand cubic meters) } \\
\hline Wellhead (Marketed Production) & $\$ 5968$ & $\$ 5968$ & $\$ 60.39$ & $\$ 5792$ & $\$ 6180$ \\
\hline Imports & 64.98 & 64.27 & 6851 & 6427 & 6533 \\
\hline Exports $\ldots \ldots$ & 9676 & 88.64 & 10948 & 9146 & 7946 \\
\hline$\ldots \ldots \ldots \ldots$ & 7416 & 70.98 & 68.86 & 6604 & 7310 \\
\hline$\ldots \ldots \ldots \ldots \ldots$ & 10312 & 10630 & 10700 & 10241 & 10630 \\
\hline Delivered to Consumers & & & & & \\
\hline Residential ................. & 19317 & 19917 & 20483 & 20553 & 20800 \\
\hline 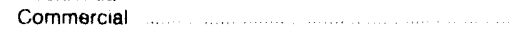 & 16351 & 167.39 & 17057 & 16986 & 17234 \\
\hline Industrial $\ldots$ & 10418 & 10453 & 10347 & 9500 & 10029 \\
\hline$(\ldots, \ldots \ldots \ldots \ldots \ldots \ldots+\ldots$ & NA & NA & 11972 & 13985 & 14302 \\
\hline \multirow[t]{2}{*}{ Electric Utilities } & $\$ 82.28$ & $\$ 8581$ & 8405 & 7699 & 8334 \\
\hline & \multicolumn{5}{|c|}{$\begin{array}{l}\text { Average Price of Purchases from Producers. Gatherers. } \\
\text { and/or Processing Plant Operators } \\
\text { (dollars per thousand cubic meters) }\end{array}$} \\
\hline by Interstate Pipelines. & $\$ 7204$ & $\$ 7134$ & $\$ 7593$ & $\$ 7028$ & $\$ 7593$ \\
\hline by Intrastate Pipelines & 6639 & 6639 & 6780 & 5968 & 6321 \\
\hline by Distributors and Municipalities & 9641 & 9500 & 9500 & 9182 & 9076 \\
\hline by Other Companies $\ldots \ldots \ldots$ & 6498 & 6498 & 6569 & 6357 & 62.86 \\
\hline \multirow[t]{2}{*}{ Total $\ldots \ldots \ldots \ldots \ldots \ldots$} & 7310 & 7451 & 7699 & 7204 & 7522 \\
\hline & \multicolumn{5}{|c|}{$\begin{array}{l}\text { Average Price of Purchases from Interstate Pipelines. Intrastale Pipelines } \\
\text { and/or Distributors } \\
\text { (dollars per thousand cubic meters) }\end{array}$} \\
\hline by Interstate Pipelines & $\$ 106.65$ & $\$ 10842$ & $\$ 9817$ & $\$ 9464$ & $\$ 9111$ \\
\hline by Intrastate Pipelines & 8864 & 8405 & 7381 & 6463 & 6992 \\
\hline by Distributors and Municipalities & 10948 & 11301 & 11689 & 11230 & 11583 \\
\hline by Other Companies & 9712 & 9994 & 10488 & 9782 & 10065 \\
\hline \multirow[t]{2}{*}{ Total } & 10630 & 110.53 & 11059 & 10630 & 10948 \\
\hline & \multicolumn{5}{|c|}{ Average Price of Sales for Resale (dollars per thousand cutic melers) } \\
\hline Dy interstate Pipelines & $\$ 11548$ & $\$ 141.96$ & $\$ 13561$ & $\$ 13773$ & $\$ 14444$ \\
\hline by Intrastate Pipelines & 8652 & 9888 & 10100 & 9252 & 9570 \\
\hline by Distributors and Municipalities & 12507 & 12607 & 12678 & 12643 & 11336 \\
\hline by Other Companies & 72.75 & 5827 & 5792 & 6180 & 6145 \\
\hline Total $\ldots \ldots \ldots \ldots \ldots$ & 9606 & 1077 & 9994 & 10594 & 108.42 \\
\hline
\end{tabular}

Aevised data

Note Beginning in 1987, prices for gas delivered to consumers are calculated using only onsysterm sales data No imputations are made tor prices of gas delivered tor the account of others in previous years, prices were calculated using reported values and values imputed for gas delivered for the account of others The United States includes account of others in previous years. prices were calculated using reported values and values impuled tor gas delver

Sources Energy Information Administration (EIA), Form EIA-176. "Annual Report of Natural and Supplemental Gas Supply and Disposition.". Form ElA.627. "Annual Quaritity

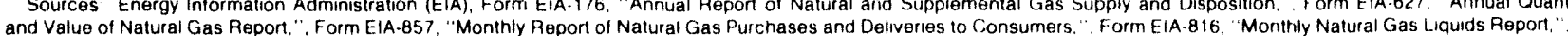
Form EIA-759. "Monthly Power Plant Report.", Form FERC-423. "Monthly Peport of Cost and Quality of Fuels tor Electric Plants," Forms EIA-191/FERC-8. "Underground Gas Storage Report.": Form FPC-14, "Annual Report for importers and Exporters of Natural Gas,". US. Cnude Oil. Natural Gas, and Natural Gas Liquids Reserves, 1992 Annual Report. DOE/EIA-0216(92); ariu the US Minerals Management Service 
Appendix C

Selected Natural Gas and Related Reports 


\section{Appendix C}

\section{Selected Natural Gas and Related Reports}

\section{Recurring Natural Gas Reports}

- Natural Gas Monthly, DOE/EIA-0130. Published monthly.

\section{Other Reports Covering Natural Gas, Natural Gas Liquids, and Other Energy Sources}

- U.S. Crude Oil, Natural Gas, and Natural Gas Liquids Reserves - 1992 Annual Report, DOE/EIA-0216(91), September 1993.

- Monthly Energy Review, DOE/EIA-0035. Published monthly. Provides national aggregate data for natural gas, natural gas liquids, and other energy sources.

- Annual Report to Congress 1992, DOE/ EIA-0173(92), March 1993. Published annually.

- Annual Energy Outlook 1993, DOE/ EIA-0383(93), January 1993. Published annually.

- Annual Energy Review 1992, DOE/ EIA-0384(92), June 1993. Published annually.

- Short-Term Energy Outlook, DOE/EIA-0202. Published quarterly. Provides forecasts for next six quarters for natural gas and other energy sources.

- Statistics of Interstate Natural Gas Pipeline Companies 1991. DOE/EIA-0145(91), December 1992.

- Gas Supplies of Interstate Natural Gas Pipeline Companies 1991, DOE/EIA-0167(91), December 1992.

- Annual Outlook for Oil and Gas: 1991 DOE/EIA-0517(91), June 1991.
- State Energy Data Report, Consumption Estimates, 1960-1991, DOE/EIA-0214(91), May 1993.

- State Energy Price and Expenditure Report 1990, DOE/EIA-0376(90), September 1992.

\section{One-Time Reports}

- U.S. Production of Natural Gas from Tight Reservoirs DOE/EIA-TR-0574, October 1993.

- Natural Gas 1992: Issues and Trends DOE/E!A-0560(20), March 1993.

- Natural Gas Productive Capacity for the Lower $48 \quad$ States 1982 through 1993. DOE/EIA-0542(93), March 1993.

- Geologic Distributions of U.S. Oil and Gas. DOE/ EIA-0557, July 1992.

- Capacity and Service on the Interstate Natural Gas Pipeline System 1990, DOE/EIA-0556, June 1992.

- Effects of Interruptible Natural Gas Service: Winter 1989-1990, SR/OG-91-01, June 1991.

- The Outlook for Natural Gas Imports: Supporting Analysis for the National Energy Strategy, SR/ NES/90-06, January 1991.

- The Domestic Oil and Gas Recoverable Resource Base: Supporting Analysis for the National Energy Strategy, SR/NES/90-05, December 1990.

\section{Reference Reports}

- Directory of Energy Data Collection Forms, DOE/ EIA-0249(92), January 1993.

- Oil and Gas Field Code Master List, 1992. EIA-0370(92), December 1992. 


\section{Glossary}

Balancing Item: Represents differences between the sum of the components of natural gas supply and the sum of the components of natural gas disposition. These differences may be due to quantities lost or to the effects of data-ieporting problems. Reporting problems include differences due to the net result of conversions of flow data metered at varying temperature and pressure bases and converted to a standard temperature and pressure base; the effect of variations in company accounting and billing practices; differences between billing cycle and calendar period time frames; and imbalances resulting from the merger of data-reporting systems that vary in scope, format, definitions, and type of respondents.

Biomass Gas: A medium Btu gas containing methane and carbon dioxide, resulting from the action of microorganisms on organic materials such as a landfill.

British Thermal Unit (Btu): The quality of heat required to raise the temperature of 1 pound of water by 1 degree Fahrenheit at or near 39.2 degrees Fahrenheit.

City Gate: A point or measuring station at which a gas distribution company receives gas from a pipeline company or transmission system.

Coke Oven Gas: The gaseous portion of volatile substances driven off in the coking process after other coal chemicals are removed.

Commercial Consumption: Gas used by nonmanufacturing establishments or agencies primarily engaged in the sale of goods or services. Included are such establishments as hotels, restaurants, wholesale and retail stores and other service enterprises: gas used hy establishments engaged in agriculture, forestry, and fisheries; and gas used by local. State, and Federal agencies engaged in nonmanufacturing activities.
Delivered: The physical transfer of natural, synthetic, and/or supplemental gas from facilities operated by the responding company to facilitien un rated by oth. ers or to consumers.

Dry Natural Gas Product led production less extraction loss.

Electric Utilities: Establishments primarily engaged in the generation, transmission, and/or distribution of electricity for sale or resale.

Electric Utility Consumption: Gas used as fuel in electric utility plants.

Exports: Natural gas deliveries out of the continental United States and Alaska to foreign countries.

Extraction Loss: The reduction in volume of natural gas due to the removal of natural gas liquid constituents such as ethane, propane, and butane at natural gas processing plants.

Flared: Natural gas burned in flares at the base sile or at gas-processing plants.

Gas Condensate $\mathrm{W}$ ell: A gas well that produces from a gas reservoir containing considerable quantities of liquid hydrocarbons in the pentane and heavier range generally described as "condensate."

Gas Well: A well completed for the prociuction of natural gas from one or more gas zones or reservoirs.

Gross Withdrawals: Full well-stream volume, including all natural gas plant liquids and all nonhydrocarbon gases, hut excluding lease condensate. 
Heating Value: The average number of British thermal units per cubic foot of natural gas as determined from tests of fuel samples.

Imports: Gas receipts into the United States from a foreign country.

Industrial Consumers: Establishments engaged in a process which creates or changes raw or unfinished materials into another form or product. Generation of electricity, other than by electric utilities, is included.

Industrial Consumption: Natural gas used by manufacturing and mining establishments for heat, power, and chemical feedstock.

Intransit Deliveries: Redeliveries to a foreign country of foreign gas received for transportation across U.S. territory and deliveries of U.S. gas to a foreign country for transportation across its territory and redelivery to the United States.

Intransit Receipts: Receipts of foreign gas for transportation across U.S. territory and redelivery to a foreign country and redeliveries to the United States of U.S. gas transported across foreign territory.

Lease and Plant Fuel: Natural gas used in well, field. and lease operations, (such as gas used in drilling operations, heaters, dehydrators, and field compressors), and as fuel in natural gas processing plants.

Liquefied Natural Gas (LNG): Natural gas (primarily methane) that has been liquefied by reducing its temperature to minus 260 degrees Fahocinheit at atmospheric pressure.

Manufactured Gas: A gas obtained by destructive distillation of coal, or by the thermal decomposition of oil, or by the reaction of steam passing through a bed of heated coal or coke. Examples are coal gases. coke oven gases, producer gas, blast furnace gas, blue (water) gas, carbureted water gas. Btu content varies widely.

Marketed Production: Gross withdrawals less gas used for repressuring, quantities vented and flared, and nonhydrocarbon gases removed in treating or processing operations.

Natural Gas: A mixture of hydrocarbon compounds and small quantities of various nonhydrocarbons existing in the gaseous phase or in solution with crude oil in natural underground reservoirs at reservoir conditions.

Natural Gas, Wet After Lease Separation: The volume of natural gas remaining after removal of lease condensate in lease and/or field separation facilities, if any, and after exclusion of nonhydrocarbon gases where they occur in sufficient quantity to render the gas unmarketable. Natural gas liquids may be recovered from volumes of natural gas, wet after lease separation, at natural gas processing plants.

Nonhydrocarbon Gases: Typical nonhydrocarbon gases which may be present in reservoir natural gas, such as carbon dioxide, helium, hydrogen sulfide, and nitrogen.

Offshore Reserves and Production: Unless otherwise indicated, reserves and production that are in either State or Federal domains, located seaward of the coastline.

Oil Well (Casinghead) Gas: Associated and dissolved gas produced along with crude oil from oil completions.

Outer Continental Shelf: Offshore Federal domain.

Pipeline: A continuous pipe conduit, complete with such equipment as valves, compressor stations, communications systems, and meters, for transporting natural and/or supplemental gas from one point to another, usually from a point in or beyond the producing field or processing plant to another pipeline or to points of use. Also refers to a company operating such facilities.

Pipeline Fuel: Gas consumed in the operation of pipelines, primarily in compressors.

Production, Wet After Lease Separation: Gross withdrawals less gas used for repressuring and 
nonhydrocarbon gases removed in treating or processing operations.

Propane-air: A mixture of propane and air resulting in a gaseous fuel suitable for pipeline distribution.

Proved Reserves: The estimated quantities that analysis of geological and engineering data demonstrate with reasonable certainty to be recoverable in future years from known oil and gas reservoirs under existing economic and operating conditions.

Receipts: Gas physically transferred into the responding company's transportation, storage, and/or distribution facilities.

Refinery Gas: Noncondensate gas collected in petroleum refineries.

Repressuring: The injection of gas into oil or gas reservoir formations to effect greater ultimate recovery.

Residential Consumption: Gas used in private dwellings, including apartments, for heating, air-conditioning, cooking, water heating, and other household uses.

Storage Additions: Volumes of gas injected or otherwise added to underground natural gas reservoirs or liquefied natural gas storage.

Storage Withdrawals: Volumes of gas withdrawn from underground storage or liquefied natural gas storage.
Supplemental Gaseous Fuels Supplies: Synthetic natural gas, propane-air, coke oven gas, refinery gas, biomass gas, air injected for Btu stabilization, and manufactured gas commingled and distributed with natural gas.

Synthetic Natural Gas (SNG): A manufactured product chemically similar in most respects to natural gas, resulting from the conversion or reforming of petroleum hydrocarbons or from coal gasification. It may easily be substituted for or interchanged with pipeline quality natural gas.

Therm: One hundred thousand British thermal units.

Underground Storage: The storage of natural gas in underground reservoirs at a different location from which it was produced.

Underground Storage Injections: Gas from extraneous sources put into underground storage reservoirs.

Underground Storage Withdrawals: Gas removed from underground storage reservoirs.

Unit Value, Consumption: Total price per specified unit, including all taxes, at the point of consumption.

Unit Value, Wellhead: The wellhead sales price, including charges for natural gas plant liquids subsequently removed from the gas, gathering and compression charges, and State production, severance, and/or similar charges.

Vented: Gas released into the air on the base site or at processing plants. 

